\title{
IMPACTS OF THE WEATHERIZATION ASSISTANCE PROGRAM IN FUEL-OIL HEATED HOUSES
}

\author{
William P. Levins \\ Mark P. Ternes \\ Energy Division
}

October 1994

\section{Prepared for the}

Office of Technical and Financial Assistance

Weatherization Assistance Program Division

U. S. Department of Energy

Prepared by the

OAK RIDGE NATIONAL LABORATORY

Oak Ridge, Tennessee 37831

$$
\text { managed by }
$$

MARTIN MARIETTA ENERGY SYSTEMS, INC.

for the

U. S. DEPARTMENT OF ENERGY

under Contract DE-AC05-84OR21400 


\section{DISCLAIMER}

This report was prepared as an account of work sponsored by an agency of the United States Government. Neither the United States Government nor any agency thereof, nor any of their employees, make any warranty, express or implied, or assumes any legal liability or responsibility for the accuracy, completeness, or usefulness of any information, apparatus, product, or process disclosed, or represents that its use would not infringe privately owned rights. Reference herein to any specific commercial product, process, or service by trade name, trademark, manufacturer, or otherwise does not necessarily constitute or imply its endorsement, recommendation, or favoring by the United States Government or any agency thereof. The views and opinions of authors expressed herein do not necessarily state or reflect those of the United States Government or any agency thereof. 


\section{DISCLAIMER}

Portions of this document may be illegible in electronic image products. Images are produced from the best available original document. 
TABLE OF CONTENTS $\ldots \ldots \ldots \ldots \ldots \ldots \ldots \ldots \ldots \ldots \ldots \ldots \ldots \ldots \ldots$ iii

LIST OF FIGURES $\ldots \ldots \ldots \ldots \ldots \ldots \ldots \ldots \ldots \ldots \ldots \ldots \ldots \ldots \ldots \ldots$

LIST OF TABLES $\ldots \ldots \ldots \ldots \ldots \ldots \ldots \ldots \ldots \ldots \ldots \ldots \ldots \ldots \ldots \ldots \ldots$

LIST OF APPENDICES $\ldots \ldots \ldots \ldots \ldots \ldots \ldots \ldots \ldots \ldots \ldots \ldots \ldots \ldots \ldots$

ACKNOWLEDGMENTS $\ldots \ldots \ldots \ldots \ldots \ldots \ldots \ldots \ldots \ldots \ldots \ldots \ldots \ldots \ldots \ldots \ldots$

ABSTRACT $\ldots \ldots \ldots \ldots \ldots \ldots \ldots \ldots \ldots \ldots \ldots \ldots \ldots \ldots \ldots \ldots \ldots \ldots$

EXECUTTVE SUMMARY $\ldots \ldots \ldots \ldots \ldots \ldots \ldots \ldots \ldots \ldots \ldots \ldots \ldots \ldots$ xvii

1. INTRODUCTION $\ldots \ldots \ldots \ldots \ldots \ldots \ldots \ldots \ldots \ldots \ldots \ldots \ldots \ldots \ldots \ldots \ldots \ldots \ldots$

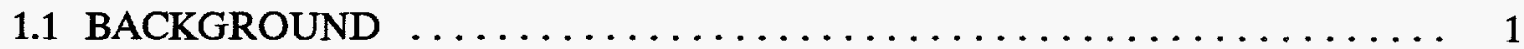

1.2 OBJECTIVES . . . . . . . . . . . . . . . . . . . . . . 1

2. EVALUATION DESIGN $\ldots \ldots \ldots \ldots \ldots \ldots \ldots \ldots \ldots \ldots \ldots \ldots \ldots \ldots \ldots \ldots$

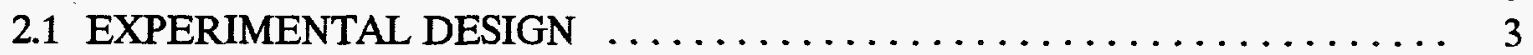

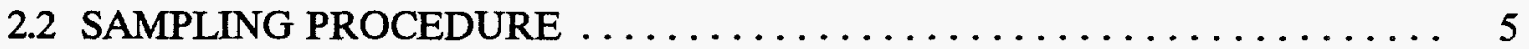

2.3 HOUSE ELIGIBILITY $\ldots \ldots \ldots \ldots \ldots \ldots \ldots \ldots \ldots \ldots \ldots \ldots \ldots \ldots$

2.4 DATA PARAMETERS AND INSTRUMENTATION . . . . . . . . . . 9

2.4.1 Time-Sequential Measurements .................. 9

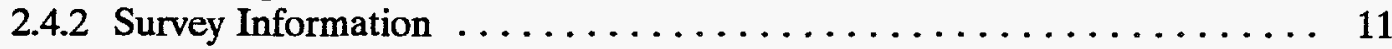

2.4 .3 Point-in-Time Measurements . . . . . . . . . . . . . 12

3. OCCUPANT AND HOUSE CHARACTERISTICS $\ldots \ldots \ldots \ldots \ldots \ldots \ldots \ldots \ldots \ldots \ldots$

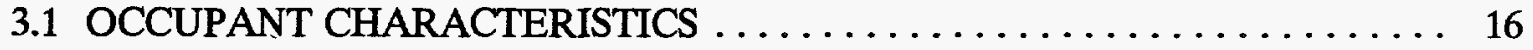

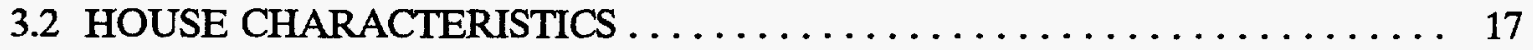

3.3 COMPARISON OF WEATHERIZED AND CONTROL GROUPS $\ldots \ldots \ldots 21$

4. DESCRIPTION OF WEATHERIZATION ACTIVITIES $\ldots \ldots \ldots \ldots \ldots \ldots \ldots \ldots \ldots$

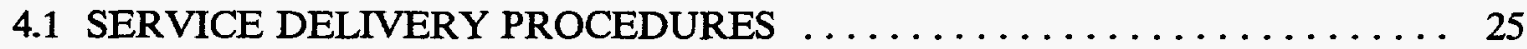

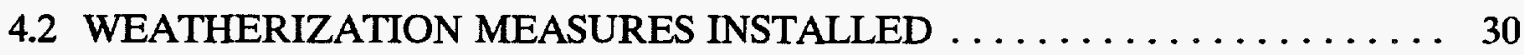

5. FUEL-OIL CONSUMPTIONS AND SAVINGS $\ldots \ldots \ldots \ldots \ldots \ldots \ldots \ldots \ldots \ldots$

5.1 METHOD OF ANALYSIS $\ldots \ldots \ldots \ldots \ldots \ldots \ldots \ldots \ldots \ldots \ldots \ldots \ldots \ldots \ldots \ldots$

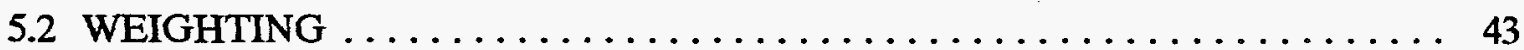

5.3 FUEL-OIL CONSUMPTION AND SAVINGS RESULTS . . . . . . . . 44

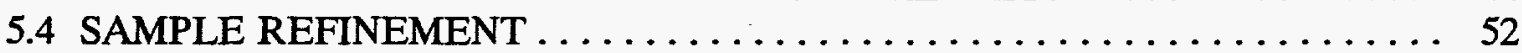

5.5 INDOOR TEMPERATURES $\ldots \ldots \ldots \ldots \ldots \ldots \ldots \ldots \ldots \ldots \ldots \ldots$

6. AIR-LEAKAGE REDUCTIONS $\ldots \ldots \ldots \ldots \ldots \ldots \ldots \ldots \ldots \ldots \ldots \ldots \ldots \ldots \ldots$

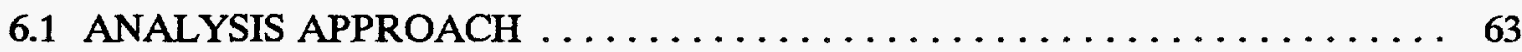

6.2 RESULTS . . . . . . . . . . . . . 64 
7. HEATING SYSTEM MEASUREMENTS AND INSPECTIONS $\ldots \ldots \ldots \ldots \ldots \ldots \ldots$

7.1 THE COMBUSTION OF FUEL OIL $\ldots \ldots \ldots \ldots \ldots \ldots \ldots \ldots \ldots \ldots \ldots$

7.2 CLEAN AND TUNE-UP SERVICE $\ldots \ldots \ldots \ldots \ldots \ldots \ldots \ldots \ldots \ldots \ldots \ldots$

7.3 HEATING SYSTEM SAFETY INSPECTIONS $\ldots \ldots \ldots \ldots \ldots \ldots \ldots \ldots \ldots$.

7.3 .1 Visual Inspection $\ldots \ldots \ldots \ldots \ldots \ldots \ldots \ldots \ldots \ldots \ldots \ldots$

7.3 .2 Heating System Limit Settings $\ldots \ldots \ldots \ldots \ldots \ldots \ldots \ldots \ldots$

7.3 .3 Spillage $\ldots \ldots \ldots \ldots \ldots \ldots \ldots \ldots \ldots \ldots \ldots \ldots \ldots \ldots \ldots$

7.3.4 Carbon Monoxide Measurements $\ldots \ldots \ldots \ldots \ldots \ldots \ldots \ldots$

8. OCCUPANT FEEDBACK $\ldots \ldots \ldots \ldots \ldots \ldots \ldots \ldots \ldots \ldots \ldots \ldots \ldots \ldots \ldots \ldots$

8.1 INDOOR TEMPERATURES $\ldots \ldots \ldots \ldots \ldots \ldots \ldots \ldots \ldots \ldots \ldots \ldots$

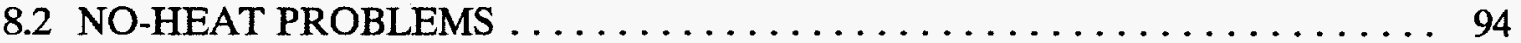

8.3 OTHER INDOOR CONDITIONS $\ldots \ldots \ldots \ldots \ldots \ldots \ldots \ldots \ldots \ldots \ldots \ldots \ldots$

9. PROGRAM COSTS $\ldots \ldots \ldots \ldots \ldots \ldots \ldots \ldots \ldots \ldots \ldots \ldots \ldots \ldots \ldots \ldots$

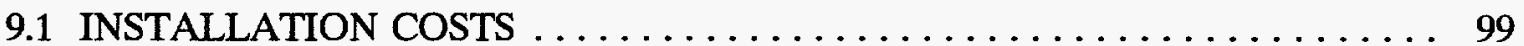

9.2 OVERHEAD AND MANAGEMENT COSTS . . . . . . . . . . . . 102

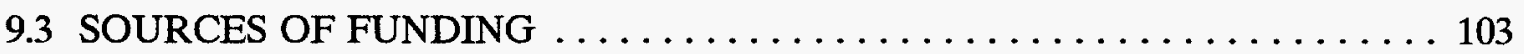

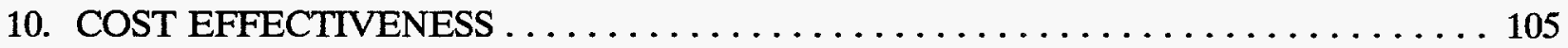

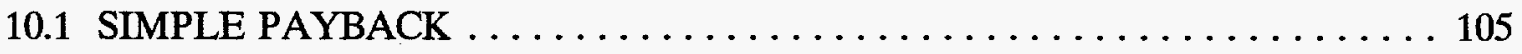

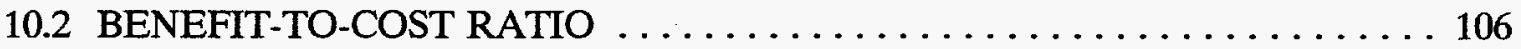

11. FACTORS ASSOCIATED WITH SAVINGS . . . . . . . . . . . . . . 109

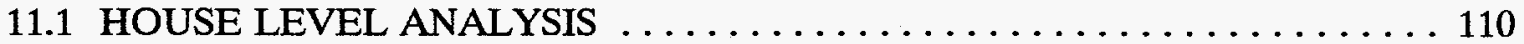

11.1.1 Pre-Weatherization Consumption and Savings $\ldots \ldots \ldots \ldots \ldots \ldots \ldots$

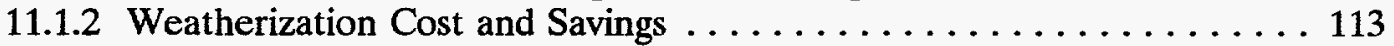

11.1.3 Occupant and Dwelling Characteristics Associated With Savings . . . 115

11.1.4 Energy Savings Associated with Installed Measures ... . . . . . . . . . 116

11.1.5 Energy Savings Associated with Delivery Procedures . . . . . . . . 122

11.1.6 High and Low Fuel-Oil Saving Houses . . . . . . . . . . . . . 122

11.2 AGENCY AND STATE-LEVEL ANALYSES $\ldots \ldots \ldots \ldots \ldots \ldots \ldots \ldots \ldots$

12. CONCLUSIONS AND RECOMMENDATIONS $\ldots \ldots \ldots \ldots \ldots \ldots \ldots \ldots \ldots$

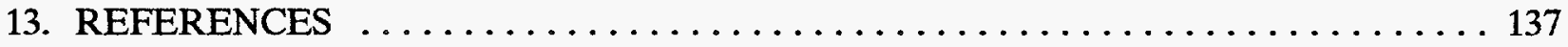




\section{LIST OF FIGURES}

ES.1. Split-winter experimental design. . . . . . . . . . . . . . . . . . xviii

ES.2. Installation frequency of general types of weatherization measures in fuel-oil heated houses during program years 1991 and 1992 for the northeast region . . . . . . . xxi

ES.3. Distribution of fuel-oil savings for the control and weatherized houses. For the control houses, the sample (unweighted) mean was -20 gallons/year and the standard deviation was 117 . For the weatherized houses, the sample mean was 143 gallons/year and the standard deviation was $195 . \ldots \ldots \ldots \ldots \ldots \ldots \ldots \ldots \ldots$ xiv

ES.4. Comparison of the change in adjusted steady-state efficiency to the preweatherization efficiency for the weatherized houses receiving a clean and tune. ... xxvii

ES.5. Average rating provided by the occupants on indoor conditions and heating affordability before and after weatherization. A scale of 1 to 7 was used, where 1 was poor and 7 was very good. $\ldots \ldots \ldots \ldots \ldots \ldots \ldots \ldots \ldots \ldots \ldots \ldots \ldots \ldots \ldots \ldots$

ES.6. Material cost breakdown for an average weatherized house (total cost was

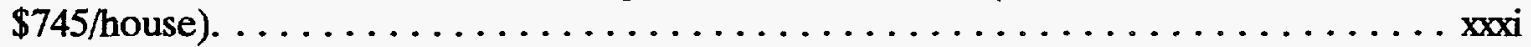

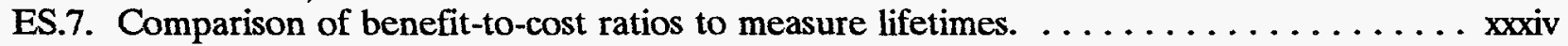

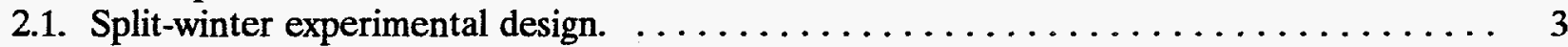

2.2. Locations of weatherization agencies taking part in the Fuel-Oil Study. . . . . . . . 5

3.1. Distribution of the number of occupants per house (mean $=3$, and standard

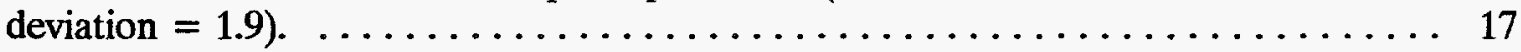

3.2. Distribution of house age (mean $=1928$, and standard deviation $=30$ ) $\ldots \ldots \ldots \ldots$

3.3. Distribution of house living area (mean $=1332 \mathrm{ft}^{2}$, and standard deviation $=465$ ). $\ldots 19$

4.1. Application frequency of measure selection procedures in fuel-oil heated houses during program years 1991 and 1992 for the northeast region. . . . . . . . . . 26

4.2. Application frequency of selected diagnostic procedures in fuel-oil heated houses during program years 1991 and 1992 for the northeast region. . . . . . . . . 28

4.3. Application frequency of quality control inspections in fuel-oil heated houses during program years 1991 and 1992 for the northeast region. . . . . . . . . . . . . . . . . 29

4.4. Installation frequency of general types of weatherization measures in fuel-oil heated houses during program years 1991 and 1992 for the northeast region. . . . . . . . . .

4.5. Installation frequency of specific air leakage measures in fuel-oil heated houses during program years 1991 and 1992 for the northeast region. . . . . . . . . . .

4.6. Installation frequency of specific insulation measures in fuel-oil heated houses during program years 1991 and 1992 for the northeast region. . . . . . . . . . . . . . .

4.7. Installation frequency of specific domestic water-heating system measures in fuel-oil heated houses during program years 1991 and 1992 for the northeast region. ......

4.8. Installation frequency of specific space-heating system measures in fuel-oil heated houses during program years 1991 and 1992 for the northeast region. . . . . . . . .

4.9. Installation frequency of specific window and door measures in fuel-oil heated houses during program years 1991 and 1992 for the northeast region. . . . . . . . . . .

4.10. Installation frequency of structural weatherization measures and repairs in fuel-oil heated houses during program years 1991 and 1992 for the northeast region. . . . . .

4.11. Frequency of client education provided in fuel-oil heated houses during program years 1991 and 1992 for the northeast region. . . . . . . . . . . . . . . . 
5.1. Distributions of pre- and post-weatherization coefficients of determination $\left(R^{2}\right)$ for control ( $a$ and $b$ ) and weatherized ( $c$ and d) houses, respectively. Mean values for the pre- and post-weatherization periods were 0.84 for the control houses, and 0.80 and 0.82 for the weatherized houses. Standard deviations for the pre- and post-weatherization periods were 0.18 and 0.19 for the control houses, and 0.23 and 0.19 for the weatherized houses. . . . . . . . . . . . . . . . . . .

5.2. Distribution of pre-weatherization fuel-oil consumptions for the control (a) and weatherized (b) houses. For the control houses, the sample mean was 938 gallons/year and the standard deviation was 407 . For the weatherized houses, the sample mean was 882 gallons/year and the standard deviation was $379 . \ldots \ldots \ldots \ldots$

5.3. Distribution of post-weatherization fuel-oil consumptions for the weatherized houses. The sample mean was 739 gallons/year and the standard deviation was 340 .

5.4. Distribution of pre- and post-weatherization fuel-oil consumptions for the control (a) and weatherized (b) houses, where the abscissa ( $\mathrm{x}$-axis) represents a cumulative percent of the sample. . . . . . . . . . . . . . . . . . . .

5.5. Distribution of fuel-oil savings for the control (a) and weatherized (b) houses. For the control houses, the sample mean was -20 gallons/year and the standard deviation was 117. For the weatherized houses, the sample mean was 143 gallons/year and the standard deviation was 195.

5.6. Distribution of percent fuel-oil savings for the control (a) and weatherized (b) houses, where the abscissa ( $\mathrm{x}$-axis) represents a cumulative percent of the sample. ...

5.7. Average sample pre-weatherization fuel-oil consumption (a), savings (b), and percent savings (c) for the control and weatherized houses using different data sets depending on the adequacy of the consumption regressions. . . . . . . . . . . .

5.8. Distribution of pre- and post-weatherization indoor temperatures for the control (a) and weatherized (b) houses, where the abscissa ( $\mathrm{x}$-axis) represents a cumulative

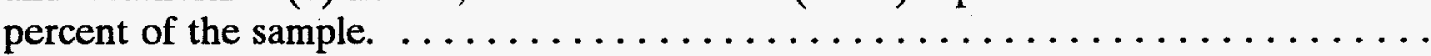

5.9. Distribution of indoor temperature differences for the control (a) and weatherized (b) houses, where the abscissa (x-axis) represents a cumulative percent of the sample (negative temperature differences mean that the indoor temperature was lower during the post-weatherization period than it was during the preweatherization period)

6.1. Distribution of pre-weatherization air leakages for the control (a) and weatherized

(b) houses. For the control houses, the mean was $3468 \mathrm{cfm} 50$ and the standard deviation was 1735 . For the weatherized houses, the mean was $3295 \mathrm{cfm} 50$ and

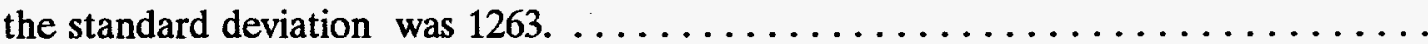

6.2. Distribution of air-leakage reductions in the control (a) and weatherized (b) houses. For the control houses, the mean was $164 \mathrm{cfm} 50$ and the standard deviation was 1099. For the weatherized houses, the mean was $570 \mathrm{cfm} 50$ and the standard deviation was 821 .

6.3. Comparison of the air-leakage reductions of the control (a) and weatherized (b) houses to pre-weatherization air leakages.

6.4. Distribution of post-weatherization air leakages for the weatherized houses. The mean was $2725 \mathrm{cfm} 50$ and the standard deviation was 1165 . 
7.1. Control houses (none of which received a clean and tune-up) - Distribution of preweatherization adjusted steady-state efficiency (a) and efficiency change (b). The mean pre-weatherization steady-state efficiency was $75 \%$ and the standard deviation was 5.3 . The mean efficiency change was +1.5 percentage points and the standard deviation was $3.7 . \ldots \ldots \ldots \ldots \ldots \ldots \ldots \ldots \ldots \ldots \ldots \ldots$

7.2. Weatherized houses receiving a clean and tune-up - Distribution of preweatherization adjusted steady-state efficiency (a) and efficiency change (b). The mean pre-weatherization steady-state efficiency was $75.0 \%$ and the standard deviation was 6.0. The mean efficiency change was +0.8 percentage points and

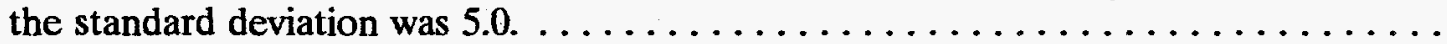

7.3. Weatherized house not receiving a clean and tune-up - Distribution of preweatherization adjusted steady-state efficiency (a) and efficiency change (b). The mean pre-weatherization steady-state efficiency was $77.2 \%$ and the standard deviation was 6.1 . The mean efficiency change was +0.5 percentage points and

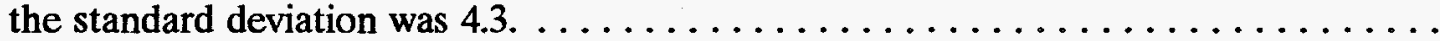

7.4. Control houses - Comparison of the change in adjusted steady-state efficiency to the pre-weatherization efficiency. . . . . . . . . . . . . . . . . . . . . .

7.5. Weatherized houses receiving a clean and tune-up - Comparison of the change in adjusted steady-state efficiency to the pre-weatherization efficiency. . . . . . . . .

7.6. Weatherized houses not receiving a clean and tune-up - Comparison of the change in adjusted steady-state efficiency to the pre-weatherization efficiency. . . . . . . . .

7.7. Safety inspection results for the control and weatherized houses showing the percent of passing evaluations for each safety area covered by the inspection. . . . . . . . . . comparison of the average measured draft to time for forced-air furnaces and hydronic boilers. . . . . . . . . . . . . . . . . . . . . . . . . . .

7.8. Comparison of the
hydronic boilers.

8.1. Percentage of control (a) and weatherized (b) houses experiencing different types of no-heat problems before and after weatherization. . . . . . . . . . . . . . .

8.2. Average rating provided by the occupants on indoor conditions and heating affordability before and after weatherization. A scale of 1 to 7 was used, where 1 was poor and 7 was very good. . . . . . . . . . . . . . . . 96

9.1. Distribution of installation costs. The sample mean was $\$ 1253$ and the sample

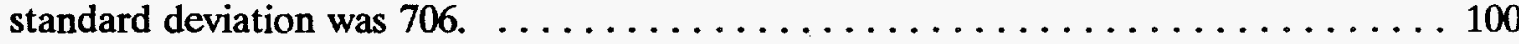

9.2. Installation costs for houses subdivided by type of crew performing the weatherizations. ............................... 101

9.3. Material cost breakdown for an average weatherized house (average material cost for

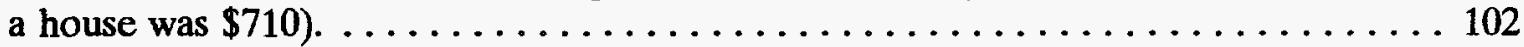

10.1. Comparison of benefit-to-cost ratios to measure lifetimes. . . . . . . . . . . 108

11.1. Comparison of annual pre-weatherization fuel-oil consumption to postweatherization consumption for the weatherized houses. $\ldots \ldots \ldots \ldots \ldots \ldots \ldots 11$

11.2. Comparison of fuel-oil savings to pre-weatherization fuel-oil consumption for the weatherized houses. . . . . . . . . . . . . . . . . . . . . . . 112

11.3. Effects of cost of weatherization on measured fuel-oil savings. . . . . . . . . 114

11.4. Mean fuel-oil savings for houses receiving selected insulation, air-leakage, structural,

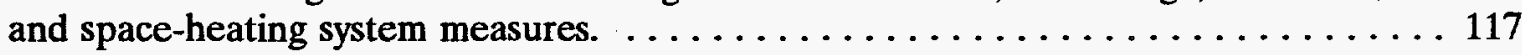

11.5. Installation frequency of weatherization measures in high and low saver groups. . . . 126

11.6. Frequency of use of different measure selection approaches, diagnostic techniques, quality control inspections, and client education. . . . . . . . . . . . 127 
11.7. Average annual fuel-oil savings for each local weatherization agency (in increasing order of savings) with the number of houses monitored in each agency identified along the abscissa ( $\mathrm{x}$-axis).

11.8. Comparison of average annual fuel-oil savings for each local weatherization agency

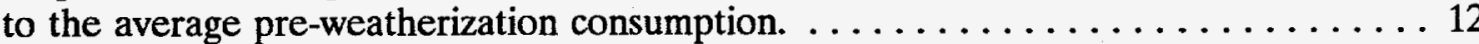

11.9. Distribution of the average annual fuel-oil savings achieved by each local weatherization agency.

11.10. Average annual fuel-oil savings for each state (in increasing order of savings).

K.1. Distribution of occupant ratings for indoor comfort for control and weatherized houses. A scale of 1 to 7 was used, where 1 was poor and 7 was excellent. . . . . 281

K.2. Distribution of occupant ratings for house draftiness for control and weatherized houses. A scale of 1 to 7 was used, where 1 was poor and 7 was excellent. . . . . 282

K.3. Distribution of occupant ratings for health of the occupants for control and weatherized houses. A scale of 1 to 7 was used, where 1 was poor and 7 was excellent.

K.4. Distribution of occupant ratings for house safety for control and weatherized houses.

A scale of 1 to 7 was used, where 1 was poor and 7 was excellent.

K.5. Distribution of occupant ratings for heating affordability for control and weatherized houses. A scale of 1 to 7 was used, where 1 was poor and 7 was excellent. 285 


\section{LIST OF TABLES}

ES.1. Regional (weighted) fuel-oil consumptions and savings $\ldots \ldots \ldots \ldots \ldots \ldots \ldots \ldots$ xiii

ES.2. Control and weatherized house air-leakages $\ldots \ldots \ldots \ldots \ldots \ldots \ldots \ldots \ldots \ldots \ldots$

ES.3. Mean values of measured space-heating system performance parameters $\ldots \ldots \ldots \ldots$ xxvi

ES.4. Cost-effectiveness estimates . . . . . . . . . . . . . . . . . . . .

ES.5. House-level energy savings associated with selected measures $\ldots \ldots \ldots \ldots \ldots \ldots$ xxxvi

ES.6. Mean values of measured variables $\ldots \ldots \ldots \ldots \ldots \ldots \ldots \ldots \ldots \ldots \ldots \ldots \ldots \ldots$

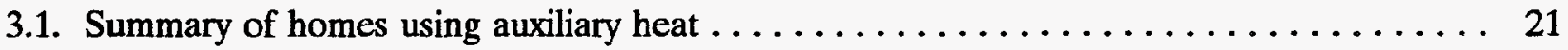

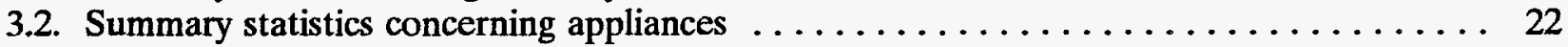

3.3. Comparison of mean values of selected house characteristics $\ldots \ldots \ldots \ldots \ldots \ldots \ldots$

4.1. Comparison of measure selection procedures used by program year $\ldots \ldots \ldots \ldots \ldots 27$

5.1. Summary of fuel-oil consumptions and savings $\ldots \ldots \ldots \ldots \ldots \ldots \ldots \ldots \ldots \ldots$

5.2. Confidence intervals of regional fuel-oil consumptions and savings $\ldots \ldots \ldots \ldots \ldots \ldots 47$

5.3. Effect of use of auxiliary heat on $\mathrm{R}^{2}$ fit of fuel-oil consumption data $\ldots \ldots \ldots \ldots \ldots$

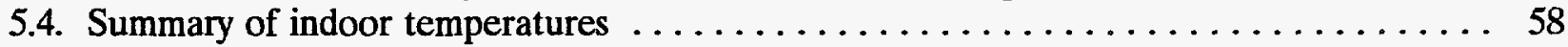

6.1. Control and weatherized house air-leakages $\ldots \ldots \ldots \ldots \ldots \ldots \ldots \ldots \ldots \ldots \ldots$

6.2. Factors effecting air-leakage reductions in the weatherized houses $\ldots \ldots \ldots \ldots \ldots \ldots$

7.1. Description of smoke number . . . . . . . . . . . . . . . . . . 74

7.2. Mean values of measured space-heating system performance parameters $\ldots \ldots \ldots \ldots 77$

7.3. Comparison of safety related observations between groups $\ldots \ldots \ldots \ldots \ldots \ldots \ldots$

7.4. Draft pressures . . . . . . . . . . . . . . . . . . . . . . . . 89

7.5. Standards and guidelines for exposure to carbon monoxide $\ldots \ldots \ldots \ldots \ldots \ldots \ldots \ldots$. 91

7.6. Results of carbon monoxide measurements $\ldots \ldots \ldots \ldots \ldots \ldots \ldots \ldots \ldots \ldots \ldots \ldots \ldots$

9.1. Cost categories used in this study $\ldots \ldots \ldots \ldots \ldots \ldots \ldots \ldots \ldots \ldots \ldots \ldots \ldots$

9.2. Average costs . . . . . . . . . . . . . . . . . . . . . . . . 99

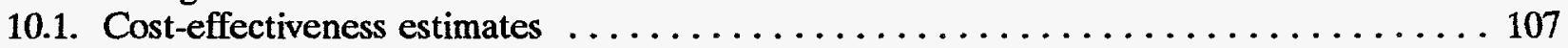

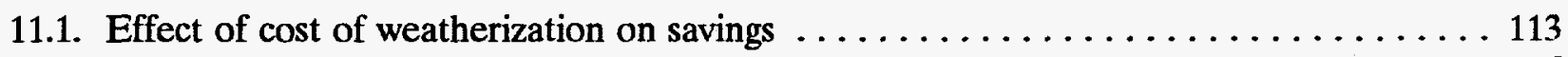

11.2. Energy savings by occupant and dwelling characteristic $\ldots \ldots \ldots \ldots \ldots \ldots \ldots \ldots \ldots$

11.3. House-level energy savings associated with selected measures $\ldots \ldots \ldots \ldots \ldots \ldots \ldots$

11.4. Correlations between measures associated with statistically significant, higher-than-

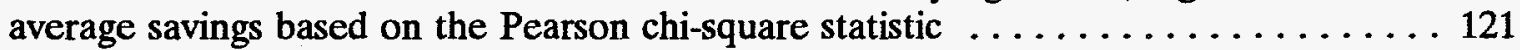

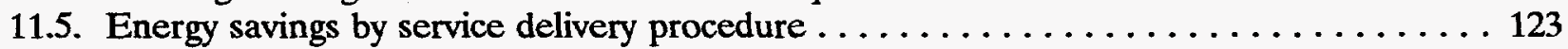

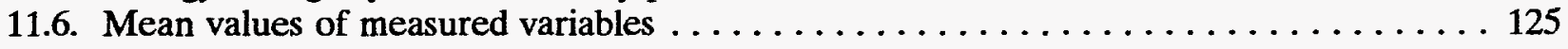

G.1. Summary statistics concerning occupants . . . . . . . . . . . . . . . . 239

G.2. Distribution of various house parameters for the control and weatherized houses . . . 240

G.3. Survey statistics concerning house physical characteristics $\ldots \ldots \ldots \ldots \ldots \ldots \ldots$

G.4. Summary statistics concerning windows and exterior doors $\ldots \ldots \ldots \ldots \ldots \ldots \ldots$

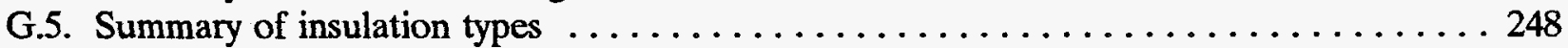

G.6. Occupant responses to type and amount of auxiliary fuel usage . . . . . . . . . . 249

G.7. Weatherized homes using auxiliary heat in both pre and post periods . . . . . . 250

H.1. TMY weather file used for each local weatherization agency $\ldots \ldots \ldots \ldots \ldots \ldots \ldots$

H.2. Summary of sample (unweighted) results for $1990-1992 \ldots \ldots \ldots \ldots \ldots \ldots \ldots \ldots$

H.3. Distributions of energy related parameters for the control houses . . . . . . . . 259

H.4. Distribution of energy related parameters for the weatherized houses $\ldots \ldots \ldots \ldots$

H.5. Summary statistics for different control house data sets $\ldots \ldots \ldots \ldots \ldots \ldots \ldots \ldots \ldots$

H.6. Summary statistics for different weatherized house data sets $\ldots \ldots \ldots \ldots \ldots 2$

H.7. Distribution of energy related parameters for control houses with $R^{2}>0.7 \ldots \ldots 263$ 
H.8. Distribution of energy related parameters for weatherized houses with $\mathrm{R}^{2}>0.7 \ldots \ldots 264$

I.1. Summary of weights used for energy-use calculations $\ldots \ldots \ldots \ldots \ldots \ldots \ldots \ldots \ldots$

J.1. Combustion steady-state efficiency chart for No. 2 fuel oil . . . . . . . . . . . . 275

J.2. Mean values and standard errors of steady-state efficiencies for different heating system types . . . . . . . . . . . . . . . . . . . . . . . . 276

J.3. Mean values and standard errors of steady-state efficiencies for systems with and

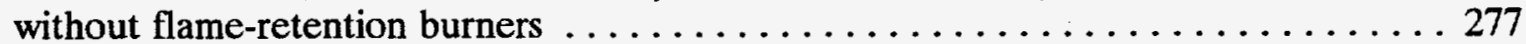

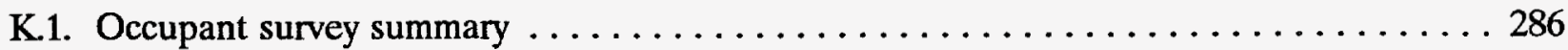




\section{LIST OF APPENDICES}

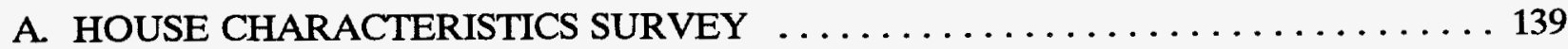

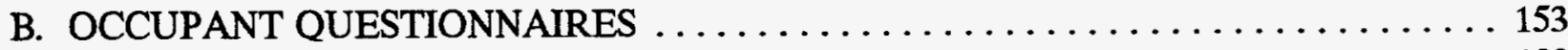

C. WEATHERIZATION INFORMATION SURVEY $\ldots \ldots \ldots \ldots \ldots \ldots \ldots \ldots \ldots \ldots \ldots$

D. AIR-LEAKAGE MEASUREMENT TEST PROCEDURE $\ldots \ldots \ldots \ldots \ldots \ldots \ldots \ldots$

E. STEADY-STATE EFFICIENCY MEASUREMENT PROCEDURE . . . . . . . 221

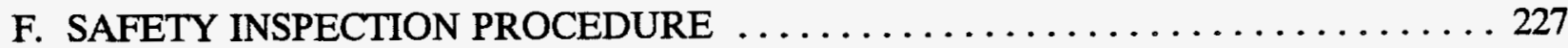

G. TABLES OF OCCUPANT AND HOUSE CHARACTERISTICS $\ldots \ldots \ldots \ldots \ldots \ldots$

H. TABLES OF FUEL-OIL CONSUMPTIONS AND SAVINGS $\ldots \ldots \ldots \ldots \ldots \ldots \ldots \ldots$

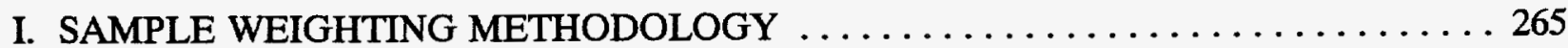

J. TABLES FOR STEADY-STATE EFFICIENCY $\ldots \ldots \ldots \ldots \ldots \ldots \ldots \ldots \ldots \ldots \ldots 273$

K. OCCUPANT RESPONSES TO QUESTIONNAIRES $\ldots \ldots \ldots \ldots \ldots \ldots \ldots \ldots \ldots .279$ 


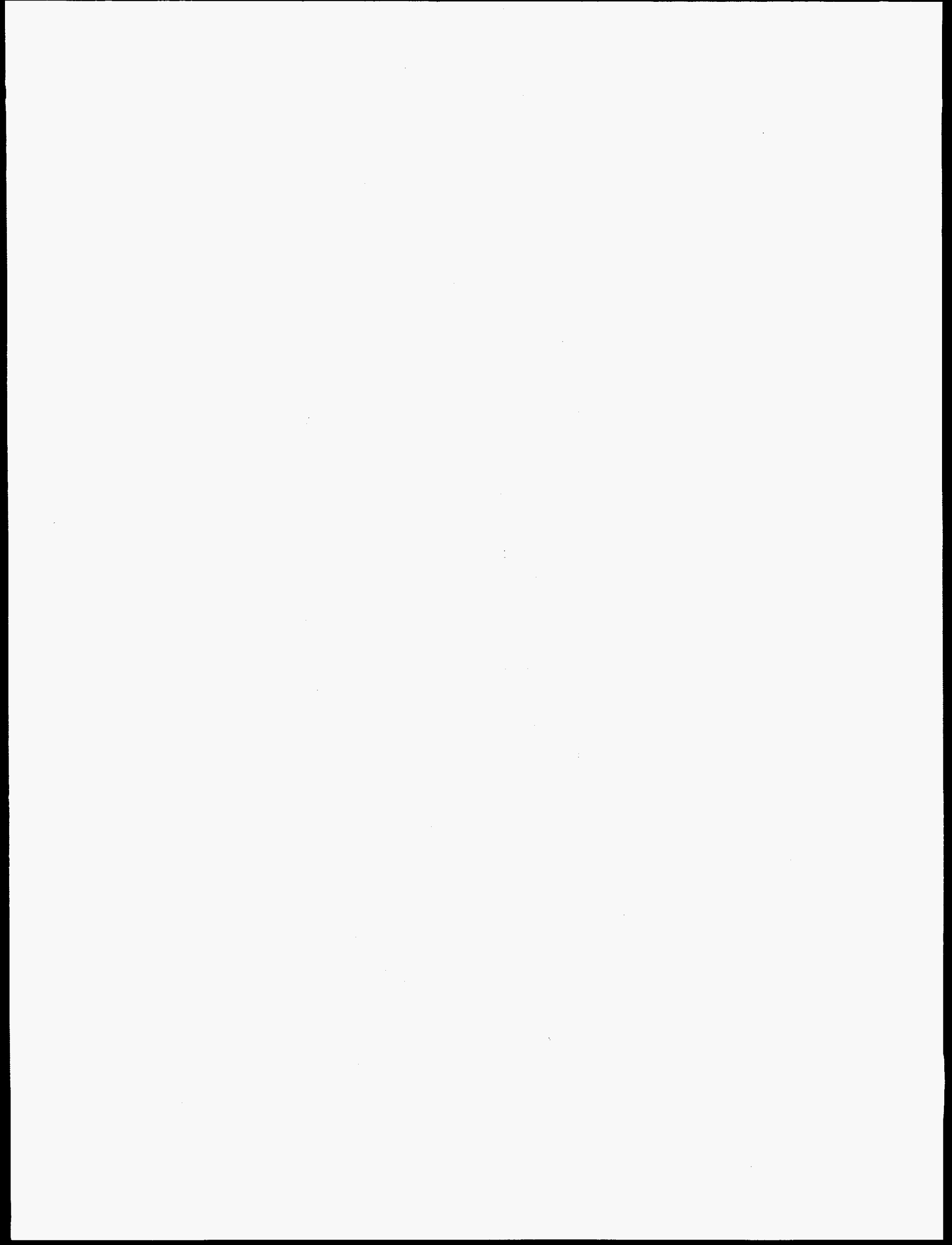




\section{ACKNOWLEDGMENTS}

The authors are grateful for the help and contributions of the following individuals and groups. This study could not have been completed without their assistance. Two working groups, a planning and implementation group and a methodology group, provided valuable input on technical issues and project focus in support of the study.

Jeff Ackermann

Colorado Department of Local

Affairs

Don Barnett

Missouri Department of Natural

Resources

Gary Bennethum

Office of Management and

Budget

Mary Ann Bernald

Edison Electric Institute

\section{Jeff Brown}

North Carolina Department of

Commerce

\section{Dale Canning}

Salt Lake Community Action

Agency

\section{David Carroll}

Response Analysis

Corporation

Mert Dahn

Arizona Department of

Commerce

Margaret Fels

Princeton University Center for Energy and Environmental

Studies

Michael Foley

National Association of

Regulatory Utility Commissioners

Michael Ganley

National Rural Electric

Cooperative Association

Richard Gerardi

New York Department of State

\section{Sharon Gill \\ Department of Energy \\ Chicago Support Office \\ Larry Goldberg \\ Sequoia Technical Services \\ Miriam Goldberg \\ U.S. Department of Energy \\ Judy Gregory \\ Center for Neighborhood \\ Development}

Al Guyant
Public Services Commission of
Wisconsin

Martha Hewett

Center for Energy and the Urban

Environment

Bion Howard

Alliance to Save Energy

Ken Keating

Bonneville Power Administration

Larry Kinney

Synertech Systems Corporation

Lauri Krause

Office of Management and

Budget

Patrick Lana

U.S. Department of Energy

Kansas City Support Office

Judith Lankau

Orange and Rockland Utilities

Leon Litow

Department of Health and

Human Services

Ron Marabate

Michigan Department of Labor
Jane Marden

American Gas Association

John Mitchell

American Gas Association

Barry Moline

American Public Power

Association

John Nelson

Wisconsin Gas Company

Karl Pnazek

CAP Services, Inc.

Meg Power

National Community Action

Foundation

Bill Prindle

Alliance to Save Energy

Ken Rauseo

The Commonwealth of

Massachusetts

Jeff Schlegel

Wisconsin Energy Conservation

Corporation

Theresa Speake

California Office of Economic

Opportunity

Ken Tohinaka

Vermont Energy Investment

Corp.

Wendal Thompson

U.S. Department of Energy

Marjorie Witherspoon

National Association of State

Community Services Program 
Darrell Beschen, the initial U.S. Department of Energy (DOE) Project Manager for this study, provided insightful comments throughout the study, as well as support and guidance. Darrell helped define the overall goals of the study, contributed significantly to the study's overall design, enlisted the cooperation of the states and local weatherization agencies, assisted in the dissemination of information and progress, and provided other management support as needed.

Jean Van Vlandren, Director of the Weatherization Assistance Program, fully supported the project. She provided management oversight and added many edifying comments to the results.

Tommy Wright of the Oak Ridge National Laboratory (ORNL) Engineering Physics and Mathematics Division designed the sample weighting methodology and offered valuable advice on its implementation.

The cooperation of the various State offices administering the Weatherization Assistance Program was essential to the execution and success of this project, as was the cooperation and diligence of the randomly selected local weatherization agencies. The State offices provided comments on the study design and implementation, enlisted the cooperation of the agencies and assisted in their selection, provided program information as needed, and helped manage the study at the state level. The agencies received little compensation for their involvement in the study, yet participated in many facets of the study. The agencies identified a sample of eligible houses; assisted in the installation, maintenance, and removal of instrumentation; provided information on the weatherization measures installed in the study houses; gathered fuel-oil delivery data; administered payments to the households for their assistance in the study; and answered many questions about many subjects throughout the study. The agencies also weatherized the houses following their standard procedures during short two-week time periods in January. The study would not have been possible without support of the local weatherization agencies.

As a subcontractor to ORNL, Synertech Systems Corporation assumed the major role in implementing field related activities, in close cooperation with the local weatherization agencies, State offices, DOE, and ORNL. These activities included installing the supplied instrumentation; solving instrumentation problems that arose; collecting space-heating, indoor temperature, and outdoor temperature data; collecting detailed survey data on the houses and space-heating systems; administering the occupant survey; measuring pre- and post-weatherization air leakages and space-heating system steady-state efficiencies; performing safety inspections of the space- and water-heating systems; and removing instrumentation. Their diligence in performing these tasks was essential, and their dedication to the study is very much appreciated. 


\begin{abstract}
In 1990, the U.S. Department of Energy (DOE) initiated a national evaluation of its lowincome Weatherization Assistance Program. This report, which is one of five parts of that evaluation, evaluates the energy savings and cost-effectiveness of the Program as it had been applied to single-family houses heated primarily by fuel-oil. The study was based upon a representative sample ( 41 local weatherization agencies, 222 weatherized and 115 control houses) from the nine northeastern states during 1991 and 1992 program years.

Dwelling-specific and agency-level data on measures installed, costs, and service delivery procedures were collected from the sampled agencies. Space-heating fuel-oil consumption, indoor temperature, and outdoor temperature were monitored at each house. Dwelling characteristics, air-leakage measurements, space-heating system steady-state efficiency measurements, safety inspections, and occupant questionnaires were also collected or performed at each monitored house.
\end{abstract}

We estimate that the Program weatherized a total of 23,400 single-family fuel-oil heated houses in the nine northeastern states during program years 1991 and 1992. Annual fuel-oil savings were calculated using regression techniques to normalize the savings to standard weather conditions. For the northeast region, annual net fuel-oil savings averaged 160 gallons per house, or $17.7 \%$ of pre-weatherization consumption. Although indoor temperatures changed in individual houses following weatherization, there was no average change and no significant difference as compared to the control houses; thus, there was no overall indoor temperature takeback effect influencing fuel-oil savings.

The weatherization work was performed cost effectively in these houses from the Program perspective, which included both installation costs and overhead and management costs but did not include non-energy benefits (such as employment and environmental). Total average costs were $\$ 1819$ per house ( $\$ 1192$ for installation labor and materials, and $\$ 627$ for overhead and management), and the benefit-to-cost ratio was 1.48 .

A general trend toward higher-than-average fuel-oil savings was observed in houses with high pre-weatherization fuel-oil consumption. Program savings could likely be increased by targeting higher energy consumers for weatherization, although equity issues would have to be considered. Weatherization measures associated with higher-than-average savings were use of a blower door for air-sealing, attic and wall insulation, and replacement space-heating systems. Space-heating system tune-ups were not particularly effective at improving the steady-state efficiency of systems, although other benefits such as improved seasonal efficiency, and system safety and reliability may have resulted. The Program should investigate methods of improving the selection and/or application of space-heating system tune-ups and actively promote improved tune-up procedures that have been developed as a primary technology transfer activity. Houses were more air-tight following weatherization, but still leakier than what is achievable. Additional technology transfer effort is recommended to increase the use of blower doors considering that only half the weatherized houses used a blower door during air sealing. A guidebook developed by a committee of experts and covering a full range of blower-door topics might be a useful technology transfer and training document. Weatherization appeared to make occupants feel better about their house and house environment. 


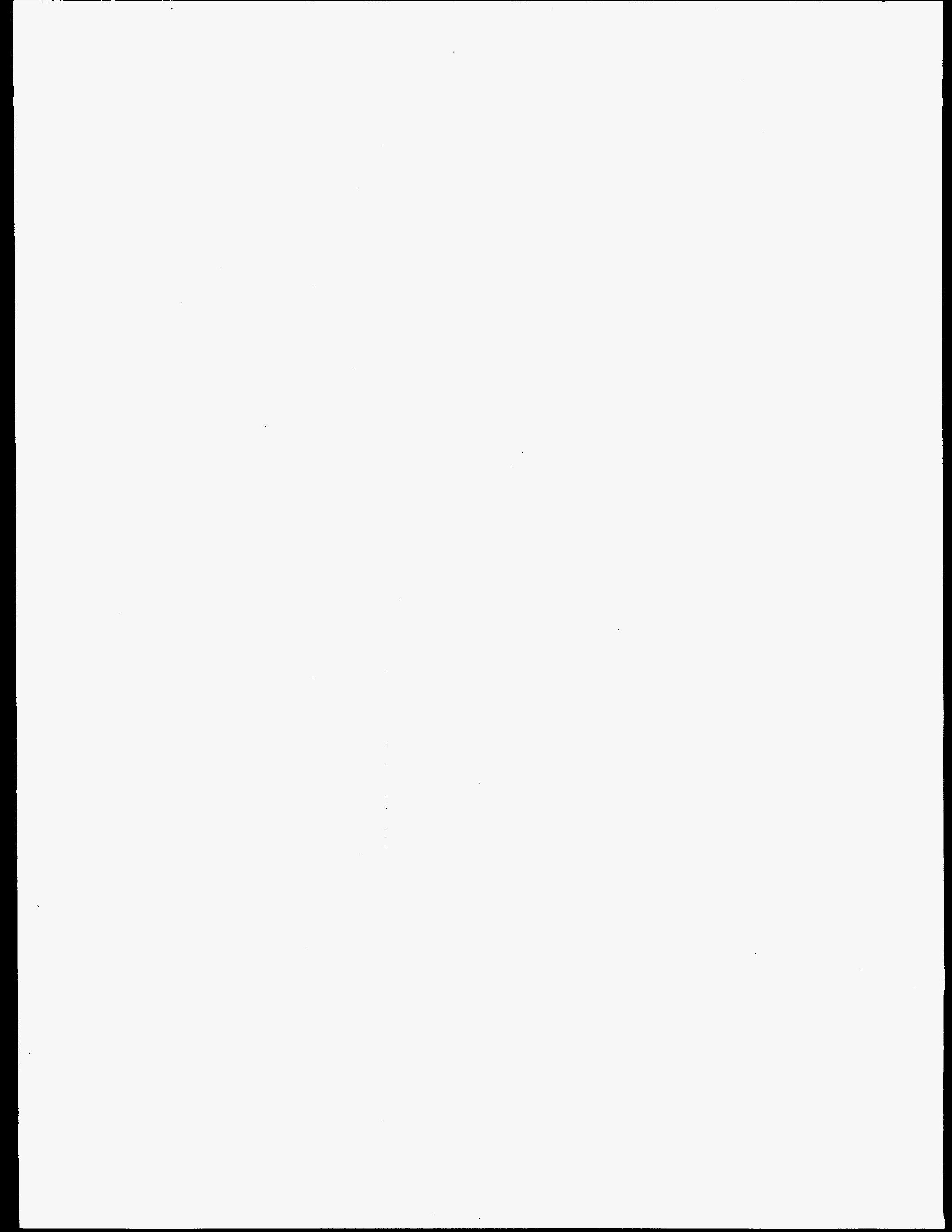




\section{EXECUTIVE SUMMARY}

\section{BACKGROUND AND PURPOSE}

The U.S. Department of Energy (DOE) requested Oak Ridge National Laboratory to help design and conduct an up-to-date assessment of their Weatherization Assistance Program. Five separate studies make up the overall evaluation (Beschen and Brown 1991), which includes a single-family study (Brown et al. 1993, Berry et al. 1991), a high-density multifamily study (MacDonald 1993), and a fuel-oil study. The Fuel-Oil Study is the subject of this report.

The primary goal of the Fuel-Oil Study was to provide a region-wide estimate of the space-heating fuel oil saved by the Program in the Northeast during the 1991 and 1992 program years. Other goals were to identify and quantify non-energy impacts of the Program, to assess the cost effectiveness of the Program within the fuel-oil submarket, and to assess factors which caused fuel-oil savings to vary.

\section{METHODOLOGY}

The Fuel-Oil Study analyzed only single-family houses in the nine states in the Northeast census region and was performed over two heating seasons (1991 and 1992 program years). A total of 337 houses were instrumented to obtain field measurements of space-heating fuel-oil consumption and indoor and outdoor temperatures. A split-winter experimental design containing pre- and post-weatherization periods and including a control group was used (Fig. ES.1). Energy conservation measures were installed in each weatherized house by the local weatherization agency in January of each program year utilizing their usual audit and implementation procedures. Each house was monitored over one heating season.

Of the total 337 houses (222 weatherized houses and 115 control houses) monitored, there were 121 weatherized houses and 70 control houses monitored and distributed among 25 local weatherization agencies over the 1990-1991 heating season. The remaining 101 weatherized houses and 45 control houses were monitored from a different set of 16 agencies over the 19911992 heating season. All houses met a set of requirements concerning household Program 


\begin{tabular}{|c|c||}
\hline Group 1 & 1990-1991 Heating season \\
\hline $\begin{array}{c}\text { Weatherized group } \\
\text { (121 houses) }\end{array}$ & pre W post \\
\hline $\begin{array}{c}\text { Control group } \\
\text { (70 houses) }\end{array}$ & pre \\
\hline
\end{tabular}

\begin{tabular}{||c|c|c||}
\hline Group 2 & 1991-1992 Heating season \\
\hline $\begin{array}{c}\text { Weatherized group } \\
\text { (101 houses) }\end{array}$ & pre W post \\
\hline $\begin{array}{c}\text { Control group } \\
\text { (45 houses) }\end{array}$ & pre \\
\hline
\end{tabular}

Note: $\mathbf{W}=$ Weatherization performed

Fig. ES.1. Split-winter experimental design.

eligibility, single-family construction, and fuel-oil heating systems. At least two agencies were chosen from each state during the 1990-1991 heating season and one from each state during the 1991-1992 heating season to ensure a representative sample. Selection of agencies and test houses was random.

Information about the physical characteristics of each house and its space-heating, spacecooling, and water-heating systems was collected at the end of the post-weatherization period. A comprehensive occupant questionnaire was conducted at the end of the post-weatherization period. The questionnaire provided occupant and house characteristics and occupant perceptions of Program impacts on health, safety, comfort, and heating affordability.

Air-leakage tests were performed in all houses using blower doors before and after weatherization to determine changes caused by the combined weatherization measures. The steady-state efficiency of each space-heating system was measured for both pre- and postweatherization periods. A safety inspection of the space- and domestic water-heating systems was performed at the end of the post-weatherization period in all houses. 


\section{HOUSE AND OCCUPANT CHARACTERISTICS}

The average number of occupants per house was three. The age distribution of the occupants was $13 \%$ preschool, $27 \%$ school age, $42 \%$ adults, and $18 \%$ over 65 . Each family had resided at their present address for 19 years on average. Homeowners accounted for $87 \%$ of our sample, with half of these having no mortgage payments. The average monthly rent paid by the renters was $\$ 333$. The average annual household income was $\$ 10,800$.

Control and weatherized houses were similar in most respects. An average house participating in the field test was 63 years old (it was built in 1928) and had two floors built above a concrete basement. The non-basement floor area of the house was $1332 \mathrm{ft}^{2}$ and the total floor area of the house, including the usually unheated basement, was $1989 \mathrm{ft}^{2}$. An average of 1274 $\mathrm{ft}^{2}$ of the total non-basement floor area, or $96 \%$, was intentionally heated and $13 \%$ of the homeowners reported they heated their basements. The houses were wood-framed, with a wood siding exterior wall area of $1608 \mathrm{ft}^{2}$ and a window area (wooden-framed single-pane with metal storm windows) of $169 \mathrm{ft}^{2}$.

Control houses had less insulation, on average, than weatherized houses. Exterior wall cavity insulation was present in $52 \%$ of the control houses and in $60 \%$ of the weatherized houses after weatherization. Attic insulation was present in $82 \%$ of the control houses and $91 \%$ of the weatherized houses. Floor and foundation insulation were usually not present.

Forced-air furnaces were used in $44 \%$ of the houses, gravity furnaces were used in $2 \%$ of the houses, steam boilers were used in $12 \%$ of the houses, and boilers with hydronic distribution systems were used in $41 \%$ of the houses. The average ages of the heating systems by type were: forced-air furnaces, 14 years; gravity furnaces, 58 years; steam boilers, 26 years; and hydronic boilers, 18 years. Fifty-five percent of the burners were of the flame-retention type. Most of the participants, $(67 \%)$ in the pre-weatherization period and $76 \%$ in the post-weatherization period, said they did not use any type of auxiliary heat.

Stand-alone systems accounted for $61 \%$ of the total domestic water-heating systems, while tankless or integrated systems comprised $39 \%$. Electric stand-alone systems comprised $37 \%$ of the 
total, natural gas stand-alone systems $11 \%$, propane stand-alone systems $8 \%$, and stand-alone fueloil systems $5 \%$. The average estimated hot water temperature was about $130^{\circ} \mathrm{F}$.

\section{INSTALLED MEASURES AND PROCEDURES}

Based on data collected in the study, we estimated that 23,400 single-family houses heated by fuel-oil were weatherized by the local weatherization agencies over the 1991 and 1992 program years in the northeast. Weatherization activity in a house was performed completely by employees of local weatherization agencies in $27 \%$ of the houses, while activity was performed completely by contractor crews in $55 \%$ of the houses. Both in-house and contractor crews performed the work in the remaining houses. Space-heating system measures (predominately tune-ups) were primarily performed by heating contractors ( $78 \%$ ).

An envelope measure selection procedure (usually a priority list) was applied to virtually all of the houses weatherized in the northeast region in 1991 and 1992. Blower doors were used to diagnose air leakage problems in about $75 \%$ of the houses. Diagnostic procedures to examine space-heating systems (primarily steady-state efficiency test and safety inspection) were used in about $80 \%$ of the houses. Carbon monoxide tests were performed in $28 \%$ of the houses and radon tests were never performed.

Insulation measures were installed in $82 \%$ of the houses, with $96 \%$ of the houses receiving air leakage measures (see Fig. ES.2). Measures addressing the domestic water-heating system were installed in $62 \%$, and energy-efficiency improvements to windows and doors were made in only $41 \%$ of the houses. Space-heating system measures were installed in $53 \%$ of the houses. Funding from several sources were used for weatherization. Although most funds were spent following Weatherization Assistance Program rules, funds with fewer restrictions could also have been used.

A visual quality control inspection was performed on almost all houses, while a blower door was used as a post-inspection device in less than half the houses. A space-heating system quality control inspection was performed in all of the houses receiving a space-heating system measure. 


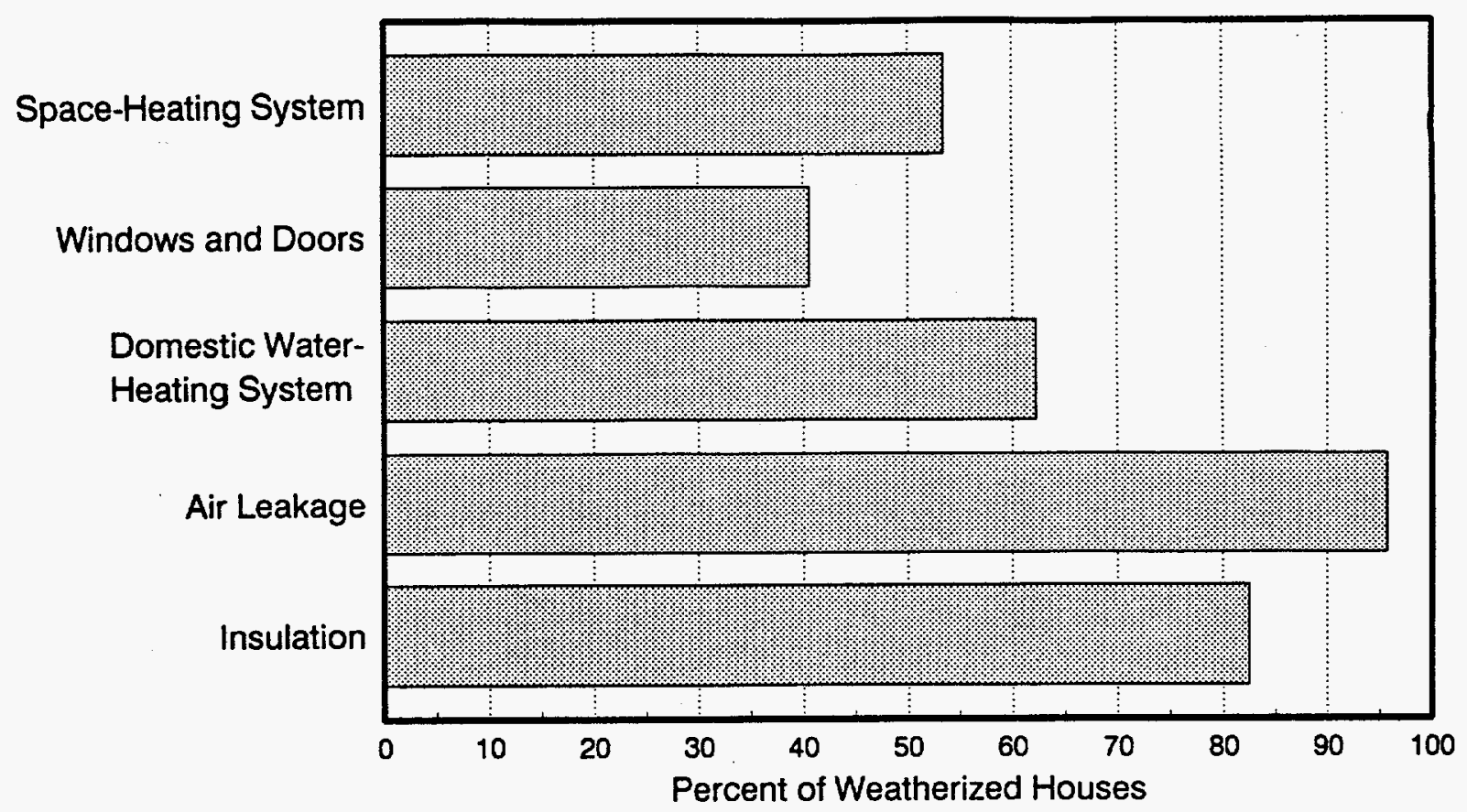

Fig. ES.2. Installation frequency of general types of weatherization measures in fuel-oil heated houses during program years 1991 and 1992 for the northeast region.

Client education was provided to over $95 \%$ of the weatherized households. In-person education was provided to $91 \%$ of the households, and literature was mailed or left with the client about half of the time.

\section{ESTIMATES OF SAVINGS}

Analyses were performed on 298 of the monitored houses (105 control houses and 193 weatherized houses). A useful set of pre- and post-weatherization monitoring data could not be collected from 39 houses because of various problems.

The measured pre- and post-weatherization consumptions could not be directly compared on the same basis because data were collected over different parts of the split-heating season. Therefore, it was necessary to normalize the measured consumptions. A predictive linear regression modeling equation relating consumption to an indoor-outdoor temperature difference was fitted to the daily measured data for each site for pre- and post-weatherization periods. An 
average indoor temperature for each site was determined for the pre-weatherization period and for the post-weatherization period. "Typical Meteorological Year" weather data tapes (based on historical data from the various locations they represent) were used with pre- and postweatherization regression coefficients and average indoor temperatures from each site to estimate normalized annual fuel-oil consumptions. A normalized annual savings for each house was obtained by subtracting the normalized annual post-weatherization consumption from the normalized annual pre-weatherization value.

A weighted ratio-estimator averaging procedure was used to determine average regional weighted values of consumption and savings in the northeast region. Table ES.1 contains a summary of regional (weighted) results for both control and weatherized homes for the combined test years, 1990-1992. The average regional pre-weatherization fuel-oil consumption for the control houses was 918 gallons/year and 905 gallons/year for the weatherized houses ${ }^{1}$. The average regional fuel-oil consumption of the control houses increased to 956 gallons/year, for a gross change of -38 gallons/year (the control houses used 38 gallons/year more in the postweatherization period than the pre-weatherization period) or negative $4.1 \%$ of pre-weatherization consumption. The average regional fuel-oil consumption of the weatherized houses decreased to 783 gallons/year following weatherization, for a gross savings of 122 gallons/year or $13.5 \%$ of preweatherization consumption. Gross savings measured for the weatherized houses were nearly identical for each program year. The regional gross savings for control and weatherized houses were statistically different from zero and from each other at a $0.05 \%$ level of significance.

The best estimate for the regional savings obtained from the Fuel-Oil Study is the net savings of weatherized houses (the gross change of the control houses subtracted from the gross savings of the weatherized houses). The net regional savings was 160 gallons/year, or $17.7 \%$ of pre-weatherization consumption. The dollar value of the net savings was $\$ 162$, assuming a fuel cost of $\$ 1.01 /$ gallon. The $90 \%$ confidence interval for the savings was \pm 31 gallons/year $( \pm 3.4 \%$ of pre-weatherization consumption).

${ }^{1}$ Fuel-oil consumptions can be converted from gallons to Btu by multiplying gallons by 140,000 Btu/gallon, the higher heating value of fuel oil. 
Table ES.1. Regional (weighted) fuel-oil consumptions and savings

\begin{tabular}{|c|c|c|c|c|}
\hline \multirow[b]{2}{*}{ Item } & \multicolumn{2}{|c|}{ Control houses } & \multicolumn{2}{|c|}{ Weatherized houses } \\
\hline & $\begin{array}{c}\text { Weighted } \\
\text { mean value } \\
\text { (gallons) }\end{array}$ & $\begin{array}{c}90 \% \\
\text { confidence } \\
\text { interval }\end{array}$ & $\begin{array}{l}\text { Weighted } \\
\text { mean value } \\
\text { (gallons) }\end{array}$ & $\begin{array}{c}90 \% \\
\text { confidence } \\
\text { interval }\end{array}$ \\
\hline $\begin{array}{l}\text { Annual pre-weatherization } \\
\text { consumption }\end{array}$ & 918 & \pm 64 & 905 & \pm 51 \\
\hline $\begin{array}{l}\text { Annual post-weatherization } \\
\text { consumption }\end{array}$ & 956 & \pm 71 & 783 & \pm 52 \\
\hline Annual gross change & -38 & \pm 24 & 122 & \pm 19 \\
\hline Annual net savings & & & 160 & \pm 31 \\
\hline
\end{tabular}

Note: Fuel-oil consumptions can be converted from gallons to Btu by multiplying gallons by $140,000 \mathrm{Btu} / \mathrm{gallon}$, the higher heating value of fuel oil.

As shown in Fig. ES.3, 65\% of the weatherized houses had measured savings between 0 and 300 gallons/year. Only $4 \%$ of the sample had savings greater than 500 gallons/year and about $17 \%$ had negative savings (with most of these being limited to -100 to 0 gallons/year).

The average regional pre-weatherization indoor temperatures of the control and weatherized houses were nearly the same: $70.3^{\circ} \mathrm{F}$ and $70.5^{\circ} \mathrm{F}$, respectively. The average regional indoor temperature change for the control houses was nearly zero, and only $-0.1^{\circ} \mathrm{F}$ for the weatherized houses. This indicates that, on average, an indoor temperature "takeback" effect did not exist in our sample. ${ }^{2}$

\section{AIR LEAKAGE MEASUREMENTS}

The average sample pre-weatherization air leakage was $3468 \mathrm{cfm} 50$ for the control houses and $3295 \operatorname{cfm} 50$ for the weatherized houses (see Table ES.2). The two groups were statistically the same at a 0.05 level of significance. Houses in the northeast with air leakages between 1000

\footnotetext{
${ }^{2}$ For this study, a "takeback effect" would be an increase in the indoor temperature after weatherization has been completed in order to obtain more comfort by reinvesting some of the weatherization savings back into fuel oil.
} 

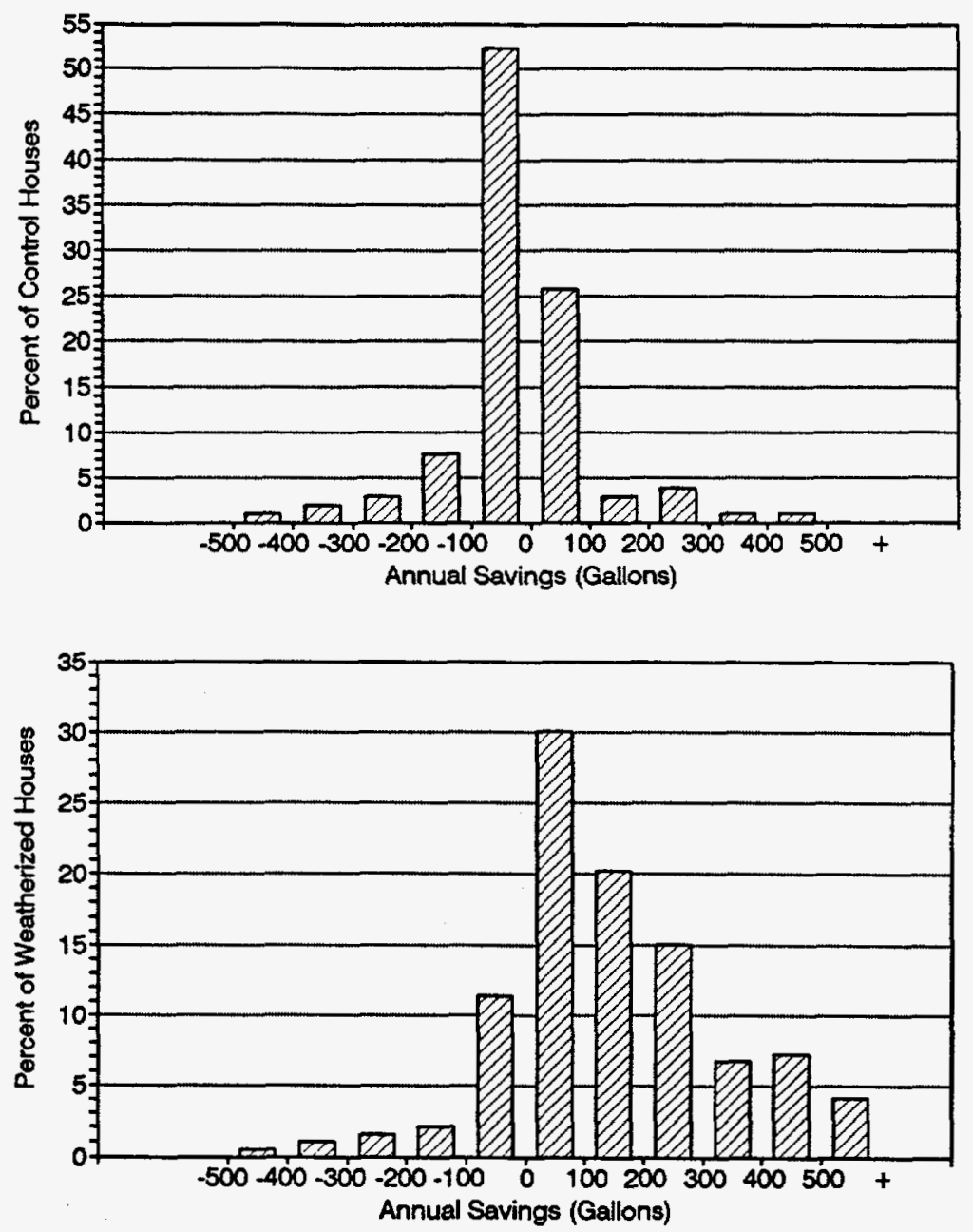

Fig. ES.3. Distribution of fuel-oil savings for the control and weatherized houses. For the control houses, the sample (unweighted) mean was -20 gallons/year and the standard deviation was 117. For the weatherized houses, the sample mean was 143 gallons/year and the standard deviation was 195.

and $1400 \mathrm{cfm} 50$ are generally considered to be tight (Tsongas 1993), requiring no infiltration reduction work.

Weatherization work performed under the study achieved statistically significant reductions in air leakage. The average sample air-leakage reduction was $164 \mathrm{cfm} 50$ for the control houses and $570 \mathrm{cfm} 50$ for the weatherized houses. The control house reduction was not statistically different from zero at a 0.05 level of significance; the weatherized house reduction was statistically different from zero and from the control house reduction at this same confidence level. 
Table ES.2. Control and weatherized house air-leakages

\begin{tabular}{||l|c|c||}
\hline & Control houses & Weatherized houses \\
\hline \hline Number of houses & 54 & 113 \\
\hline Pre-weatherization air leakage (cfm50) & 3468 & 3295 \\
\hline Post-weatherization air leakage (cfm50) & 3304 & 2725 \\
\hline Air-leakage reduction (cfm50) & 164 & 570 \\
\hline
\end{tabular}

On average, air leakage reductions were $240 \mathrm{cfm} 50$ greater in houses in which blower doors were used in sealing work compared to houses not receiving this treatment. Similarly, reductions were $175 \mathrm{cfm} 50$ greater in houses receiving wall insulation, and $300 \mathrm{cfm} 50$ greater in houses receiving high-density wall insulation. Houses with forced-air distribution systems did not have greater air leakage reductions than houses without forced-air distribution systems, despite the fact that air distribution systems are often leaky and contribute to total house leakage. None of these differences were statistically significant at a 0.10 level of significance (use of a blower door and installation of high-density wall insulation would just be significant at a 0.20 level of significance).

\section{HEATING SYSTEM MEASURES}

A clean and tune-up was a measure performed on many heating systems. This service is supposed to increase system efficiency (both steady-state and seasonal) and also assure that a system is functioning reliably and safely. A sample group was selected containing all houses which did not receive a new heating system or a new burner, and had valid steady-state efficiency (SSE) data for both pre- and post-weatherization periods. A total of 208 houses were in the sample: 72 control houses and 136 weatherized houses. None of the control houses received a clean and tune, while 71 of the 136 weatherized houses received a clean and tune-up.

The weatherized houses receiving a clean and tune-up were originally less efficient and more in need of a tune-up than weatherized houses not receiving this services (see Table ES.3). The control houses, which received no clean and tune-up services, showed the greatest SSE increase of all three groups. 
Table ES.3. Mean values of measured space-heating system performance parameters

\begin{tabular}{|c|c|c|c|c|}
\hline \multirow{2}{*}{$\begin{array}{c}\text { Type } \\
\text { of } \\
\text { house }\end{array}$} & \multirow{2}{*}{$\begin{array}{c}\text { Number } \\
\text { in } \\
\text { sample }\end{array}$} & \multicolumn{3}{|c|}{ Adjusted steady-state efficiency ${ }^{1}$} \\
\hline & & $\begin{array}{c}\text { Pre- } \\
\text { weatherization }\end{array}$ & $\begin{array}{c}\text { Post- } \\
\text { weatherization }\end{array}$ & Difference \\
\hline WEATHERIZED & 136 & & & \\
\hline No clean and tune-up & 65 & 77.2 & 77.7 & 0.5 \\
\hline Clean and tune-up & 71 & 75.0 & 75.8 & 0.8 \\
\hline CONTROL & 72 & & & \\
\hline No clean \& tune-up & 72 & 75.0 & 76.6 & 1.5 \\
\hline
\end{tabular}

${ }^{1}$ Steady-state efficiencies were adjusted for smoke numbers.

Figure ES.4 offers more insight into the effectiveness of clean and tune-up services. It shows a general trend (the $R^{2}$ value was low at about 0.2 ) for measured changes in SSE to be greater for sites with low SSEs at the beginning of a heating season. The change in SSE was usually negligible or negative if the pre-weatherization SSE was greater than about $77 \%$. A 3 percentage point improvement was obtained at sites with a pre-weatherization SSE of $70 \%$. Unfortunately, the same trend was observed for control houses and weatherized houses not receiving a clean and tune-up. Ternes et al. (1991) found the same type of behavior in a study dealing with gas space-heating systems in New York state.

The results for the weatherized houses receiving a clean and tune-up, interpreted by themselves, indicate that clean and tune-ups should be performed only when pre-weatherization efficiencies are less than $70 \%$; clean and tune-ups consistently increased steady-state efficiencies only when pre-weatherization efficiencies were less than $70 \%$. The scattered results and low average increases in SSE obtained from clean and tune-ups performed at houses with higher preweatherization efficiencies suggest that clean and tune-ups are not long lasting (our SSE measurements were made at the end of the heating season), clean and tunes are not done properly, or systems in these houses are already operating at their maximum efficiency. The results from the control houses and weatherized houses not receiving a clean and tune-up indicate that clean and tune-ups were not the cause for efficiency increases, suggesting that clean and tune-ups should not be performed with expectations of improved SSEs. 


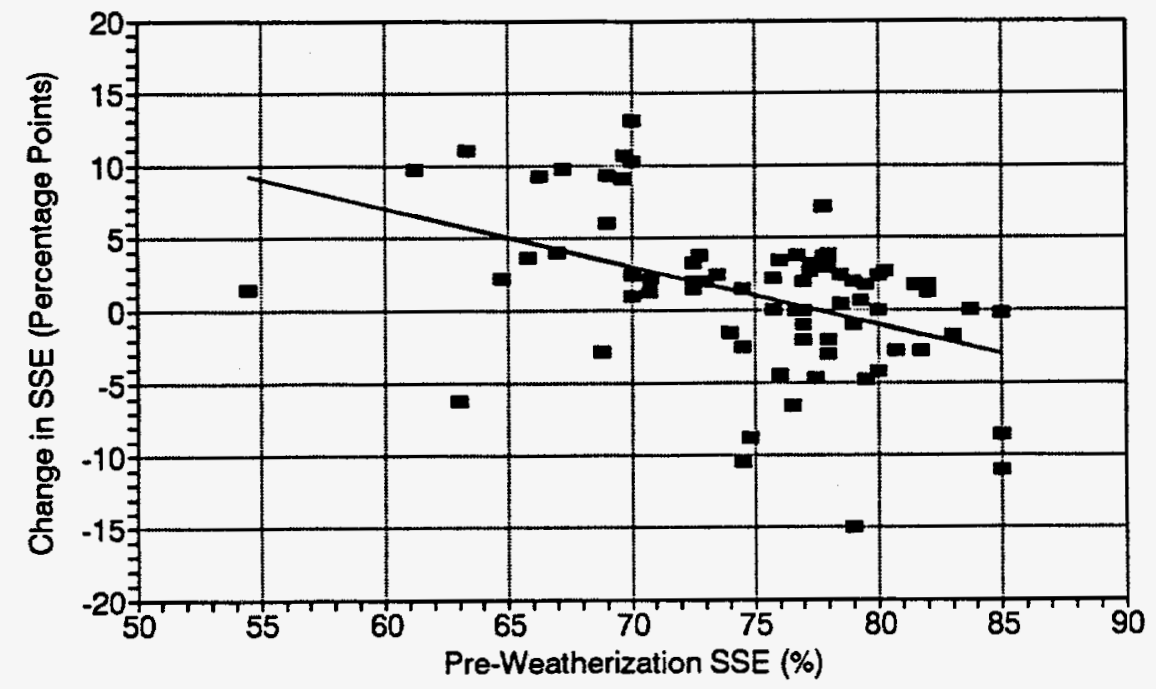

Fig. ES.4. Comparison of the change in adjusted steady-state efficiency to the preweatherization efficiency for the weatherized houses receiving a clean and tune.

A visual and instrumented inspection of each heating system was conducted at the conclusion of each heating season. Overall, the systems were relatively safe. Visual inspections showed little difference overall in safety between control and weatherized houses, although the severity of problems can differ between groups. Combustible material near the flue, distribution system structural problems, no return air system present, and presence of a barometric damper were the main areas where weatherized and control houses differed. All differences favored weatherized houses, indicating that the weatherized houses were safer.

The safety inspection included checking the settings of fan operating (high and low limit) and cutout (maximum operating temperature limit) switches. All forced-air heating systems in both groups had fan operating and cutout switches present. Average switch settings for control and weatherized forced-air heating systems were essentially the same. Fan-on (upper-limit) switches for control and weatherized houses both averaged $137^{\circ} \mathrm{F}$, while fan-off (lower-limit) switches averaged $99^{\circ} \mathrm{F}$ for control houses and $100^{\circ} \mathrm{F}$ for weatherized houses. Cutout switch settings averaged $197^{\circ} \mathrm{F}$ for control houses and $196^{\circ} \mathrm{F}$ for weatherized houses. Two control 
houses $(7 \%)$ and two weatherized houses $(2 \%)$ were noted as having potentially dangerous fan-on settings of $190^{\circ} \mathrm{F}$ to $200^{\circ} \mathrm{F}$. The average operating temperatures for hydronic boilers was $164^{\circ} \mathrm{F}$ for both control and weatherized houses. Cutoff temperatures averaged about $190^{\circ} \mathrm{F}$. Two (4\%) hydronic boilers in control houses had operating temperatures of $200^{\circ} \mathrm{F}$, while three $(4 \%)$ boilers in weatherized houses were operating above $195^{\circ} \mathrm{F}$. These five systems were operating at toohigh a temperature for maximum efficiency and safety.

The average time for all heating systems to establish a draft was about 9 seconds. However, two control houses and one weatherized house took over 60 seconds to establish a draft, with one of each type requiring 180 seconds.

Measurements were made of carbon monoxide $5 \mathrm{ft}$ from furnaces, in living rooms, in kitchens, and from hot-air registers. No houses had an appreciable carbon monoxide problem (carbon monoxide level $\geq 10 \mathrm{ppm}$ ) at the end of the heating season. Differences between control and weatherized houses were minor.

\section{OCCUPANT FEEDBACK}

The average indoor temperature levels reported by the occupants when a house was occupied was $69^{\circ} \mathrm{F}$. Measured temperatures were about a degree or so higher than perceived temperatures. Fifty-three percent of weatherized-house respondents said they regularly changed the temperature in their house during the day in the pre-weatherization period, and $51 \%$ said they changed it during the post-weatherization period. Control house responses were similar: $56 \%$ said the temperature was changed during the day in the pre-weatherization period, and $55 \%$ said the temperature was changed in the post-weatherization period. Setbacks of temperatures reported by the occupants when a house was unoccupied or when the occupants were sleeping averaged about $5^{\circ} \mathrm{F}$.

About $16 \%$ of control and weatherized households had inoperative space-heating systems sometime during the pre-weatherization period such that heat could not be provided. About $13 \%$ of the households did not have any fuel oil at some time during the pre-weatherization period. Mechanical problems decreased during the post-weatherization period (12\% of control and 
weatherized households had problems), while running out of fuel oil decreased to $11 \%$ for weatherized houses and $8 \%$ for control houses. A utility stopped service because of failure to pay bills in about $5 \%$ of all houses during each period.

Occupants were asked to rate various indoor conditions and heating affordability on a scale of 1 to 7 , where 1 was poor and 7 was very good. Control house responses did not change significantly from pre- to post-weatherization periods, whereas weatherized house perceptions all improved after weatherization (see Fig. ES.5). Control house responses were higher than weatherized responses in the pre-weatherization period, which could illustrate some bias to the weatherized group responses - they were thankful for the weatherization work and wanted to make us feel good. Nevertheless, weatherized house responses were higher than control house responses in the post-weatherization period, indicating improved satisfaction from weatherization. The areas of health and safety were the only areas both groups thought were acceptable before weatherization. Most people thought their homes were expensive to heat in the preweatherization period; occupants of weatherized houses felt that costs were much more reasonable after weatherization. Comfort, and especially draftiness, were also improved after weatherization according to weatherized home responses.

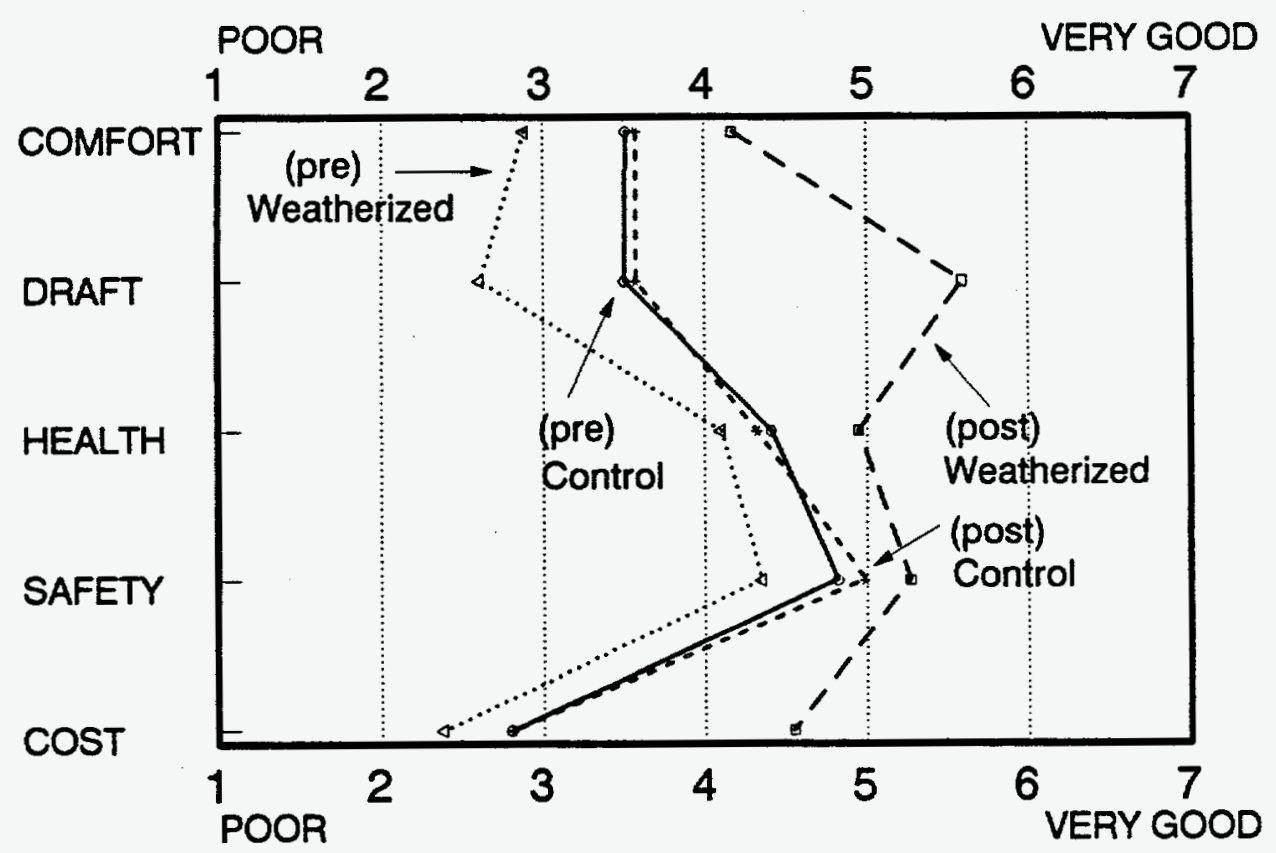

Fig. ES.5. Average rating provided by the occupants on indoor conditions and heating affordability before and after weatherization. A scale of 1 to 7 was used, where 1 was poor and 7 was very good. 


\section{PROGRAM COSTS}

Total program costs were divided into installation costs and overhead and management costs. Installation costs included the actual costs for (1) materials installed in the houses and (2) labor required to install the materials and perform other energy-efficiency-improvement work on the house. Overhead and management costs include all other costs associated with providing the weatherization services. These expenses were divided into installation-related overhead and program management categories. Installation-related overhead expenses for contractors were estimated to be $15 \%$ of total billed cost. Installation labor costs for contractors were then calculated by subtracting material and overhead costs from the total billed cost. State expenditures for implementation of the Program were not included in the overhead and management costs presented in this section.

The regionwide average value for installation costs was $\$ 1192$ for program years 1991 and 1992 combined. Material costs for these years were $\$ 745$ for an average house weatherized, and labor costs were $\$ 447$. Installation costs and their breakdown into material and labor costs were consistent for each program year. Installation costs for an individual house differed substantially from the average value of $\$ 1192$, but was between $\$ 600$ and $\$ 1500$ in $58 \%$ of the houses. The minimum expenditure was $\$ 15$ and the maximum was $\$ 4383$.

Contractor expenditures accounted for $63 \%$ of the average installation costs. As previously stated, $27 \%$ of the houses had work performed completely by in-house crews only, 55\% completely by contractors only, with the remaining done by a mixture of both. In houses in which both crew types were involved, about $75 \%$ of the expenditures were by the in-house crew. Higher costs associated with contractors were likely due to differences in the measures performed by contractors, and do not imply that they were inherently more expensive than in-house crews.

Figure ES.6 shows a cost breakdown of materials for an average weatherized house. Insulation materials accounted for a third of the total material expenditure. Material costs for air leakage, window and door, and space-heating system measures were approximately equal (12\% $18 \%$ ). Expenditures on domestic water-heating system materials were rather small, being only $2 \%$ of the total material costs. 


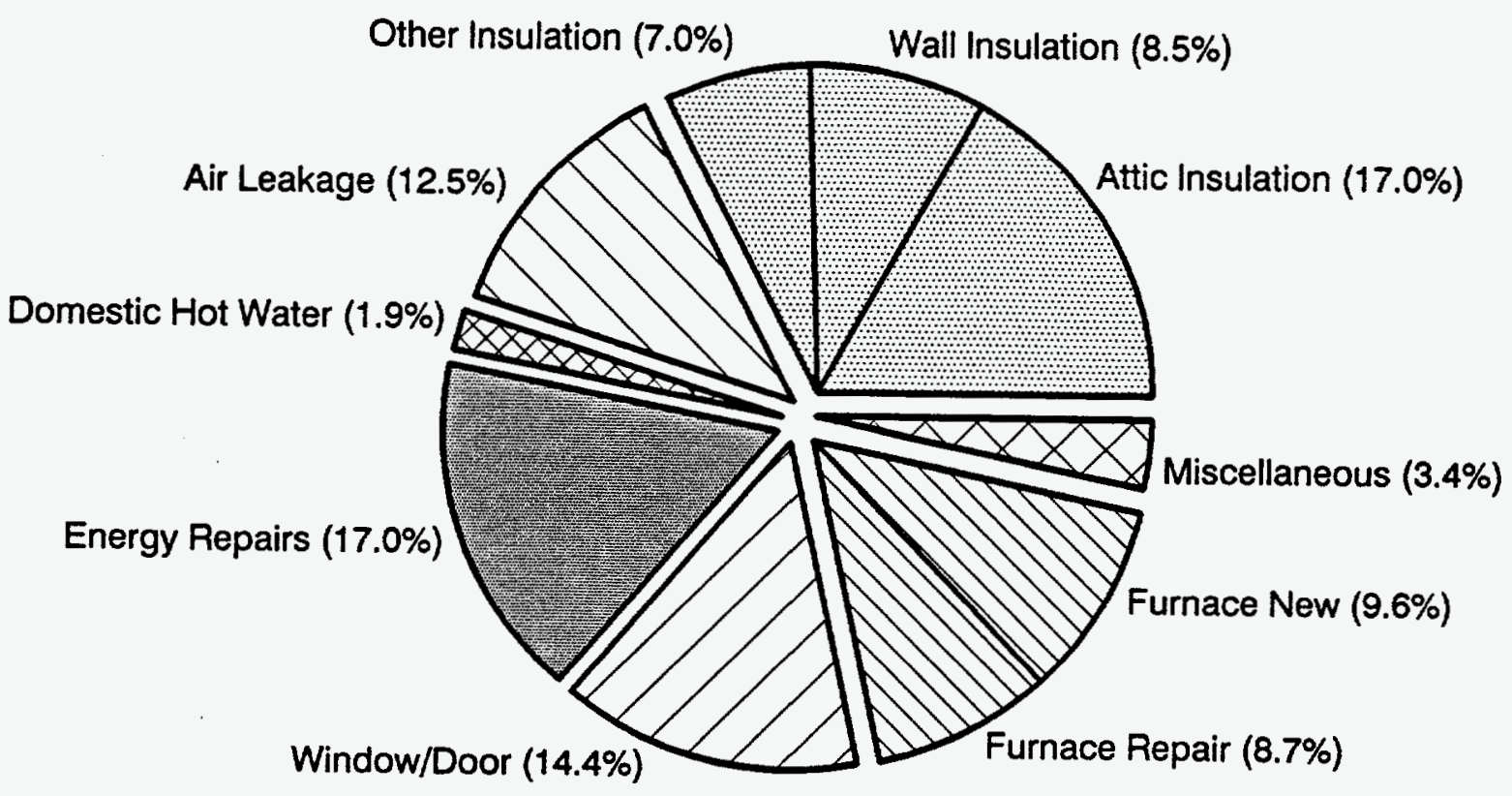

Fig. ES.6. Material cost breakdown for an average weatherized house (total cost was \$745/house).

We estimated an average overhead and management cost of $\$ 627$ per house to weatherize a single-family fuel-oil heated house in the northeast region. This cost included $\$ 438$ for program management, $\$ 59$ for in-house crew installation-related overhead, and $\$ 130$ for contractor installation-related overhead.

Local weatherization agencies rely on a number of different funding sources to perform weatherizations, including the DOE Weatherization Assistance Program, Petroleum Violation Escrow (PVE) funds, the Low-Income Heating Energy Assistance Program operated by the Department of Health and Human Services, and various foundation, state, and utility programs. For single-family fuel-oil heated houses weatherized in the northeast region, $73 \%$ of the installation costs were provided by the Weatherization Assistance Program and PVE.

Average per house installation expenditures increased as the percent of total house costs covered by the Weatherization Assistance Program funds decreased. Average costs were \$1114 in houses receiving just Weatherization Assistance Program funds, $\$ 1227$ in houses where 
Weatherization Assistance Program funds covered 50\% or more of the total house expenditure, and $\$ 1417$ in houses where Weatherization Assistance Program funds covered less than 50\% of total house expenditures. This result was consistent with expectations because funding sources other than Weatherization Assistance Program funds were often used to install measures that were not allowed under Program guidelines (such as space-heating system replacements).

\section{COST EFFECTIVENESS}

The cost effectiveness of weatherization measures was estimated using benefit-to-cost ratio. This indicator compares the discounted lifetime benefits obtained from the Program to the costs of achieving them. A program is cost-effective whenever the benefit-to-cost ratio is greater than or equal to unity.

Measured input values used to calculate benefit-to cost-ratios were a regional net average fuel-oil savings of 160 gallons/year, an average regional installation cost of $\$ 1192$, and an average overhead and management cost of $\$ 627$. Fuel-oil savings were converted to regional dollar value estimates using a fuel-oil cost of $\$ 1.01 /$ gallon (the average regional fuel-oil cost in the northeast during the study). A "real" discount rate of $4.7 \%$ and a fuel escalation rate were used in the calculation of benefit-to-cost ratio as recommended by the Department of Commerce for the year 1991 (Lippiat and Ruegg 1990).

Benefit-to-cost ratios were calculated from three perspectives. An installation perspective is defined to consider only energy savings benefits and on-site installation costs. This perspective is the most narrowly defined. It provides insight into how well the measures performed based on their primary function (i.e., to save energy) without considering the indirect costs required to operate a program. A program perspective is defined to consider energy savings benefits and the total costs required for weatherization (installation costs combined with overhead and management costs). The program perspective is the most conservative estimate of program cost effectiveness. A societal perspective was developed to consider the broadest definitions of benefits and costs: benefits include energy and nonenergy benefits, and costs include installation, overhead, and management expenses.

xxxii 
Table ES.4. Cost-effectiveness estimates

\begin{tabular}{|c|c|c|c|}
\hline \multirow{2}{*}{$\begin{array}{c}\text { Measure } \\
\text { life } \\
\text { (years) }\end{array}$} & \multicolumn{3}{|c|}{ Benefit-to-cost ratio } \\
\cline { 2 - 4 } & Installation perspective & Program perspective & Societal perspective \\
\hline 10 & 1.25 & 0.82 & 1.35 \\
\hline 15 & 1.79 & 1.17 & 1.71 \\
\hline 20 & 2.26 & 1.48 & 2.01 \\
\hline 25 & 2.65 & 1.74 & 2.27 \\
\hline
\end{tabular}

Nonenergy (or societal) benefits can result from the weatherization activity performed under the Program. A quantitative value for these nonenergy benefits is not as simple to estimate as are the energy savings and costs associated with weatherization. Nonenergy benefits can be grouped into five major categories:

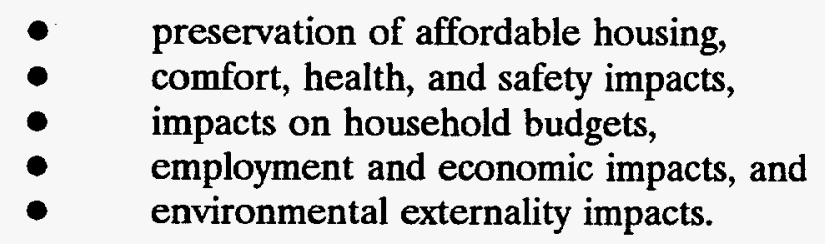

Brown et al. (1993) extensively examined nonenergy impacts of low-income weatherization and concluded that the average net present dollar value of nonenergy impacts for the Program in 1989 was $\$ 976$ per weatherized house. This value was used for the societal perspective.

Table ES.4 summarizes the results of the benefit-to-cost ratio calculations performed. These results are plotted in Fig. ES.7. The program is cost effective from all three perspectives under the conditions analyzed except for the program perspective assuming a 10-year lifetime for the measures. The Program is cost effective from the societal and installation perspectives assuming measure lifetimes as low as six and eight years, respectively. The Program is cost effective from a program perspective when measure lifetimes exceed 12.5 years. 


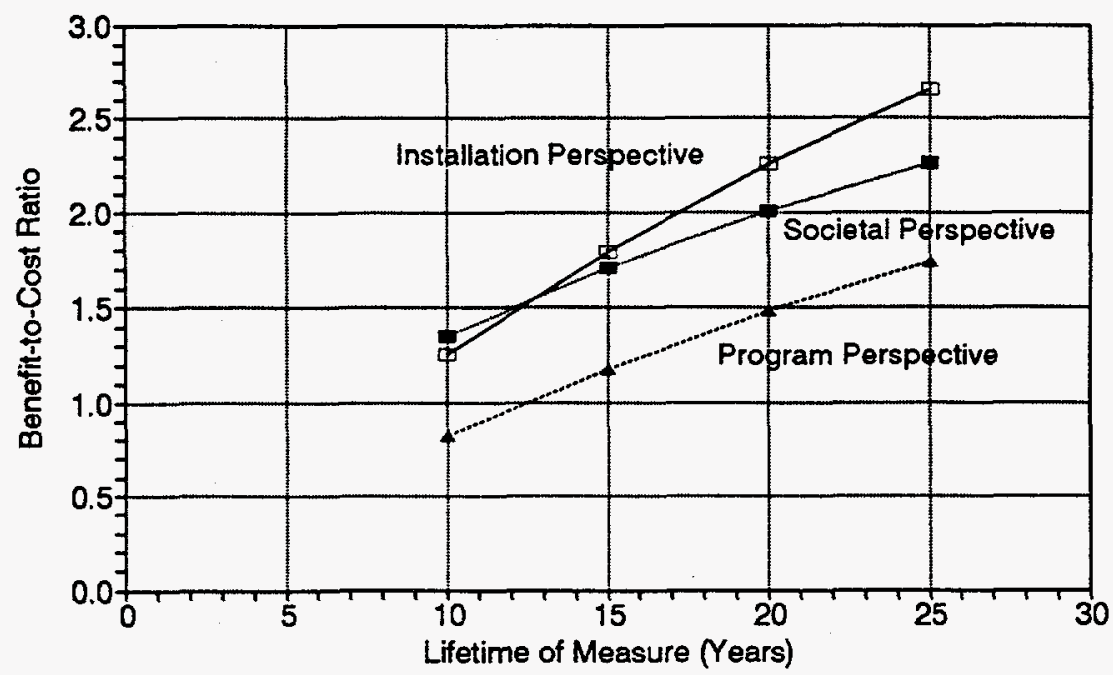

Fig. ES.7. Comparison of benefit-to-cost ratios to measure lifetimes.

Estimated lifetimes for the various weatherization measures installed in the study houses range from 1 to 5 years for caulking to 30 plus years for insulation, with 20 years being a fair average for all measures combined (Brown et al. 1993). A 20-year estimated life results in a benefit-to-cost ratio of 2.26 from an installation perspective, 2.01 from a societal perspective, and 1.48 from a program perspective. All three estimates show that the Weatherization Assistance Program is indeed cost effective for fuel-oil heated houses in the northeast.

\section{FACTORS ASSOCIATED WITH SAVINGS}

An analysis conducted to determine which measures provided the most savings in this study was difficult. Sample houses were randomly chosen to determine energy savings rather than to determine what caused the savings. A sample aimed at differentiating savings among measures would have contained houses receiving individual measures and selected combinations of measures. For example, almost all houses in our sample received standard caulking and weatherstripping, making it impossible to study this measure. Also, the sample size was too small 
and not sufficiently randomly distributed to study the large number of combinations of measures installed, house characteristics, procedures, etc. Another item to note is that inspections were conducted on the test houses after weatherization had been accomplished and not before. Thus, detailed information is available on conditions existing in a house after weatherization was done, but not before weatherization.

This study showed a definite trend for savings to be greater in houses with high preweatherization consumption and high pre-weatherization consumption per unit floor area. On average, households in this study with a pre-weatherization fuel-oil usage of 1 gallon/square foot/year achieved a savings of $20 \%$.

The cost to weatherize a house was found to be associated with the savings obtained by that house. The houses on which more than $\$ 1200$ was spent for installation (labor and materials) saved more than twice as much fuel-oil as houses that had less than $\$ 1200$ spent on them. The houses receiving the higher expenditures also used more fuel-oil in the preweatherization period. This suggests that the money spent to weatherize houses was, on average, spent properly because the most needy houses (the largest consumers) received more than the more efficient houses.

The effect of four occupant and dwelling characteristics on the savings obtained from weatherization were investigated: ownership, occupancy by an elderly or handicapped person, and number of stories in the house. All four factors were not associated with higher-than-average savings.

Average measured savings in houses receiving a particular measure during weatherization were compared to the remaining houses to determine the savings associated with the particular measure (see Table ES.5). It is not possible to precisely estimate how much energy is saved by a single measure based on this analysis approach because the savings are for the house with the specific measure in question plus all other measures that may have been installed in the house. The particular measure being examined may not be the cause of a significant difference in energy savings because extensive correlation existed among the variables. 
Table ES.5. House-level energy savings associated with selected measures

\begin{tabular}{|c|c|c|c|c|}
\hline $\begin{array}{l}\text { Houses receiving measures } \\
\text { including: }\end{array}$ & $\begin{array}{l}\text { Annual pre- } \\
\text { weatherization } \\
\text { consumption } \\
\text { (gallons) }\end{array}$ & $\begin{array}{l}\text { Annual } \\
\text { savings } \\
\text { (gallons) }\end{array}$ & $\begin{array}{c}\text { Number } \\
\text { of } \\
\text { dwellings }\end{array}$ & $\begin{array}{c}\text { Significance } \\
\text { level }\end{array}$ \\
\hline All Houses & 930 & 162 & 149 & \\
\hline \multicolumn{5}{|l|}{ Air Leakage } \\
\hline General caulking & 936 & 168 & 136 & -- \\
\hline Air sealing without a blower door & 919 & 162 & 77 & --- \\
\hline Air sealing with a blower door & 1041 & 193 & 40 & $*$ \\
\hline Distribution system & 952 & 206 & 26 & --- \\
\hline Other & 924 & 195 & 31 & --- \\
\hline \multicolumn{5}{|l|}{ Insulation } \\
\hline Attic insulation, first time & 1032 & 237 & 54 & * \\
\hline Attic insulation, added & 829 & 165 & 55 & --- \\
\hline Wall insulation, standard & 970 & 223 & 42 & $*$ \\
\hline Wall insulation, high-density & 965 & 313 & 16 & $*$ \\
\hline Rim or band joist insulation & 1012 & 171 & 32 & --- \\
\hline Floor insulation & 970 & 194 & 58 & --- \\
\hline Other & 986 & 193 & 33 & --- \\
\hline \multicolumn{5}{|l|}{ Windows and Doors } \\
\hline Storm window(s) & 951 & 154 & 46 & -- \\
\hline Storm door(s) & 784 & 30 & 7 & * \\
\hline Window films of shades & - & -- & 0 & -- \\
\hline Other & 795 & 71 & 6 & $\cdots$ \\
\hline \multicolumn{5}{|l|}{ Space-Heating System } \\
\hline Clean and tune-up & 998 & 191 & 63 & --- \\
\hline New system & 1031 & 305 & 5 & * \\
\hline Set-back thermostat & 972 & 190 & 9 & -- \\
\hline Component retrofit & 996 & 163 & 9 & -- \\
\hline
\end{tabular}

* means that differences in savings are different from zero at the 0.05 level of significance.

-.- means that differences in savings are not significantly different from zero. 
Table ES.5. House-level energy savings associated with selected measures (continued)

\begin{tabular}{|c|c|c|c|c|}
\hline $\begin{array}{l}\text { Houses receiving measures } \\
\text { including: }\end{array}$ & $\begin{array}{l}\text { Annual pre- } \\
\text { weatherization } \\
\text { consumption } \\
\text { (gallons/year) }\end{array}$ & $\begin{array}{l}\text { Annual } \\
\text { savings } \\
\text { (gallons) }\end{array}$ & $\begin{array}{c}\text { Number } \\
\text { of } \\
\text { dwellings }\end{array}$ & $\begin{array}{c}\text { Significance } \\
\text { level }\end{array}$ \\
\hline \multicolumn{5}{|l|}{ Water Heating Measures } \\
\hline Tank insulation & 843 & 171 & 43 & -- \\
\hline New system & 953 & 456 & 1 & -- \\
\hline Pipe insulation & 914 & 166 & 80 & --- \\
\hline Temperature reduction & 1019 & 219 & 22 & -- \\
\hline Low-flow showerhead & 923 & 214 & 15 & --- \\
\hline Other & 982 & 160 & 18 & -- \\
\hline \multicolumn{5}{|l|}{ Structural Measures } \\
\hline Attic ventilation & 938 & 203 & 71 & $*$ \\
\hline Roof & 743 & 125 & 5 & --- \\
\hline Doors & 959 & 190 & 34 & $\cdots$ \\
\hline Doors replacement & 968 & 222 & 24 & -- \\
\hline Windows glazing & 933 & 177 & 89 & -- \\
\hline Window replacement & 1014 & 126 & 26 & -- \\
\hline Walls & 997 & 185 & 9 & -- \\
\hline Floor & 755 & 157 & 2 & -- \\
\hline Other & 838 & 168 & 53 & -- \\
\hline
\end{tabular}

* means that differences in savings are different from zero at the 0.05 level or greater.

--- means that differences in savings are not significantly different from zero.

Using a blower door for sealing was the only air-leakage control measure that showed statistically significant ( 0.05 level of significance) higher-than-average savings. Houses receiving this treatment also appeared to have higher-than-average pre-weatherization consumptions. No statistically significant differences existed between houses receiving general caulking, distribution system work, or other infiltration reduction techniques and houses not receiving these measures. 
Houses in which new attic insulation, normal wall insulation, and high-density wall insulation were added had statistically significant, higher-than-average savings. Houses receiving new attic insulation had pre-weatherization consumptions greater than average, while houses receiving wall insulation were about average. Pre-weatherization consumptions of houses receiving and not receiving wall insulation may not have been as different as one would expect because some houses needing wall insulation still did not receive this measure.

Houses receiving the addition of storm doors had statistically significant, lower-thanaverage savings (30 gallons/year). This does not imply that storm doors increase fuel-oil consumption. The pre-weatherization consumption of houses receiving a storm door were much lower than average, indicating that the houses were already relatively efficient. Storm doors may have been installed in these houses because other, more effective measures were already in place. There were only seven houses receiving storm doors, so the results may possibly be viewed as being inconclusive because of the small sample size. Savings for houses receiving all other window and door measures such as adding storm windows were not statistically different from houses not receiving these measures.

The only space-heating and water-heating system measure associated with statistically significant higher-than-average savings was replacement of the entire heating system. Houses receiving this measure saved 305 gallons/year, or about twice the average of all houses. A small sample size of five units may add some uncertainty to this result. This measure was expensive, typically costing about $\$ 2000$ to $\$ 2500$ to complete. Houses receiving a new system had higher pre-weatherization consumptions than average; in fact, houses receiving any space-heating system measure generally had higher-than-average pre-weatherization consumptions.

Attic ventilation was the only structural measure (i.e., those measures which are either energy related, such as replacing broken window glass, or are necessary in order to enable other energy-related repairs to be accomplished) associated with statistically significant, higher-thanaverage savings. Obviously, attic ventilation by itself cannot bring about such savings, so it must be correlated with some other variable like attic insulation. Discussions with weatherization agency employees confirmed that an attic was often not vented if it did not have any insulation in 
it. A check of 54 houses receiving new attic insulation showed that $80 \%$ of them also received attic ventilation. Chi-square tests verified this correlation.

None of the measure selection approaches or diagnostic procedures were associated with statistically significant above-average savings. The use of heating system performance data to select space-heating system measures and the use of a blower door to measure leakage rates were significant at a 0.10 level of significance, however.

Houses receiving a visual inspection of space-heating systems had a statistically significant, above-average savings of 200 gallons/year. However, the savings improvement observed could be due to the fact that space-heating system work was performed (and thus inspected). Almost all houses (95\%) receiving a space-heating system measure also received a visual inspection.

None of the client education measures were associated with statistically significant, aboveaverage savings, perhaps because almost all houses (94\%) received in-person education.

In order to examine why differences occurred between those houses which saved the most energy and those which saved the least, two groups were formed which contained the top and bottom 12\%. As shown in Table ES.6, the high savers averaged 498 gallons/year of fuel oil saved (37\%) while the low savers saved -44 gallons/year $(-6 \%)$. The low savers used considerably less fuel in the pre-weatherization period than the high savers (873 vs 1392 gallons/year, respectively) even though both groups were identical in heated area. After weatherization, however, the high savers used about the same amount of fuel as the low savers ( 894 vs 917 gallons/year, respectively). The high savers were weatherized cost effectively with an average of $\$ 1604$ being spent on each for labor and materials. The low savers were not weatherized cost effectively, even though an average of $\$ 892$ was spent on each. The high savers benefitted more from air leakage measures than the low savers, but both ended up at about the same level of tightness. The low savers had more efficient heating systems and higher indoor temperatures than the high savers. These facts suggest the high savers were houses that really needed weatherization, while the low savers were houses that were relatively more energy efficient. The annual consumption of the low savers averaged $0.67 \mathrm{gal} / \mathrm{ft}^{2} /$ year, which also was the post-weatherization consumption of the high savers. 
Table ES.6. Mean values of measured variables

\begin{tabular}{||l|c|c||}
\hline \multicolumn{1}{|c|}{ Variable } & Bottom 12\% (losers) & Top 12\% (winners) \\
\hline \hline Annual savings (gallons) & -44 & 498 \\
Percent savings & -5.7 & 37.5 \\
Weatherization cost (\$ for labor + materials) & 892 & 1604 \\
Pre-weatherization gal/ft ${ }^{2} /$ year & 0.67 & 1.06 \\
Post-weatherization gal/ft ${ }^{2} /$ year & 0.71 & 0.66 \\
Pre-weatherization inside temperature ( ${ }^{\circ} \mathrm{F}$ ) & 72.3 & 70.7 \\
Post-weatherization inside temperature ( ${ }^{\circ}$ F) & 72.4 & 70.1 \\
Heated area (ft ${ }^{2}$ ) & 1457 & 1467 \\
Pre-weatherization consumption (gallons) & 873 & 1393 \\
Post-weatherization consumption (gallons) & 917 & 895 \\
Pre-weatherization air leakage (cfm50) & 3580 & 3856 \\
Post-weatherization air leakage (cfm50) & 3290 & 3191 \\
Air leakage difference (cfm50) & 290 & 665 \\
Pre-weatherization steady state efficiency & 76.5 & 72.9 \\
Program benefit-to-cost ratio at 15 years & -- & 2.96 \\
\hline
\end{tabular}

Similar measures were installed in both groups, but the frequency at which measures were installed were not the same. Measures installed in only the high savers were new space-heating systems, high-density wall insulation, low-flow showerheads, and domestic hot-water temperature reduction. Measures installed more frequently (difference of 20 percentage points or more) in the high savers than the low savers were new or additional attic insulation, regular wall insulation, floor insulation, air sealing using a blower door, replacement of broken glass in windows, and heating system clean and tunes. Measures installed more frequently in the low savers than the high savers were replacement windows and new storm doors.

The service delivery procedures differed little between these two groups. About $80 \%$ of both groups used a priority list to select envelope measures and $60 \%$ used a visual inspection to select space-heating measures. A blower door was used to find and measure leakage areas in about $80 \%$ of the high savers compared to $60 \%$ of the low savers. About $90 \%$ of both groups measured the furnace steady-state efficiency before weatherization. A visual inspection of envelope measures was performed in all houses of both groups after weatherization. A blower door was used on $50 \%$ of the high savers compared to $11 \%$ of the low savers for quality control 
of envelope measures. About $60 \%$ of the high savers conducted visual and testing inspections on heating systems compared to $35 \%$ of the low savers.

An overview agency-level analysis showed three agencies standing out as their average savings were above 400 gallons/year, but one of these agencies had only one house in its sample while a second had only two. Five agencies had mean annual savings of less than 50 gallons/house. A consumption versus savings analysis on an agency level shows a weak relationship between pre-weatherization consumption and savings. However, some agencies having high pre-weatherization consumptions had low savings and visa-versa. About $63 \%$ of the agencies obtained an average annual savings between 100-250 gallons/house, while $23 \%$ averaged below 100 gallons/house and $15 \%$ averaged above 250 gallons/house. These analyses show that differences exist in savings among agencies.

Since the agencies are monitored by their respective states, the average savings per house attained by each of the nine states in which the Fuel-Oil Study was examined. Two states attained well-below-average savings, five states attained average savings, and two states attained well-above-average savings. There was no statistical difference in savings among the states at the 95\% confidence level, but we believe that differences in state policies toward weatherization have an impact on the achievable savings of the Program.

\section{CONCLUSIONS AND RECOMMENDATIONS}

The Weatherization Assistance Program cost-effectively weatherized a total of 23,400 single-family fuel-oil-heated houses in the nine northeastern states during program years 1991 and 1992. An average annual net fuel-oil savings of 160 gallons $(17.7 \%$ of pre-weatherization consumption) was achieved at a total average cost of $\$ 1819$ ( $\$ 1192$ for installation labor and materials and $\$ 627$ for overhead and management); the resulting program-perspective benefit-tocost ratio was 1.48 and the societal perspective ratio was 2.01 . Although indoor temperatures changed in individual houses following weatherization, there was no average difference when compared to the control houses; thus, there was no overall indoor-temperature take-back effect influencing fuel-oil savings. 
A general trend toward higher-than-average fuel-oil savings was observed in houses with high pre-weatherization fuel-oil consumption. Program savings could likely be increased by targeting higher energy consumers for weatherization, although equity issues would have to be considered.

Weatherization measures associated with statistically significant, higher-than-average savings were use of a blower door for air-sealing, attic and wall insulation, and replacement spaceheating systems. More extensive analysis of the data should be performed to further investigate various interacting factors leading to improved fuel-oil savings and cost-effectiveness. An intangible factor of "state/local weatherization agency leadership and quality" that many feel is an important cause of improved performance could not be addressed by this study.

Space-heating system tune-ups were not particularly effective at improving the steady-state efficiency of systems and were not associated with statistically significant, higher-than-average savings, although improved seasonal efficiency and system safety and reliability may have resulted. Tune-ups were performed on some systems that were already operating efficiently, and they did not achieve maximum savings potential on many inefficient systems. The need to use licensed technicians to audit systems and perform tune-ups led to the extraneous tune-up problems and the increased costs, although increased use of fully qualified technicians might improve performance. The Weatherization Assistance Program should investigate methods of improving the selection and/or application of space-heating system tune-ups and actively study and promote adoption of improved tune-up procedures as a primary technology transfer activity. A committee composed of experts in the field could be assembled to develop recommended approaches and consult with states to verify benefits. State and local weatherization agency data should be collected to further study and refine tune-up techniques.

Air-leakage measurements showed that weatherized houses were more air-tight following weatherization, but still leakier than what is achievable. Although not statistically verifiable, the use of blower doors and installation of wall insulation were two measures that likely led to greater-than-average air-leakage reductions. Additional technology transfer effort is recommended to increase the use of blower doors considering that only half the weatherized houses used a blower door. A guidebook developed by a committee of experts and covering the 
following topic areas might be a useful technology transfer and training document: air-leakage theory, use of a blower door, measuring air leakage, finding and sealing leakage sites, and incorporating a blower door into a weatherization program. State and local weatherization agency data should be collected to further study the air-leakage reductions being achieved and the tightness of houses before and after weatherization.

Weatherization appeared to make occupants feel better about their house and house environment. Most occupants felt that their houses were healthy and safe, and this was supported by field inspections. Occupants felt that weatherization made their houses much more affordable to heat and much less drafty. 


\section{IMPACTS OF THE WEATHERIZATION ASSISTANCE PROGRAM \\ IN FUEL-OIL HEATED HOUSES}

\section{INTRODUCTION}

\subsection{BACKGROUND}

Recognizing the need for an up-to-date and comprehensive assessment of the Weatherization Assistance Program, the U.S. Department of Energy (DOE) requested Oak Ridge National Laboratory to help design and conduct an up-to-date evaluation of the Program. The evaluation was comprised of three "impact" studies and two "policy" studies (Beschen and Brown 1991). The three "impact" studies focused on the energy savings and cost effectiveness of the Program in key DOE markets:

- $\quad$ single-family and small multifamily dwellings using gas or electricity for heating (Brown et al. 1993, Berry et al. 1991),

- high-density multifamily buildings using gas, electricity, or fuel-oil for heating (MacDonald 1993), and

- fuel-oil heated single-family homes.

The latter study is the subject of this report.

\subsection{OBJECTIVES}

There were four main goals of the Fuel-Oil Study. The primary goal was to provide a region-wide estimate of the space-heating fuel oil saved by the Program in the Northeast during the 1991 and 1992 program years (a typical program year generally runs from April to March). This estimate focused on fuel oil used for space heating. Space cooling was not prominent in this region and was not addressed.

The second goal was to identify and quantify (to the extent possible) non-energy impacts of the Program. The impacts of interest included program-induced improvements in the affordability of housing due to reduced household energy costs; reductions in the number of 
unsafe space- and domestic water-heating systems due to remedial actions taken or recommended during weatherization; and improvements in the comfort of houses due to reduced draftiness, increased indoor temperature, increased amount of heated living space, and occupants' perception of comfort improvements.

The third goal was to assess the cost effectiveness of the Program within the fuel-oil submarket using simple payback period and benefit-to-cost ratio as indicators.

The final goal was to identify factors which caused fuel-oil savings to vary. This assessment provided, to the extent possible, insights about groups of measures that were effective in reducing fuel-oil consumption, service delivery procedures that may enhance cost effectiveness, and market segments that future program efforts should consider targeting. Factors of interest included climate, dwelling unit characteristics prior to weatherization, packages of energy efficiency measures, audit procedures, and other service delivery practices.

These major goals cover the most significant issues and also focus on producing useful and practical information for program planning, implementation, and management that could be obtained for reasonable costs. For example, information from the evaluation will be useful for identifying how to best allocate Program resources, the market segments (such as high energy users) that future program efforts should target under specific circumstances, the service delivery procedures that are most effective for particular building types, the packages of measures that are shown to provide the most benefit, and the level of energy savings that can be expected per public dollar spent.

The Fuel-Oil Study, as well as the other studies, will provide essential inputs to the process of planning future roles for the Program network in brokering, demonstrating, evaluating, and accelerating the market penetration of energy-efficient, cost-effective building technologies. 


\section{EVALUATION DESIGN}

The Fuel-Oil Study analyzed only single-family houses in the nine states in the Northeast census region. The study was performed over two heating seasons (1991 and 1992 program years) and involved submetered field measurements of space-heating fuel-oil consumption and indoor temperature in 337 houses. Detailed planning was performed to develop the evaluation design (Ternes, Levins, and Brown 1992). Details of the evaluation design as implemented are presented in this section.

\subsection{EXPERIMENTAL DESIGN}

A split-winter experimental design containing pre- and post-weatherization periods and including a control group was used (see Fig. 2.1). Submetered fuel-oil consumption was monitored in all the test houses. Each house was monitored over one heating season, with 191 test houses being monitored in 1990-1991 and 146 in 1991-1992.

\begin{tabular}{||c|c||}
\hline Group 1 & 1990-1991 Heating season \\
\hline $\begin{array}{c}\text { Weatherized group } \\
\text { (121 houses) }\end{array}$ & pre W post \\
\hline $\begin{array}{c}\text { Control group } \\
\text { (70 houses) }\end{array}$ & pre \\
\hline
\end{tabular}

\begin{tabular}{|c|c||c||}
\hline Group 2 & 1991-1992 Heating season \\
\hline $\begin{array}{c}\text { Weatherized group } \\
\text { (101 houses) }\end{array}$ & pre W post \\
\hline $\begin{array}{c}\text { Control group } \\
\text { (45 houses) }\end{array}$ & pre post W \\
\hline
\end{tabular}

Note: $\mathbf{W}=$ Weatherization performed

Fig. 2.1. Split-winter experimental design. 
Pre- and post-weatherization testing allowed individual house space-heating fuel-oil savings to be determined because the houses served as their own reference. Individual house savings were averaged to determine group savings. Inclusion of a control group allowed estimation of energy consumption changes that would have occurred in the absence of the program. For instance, it controlled for factors such as differing ground temperatures between the pre- and post-weatherization periods and trends in the price of fuel oil. Savings for weatherized houses were adjusted by the savings for the control group to account for these factors.

In the split-winter design, each house was monitored over one heating season. Energy conservation measures were installed in the weatherized houses by the local weatherization agency in January of each program year utilizing their usual audit and implementation procedures. The split-winter design was chosen instead of a full winter of pre- and post-weatherization monitoring for the following reasons:

- Houses used as controls were weatherized within a time frame agreeable to the states and local weatherization agencies.

- Instead of monitoring all study houses over two heating seasons as needed under a full winter of pre- and post-weatherization monitoring, the split-winter design allowed half the houses to be monitored one heating season and the remaining half the second heating season. The reduced number of houses monitored each heating season made it easier to identify the required number of houses for the study from current eligibility lists and reduced the time needed to install instrumentation. Additionally, reuse of instrumentation for the 1991-1992 heating season reduced instrumentation costs and allowed indoor temperature to be monitored in all the houses.

- Attrition was reduced, which was particularly important because renters were included in the sample.

Disadvantages of the split-winter design identified at the start of the study included uncertainty associated with fuel-oil savings measured from shorter-term, split-winter testing and the need to weatherize all scheduled homes in a relatively short period in January. Previous studies performed with pre- and post-weatherization data collected over just half the heating season (McCold et al. 1988, Ternes et al. 1991) had been successfully performed. Results from this present study confirmed that split-winter testing is a viable monitoring approach provided the heating season is sufficiently long in duration. Discussions with state Weatherization Program 
directors and local weatherization agency personnel at the start of the study indicated that agencies could weatherize houses in January sufficient for the study and that weatherization operations performed in the heating season were quite similar to those performed during the summer. Few significant problems in completing the weatherizations as scheduled were encountered during the study.

\subsection{SAMPLING PROCEDURE}

A total of 337 houses were monitored over the two heating seasons of the study and were drawn from the population of houses meeting the eligibility requirements listed in Sect. 2.3. The houses were divided into 222 weatherized houses and 115 control houses. Over the 1990-1991 heating season, 121 weatherized houses and 70 control houses were monitored among 25 local weatherization agencies. Over the 1991-1992 heating season, the remaining 101 weatherized houses and 45 control houses were monitored from a different set of 16 agencies. The location of agencies monitored in each heating season are identified in Fig. 2.2. Available resources limited the total number of houses that could be monitored. Calculations performed during the design of the study indicated that the estimated savings of installed weatherization measures would be within $26 \%$ of the actual savings if this design were chosen (at a $90 \%$ confidence level and assuming a $20 \%$ attrition rate).

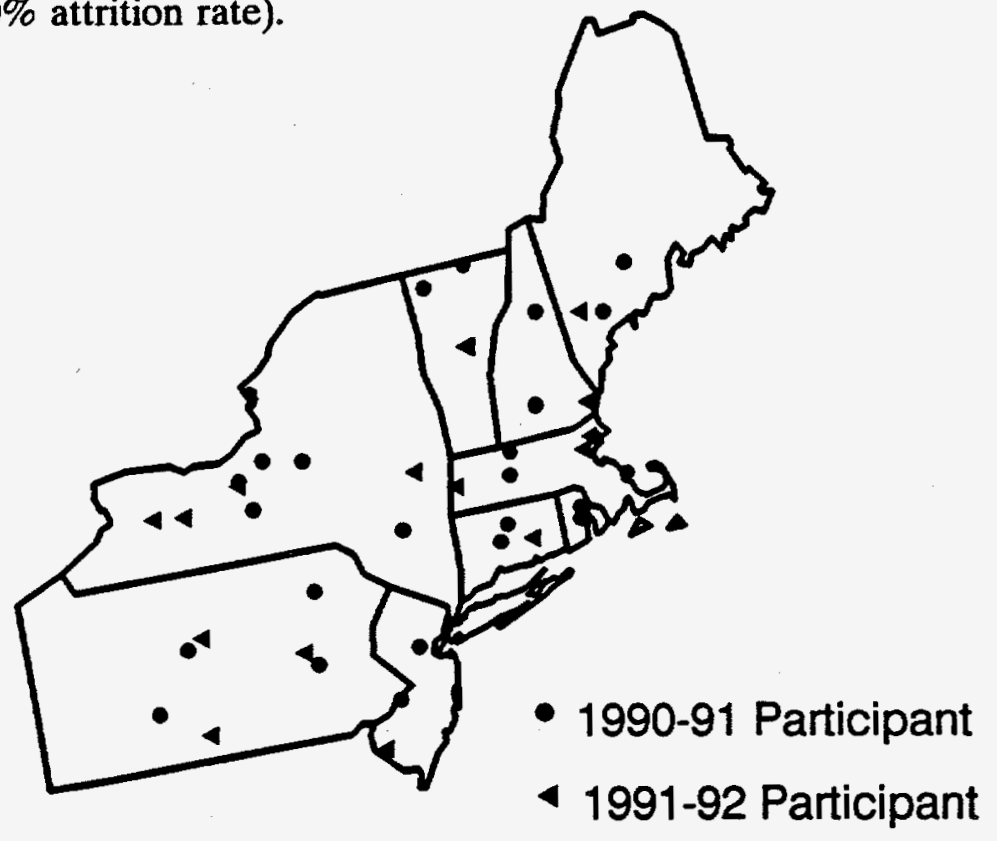

Fig. 22. Locations of weatherization agencies taking part in the Fuel-Oil Study. 
For the 1990-1991 heating season, a clustered sampling procedure was used: 25 local weatherization agencies were selected using states as a stratification variable; eight individual houses per agency were then selected. The selection of houses proceeded in two steps:

1. A total of 25 agencies were selected from the nine northeast states and distributed as follows: Maine (2), New Hampshire (2), Vermont (2), Massachusetts (4), Rhode Island (2), Connecticut (2), New York (5), Pennsylvania (4), and New Jersey (2). At least two agencies were chosen from each state to ensure a representative sample. Agencies from each state that weatherized a significant number of single-family houses heated by fuel oil (typically greater than 15 such houses per year) were identified. Sampling was limited to these agencies to ensure that eight houses eligible for the study could be identified from the agency if selected. The sample of agencies for each state was drawn randomly with probabilities proportional to the number of single-family houses heated by fuel oil and weatherized by the agency.

2. For each agency selected, houses on the waiting list and/or selected for weatherization that met the eligibility requirements listed in Sect. 2.3 were identified. A random sample of eight of these houses was then chosen. Their eligibility for the study was verified through a house visit by the agency. The household's consent (and building owner's if the household was a renter) was also obtained. If these requirements could not be met, a replacement house was selected from the original list. If eight eligible houses could not be identified, then additional outreach was performed to obtain the necessary number of houses.

The eight houses selected from each local weatherization agency were randomly divided into weatherization and control groups during the pre-weatherization period. These assignments were made as late as possible to minimize the effect of attrition creating unequal groups.

A similar procedure was used during the 1991-1992 heating season which involved 16 local weatherization agencies with 11 participating houses in each. In this year, at least one agency was chosen from each state. States in which more than one agency was monitored were: Massachusetts (3), New York (4), and Pennsylvania (3).

To reimburse those households participating in the study for any inconveniences they may have endured and for services provided during the study, the following monetary payments were made to the occupants during the heating season their house was monitored: a $\$ 75$ service payment to each participating household in January, and an additional $\$ 75$ payment to each 
control house in May. In some cases, these payments also acted as incentives to obtain the participation of the households.

\subsection{HOUSE ELIGIBIITY}

Houses included in the study were limited to those with the following characteristics:

1. Occupants were eligible for the Weatherization Assistance Program administered in their state for the respective program years.

2. Houses were single-family buildings. Mobile homes, mobile homes with room additions, or other similar housing assembled on-site from factory-built modules were excluded. A single-family building is defined in the Residential Energy Consumption Survey (RECS) (Energy Information Administration 1989):

"[A] single-family housing unit [is] a structure that provides living space for one household or family. The structure may be detached, attached on one side (semidetached), or attached on two sides. Attached houses are considered singlefamily houses as long as the house itself is not divided into more than one housing unit and has an independent outside entrance. A single-family house is contained within walls that go from the basement (or the ground floor, if there is no basement) to the roof. (A mobile home with one or more rooms added is classified as a single-family home.)"

Although a mobile home with one or more rooms added is classified as a single-family house in RECS, such a house was not considered for this study. Energy savings and weatherization techniques for mobile homes are being examined by other DOE sponsored studies and, thus, were not included in this study. In interpreting the RECS definition, 
row houses and side-by-side duplexes (twins) were single-family houses, whereas over-andunder duplexes were small multifamily buildings. ${ }^{1}$

Energy savings of single-family and small multifamily buildings heated by fuel oil were not assessed using primary data in the single-family study (Brown et al. 1993). Small multifamily buildings were not included in the Fuel-Oil Study to simplify its design and implementation, a simplification especially needed to allow monitoring to start during the 1990-1991 heating season. The 1987 RECS data (Energy Information Administration 1989 ) indicate that there are almost three times as many single-family households heated by oil with occupants whose income level is less than $125 \%$ of the poverty level as there are small multifamily households.

High-density multifamily buildings (five or more units per building) heated by fuel oil were assessed under the high-density Multifamily Study (Beschen and Brown 1991).

3. Primary space-heating systems used fuel oil. Single-family houses primarily heated by other common fuels such as gas and electricity were assessed in the Single-Family Study (Brown et al. 1993).

4. Houses were located in the nine states in the northeast census region (Maine, New Hampshire, Vermont, Massachusetts, Rhode Island, Connecticut, New York, Pennsylvania, and New Jersey). The 1987 RECS data (Energy Information Administration 1989) indicate that almost half of the single-family houses heated by fuel oil with occupants whose income is less than $125 \%$ of the poverty level are located in these nine states. About $70 \%$ of all households that use fuel oil as their main heating fuel are located in

\footnotetext{
${ }^{1}$ Small multifamily buildings are also defined by RECS: "[A] house or building with two to four housing units [is] a structure that is divided into living quarters for two, three, or four families or households. This category also includes houses originally intended for occupancy by one family (or for some other use) that have since been converted to separate dwellings for two to four families. Typical arrangements in these types of living quarters are separate apartments downstairs and upstairs, or one apartment on each of three or four floors."
} 
these states; about $40 \%$ of the households in these states heat with fuel oil (households in these latter statistics include all income levels and building types).

5. Secondary space-heating systems (such as wood stoves, fireplaces, or portable space heaters) were not used to substantially heat a house (use of supplemental space-heating systems one day per week or in the bathroom was acceptable). Energy consumption of secondary space-heating systems could not easily be monitored.

6. Occupants intended to remain at home for the entire heating season monitoring period (no lengthy vacations away from home). Houses whose occupants moved during the study were to be dropped from the analysis.

7. Occupants had a working telephone line in the house. Data collected by the data logger installed in each house were transmitted to a central computer over the telephone.

\section{DATA PARAMETERS AND INSTRUMENTATION}

The data collected for this study can be divided into three types: time-sequential data, survey information, and point-in-time measurements. The time-sequential data were recorded on an hourly basis: space-heating system fuel-oil consumption, indoor temperature, and outdoor temperature. The survey information included descriptive data on the building shell and mechanical systems of the house, data on occupant characteristics and their responses to weatherization, cost data, and other data characterizing the states and local weatherization agencies. The point-in-time measurements evaluated the building shell and mechanical systems.

\subsection{Time-Sequential Measurements}

A four-channel data logger (two temperature, one digital, and one analog voltage) was used to measure and record the time-sequential data at each house. The unit measured 8 in. $x 10$ in. $x 5$ in. and was programmable. Internal batteries, capable of powering the unit for about three months, were used as a back-up power supply to externally provided power. Each data logger contained an internal modem for communications. Data were retrieved over telephone lines 
using the internal modem and software developed by the manufacturer. The unit measured indoor and outdoor temperatures and an analog voltage (which corresponded to space-heating system run-time) once a second, and stored averaged hourly data in solid state memory. The digital channel was not used.

The amount of fuel-oil delivered to the oil-fired space-heating system was calculated from a measurement of the run-time of the oil burner. The hourly run-time was multiplied by the rated flow of the nozzle on the burner to arrive at the gallon input into the burner each hour. This was not the energy delivered into the house, but that delivered to the burner. An on-site calibration of the oil burner flow rate was not performed. The rated flow rate of the nozzle was documented both at the time instrumentation was installed and when it was removed.

The hourly run-time of the oil burner was measured using the analog voltage channel of the data logger and a low-voltage (contact closure) relay placed across the pump motor of the oil burner. The relay closed when power was supplied to the pump (delivering oil to the burner) and was open when power to the pump was interrupted. The data logger supplied the relay with a voltage source of approximately 8 volts; this was read as 5.12 volts by the data logger (its maximum or "pegged" range) when the space-heating system was on and 0.00 volts when off. By recording the average voltage over the hour, the hourly run-time of the oil burner was calculated by dividing the average voltage by 5.12 volts (i.e., 5.12 volts $=100 \%$ on time, 3.1 volts $=60.54 \%$ on time, etc.).

This approach measured burner run-time rather than the time the thermostat called for heat. Thus, it was applicable to all fuel-oil space-heating systems encountered in this study, especially hydronic systems, in which the thermostat controlled a pump circulating heated water through the house rather than delivery of fuel to the burner. The actual amount of fuel delivered to the oil burner was accurately estimated so long as the oil pump maintained a delivery pressure to the nozzle which maintained a steady flow equal to the rated nozzle flow.

The hourly indoor temperature of each house was monitored at the thermostat using an integrated-circuit temperature sensor and the data logger. The temperature at the thermostat was chosen because the thermostat operated the space-heating system in response to this temperature 
and because this temperature was expected to be reasonably representative of the house temperature. The sensor was installed to minimize its exposure to radiant energy from the sun, exterior walls, windows, lamps, and other significant radiators. The sensor was not exposed to heat or cold sources such as vents or appliances in the surrounding area.

The hourly outdoor temperature at each house was also monitored using an integratedcircuit temperature sensor and the data logger. The temperature sensor was located where it was minimally affected by heat sources or sinks in the surrounding area and where the ambient air was well mixed with the surrounding air. A sensor location on the north side of the house and below roof level was preferred. The sensor was placed in an inverted U-shaped pipe to protect it from the weather and to act as a radiation shield.

\subsubsection{Survey Information}

Information about the physical characteristics of each house and its space-heating, spacecooling, and water-heating systems was collected at the end of the post-weatherization period using the first survey provided in Appendix A. Information on the floor area, volume, number of rooms, and number of heated rooms was also collected at the beginning of the pre-weatherization period in all houses using the second survey provided in Appendix A.

A comprehensive questionnaire was conducted at the end of the post-weatherization period. Subjects included were ownership status (renter or owner), length of residence, house age, heating fuels, demographics, the amount of conditioned space, thermostat management, fuel assistance, and occupant perceptions of Program impacts on health, safety, comfort, thermostat operation, and affordability. A majority of the questions in the questionnaires (separate questionnaires were developed for the weatherized and control houses and are provided in Appendix B) were reprinted verbatim from the 1990 RECS. Similar questionnaires were used in the Single-Family Study. All questions that were not drawn from RECS were pretested. Approval from the Office of Management and Budget were obtained for the questionnaires.

The following information was collected from the local weatherization agencies using the first survey presented in Appendix $\mathrm{C}$ after the houses were weatherized: service delivery 
procedures (audit type, use of contractor or in-house crews, use of blower doors, inspection procedures, etc.), the dates the houses were weatherized, installed measures and costs, the average overhead and management costs per housing unit for the agency, and household income. Household income was also collected from the control houses (second survey provided in Appendix C). The number of single-family houses heated by fuel oil and weatherized in the monitored program year were obtained from the states and participating agencies.

\subsubsection{Point-in-Time Measurements}

Air-leakage tests were performed in all houses using blower doors. Each weatherized house was tested before and after weatherization to determine changes in house air-leakage caused by the combined weatherization measures. Control houses were tested during the preand post-weatherization periods. Data collected included blower-door air flow rates at different pressure differences between the inside and outside of the house, indoor and outdoor temperatures during the test, and local shielding class.

The air-leakage tests were performed following the procedure provided in Appendix D. The procedure minimized errors from procedural differences between technicians. It also minimized gauge-induced errors due to calibration and hysteresis. The procedure was sufficiently rigorous to ensure comparability of individual house measurements made under this study and the Single-Family Study even after considering that:

- tests were performed by different personnel,

- tests were performed by different organizations,

- tests were performed using different brands of blower doors,

- houses were located in a wide variety of locations, elevations, and terrains, and

- houses likely had air leakages that varied greatly.

This procedure was adapted from a procedure developed for the Bonneville Power Administration to evaluate air-leakage characteristics of over 500 Northwest houses (Ecotope 1989). Bonneville's procedure was extensively field tested and proven capable of producing high quality results - i.e., collecting data with minimal random errors that could be extrapolated to the 
required conditions for standard analysis with the Lawrence Berkeley Laboratory Infiltration Model (Sherman and Modera 1984).

Only tests in which the house volume was depressurized were performed. Both depressurized and pressurized tests (averaged to obtain a composite result) are specified in Standard E779-87 for measuring air leakage (ASTM 1987) to reduce the effect of random errors in individual data sets and thereby increase the accuracy of estimating the air leakage. Reliance on depressurized tests only was selected based on a study performed by Sherman et al. (1984). Sherman determined that systematic errors between pressurized and depressurized tests did not occur, but significant random errors in individual tests could be compensated for by combining the results from both tests. Results from the Bonneville project (upon which the test procedure in Appendix D was based) indicated that the pressurization test did not improve the accuracy of the air-leakage measurement or reduce its standard error. Based on these latter results and because of the increased cost to perform a pressurized test (especially to seal all vent areas), pressurized tests were not performed.

Each house was measured in its normal leakage condition for this study. Only those openings in the envelope that could naturally be shut (such as windows, external doors, and fireplace dampers) were closed for the test rather than sealing all possible openings in the envelope (such as vents, animal gates, and window air conditioners). Reasons for this choice were:

- to represent the "as found" condition of the house desired for the evaluation,

- to test the house in the condition requiring the least modification by testing personnel to limit the time required for setup of the house, and

- to reduce the number of special leakage areas sealed for the pre-weatherization test that would have to be replicated for the post-weatherization test to ensure comparable results.

The steady-state efficiency of each space-heating system was measured for both pre- and post-weatherization periods. These measurements were made following the procedure in Appendix E. A smoke test was also conducted when the efficiency was measured. 
A safety inspection of the space- and domestic water-heating systems was performed at the end of the post-weatherization period in all houses. The inspection included examination for cracked heat-exchanger, excessive carbon monoxide in the flue gases (incomplete combustion), carbon monoxide in the air surrounding the system, carbon monoxide in the distribution air (force\$-air system), insufficient draft, damaged or improperly installed flue/chimney, oil leak, improperly set safety switches, improperly set pressure switches (boiler systems), and missing or dirty filters. If an unsafe condition was found, it was brought to the attention of the local weatherization agency and resolved either through the Program or this study. The inspection was performed following the procedure in Appendix F. 


\section{OCCUPANT AND HOUSE CHARACTERISTICS}

Occupant and house descriptive information was collected for both control and weatherized houses during the removal of the monitoring instrumentation at the end of each heating season. Each program applicant (or another responsible adult member of the household) was personally queried to obtain occupant information through the use of the Fuel-Oil Study Occupant Questionnaire provided in Appendix B. The Fuel-Oil Study House Characteristics Survey (Appendix A) and the Oil-Fired Space- and Water-Heating System Inspection Procedure (Appendix F) were used to record specific house physical measurements and visual observations. Air leakage and steady-state heating-system efficiencies were measured before and after weatherization, and a safety inspection of the space- and domestic water-heating systems was performed at the end of the post-weatherization period. These results latter are presented in Sects. 6 and 7.

Because this information was taken after the weatherized houses were weatherized, information concerning the condition of the weatherized houses before weatherization was not available. Control house data represent, for the most part, the original condition of the control houses.

House descriptive information was collected after the houses were weatherized because our prime concern was to install energy-consumption monitoring equipment in all houses before the start of the heating season in order to obtain sufficient data for split-season analysis. About three or four hours were required per house to properly install the instrumentation and verify its operation. Additionally, some houses were not selected until the heating season had started because of Program logistics (many people do not apply until the weather becomes cold, and many are directed to the Program by other agencies such as The Low-Income Heating Energy Assistance Program). These reasons and financial considerations made the collection of house physical and occupant characteristic data impractical until the end of the heating season.

We installed instrumentation in 337 houses ( 115 control and 222 weatherized), but only collected physical data on 320 houses (106 control and 214 weatherized) and occupant survey data on 306 families ( 99 control and 207 weatherized). Attrition was caused by factors such as the 
death of an occupant, families moving, house sales, loss of a house because of nonpayment of a mortgage, and uncooperative or unavailable occupants.

Discussions in this section are based on unweighted sample statistics since we are describing the sample and its distribution. Statistics for parameters unaffected by the weatherization process represent the control and weatherized houses combined. Separate statistics for control and weatherized houses are provided for parameters affected by the weatherization process (such as insulation levels).

Tables and distribution plots for most of the occupant and house characteristics are provided in Appendix $\mathrm{G}$ to supplement the discussion provided below. Some questions were not answered by an occupant and some measurements were not able to be made in some houses for a multitude of reasons. Therefore, the number of responses to different questions and measurements vary, but we do not feel that those random omissions bias our findings. The number of responses is given for each category presented in the Appendix.

\subsection{OCCUPANT CHARACTERISTICS}

The number of occupants in each house varied between 1 and 10 . About $90 \%$ of the houses had five or fewer occupants, and about $50 \%$ had either one or two occupants (see Fig. 3.1). The average number of occupants per house was three. The most common number of occupants per house was one, with two the next most common. The age distribution of the occupants was $13 \%$ preschool, $27 \%$ school age, $42 \%$ adults, and $18 \%$ over 65 .

The length of time each family had resided at their present address varied between 1 and 60 years, the mean being 19 years. Homeowners accounted for $87 \%$ of our sample, with half of these having no mortgage payments. Renters paid an average monthly rent of $\$ 333$. The average annual household income of our sample was $\$ 10,800 .^{2}$

${ }^{2}$ Household income data provided to us by the local weatherization agencies was sometimes for a 30-60 day period. Because of fluctuations in monthly income, extrapolation of these values may not be a precise representation of annual income. 


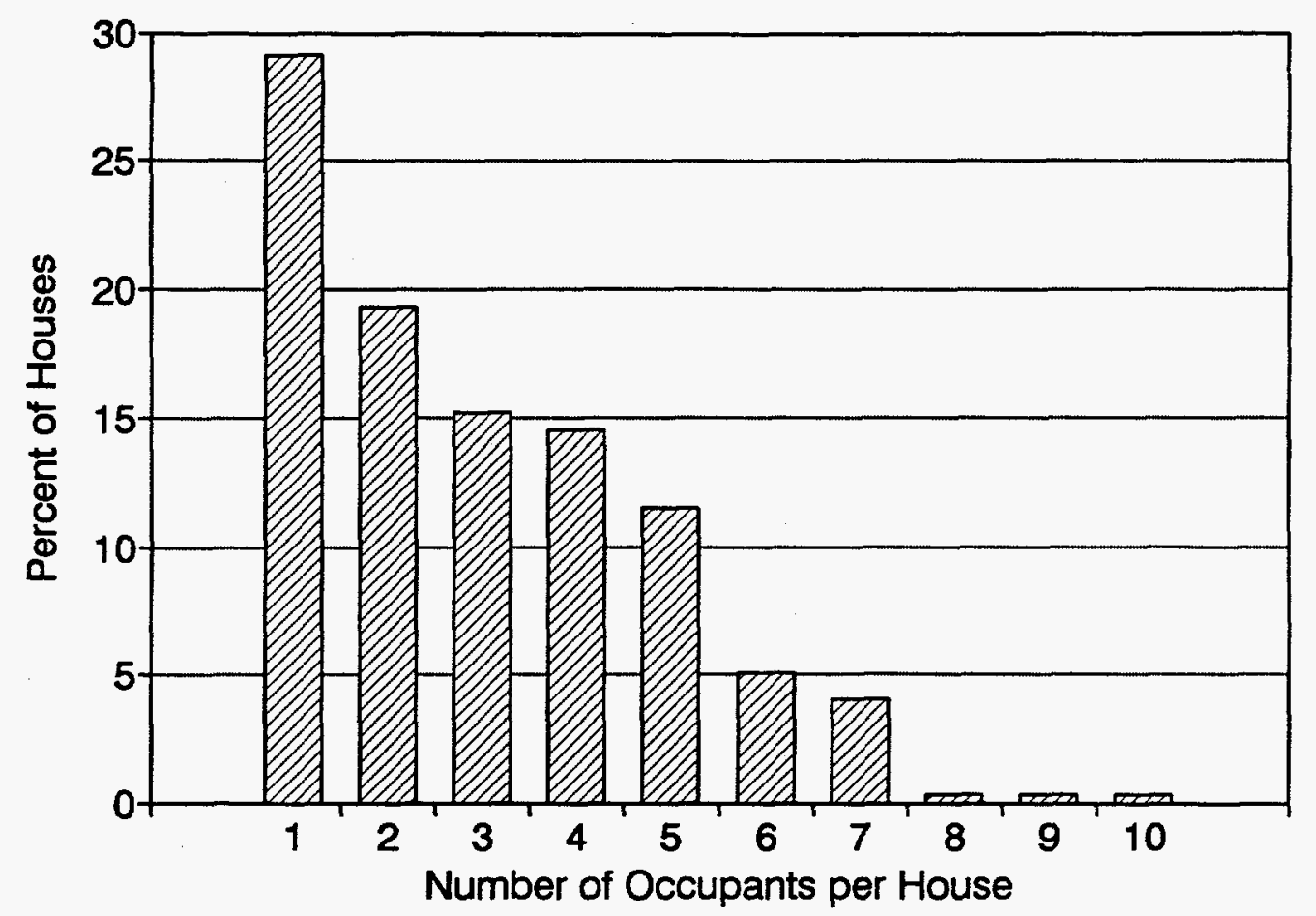

Fig. 3.1. Distribution of the number of occupants per house (mean $=3$, and standard deviation $=1.9$ ).

\subsection{HOUSE CHARACTERISTICS}

An average house participating in the field test was approximately 63 years old (it was built in 1928) and had two floors built above a concrete basement. The non-basement floor area of the house (which in most cases was the main living area and intentionally heated) was $1332 \mathrm{ft}^{2}$ and the total floor area of the house (which included the usually unheated basement) was 1989 $\mathrm{ft}^{2}$. The average house was heated with a 19-year old oil-fired forced-air furnace or hydronic boiler, with no auxiliary heat used. The house had some insulation in the attic and in the exterior walls, but none in the floors or foundation.

As shown in Fig. 3.2, 27\% of the houses were built before 1900, with about $5-10 \%$ of the houses being built each decade from 1900 to 1980 . About $40 \%$ of the houses in the field test were built during the 1930's through the 1960's. Those houses built prior to 1900 were arbitrarily assumed to have been built in 1890 , since an exact construction date was unobtainable on most. The average age of 63 years was obtained using this assumption. 


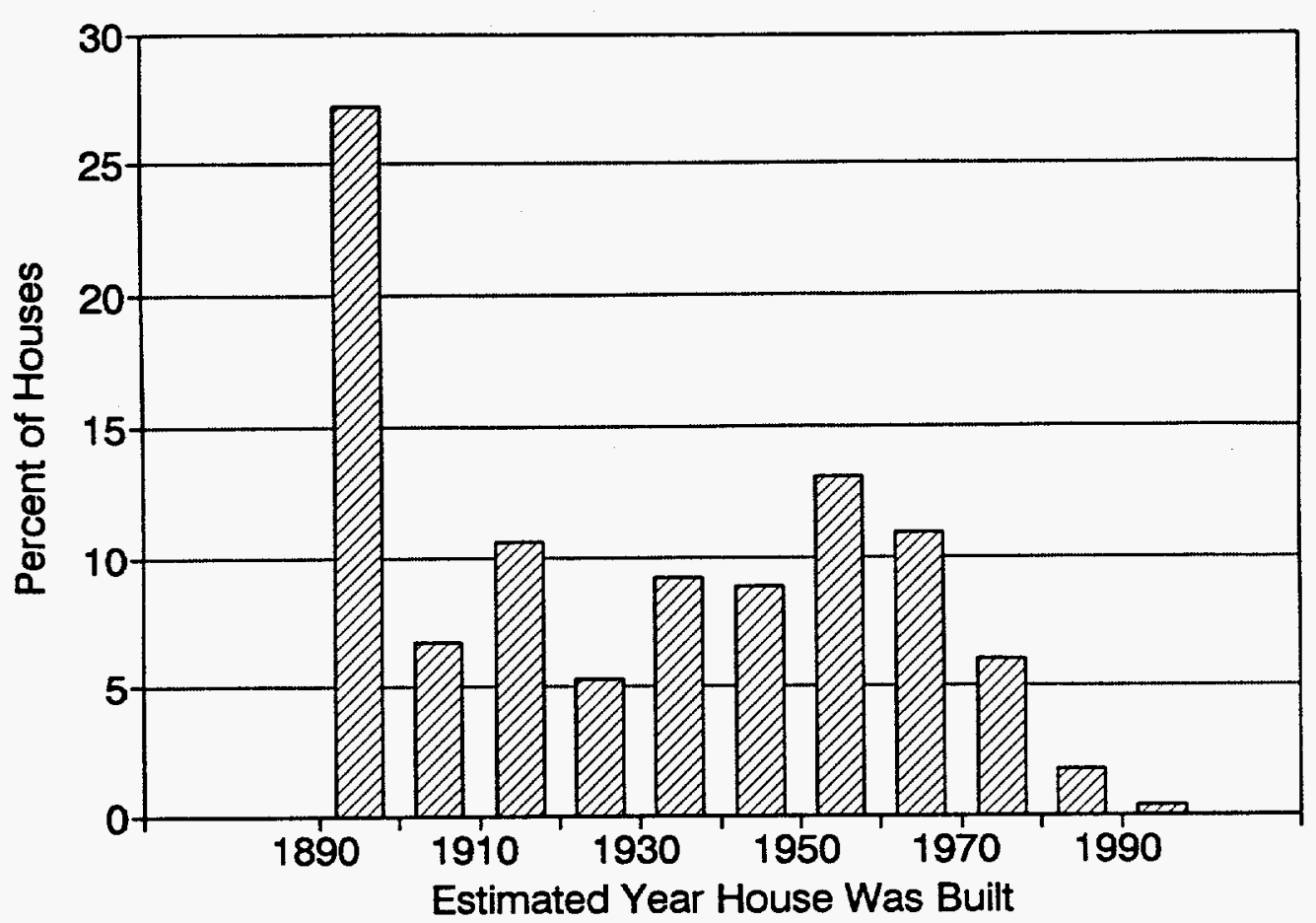

Fig. 3.2. Distribution of house age (mean $=1928$, and standard deviation $=30$ ).

Most of the houses (303 of 320 or $95 \%$ ) had basements and 234 of 320 (73\%) houses were multi-story. The basements were made from either poured concrete or concrete block walls. For those houses with a basement, the basement floor areas averaged $694 \mathrm{ft}^{2}$. The ratio of the basement floor area to total floor area averaged $34 \%$.

The non-basement floor area of the field-test houses averaged $1332 \mathrm{ft}^{2}$. The distribution of floor area is shown in Fig. 3.3. An average of $1274 \mathrm{ft}^{2}$ of the total non-basement floor area, or $96 \%$, was intentionally heated. Additionally, $43(13 \%)$ of the homeowners reported that they typically heated their basements.

The predominately two-story houses were wood-framed, with wood, aluminum, and brick being the most popular siding in that order. Total exterior wall area averaged $1608 \mathrm{ft}^{2}$, and window area averaged $169 \mathrm{ft}^{2}$, varying between 50 and $563 \mathrm{ft}^{2}$. The predominant type of window used in the participating houses was wooden single-pane with a metal storm window. 


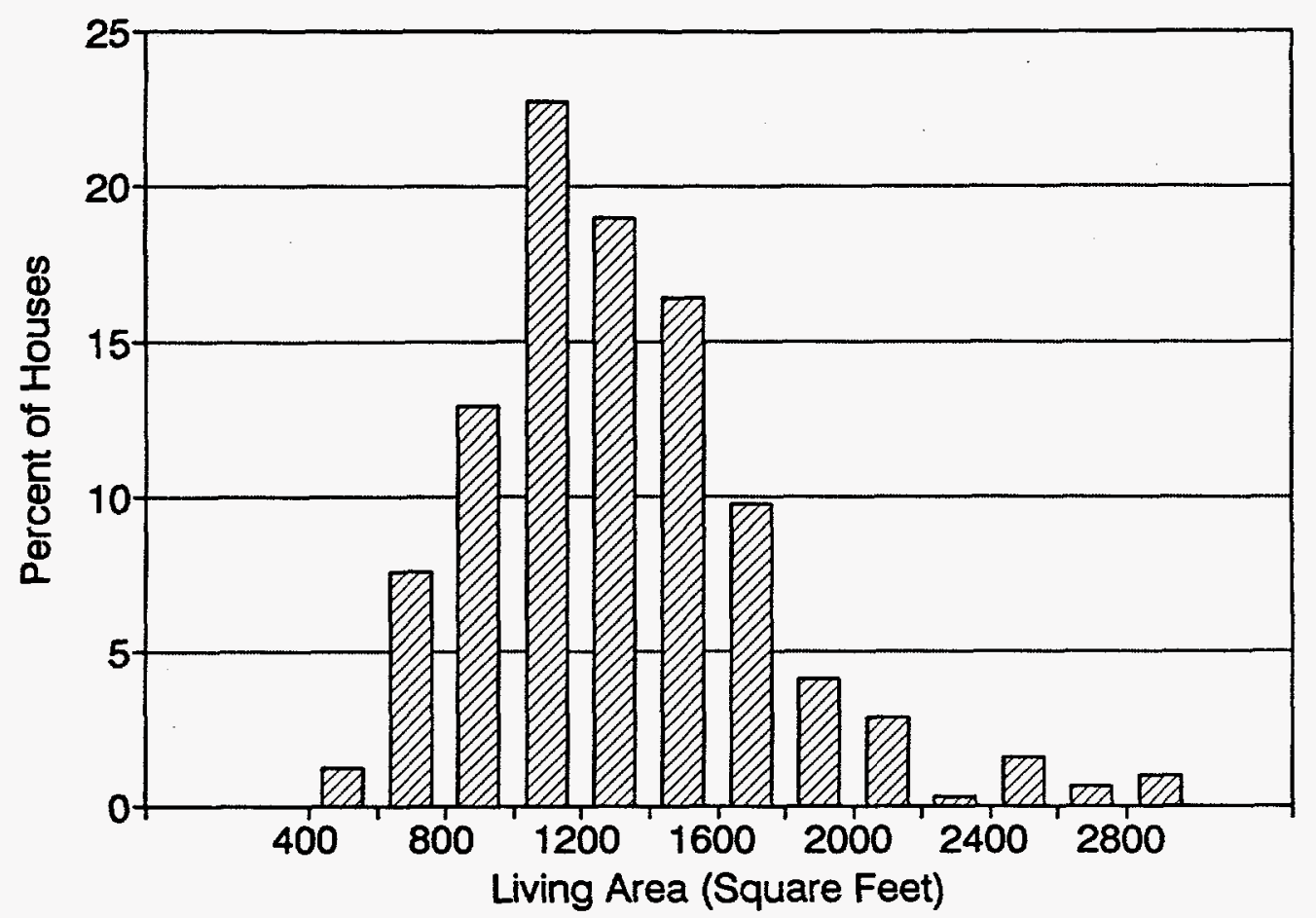
465).

Fig. 3.3. Distribution of house living area (mean $=1332 \mathrm{ft}^{2}$, and standard deviation $=$

Since the weatherized houses had already been weatherized, one would expect to find both more houses with insulation and higher insulation levels in the weatherized houses than in the control houses. Foundation ceiling insulation (also called floor insulation) was present in $8 \%$ of the control houses and $21 \%$ of the weatherized houses. Exterior wall-cavity insulation was present in $52 \%$ of the control houses and in $60 \%$ of the weatherized houses. Attic insulation was present in $82 \%$ of the control houses and $91 \%$ of the weatherized houses. Only about $6 \%$ of the control and weatherized houses had any foundation wall insulation.

The most popular type of wall and attic insulation present in weatherized houses was blown cellulose, followed by fiberglass batts. Control houses had more fiberglass batts in the wall than blown cellulose. These two insulating materials were used with equal frequency in the attics of both groups. All other insulating materials lagged far behind blown cellulose and fiberglass batts in usage. 
Control houses had less insulation, on average, than weatherized houses except with respect to the foundation wall. Average insulation depths, in inches, for all control and weatherized houses, respectively, were: exterior wall, 1.62 and 1.90; unfinished attic, 4.59 and 6.57; finished attic, 2.84 and 4.68; foundation wall, 0.25 and 0.19 ; and foundation ceiling, 0.44 and 0.97 .

As specified by the house selection criteria presented in Sect. 2.3, all primary spaceheating systems used fuel oil. Forced-air furnaces were used in $138(44 \%)$ of the houses, gravity furnaces were used in $7(2 \%)$ of the houses, steam boilers were used in $39(12 \%)$ of the houses, and boilers with hydronic distribution systems were used in $128(41 \%)$ of the houses. The average ages of the heating systems by type were: forced-air furnaces, 14 years; gravity furnaces, 58 years; steam boilers, 26 years; and hydronic boilers, 18 years.

The average firing rate of all space-heating systems was $132,500 \mathrm{Btu} / \mathrm{h}$ (corresponding to a nozzle size of 0.95 gallons $/ \mathrm{h}$ ). The burners were of the flame-retention type in $152(54 \%)$ of the houses, and vent dampers were present on 89 (29\%) of the systems.

Most of the participants, 139 of $209(67 \%)$ in the pre-weatherization period and 159 of $208(76 \%)$ in the post-weatherization period, said they did not use any type of auxiliary heat (see Table 3.1). Electricity and wood were the most common auxiliary heat sources used. Of the 70 families using auxiliary heat during the pre-weatherization period, $62 \%$ said they used it all the time, $24 \%$ said they used it $75 \%$ of the time, and $14 \%$ said they used it $50 \%$ or less. Of the 49 families using auxiliary heat in the post-weatherization period, $69 \%$ used it all the time, $24 \%$ used it $75 \%$ of the time, and $7 \%$ used it $50 \%$ of the time or less. Of the 29 weatherized houses using auxiliary heat in both the pre- and post-weatherization periods, $80 \%$ did not change their time of usage, $20 \%$ increased their time of usage, and none decreased it. Tables G.6 and G.7 in Appendix $\mathrm{G}$ contain more information on auxiliary fuel usage.

The domestic water-heating systems in the houses varied in both fuel type and type of system. Stand-alone systems accounted for $61 \%$ of the total, while tankless or integrated systems (those systems with a water-heating coil located in the boiler and no storage tank) comprised the remaining 39\%. There were 115 (37\%) stand-alone electric systems, $35(11 \%)$ stand-alone 
Table 3.1. Summary of homes using auxiliary heat

\begin{tabular}{||c|c|c|c|c|}
\hline \multirow{2}{*}{$\begin{array}{c}\text { Period(s) auxiliary heat } \\
\text { was used }\end{array}$} & \multicolumn{2}{|c|}{ Control houses } & \multicolumn{2}{c|}{ Weatherized houses } \\
\cline { 2 - 5 } & Number & $\begin{array}{c}\text { Percent of } \\
\text { controls }\end{array}$ & Number & $\begin{array}{c}\text { Percent of } \\
\text { weatherized }\end{array}$ \\
\hline \hline Pre period only & 4 & $6 \%$ & 22 & $16 \%$ \\
\hline Both pre and post periods & 15 & $23 \%$ & 29 & $20 \%$ \\
\hline Post period only & 1 & $1 \%$ & 4 & $3 \%$ \\
\hline
\end{tabular}

natural gas systems, $25(8 \%)$ stand-alone propane systems, $15(5 \%)$ stand-alone fuel-oil systems, and $120(39 \%)$ tankless fuel-oil systems. The average estimated hot water temperature was about $130^{\circ} \mathrm{F}$, with the oil-heated tankless heaters running at about $160^{\circ} \mathrm{F}^{3}$. The domestic waterheating system was usually located in an unintentionally conditioned (maintained unintentionally at $55^{\circ} \mathrm{F}$ or higher) basement area.

A summary of the appliances found in the houses is provided in Table 3.2. Almost all houses had a cooking range, a conventional refrigerator/freezer, and at least one television set. A large percentage of houses also contained a clothes washer, clothes dryer, and microwave oven. About $26 \%$ of the cooking ranges used either natural gas or propane; just about all other appliance types, including clothes dryers, were electrically operated. More than half of the washers and dryers were located in intentionally heated areas of a house.

\subsection{COMPARISON OF WEATHERIZED AND CONTROL GROUPS}

Field test houses were divided into weatherized and control groups using a random assignment procedure in order to remove any bias between the two groups. In some limited cases, certain houses were designated as weatherized houses because the occupants did not want to go a whole heating season without undergoing any house weatherization. While it is physically impossible to achieve absolute "equality" among the houses in each group, the random assignment

\footnotetext{
${ }^{3}$ Although this temperature is higher than desired for efficiency and safety reasons, the available control over the water temperature in tankless systems is often limited.
} 
Table 3.2. Summary statistics concerning appliances (320 total observations)

\begin{tabular}{||c|c|c|c|c|c|c|c|c|c|c||}
\hline \multirow{2}{*}{$\begin{array}{c}\text { Type of } \\
\text { appliance }\end{array}$} & \multicolumn{2}{|c|}{ Total } & \multicolumn{2}{c|}{ Electric } & \multicolumn{2}{c|}{ Natural gas } & \multicolumn{2}{c|}{ Propane } & \multicolumn{2}{c|}{ Location } \\
\cline { 2 - 11 } & Number & $\%$ & Number & $\%$ & Number & $\%$ & Number & $\%$ & $\begin{array}{c}\text { IH } \\
(\%)\end{array}$ & $\begin{array}{c}\text { UH } \\
(\%)\end{array}$ \\
\hline \hline Cooking range & 298 & 93 & 222 & 74 & 44 & 15 & 32 & 11 & 100 & 0 \\
Stove top range & 20 & 6 & 16 & 75 & 1 & 5 & 3 & 5 & 85 & 15 \\
Detached oven & 30 & 9 & 25 & 83 & 1 & 3 & 4 & 13 & 100 & 0 \\
Refrigerator & 307 & 96 & 307 & 100 & 0 & 0 & 0 & 0 & 99 & 1 \\
Microwave oven & 212 & 66 & 212 & 100 & 0 & 0 & 0 & 0 & 99 & 1 \\
Dishwasher & 70 & 22 & 70 & 100 & 0 & 0 & 0 & 0 & 100 & 0 \\
Freezer & 82 & 26 & 82 & 100 & 0 & 0 & 0 & 0 & 65 & 35 \\
Clothes washer & 267 & 83 & 267 & 100 & 0 & 0 & 0 & 0 & 62 & 38 \\
Clothes dryer & 219 & 68 & 208 & 95 & 8 & 4 & 3 & 1 & 56 & 44 \\
Television & 300 & 94 & 300 & 100 & 0 & 0 & 0 & 0 & 96 & 4 \\
Well pump & 100 & 31 & 100 & 100 & 0 & 0 & 0 & 0 & 38 & 62 \\
\hline
\end{tabular}

Notes: Total - houses containing a specific appliance regardless of fuel type

Electric - part of "Total" that primarily runs on electricity

Natural gas - part of "Total" that primarily runs on natural gas

Propane - part of "Total" that primarily runs on propane

Number - number of houses containing a specific appliance

$\%$ - percent of houses containing a specific appliance

Location - physical location of a specific appliance

IH - intentionally heated area

$\mathrm{UH}$ - unintentionally heated area

procedure appeared to work well. Examination of Table 3.3 and the distribution plots and tables in Appendix $G$ showed that house and occupant characteristics between groups were similar in most areas deemed to be important. 


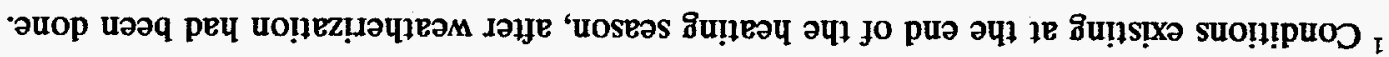

\begin{tabular}{|c|c|c|c|}
\hline$\% \$ S$ & $\% 05$ & \%ES & 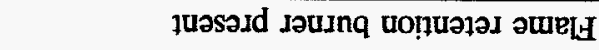 \\
\hline \multirow[t]{2}{*}{$000^{\circ} 6 Z \mathrm{I}$} & $000^{6} 0 t I$ & $00 \mathcal{S}^{2} z \varepsilon \mathrm{I}$ & 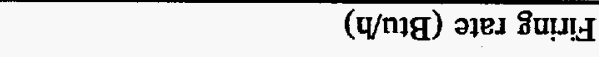 \\
\hline & & & ¡WEILSXS DNILVAH-GDVAS \\
\hline$L^{\prime} t$ & $8 z$ & Ito & 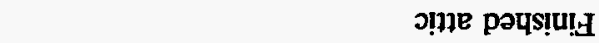 \\
\hline 999 & $9+5$ & 6.5 & s!ne paqșigun \\
\hline $6 \mathrm{I}$ & 9'I & 8I I & 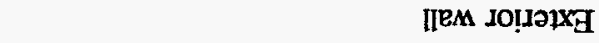 \\
\hline $6 L^{\circ} 0$ & $S Z 0$ & I $z^{\prime} 0$ & lleм uo!̣epunoy \\
\hline \multirow[t]{2}{*}{$\angle 60$} & $t t^{0} 0$ & $6 L 0$ & 8ิu!!ฺว uо!̣epuno \\
\hline & & & 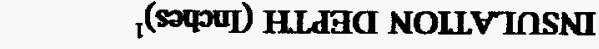 \\
\hline \%I6 & $\% 28$ & $\% 88$ & $\operatorname{a!nV}$ \\
\hline$\% 09$ & $\% 25$ & $\%$ LS & [IRM IO!Ja1X] \\
\hline$\% 9$ & $\% 9$ & $\% 9$ & \|ем uo!̣epuno \\
\hline \multirow[t]{2}{*}{$\% \mathrm{IZ}$} & $\% 8$ & $\%$ LI & 8̊u!!!əo นo!̣epuno \\
\hline & & & I $(\operatorname{sesnoH}$ jo \%) INESH\&d NOLLVTISNI \\
\hline $26 L$ & $6 \varepsilon 8$ & $28 L$ & э!ne pəuș̣ugu $\Omega$ \\
\hline$\varepsilon L L$ & $t 6 L$ & $9 \mathscr{E L}$ & 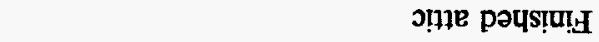 \\
\hline t9I & $08 \mathrm{I}$ & 69I & мори!M \\
\hline $8 L S I$ & OL9I & $809 I$ & ІІем ןЕшәџХВ \\
\hline$\varepsilon+Z I$ & LEEI & $t \angle Z I$ & 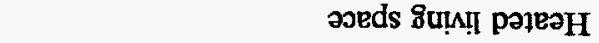 \\
\hline EIEI & ZLEI & ZEEI & วJeds Iu!̣̣TT \\
\hline \multirow[t]{2}{*}{$\angle 99$} & $\angle \forall L$ & $\varepsilon 69$ & 10วшวรEg \\
\hline & & & (zRd) SVAYY GSกOH \\
\hline$\angle 26 I$ & $0 \varepsilon 6 \mathrm{I}$ & $826 I$ & I!!nq әsnoq IEәX \\
\hline E9L'0I & IOI'II & $698^{\circ} 0 \mathrm{I}$ & (\$) әwOou! jenudy \\
\hline $9 \tau \varepsilon$ & SSE & $\varepsilon \varepsilon \varepsilon$ & 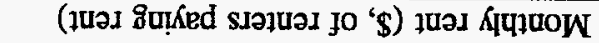 \\
\hline tII & $\varepsilon \mathbf{I}$ & EI & 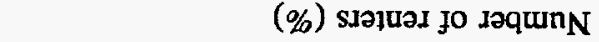 \\
\hline $6 \mathrm{I}$ & $6 I$ & $6 \mathrm{I}$ & 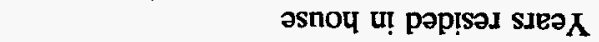 \\
\hline \multirow[t]{2}{*}{$t 8 z$} & $\mathcal{S Z E}$ & $\angle 6 Z$ & słuednsso jo dəqunn $\mathbf{N}$ \\
\hline & & & NOLLVKDOANI TVAGNAD \\
\hline рад!ачцеәм & jonuos & səsnoY IIV & 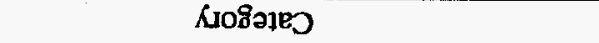 \\
\hline
\end{tabular}

ș̣s! 



\section{DESCRIPTION OF WEATHERIZATION ACTIVITIES}

Information was collected on the service delivery procedures and weatherization measures applied to 218 of the 222 weatherized houses monitored during the study using the Fuel-Oil Study Weatherization Information Survey provided in Appendix $\mathrm{C}^{4}$. Estimates of the frequency with which service delivery procedures were applied and weatherization measures were installed for the northeast region as a whole are presented in this section. Weighted analyses were performed to be consistent with the regional fuel-oil savings calculated in Sect. 5 .

From the data collected under the study, we estimated that 23,400 single-family houses heated by fuel-oil were weatherized by local weatherization agencies in the 1991 and 1992 program years in the northeast: 11,751 in program year 1991 and 11,670 in program year 1992. The results presented in this section are primarily for both program years combined. Unless otherwise noted, percentages for individual years were within five percentage points of the value for the combined years. Differences between years were likely due to sampling different local weatherization agencies rather than changes in DOE or state policies, guidance, and program design.

\subsection{SERVICE DELIVERY PROCEDURES}

An envelope measure selection procedure was applied to virtually all fuel-oil heated houses weatherized in the northeast region during program years 1991 and 1992 (Fig. 4.1). A space-heating system measure selection procedure was applied to $77 \%$ of the houses, implying

\footnotetext{
${ }^{4}$ Information used in this section was obtained directly from the local weatherization agencies and was based upon their records. Some inconsistencies associated with the information remained following close examination of the data and discussions with the agencies. Major weatherization measures (attic insulation, storm windows, etc.) were correctly identified. Some ambiguity remained in differentiating between air leakage measures, window and door measures, and other energy-efficiency work because of the similarity between these categories. Examples include identifying weatherstripping as a window and door "other" measure rather than general caulking and weatherstripping, listing window pane installations as a window and door "other" measure rather than structural weatherization measure, and identifying sash lock installation as an "other" measure of either air leakage, window and door, or structural measure. Thus, the frequency of the minor weatherization measures and "other" categories should be considered with caution.
} 


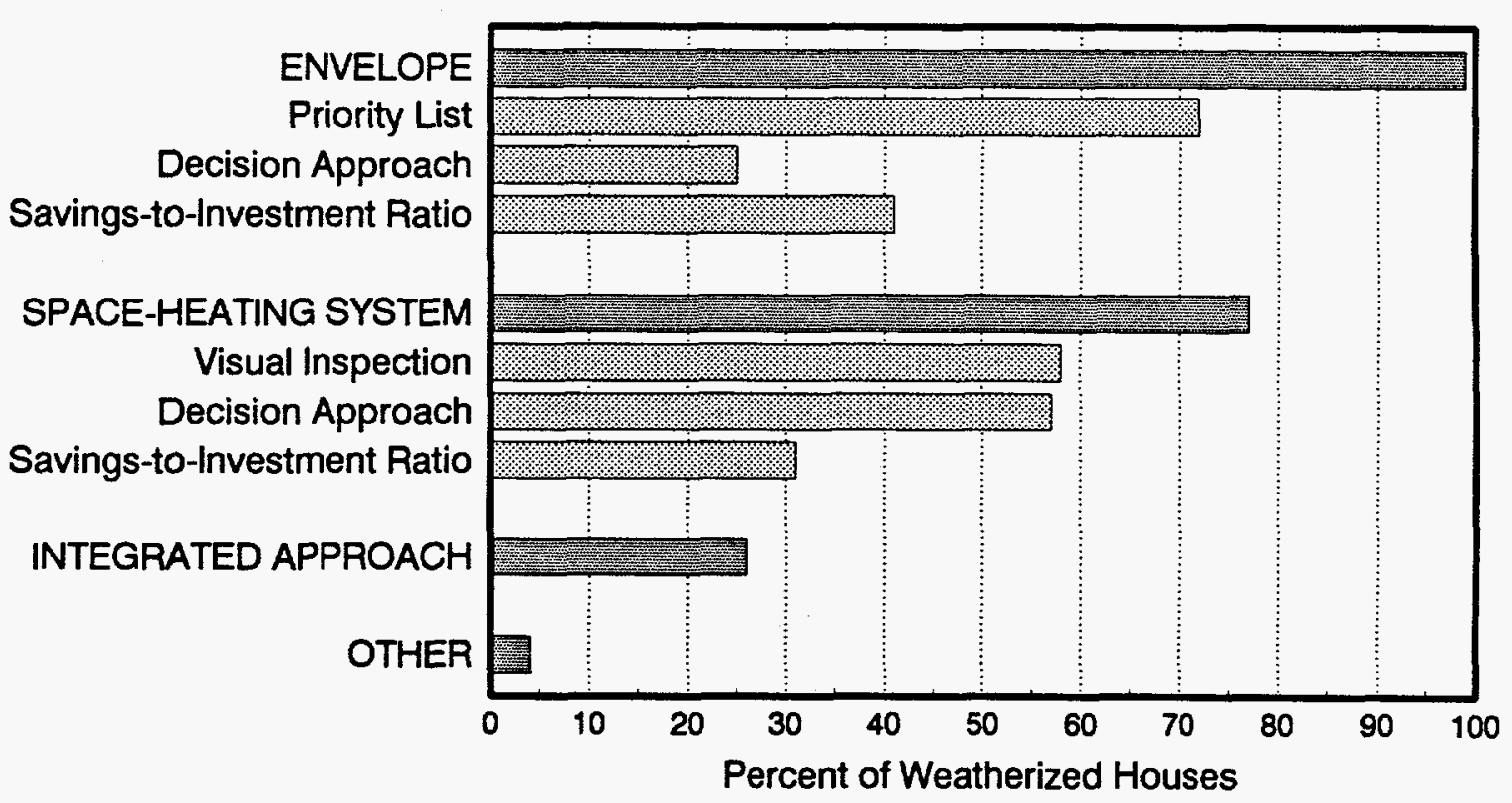

Fig. 4.1. Application frequency of measure selection procedures in fuel-oil heated houses during program years 1991 and 1992 for the northeast region.

that space-heating system measures were not options in the remaining $23 \%$ of the houses. These procedures were generally applied separately, although an integratEd approach (accounting for the influence among measures) was used in $25 \%$ of the houses.

A priority list (a checklist or prescribed list of measures) was usually employed to select envelope measures, whereas a decision approach or scoring (calculation) performed for each house was not used very often. A space-heating system measure selection procedure based on physical characteristics or a standard approach (this included a visual inspection and safety inspection) was used in $58 \%$ of the houses. Similarly, a decision approach or scoring (calculation) based on operating performance (steady-state efficiency, smoke number, or carbon monoxide reading) was used in $57 \%$ of the houses. Envelope measures were selected in $41 \%$ of the houses and space-heating system measures were selected in $31 \%$ of the houses based on an analysis of energy savings per dollar invested for that particular house. 
Table 4.1. Comparison of measure selection procedures used by program year

\begin{tabular}{||c|c|c|c||}
\hline \multirow{2}{*}{} & \multicolumn{3}{|c|}{ Program year } \\
\cline { 2 - 4 } & 1991 & 1992 & Combined \\
\hline \hline Envelope selection procedure applied & $99 \%$ & $99 \%$ & $99 \%$ \\
\hline priority list & $76 \%$ & $67 \%$ & $72 \%$ \\
\hline decision approach & $18 \%$ & $32 \%$ & $25 \%$ \\
\hline analysis of energy savings per dollar invested & $31 \%$ & $50 \%$ & $41 \%$ \\
\hline \hline Space-heating system selection procedure applied & $97 \%$ & $56 \%$ & $77 \%$ \\
\hline physical characteristics based on visual inspection & $74 \%$ & $43 \%$ & $58 \%$ \\
\hline decision approach based on operating performance & $72 \%$ & $41 \%$ & $57 \%$ \\
\hline analysis of energy savings per dollar invested & $23 \%$ & $39 \%$ & $31 \%$ \\
\hline
\end{tabular}

Table 4.1 shows that there were significant differences in the selection procedures used during the two program years. There was a shift in program year 1992 from envelope measure selection procedures based on a priority list to a decision approach or analysis of energy savings per dollar invested for the house. A space-heating system measure selection procedure was applied in only $56 \%$ of the houses in program year 1992 compared to $97 \%$ in 1991 . In program year 1992, there was greater emphasis on an analysis of energy savings per dollar invested in selecting the space-heating system measures.

The frequency of use of selected diagnostic procedures is shown in Fig. 4.2. Blower doors were used to diagnose air leakage problems in about $75 \%$ of the houses. The blower doors were used in almost all of these houses to measure air leakage rates and locate leakage areas. In over half of these houses, a cost-effective guideline was also used to help determine when to stop sealing. Diagnostic procedures to examine space-heating systems were used in about $80 \%$ of the houses. $^{5}$ In almost all cases, a steady-state efficiency test and safety inspection were conducted.

${ }^{5}$ This is somewhat inconsistent with the data indicating that a space-heating system measure selection procedure was applied in $77 \%$ of the houses and that a selection procedure based on operating performance was applied in just $57 \%$ of the houses. This inconsistency may have resulted from the fact that space-heating system measures were installed in some houses before 


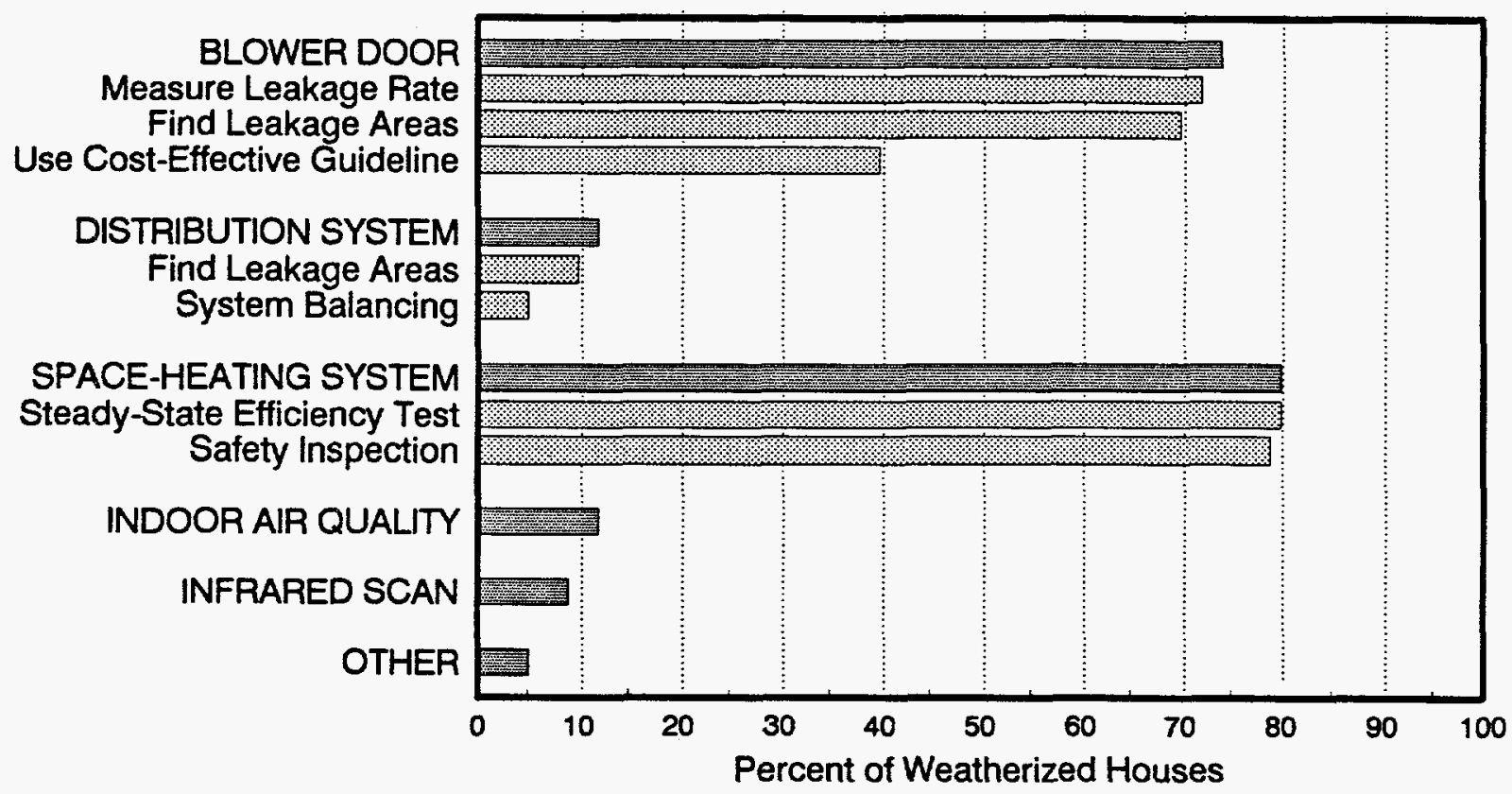

Fig. 4.2. Application frequency of selected diagnostic procedures in fuel-oil heated houses during program years 1991 and 1992 for the northeast region.

Air distribution system diagnostics were used in $11 \%$ of the houses, but this represented a usage rate of over $20 \%$ in houses that had air distribution systems. Indoor air quality tests and infrared scans were performed infrequently in the houses. Carbon monoxide tests were performed in $28 \%$ of the houses and radon tests were never performed. Because indoor air quality tests were performed in just $12 \%$ of the houses, a large portion of the carbon monoxide tests were likely performed in conjunction with the space-heating system diagnostics and did not specifically address the main living areas of the house.

A space-heating system steady-state efficiency test and safety inspection was performed in almost every house (97\% and $96 \%$, respectively) in program year 1991, whereas these diagnostics were performed in just $63 \%$ and $61 \%$, respectively, of the houses in program year 1992 . This is consistent with the difference between years observed in the use of a space-heating system

pre-weatherization data were collected because the systems were determined to be inoperative or operating unsafely. 
measure selection procedure. The use of blower doors to find leakage areas was slightly greater in program year 1992 compared to 1991.

A quality control inspection of the installed envelope measures was performed in almost all houses (Fig. 4.3). A visual inspection was performed in all inspected houses, and a blower door was used as a post inspection device in less than $40 \%$ of the houses, which was much less frequent than its use as a pre-inspection device. A quality control inspection of the space-heating system was performed in every house receiving a space-heating system measure $153 \%$ of the houses, as will be discussed in Sect 4.2). Inspections based on visual examinations and diagnostic testing (primarily steady-state efficiency testing) were used with equal frequency (both were used in about $80 \%$ of the houses receiving a space-heating system measure). Visual inspections were performed more frequently in program year 1991 (in $91 \%$ of the houses receiving space-heating system measures) than $1992(64 \%)$.

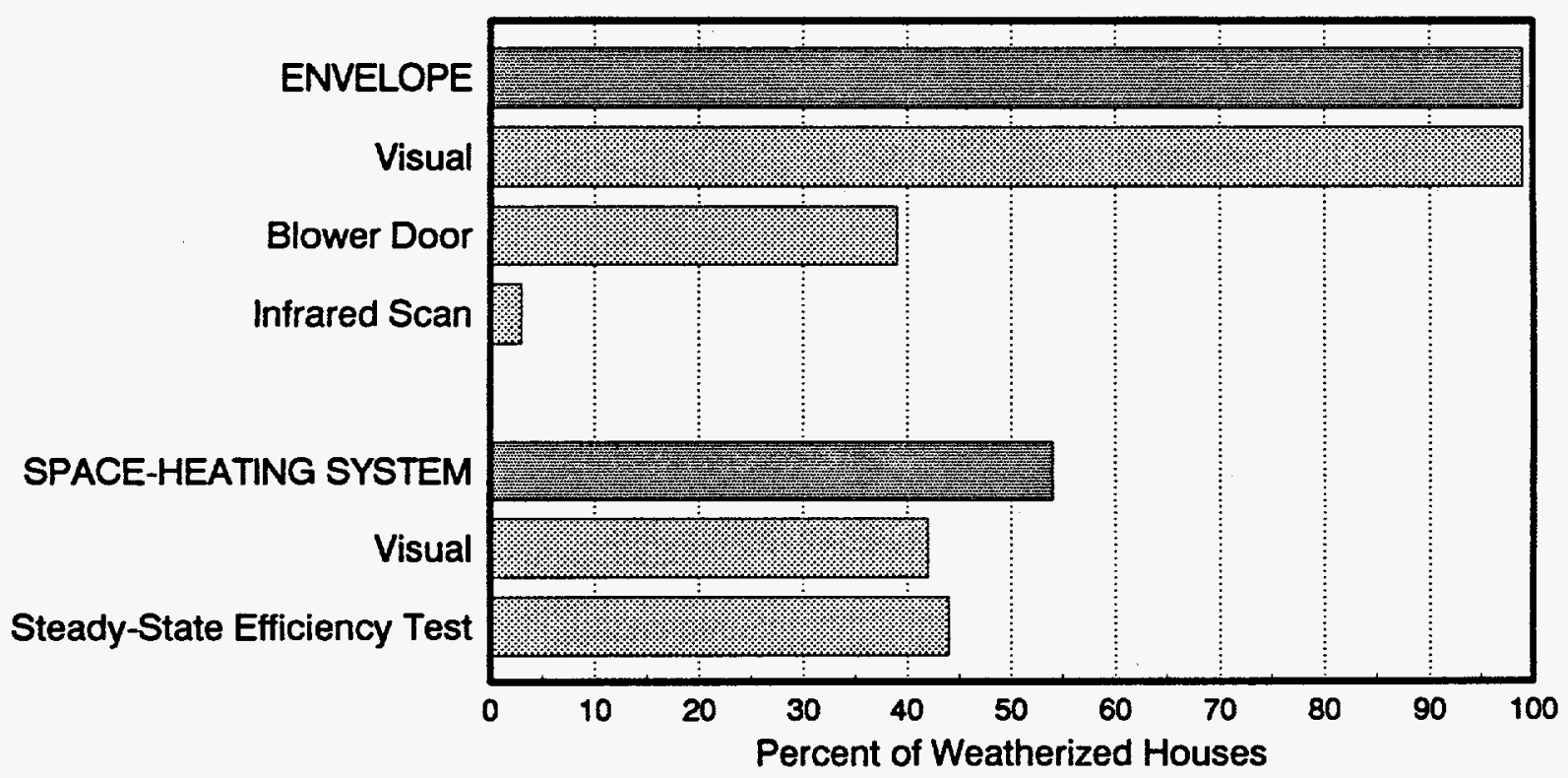

Fig. 4.3. Application frequency of quality control inspections in fuel-oil heated houses during program years 1991 and 1992 for the northeast region. 


\subsection{WEATHERIZATION MEASURES INSTALLED}

The five most common types of weatherization measures are shown in Fig. 4.4. We estimated that insulation measures were installed in $82 \%$ of the 23,421 fuel-oil heated houses weatherized in the northeast region during program years 1991 and 1992 , with $96 \%$ of the houses receiving air leakage measures. This is consistent with the Program's historical emphasis on infiltration mitigation and envelope improvements. Measures addressing the domestic waterheating system were installed in $62 \%$ of the houses, and energy-efficiency improvements to windows and doors were made in only $41 \%$ of the houses. Space-heating system measures, which have received increasing emphasis in recent years, were installed in 53\% of the houses. Spacecooling system measures (such as air-conditioner tune-ups and replacements) were never performed.

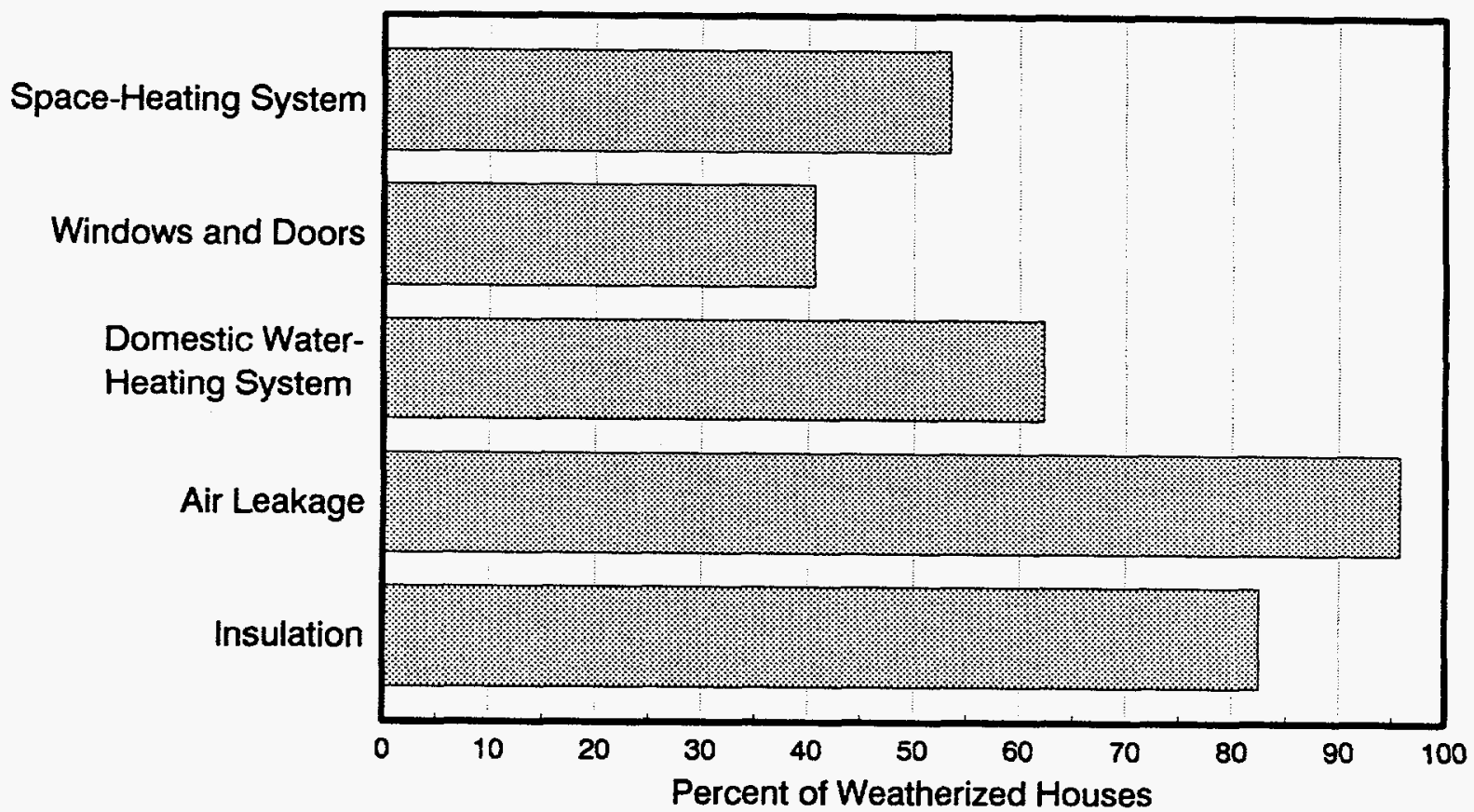

Fig. 4.4. Installation frequency of general types of weatherization measures in fuel-oil heated houses during program years 1991 and 1992 for the northeast region. 


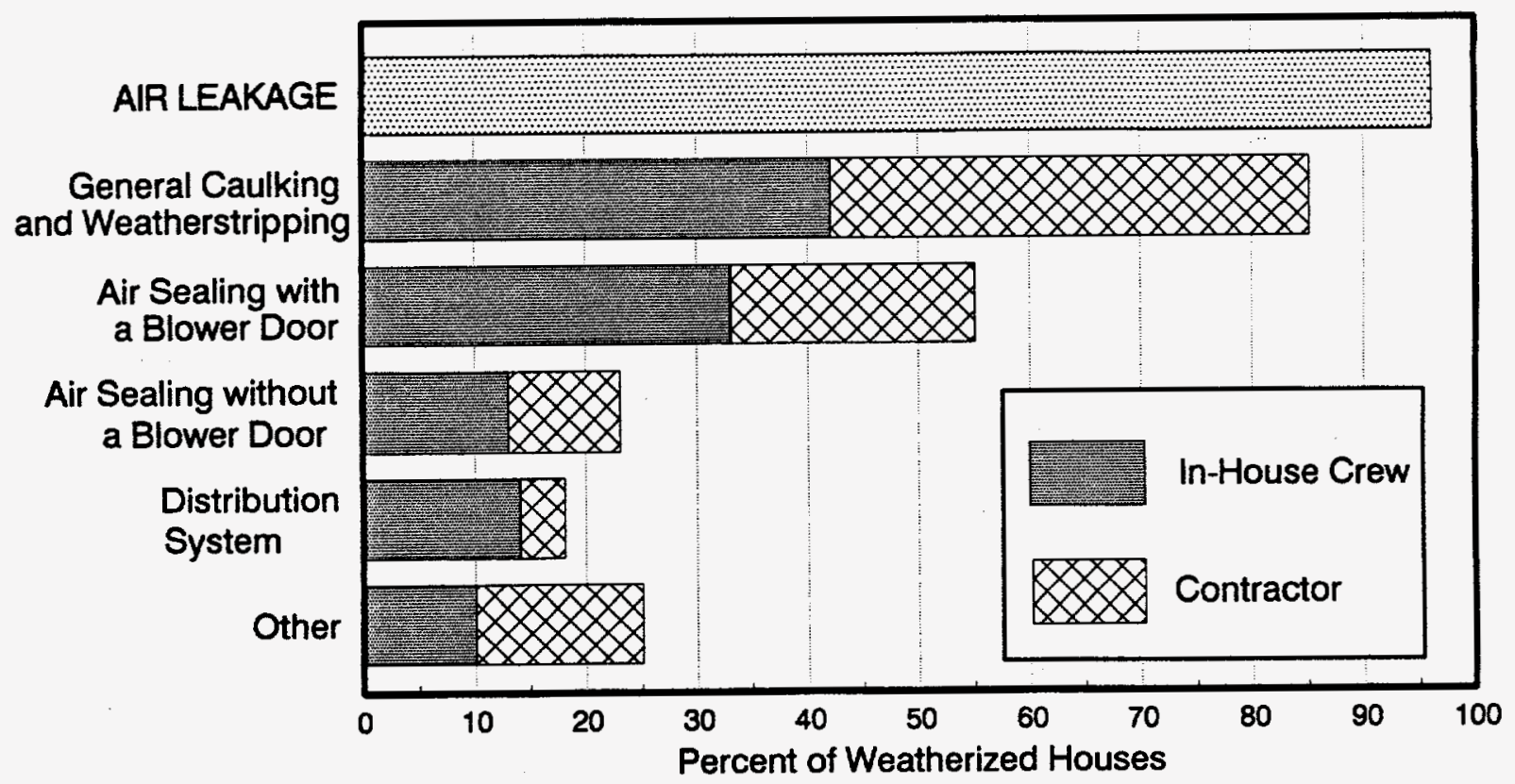

Fig. 4.5. Installation frequency of specific air leakage measures in fuel-oil heated houses during program years 1991 and 1992 for the northeast region.

Each of these categories is examined in more depth in the following paragraphs. It should be remembered that the presentation identifies all measures installed in the houses regardless of funding source. Although most funds may have required following Program rules, funds with fewer restrictions could also have been used.

General caulking and weatherstripping of doors and windows was the most frequent air leakage measure performed on the houses (Fig. 4.5). Air sealing work (defined as work emphasizing air-leakage bypasses) was also an important air leakage measure, being performed most often using a blower door. Air sealing work using a blower door was performed in $46 \%$ of the houses in program year 1990, compared to $63 \%$ in program year 1992 . For both years combined, $54 \%$ of the houses had air sealing work performed using a blower door. This is somewhat inconsistent with the reported use of blower doors as a diagnostic tool in about $75 \%$ of the houses (Sect. 4.1). This discrepancy may be explained if houses receiving a blower-door diagnostic did not require air sealing work. Air distribution system leaks were repaired in only $18 \%$ of the houses, but this represents a repair rate of a little less than $50 \%$ in houses with air distribution systems. This, too, is somewhat inconsistent with the reported use of air distribution 


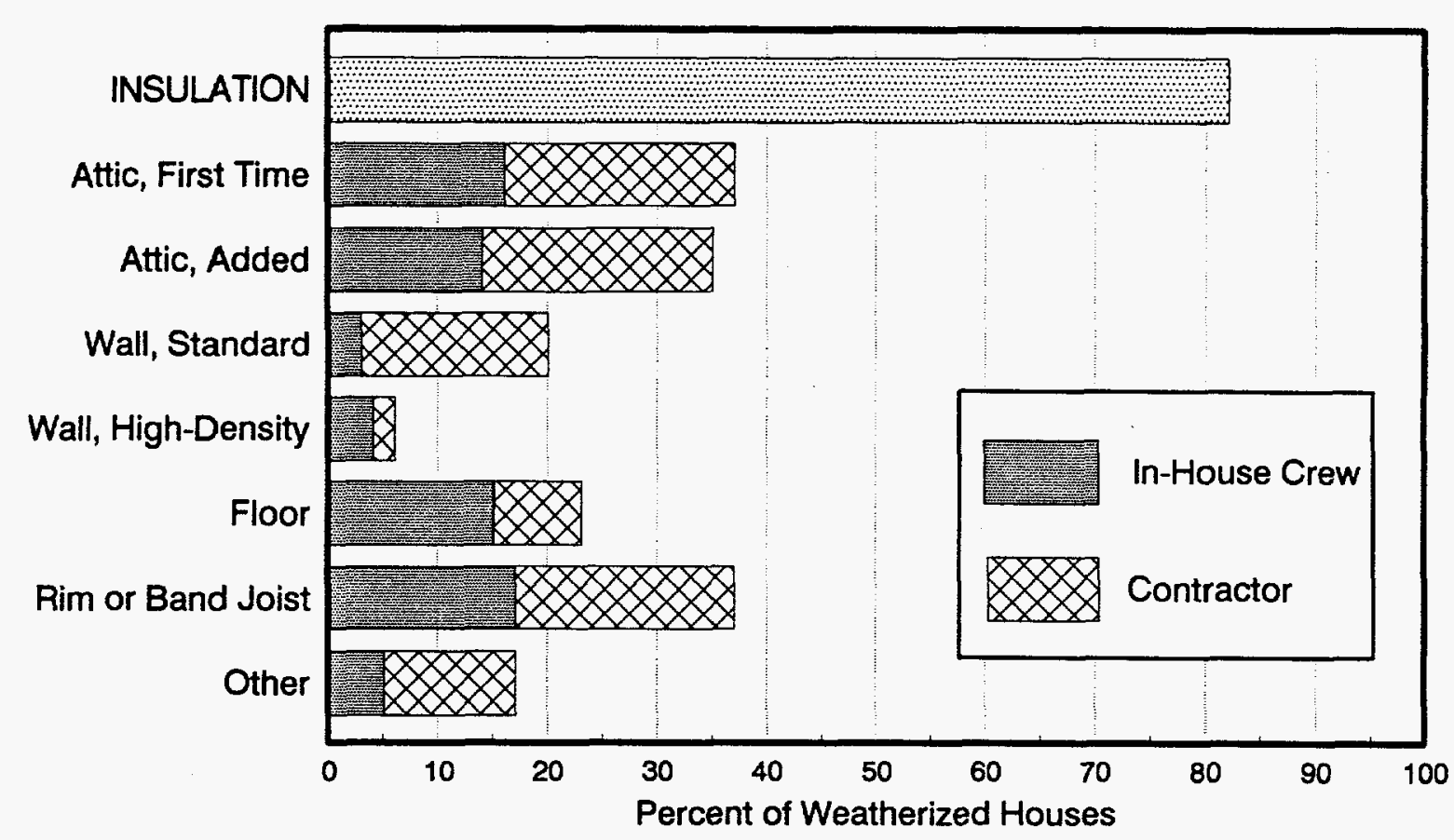

Fig. 4.6. Installation frequency of specific insulation measures in fuel-oil heated houses during program years 1991 and 1992 for the northeast region.

system diagnostics in $11 \%$ of the houses, although identification of distribution system leakage areas as part of the general air sealing work could explain this difference.

Installation of attic insulation (either for the first time where no insulation previously existed or added to existing insulation) was commonly performed in fuel-oil heated houses weatherized during program years 1991 and 1992 (Fig. 4.6) ${ }^{6}$. As with the two types of attic insulation, rim or band joist insulation was installed in about a third of the weatherized houses. Floor insulation and wall insulation were installed in $25 \%$ and $20 \%$ of the houses, respectively. The standard, two-hole technique for installing wall insulation was usually employed, although some installations were performed using a single-hole, tube-fill approach. This latter approach allowed wall insulation to be installed at higher densities, which can decrease air infiltration, and it emphasized concurrent sealing of major air-leakage bypasses while insulating the walls.

\footnotetext{
${ }^{6} \mathrm{~A}$ house could receive both new and added insulation if a portion of the attic was uninsulated and another portion had an insufficient level of insulation.
} 


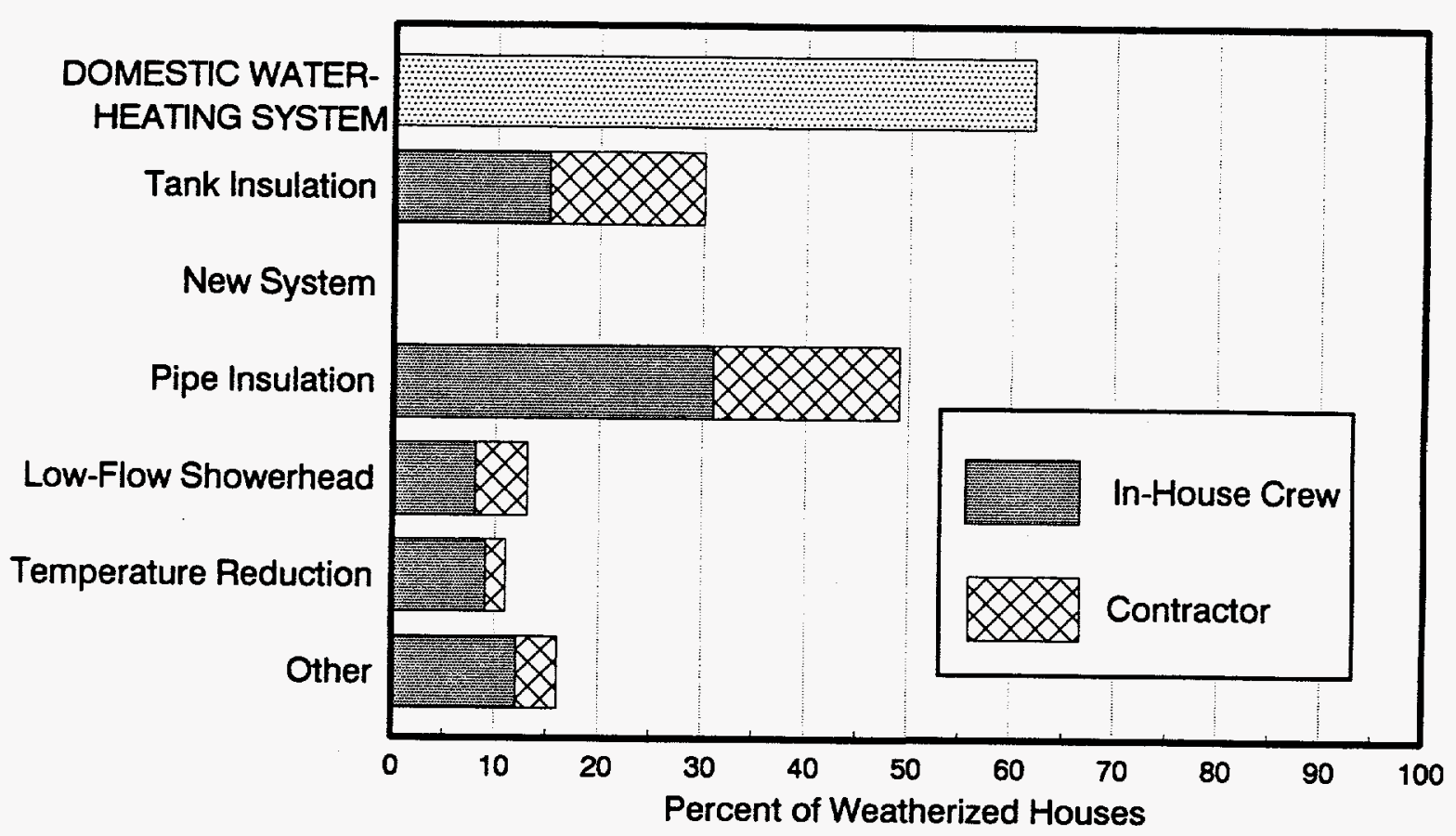

Fig. 4.7. Installation frequency of specific domestic water-heating system measures in fueloil heated houses during program years 1991 and 1992 for the northeast region.

Primary domestic water-heating system measures were pipe and tank insulation (Fig. 4.7). No new systems were installed, which is consistent with the fact that new systems are not an approved Program measure. Tank insulation was installed relatively infrequently (in just $29 \%$ of the houses) primarily because $39 \%$ of the houses had tankless systems (for which this measure is not applicable). Tank insulation was installed in about $50 \%$ of the houses with stand-alone systems for which insulation is applicable. Somewhat surprisingly, tank set-point temperatures were reduced in only $11 \%$ of the houses. This, again, may be partly due to the presence of tankless systems which allow little control over domestic hot water temperature. The installation of low-flow showerheads was much less the second year: $21 \%$ of the houses received low-flow showerheads in program year 1991 while only 4\% received them in program year 1992.

Energy-efficiency improvements were made to space-heating systems in $53 \%$ of the houses weatherized during the two program years, or about $70 \%$ of the houses in which space-heating system measures were considered an option. Measures were installed somewhat more frequently in program year 1991 (59\% of the houses) than in 1992 (48\%). This is consistent with the fact 


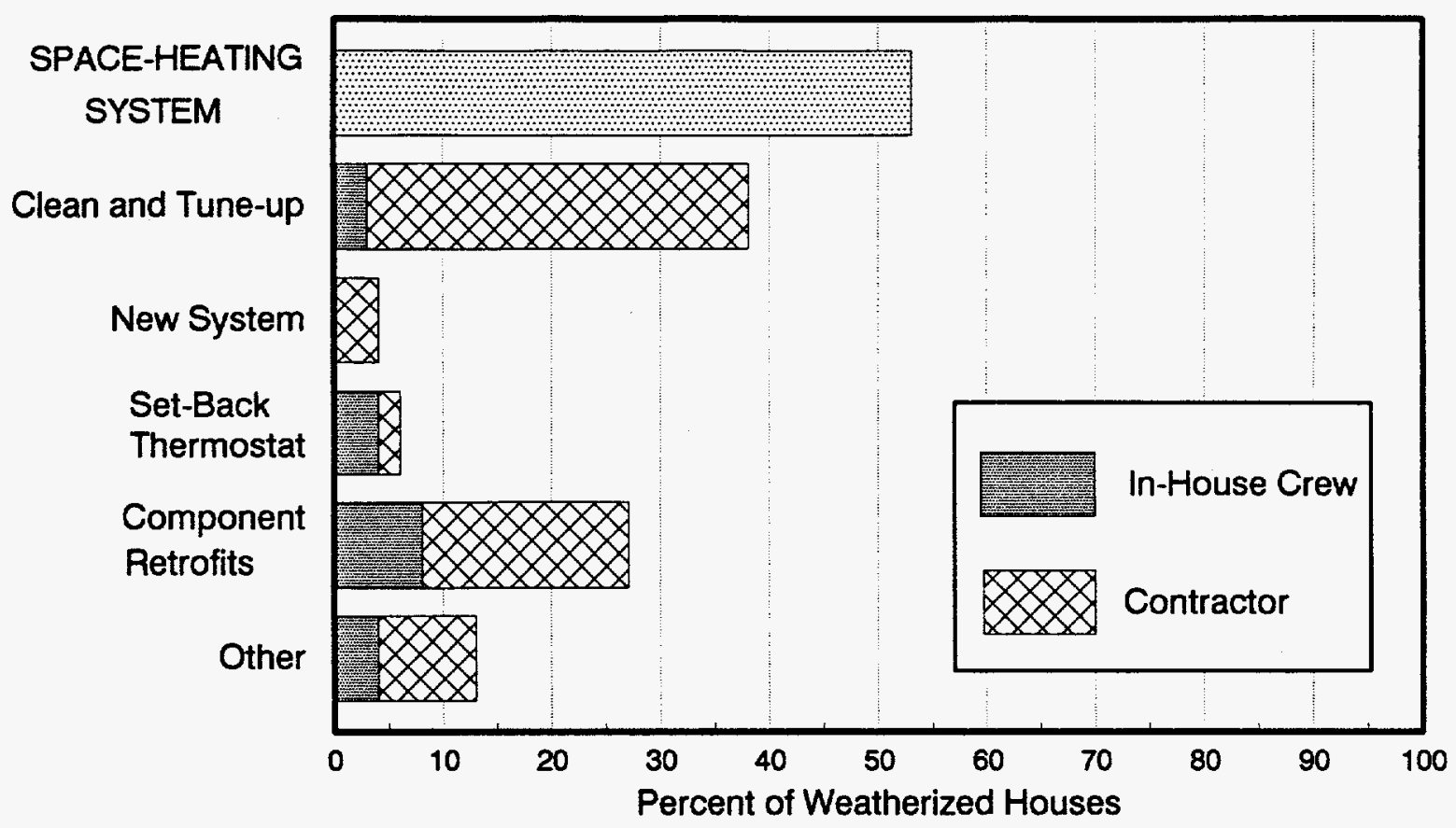

Fig. 4.8. Installation frequency of specific space-heating system measures in fuel-oil heated houses during program years 1991 and 1992 for the northeast region.

that space-heating system measures were considered as options more frequently in program year 1991. A system clean and tune-up was the most commonly performed space-heating system measure (Fig. 4.8). This measure was performed in $38 \%$ of the houses, or more than two-thirds of the houses receiving a space-heating system measure. Installation or repair of heating system components was also a frequently performed measure. Examples of components include vent dampers, flame-retention burners, duct insulation, and system balancing. Repairs were performed to fix inoperative equipment and/or for safety reasons. One common concern with performing space-heating system measures is that new, expensive systems will be frequently installed. This concern may be unfounded, because new, complete heating systems were installed in only $4 \%$ of all the houses, or less than $10 \%$ of those houses receiving a space-heating system measure. One noteworthy finding is that all of the new burners installed as components or as part of a new system were of the flame-retention type. These are very efficient burners.

Space-heating system items accounted for most of the measures performed outside of the weatherization period. 


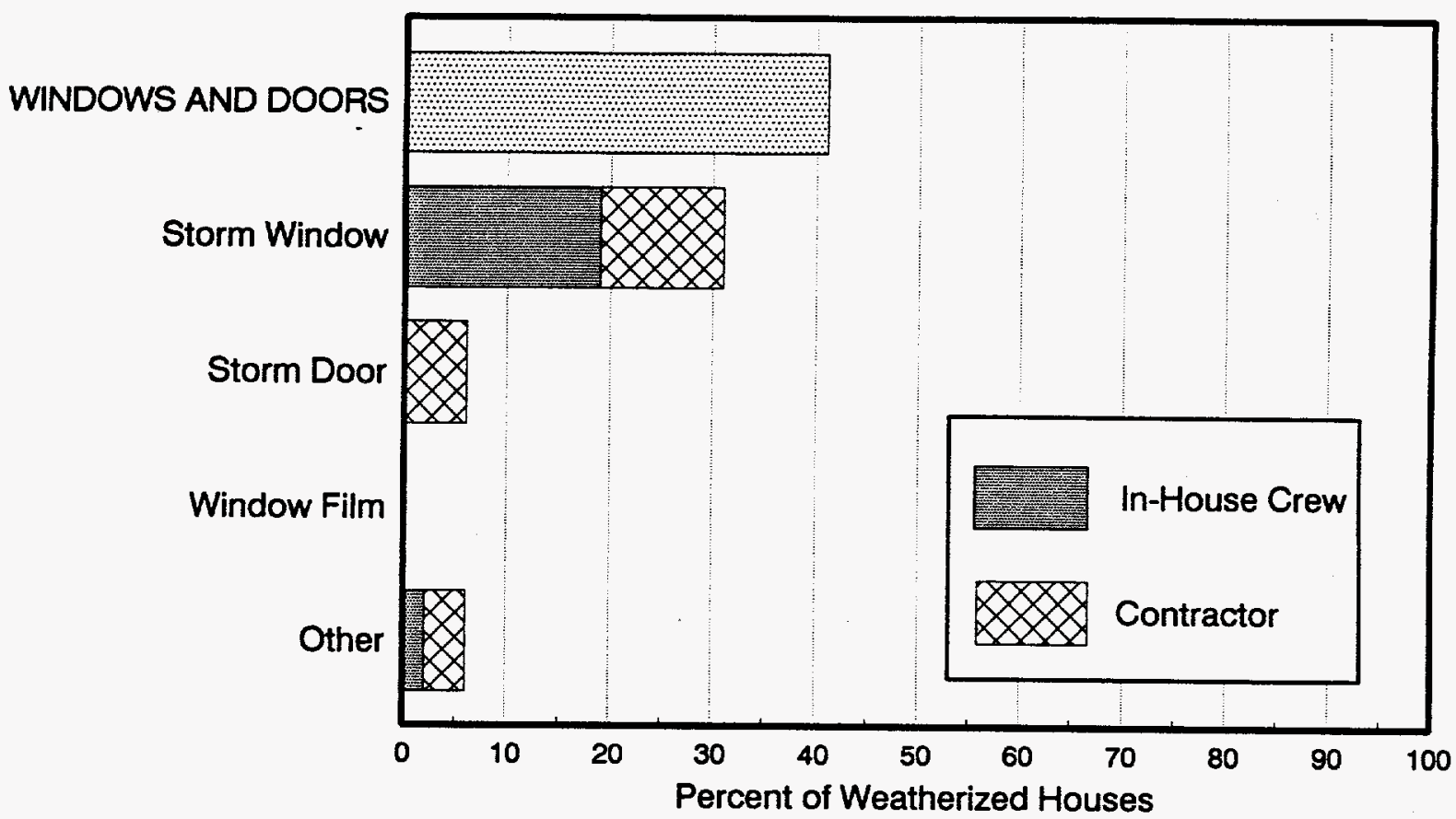

Fig. 4.9. Installation frequency of specific window and door measures in fuel-oil heated houses during program years 1991 and 1992 for the northeast region.

Energy-efficiency improvements to windows and doors were performed more frequently in program year 1992 (in 53\% of the houses) than program year 1991 (28\% of the houses). Storm windows were predominately installed (Fig. 4.9), and were the primary reason for the difference in window and door installation frequency between the two program years (storm windows were installed in $25 \%$ of the houses in program year 1991 and in 37\% in program year 1992). Storm doors were installed in only $6 \%$ of the houses. Window films, which are measures designed primarily to reduce cooling loads, were never installed.

Other energy-efficiency items not falling within the five major weatherization categories discussed above were frequently performed in the houses (Fig. 4.10). Structural weatherization measures were common, being performed in over $80 \%$ of the houses. This work involved replacing broken window panes or entire window units, reglazing windows, fixing or replacing doors, and increasing attic ventilation. The degree of window glazing activity (in over $50 \%$ of the houses) is consistent with the level of caulking and weatherstripping performed as air leakage; these activities are often performed as general heat waste reduction. The frequent installation of 


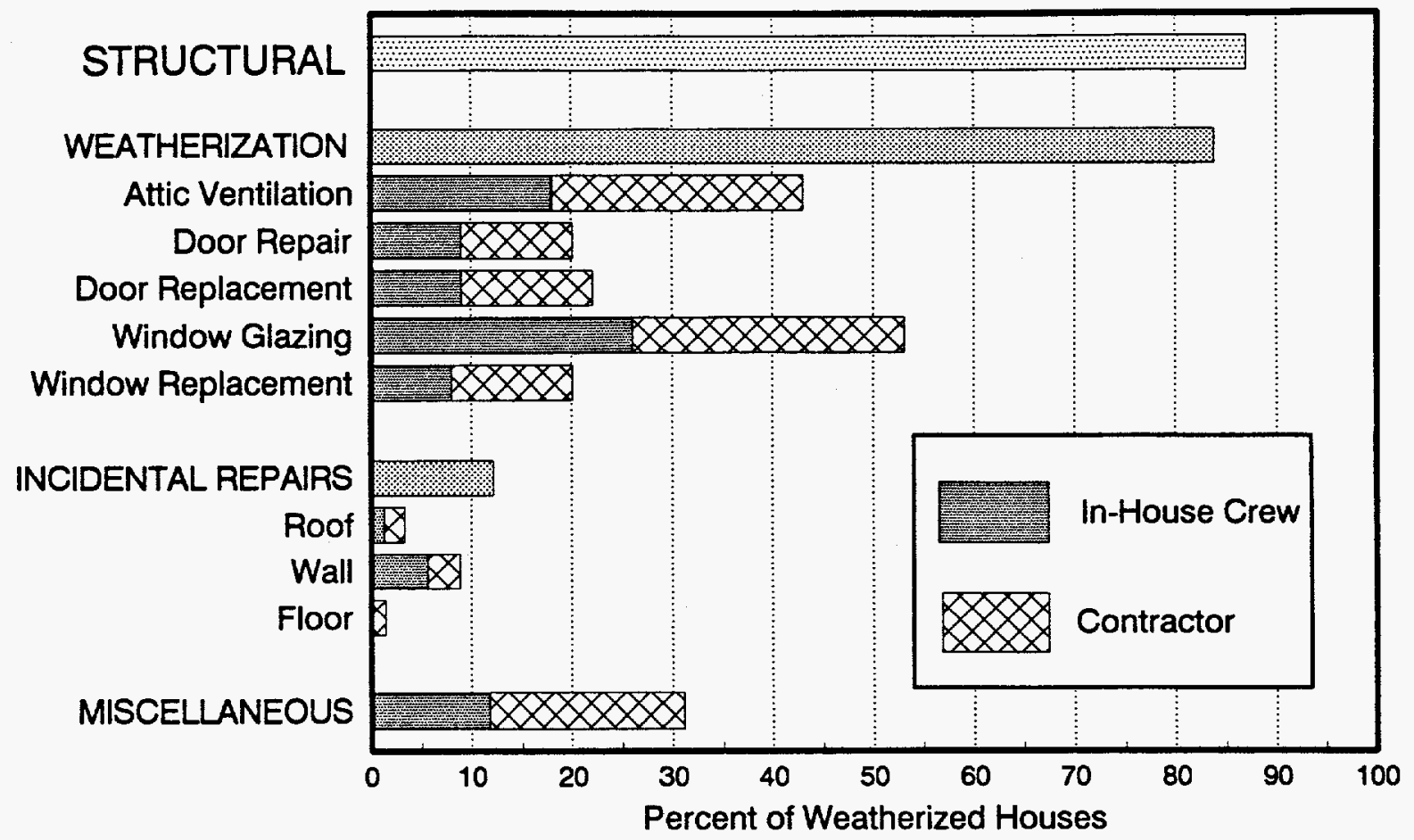

Fig. 4.10. Installation frequency of structural weatherization measures and repairs in fueloil heated houses during program years 1991 and 1992 for the northeast region.

attic ventilation (in $43 \%$ of the houses) is explained by its association with attic insulation; installation of adequate attic ventilation is often required before attic insulation can be installed. Incidental repairs made to the roof, wall, and floor to protect the integrity of installed efficiency measures were performed in only about $10 \%$ of the houses. Miscellaneous work that could not be categorized was performed in about $30 \%$ of the houses.

Client education was provided to over $95 \%$ of the weatherized households (Fig. 4.11). Inperson education was provided to $91 \%$ of the households, and literature was mailed or left with the client about half of the time. Smoke detectors were installed in $3 \%$ of the houses as a health and safety measure.

Weatherization activity in a house was performed completely by employees of local weatherization agencies (in-house crews) in $27 \%$ of the houses, while activity was performed completely by contractor crews in 55\% of the houses. Both in-house and contractor crews performed the work in the remaining houses. In-house crews and contractors generally installed 


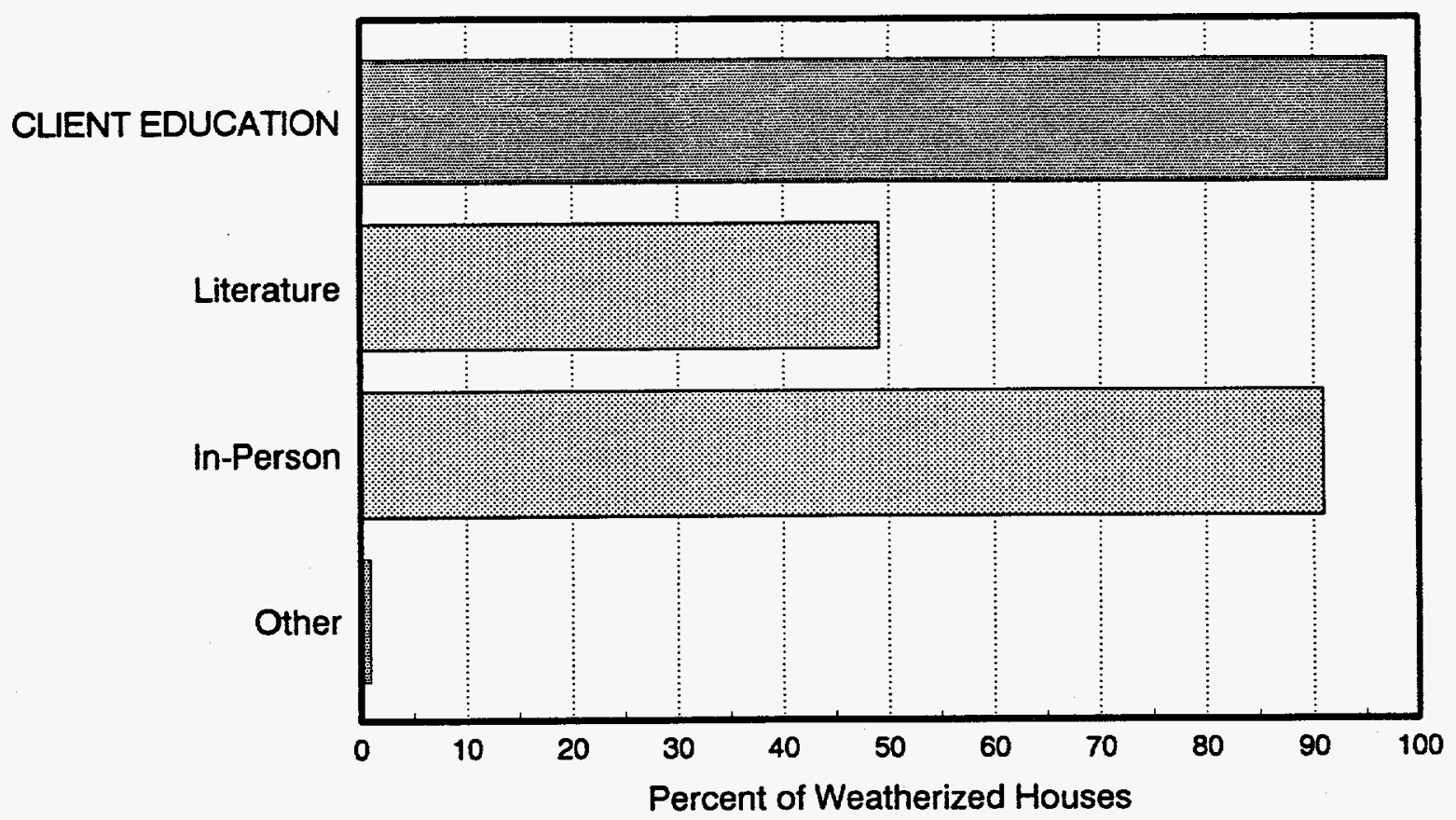

Fig. 4.11. Frequency of client education provided in fuel-oil heated houses during program years 1991 and 1992 for the northeast region.

window and door measures and air-leakage measures with equal frequency. Space-heating system measures (predominately tune-ups) were primarily performed by contractor crews $(78 \%)$, whereas domestic water-heating system measures (predominately pipe insulation) were performed more often by in-house crews (63\%). Insulation measures were performed somewhat more frequently by contractors ( $58 \%)$, especially standard wall insulation. In Figs. $4.5-4.10$, the division between in-house and contractor crews is indicated for each specific measure. 


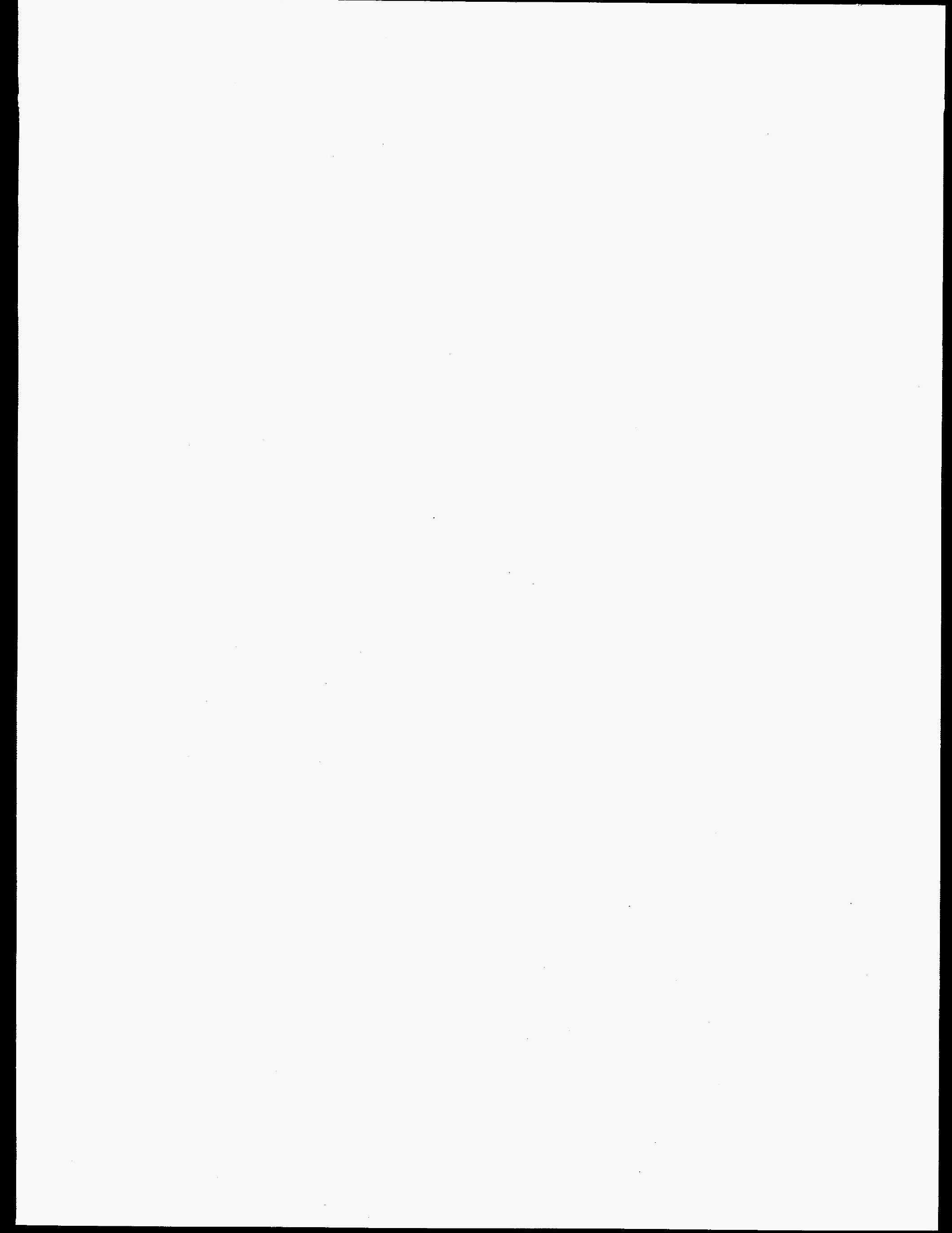




\section{FUEL-OIL CONSUMPTIONS AND SAVINGS}

Data loggers were installed in 337 houses (191 in program year 1991 and 146 in program year 1992) in order to monitor space-heating system fuel-oil consumption as well as indoor and outdoor air temperatures for the split-season study. The data loggers remained in each house for only one heating season. Each heating season was split into a pre-weatherization period and a post-weatherization period. The weatherized houses were weatherized during January of each respective year, while the control group remained unchanged, except for any emergency measures necessary to keep them operational. The periods were slightly different for each control and weatherized house for a number of reasons:

- The pre-weatherization period started when instrumentation was installed in each house. This varied for each house, typically between October and November.

- The pre-weatherization period ended when weatherization of the house was started, usually in about the middle of January.

- The post-weatherization period started when weatherization was completed, a process that usually took less than a week.

- Post-weatherization periods ended at the end of April, when house heating needs became sporadic in most areas.

Control houses were arbitrarily assigned a January 15 date for the end of the pre-weatherization period and the start of the post-weatherization period.

A majority of the houses monitored in the study had separate space-heating and domestic water-heating systems. For these houses, the fuel-oil consumption and savings presented in this section are normalized annual space-heating system values. The remaining houses ( $48 \%$ of the control houses and $34 \%$ of the weatherized houses) had tankless domestic hot-water systems. The space-heating system provides heat for domestic hot water in tankless systems during the winter and summer using a coil imbedded in the space-heating system boiler. The fuel-oil consumption and savings presented for these latter houses are normalized annual space-heating values and heating-season only domestic hot-water values combined. 
The terms "gross savings" or "gross change" are used to represent the difference between weather-normalized pre- and post-weatherization fuel-oil consumptions for both control and weatherized houses. An average gross savings was found by summing across houses and dividing by the number of houses summed. A positive savings means the pre-weatherization consumption was higher than the post-weatherization value, and visa versa for a negative savings. Using "savings" may sound strange when referring to a control house value, but it allows explaining differences between control and weatherized variables in the same terms. A "net savings" per weatherized house is also reported. The net savings was determined by subtracting the average gross savings of the control houses from the average gross savings of the weatherized houses. This adjustment accounts for non-Program induced factors affecting space-heating fuel-oil consumption not included in the normalization process. Average gross and net percent savings were calculated by dividing the average savings by the average pre-weatherization consumption and multiplying by 100 .

In order to utilize measured data for predicting savings, measured pre- and postweatherization consumptions were normalized so that they could be compared on the same basis. Normalization of the data was necessary because pre- and post-weatherization data collection periods occurred over different parts of the split heating season, so outdoor temperatures were different and data did not represent a full heating season. Also, indoor temperatures may not have remained constant at each site for both periods. The normalization process is described in more detail in Sect. 5.1.

Analyses were performed on 298 of the monitored houses (105 control houses and 193 weatherized houses). A useful set of pre- and post-weatherization monitoring data could not be collected from 10 control and 29 weatherized houses (12\% of our sample) because of:

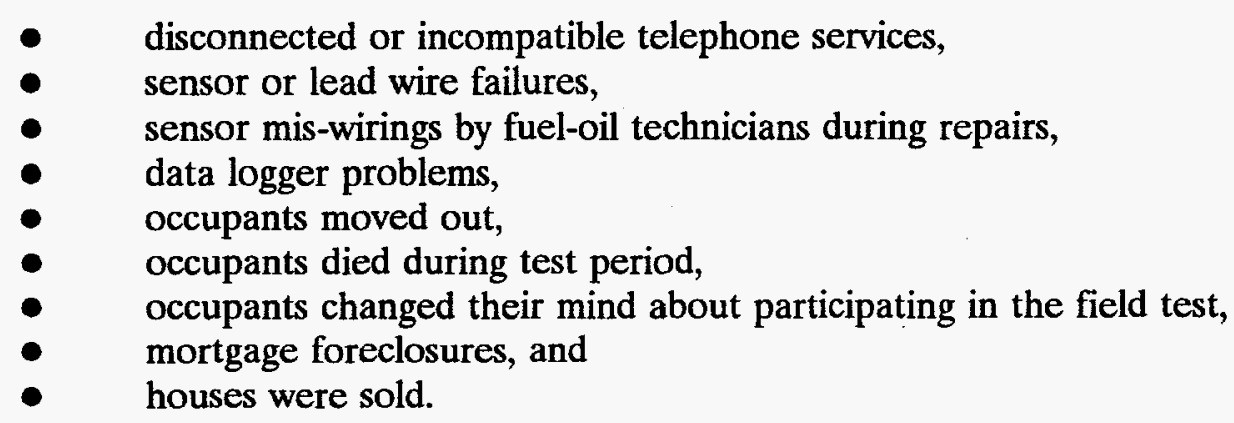


The $12 \%$ attrition rate was lower than our initial estimate of $20 \%{ }^{7}$

\subsection{METHOD OF ANALYSIS}

Measured hourly heating system run-time data were multiplied by the burner nozzle size for each site to obtain the hourly amount of fuel oil consumed. These were summed to obtain daily values for each house. Any changes in replacement nozzle sizes (following space-heating system tune-ups, for example) were accounted for in the calculations. Measured hourly indoor and outdoor temperatures were also converted into daily averages. A predictive linear regression modeling equation of the form

Fuel-oil consumption $=\mathrm{Mx}$ (Indoor temperature - Outdoor temperature $)+\mathrm{B}$

was fitted to the daily measured data for each site, where $M$ (the slope) and B (a regression constant) are empirical constants determined by a regression analysis of the data. The model states that fuel-oil consumption (energy input into the burner) is equal to a driving force (temperature difference) multiplied by a resistance (primarily the thermal integrity of the house envelope) plus a constant (which includes contributions from items such as heat generated from house internal loads). For tankless systems, the constant includes domestic hot-water fuel-oil consumption and the slope includes temperature dependent fuel-oil consumption for hot water.

The data from each house were divided into pre- and post-weatherization sets. A separate regression was run on each measured data set, so that two sets of regression coefficients were obtained for each house - one set describing the house fuel-oil consumption before weatherization, and one set describing fuel-oil consumption after weatherization.

Indoor temperatures for each house and historical outdoor temperatures for each location were needed to calculate normalized annual consumptions and savings. An average indoor temperature for each site was determined for the pre-weatherization period and for the post-

${ }^{7} \mathrm{~A} 15 \%$ attrition rate appears to be an attainable goal in a large-scale field test, but persistence on the part of the supporting field personnel is essential. 
weatherization period by averaging measured data for each period. "Typical Meteorological Year" (TMY) weather data tapes, available from the National Oceanographic and Atmospheric Administration, were obtained for the Northeast region. ${ }^{8}$ These weather data, which represent average annual weather conditions, are based on historical data from the various locations they represent and are in an hourly format. Table H.1 contains information on which TMY city was used for each local weatherization agency. ${ }^{9}$ The TMY hourly outdoor temperature data were converted into average daily temperatures for use in the normalizations.

The pre-weatherization regression coefficients from each site, the average preweatherization indoor temperatures from that site, and the selected-city daily TMY outdoor temperature data were used to estimate pre-weatherization daily fuel-oil consumptions for each house beginning October 1 and ending April 30 (essentially representing a typical heating season). Negative values of fuel-oil consumption (which occurred when outdoor temperatures were sufficiently warm to cause the regression models to predict negative fuel-oil usages) were set equal to zero. Normalized annual pre-weatherization fuel-oil consumptions for each house were then calculated by summing the daily estimates for the heating season.

The same procedure, but using post-weatherization regression coefficients and postweatherization indoor temperatures, was followed to calculate normalized annual postweatherization fuel-oil consumptions for each house.

A normalized annual gross savings for each house was obtained by subtracting the normalized annual post-weatherization consumption from the normalized annual preweatherization value. A percent savings was obtained by dividing the normalized gross annual savings by the normalized pre-weatherization consumption and multiplying the result by 100 .

${ }^{8}$ Evaluations based on the Princeton Scorekeeping Method (PRISM) typically use 10-year historical weather to perform normalizations rather than TMY data.

${ }^{9}$ Every effort was made to choose a TMY city that represented the climate for the local weatherization agency. In some instances, though, the limited choice of TMY cities resulted in less than optimum selections. 


\subsection{WEIGHTING}

A weighted ratio-estimator averaging procedure was used to determine average regional weighted values of consumption and savings for the nine states in the northeast region (average weighted or regional values). A direct or unweighted analysis of test house data was also performed to determine the average consumptions and savings for the sample itself (average unweighted or sample values). Although sample statistics are very interesting and informative, weighted statistics are necessary to accurately estimate regional values.

A weighted analysis was performed to develop regional values because a clustered sampling procedure (see Sect. 2.2) was used to select sample houses for the study rather than selecting a sample directly proportional to the population of eligible houses in the region. Under the clustered sampling procedure, at least three local weatherization agencies were monitored from each state in the region over the two program years to ensure that each state (despite the number of single-family, fuel-oil heated houses weatherized) was represented in the study.

A ratio-estimator averaging procedure was used to estimate the average savings for a given state over one program year. A ratio-estimator of the average may have potential bias, although in many cases it can be better than an unbiased estimator. A ratio estimator was used because it did not require knowing the exact number of single-family, fuel-oil heated homes weatherized by each state over each program year. These numbers, which were not known, would have been required to determine an unbiased estimate of the average. The use of estimated numbers would have introduced bias and/or error into the calculation of an "unbiased estimator."

The equations used to calculate the average regional values under the weighted ratioestimator averaging procedure are provided in Appendix I. Under this procedure, each monitored house represents a number of houses in the overall population of interest. This number is often referred to as a weighting factor. Development of weighting factors is also described in Appendix I. Weighting factors are presented in Table I.1.

The weighted averaging procedure was used separately for the weatherized and control houses to arrive at regional estimates for each group. For the sample of houses monitored from 
an individual local weatherization agency, the following were known: the average value of a variable for the houses, the number of houses monitored, the standard deviation of the value, and the total number of single-family, fuel-oil heated houses weatherized by the agency during the program year. Additionally, the number of agencies in each state that weatherized single-family, fuel-oil heated houses and the number of agencies monitored in each state were known. A regional average value and accompanying variance were determined for each program year by first calculating and then combining state values. Results for each program year were then combined to obtain the final regional estimates.

\subsection{FUEL-OIL CONSUMPTION AND SAVINGS RESULTS}

Table 5.1 summarizes the sample (unweighted) results and regional (weighted) results for both control and weatherized homes for each test year, 1990-1991 and 1991-1992, and the combined test years, 1990-1992. Average regional results are primarily discussed in the remainder of the report. Table 5.2 presents $90 \%$ confidence intervals for regional consumptions and savings. Table H.2 contains a detailed summary of data and results for each house taking part in the study. Tables H.3 and H.4 present detailed statistical descriptions of the following variables for the control and weatherized houses, respectively: pre- and post-weatherization indoor temperatures, pre- and post-weatherization fuel-oil consumptions, and fuel-oil savings (expressed in gallons and percent).

Coefficients of determination $\left(R^{2}\right)$ derived from the pre- and post-weatherization regressions for each house are contained in Table H.2, with pre- and post-weatherization distributions for both control and weatherized houses being shown in Fig. 5.1. The coefficient of determination is one of the most often used measures to judge the adequacy of a linear regression model. Coefficients for control houses were slightly better than for weatherized houses: $90 \%$ of the control house values were above 0.70 , while $84 \%$ of the weatherized house values were above 0.70. There was little difference between pre- and post-weatherization periods. All houses regardless of their coefficients of determination were used in the analysis presented in this section. Section 5.4 discusses changes in results when houses with low coefficients of determination are dropped from the analysis. 

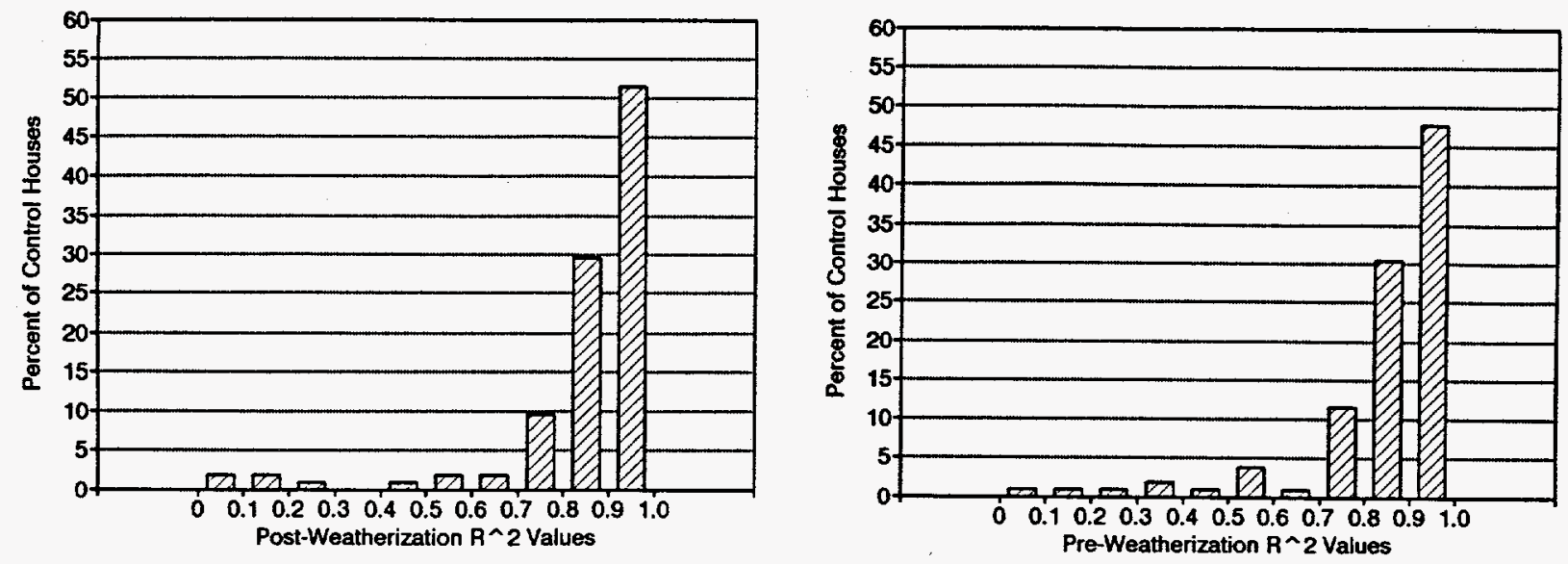

(c)

(d)
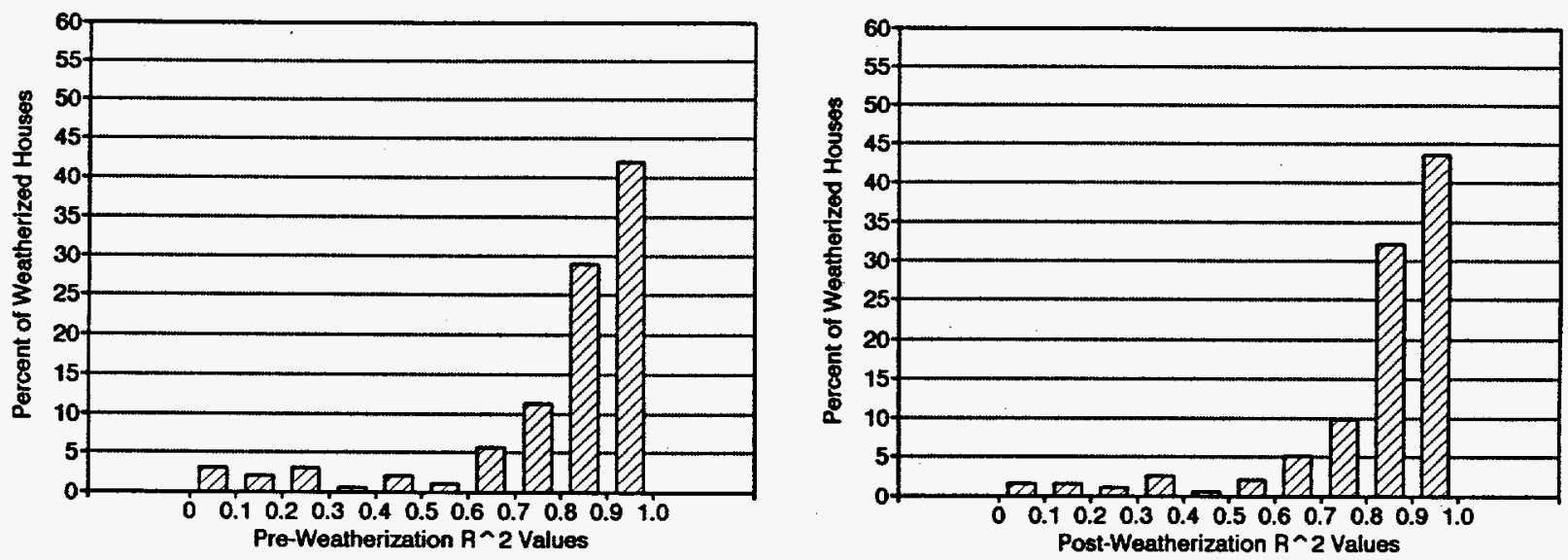

Fig. 5.1. Distributions of pre- and post-weatherization coefficients of determination $\left(\mathbf{R}^{2}\right)$ for control ( $a$ and $b$ ) and weatherized ( $c$ and d) houses, respectively. Mean values for the preand post-weatherization periods were 0.84 for the control houses, and 0.80 and 0.82 for the weatherized houses. Standard deviations for the pre- and post-weatherization periods were 0.18 and 0.19 for the control houses, and 0.23 and 0.19 for the weatherized houses.

Tables 5.1 and 5.2 show that the average regional pre-weatherization fuel-oil consumption for the control houses was greater than the weatherized houses, 918 gallons/year compared to 905 gallons/year. ${ }^{10}$ The comparison between groups is reversed if consumption is normalized by floor area: the consumptions were 0.638 gallons/year $/ \mathrm{ft}^{2}$ for the control houses and 0.676

${ }^{10}$ Fuel-oil consumptions can be converted from gallons to Btu by multiplying gallons by $140,000 \mathrm{Btu} / \mathrm{gallon}$, the higher heating value of fuel oil. 
Table 5.1. Summary of fuel-oil consumptions and savings

Summary of Sample: Control Houses

\begin{tabular}{|c|c|c|c|c|c|c|}
\hline \multirow{2}{*}{ Year } & \multirow{2}{*}{$\begin{array}{c}\text { Number } \\
\text { of houses }\end{array}$} & \multirow{2}{*}{$\begin{array}{c}\text { Heated } \\
\text { area }\left(\mathrm{ft}^{2}\right)\end{array}$} & \multicolumn{4}{|c|}{ Annual fuel-oil consumption (gallons) } \\
\cline { 4 - 7 } & & Pre & Post & Gross savings & Percent savings \\
\hline \hline $1990-91$ & 60 & 1431 & 996 & 1025 & -29 & -2.9 \\
\hline $1991-92$ & 45 & 1468 & 860 & 869 & -9 & -1.0 \\
\hline \hline $1990-92$ & 105 & 1447 & 938 & 958 & -20 & -2.2 \\
\hline
\end{tabular}

Summary of Sample: Weatherized Houses

\begin{tabular}{|c|c|c|c|c|c|c||}
\hline \multirow{2}{*}{ Year } & \multirow{2}{*}{$\begin{array}{c}\text { Number } \\
\text { of houses }\end{array}$} & \multirow{2}{*}{$\begin{array}{c}\text { Heated } \\
\text { area }\left(\mathrm{ft}^{2}\right)\end{array}$} & \multicolumn{4}{|c|}{ Annual fuel-oil consumption (gallons) } \\
\cline { 4 - 7 } & & Pre & Post & Gross savings & Percent savings \\
\hline \hline $1990-91$ & 102 & 1237 & 913 & 757 & 156 & 17.1 \\
\hline $1991-92$ & 91 & 1398 & 847 & 719 & 128 & 15.1 \\
\hline \hline $1990-92$ & 193 & 1313 & 882 & 739 & 143 & 16.2 \\
\hline
\end{tabular}

Regional Summary: Control Houses

\begin{tabular}{||c|c|c|c|c|c|c||}
\hline \multirow{2}{*}{ Year } & \multirow{2}{*}{$\begin{array}{c}\text { Number } \\
\text { of houses }\end{array}$} & \multirow{2}{*}{$\begin{array}{c}\text { Heated } \\
\text { area }\left(\mathrm{ft}^{2}\right)\end{array}$} & \multicolumn{4}{|c|}{ Annual fuel-oil consumption (gallons) } \\
\cline { 5 - 7 } & & Pre & Post & Gross savings & Percent savings \\
\hline \hline $1990-91$ & 60 & 1459 & 969 & 1026 & -57 & -5.9 \\
\hline $1991-92$ & 45 & 1418 & 859 & 874 & -15 & -1.8 \\
\hline \hline $1990-92$ & 105 & 1438 & 918 & 956 & -38 & -4.1 \\
\hline
\end{tabular}

Regional Summary: Weatherized Houses

\begin{tabular}{|c|c|c|c|c|c|c|}
\hline \multirow{2}{*}{ Year } & \multirow{2}{*}{$\begin{array}{c}\text { Number } \\
\text { of houses }\end{array}$} & \multirow{2}{*}{$\begin{array}{c}\text { Heated } \\
\text { area }\left(\mathrm{ft}^{2} \text { ) }\right.\end{array}$} & \multicolumn{4}{|c|}{ Annual fuel-oil consumption (gallons) } \\
\cline { 4 - 7 } & & & Pre & Post & Gross savings & Percent savings \\
\hline $1990-91$ & 102 & 1249 & 913 & 790 & 123 & 13.5 \\
\hline $1991-92$ & 91 & 1429 & 897 & 776 & 121 & 13.4 \\
\hline \hline $1990-92$ & 193 & 1339 & 905 & 783 & 122 & 13.5 \\
\hline
\end{tabular}

Note: Fuel-oil consumptions and savings can be converted from gallons to Btu by multiplying gallons by $140,000 \mathrm{Btu} /$ gallon, the higher heating value of fuel oil. 
Table 5.2. Confidence intervals of regional fuel-oil consumptions and savings

\begin{tabular}{||l|c|c|c|c||}
\hline \multirow{2}{*}{ Item } & \multicolumn{2}{|c|}{ Control houses } & \multicolumn{2}{c|}{ Weatherized houses } \\
\cline { 2 - 5 } & $\begin{array}{c}\text { Weighted } \\
\text { mean value } \\
\text { (gallons) }\end{array}$ & $\begin{array}{c}90 \% \\
\text { confidence } \\
\text { interval }\end{array}$ & $\begin{array}{c}\text { Weighted } \\
\text { mean value } \\
\text { (gallons) }\end{array}$ & $\begin{array}{c}90 \% \\
\text { confidence } \\
\text { interval }\end{array}$ \\
\hline \hline $\begin{array}{l}\text { Annual pre-weatherization } \\
\text { consumption }\end{array}$ & 918 & \pm 64 & 905 & \pm 51 \\
\hline $\begin{array}{l}\text { Annual post-weatherization } \\
\text { consumption }\end{array}$ & 956 & \pm 71 & 783 & \pm 52 \\
\hline Annual gross savings & -38 & \pm 24 & 122 & \pm 19 \\
\hline Annual net savings & -18.8 & 160 & \pm 31 \\
\hline
\end{tabular}

Note: Fuel-oil consumptions and savings can be converted from gallons to Btu by multiplying gallons by 140,000 Btu/gallon, the higher heating value of fuel oil.

gallons/year $/ \mathrm{ft}^{2}$ for the weatherized houses. ${ }^{11}$ These sets of values were not statistically different from each other at a 0.05 level of significance. The large variation in individual house consumptions for both groups was similar as shown in Fig. 5.2: $49 \%$ of the control houses and $45 \%$ of the weatherized houses had pre-weatherization consumptions between 600 and 1000 gallons/year, with most houses being between 400 and 1200 gallons/year. The fact that $40 \%$ of the houses include fuel-oil consumption to heat domestic hot water likely contributes to the high end of the observed distribution.

As shown in Tables 5.1 and 5.2, the average regional fuel-oil consumption of the control houses increased to 956 gallons/year, for a gross change of $\mathbf{- 3 8}$ gallons/year (the control houses averaged 38 gallons/year more in the post-weatherization period than the pre-weatherization period) or negative $4.1 \%$ of pre-weatherization consumption. The average regional fuel-oil consumption of the weatherized houses decreased to 783 gallons/year following weatherization,

\footnotetext{
${ }^{11}$ Control houses being $6.5 \%$ more efficient on a square foot basis could indicate some bias in the selection process. Obtaining occupant agreement to act as a control for the heating season was more difficult than obtaining occupant agreement to be in the weatherized group. The occupants' decisions may have been based, to some degree, on the thermal integrity of their houses, which would have tended to put more "energy-inefficient" houses in the weatherized group. However, this is pure speculation, and we have no evidence to support such a hypothesis.
} 
(a)

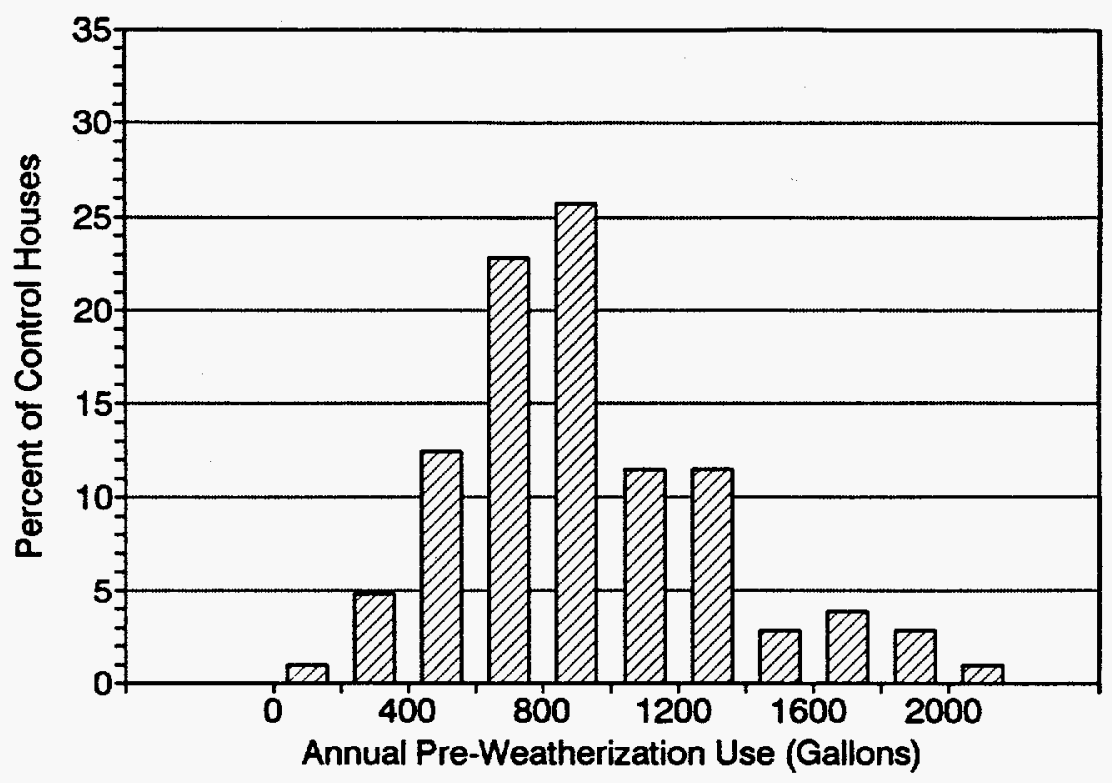

(b)

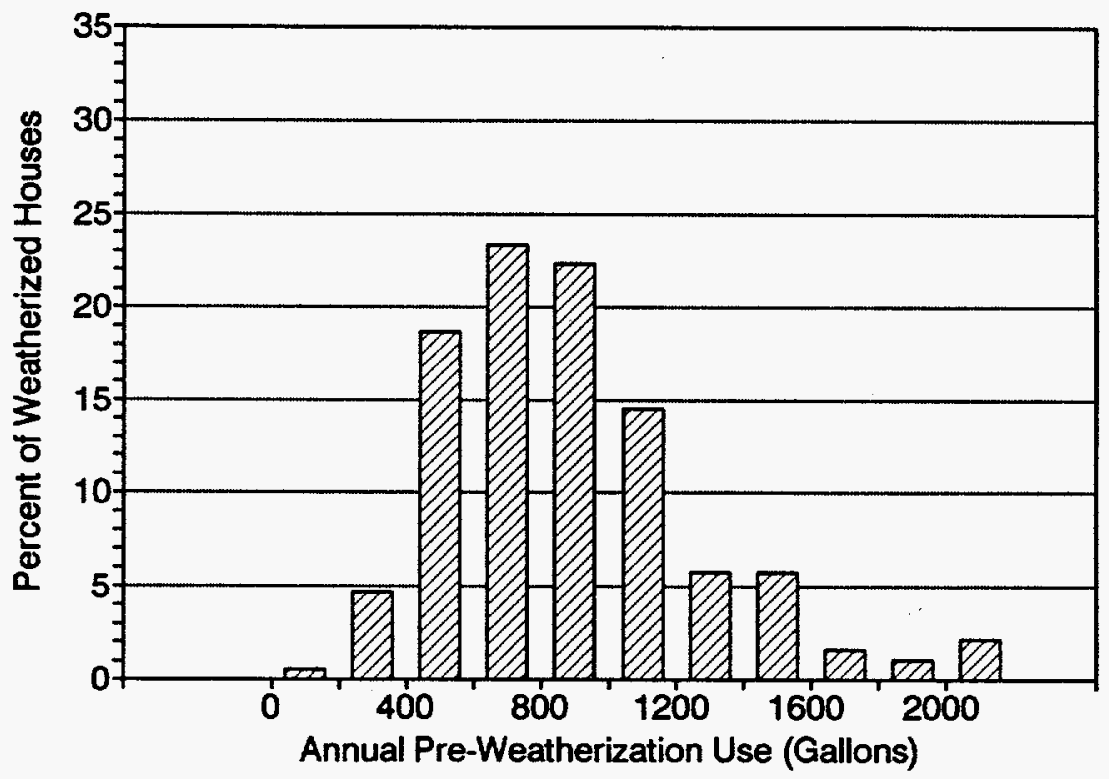

Fig. 5.2 Distribution of pre-weatherization fuel-oil consumptions for the control (a) and weatherized (b) houses. For the control houses, the sample mean was 938 gallons/year and the standard deviation was $\mathbf{4 0 7}$. For the weatherized houses, the sample mean was 882 gallons/year and the standard deviation was 379. 
for a gross savings of 122 gallons/year or $13.5 \%$ of pre-weatherization consumption. ${ }^{12}$ The regional gross savings for the control and weatherized houses were statistically different from zero and from each other at a 0.05 level of significance. Gross savings measured for the weatherized houses were nearly identical for each program year. Also, the savings measured in houses that used auxiliary heat were not statistically different than those measured in houses that did not use auxiliary heat.

To remain consistent with results reported from evaluations from other programs, the best estimate for the regional savings obtained from the Fuel-Oil Study is the net savings of the weatherized houses (the gross change of the control houses subtracted from the gross savings of the weatherized houses). The net regional savings was 160 gallons/year, or $17.7 \%$ of preweatherization consumption. The dollar value of the net savings was $\$ 162$, assuming a fuel cost of $\$ 1.01 /$ gallon. The $90 \%$ confidence interval for the savings was \pm 31 gallons/year $( \pm 3.4 \%$ of preweatherization consumption). The ratio of the confidence interval to the savings was $19 \%$. This was lower than the ratio of $26 \%$ estimated in the experimental design for a $90 \%$ confidence interval because of higher savings and lower standard errors than our original estimates. Thus, the measured savings were more accurate than expected. ${ }^{13}$

The distribution of post-weatherization consumptions for the weatherized houses is shown in Fig. 5.3 (the distribution of post-weatherization consumptions for the control houses was nearly identical to their pre-weatherization distribution). Almost $60 \%$ of the weatherized houses had consumptions between 400 and 800 gallons/year.

Two distribution plots of pre- and post-weatherization fuel-oil consumptions for the control and weatherized houses are shown in Fig. 5.4. The data in these figures are plotted

\footnotetext{
${ }^{12}$ Average sample consumptions and savings were in close agreement with the regional (weighted) results. The average sample savings was $-2.2 \%$ for the control houses and $16.2 \%$ for the weatherized houses, for an average net savings of $18.4 \%$.

${ }^{13}$ The $95 \%$ confidence interval for the net savings of the weatherized houses was \pm 37 gallons/year $( \pm 4.1 \%$ of pre-weatherization regional consumption). The ratio of the $95 \%$ confidence interval to the savings was $23 \%$, which was still more accurate than estimated in the experimental design.
} 


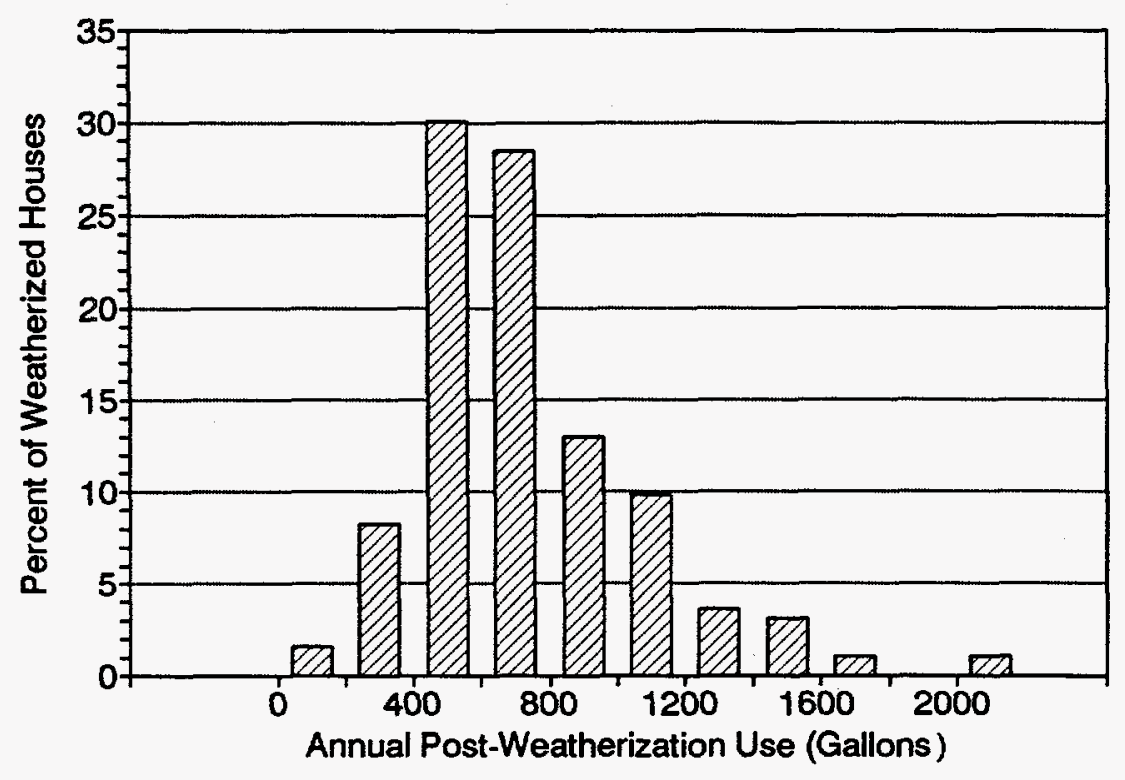

Fig. 53. Distribution of post-weatherization fuel-oil consumptions for the weatherized houses. The sample mean was 739 gallons/year and the standard deviation was 340.

differently than usual distribution plots, in that the abscissa ( $\mathrm{x}$-axis) represents a cumulative percent of the sample. Medians are easily seen on these plots as the points where curves cross the $50 \%$ grids of the abscissas. Note that all medians lie below the sample averages for pre- and post-weatherization fuel consumption. Since these figures are distribution plots, there is no relationship between the pre- and post-weatherization fuel-oil consumptions lying along the same value of the abscissa. The two curves plotted on each figure were generated from independent and sorted data sets. These plots do, however, illustrate a slightly higher average fuel-oil consumption for control houses during the post-weatherization period, and a lower average fueloil consumption for weatherized houses after weatherization.

As shown in Fig. 5.5(a), about $80 \%$ of the control houses had measured gross savings between -100 and 100 gallons/year, with about twice as many houses between -100 and 0 gallons/year compared to 0 to 100 gallons/year. Because the control houses were not weatherized, a distribution of savings around zero was expected. 
(a)

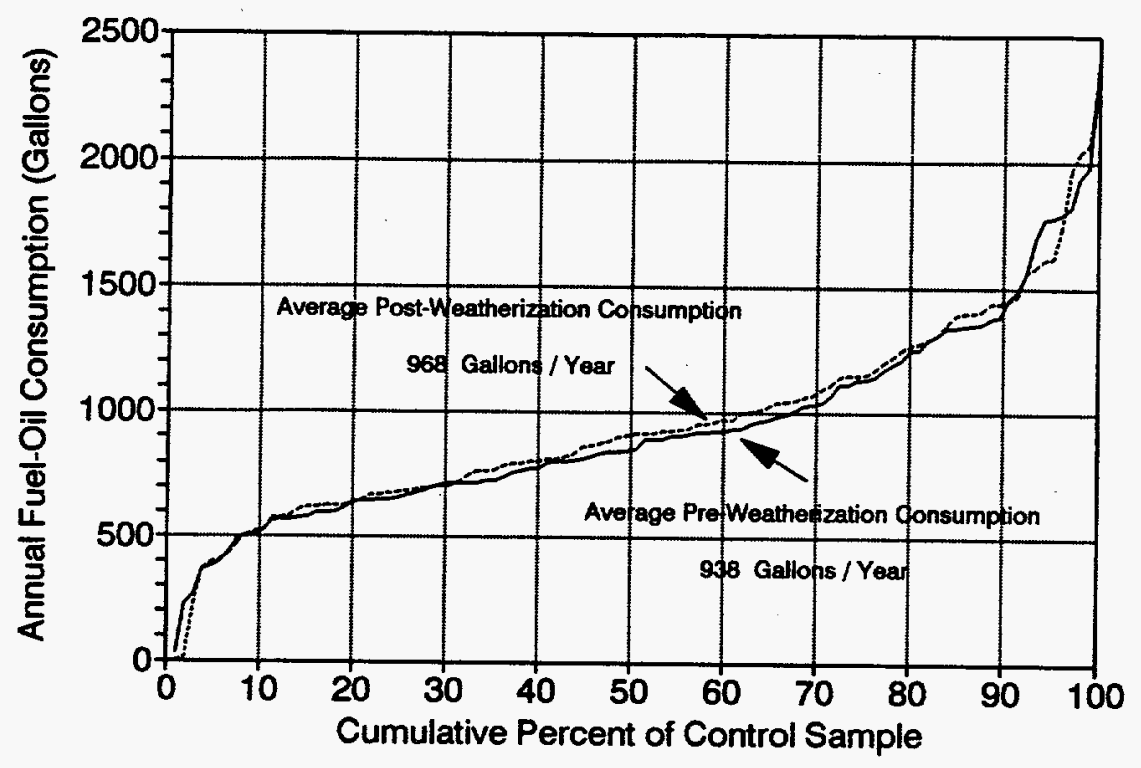

(b)

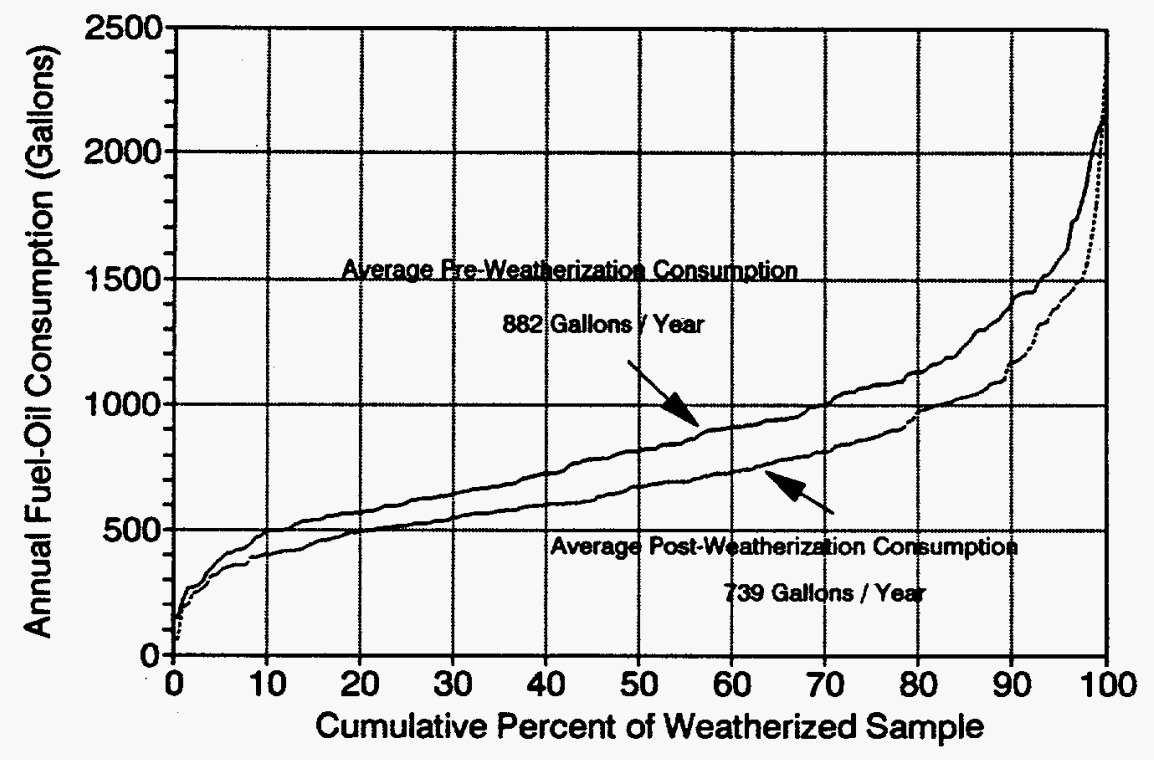

Fig. 5.4. Distribution of pre- and post-weatherization fuel-oil consumptions for the control (a) and weatherized (b) houses, where the abscissa ( $x$-axis) represents a cumulative percent of the sample. 
As shown in Fig. 5.5(b), 65\% of the weatherized houses had measured savings between 0 and 300 gallons/year. Only $4 \%$ of the sample had savings greater than 500 gallons/year and about $17 \%$ had negative savings (with most of these being limited to -100 to 0 gallons/year).

Cumulative distribution plots for percent fuel-oil savings are shown in Fig. 5.6. Figure 5.6(a) shows that the control group is more closely grouped (the percent savings span is less) in the middle $20 \%$ to $80 \%$ of the sample than is the weatherized group in Figure $5.6(\mathrm{~b})$.

\subsection{SAMPLE REFINEMENT}

The results presented in Sect. 5.3 are based on an analysis of all 298 houses with complete monitored data sets, disregarding the adequacy of the regression results. Figure 5.7 shows plots of average sample (unweighted) pre-weatherization fuel-oil consumptions, fuel-oil savings, and percent savings for the control and weatherized houses when using data from:

- all sites regardless of the $\mathrm{R}^{2}$ value,

- houses with an $\mathrm{R}^{2}$ above 0.5 for both pre- and post-weatherization periods, and - houses with an $\mathrm{R}^{2}$ above 0.7 for both periods.

Table H.5 contains a summary of control house sample statistics for each of the three data sets, and Table H.6 contains similar sample statistics for the weatherized houses. Figure 5.7 shows that values for all three variables increased for the weatherized houses as the minimum $R^{2}$ value increased. The greatest change occurred with the savings, which increased from 143 to 162 gallons/year (a change of 13\%). Values changed less for the control houses, increasing as the minimum $\mathrm{R}^{2}$ changed from 0.0 to 0.5 , but decreasing as the minimum $\mathrm{R}^{2}$ changed from 0.5 to 0.7 . The sample size decreased by about $25 \%$ when moving from a minimum $R^{2}$ of 0 to a minimum $\mathrm{R}^{2}$ of 0.7 .

Tables H.7 and H.8 contain information with distribution plots on the following variables for control and weatherized houses, respectively, with a minimum $\mathrm{R}^{2}$ of 0.7 : pre- and postweatherization period indoor temperatures, pre- and post-weatherization fuel-oil consumption, and fuel-oil savings (gallons and percent). Comparison of these tables directly with Tables H.4 and H.5, which contain the same data for all houses, indicated little differences in the distribution 
(a)

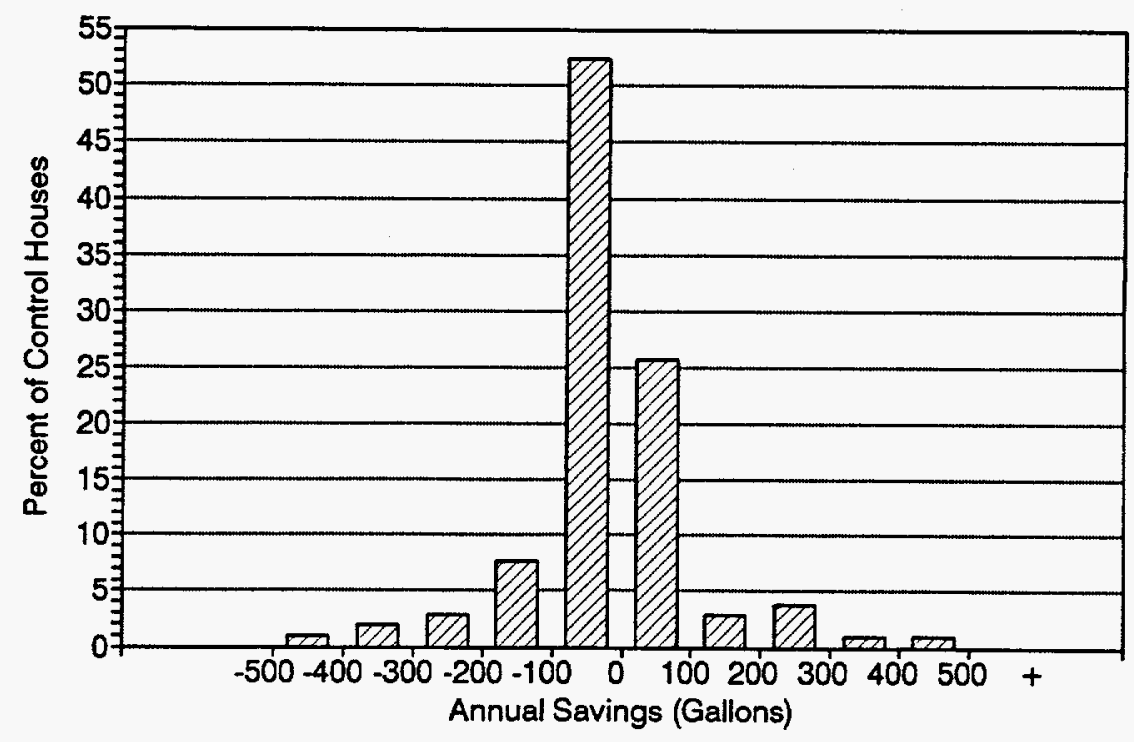

(b)

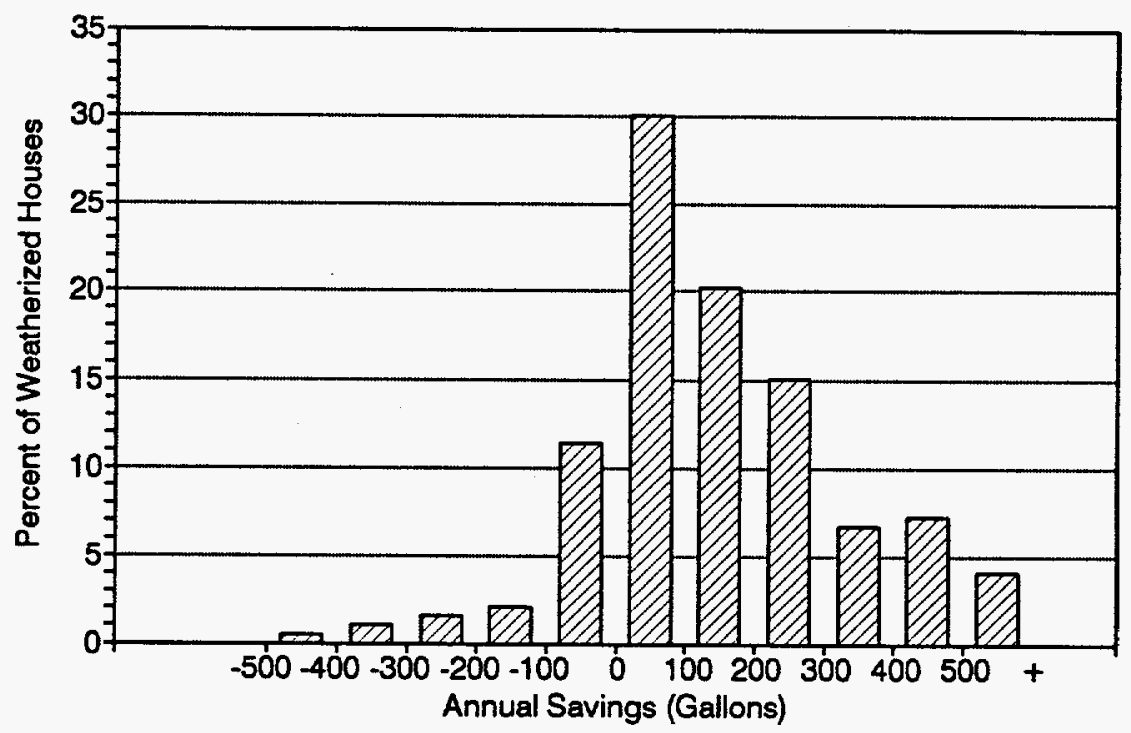

Fig. 5.5. Distribution of fuel-oil savings for the control (a) and weatherized (b) houses.

For the control houses, the sample mean was -20 gallons/year and the standard deviation was 117 . For the weatherized houses, the sample mean was 143 gallons/year and the standard deviation was 195. 
(a)

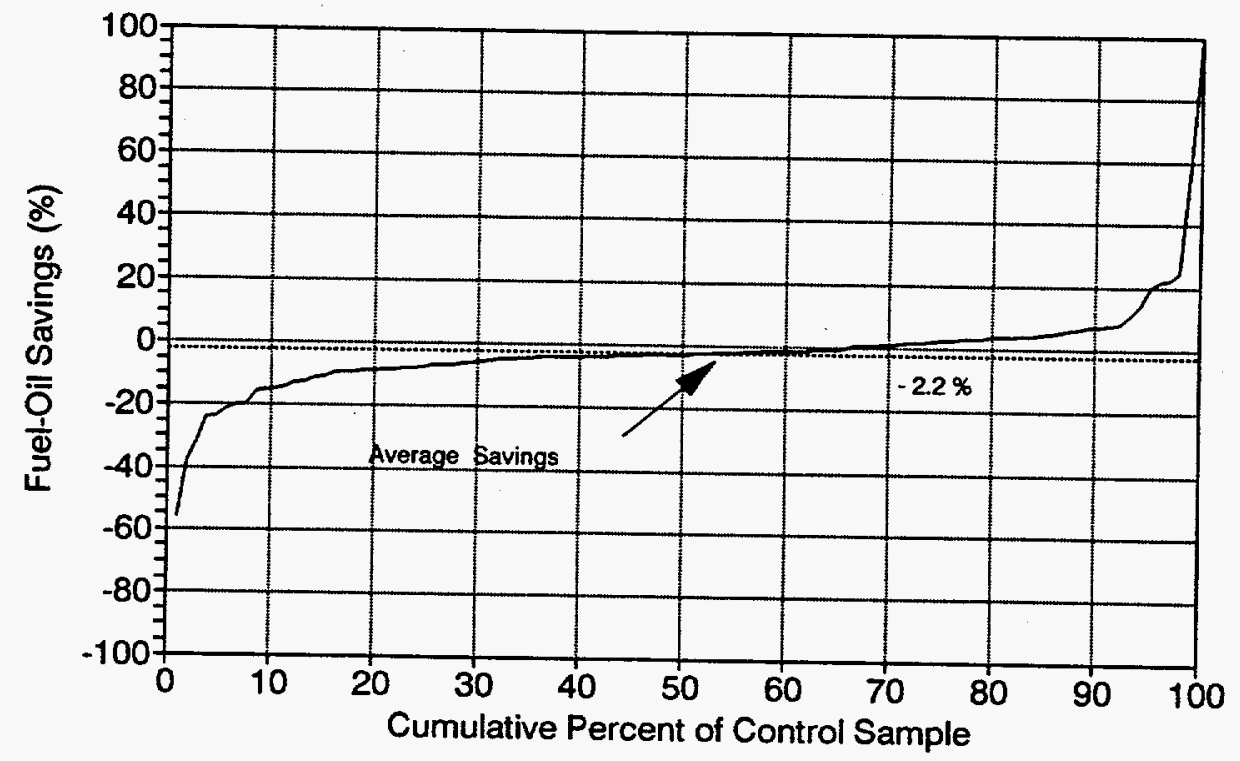

(b)

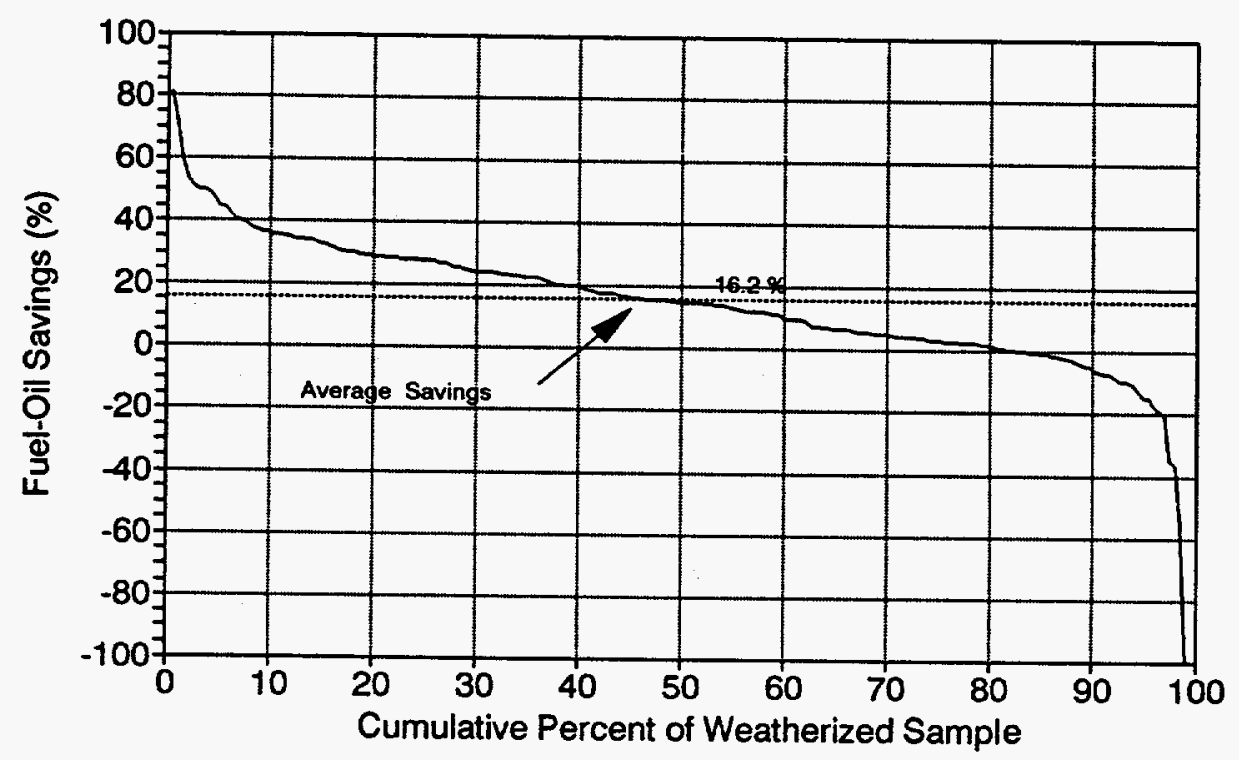

Fig. 5.6. Distribution of percent fuel-oil savings for the control (a) and weatherized (b) houses, where the abscissa ( $x$-axis) represents a cumulative percent of the sample. 
(a)

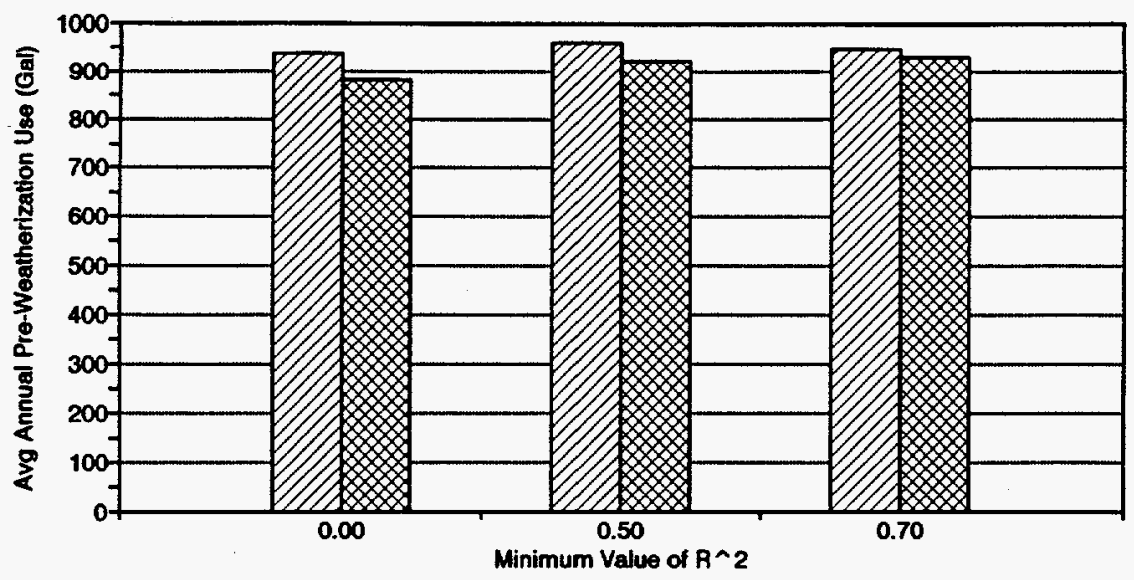

(b)

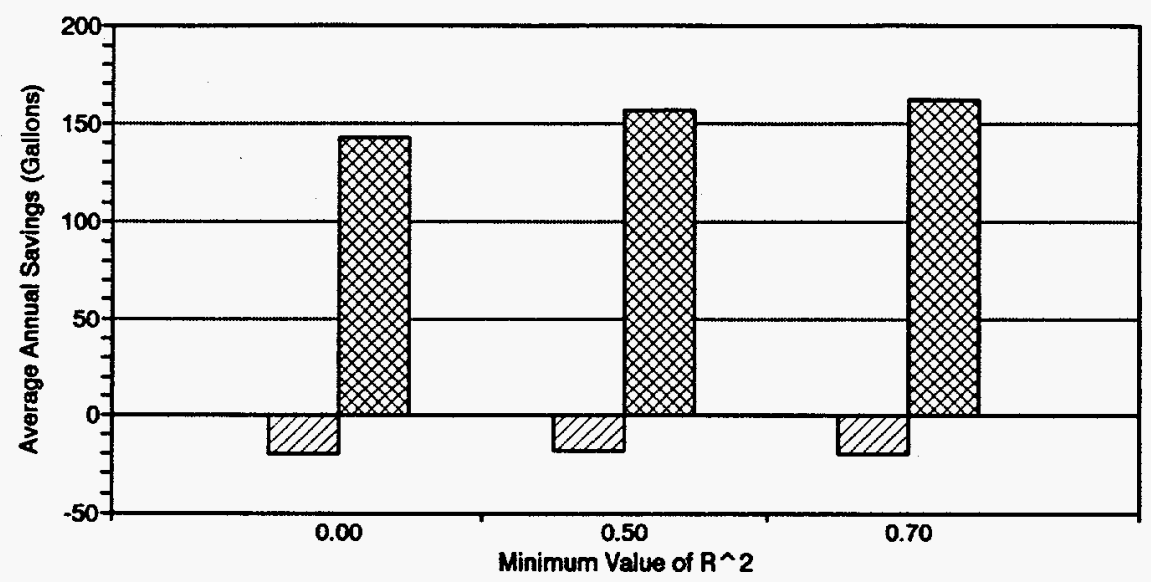

(c)

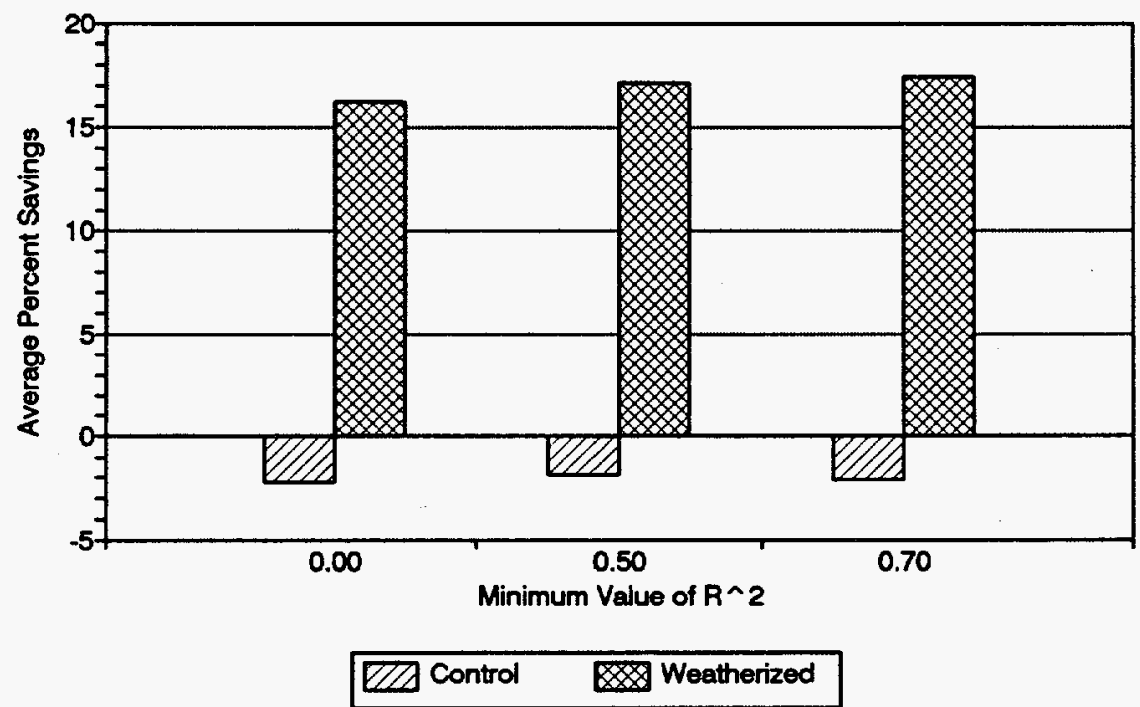

Fig. 5.7. Average sample pre-weatherization fuel-oil consumption (a), savings (b), and percent savings (c) for the control and weatherized houses using different data sets depending on the adequacy of the consumption regressions. 
of pre-weatherization consumption for the refined data set. Savings distributions were also similar, although there were fewer outlying data points with the refined data set.

Primary analysis was performed without excluding any houses due to regression curvefit inadequacies. Although this decision estimated a slightly lower percentage savings than would have been obtained by limiting the analysis to houses with higher $\mathrm{R}^{2}$ fits, it allowed a more accurate estimation of the confidence interval of the savings estimate because of the higher number of houses used in the determination. Standard deviations between test sites in a local weatherization agency were necessary for confidence-interval estimation; increasing the minimum $R^{2}$ value reduced the available sample size in some agencies to the point where one or no control and/or weatherized sites were left from which to determine standard deviations. Standard deviations between agencies in a given state were also needed to avoid use of assumptions about the sample; again, increasing the minimum $R^{2}$ value would have eliminated entire agencies to the point where there was only one per state.

An additional investigation showed that the use of auxiliary heat effected the $\mathrm{R}^{\mathbf{2}}$ values of the fuel-oil consumption regressions, primarily in the weatherized houses (see Table 5.3). T-tests showed that the average $\mathbf{R}^{2}$ value for the weatherized houses using auxiliary heat in both periods was lower than the value for weatherized houses not using auxiliary heat at a significance level of 0.002 for both the pre- and post-weatherization periods. The average control house $\mathrm{R}^{2}$ values, however, were only different from each other for the pre period at a significance level of about 0.07 , but not significantly different from each other in the post period.

Weatherized houses using some form of auxiliary heat were two to three times more likely to have low $\mathrm{R}^{2}$ fits than the control houses using some form of auxiliary heat: $36 \%$ of the weatherized houses but only $20 \%$ of the control houses that used auxiliary heat in the preweatherization period had $\mathrm{R}^{2}$ values less than 0.7 , while $33 \%$ of the weatherized houses but only $10 \%$ of the control houses that used auxiliary heat in the post-weatherization period had $\mathbf{R}^{2}$ values less than 0.7 . Recall from Sect. 5.3 that $90 \%$ of all the control houses and $84 \%$ of all the weatherized houses had $R^{2}$ values of 0.7 or higher. 
Table 5.3. Effect of use of auxiliary heat on $\mathbf{R}^{2}$ fit of fuel-oil consumption data

\begin{tabular}{||c|c|c|c|c|c|c|c|c|c||}
\hline \multirow{2}{*}{$\begin{array}{c}\text { Type of } \\
\text { house }\end{array}$} & $\begin{array}{c}\text { Auxiliary } \\
\text { heat } \\
\text { usage }\end{array}$ & No. & & \multicolumn{3}{|c|}{ Pre-weatherization } & \multicolumn{3}{|c|}{ Post-weatherization } \\
\cline { 4 - 12 } & & $\begin{array}{c}\text { Number of } \\
R^{2}<0.7\end{array}$ & $\begin{array}{c}\text { Usage } \\
\text { (gallons) }\end{array}$ & $R^{2}$ & $\begin{array}{c}\text { Number of } \\
R^{2}<0.7\end{array}$ & $\begin{array}{c}\text { Usage } \\
\text { (gallons) }\end{array}$ & $\begin{array}{c}\text { Savings } \\
\text { (gallons) }\end{array}$ \\
\hline \hline Weatherized & Pre & 15 & 0.73 & 4 & 1060 & 0.84 & 2 & 903 & 157 \\
\hline Weatherized & Post & 2 & 0.89 & 0 & 887 & 0.88 & 0 & 710 & 177 \\
\hline Weatherized & Both & 25 & 0.60 & 11 & 772 & 0.63 & 12 & 671 & 101 \\
\hline Weatherized & None & 80 & 0.86 & 8 & 860 & 0.87 & 4 & 706 & 154 \\
\hline \hline Control & Pre & 4 & 0.81 & 1 & 824 & 0.94 & 0 & 848 & -24 \\
\hline Control & Post & 1 & 0.96 & 0 & 2419 & 0.97 & 0 & 2349 & 70 \\
\hline Control & Both & 15 & 0.76 & 3 & 830 & 0.79 & 2 & 879 & -48 \\
\hline Control & None & 42 & 0.87 & 3 & 926 & 0.86 & 3 & 969 & -43 \\
\hline
\end{tabular}

The use of auxiliary heat did not have any major effects on the savings results. T-tests revealed that the pre fuel-oil consumptions, post fuel-oil consumptions, and fuel-oil savings for the weatherized houses using auxiliary heat during both periods were not statistically different from weatherized houses that did not use any auxiliary heat. A similar result occurred for the control houses.

\subsection{INDOOR TEMPERATURES}

Table 5.4 shows that the average regional pre-weatherization indoor temperatures of the control and weatherized houses were nearly the same: $70.3^{\circ} \mathrm{F}$ and $70.5^{\circ} \mathrm{F}$, respectively. Control houses were about $1^{\circ} \mathrm{F}$ warmer the first year compared to the second year, while the weatherized house were about $0.7^{\circ} \mathrm{F}$ warmer the second year. The control houses were $0.6^{\circ} \mathrm{F}$ warmer than the weatherized houses the first year and $1.2^{\circ} \mathrm{F}$ cooler the second year.

Figure 5.8 shows cumulative distribution plots of control and weatherized indoor temperatures. The most striking part of Fig. 5.8 is that there is very little difference between the pre- and post-weatherization temperature distributions for each group. About $80 \%$ of the houses were maintained between $65^{\circ} \mathrm{F}$ and $75^{\circ} \mathrm{F}$ throughout the monitoring periods. Little change between pre- and post-weatherization periods is evident. 
Table 5.4. Summary of indoor temperatures

\begin{tabular}{||c|c|c|c|c|c|c|c||}
\hline \multirow{3}{*}{ Year } & \multirow{3}{*}{$\begin{array}{c}\text { Number } \\
\text { of } \\
\text { houses }\end{array}$} & \multicolumn{5}{|c|}{ Indoor temperature $\left(^{\circ} \mathrm{F}\right)$} \\
\cline { 3 - 8 } & & \multicolumn{5}{|c|}{ Sample } & \multicolumn{3}{c|}{ Regional (weighted) } \\
\cline { 3 - 8 } & 60 & 70.3 & 70.2 & -0.1 & 70.8 & 71.0 & 0.2 \\
\hline $1990-91$ & 60 Post & Change & Pre & Post & Change \\
\hline $1991-92$ & 45 & 69.4 & 69.1 & -0.3 & 69.7 & 69.4 & -0.3 \\
\hline \hline $1990-92$ & 105 & 69.9 & 69.8 & -0.1 & 70.3 & 70.3 & 0.0 \\
\hline
\end{tabular}

Weatherized Houses

\begin{tabular}{|c|c|c|c|c|c|c|c|}
\hline \multirow{2}{*}{ Year } & \multirow{3}{*}{\begin{tabular}{c} 
Number $\begin{array}{c}\text { of } \\
\text { houses }\end{array}$ \\
\cline { 3 - 8 }
\end{tabular}} & \multicolumn{5}{|c|}{ Sample } & \multicolumn{3}{|c|}{ Regional (weighted) } \\
\cline { 3 - 8 } & & Pre & Post & Change & Pre & Post & Change \\
\hline $1990-91$ & 102 & 69.9 & 70.2 & 0.3 & 70.2 & 70.3 & 0.1 \\
\hline $1991-92$ & 91 & 70.5 & 70.0 & -0.5 & 70.9 & 70.5 & -0.4 \\
\hline $1990-92$ & 193 & 70.2 & 70.1 & -0.1 & 70.5 & 70.4 & -0.1 \\
\hline
\end{tabular}

Table 5.4 shows that the average regional indoor temperature change for the control houses was nearly zero, and only $-0.1^{\circ} \mathrm{F}$ for the weatherized houses (the negative value means that the indoor temperature was lower during the post-weatherization period than it was during the pre-weatherization period). Indoor temperatures tended to increase the first year during the post-weatherization period for both control and weatherized houses, but tended to decrease the second year.

Figure 5.9 shows cumulative distribution plots of indoor-temperature differences for the control and weatherized groups. Although the average indoor temperature difference for both groups was nearly zero, the distribution is interesting. Assuming differences between $\pm 1^{\circ} \mathrm{F}$ were too close to be significantly different, Fig. 5.9 shows about $20 \%$ of the weatherized houses had a lower indoor temperature after weatherization, while $15 \%$ of the weatherized houses increased their indoor temperature. Control house results were slightly different. About $15 \%$ of the 
(a)

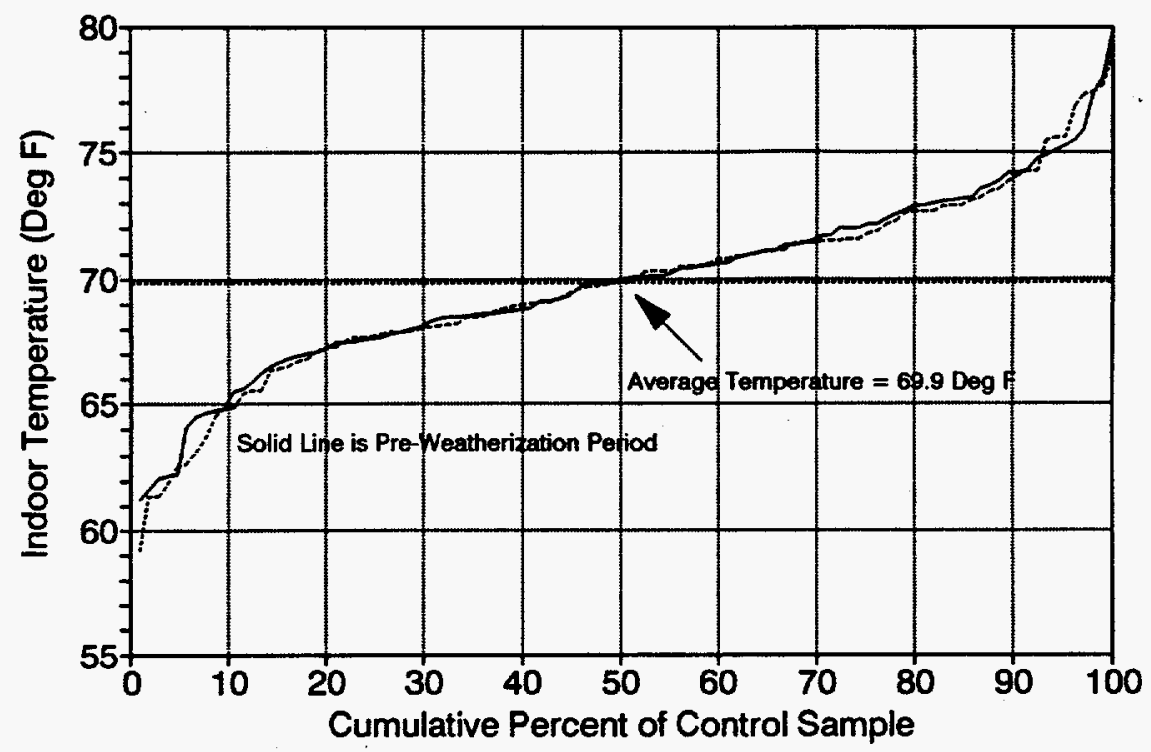

(b)

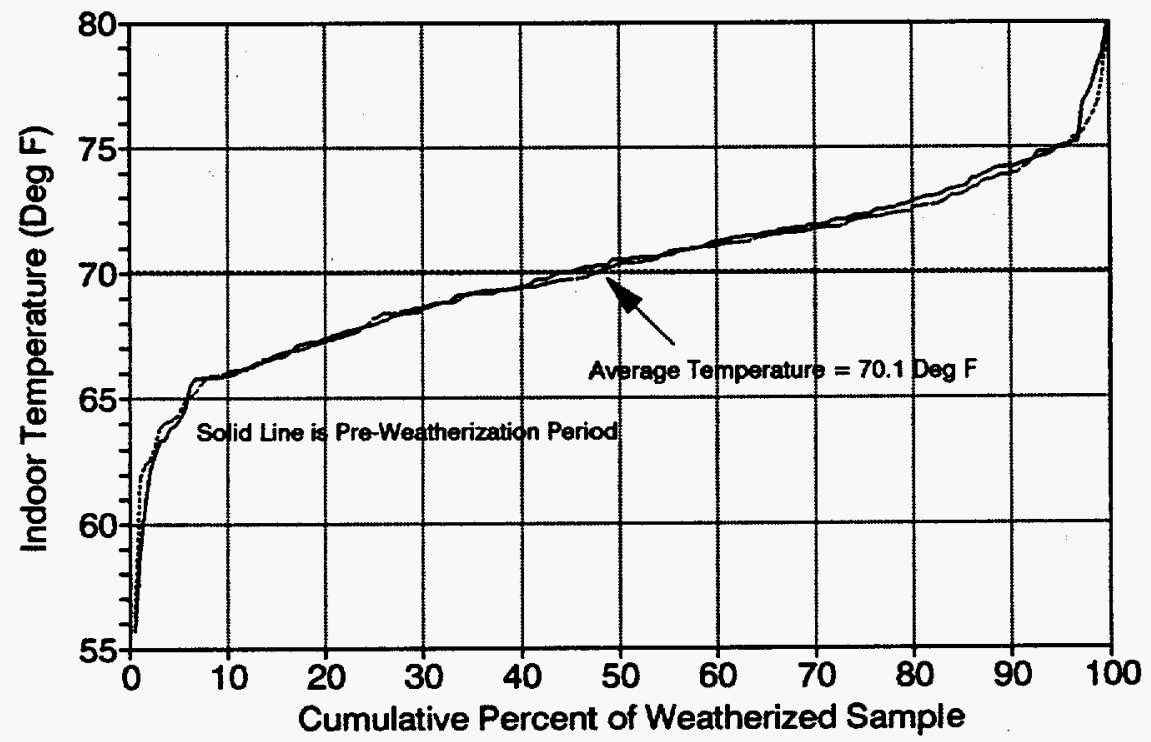

Fig. 5.8. Distribution of pre- and post-weatherization indoor temperatures for the control (a) and weatherized (b) houses, where the abscissa ( $x$-axis) represents a cumulative percent of the sample. 
(a)

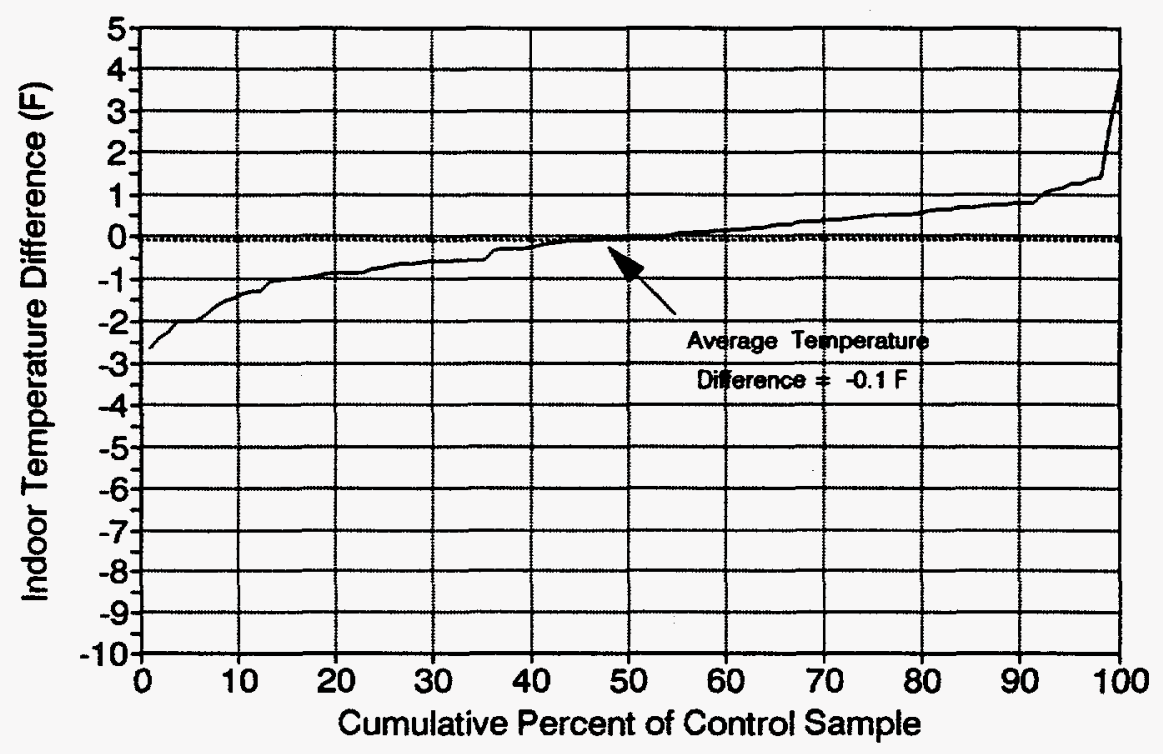

(b)

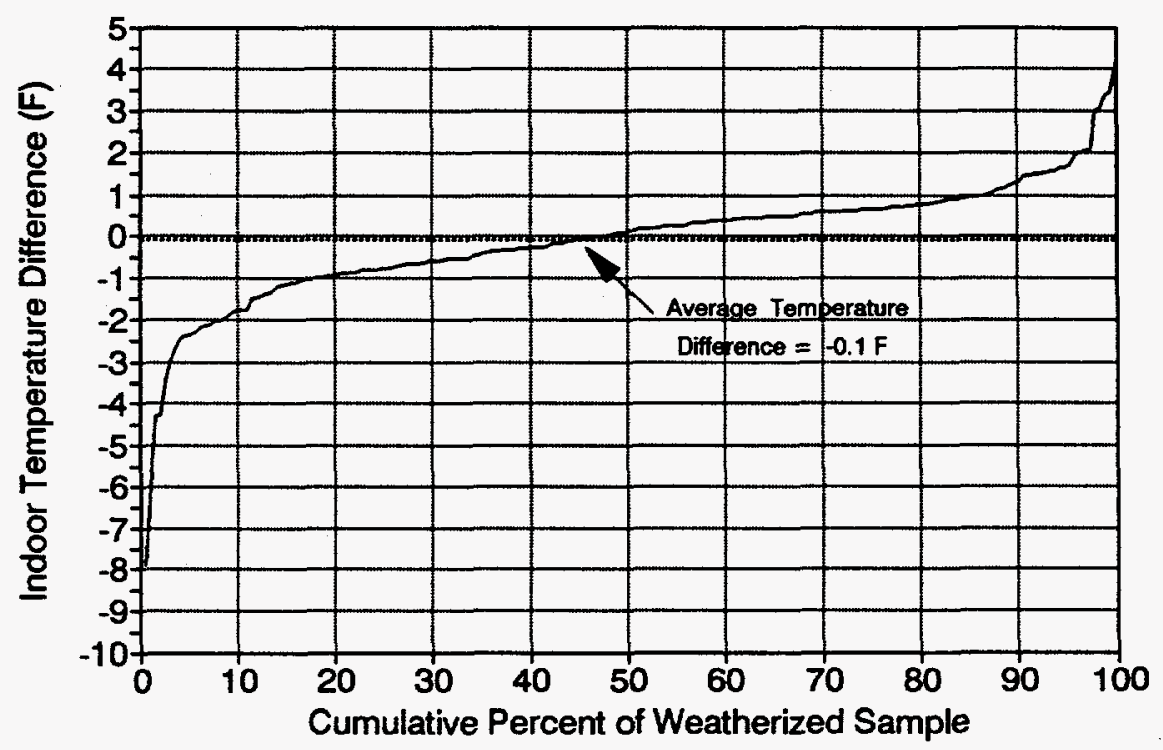

Fig. 5.9. Distribution of indoor temperature differences for the control (a) and weatherized (b) houses, where the abscissa ( $x$-axis) represents a cumulative percent of the sample (negative temperature differences mean that the indoor temperature was lower during the postweatherization period than it was during the pre-weatherization period). 
control houses lowered their indoor temperature more than $1^{\circ} \mathrm{F}$ for the post-weatherization period, while only $8 \%$ increased their indoor temperature by more than $1^{\circ} \mathrm{F}$. The control houses displayed a slightly tighter grouping than did the weatherized group.

These results indicate that client education (a measure provided to almost every house) did not lead to lower temperatures. These results also indicate that, on average, an indoor temperature "takeback" effect did not exist in our sample. ${ }^{14}$

${ }^{14}$ For this study, a "takeback" effect would be an increase in the indoor temperature after weatherization has been completed in order to get more comfort by reinvesting some of the weatherization savings back into fuel oil. 



\section{AIR-LEAKAGE REDUCTIONS}

House air-leakages were measured at the beginning of the pre-weatherization period and at the end of the post-weatherization period following the procedure outlined in Appendix D. ${ }^{15}$ Differences between pre- and post-weatherization measurements in the weatherized houses represent changes due to all the work performed in the houses (including, for example, wall insulation and storm windows) rather than just specific infiltration-reduction work because measurements were made at the beginning and end of the heating season.

Pre- and/or post-weatherization measurements were made in 329 houses, but both preand post-weatherization measurements were made in only 250 of these houses. The data set was further refined for the analysis presented in this section by only including houses with high quality pre- and post-weatherization air-leakage data (coefficients of determination $\left[R^{2}\right]$ were greater than 0.96) and with consistent basement door positions (closed or open) for the pre- and postweatherization measurements (most measurements were performed with the basement door closed). The final sample size was 167 houses (54 control houses and 113 weatherized houses). The coefficient of determination criteria eliminated 35 houses and the basement door position criteria eliminated the remaining 48 houses. $^{16}$

\subsection{ANALYSIS APPROACH}

The air tightness of the houses and the change following weatherization were analyzed using the air flow rate at a 50 Pa pressure difference (house depressurized) across the building shell (cfm50). ${ }^{17}$ The cfm50 value was calculated from the data collected under the air-leakage tests. An air-leakage test consisted of a series of air flow measurements (Q) made at pressure

\footnotetext{
${ }^{15}$ In a few limited cases, agency measurements were recorded because independent measurements for the study could not be performed.

${ }^{16}$ Raising the coefficient of determination cutoff to 0.98 would have reduced the sample size by another 19 houses.

${ }^{17}$ Other possible indicators include effective leakage area, average seasonal air exchange rate $\left(\mathrm{cfm}_{\text {natural }}\right)$, and these indicators normalized to the total exposed surface area of the house or house volume.
} 
Table 6.1. Control and weatherized house air-leakages

\begin{tabular}{||l|c|c||}
\hline & Control houses & Weatherized houses \\
\hline \hline Number of houses & 54 & 113 \\
\hline Pre-weatherization air leakage $(\mathrm{cfm50)}$ & 3468 & 3295 \\
\hline Post-weatherization air leakage $(\mathrm{cfm} 50)$ & 3304 & 2725 \\
\hline Air-leakage reduction (cfm50) & 164 & 570 \\
\hline
\end{tabular}

differences between the inside and outside of the house $(\Delta P)$. These data follow the power law form

$$
Q=C(\Delta P)^{N}
$$

where $\mathrm{C}$ and $\mathrm{N}$ are constants. These values were regressed by the method of weighted least squares (CGSB 1986) to determine the best values of $C$ and $N$ because $\ln (Q)$ vs $\ln (\Delta P)$ is a linear relation. Values of $Q$ can then be estimated for selected values of $\Delta P$. The $\mathrm{cfm} 50$ value was calculated using the above equation and $50 \mathrm{~Pa}$ as the value of $\Delta \mathrm{P}$.

Throughout this section, sample (unweighted) statistics rather than regional (weighted) values are presented.

\subsection{RESULTS}

As shown in Table 6.1, the average sample pre-weatherization air leakage was $3468 \mathrm{cfm} 50$ for the control houses and $3295 \operatorname{cfm} 50$ for the weatherized houses. The two groups were statistically the same at a 0.05 level of significance. Distributions of pre-weatherization air leakages are shown in Fig. 6.1. The distributions of the two groups were generally similar, with the majority of the houses ( $69 \%$ of the control houses and $78 \%$ of the weatherized houses) having air leakages between 1500 and $4500 \mathrm{cfm} 50$.

Pre-weatherization air leakages were less than $1500 \mathrm{cfm} 50$ in $11 \%$ of the control houses and $4 \%$ of the weatherized houses. Houses in the northeast with air leakages between 1000 and 
(a)

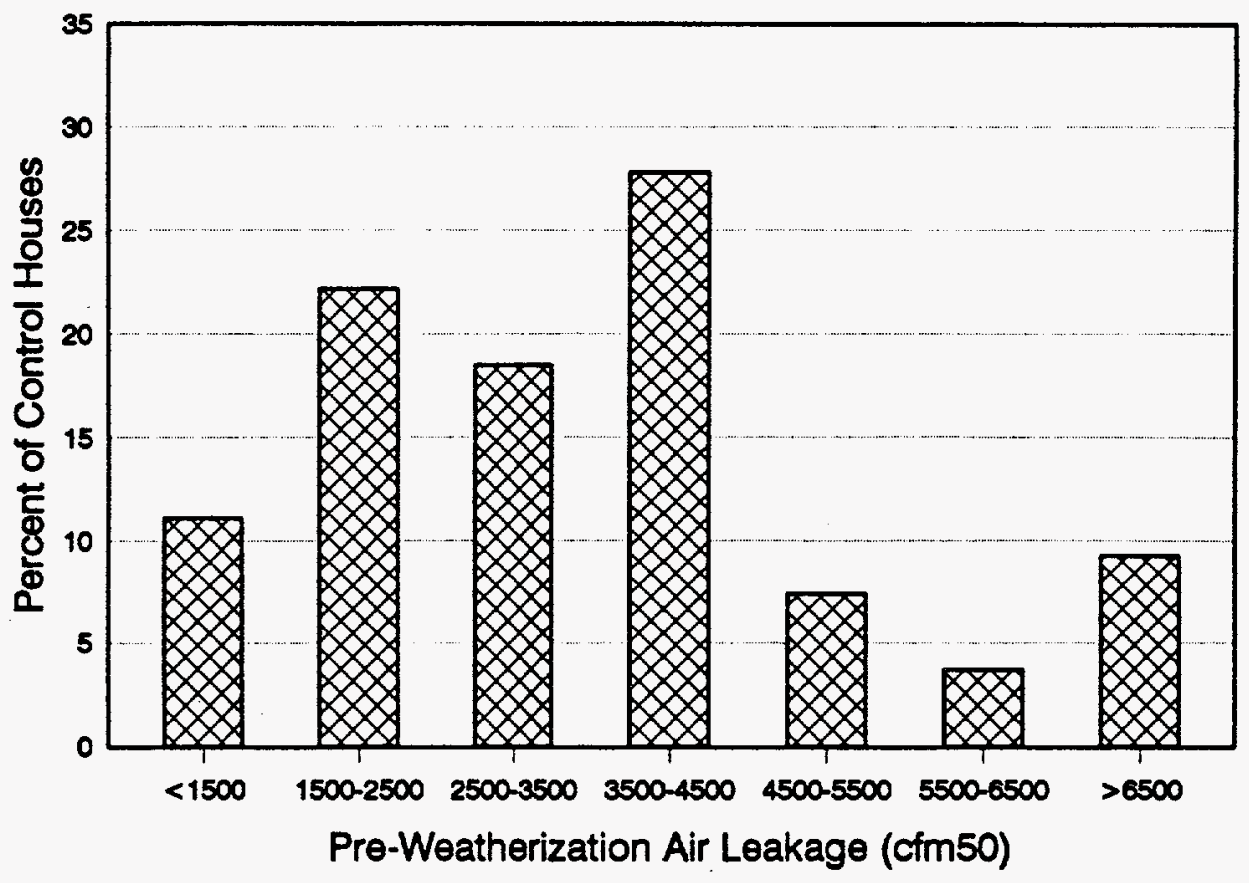

(b)

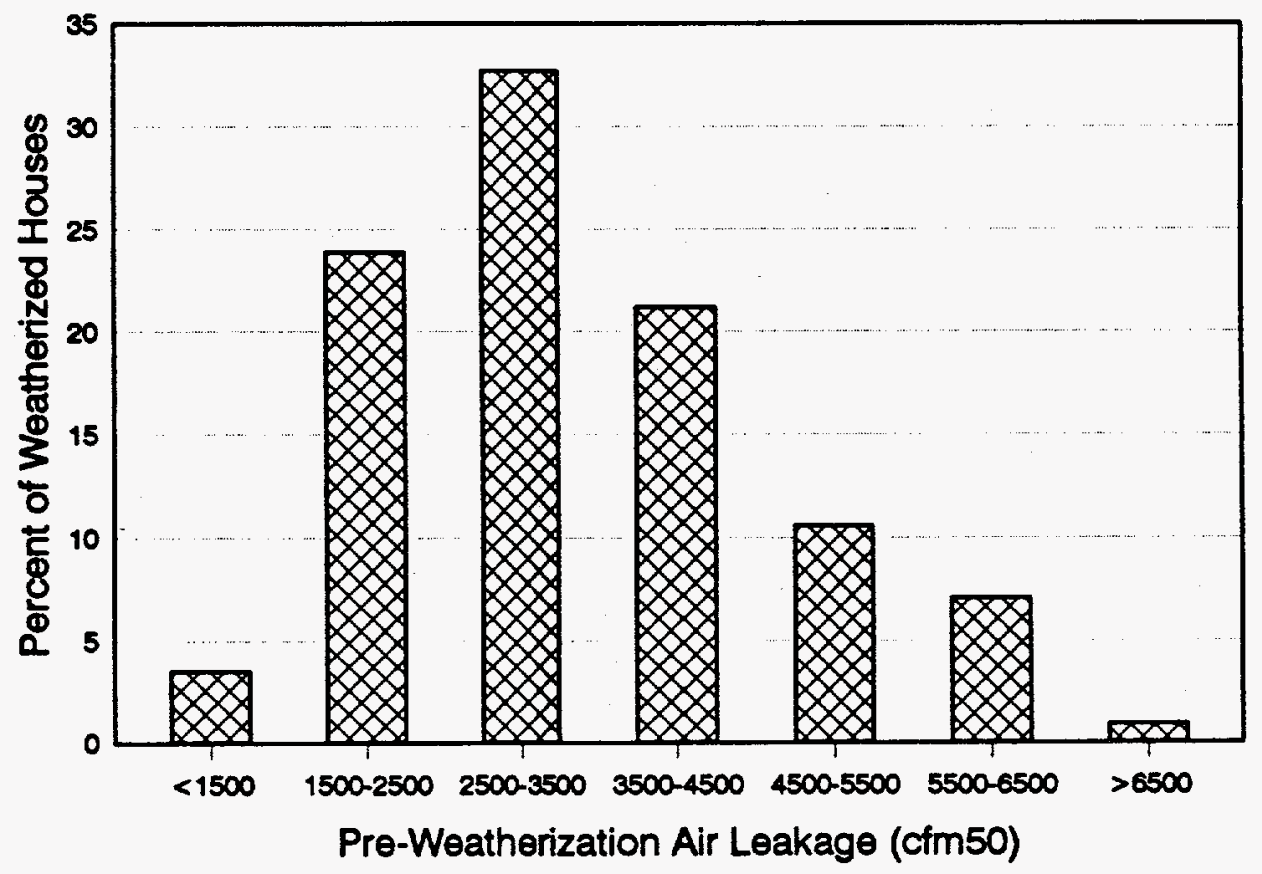

Fig. 6.1. Distribution of pre-weatherization air leakages for the control (a) and weatherized (b) houses. For the control houses, the mean was $3468 \mathrm{cfm50}$ and the standard deviation was 1735. For the weatherized houses, the mean was $3295 \mathrm{cfm} 50$ and the standard deviation was 1263. 
$1400 \mathrm{cfm} 50$ are generally considered to be tight (Tsongas 1993), requiring no infiltration reduction work $^{18}$. Any infiltration reduction work performed on such houses would generally achieve small reductions and could potentially cause indoor health and moisture problems.

On the other hand, $9 \%$ of the control houses and only $1 \%$ of the weatherized houses had pre-weatherization air leakages greater than $6500 \mathrm{cfm} 50$. These houses have severe air leakage problems that should benefit considerably from air-sealing work.

Weatherization work performed under the study achieved statistically significant reductions in air leakage. Table 6.1 shows that the average sample air-leakage reduction was $164 \mathrm{cfm} 50$ for the control houses and $570 \mathrm{cfm} 50$ for the weatherized houses. The average control house reduction was not statistically different from zero at a 0.05 level of significance; the average weatherized house reduction was statistically different from zero and from the control house reduction at this same confidence level.

The distribution of air-leakage reductions for both the control and weatherized houses is shown in Fig. 6.2, and air-leakage reductions are plotted versus pre-weatherization values in Fig. 6.3. A majority of the control houses had reductions between -500 and $500 \mathrm{cfm} 50$, with $43 \%$ of the control houses having negative reductions and $57 \%$ having positive reductions. ${ }^{19}$ Figure 6.3(a) shows this relatively even distribution of positive and negative reductions for the control houses. Figure 6.3(a) also shows that the pre-weatherization air leakage was not a determining factor in the sign of the reduction. Changes in air leakages for the control houses were expected to be more closely distributed around zero because no weatherization work was performed in them. Analysis was performed using the refined data set to ensure that data quality did not

${ }^{18}$ This range assumes five or fewer occupants live in the house, normal shielding, and a living area less than $1610 \mathrm{ft}^{2}$. The range is higher for more occupants, better shielding, and larger living areas.

${ }^{19}$ Similar results are reported for control houses from other field tests (Ternes et al. 1991), although the reductions are more closely distributed around zero than they are here. On the other hand, consistent air leakages can be measured as demonstrated in other field tests (Ternes, Wilkes, and McLain 1993). 
(a)

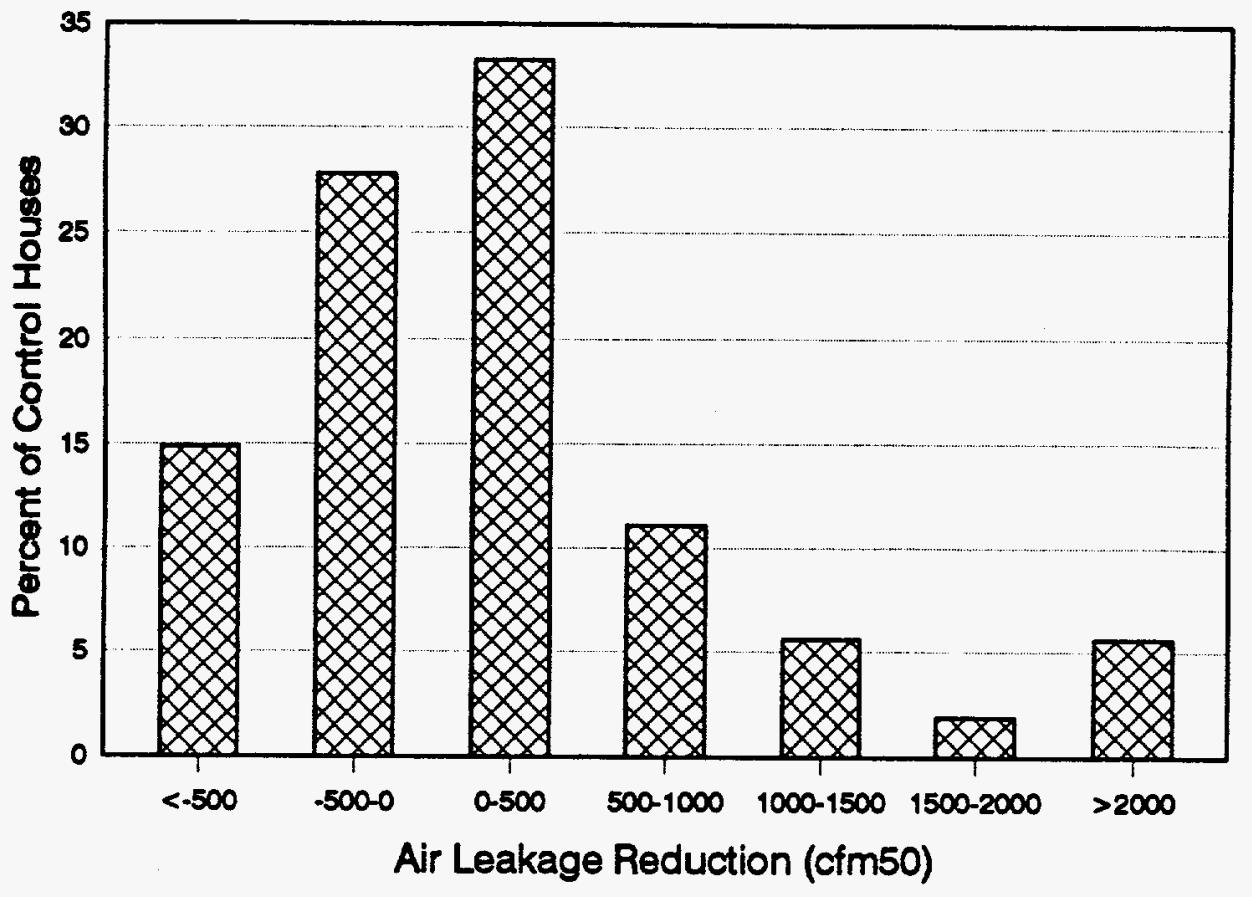

(b)

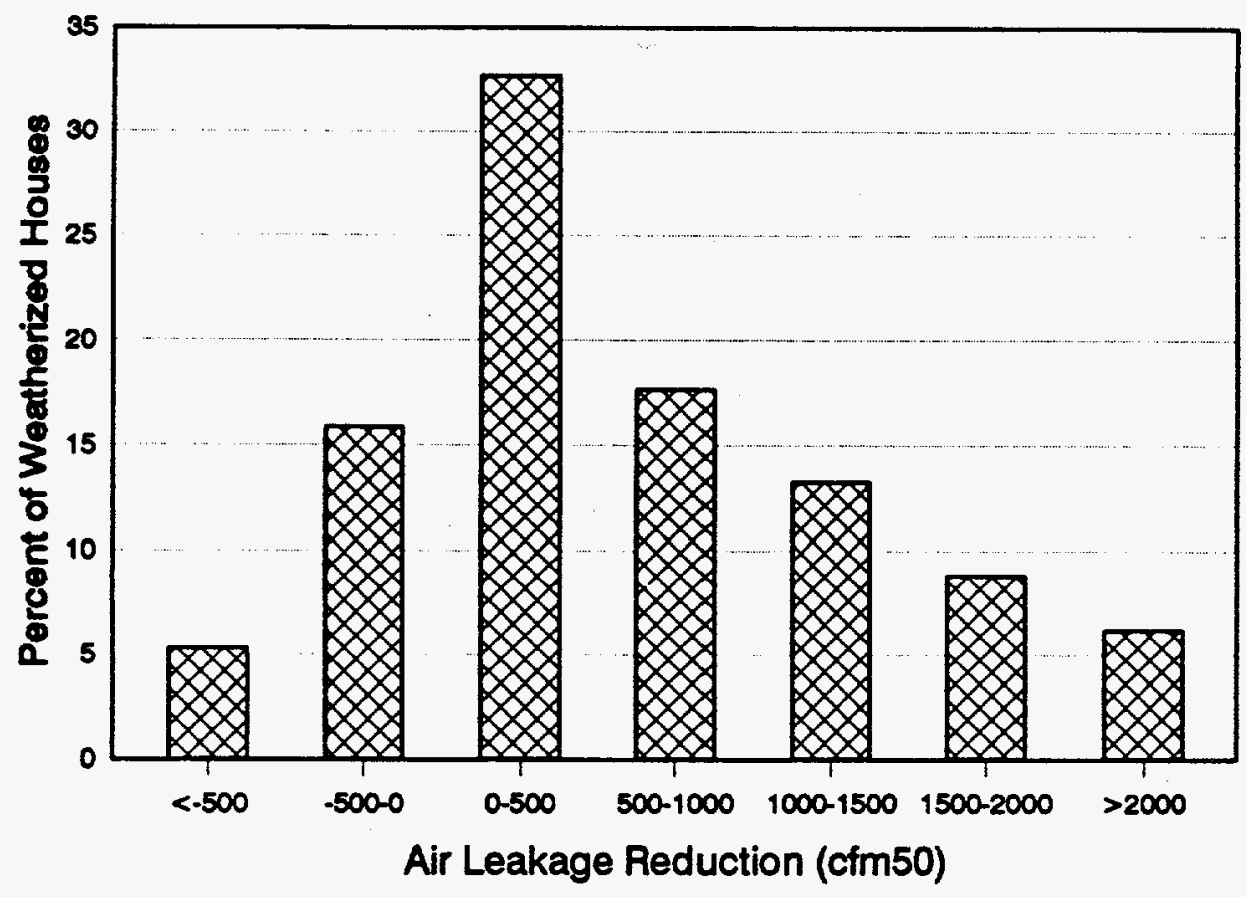

Fig. 6.2. Distribution of air-leakage reductions in the control (a) and weatherized (b) houses. For the control houses, the mean was $164 \mathrm{cfm50}$ and the standard deviation was 1099. For the weatherized houses, the mean was $570 \mathrm{cfm50}$ and the standard deviation was 821 . 
(a)

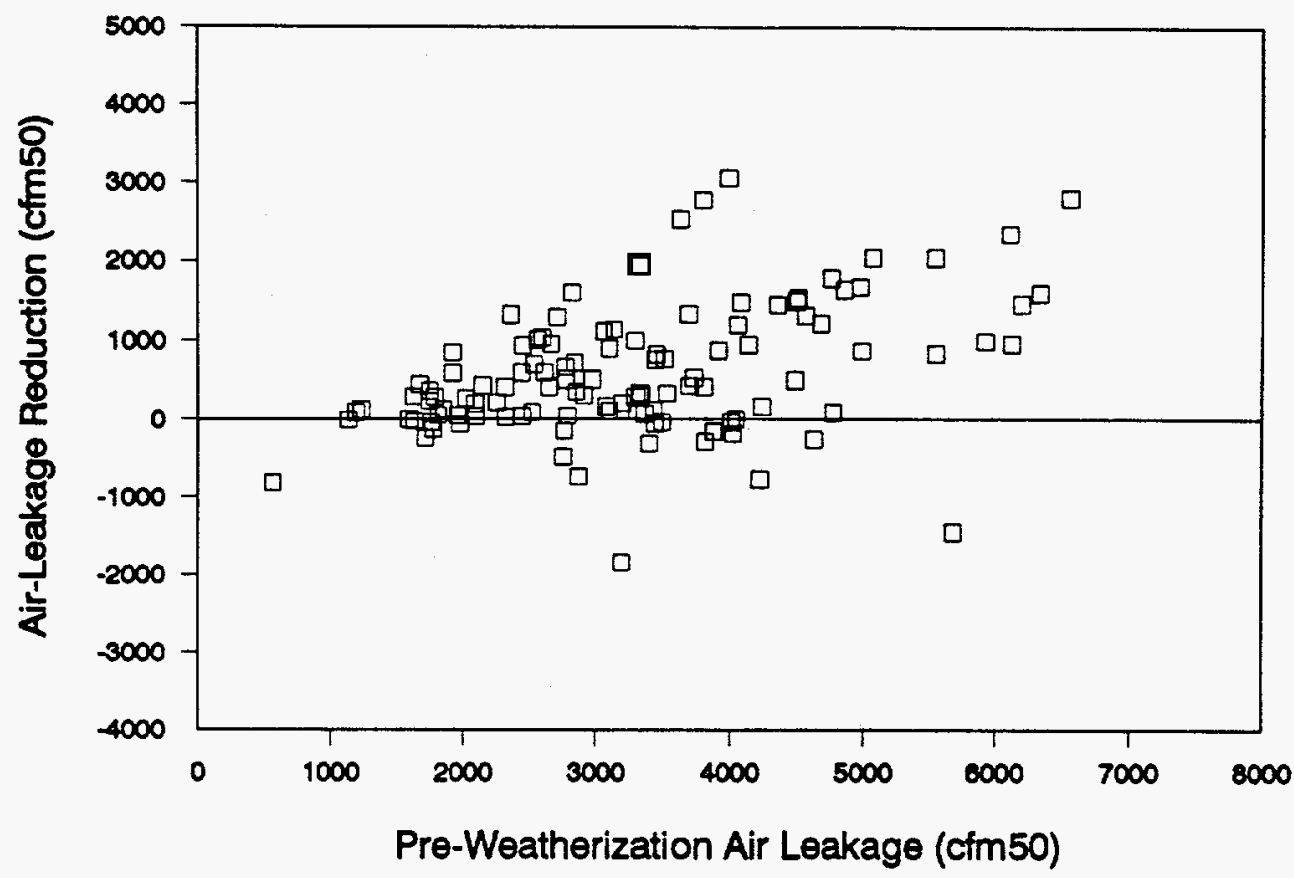

(b)

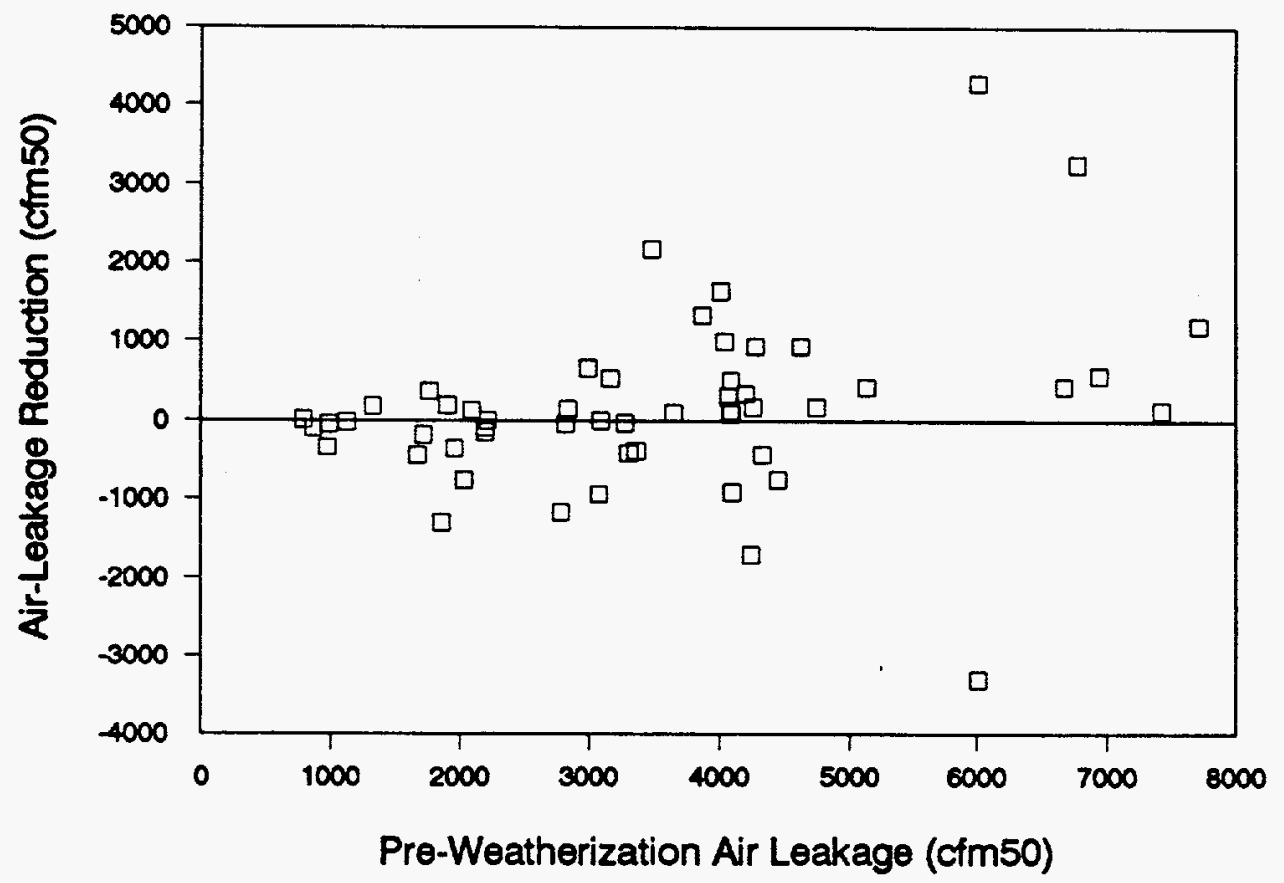

Fig. 6.3. Comparison of the air-leakage reductions of the control (a) and weatherized (b) houses to pre-weatherization air leakages. 


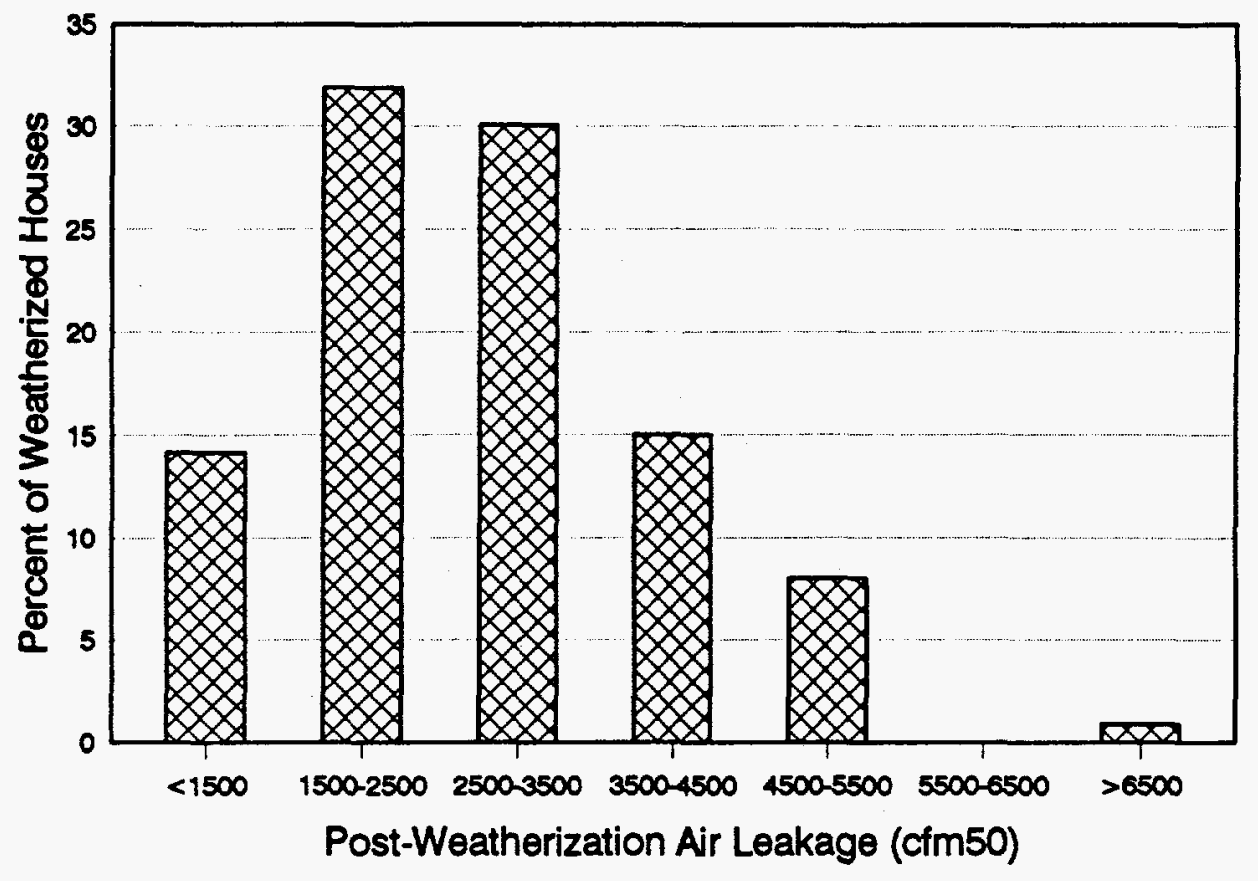

Fig. 6.4. Distribution of post-weatherization air leakages for the weatherized houses. The mean was 2725 cfm50 and the standard deviation was 1165.

contribute to this behavior. Changes observed for individual houses could be due to random measurement errors, although the test procedure in Appendix D was intended to minimize this.

About a third of the weatherized houses had relatively small air-leakage reductions ( 0 to $500 \mathrm{cfm} 50$ ) and about a third had reductions between 500 and $1500 \mathrm{cfm} 50$. Negative reductions were still experienced in $21 \%$ of the houses, mainly between 0 and $-500 \mathrm{cfm} 50{ }^{20}$ The shift to lower air leakages is evident in comparing the distribution of post-weatherization values (Fig. 6.4) to the pre-weatherization distribution shown in Fig. 6.1(b). Following weatherization, 76\% of the weatherized houses had air leakages less than $3500 \mathrm{cfm} 50$, while $60 \%$ did before weatherization. As shown in Fig. 6.3(b), the air-leakage reductions of the weatherized houses are somewhat dependent on pre-weatherization air leakages, although significant scatter does exist. Generally, small reductions were achieved for houses with pre-weatherization air leakages below $2000 \mathrm{cfm} 50$.

\footnotetext{
${ }^{20}$ Previous field studies (Ternes et al. 1991, Ternes and Levins 1992) report few weatherized houses with negative reductions.
} 
The effect of the following four factors on air-leakage reductions achieved in the weatherized houses was investigated, with results summarized in Table 6.2: use of a blower door to perform infiltration reduction work, presence of a forced-air distribution system in the house, installation of any type of wall insulation, and installation of high-density wall insulation. In all cases, average pre-weatherization air leakages were statistically the same for houses with the factor as without. This result implies that

- Houses weatherized using a blower door were not leakier than other houses to begin with (leaky houses did not receive preferential treatment).

- Houses with forced-air distribution systems did not have natural infiltration rates greater than houses with other distribution systems (the forced-air distribution system, when operating, may still affect house air leakage).

- Houses receiving wall insulation were not inherently leakier than houses that did not. This result does not address the question of whether houses without wall insulation were more leaky than houses with insulated walls because all houses without wall insulation did not necessarily receive this measure.

On average, air leakage reductions were $240 \mathrm{cfm} 50$ greater in houses in which blower doors were used in sealing work compared to houses not receiving this treatment. Similarly, reductions were $175 \mathrm{cfm} 50$ greater in houses receiving wall insulation, and $300 \mathrm{cfm} 50$ greater in houses receiving high-density wall insulation. Houses with forced-air distribution systems did not have greater air leakage reductions than houses without forced-air distribution systems, despite the fact that air distribution systems are often leaky and contribute to total house leakage. None of these differences were statistically significant at a 0.10 level of significance (use of a blower door and installation of high-density wall insulation would just be significant at a 0.20 level of significance). 
Table 6.2. Factors effecting air-leakage reductions in the weatherized houses

\begin{tabular}{||l|c|c|c||}
\hline \multicolumn{1}{|c|}{ Factor } & $\begin{array}{c}\text { Number of } \\
\text { houses } \\
\text { in the sample }\end{array}$ & $\begin{array}{c}\text { Pre-weatherization } \\
\text { air leakage } \\
\text { (cfm50) }\end{array}$ & $\begin{array}{c}\text { Air-leakage } \\
\text { reduction } \\
\text { (cfm50) }\end{array}$ \\
\hline \hline Blower door used & 88 & 3290 & 623 \\
\hline Blower door not used & 25 & 3312 & 383 \\
\hline \hline $\begin{array}{l}\text { Forced-air distribution } \\
\text { system present }\end{array}$ & 56 & 3217 & 588 \\
\hline $\begin{array}{l}\text { Forced-air distribution } \\
\text { system not present }\end{array}$ & 57 & 3372 & 552 \\
\hline \hline $\begin{array}{l}\text { Wall insulation } \\
\text { installed }\end{array}$ & 43 & 3271 & 678 \\
\hline $\begin{array}{l}\text { Wall insulation not } \\
\text { installed }\end{array}$ & 70 & 3310 & 503 \\
\hline \hline $\begin{array}{l}\text { High density wall } \\
\text { insulation installed }\end{array}$ & 14 & 3253 & 833 \\
\hline $\begin{array}{l}\text { High density wall } \\
\text { insulation not installed }\end{array}$ & 99 & 3301 & 533 \\
\hline
\end{tabular}





\section{HEATING SYSTEM MEASUREMENTS AND INSPECTIONS}

Space-heating system steady-state efficiencies were measured at the beginning of the preweatherization period and at the end of the post-weatherization period following the measurement procedure provided in Appendix E. Additionally, a safety inspection of the spaceand domestic water-heating systems was performed at the end of the post-weatherization period following the inspection procedure provided in Appendix F.

\subsection{THE COMBUSTION OF FUEL OIL}

An oil-fired heating system must both burn fuel oil efficiently and transfer the heat generated from combustion to the living area in order to efficiently heat a dwelling. The main chemical components of fuel oil are carbon and hydrogen (about $85 \%$ and $15 \%$ by weight, respectively). An efficient combustion process requires that fuel oil mix with oxygen from air and burn completely so that the products of combustion are carbon dioxide and water. Any inefficiency in the combustion process results in unburned fuel oil, soot (carbon), and carbon monoxide. Their presence reduces the amount of heat produced per unit of fuel oil delivered to the heating system and also creates potential health, safety, and operational problems.

The burner nozzle breaks the stream of liquid fuel into a spray of very small diameter droplets (large surface area per unit volume) so that the fuel may be more easily vaporized, mixed with oxygen from the air, and burned. Insufficient mixing of oxygen and fuel causes incomplete combustion. Since air is the source of oxygen for the combustion process, those components of air, such as nitrogen and argon, which do not enter into the combustion process actually inhibit combustion by lowering the temperature at which the reaction takes place. This means that the amount of excess air - that amount of air above the theoretical quantity necessary to burn all the fuel to carbon dioxide and water - should be minimized. Experience dictates that $40 \%$ is usually the optimum amount of excess air to be mixed with fuel oil to ensure proper combustion (Alliance to Save Energy 1985).

Heat produced as fuel oil is burned is removed from the hot combustion gas by a heat exchanger in order to heat a dwelling. Any soot formed during the combustion process reduces 
Table 7.1. Description of smoke number

\begin{tabular}{|c|l||}
\hline \hline Smoke number & \multicolumn{1}{|c|}{ Burner performance } \\
\hline \hline $0-1$ & Excellent - Little, if any, sooting of furnace or boiler surfaces. \\
\hline 2 & $\begin{array}{l}\text { Good - May be slight sooting with some types of furnace or boiler but } \\
\text { little increase in flue gas temperature. }\end{array}$ \\
\hline 3 & $\begin{array}{l}\text { Fair - Substantial sooting with some types of furnace or boiler and will } \\
\text { require cleaning more than once a year on most types of furnace or } \\
\text { boiler. }\end{array}$ \\
\hline 4 & $\begin{array}{l}\text { Poor - This is a borderline smoke - some units may soot only } \\
\text { moderately, others may soot rapidly. }\end{array}$ \\
\hline 5 & $\begin{array}{l}\text { Very Poor - Heavy sooting in all cases - may require cleaning several } \\
\text { times during the season. }\end{array}$ \\
\hline $6-9$ & $\begin{array}{l}\text { Extremely Poor - Severe and rapid sooting - may result in damage to } \\
\text { stack control and reduce overfire draft to danger point. }\end{array}$ \\
\hline
\end{tabular}

combustion efficiency and may attach to the heat exchanger to further reduce the transfer of heat to a dwelling. Any heat not removed from the combustion gas is essentially wasted by going up the chimney, although some heat is needed to vaporize the fuel oil for combustion and to form a draft to vent combustion gases.

The steady-state efficiency (SSE) measures both how completely a fuel burns and how well the heating system removes heat from the combustion gases under steady-state operation. Theory dictates that about $13 \%$ of the heat generated in the combustion process is needed for proper operation of a non-condensing draft-vented fuel-oil heating system, so that $87 \%$ is the maximum obtainable SSE for this type of system (Alliance to Save Energy 1985). The annual fuel utilization efficiency (AFUE) differs from the SSE in that it also includes cycling losses.

The SSE of an oil-fired furnace is determined by measuring the percent oxygen (or percent carbon dioxide) in the flue gas, the net stack temperature, and the smoke number. The first two measurements can be used with tables derived from combustion stoichiometry (see Table J.1) to determine the SSE assuming complete combustion. This efficiency must be adjusted by the smoke number (a number on a scale from 0 to 9 ) to account for incomplete combustion. A description of the smoke number is provided in Table 7.1 (Bacharach). Adjustments to the steady-state efficiency are provided in Table J.1. 


\subsection{CLEAN AND TUNE-UP SERVICE}

A clean and tune-up was a measure performed on many heating systems. This service is suppose to address the steady-state efficiency, seasonal efficiency, reliability, and safety of the heating system. A fully trained oil-burner technician should clean the nozzle and heat exchanger, assure that the system is functioning and venting properly, and then tune-up the system so that it operates at its optimum SSE with minimum smoke. The tune-up should be performed while monitoring the SSE and is accomplished through adjustments to the air supply, burner, etc. The technician should then measure the final SSE and smoke value. The Alliance to Save Energy (1985) recommends as a retrofit goal an SSE of $80 \%$, an oxygen level in the flue gas of $\leq 7 \%$, and a smoke number of $\leq 1$.

The technician should adjust fan limit switches to achieve maximum seasonal efficiency. The technician should also correct any malfunctions with the system and/or perform necessary repairs (e.g., cad cells, ignitors, limit switches, and barometric dampers) to address system reliability and safety.

A sample group was selected containing all houses which did not receive a new heating system or a new burner in order to determine the effect of clean and tune-up services on SSE and other combustion-related parameters of oil burners. Each heating system had to have valid SSE data for both pre- and post-weatherization periods in order to be included in the sample. A total of 208 houses were in the sample: 72 control houses and 136 weatherized houses. None of the control houses received a clean and tune-up, while 71 of the 136 weatherized houses received a clean and tune-up.

All measured SSEs reported in this section were adjusted for smoke number levels to correct table readings for incomplete combustion. Specifications for the analyzers used to perform the measurements state that they were accurate to within $\pm 0.25 \%$ of the oxygen reading and to within $1 \%$ of the temperature reading. Based on the instrument specifications and Table J.1, SSE measurements readings should be within $\pm 1 \%$ of the true value if procedures were properly followed. A potential source of error in the procedure involved interpolation errors when reading Table $\mathrm{J} .1$. 
Table 7.2 contains a summary of the unweighted sample data for all heating-system types and various subsets of the houses. Tables J.2 and J.3 in Appendix J contain information on standard errors of the mean for the measured SSEs.

The weatherized houses receiving a clean and tune-up were originally less efficient and more in need of a tune-up than weatherized houses not receiving this service. The average value of the SSE at the start of the pre-weatherization period was $75.0 \%$ for the control houses, $77.2 \%$ for the weatherized houses receiving no clean and tune-up, and $75.0 \%$ for the weatherized houses receiving a clean and tune-up. Distributions of the pre-weatherization SSEs for these groups are shown in Figs. 7.1(a), 7.2(a), and 7.3(a), respectively. Almost twice as many weatherized houses that did not receive a clean and tune-up had a SSE $280 \%$ compared to weatherized houses that did receive this service (37\% compared to $18 \%$, respectively). A t-test showed that the difference between the average pre-weatherization SSE values of weatherized houses receiving a clean and tune-up and weatherized houses not receiving this service was significant at a 0.05 level of significance.

The control houses, which received no clean and tune-up services, showed the greatest SSE increase of all three groups, and their distribution appeared to have much less variance than those of the weatherized groups. The average values of the SSE at the end of the postweatherization period were $76.6 \%$ for the control houses (an average increase of 1.5 percentage points), $77.7 \%$ for the weatherized houses not receiving a clean and tune-up (an average increase of 0.5 percentage points), and $75.8 \%$ for weatherized houses receiving a clean and tune-up (an average increase of 0.8 percentage points). Distributions of the SSE changes for these groups are shown in Figs. 7.1(b), 7.2(b), and 7.3(b), respectively. Figure 7.2(b) shows that over half of the weatherized houses receiving a clean and tune-up increased in SSE from 0 to 4 percentage points, with a third of the total increasing from 2 to 4 percentage points; however, the SSE decreased in $21 \%$ of the houses by 2 to 14 percentage points! Figure $7.3(\mathrm{~b})$ shows that about half of the weatherized houses not receiving a clean and tune changed in SSE within a -2 to 2 percentage point range. T-tests showed that SSE changes of the three groups were not significantly different from zero or each other at a 0.05 level of significance. 
Table 7.2. Mean values of measured space-heating system performance parameters

(a)

ALL SYSTEMS (Forced Air, Hydronic, Steam, and Gravity)

\begin{tabular}{|c|c|c|c|c|c|c|c|c|}
\hline \multirow[b]{2}{*}{ Type $^{1}$} & \multirow{2}{*}{$\begin{array}{l}\text { Number } \\
\text { in sample }\end{array}$} & \multicolumn{3}{|c|}{ Adjusted steady-state efficiency } & \multicolumn{2}{|c|}{ Smoke number } & \multirow{2}{*}{$\begin{array}{l}\text { CO in } \\
\text { flue gas } \\
(\mathrm{ppm})^{2}\end{array}$} & \multirow{2}{*}{$\begin{array}{l}\text { Age of } \\
\text { heating } \\
\text { system }\end{array}$} \\
\hline & & Pre & Post & Difference & Pre & Post & & \\
\hline WEATHERIZED & 136 & & & & & & & \\
\hline No C\&T & 65 & 77.2 & 77.7 & 0.5 & 1.5 & 1.7 & 134 & 18 \\
\hline With C\&T & 71 & 75.0 & 75.8 & 0.8 & 2.2 & 2.1 & 73 & 24 \\
\hline CONTROL & 72 & & & & & & & \\
\hline No C\&T & 72 & 75.0 & 76.6 & 1.5 & 2.2 & 1.7 & 89 & 20 \\
\hline
\end{tabular}

(b)

FORCED AIR SYSTEMS

\begin{tabular}{|c|c|c|c|c|c|c|c|c|}
\hline \multirow[b]{2}{*}{ Type $^{1}$} & \multirow{2}{*}{$\begin{array}{c}\text { Number } \\
\text { in sample }\end{array}$} & \multicolumn{3}{|c|}{ Adjusted steady-state efficiency } & \multicolumn{2}{|c|}{ Smoke number } & \multirow{2}{*}{$\begin{array}{l}\mathrm{CO} \text { in } \\
\text { flue gas } \\
(\mathrm{ppm})^{2}\end{array}$} & \multirow{2}{*}{$\begin{array}{l}\text { Age of } \\
\text { heating } \\
\text { system }\end{array}$} \\
\hline & & Pre & Post & Difference & Pre & Post & & \\
\hline WEATHERIZED & 65 & & & & & & & \\
\hline No C\&T & 32 & 77.7 & 77.6 & -0.1 & 1.1 & 1.3 & 84 & 14 \\
\hline With C\&T & 33 & 75.9 & 76.3 & 0.4 & 2.1 & 2.2 & 80 & 20 \\
\hline CONTROL & 16 & & & & & & & \\
\hline No $C \& T$ & 16 & 76.5 & 77.7 & 1.2 & 1.2 & 0.9 & 64 & 10 \\
\hline
\end{tabular}

(c)

HYDRONIC BOILER SYSTEMS

\begin{tabular}{|c|c|c|c|c|c|c|c|c|}
\hline \multirow[b]{2}{*}{ Type $^{1}$} & \multirow{2}{*}{$\begin{array}{l}\text { Number } \\
\text { in sample }\end{array}$} & \multicolumn{3}{|c|}{ Adjusted steady-state efficiency } & \multicolumn{2}{|c|}{ Smoke number } & \multirow{2}{*}{$\begin{array}{l}\mathrm{CO} \text { in } \\
\text { flue gas } \\
(\mathrm{ppm})^{2}\end{array}$} & \multirow{2}{*}{$\begin{array}{l}\text { Age of } \\
\text { heating } \\
\text { system }\end{array}$} \\
\hline & & Pre & Post & Difference & Pre & Post & & \\
\hline WEATHERIZAD & 45 & & & & & & & \\
\hline No C\&T & 18 & 79.1 & 78.9 & -0.2 & 1.2 & 1.4 & 96 & 13 \\
\hline With C\&T & 27 & 76.0 & 76.9 & 0.9 & 2.3 & 2.0 & 56 & 22 \\
\hline CONTROL & 44 & & & & & & & \\
\hline No C\&T & 44 & 74.9 & 76.6 & 1.7 & 2.4 & 1.7 & 105 & 21 \\
\hline
\end{tabular}

(d) SYSTEMS WTTH FLAME RETENTION BURNERS

\begin{tabular}{|c|c|c|c|c|c|c|c|c|}
\hline \multirow[b]{2}{*}{ Type $^{1}$} & \multirow{2}{*}{$\begin{array}{l}\text { Number } \\
\text { in sample }\end{array}$} & \multicolumn{3}{|c|}{ Adjusted steady-state efficiency } & \multicolumn{2}{|c|}{ Smoke number } & \multirow{2}{*}{$\begin{array}{l}\mathrm{CO} \text { in } \\
\text { flue gas } \\
(\mathrm{ppm})^{2}\end{array}$} & \multirow{2}{*}{$\begin{array}{l}\text { Age of } \\
\text { heating } \\
\text { system }\end{array}$} \\
\hline & & Pre & Post & Difference & Pre & Post & & \\
\hline WEATHERIZED & 66 & & & & & & & \\
\hline No C\&T & 40 & 79.0 & 79.5 & 0.6 & 1.2 & 1.1 & 111 & 8 \\
\hline With C\&T & 26 & 77.2 & 78.4 & 1.2 & 1.7 & 1.5 & 63 & 20 \\
\hline CONTROL & 34 & & & & & & & \\
\hline No C\&T & 34 & 76.7 & 78.8 & 2.0 & 1.7 & 1.2 & 67 & 13 \\
\hline
\end{tabular}

${ }^{1} \mathrm{C} \& \mathrm{~T}$ - clean and tune-up.

${ }^{2}$ Measurements of carbon monoxide (CO) in the flue gas were only taken at the end of the heating season. 
(a)

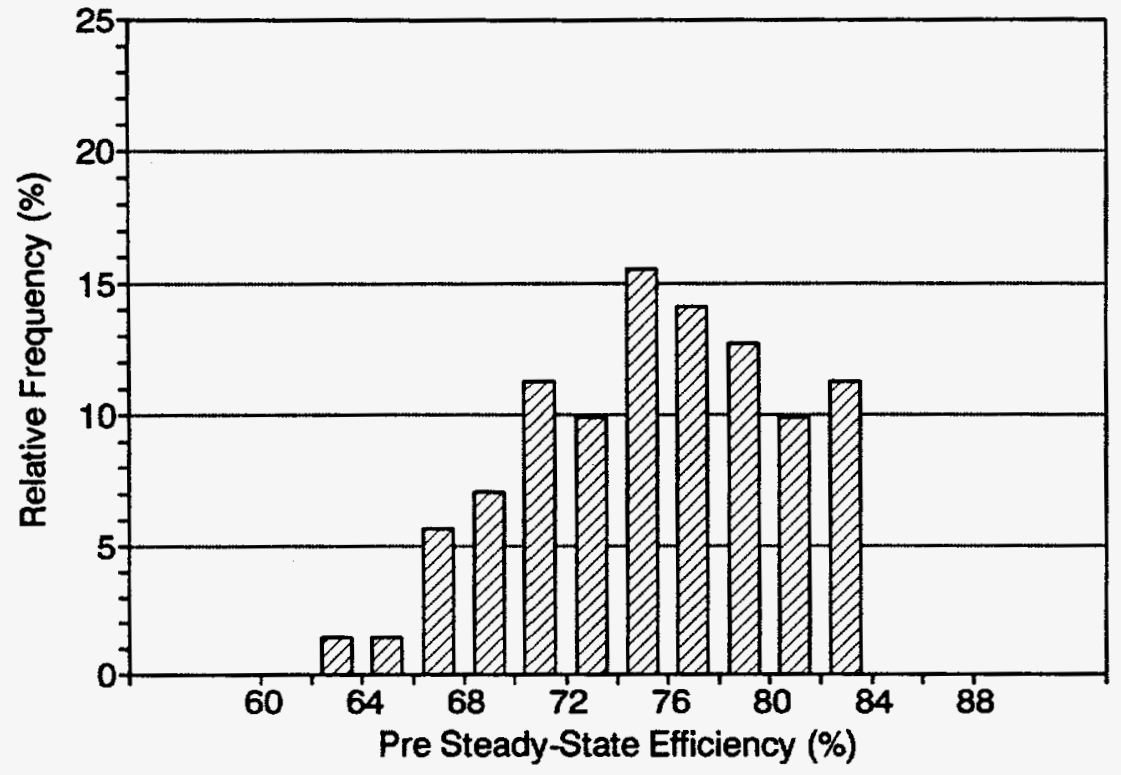

(b)

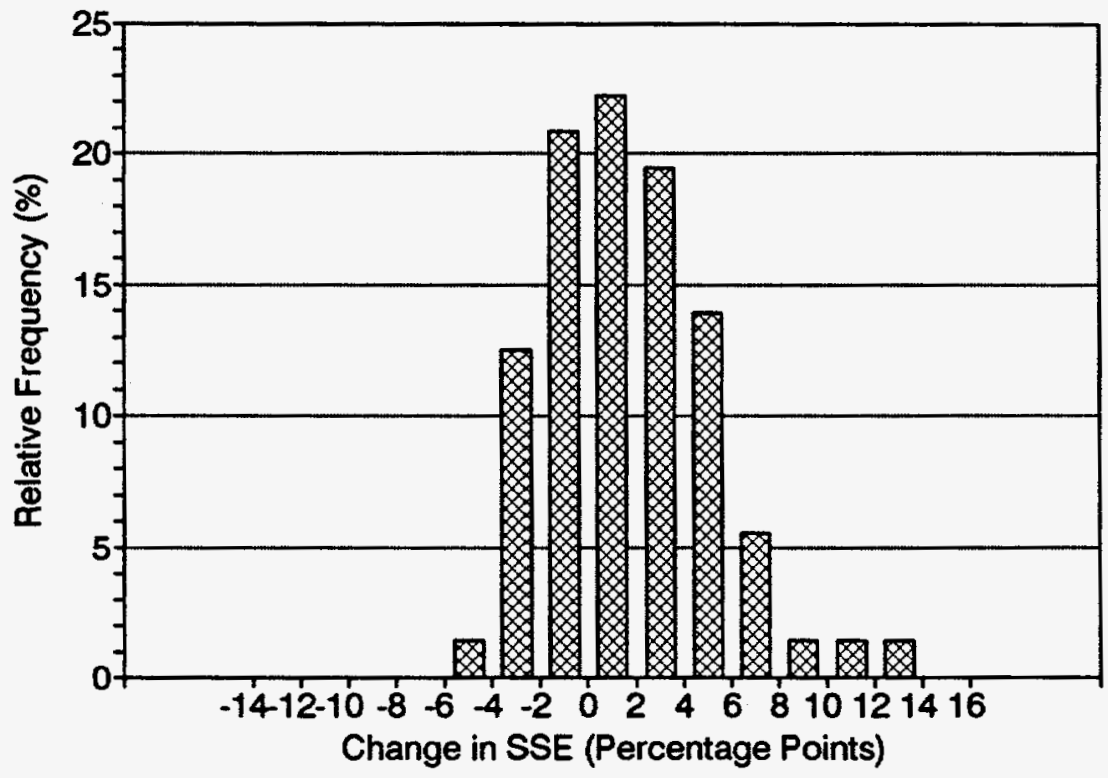

Fig- 7.1. Control houses (none of which received a clean and tune-up) - Distribution of pre-weatherization adjusted steady-state efficiency (a) and efficiency change (b). The mean preweatherization steady-state efficiency was $75 \%$ and the standard deviation was 5.3 . The mean efficiency change was +1.5 percentage points and the standard deviation was 3.7. 
(a)

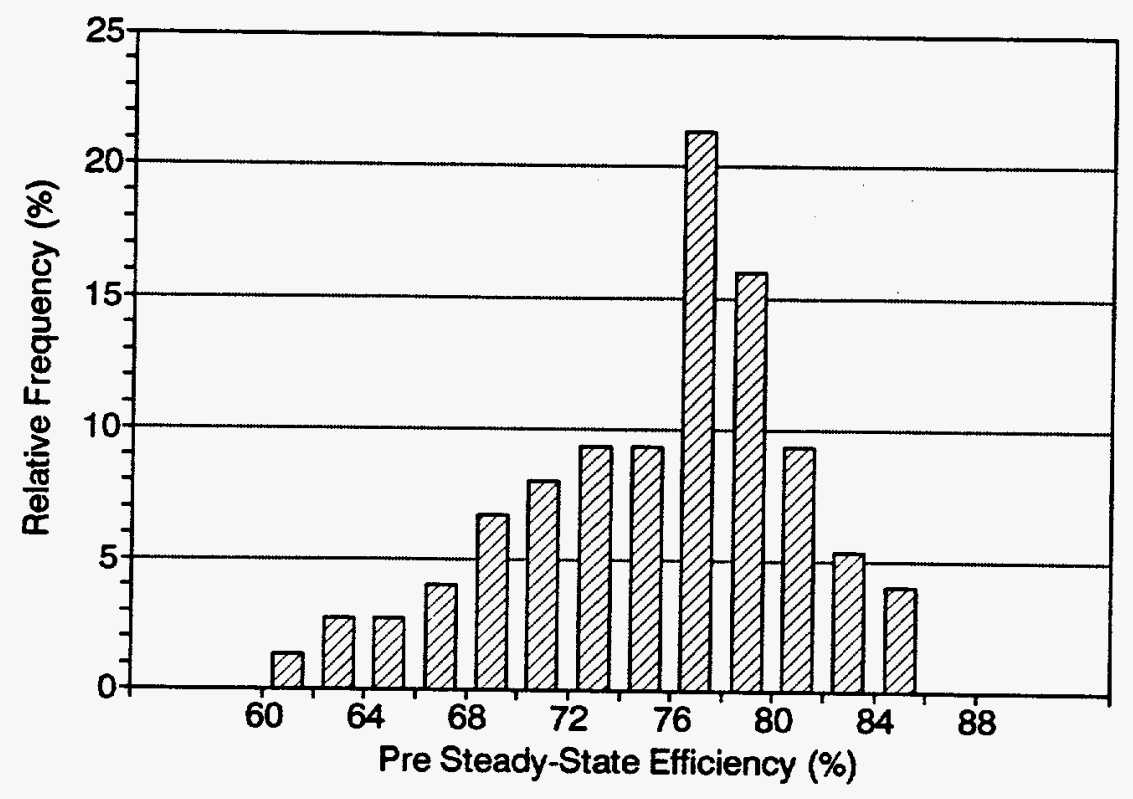

(b)

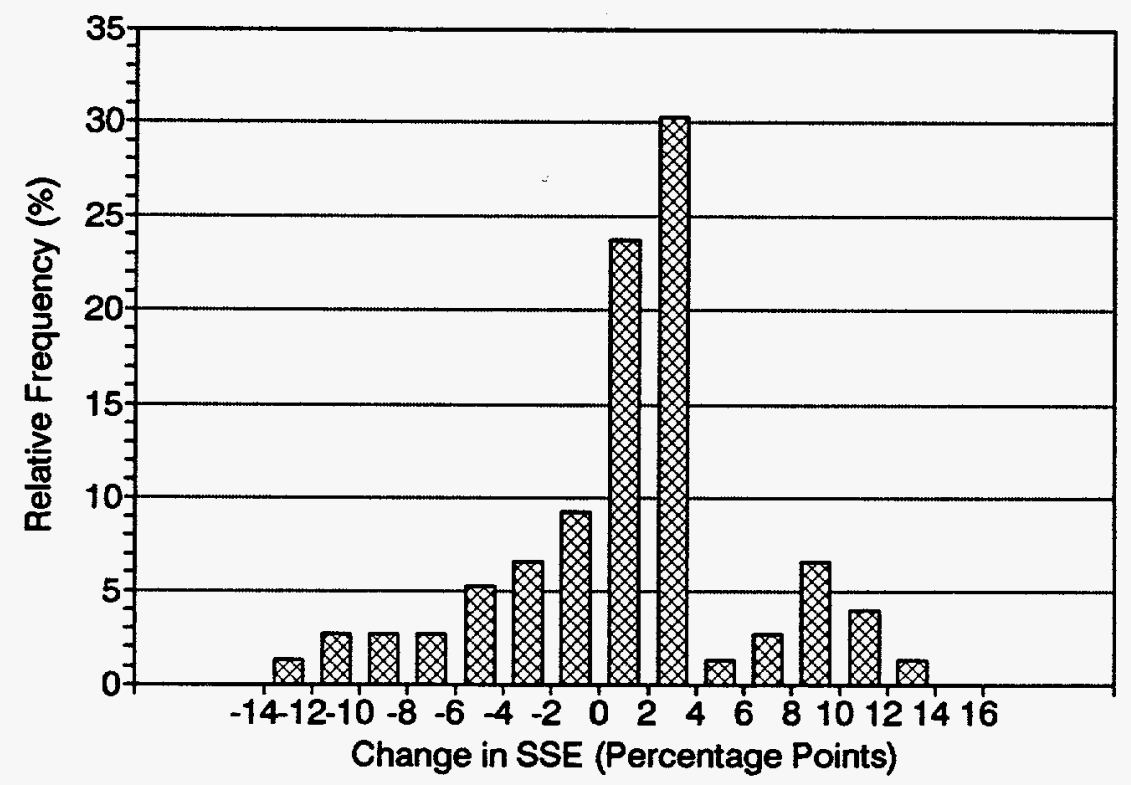

Fig. 7.2. Weatherized houses receiving a clean and tune-up - Distribution of preweatherization adjusted steady-state efficiency (a) and efficiency change (b). The mean preweatherization steady-state efficiency was $75.0 \%$ and the standard deviation was 6.0. The mean efficiency change was +0.8 percentage points and the standard deviation was 5.0. 
(a)

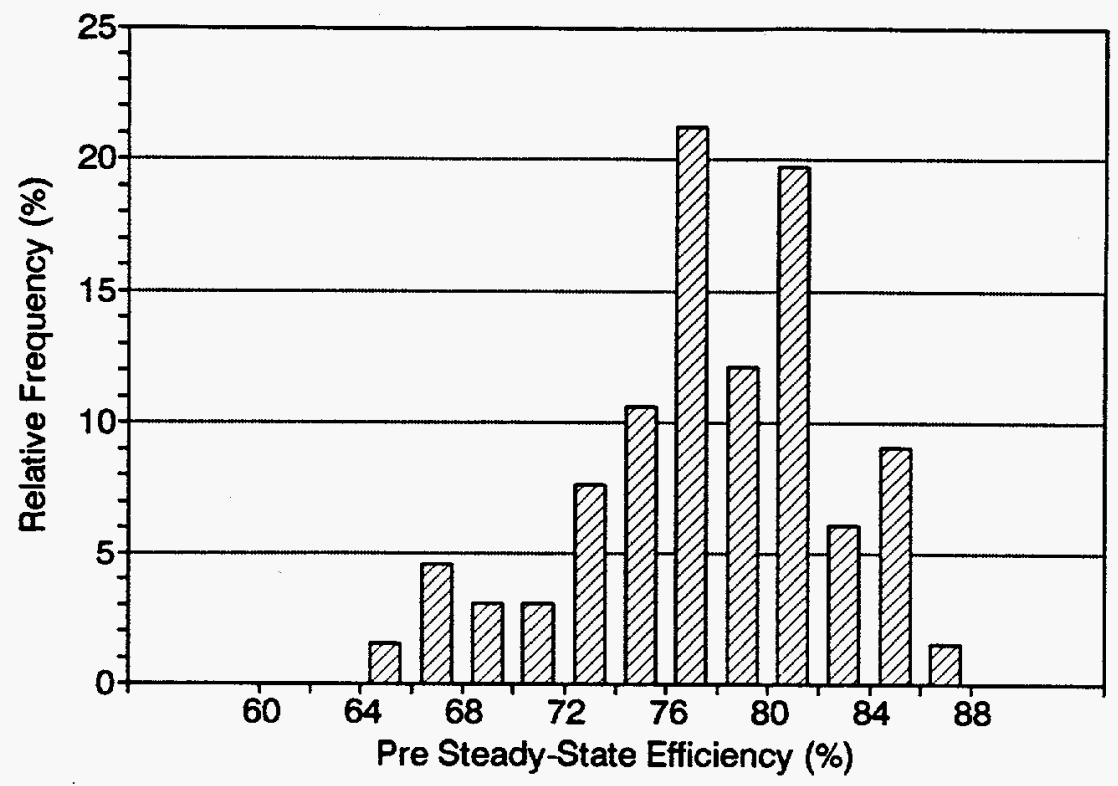

(b)

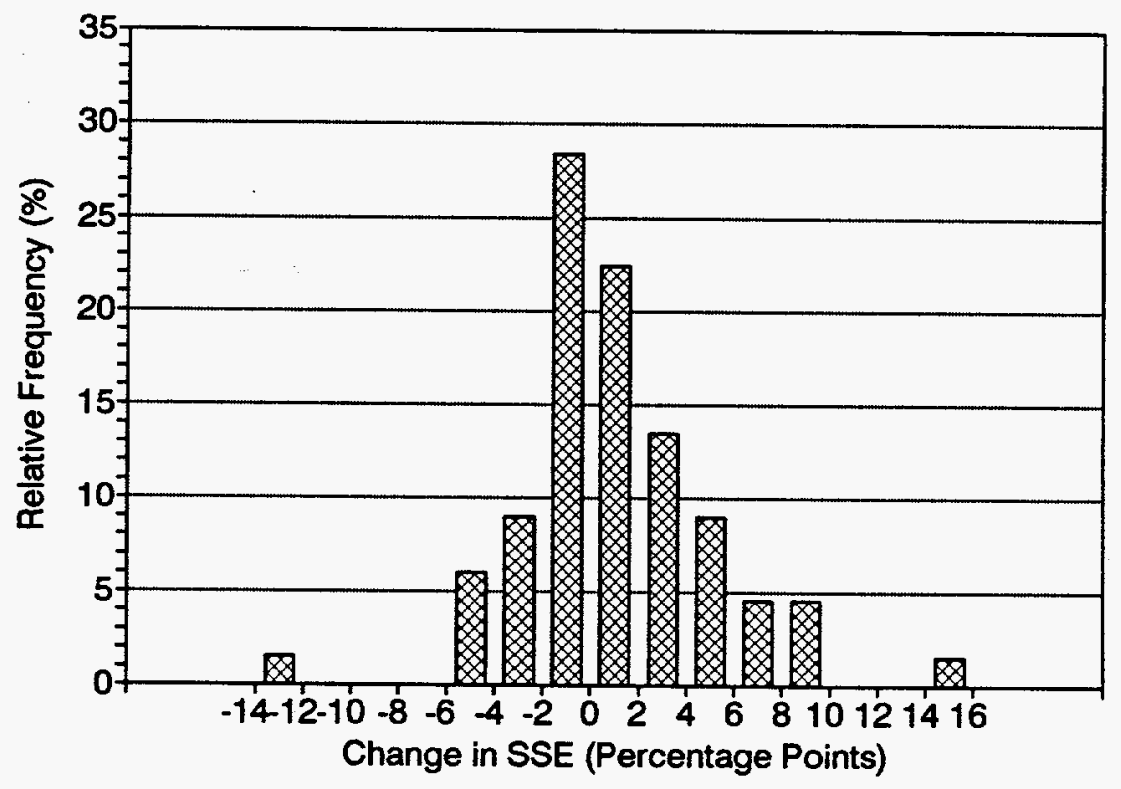

Fig. 7.3. Weatherized house not receiving a clean and tune-up - Distribution of preweatherization adjusted steady-state efficiency (a) and efficiency change (b). The mean preweatherization steady-state efficiency was $77.2 \%$ and the standard deviation was 6.1. The mean efficiency change was +0.5 percentage points and the standard deviation was 4.3 . 
Tables 7.2(b) and 7.2(c) contain data for the two most common subsets of Table 7.2(a): forced-air furnaces and hydronic boilers, respectively (gravity furnaces and steam boilers are remaining systems that are not included). These tables show little difference in performance improvements from clean and tune-up services between forced-air furnaces and hydronic boilers.

Figures 7.4 - 7.6 offer more insight into the SSE measurements and the effectiveness of clean and tune-up services. These figures are plots of pre-weatherization SSE versus change in SSE for control houses, weatherized houses with clean and tune-up, and weatherized houses without clean and tune-up, respectively. These figures all show a general trend (the $\mathbf{R}^{\mathbf{2}}$ values were low at about 0.2): the measured change in SSE was greater for sites with lower SSEs at the beginning of the heating season. All three plots show that the change in SSE was usually negligible or negative if the pre-weatherization SSE was greater than about $77 \%$, whether or not a clean and tune-up had been performed. Similarly, about a 3 percentage point improvement was obtained at sites with a pre-weatherization SSE of $70 \%$, whether a clean and tune-up was performed or not. Ternes et al. (1991) found the same type of behavior in a study dealing with gas space-heating systems in New York state.

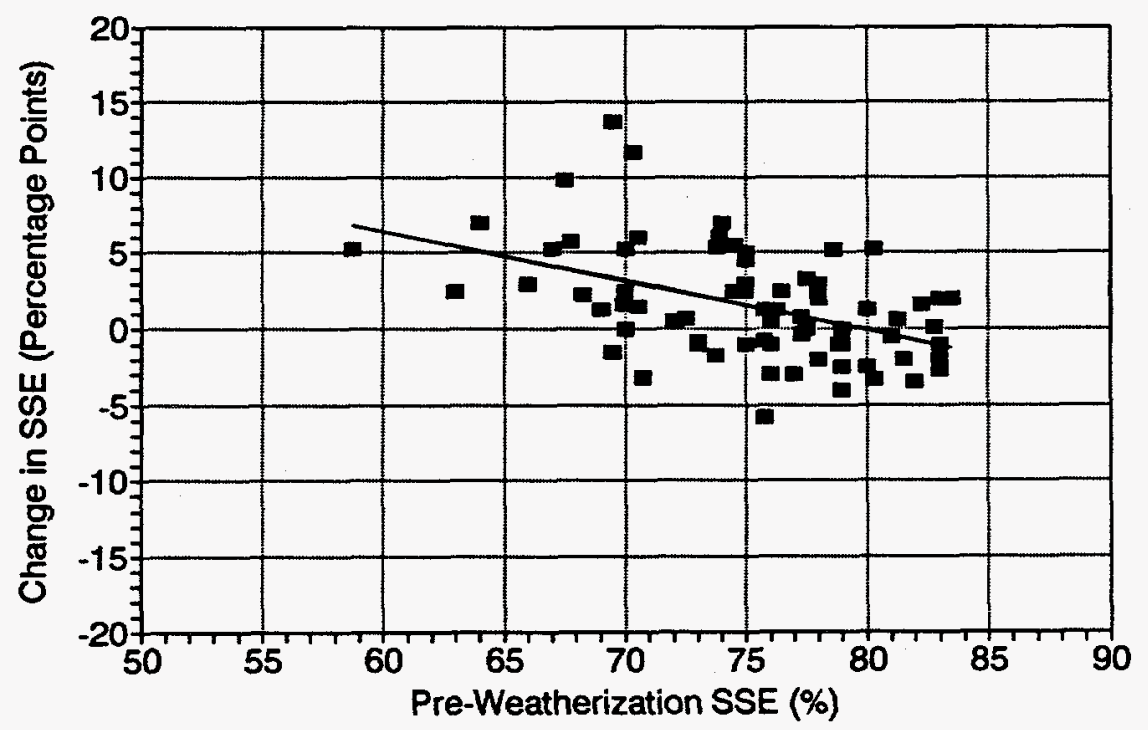

Fig. 7.4. Control houses - Comparison of the change in adjusted steady-state efficiency to the pre-weatherization efficiency. 


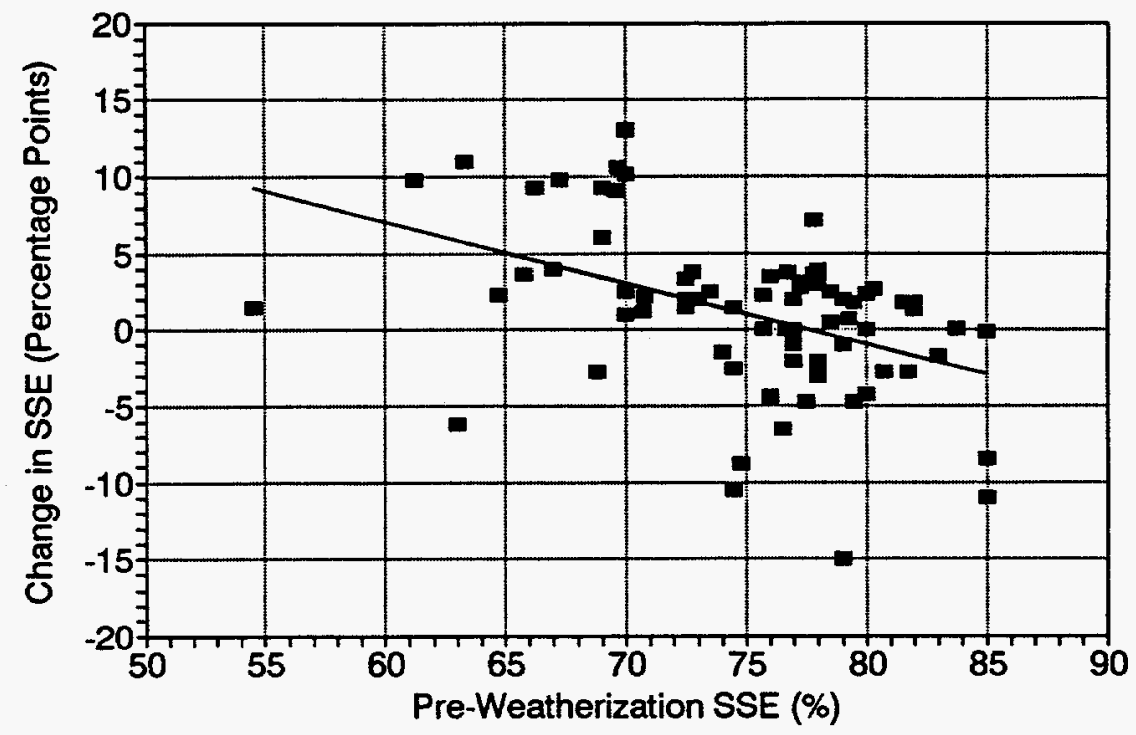

Fig. 7.5. Weatherized houses receiving a clean and tune-up - Comparison of the change in adjusted steady-state efficiency to the pre-weatherization efficiency.

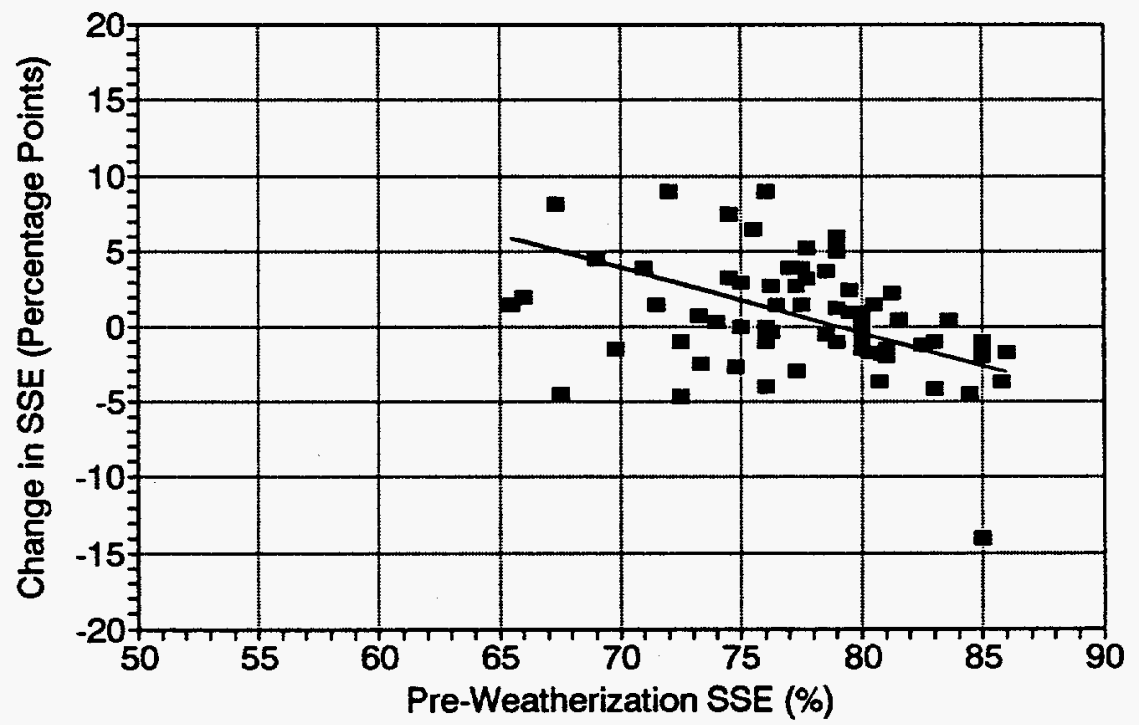

Fig. 7.6. Weatherized houses not receiving a clean and tune-up - Comparison of the change in adjusted steady-state efficiency to the pre-weatherization efficiency. 
The results for the weatherized houses receiving a clean and tune-up, interpreted by themselves, indicate that clean and tune-ups should be performed only when pre-weatherization efficiencies are less than 70\%; clean and tune-ups consistently increased steady-state efficiencies only when pre-weatherization efficiencies were less than $70 \%$. The scattered results and low average increases in SSE obtained from clean and tune-ups performed at houses with higher preweatherization efficiencies suggest that clean and tune-ups are not long lasting (our SSE measurements were made at the end of the heating season), clean and tune-ups are not done properly, or systems in these houses are already operating at their maximum efficiency. The results from the control houses and weatherized houses not receiving a clean and tune-up indicate that clean and tune-ups were not the cause for efficiency increases. This suggests that clean and tune-ups should perhaps not be performed with expectations of improved SSEs.

The current SSE must be measured in order to decide whether or not a system should be cleaned and tuned. The cost of the clean and tune-up is rather insignificant once a burner technician is on site and has made the initial SSE measurement. An agency auditor, however, could measure the SSE as part of an audit and avoid the cost of having a burner technician make a special trip to decide whether or not to conduct a clean and tune-up. Indeed, this situation occurred in many of the agencies in our sample. It should be remembered that, in addition to increasing the SSE, a clean and tune-up might improve the seasonal performance of an oil system and assure that a system is operating properly, reliably, and safely.

Smoke is a primary sign of incomplete combustion and fouling. Smoke numbers averaged between 1.5 and 2.2 in the three groups of houses analyzed before weatherization (Table 7.2a). Average smoke numbers improved little in the weatherized houses receiving a clean and tune-up, and actually improved the most in the control houses.

The Alliance to Save Energy's goals for performance following a clean and tune-up were generally not obtained. Referring to the goal of $80 \%$ SSE with a flue gas containing $\leq 7 \%$ oxygen and a smoke number $\leq 1,3$ of the 71 houses $(4 \%)$ receiving a clean and tune-up service met the goal. Ignoring the $\leq 7 \%$ oxygen requirement, 12 of the 71 houses $(17 \%)$ receiving a clean and tune-up service met the goal. However, the average pre-weatherization SSE value for this group of 12 houses was $80.3 \%$, already above the $80 \%$ goal. If the desired smoke number 
requirement of $\leq 1$ is also ignored, then 21 of the 71 homes (30\%) had a final SSE of $80 \%$ or greater. However, 27 of $65(42 \%)$ of the weatherized houses not receiving clean and tune-ups had a final SSE of $80 \%$ or greater.

Table 7.2(d) contains data for another subset of Table 7.2(a), systems with flame-retention burners. Not shown in Table 7.2 (but also of interest) is a subset consisting of systems without flame-retention burners. Systems with flame-retention burners were more efficient than systems without flame-retention burners. Average pre-weatherization SSEs were $77.2 \%$ vs $74.1 \%$ for weatherized houses receiving clean and tune-ups and $79.0 \%$ vs $73.9 \%$ for weatherized houses not receiving clean and tune-ups. These data confirm that a flame retention burner should be seriously evaluated on a cost effectiveness basis as a retrofit option compared to a conventional burner when a burner replacement is needed. All 20 new systems installed in this study contained flame-retention burners and all 11 new burners installed were also of the flame retention type. The changes in SSE for systems with flame-retention burners after a clean and tune-up were small.

\subsection{HEATING SYSTEM SAFETY INSPECTIONS}

The inspection performed on each heating system at the conclusion of each heating season was mostly visual, but some measurements were taken, such as time for spillage to stop, draft buildup time, and carbon monoxide measurements.

\subsubsection{Visual Inspection}

The visual inspection was mostly safety oriented. It consisted of checking the heating system externally, the distribution system, the fuel supply system, the chimney or venting system, the heating system internally, the operational peripherals of the heating system, and the domestic water-heating system. Table 7.3 contains the results of the inspections in a format where a "Yes" answer represents a passing evaluation and a "No" answer represents an unacceptable evaluation.

Figure 7.7 shows that, overall, the systems were relatively safe. This figure quantifies the results of the overall system evaluation inspections in a simple manner. The "percent passing 
Table 7.3. Comparison of safety related observations between groups

\begin{tabular}{|c|c|c|c|c|c|c|}
\hline \multirow{2}{*}{ Description of safety item } & \multicolumn{3}{|c|}{ Weatherized homes } & \multicolumn{3}{|c|}{ Control homes } \\
\hline & Yes & No & Percent & Yes & No & Percent \\
\hline \multicolumn{7}{|l|}{ HVAC EXTERNAL } \\
\hline Vent Damper Present & 61 & 153 & 28.5 & 27 & 77 & 26.0 \\
\hline Wiring Secure & 196 & 17 & 920 & 93 & 11 & 89.4 \\
\hline Electrical Cutoff Switch Present & 201 & 11 & 94.8 & 95 & 8 & 92.2 \\
\hline Fan Limit Switch Present & 98 & 1 & 99.0 & 26 & 0 & 100.0 \\
\hline No Combustible Material Near Flue & 166 & 42 & 79.8 & 85 & 14 & 85.9 \\
\hline No Asbestos Present on HVAC system & 172 & 38 & 81.9 & 85 & 20 & 81.0 \\
\hline \multicolumn{7}{|l|}{ DISTRIBUTION SYSTEM } \\
\hline Intentionally Heated Distribution System Structurally OK & 35 & 4 & 89.7 & 22 & 3 & 88.0 \\
\hline Unintentionally Heated Distribution System Structurally OK & 145 & 2 & 98.6 & 67 & 5 & 93.1 \\
\hline Not Heated Distribution System Structurally OK & 10 & 2 & 83.3 & $\mathbf{0}$ & 1 & 0.0 \\
\hline No Asbestos on Distribution System & 152 & 38 & 80.0 & 73 & 18 & 80.2 \\
\hline Return System Present & 98 & 2 & 98.0 & 29 & 3 & 90.6 \\
\hline Return Air Filter Clean & 48 & 40 & 54.5 & 12 & 12 & 50.0 \\
\hline \multicolumn{7}{|l|}{ FUEL LEAKS } \\
\hline No Leaks in Fuel-Oil Supply Line & 188 & 13 & 93.5 & 89 & 5 & 94.7 \\
\hline \multicolumn{7}{|l|}{ CHIMNEY SYSTEM } \\
\hline Chimney Structurally Sound & 191 & 12 & 94.1 & 93 & 5 & 94.9 \\
\hline Chimney Extends 2 Ft Above Roof & 182 & 16 & 91.9 & 88 & 6 & 93.6 \\
\hline Chimney Top Clearance $10 \mathrm{Ft}$ & 173 & 17 & 91.1 & 85 & 6 & 93.4 \\
\hline No Chimney leaks & 175 & 19 & 90.2 & 81 & 12 & 87.1 \\
\hline No Thick Debris in Chimney & 161 & 19 & 89.4 & 75 & 13 & 85.2 \\
\hline Flue Liner Present in Chimney & 113 & 66 & 63.1 & 56 & 29 & 65.9 \\
\hline Barometric Damper Present & 192 & 17 & 91.9 & 86 & 15 & 85.1 \\
\hline Barometric Damper Installed OK & 171 & 18 & 90.5 & 75 & 10 & 88.2 \\
\hline \multicolumn{7}{|l|}{ HVAC INTERNALS } \\
\hline No Visual Heat Exchanger Cracks & 124 & 4 & 96.9 & 48 & 1 & 98.0 \\
\hline No Flue Gas Odor in House & 133 & 11 & 924 & 57 & 5 & 91.9 \\
\hline \multicolumn{7}{|l|}{ HVAC PERIPHERALS } \\
\hline Circulating Fan OK & 115 & 2 & 98.3 & 35 & 0 & 100.0 \\
\hline Zone Valves OK & 23 & 3 & 88.5 & 24 & 2 & 92.3 \\
\hline No Furnace Leaks & 87 & 13 & 87.0 & 54 & 5 & 91.5 \\
\hline Barometric Damper Works & 146 & 18 & 89.0 & 62 & 9 & 87.3 \\
\hline Thermostat Works (On/Off) & 178 & 4 & 97.0 & 92 & 0 & 100.0 \\
\hline \multicolumn{7}{|l|}{ DOMESTIC WATER-HEATING SYSTEM } \\
\hline No Combustible Material Near Flue & 61 & 9 & 87.1 & 24 & 4 & 85.7 \\
\hline Pressure Relief Valve Present & 185 & 7 & 96.4 & 87 & 2 & 97.8 \\
\hline
\end{tabular}




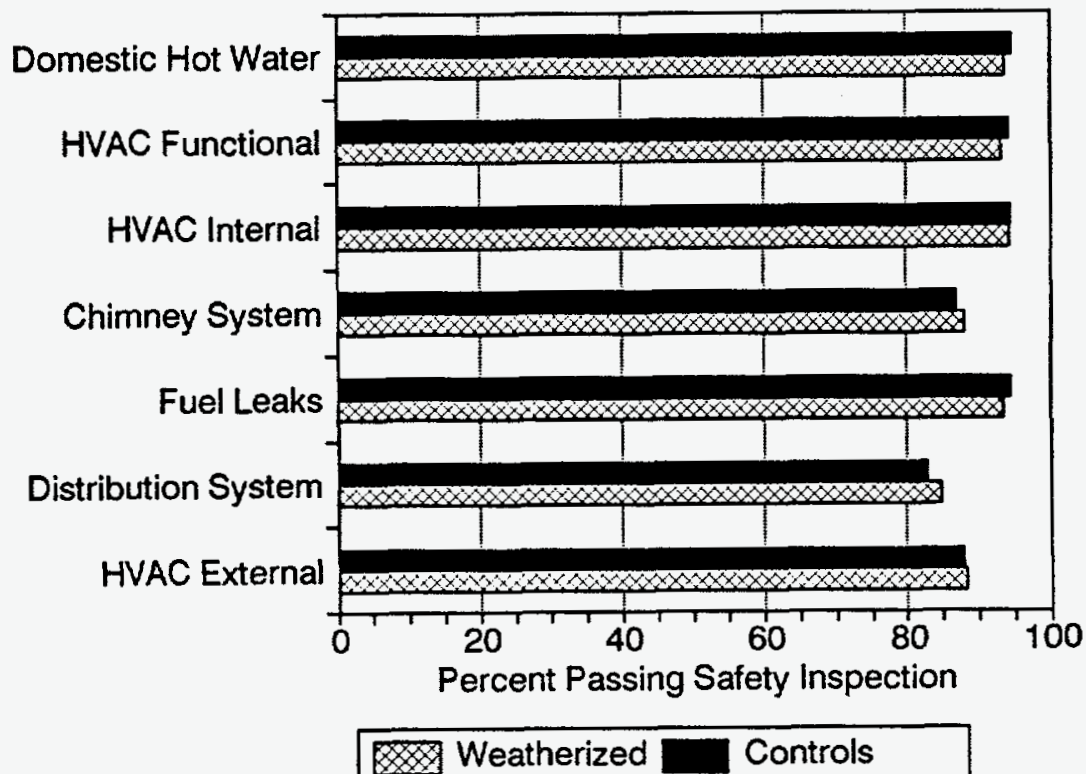

Fig. 7.7. Safety inspection results for the control and weatherized houses showing the percent of passing evaluations for each safety area covered by the inspection.

inspection" bars on the plot for both weatherized and control houses were calculated by summing the favorable responses for each of the seven areas covered by the inspection and dividing by the total number of responses (the total number of yes and no answers). The presence of a vent damper on the flue, which is predominately an energy-related item, was not included in Fig. 7.7. Dirty return air filters and the presence of asbestos (very little of it was friable) caused the distribution system area to have the lowest degree of safety while asbestos (again, very little friable) and the presence of combustible material near a flue caused the HVAC external area to have some safety deficiencies. These items were either not of immediate concern (in the case of asbestos) or more of a maintenance problem (in the case of dirty filters or combustible material near a flue). Thus, the lower results for these areas are not a major concern. The main area of concern was in the chimney system, where a lack of flue liners in chimneys appears to be more of a major problem. Flue liners can prevent potential fires and exhaust gas leakage problems, but are rather difficult and expensive to install properly. 
Visual inspections showed little average difference overall in safety between control and weatherized houses. About $18 \%$ of the individual houses from each group passed all of the safety inspection items. However, the severity of problems can differ between groups. If a difference of five percentage points or greater between control and weatherized groups in any of the items in Table 7.3 is arbitrarily chosen to be significant, then one item in the HVAC external area (combustible material near the flue), three items in the distribution system area (distribution system structural problems in unintentionally heated and non-heated areas, and no return system present), and one item in the chimney system area (presence of a barometric damper) were the main areas where weatherized and control houses differed. All differences favored weatherized houses, indicating that the weatherized houses were safer than the controls.

\subsubsection{Heating System Limit Settings}

The safety inspection included checking the settings of fan operating (high and low limit) and cutout (maximum operating temperature limit) switches. Proper setting of these limit switches affects seasonal efficiency, as improper settings will result in lost heat going up the flue.

Results for forced-air heating systems were based on data from 28 control and 102 weatherized houses. All forced-air heating systems in both groups had fan operating and cutout switches present. Average switch settings for control and weatherized forced-air heating systems were essentially the same. Fan-on (upper-limit) settings for control and weatherized houses both averaged $137^{\circ} \mathrm{F}$, while fan-off (lower-limit) settings averaged $99^{\circ} \mathrm{F}$ for control houses and $100^{\circ} \mathrm{F}$ for weatherized houses. Cutout switch settings averaged $197^{\circ} \mathrm{F}$ for control houses and $196^{\circ} \mathrm{F}$ for weatherized houses. Two control houses (7\%) and two weatherized houses (2\%) were noted as having potentially dangerous fan-on settings of $190^{\circ} \mathrm{F}$ to $200^{\circ} \mathrm{F}$. The settings for these four houses likely decreased the seasonal efficiency of the units considerably and posed the potential problem of the systems not operating properly, since their settings were very close to the furnace cutoff settings.

Results for hydronic boilers were based on data from 52 control houses and 67 weatherized houses. The average operating temperatures for hydronic boilers was $164^{\circ} \mathrm{F}$ for both control and weatherized houses. Cutoff temperatures for control houses averaged $189^{\circ} \mathrm{F}$, while 
weatherized houses averaged $190^{\circ} \mathrm{F}$. Two (4\%) hydronic boilers in control houses had operating temperatures of $200^{\circ} \mathrm{F}$, while three (4\%) boilers in weatherized houses were operating above $195^{\circ} \mathrm{F}$. These five systems were operating at too-high a temperature for maximum efficiency and safety.

\subsubsection{Spillage}

Another potential safety problem can occur if a fossil-fueled heating system does not establish a proper draft after a short time because flue gas spills back into the furnace room. Besides containing soot and foul smelling gases, flue gases can also contain carbon monoxide, which can be deadly. Therefore, it is necessary to establish a draft in a fossil-fueled heating system as soon as possible. Table 7.4 contains measured fluedraft data for weatherized and control houses.

The average time for all heating systems to establish a draft was about 9 seconds. However, two control houses and one weatherized house took over 60 seconds to establish a draft, with one of each type requiring 180 seconds. Spillage appeared to stop at a pressure differential of about $\mathbf{0 . 0 1}$ in. of water (inside to outside) on a draft gauge. Forced-air furnaces were slower than hydronic boilers in the time necessary to stop spillage. On average, hydronic boilers established a draft in about 5 seconds, while forced-air furnaces took about 14 seconds to establish a draft.

Figure 7.8 shows the average fluedraft pressure as a function of time for all forced-air furnaces and all hydronic boilers. Stronger drafts were established by hydronic boilers for the first three minutes, at which time data collection was stopped. Drafts of 0.02 to 0.06 inches $\mathrm{H}_{2} \mathrm{O}$ are usually recommended to ensure that there is continuous negative pressure in the combustion system without creating excess draft which will decrease efficiency (Bacharach).

\subsubsection{Carbon Monoxide Measurements}

Another part of the safety inspection involved taking measurements of carbon monoxide 5 $\mathrm{ft}$ from furnaces, in living rooms, in kitchens, and from hot-air registers. Carbon monoxide is a 
Table 7.4. Draft pressures (in. of water)

CONTROL HOUSES

\begin{tabular}{|c|c|c|c|c|c|c|c|}
\hline \multirow{2}{*}{$\begin{array}{c}\text { Type of } \\
\text { heating system }\end{array}$} & \multirow{2}{*}{$\begin{array}{c}\text { Size } \\
\text { of } \\
\text { sample }\end{array}$} & \multicolumn{5}{|c|}{ Time from ignition (seconds) } & \multirow{2}{*}{$\begin{array}{c}\text { Time } \\
\text { to stop } \\
\text { spillage } \\
\text { (seconds) }\end{array}$} \\
\hline & & 0 & 30 & 60 & 120 & 180 & \\
\hline Forced air & 22 & 0.002 & 0.020 & 0.022 & 0.023 & 0.021 & 16.7 \\
\hline Gravity & 3 & 0.007 & 0.037 & 0.040 & 0.043 & 0.045 & 1.3 \\
\hline Steam boiler & 11 & 0.008 & 0.030 & 0.037 & 0.036 & 0.037 & 15.0 \\
\hline Hydronic boiler & 46 & 0.009 & 0.031 & 0.030 & 0.032 & 0.033 & 4.1 \\
\hline Unspecified & 3 & 0.002 & 0.020 & 0.033 & 0.035 & 0.035 & 3.0 \\
\hline All combined & 85 & 0.007 & 0.028 & 0.029 & 0.031 & 0.031 & 8.1 \\
\hline
\end{tabular}

WEATHERIZED HOUSES

\begin{tabular}{||c|c|c|c|c|c|c|c||}
\hline \multirow{2}{*}{$\begin{array}{c}\text { Type of } \\
\text { heating system }\end{array}$} & \multirow{2}{*}{$\begin{array}{c}\text { Size } \\
\text { of } \\
\text { sample }\end{array}$} & \multicolumn{4}{|c||}{ Time from ignition (seconds) } & \multirow{2}{*}{$\begin{array}{c}\text { Time } \\
\text { to stop } \\
\text { spillage } \\
\text { (seconds) }\end{array}$} \\
\cline { 4 - 7 } & & 0 & 30 & 60 & 120 & 180 & 12.5 \\
\hline \hline Forced air & 73 & 0.003 & 0.019 & 0.020 & 0.022 & 0.022 & 4.0 \\
Gravity & 3 & 0.002 & 0.012 & 0.016 & 0.015 & 0.018 & 6.8 \\
Steam boiler & 21 & 0.004 & 0.030 & 0.032 & 0.035 & 0.039 & 6.1 \\
Hydronic boiler & 57 & 0.006 & 0.027 & 0.030 & 0.028 & 0.029 & 0.5 \\
Unspecified & 4 & 0.008 & 0.025 & 0.030 & 0.030 & 0.039 & 9.2 \\
\hline All combined & 158 & 0.004 & 0.024 & 0.025 & 0.026 & 0.027 & \\
\hline
\end{tabular}

dangerous indoor air pollutant because it is colorless, odorless, and readily absorbed by blood in the lungs. Carbon monoxide can cause headaches, nausea, and death. Carbon monoxide is produced in a home in combustion processes occurring in heating systems, fossil-fuel cooking, and smoking. 


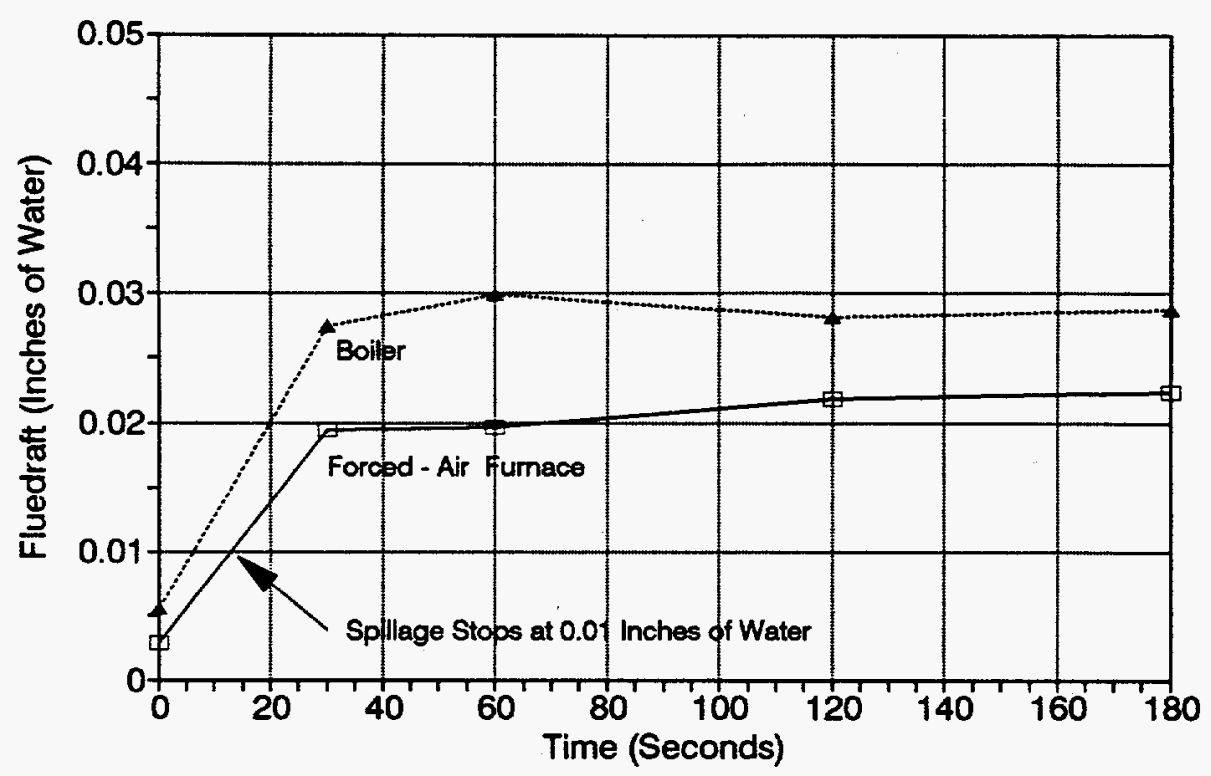

Fig. 7.8. Comparison of the average measured draft to time for forced-air furnaces and hydronic boilers.

Standards and guidelines for exposure to carbon monoxide are summarized in Table 7.5 (Bacharach). The Office of Occupational Safety and Health Administration (OSHA) mandates a maximum limit of $35 \mathrm{ppm}$ for an 8-hour period. The American Society of Heating, Refrigerating, and Air-Conditioning Engineers (ASHRAE 1989) recommends a maximum 8-hour carbon monoxide concentration of $9 \mathrm{ppm}$ in a living space. Examination of the available guidelines indicate that actions such as better venting of an area or removing/abating the carbon monoxide source should be taken as soon as possible if a level of $10 \mathrm{ppm}$ or more is present, especially for long-term exposure.

Table 7.6 contains a summary of the carbon monoxide measurements. No houses had an appreciable carbon monoxide problem (carbon monoxide level $\geq 10 \mathrm{ppm}$ ) at the end of the heating season. Differences between control and weatherized houses were minor. 
Table 7.5. Standards and guidelines for exposure to carbon monoxide

\begin{tabular}{|c|c|}
\hline $\begin{array}{l}\text { Concentration of } \\
\text { carbon monoxide in air }\end{array}$ & $\begin{array}{l}\text { Inhalation time and } \\
\text { toxic symptoms developed }\end{array}$ \\
\hline 9 ppm $(0.0009 \%)$ & $\begin{array}{l}\text { The maximum allowable concentration for an 8-hour exposure in a } \\
\text { living area according to ASHRAE. }\end{array}$ \\
\hline 35 ppm $(0.0035 \%)$ & $\begin{array}{l}\text { The maximum allowable concentration for a 1-hour exposure } \\
\text { according to ASHRAE. }\end{array}$ \\
\hline $200 \mathrm{ppm}(0.02 \%)$ & Slight headache, tiredness, dizziness, nausea after $2-3$ hours. \\
\hline 400 ppm $(0.04 \%)$ & $\begin{array}{l}\text { Frontal headaches within } 1-2 \text { hour, life-threatening after } 3 \text { hours, } \\
\text { also maximum parts per million in flue gas (on an air free basis) } \\
\text { according to EPA and AGA. }\end{array}$ \\
\hline $800 \mathrm{ppm}(0.08 \%)$ & $\begin{array}{l}\text { Dizziness, nausea and convulsions within } 45 \text { minutes. } \\
\text { Unconsciousness within } 2 \text { hours. Death within } 2-3 \text { hours. }\end{array}$ \\
\hline $1,600 \mathrm{ppm}(0.16 \%)$ & $\begin{array}{l}\text { Headache, dizziness and nausea within } 20 \text { minutes. Death within } 1 \\
\text { hour. }\end{array}$ \\
\hline $3,200 \mathrm{ppm}(0.32 \%)$ & $\begin{array}{l}\text { Headache, Dizziness and nausea within } 5-10 \text { minutes. Death within } \\
30 \text { minutes. }\end{array}$ \\
\hline 6,400 ppm $(0.64 \%)$ & $\begin{array}{l}\text { Headache, dizziness and nausea within 1-2 minutes. Death within } \\
10-15 \text { minutes. }\end{array}$ \\
\hline 12,800 ppm (1.28\%) & Death within 1-3 minutes. \\
\hline
\end{tabular}

Reference: Bacharach 
Table 7.6. Results of carbon monoxide measurements

\begin{tabular}{|c|c|c|}
\hline \multirow{2}{*}{$\begin{array}{l}\text { Measured carbon monoxide } \\
\text { concentration }(\mathrm{ppm})\end{array}$} & \multicolumn{2}{|c|}{ Total number of houses } \\
\hline & Weatherized & Control \\
\hline \multicolumn{3}{|l|}{$5 \mathrm{ft}$ from space-heating system: } \\
\hline $5-10 \mathrm{ppm}$ & 18 & 7 \\
\hline $10-15$ ppm & 2 & 2 \\
\hline $15-20 \mathrm{ppm}$ & 2 & 0 \\
\hline$>20 \mathrm{ppm}$ & 0 & 0 \\
\hline \multicolumn{3}{|l|}{ Living room: } \\
\hline $5-10 \mathrm{ppm}$ & 3 & 0 \\
\hline$>10 \mathrm{ppm}$ & 0 & 0 \\
\hline \multicolumn{3}{|l|}{ Kitchen: } \\
\hline $5-10$ ppm & 1 & 3 \\
\hline$>10 \mathrm{ppm}$ & 0 & 0 \\
\hline \multicolumn{3}{|l|}{ Hot air register: } \\
\hline $5-10 \mathrm{ppm}$ & 1 & 0 \\
\hline$>10 \mathrm{ppm}$ & 0 & 0 \\
\hline
\end{tabular}




\section{OCCUPANT FEEDBACK}

An adult occupant of each household was interviewed at the end of each heating season to obtain feedback as to how the occupant(s) felt about the weatherization process and also to gather information about occupant behavior and status. Sample questionnaires used for the control and weatherized house are contained in Appendix B. Some of the input from these questionnaires has already been presented in Sect. 3, which dealt with occupant and house characteristics.

Table K.1 contains responses from the occupants. The reader should keep in mind when reading this section that the responses are based on the occupant's perception of a question or condition, and may or may not agree with what actually occurred or was present.

\subsection{INDOOR TEMPERATURES}

The average indoor temperature levels reported by the occupants when a house was occupied was $69^{\circ} \mathrm{F}$. The average measured temperature for all houses during both periods was about $70^{\circ} \mathrm{F}$ (see Table 5.3). Therefore, measured and perceived temperatures were not too far apart, with measured temperatures being about a degree or so higher than perceived temperatures.

Of the 198 responses from weatherized houses, 106 of $198(53 \%)$ said they regularly changed the temperature in their house during the day in the pre-weatherization period, and 100 of $195(51 \%)$ said they changed it during the post-weatherization period. Control house responses were similar: 54 of $96(56 \%)$ said the temperature was changed during the day in the pre-weatherization period, and 53 of $96(55 \%)$ said the temperature was changed in the postweatherization period. Setbacks of temperatures reported by the occupants when a house was unoccupied or when the occupants were sleeping averaged about $5^{\circ} \mathrm{F}$. 


\subsection{NO-HEAT PROBLEMS}

Figure 8.1 depicts the number of no-heat problems for each period. The figure shows a definite decline in no-heat problems from pre- to post-weatherization periods, except for control house utility cutoffs. About $16 \%$ of control and weatherized households had problems at one or more times in the pre-weatherization period with not being able to operate their heating systems because of mechanical problems. About $13 \%$ of the households did not have any fuel oil at some time during the pre-weatherization period. Mechanical problems decreased during the postweatherization period ( $12 \%$ of control and weatherized households had problems), while running out of fuel oil decreased to $11 \%$ for weatherized houses and $8 \%$ for control houses. A utility stopped service because of failure to pay bills in about $5 \%$ of all houses during each period.

The total duration of no-heat days, obtained by summing the products of occurrences times duration, decreased substantially (by 84\%) for weatherized houses, from 196 days for the pre-weatherization period to 31 days for the post-weatherization period. Control houses went from 57 to 26 total no-heat days (a 54\% decrease) during the same period.

\subsection{OTHER INDOOR CONDITIONS}

Occupants were asked to rate various indoor conditions (comfort, draftiness, health, and safety,) and heating affordability on a scale of 1 to 7 , where 1 was poor and 7 was very good. Figure 8.2 summarizes the results. As expected, the control house responses to each category did not change significantly from the pre-weatherization period to the post-weatherization period. The weatherized house perceptions all improved after weatherization. The average value of the control house responses were higher than the weatherized house responses for all categories in the pre-weatherization period, which could illustrate some bias to the weatherized group responses - they were thankful for the weatherization work and wanted to make us feel good. Nevertheless, weatherized house responses were higher than control house responses in the postweatherization period, indicating improved satisfaction from weatherization.

The areas of health and safety were the only areas both groups thought were acceptable before weatherization, although weatherized houses still underwent about a one grade point 
(a)

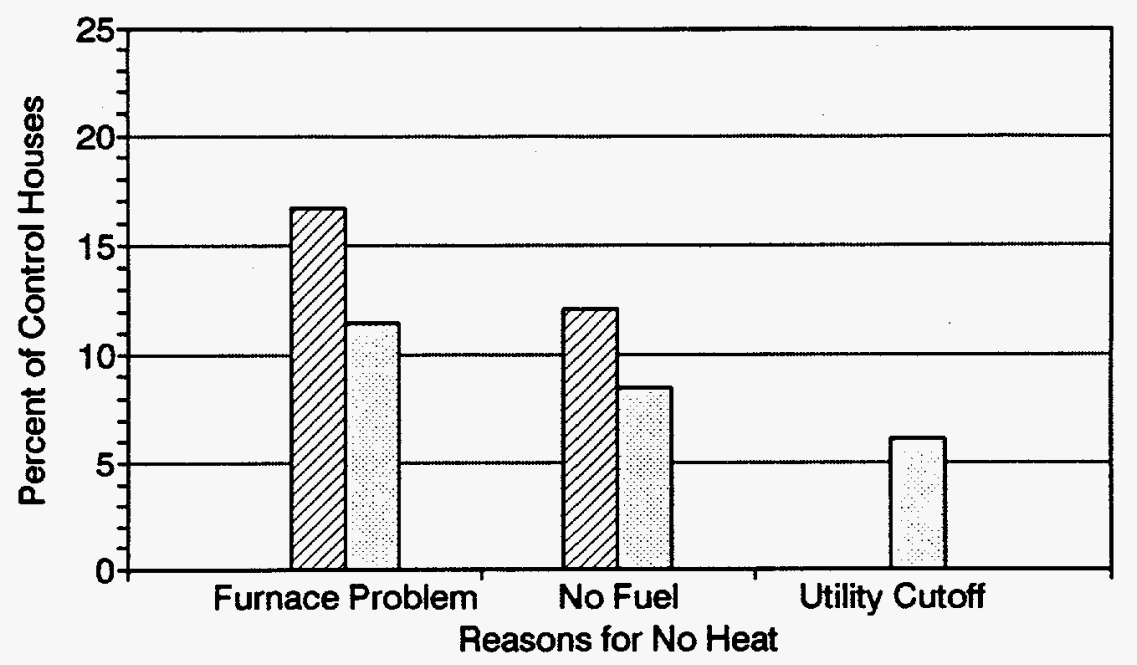

(b)
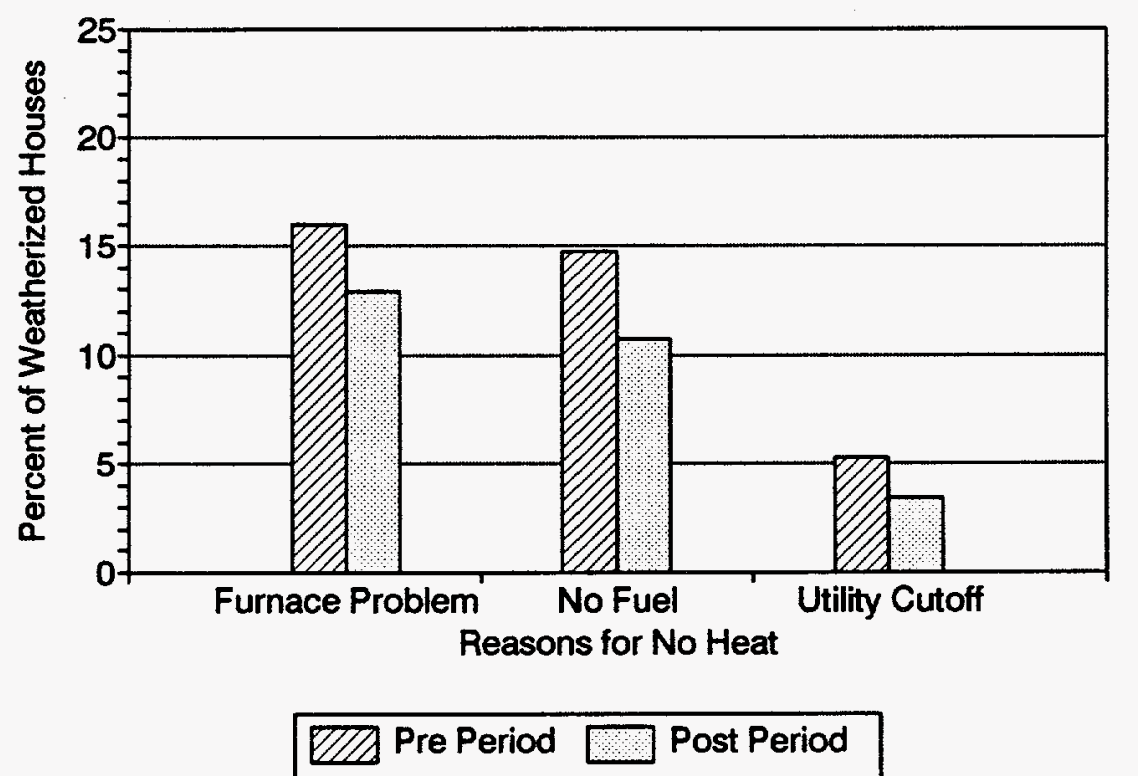

Fig. 8.1. Percentage of control (a) and weatherized (b) houses experiencing different types of no-heat problems before and after weatherization.

increase after weatherization. Most people thought their homes were expensive to heat in the pre-weatherization period; occupants of weatherized houses felt that costs were much more reasonable after weatherization (scores increased two grade points to become quite acceptable after weatherization). Comfort, and especially draftiness, were also improved after weatherization according to weatherized home responses. 


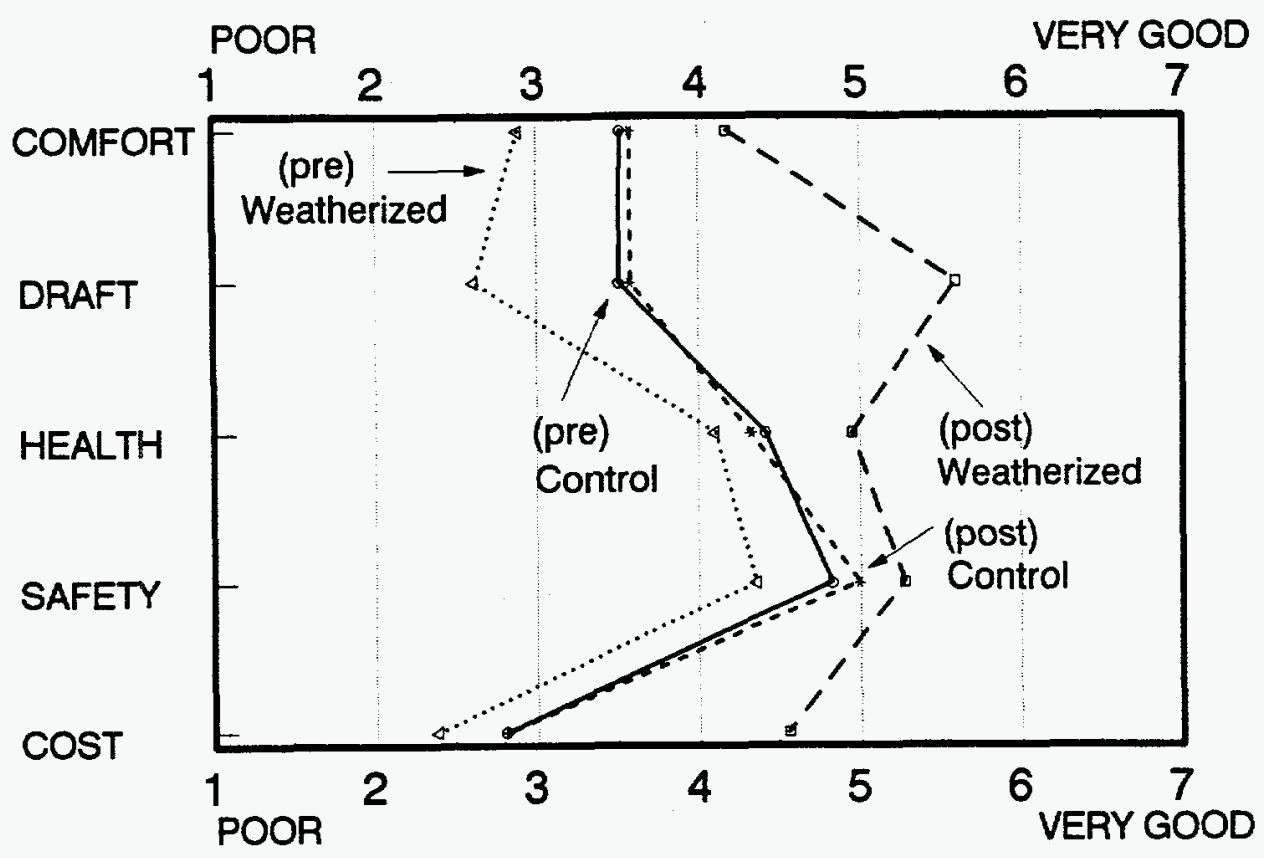

Fig. 8.2. Average rating provided by the occupants on indoor conditions and heating affordability before and after weatherization. A scale of 1 to 7 was used, where 1 was poor and 7 was very good.

Figures K.1-5 are distribution plots showing how the occupants rated conditions in their houses in pre- and post-weatherization periods. These plots indicate that weatherization definitely increased the general comfort and heating affordability of a house. Table G.5 adds validity to this statement, as the number of weatherized houses using any auxiliary heat decreased by 10 percentage points (from $57 \%$ to $47 \%$ ) after weatherization, while the number of control houses only decreased by 3 percentage points (from $53 \%$ to $50 \%$ ). 


\section{PROGRAM COSTS}

Information on program costs to weatherize 218 of the 222 weatherized houses monitored during the study was collected from the local weatherization agencies using the Fuel-Oil Study Weatherization Information Survey provided in Appendix C. Estimates of average costs to weatherize single-family fuel-oil heated houses for the northeast region as a whole are presented in this section. All analyses performed in this section were weighted to be consistent with the regional fuel-oil savings calculated in Sect. 5.

Total program costs were divided into installation costs and overhead and management costs (see Table 9.1) to allow cost-effective analyses to be performed from installation, program, and societal perspectives in Sect. 10. Installation costs included the actual costs for (1) materials installed in the houses and (2) labor required to install the materials and perform other energyefficiency-improvement work on the house. ${ }^{21}$ Overhead and management costs include all other costs associated with providing the weatherizatmon services. These expenses were divided into installation-related overhead and program management categories. Installation-related overhead expenses for contractors were estimated to be $15 \%$ of total billed cost. Installation labor costs for contractors were then calculated by subtracting material and overhead costs from the total billed cost. State expenditures for implementation of the Program were not included in the overhead and management costs presented in this section.

Previous researchers have had difficulty interpreting cost information as maintained by the local weatherization agencies because of the variety of funding sources, recordkeeping systems, cost categories, cost formats, and definitions. We chose and defined our cost categories (Table 9.1) in order to collect consistent and accurate information from the local weatherization agencies. These categories drew a logical distinction between installation costs that occurred on-site and noninstallation, or overhead and management, costs.

\footnotetext{
${ }^{21}$ Although travel time is often considered an installation-related overhead item, costs for time spent traveling to the job site were included as installation labor costs because of limitations in the collected expenditure information.
} 
Table 9.1. Cost categories used in this study

\begin{tabular}{|l||}
\hline Installation Costs: \\
Labor \\
Material \\
Overhead and Management Costs: \\
Installation-Related Overhead: \\
Vehicles \\
Equipment \\
Field Supervision \\
Insurance \\
Training \\
Contractor profit \\
Program Management: \\
Intake and eligibility \\
Audits and assessments \\
Final Inspections \\
Contractor and crew management \\
Program administration \\
Program evaluation
\end{tabular}

Our cost categories were fairly consistent with those that might be used by a typical local weatherization agency to report total program costs:

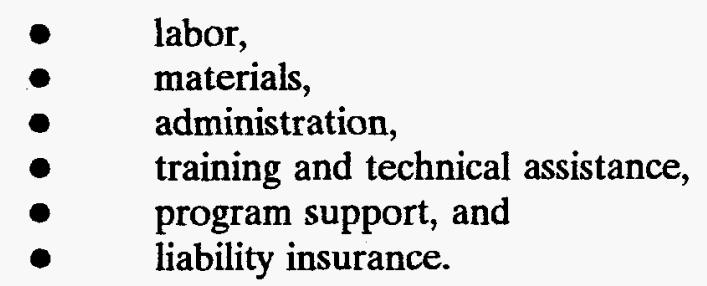

Our definition of material cost is the same as a typical weatherization agency. The last four categories listed for a typical agency are included under our definition of overhead and program management costs. The major difference between our cost categories and those for a typical agency is the costs included in the labor category. Our labor costs did not include provisions for 
Table 9.2. Average costs

\begin{tabular}{|c|c|c|c|c|c|c|c|c|c|}
\hline \multirow[b]{2}{*}{$\begin{array}{l}\text { Cost } \\
\text { type }\end{array}$} & \multicolumn{3}{|c|}{ Program years 1991 and 1992} & \multicolumn{3}{|c|}{ Program year 1991} & \multicolumn{3}{|c|}{ Program year 1992} \\
\hline & $\begin{array}{c}\text { In- } \\
\text { house }\end{array}$ & Contractor & Total & $\begin{array}{c}\text { In- } \\
\text { house }\end{array}$ & Contractor & Total & $\begin{array}{c}\text { In- } \\
\text { house }\end{array}$ & Contractor & Total \\
\hline \multicolumn{10}{|l|}{ Installation: } \\
\hline Material & 245 & 500 & 745 & 160 & 619 & 779 & 330 & 380 & 710 \\
\hline Labor & 194 & 253 & 447 & 141 & 315 & 456 & 248 & 191 & 439 \\
\hline Total & 439 & 753 & 1192 & 301 & 934 & 1235 & 578 & 571 & 1149 \\
\hline $\begin{array}{l}\text { Overhead and } \\
\text { management }\end{array}$ & & & 627 & & & 707 & & & 562 \\
\hline Total & & & 1819 & & & 1942 & & & 1711 \\
\hline
\end{tabular}

performing tasks other than the installation of measures; audit and inspection functions, for example, were not included in our definition of labor costs although they might be present in the labor costs reported by a local weatherization agency.

\subsection{INSTALLATION COSTS}

Table 9.2 shows that the regionwide mean value for installation costs was $\$ 1192$ for program years 1991 and 1992 combined. Material costs for these years were $\$ 745$ for an average house weatherized, and labor costs were $\$ 447$. Installation costs and their breakdown into material and labor costs were consistent for each program year. Expenditures by in-house crews and contractors were significantly different in program year 1991 but the same in program year 1992 , indicating a more predominant use of contractors in the first year.

Installation costs for an individual house differed substantially from the average value of \$1192. The distribution of installation costs is shown in Fig. 9.1. Installation expenditures were between $\$ 600$ and $\$ 1500$ in $58 \%$ of the houses. Installation expenditures were less than $\$ 300$ on $3 \%$ of the houses, and more than $\$ 2400$ on $6 \%$. The minimum expenditure was $\$ 15$ and the maximum was $\$ 4383$. House costs may appear higher than DOE program allowances because other sources of funds could also have been used (see Sect. 9.3). 


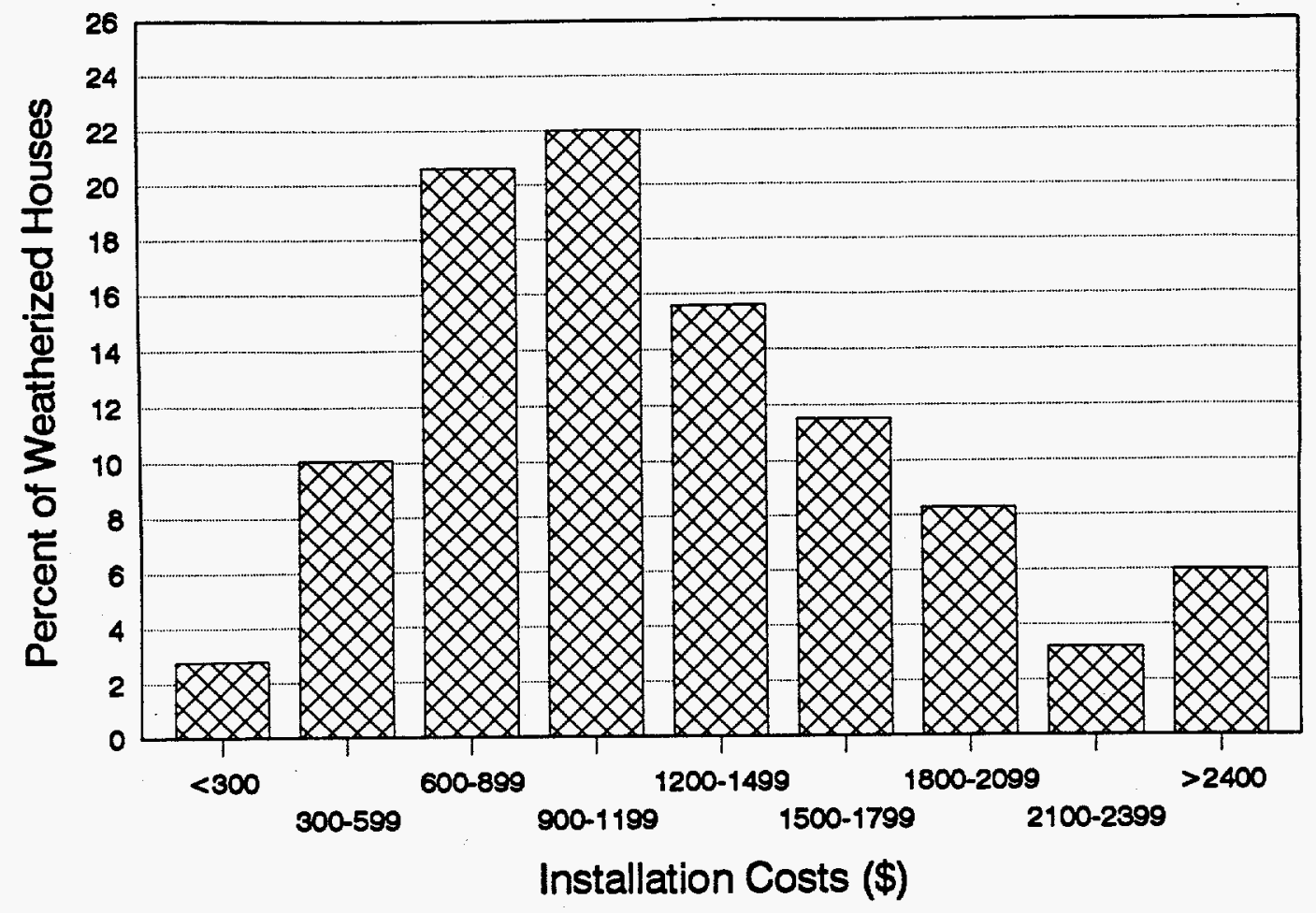

Fig. 9.1. Distribution of installation costs. The sample mean was $\$ 1253$ and the sample standard deviation was 706.

Contractor expenditures accounted for $63 \%$ of the average installation costs. Additionally, houses in which weatherization work was performed by just in-house crews had average expenditures $\$ 350$ lower than houses in which only contractors were involved (Fig. 9.2). As previously stated in Sect. 4.2, weatherization activity in the house was performed completely by inhouse crews in $27 \%$ of the houses, activity was performed completely by contractors in $55 \%$ of the houses, and both in-house crews and contractors performed the work in the remaining houses. In houses in which both crew types were involved, about $75 \%$ of the expenditures were by the inhouse crew. Higher costs associated with contractors were likely due to differences in the measures performed by contractors, and do not imply that contractors were inherently more expensive than in-house crews. Contractors performed high-cost measures such as space-heating system measures and standard wall insulation more frequently than in-house crews. 


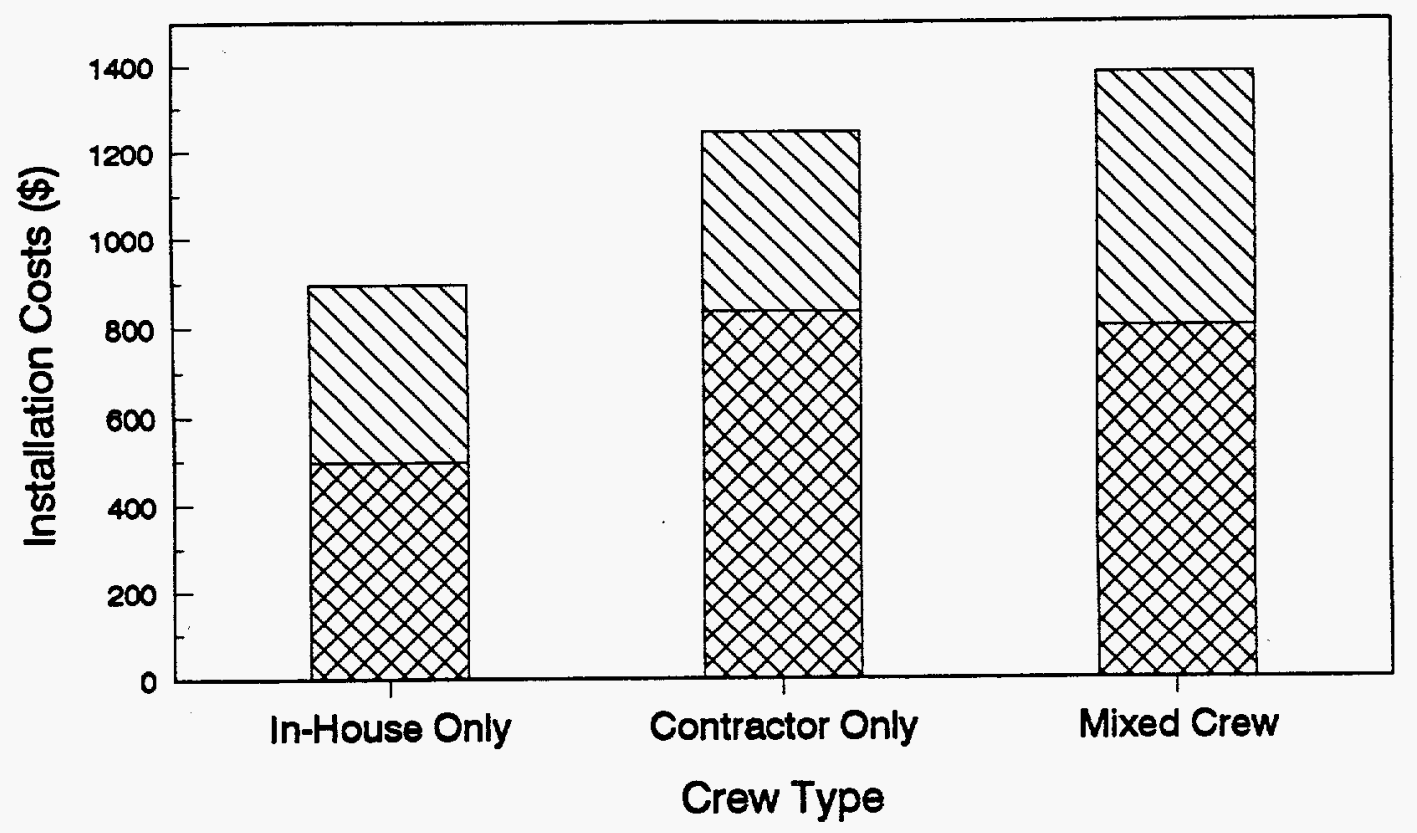

Material

Labor

Fig. 9.2. Installation costs for houses subdivided by type of crew performing the weatherizations.

Figure 9.3 shows a cost breakdown of materials for an average weatherized house. ${ }^{22}$ Insulation materials accounted for a third of the total material expenditure. Material costs for air leakage, window and door, and space-heating system measures were approximately equal (12\% $18 \%)$. Expenditures on domestic water-heating system materials were rather small, being only $2 \%$ of the total material costs.

\footnotetext{
${ }^{22}$ Material cost information was obtained directly from the local weatherization agencies and was based upon their records. Some inconsistencies associated with the breakdown of material costs into the respective cost categories remained following close examination of the data, comparison of measures installed to cost allocations, and discussions with the agencies. Total material costs were accurate. Total insulation and space-heating system material costs were also correct, but were not always properly divided into subcategories. The main difficulty was that material costs for air leakage measures, window and door measures, and other energy-efficiency work were often intermixed because of the ambiguity in identifying the correct category for some work.
} 


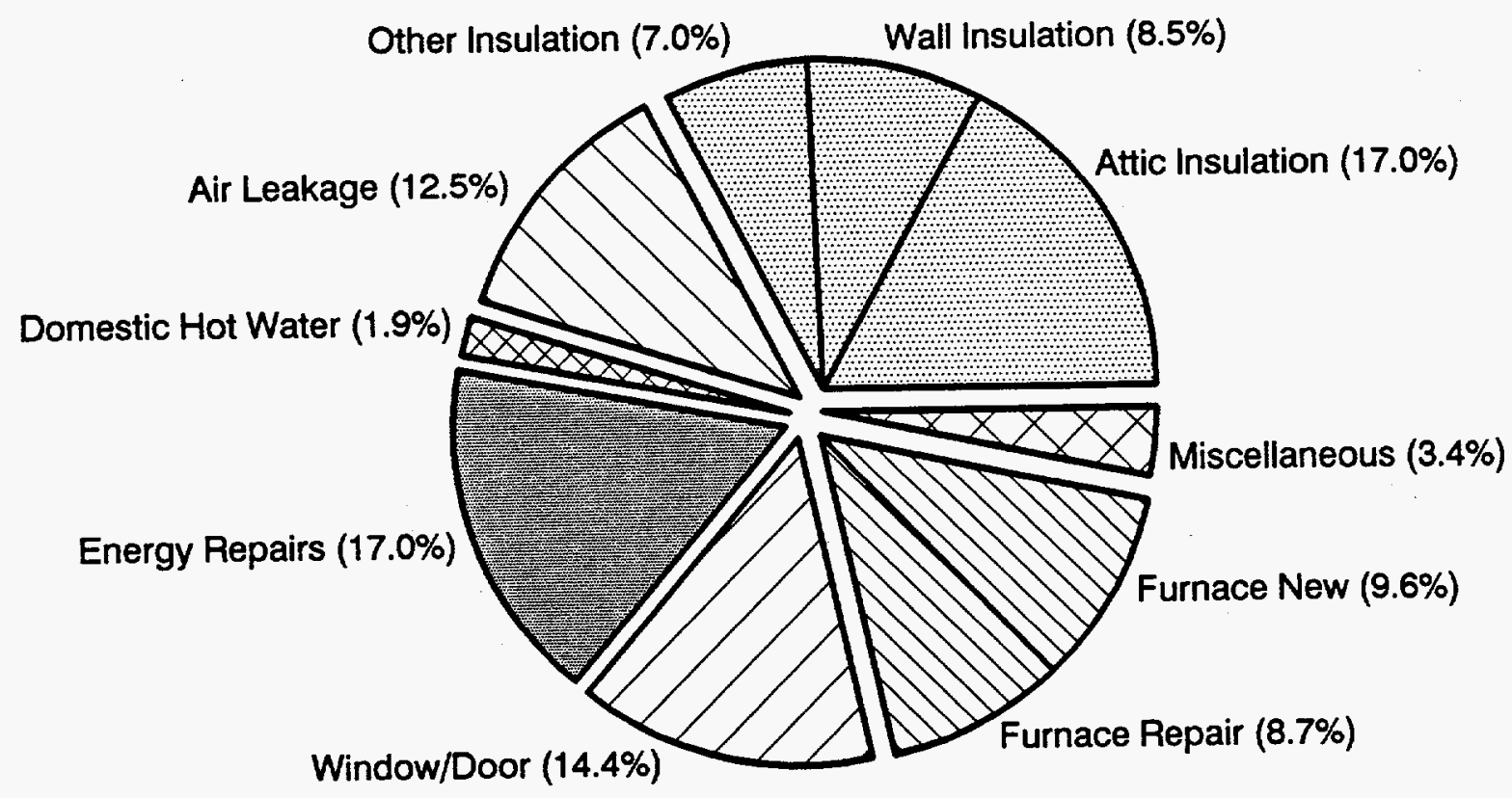

Fig. 9.3. Material cost breakdown for an average weatherized house (average material cost for a house was $\$ 710$ ).

\subsection{OVERHEAD AND MANAGEMENT COSTS}

We estimated an overage overhead and management cost of $\$ 627$ per house to weatherize a single-family fuel-oil heated house in the northeast region. This cost included $\$ 438$ for program management, $\$ 59$ for in-house crew installation-related overhead, and $\$ 130$ for contractor installation-related overhead. We estimated an average overhead and management cost of $\$ 557$ per house for houses in which only in-house crews performed weatherization work, and $\$ 651$ for houses in which contractors performed work either alone or with in-house crews. As shown in Table 9.2, there was a $\$ 145$ difference in the overhead and management cost estimated for the two program years separately.

Considerable judgement was required to perform the analysis of the overhead and management costs; consequently, the listed values should be interpreted as approximate values that best indicate order of magnitude, especially in considering the breakdown into installationrelated overhead and program management costs and comparisons by crew type and program 
years. ${ }^{23}$ In performing the analysis, two local weatherization agencies were dropped because they did not report program management $\operatorname{costs}^{24}$, and another two were dropped because their reported program management costs were unrealistically low (\$62) or high (\$1142). Program management costs for agencies using only contractors to perform the weatherization work were likely more accurate than when in-house crews were used because costs paid to the contractors were usually easily obtainable. Average program management costs were probably less than reported above, and average in-house crew installation-related costs were probably higher, for the following reasons:

- In-house crew installation-related overhead expenses were not reported for five agencies using in-house crews. We assumed these costs were included with program management costs.

- In-house crew installation-related overhead costs were set to zero for two agencies. For these two agencies, the overhead costs and program management costs were both very high. The overhead costs were set to zero because we assumed the overhead costs were already included with the reported program management costs.

\subsection{SOURCES OF FUNDING}

Local weatherization agencies rely on a number of different funding sources to perform weatherizations. These include the DOE Weatherization Assistance Program, Petroleum Violation Escrow (PVE) funds, the Low-Income Heating Energy Assistance Program (LIHEAP) operated by the Department of Health and Human Services, and various foundation, state, and utility programs. Although most funds followed Program rules, funds with fewer restrictions could also have been used. For single-family fuel-oil heated houses weatherized in the northeast region,

\footnotetext{
${ }^{23}$ In order to perform a rigorous study of overhead and management costs, we believe that an "audit" team would need to work directly and on-site with local weatherization agencies to collect the necessary cost data rather than rely on agencies completing forms. Collecting complete, consistent, and understandable information on overhead and management costs is complicated because variations exist in terminology and accounting systems used by the agencies, different programs offered by the agencies often become integrated with one another, and the diversity of funding sources often overlap.
}

${ }^{24}$ The multitude of funding sources for one local weatherization agency made it impossible for us to even help them make an estimate of program management costs. 
73\% of the installation costs were provided by the DOE Weatherization Assistance Program and PVE. $^{25}$ These figures were consistent with results obtained by Mihlmester et al. (1992), which indicate that local weatherization agency direct financial support for weatherization and other energy programs is broken down on a national basis as follows: $31 \%$ DOE Weatherization Assistance Program, 29\% PVE, 18\% LIHEAP, and 22\% other.

Average per house installation expenditures increased as the percent of total house costs covered by DOE Weatherization Assistance Program funds decreased. Average costs were $\$ 1114$ in houses receiving just DOE Weatherization Assistance Program funds, \$1227 in houses where DOE Weatherization Assistance Program funds covered 50\% or more of the total, and $\$ 1417$ in houses where DOE Weatherization Assistance Program funds covered less than $50 \%$ of the total. This result was consistent with expectations because funding sources other than DOE Weatherization Assistance Program funds were often used to install measures that were not allowed under DOE Weatherization Assistance Program guidelines (such as space-heating system replacements).

In examining the results presented in this section, it should be noted that funding sources used by local weatherization agencies are not always consistent throughout the year. Some agencies use different funding sources for different parts of the year because of the time when funds are received (for example, spending DOE Weatherization Assistance Program and PVE funds the first half of the year and state and LIHEAP money the second half of the year). Other agencies are able to spend their funds evenly over the year, allowing a mix of funding sources to be applied to individual houses. Agencies reported that no DOE Weatherization Assistance Program funds were spent in $18 \%$ of the houses weatherized under the study. In all cases, though, agencies stated that houses were treated equivalently despite the funding sources available at the time of weatherization. Thus, the results presented in this section are a snapshot of the funding sources used when weatherizations were performed in January of each program year.

\footnotetext{
${ }^{25}$ In responding to funding source questions, we believe the local weatherization agencies considered PVE funds to be equivalent to Weatherization Assistance Program funds.
} 


\section{COST EFFECTIVENESS}

The cost effectiveness of weatherization measures was estimated using simple payback and benefit-to-cost ratio. Standard formulas for these indicators were used along with regional estimates of fuel savings, published regional fuel prices, installation costs, and overhead and management costs. Lifetimes of installed energy conservation measures are critical to such evaluations; therefore, analyses using a range of values are presented, with best estimates for lifetimes noted. Also critical is the discount rate reflecting the time value of money and fuel-oil price escalation rates.

Measured input values used to calculate simple paybacks and benefit-to cost ratios were a regional net average fuel-oil savings of 160 gallons/year (recall that net savings is our best estimate of the savings achieved under the Fuel-Oil Study and is the average gross savings of the control houses subtracted from the average gross savings of the weatherized houses), an average regional installation cost of $\$ 1192$, and an average overhead and management cost of $\$ 627$. Fueloil savings were converted to regional dollar value estimates using a fuel-oil cost of $\$ 1.01 /$ gallon (the average regional fuel-oil cost in the northeast during the study). A "real" discount rate of $4.7 \%$ and a fuel escalation rate were used in the calculation of benefit-to-cost ratio as recommended by the Department of Commerce for the year $1991^{26}$ (Lippiat and Ruegg 1990).

\subsection{SIMPLE PAYBACK}

The easiest method used to assess the cost effectiveness of a program is known as the simple payback method. It is often used to obtain a rough estimate of cost effectiveness. In this method, the incurred cost is simply divided by the obtained savings or benefits. We used only installation costs, overhead and management costs, and energy saving benefits for these calculations.

\footnotetext{
${ }^{26} \mathrm{~A}$ "real" discount rate is set annually by DOE for evaluating Federal energy conservation and renewable energy projects. The "real" discount rate for 1991 was set at $4.7 \%$; this was equivalent to a market rate of $8.4 \%$ and was based on long-term treasury bond rates averaged over the previous 12-month period.
} 
Dividing the annual installation costs of $\$ 1192$ by the annual net savings of $\$ 162$ resulted in a simple payback of 7.4 years. This means that the average lifetime of installed measures must be at least 7.4 years if the program is to be cost effective, based on the foregoing assumptions. By adding overhead and management costs of $\$ 627$ per house to the installation costs, the average Program cost per house was $\$ 1819$. Dividing $\$ 1819$ by $\$ 162.34$ results in a simple payback of 11.2 years.

Both of these simple payback values imply that the weatherization work performed under the Program in single-family fuel-oil heated houses in the northeast was cost effective because reasonable lifetime estimates for weatherization measures are greater than these payback periods.

\subsection{BENEFIT-TO-COST RATIO}

Benefit-to-cost ratio is a cost-effectiveness indicator that compares the discounted lifetime benefits obtained from the Program to the costs of achieving them. A number of inputs are usually needed in addition to Program costs and benefits: a discount rate that reflects the time value of money, fuel-oil price escalation rate, and expected lifetimes of the conservation measures. A program is cost-effective whenever the benefit-to-cost ratio is greater than or equal to unity.

This section examines the benefit-to-cost ratio from three perspectives. An installation perspective is defined to consider only energy savings benefits and on-site installation costs. This perspective is the most narrowly defined. It provides insight into how well the measures performed based on their primary function (i.e., to save energy) without considering the indirect costs required to operate a program. A program perspective is defined to consider energy savings benefits and the total costs required for weatherization (installation costs combined with overhead and management costs). The program perspective is the most conservative estimate of program cost effectiveness. A societal perspective was developed to consider the broadest definitions of benefits and costs: benefits include energy and nonenergy benefits, and costs include installation, overhead, and management expenses.

Nonenergy (or societal) benefits can result from the weatherization activity performed under the Program. A quantitative value for these nonenergy benefits is not as simple to estimate 
Table 10.1. Cost-effectiveness estimates

\begin{tabular}{|c|c|c|c|}
\hline \multirow{2}{*}{$\begin{array}{c}\text { Effective } \\
\text { measure life } \\
\text { (years) }\end{array}$} & \multicolumn{3}{|c|}{ Benefit-to-cost ratio } \\
\cline { 2 - 4 } & Installation perspective & Program perspective & Societal perspective \\
\hline \hline 10 & 1.25 & 0.82 & 1.35 \\
\hline 15 & 1.79 & 1.17 & 1.71 \\
\hline 20 & 2.26 & 1.48 & 2.01 \\
\hline 25 & 2.65 & 1.74 & 2.27 \\
\hline
\end{tabular}

as are the energy savings and costs associated with weatherization. Nonenergy benefits can be grouped into five major categories:

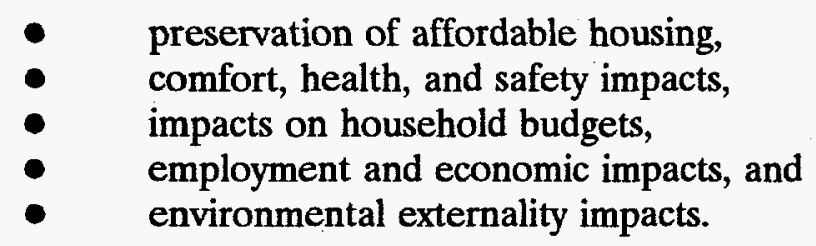

Brown et al. (1993) extensively examined nonenergy impacts of low-income weatherization and concluded that the average net present dollar value of nonenergy impacts for the Program in 1989 was $\$ 976$ per weatherized house. Additional benefits that could not be assigned a dollar value include: thermal comfort improvements, indoor air quality, benefits of increased nonenergy expenditures, and savings associated with fewer residential moves.

Table 10.1 summarizes the results of the benefit-to-cost ratio calculations performed. These results are plotted in Fig. 10.1.

The program is cost effective from all three perspectives under the conditions analyzed except for the program perspective assuming a 10-year lifetime for the measures. The Program is cost effective from the societal and installation perspectives assuming measure lifetimes as low as six and eight years, respectively. The Program is cost effective from a program perspective when measure lifetimes exceed 12.5 years. 


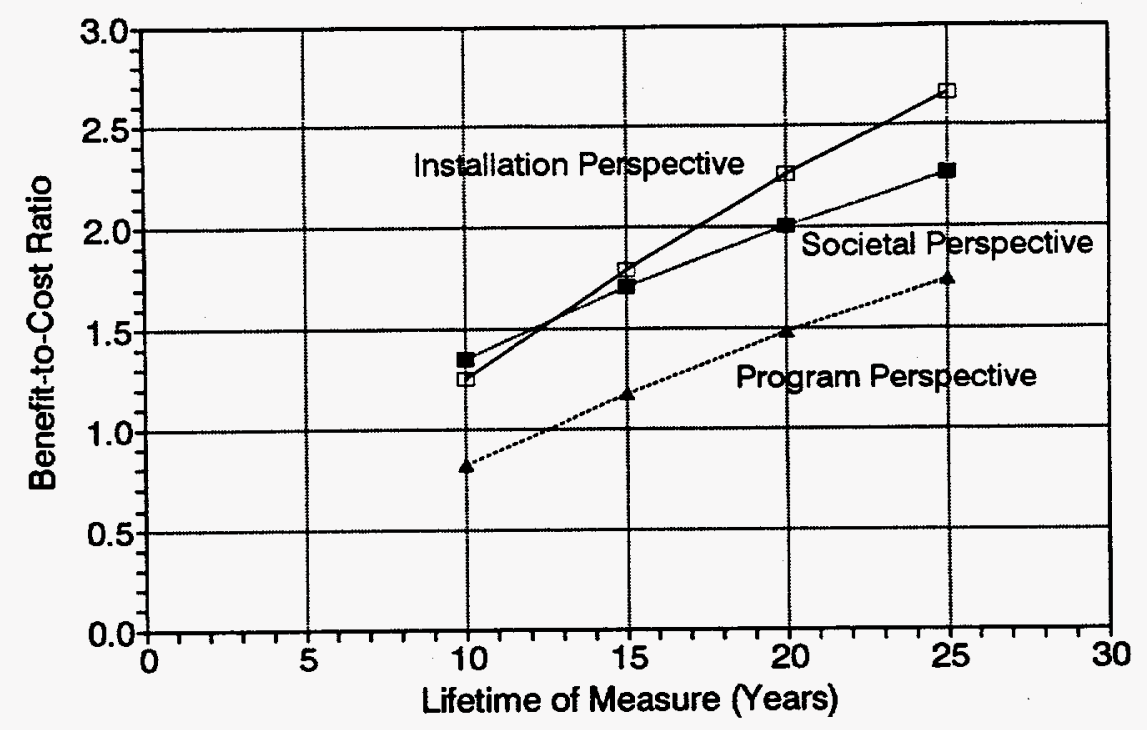

Fig. 10.1. Comparison of benefit-to-cost ratios to measure lifetimes.

Estimated lifetimes for the various weatherization measures installed in the study houses range from 1 to 5 years for caulking to 30 plus years for insulation, with 20 years being a fair average for all measures combined (Brown et al. 1993). A 20-year estimated life results in a benefit-to-cost ratio of 2.26 from an installation perspective, 2.01 from a societal perspective, and 1.48 from a program perspective. All three estimates show that the Weatherization Assistance Program is indeed cost effective for houses heated with fuel oil in the northeast. 


\section{FACTORS ASSOCIATED WITH SAVINGS}

An analysis conducted to determine which measures provided the most savings in this study was difficult. Many different measures and procedures were applied to or performed on the tested single-family fuel-oil-heated houses. The houses had many different construction characteristics and occupant types. Identical measures often perform differently with different types of houses or different conditions existing in the same type of house. For instance, six inches of attic insulation will be more beneficial when added to a house with two inches in the attic rather than eight inches in its attic. Also, a sophisticated setback thermostat installed in a house with an occupant who does not understand its workings may result in no savings and a great deal of frustration for the occupant.

Sample houses for this study were randomly chosen to determine the energy savings of the Program rather than to determine the cause of the savings. In order to determine factors affecting savings, houses would have been selected based on individual measures and selected combinations of measures received. For example, almost all houses in our sample received standard caulking and weatherstripping, making it impossible to study this measure. Also, the sample size was too small and not sufficiently randomly distributed to study the large number of combinations of measures installed, house characteristics, procedures, etc. Another item to note is that inspections were conducted on the test houses after weatherization had been accomplished and not before. Thus, detailed information is available on conditions existing in a house after weatherization was done, but not before weatherization.

Data presented and analyzed in this section were taken from a subset of the original database. An arbitrary requirement for inclusion in the subset was that all fuel-oil consumption coefficients of determination $\left(R^{2}\right)$ be 0.7 or above for both pre-weatherization and postweatherization periods. This criterion reduced the weatherized sample from 193 houses to 149 houses, but we felt that it allowed more accuracy in the analysis. The mean pre-weatherization consumption for this subgroup was 930 gallons/year, and the mean gross savings was 162 gallons/year with no control house adjustment. A discussion of control house data is not included in this section since control houses had no weatherization work done on them. Analyses were performed on a house basis (Sect. 11.1) and an agency and state basis (Sect. 11.2). 


\subsection{HOUSE LEVEL ANALYSIS}

"Independent" or "two-sample" t-tests on the equality of two means (space-heating fuel-oil savings in this study) were performed to study the importance of selected measures, procedures, and occupant and dwelling characteristics. The mean savings of houses receiving a particular measure or procedure, for example, was compared to the mean savings of the remaining houses (those not receiving the particular measure or procedure) to determine if a statistically significant difference existed. The significance of the difference depends upon the magnitude of the difference, the standard deviations of the means, and the size of each sample. The mean savings of the houses are listed in the appropriate tables in this section by the factors studied, along with their mean pre-weatherization consumption and the significance of the difference.

\subsubsection{Pre-Weatherization Consumption and Savings}

One factor which previous evaluations (Ternes et al. 1991, and Ternes and Levins 1992) have shown to be associated with savings in many programs is the level of energy consumption before any weatherization measures are performed on a house. Figures 11.1(a) and (b) plot the pre-weatherization fuel-oil consumption against the post-weatherization fuel-oil consumption for each weatherized house. Figure 11.1(b) differs from 11.1(a) in that it normalizes the annual consumptions for each house by the heated area of the house. Regression lines on these figures (the $\mathrm{R}^{2}$ values are on the order of 0.2 ) indicate that post consumptions are, on average, lower than pre consumptions. Figure 11.1(b) predicts an expected savings of $20 \%$ in a household with a pre-weatherization fuel-oil usage of 1 gallon/square foot/year. A crossover of the regression and no-change lines in Figs. 11.1(a) and (b) at low consumptions is not unexpected. Pre- and postweatherization consumptions should be about equal to each other in houses with low preweatherization consumption because these houses likely received few conservation measures.

Figures 11.2(a) and (b) compare fuel-oil savings to pre-weatherization consumptions. The regression lines show that there is a trend for savings to be greater in houses with high preweatherization consumption and high pre-weatherization consumption per unit floor area. The $R^{2}$ value of each regression line is on the order of 0.2 , so pre-weatherization consumption explains only a small amount of the variation in savings. 
(a)

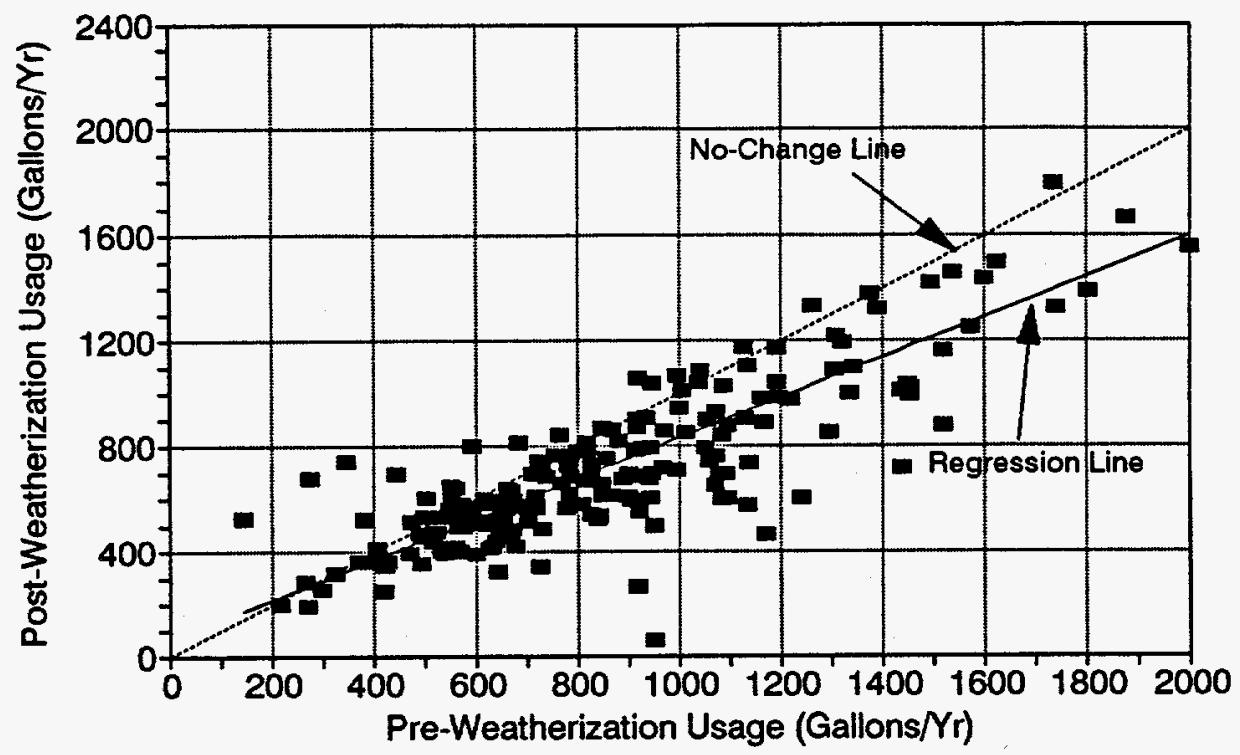

(b)

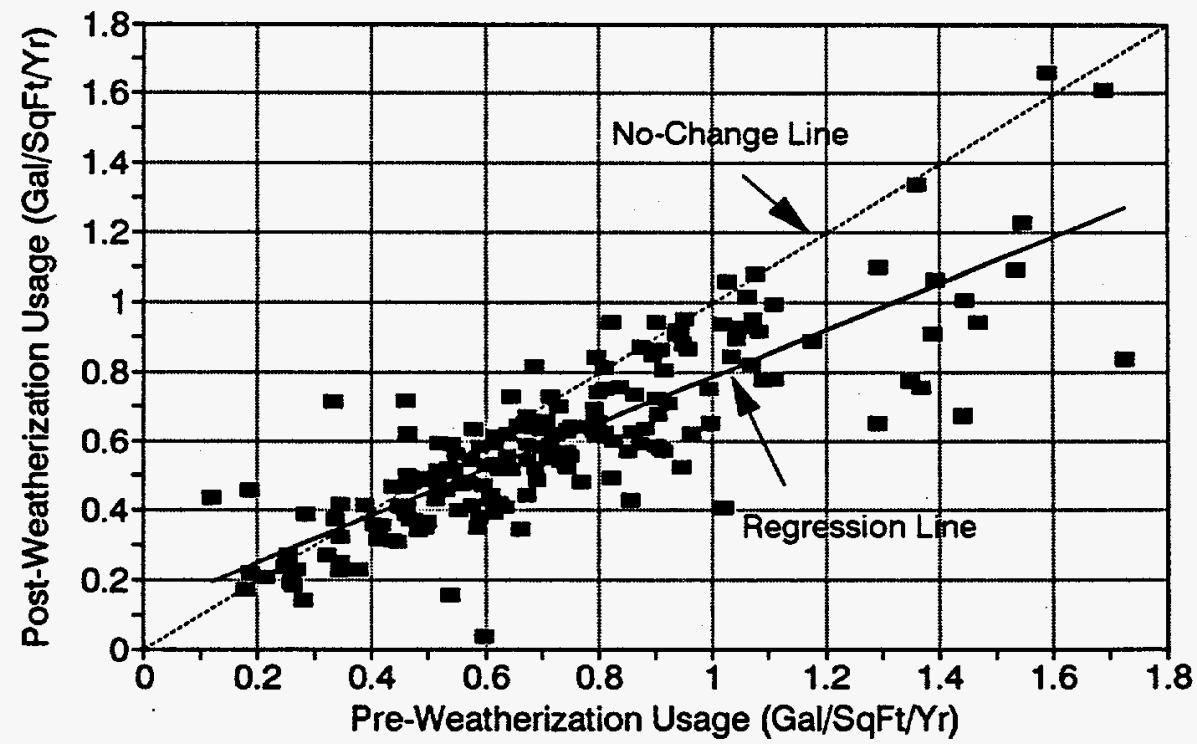

Fig. 11.1. Comparison of annual pre-weatherization fuel-oil consumption to postweatherization consumption for the weatherized houses. 
(a)

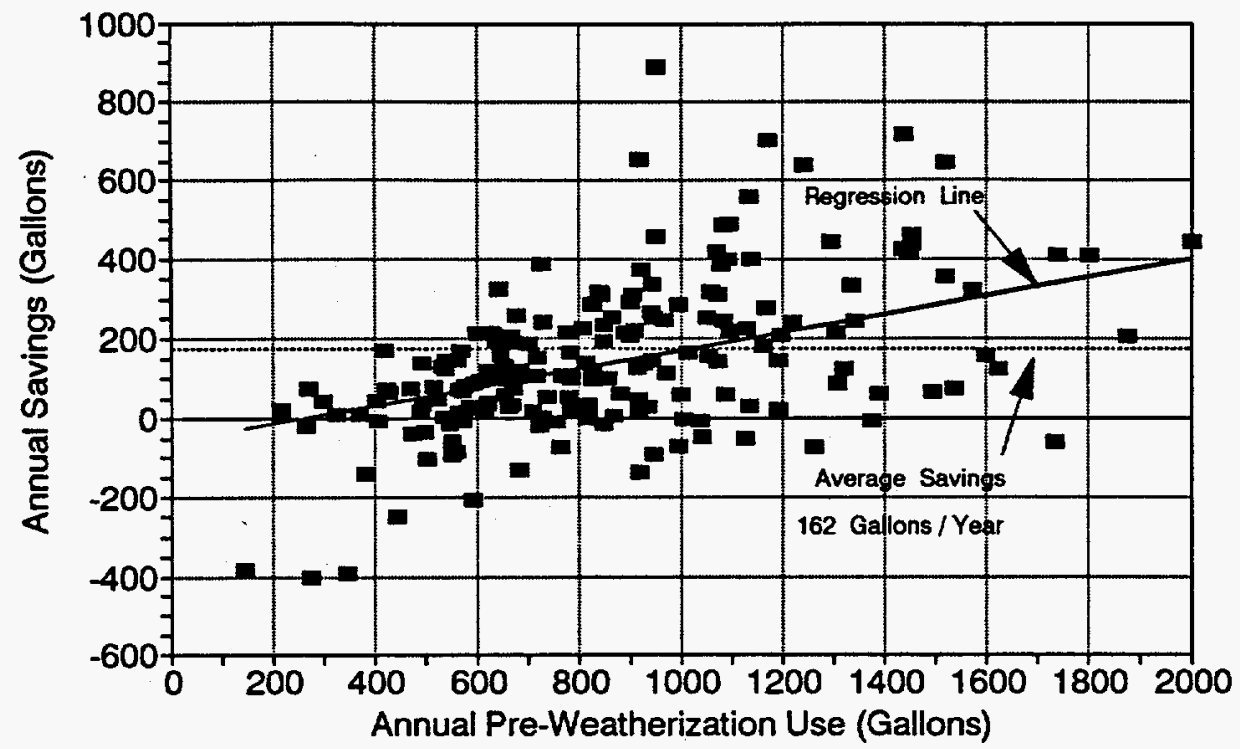

(b)

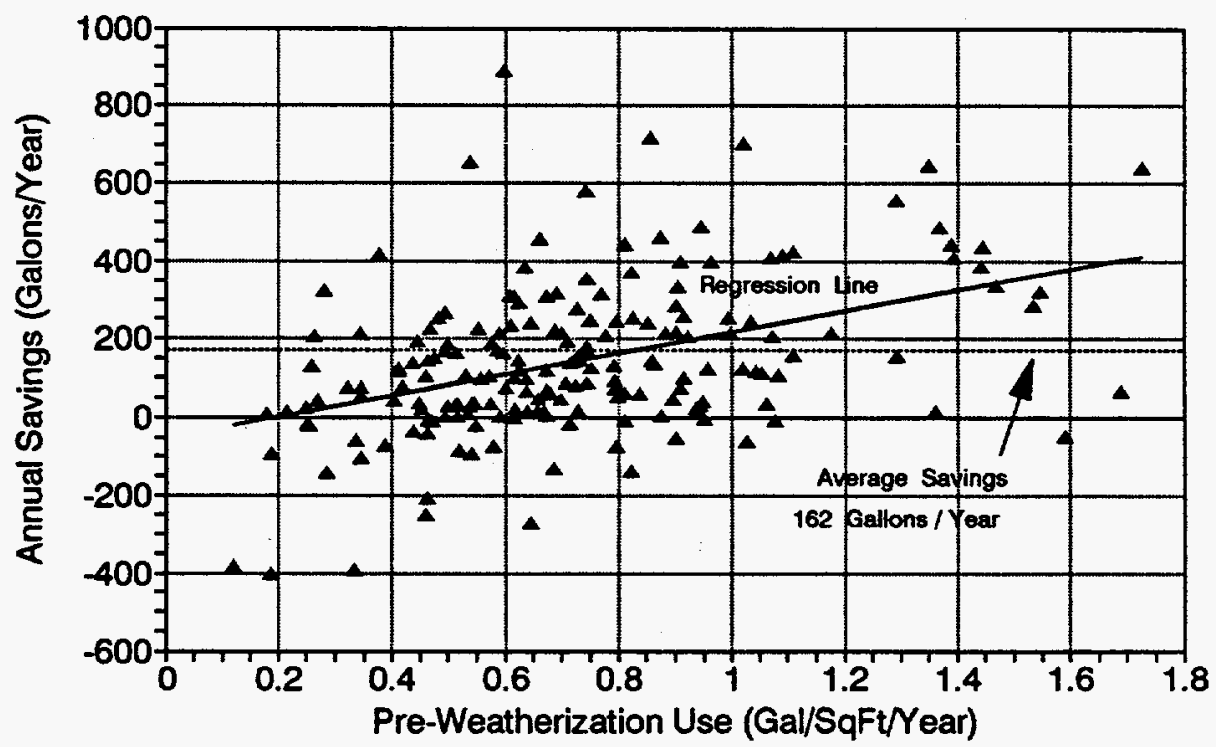

Fig. 11.2. Comparison of fuel-oil savings to pre-weatherization fuel-oil consumption for the weatherized houses. 
Table 11.1. Effect of cost of weatherization on savings

\begin{tabular}{|c||c|c|c|c|c|}
\hline Group & $\begin{array}{c}\text { Average cost } \\
\text { of } \\
\text { weatherization }\end{array}$ & $\begin{array}{c}\text { Number } \\
\text { of } \\
\text { houses }\end{array}$ & $\begin{array}{c}\text { Pre- } \\
\text { weatherization } \\
\text { usage (gallons) }\end{array}$ & $\begin{array}{c}\text { Annual } \\
\text { savings } \\
\text { (gallons) }\end{array}$ & $\begin{array}{c}\text { Annual } \\
\text { savings } \\
(\%)\end{array}$ \\
\hline \hline All & $\$ 1270$ & 147 & 934 & 164 & $17.5 \%$ \\
\hline$<\$ 1200$ & $\$ 821$ & 82 & 859 & 102 & $11.8 \%$ \\
\hline$>\$ 1200$ & $\$ 1837$ & 65 & 1028 & 241 & $23.4 \%$ \\
\hline
\end{tabular}

\subsubsection{Weatherization Cost and Savings}

The association between the cost to weatherize a house and the savings obtained by that house is examined in this section. All costs used in this discussion are installation costs (only for labor and materials) and do not include overhead and management costs. Table 11.1 contains sample data (not weighted data) from those houses with available cost data and also with consumption $\mathrm{R}^{2}$ values 0.7 or greater for both pre-and post-weatherization periods. The houses are separated into three groups in the table - all houses, those houses on which $\$ 1200$ or less was spent for weatherization during the weatherization process, and those on which more than $\$ 1200$ was spent. The cutoff of $\$ 1200$ was chosen because the mean regional installation cost was $\$ 1192$ (see Table 9.2).

T-tests between the average savings for those houses on which less than $\$ 1200$ was spent and those houses on which more than $\$ 1200$ was spent show that there is a statistically significance difference (at a $>0.001$ level of significance) between the savings of the two groups. The houses on which more than $\$ 1200$ was spent saved more than twice as much fuel oil as the other group. The houses receiving the higher expenditures also used more fuel-oil in the preweatherization period (at a 0.006 level of significance) than the other group. This suggests that the money spent to weatherize houses was on average spent properly because the most needy houses (the largest consumers) received more than the more efficient houses. 
(a)

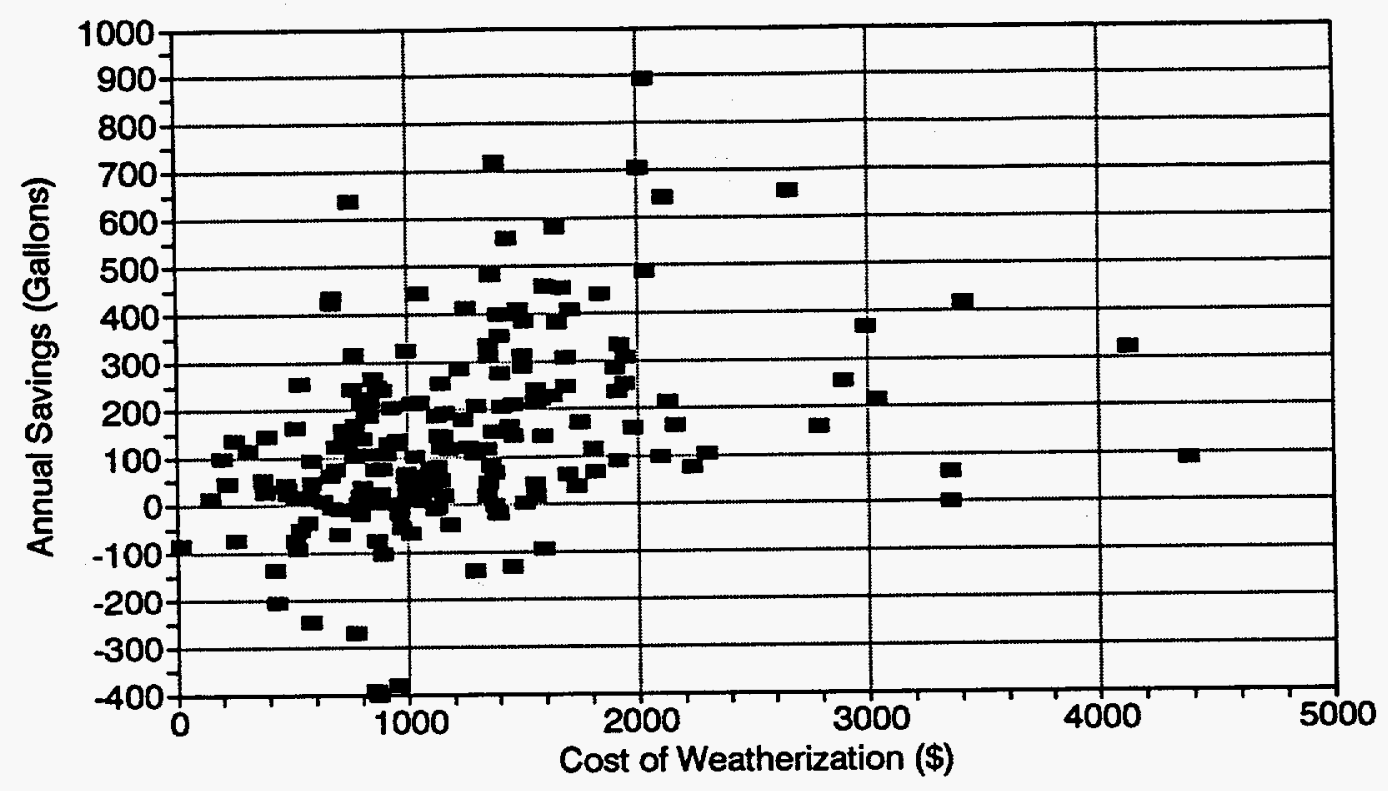

(b)

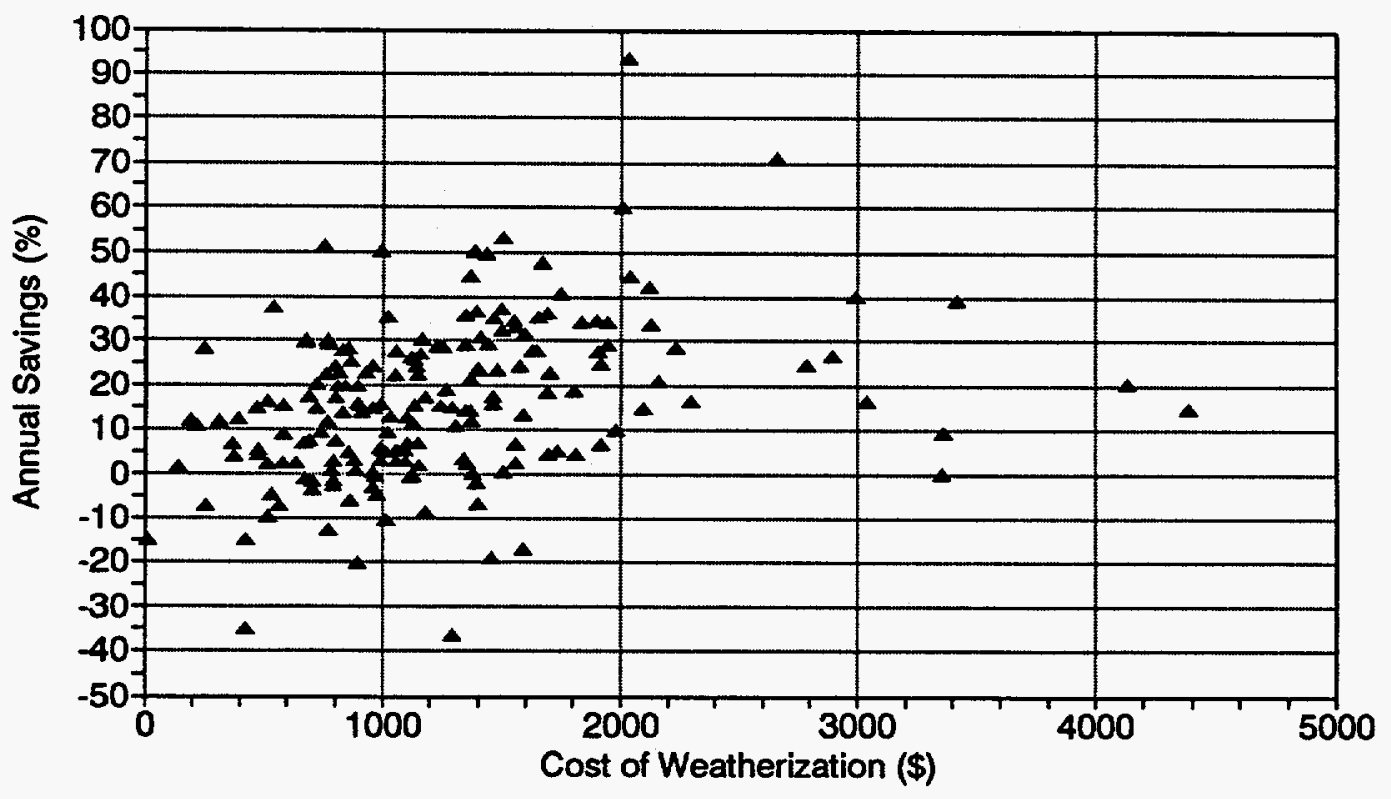

Fig. 11.3. Effects of cost of weatherization on measured fuel-oil savings. 
Table 11.2. Energy savings by occupant and dwelling characteristic

\begin{tabular}{|c|c|c|c|c|}
\hline & $\begin{array}{c}\text { Pre-weatherization } \\
\text { consumption } \\
\text { (gallons/year) }\end{array}$ & $\begin{array}{c}\text { Savings } \\
\text { (gallons/year) }\end{array}$ & $\begin{array}{c}\text { Number of } \\
\text { dwellings }\end{array}$ & $\begin{array}{c}\text { Significance } \\
\text { level }\end{array}$ \\
\hline Owners/Renters & & & & -- \\
\hline Owned & 899 & 146 & 110 & \\
\hline Rented & 944 & 250 & 15 & \\
\hline Elderly Occupants & & & & --- \\
\hline 1 or more & 972 & 179 & 60 & \\
\hline None & 902 & 150 & 89 & \\
\hline Handicapped Occupants & & & & -- \\
\hline 1 or more & 911 & 138 & 27 & \\
\hline None & 934 & 167 & 122 & \\
\hline Type of Housing & & & & --- \\
\hline Single story & 790 & 137 & 56 & \\
\hline Two stories & 1015 & 177 & 93 & \\
\hline
\end{tabular}

* means that differences in savings are different from zero at the 0.05 level of significance. --- means that differences in savings are not significantly different from zero.

Figures 11.3(a) and (b) show the effects of weatherization expenditures on the annual gallons saved and percent savings, respectively. The figures generally agree with the conclusions drawn from the table.

\subsubsection{Occupant and Dwelling Characteristics Associated With Savings}

The effect of four occupant and dwelling characteristics on the savings obtained from weatherization were investigated: ownership, occupancy by an elderly or handicapped person, and number of stories in the house. The results are contained in Table 11.2, which shows that the four factors were not associated with higher-than-average savings. Other characteristics discussed in Sect. 3 that may be associated with savings include number of occupants, change in occupancy, family income, heated floor area, and age of the house. The effect of these factors remain to be investigated. 


\subsubsection{Energy Savings Associated with Installed Measures}

Average measured savings in houses receiving a particular measure during weatherization were compared to the remaining houses to determine the savings associated with the particular measure. Table 11.3 contains a summary of the average measured savings in houses receiving a particular measure during weatherization. Measures were divided into six different major groups in the table, but the measures were not differentiated here as being installed by an in-house crew or by a contractor. Figure 11.4 shows mean savings for houses receiving insulation, air-leakage control, structural, and space-heating system measures.

The reader should bear in mind that several different measures were usually installed in a house. The savings shown are for the house with the specific measure in question plus all other measures that may have been installed. It is not possible to precisely estimate how much energy is saved by a single measure based on the analysis presented here for several reasons. First, the particular measure being examined may not be the cause of a significant difference in energy savings because measures can be co-related (see discussion of attic ventilation in this section). Second, all weatherized houses did not start out at the exact same condition (some already had attic insulation and some didn't, etc).

Using a blower door for sealing was the only air-leakage control measure that showed statistically significant ( 0.05 level of significance) higher-than-average savings. Houses receiving this treatment also appeared to have higher-than-average pre-weatherization consumptions . No statistically significant differences existed between houses receiving general caulking, distribution system work, or other infiltration reduction techniques and houses not receiving these measures, although houses that had distribution system leaks addressed had the highest mean savings.

Houses in which new attic insulation (where none was previously installed), normal wall insulation, and high-density wall insulation were added had statistically significant, higher-thanaverage savings. Houses receiving new attic insulation had pre-weatherization consumptions greater than average, while houses receiving wall insulation were about average. Preweatherization consumptions of houses receiving and not receiving wall insulation may not have 


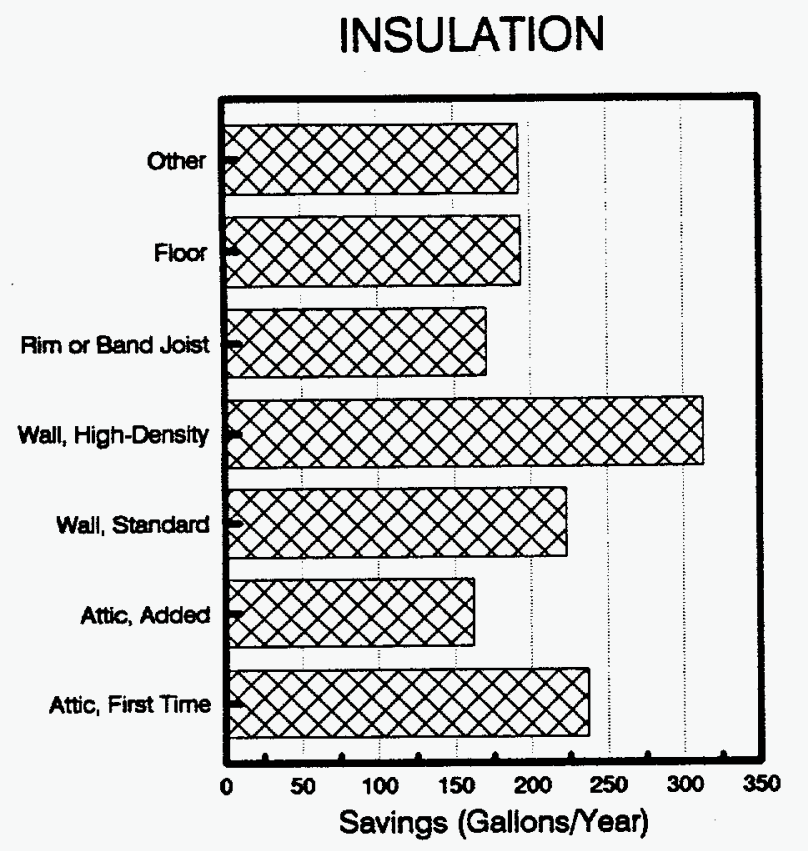

STRUCTURAL

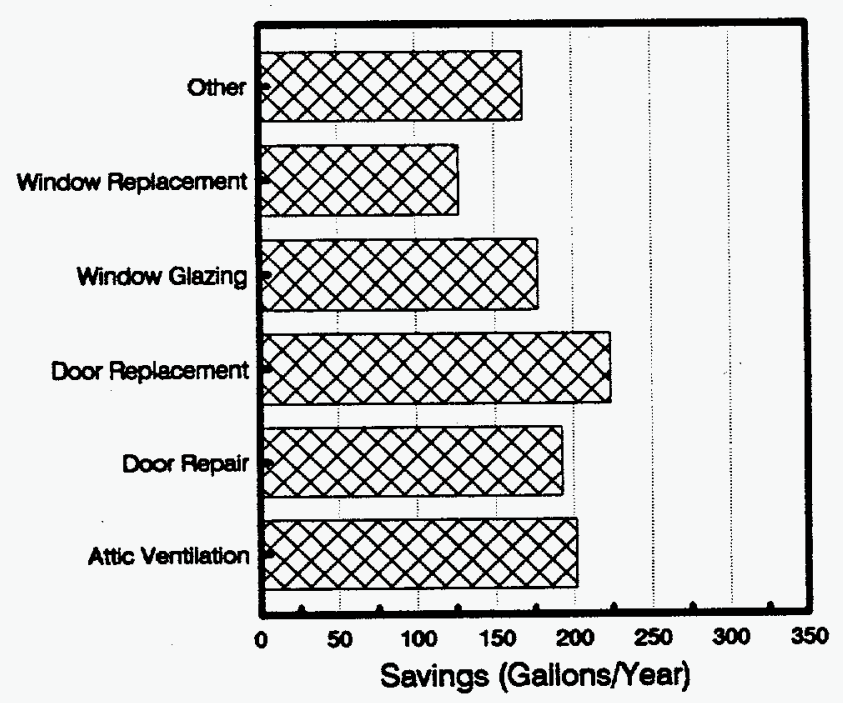

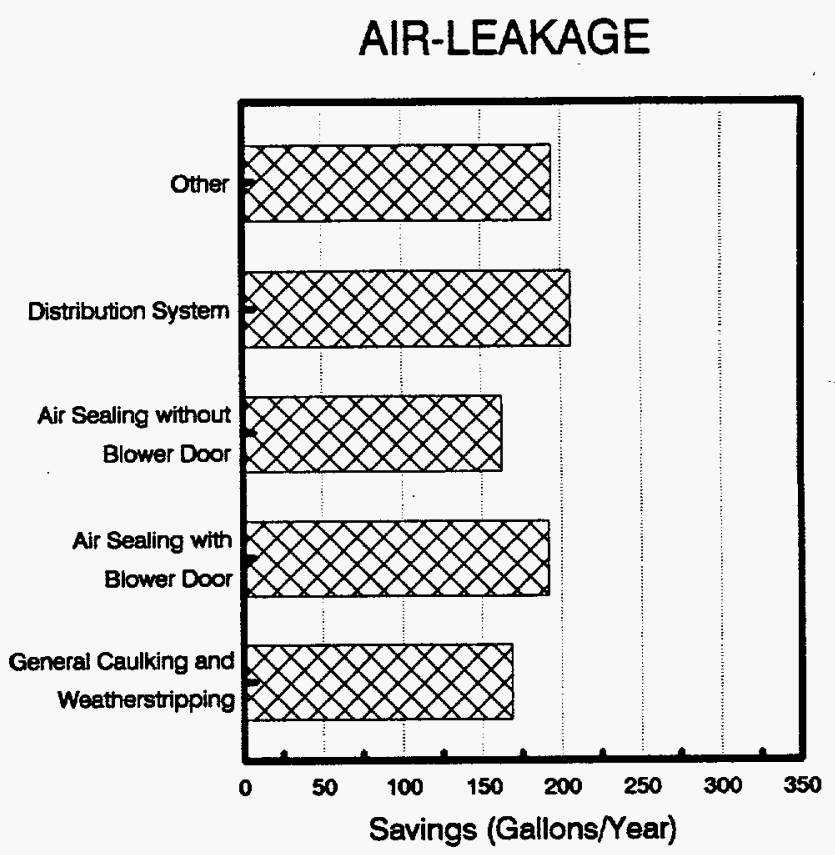

SPACE HEATING SYSTEM

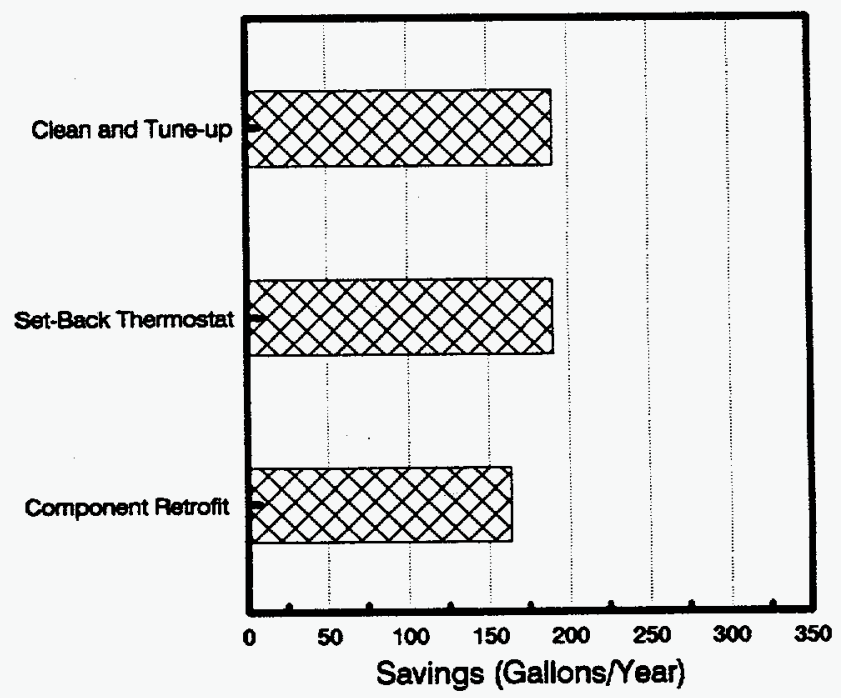

Fig. 11.4. Mean fuel-oil savings for houses receiving selected insulation, air-leakage, structural, and space-heating system measures. 
Table 11.3. House-level energy savings associated with selected measures

\begin{tabular}{|c|c|c|c|c|}
\hline $\begin{array}{l}\text { Houses receiving measures } \\
\text { including: }\end{array}$ & $\begin{array}{l}\text { Annual pre- } \\
\text { weatherization } \\
\text { consumption } \\
\text { (gallons) }\end{array}$ & $\begin{array}{l}\text { Annual } \\
\text { savings } \\
\text { (gallons) }\end{array}$ & $\begin{array}{c}\text { Number } \\
\text { of } \\
\text { dwellings }\end{array}$ & $\begin{array}{c}\text { Significance } \\
\text { level }\end{array}$ \\
\hline All Houses & 930 & 162 & 149 & \\
\hline \multicolumn{5}{|l|}{ Air Leakage } \\
\hline General caulking & 936 & 168 & 136 & --- \\
\hline Air sealing without a blower door & 919 & 162 & 77 & -- \\
\hline Air sealing with a blower door & 1041 & 193 & 40 & * \\
\hline Distribution system & 952 & 206 & 26 & -- \\
\hline Other & 924 & 195 & 31 & --- \\
\hline \multicolumn{5}{|l|}{ Insulation } \\
\hline Attic insulation, first time & 1032 & 237 & 54 & $*$ \\
\hline Attic insulation, added & 829 & 165 & 55 & -- \\
\hline Wall insulation, standard & 970 & 223 & 42 & * \\
\hline Wall insulation, high-density & 965 & 313 & 16 & * \\
\hline Rim or band joist insulation & 1012 & 171 & 32 & --- \\
\hline Floor insulation & 970 & 194 & 58 & --- \\
\hline Other & 986 & 193 & 33 & -- \\
\hline \multicolumn{5}{|l|}{ Windows and Doors } \\
\hline Storm window(s) & 951 & 154 & 46 & -- \\
\hline Storm door(s) & 784 & 30 & 7 & $*$ \\
\hline Window films of shades & -- & -- & $\mathbf{0}$ & --- \\
\hline Other & 795 & 71 & 6 & --- \\
\hline \multicolumn{5}{|l|}{ Space-Heating System } \\
\hline Clean and tune-up & 998 & 191 & 63 & --- \\
\hline New system & 1031 & 305 & 5 & * \\
\hline Set-back thermostat & 972 & 190 & 9 & --- \\
\hline Component retrofit & 996 & 163 & 9 & --- \\
\hline
\end{tabular}

* means that differences in savings are different from zero at the 0.05 level of significance.

-.- means that differences in savings are not significantly different from zero. 
Table 11.3. House-level energy savings associated with selected measures (continued)

\begin{tabular}{|c|c|c|c|c|}
\hline $\begin{array}{l}\text { Houses receiving measures } \\
\text { including: }\end{array}$ & $\begin{array}{l}\text { Annual pre- } \\
\text { weatherization } \\
\text { consumption } \\
\text { (gallons/year) }\end{array}$ & $\begin{array}{l}\text { Annual } \\
\text { savings } \\
\text { (gallons) }\end{array}$ & $\begin{array}{c}\text { Number } \\
\text { of } \\
\text { dwellings }\end{array}$ & $\begin{array}{c}\text { Significance } \\
\text { level }\end{array}$ \\
\hline \multicolumn{5}{|l|}{ Water Heating Measures } \\
\hline Tank insulation & 843 & 171 & 43 & --- \\
\hline New system & 953 & 456 & 1 & --- \\
\hline Pipe insulation & 914 & 166 & 80 & --- \\
\hline Temperature reduction & 1019 & 219 & 22 & -- \\
\hline Low-flow showerhead & 923 & 214 & 15 & --- \\
\hline Other & 982 & 160 & 18 & $-\cdots$ \\
\hline \multicolumn{5}{|l|}{ Structural Measures } \\
\hline Attic ventilation & 938 & 203 & 71 & $*$ \\
\hline Roof & 743 & 125 & 5 & -- \\
\hline Doors & 959 & 190 & 34 & -- \\
\hline Doors replacement & 968 & 222 & 24 & --- \\
\hline Windows glazing & 933 & 177 & 89 & --- \\
\hline Window replacement & 1014 & 126 & 26 & --- \\
\hline Walls & 997 & 185 & 9 & --- \\
\hline Floor & 755 & 157 & 2 & -- \\
\hline Other & 838 & 168 & 53 & -- \\
\hline
\end{tabular}

* means that differences in savings are different from zero at the 0.05 level or greater.

-- means that differences in savings are not significantly different from zero.

been as different as one would expect because some houses needing wall insulation still did not receive this measure.

Houses receiving the addition of storm doors had statistically significant, lower-thanaverage savings ( 30 gallons/year). This does not imply that storm doors increase fuel-oil consumption. The pre-weatherization consumption of houses receiving a storm door were much 
lower than average, indicating that the houses were already relatively efficient. Storm doors may have been installed in these houses because other, more effective measures were already in place. Additionally, measures other than storm doors that save more significant amounts of energy may not have been installed with the storm doors. There were only seven houses receiving storm doors, so the results may possibly be viewed as being inconclusive because of the small sample size. Savings for houses receiving all other window and door measures such as adding storm windows were not statistically different from houses not receiving these measures.

The only space-heating system measure associated with statistically significant, higher-thanaverage savings was replacement of the entire heating system. Houses receiving this measure saved 305 gallons/year, or about twice the average of all houses. A small sample size of five units may add some uncertainty to this result. This measure was expensive, typically costing about $\$ 2000$ to $\$ 2500$ to complete. Houses receiving a new system had higher pre-weatherization consumptions than average; in fact, houses receiving any space-heating system measure generally had higher-than-average pre-weatherization consumptions.

None of the domestic water heating measures were associated with statistically significant higher-than-average savings. Houses receiving hot-water temperature reduction, though, had high pre-weatherization consumptions and high savings.

Attic ventilation was the only structural measure (i.e., those measures which are either energy related, such as replacing broken window glass, or are necessary in order to enable other energy-related repairs to be accomplished) associated with statistically significant, higher-thanaverage savings. Obviously, attic ventilation by itself cannot bring about such improved savings, so it must be correlated with some other variable like attic insulation. Discussions with weatherization agency employees confirmed that an attic was often not vented if it did not have any insulation in it. Attic ventilation, if none existed, was usually added when new attic insulation was installed. A check of 54 houses receiving new attic insulation showed that $43(80 \%)$ of them also received attic ventilation.

A Pearson chi-squared analysis was conducted among those measures shown to be associated with statistically significant, higher-than-average savings - new attic insulation, standard 
Table 11.4. Correlations between measures associated with statistically significant, higher-than-average savings based on the Pearson chi-square statistic

\begin{tabular}{|c|c|c|c|c|c|c|c|}
\hline Measure & $\begin{array}{l}\text { New attic } \\
\text { insulation }\end{array}$ & $\begin{array}{l}\text { Standard } \\
\quad \text { wall } \\
\text { insulation }\end{array}$ & $\begin{array}{c}\text { High - } \\
\text { density } \\
\text { wall } \\
\text { insulation }\end{array}$ & $\begin{array}{c}\text { Air } \\
\text { sealing } \\
\text { using a } \\
\text { blower } \\
\text { door }\end{array}$ & $\begin{array}{c}\text { Attic } \\
\text { ventilation }\end{array}$ & $\begin{array}{l}\text { New } \\
\text { storm } \\
\text { door }\end{array}$ & $\begin{array}{l}\text { New } \\
\text { heating } \\
\text { system }\end{array}$ \\
\hline $\begin{array}{l}\text { New attic } \\
\text { insulation }\end{array}$ & & $\checkmark$ & $\mathbf{X}$ & $\checkmark$ & $\checkmark$ & - & - \\
\hline $\begin{array}{l}\text { Standard wall } \\
\text { insulation }\end{array}$ & $\checkmark$ & & $\mathbf{X}$ & $\mathrm{X}$ & $\checkmark$ & - & - \\
\hline $\begin{array}{l}\text { High-density } \\
\text { wall Insulation }\end{array}$ & $\mathrm{X}$ & $\mathbf{X}$ & & $\checkmark$ & $\mathrm{X}$ & - & - \\
\hline $\begin{array}{l}\text { Air sealing } \\
\text { using a blower } \\
\text { door }\end{array}$ & $\checkmark$ & $\mathbf{X}$ & $\checkmark$ & & $\mathbf{X}$ & - & - \\
\hline $\begin{array}{l}\text { Attic } \\
\text { ventilation }\end{array}$ & $\checkmark$ & $\checkmark$ & $X$ & $\mathrm{X}$ & & - & - \\
\hline $\begin{array}{l}\text { New storm } \\
\text { door }\end{array}$ & - & - & - & - & - & & - \\
\hline $\begin{array}{l}\text { New heating } \\
\text { system }\end{array}$ & - & - & - & - & - & - & \\
\hline Occurrences & 3 & 2 & 1 & 2 & 2 & 0 & 0 \\
\hline
\end{tabular}

Notes: $\checkmark$ means that measures show a correlation at the $95 \%$ confidence level.

$\mathrm{X}$ means that measures do not show a correlation at the $95 \%$ confidence level.

- means that the sample is too small to form a definitive decision.

wall insulation, high-density wall insulation, air sealing using a blower door, attic ventilation, new storm doors, and a new heating system - in order to ascertain which measures might be co-related with each other. Table 11.4 shows that new storm doors and new heating systems were not installed in sufficient houses during weatherization to show a definitive co-relation with any of the other measures associated with higher-than-average savings. New attic insulation is directly corelated with three of the remaining four variables (including attic ventilation); standard wall insulation, air sealing using a blower door, and attic ventilation are directly co-related with two variables each; and high-density wall insulation is directly co-related with only air sealing using a 
blower door. It is difficult to say which variable(s) contribute directly to higher-than-average savings because of the extensive correlation among the variables.

\subsubsection{Energy Savings Associated with Delivery Procedures}

The term "delivery procedures" encompasses pre-installation, installation, and postinstallation procedures that were followed or utilized in order to decide what weatherization activity to perform on a house, how to do it, and how to inspect installed measures when the job was completed. Table 11.5 divides these procedures into four major groups: selection of measures, use of diagnostics, quality control, and client education.

None of the measure selection approaches or diagnostic procedures were associated with statistically significant above-average savings. The use of heating system performance data to select space-heating system measures and the use of a blower door to measure leakage rates were significant at a 0.10 level of significance, however.

Houses receiving a visual inspection of space-heating systems had a statistically significant, above-average savings of $\mathbf{2 0 0}$ gallons/year. Inspections can improve energy savings by promoting higher quality installations through crew motivation (initially installing measures correctly) and call-backs (correcting improper installations). However, the savings improvement observed from a visual space-heating inspection could be due to the fact that space-heating system work was performed (and thus inspected). Almost all houses (95\%) receiving a space-heating system measure also received a visual inspection.

None of the client education measures were associated with statistically significant, aboveaverage savings, perhaps because almost all houses (94\%) received in-person education.

\subsubsection{High and Low Fuel-Oil Saving Houses}

Two groups were formed based on savings in order to examine why differences occurred between those houses which saved the most energy and those which saved the least. The top and bottom $12 \%$ (18 houses each) were separated from the sample of 149 weatherized houses with 
Table 11.5. Energy savings by service delivery procedure

\begin{tabular}{|c|c|c|c|c|}
\hline & $\begin{array}{l}\text { Annual pre- } \\
\text { weatherization } \\
\text { consumption } \\
\text { (gallons) }\end{array}$ & $\begin{array}{l}\text { Annual } \\
\text { savings } \\
\text { (gallons) }\end{array}$ & $\begin{array}{l}\text { Number of } \\
\text { dwellings }\end{array}$ & $\begin{array}{c}\text { Significance } \\
\text { level }\end{array}$ \\
\hline \multicolumn{5}{|l|}{ Selection of Measures } \\
\hline Envelope priority list & 922 & 170 & 120 & -- \\
\hline Envelope decision approach & 844 & 191 & 37 & -- \\
\hline Envelope benefit-to-cost & 1001 & 142 & 44 & --- \\
\hline Space heat using test data & 934 & 181 & 90 & -- \\
\hline Combined envelope/space heat & 928 & 182 & 28 & -- \\
\hline \multicolumn{5}{|l|}{ Use of Diagnostics } \\
\hline Blower door for sealing & 913 & 175 & 99 & -- \\
\hline Blower door for leak rates & 921 & 178 & 104 & -- \\
\hline Distribution system seal & 870 & 221 & 22 & -- \\
\hline Distribution system balance & 920 & 169 & 10 & -- \\
\hline Infrared scanning & 972 & 178 & 11 & $\cdots$ \\
\hline Heating system efficiency & 942 & 166 & 118 & --- \\
\hline Other methods & 910 & 181 & 8 & -- \\
\hline \multicolumn{5}{|l|}{ Quality Control } \\
\hline Envelope visual inspection & 935 & 166 & 142 & --- \\
\hline Envelope with blower door & 970 & 187 & 60 & -- \\
\hline Space heat visual check & 955 & 200 & 59 & * \\
\hline Space heat efficiency test & 991 & 192 & 55 & -- \\
\hline \multicolumn{5}{|l|}{ Client Education } \\
\hline In-person education & 934 & 167 & 140 & -- \\
\hline Literature to client & 934 & 160 & 62 & --- \\
\hline Other client education & 877 & 201 & 5 & --- \\
\hline
\end{tabular}

* means that differences in savings are different from zero at the 0.05 level of significance.

..- means that differences in savings are not significantly different from zero. 
"reliable" data. Table 11.6 contains a listing of the mean values of selected variables of the two groups.

Several observations may be made from this table quite easily. The high savers averaged 498 gallons/year of fuel oil saved $(37 \%)$ while the low savers saved -44 gallons/year $(-6 \%)$. The low savers used considerably less fuel in the pre-weatherization period than the high savers (873 vs 1392 gallons/year, respectively), even though both groups were identical in heated area. After weatherization, however, the high savers used about the same amount of fuel as the low savers (894 vs 917 gallons/year, respectively). The high savers were weatherized cost effectively with an average of $\$ 1604$ being spent on each for labor and materials. The low savers were not weatherized cost effectively, even though an average of $\$ 892$ was spent on each for labor and materials. The high savers benefitted more from air leakage measures than the low savers, but both ended up at about the same level of tightness. The low savers had more efficient heating systems and higher indoor temperatures than the high savers. These facts suggest that the high savers were houses which really needed weatherization, while the low savers were houses that were relatively more energy efficient. The annual consumption of the low savers averaged 0.67 gal $/ \mathrm{ft}^{2} /$ year, which also was the post-weatherization consumption of the high savers.

Figure 11.5 contains plots of measures received by both groups. Similar measures were installed in both groups, but the frequency at which measures were installed were not the same. Measures installed in only the high savers were new space-heating systems and components, highdensity wall insulation, low-flow showerheads, and domestic hot-water temperature reduction. Measures installed more frequently (difference of 20 percentage points or more) in the high savers than the low savers were new or additional attic insulation, regular wall insulation, floor insulation, air sealing using a blower door, replacement of broken glass in windows, and heating system clean and tunes. Measures installed more frequently in the low savers than the high savers were replacement windows and new storm doors.

The service delivery procedures differed little between these two groups (Fig. 11.6). About $80 \%$ of both groups used a priority list to select envelope measures and $60 \%$ used a visual inspection to select space-heating measures. However, $67 \%$ of the high savers used heatingsystem efficiencies to decide upon space-heating measures compared to $50 \%$ of the low savers. 
Table 11.6. Mean values of measured variables

\begin{tabular}{|c|c|c|}
\hline Variable & $\begin{array}{c}\text { Bottom 12\% } \\
\text { (losers) }\end{array}$ & $\begin{array}{l}\text { Top 12\% } \\
\text { (winners) }\end{array}$ \\
\hline Annual savings (gallons) & -44 & 498 \\
\hline Percent savings & -5.7 & 37.5 \\
\hline Weatherization cost for labor \& materials $(\$)$ & 892 & 1604 \\
\hline Pre-weatherization consumption (gal/ft'2/year) & 0.67 & 1.06 \\
\hline Post-weatherization consumption (gal/ft $\mathrm{t}^{2} /$ year) & 0.71 & 0.66 \\
\hline Pre-weatherization inside temperature $\left({ }^{\circ} \mathrm{F}\right)$ & 72.3 & 70.7 \\
\hline Post-weatherization inside temperature $\left({ }^{\circ} \mathrm{F}\right)$ & 72.4 & 70.1 \\
\hline Indoor temperature difference $\left({ }^{\circ} \mathrm{F}\right)$ & 0.1 & -0.6 \\
\hline Heated area $\left(\mathrm{ft}^{2}\right)$ & 1457 & 1467 \\
\hline Number of stories & 1.5 & 1.7 \\
\hline Pre-weatherization consumption (gallons) & 873 & 1393 \\
\hline Post-weatherization consumption (gallons) & 917 & 895 \\
\hline Pre-weatherization $\mathbf{R}^{2}$ & 0.9 & 0.9 \\
\hline Post-weatherization $\mathbf{R}^{2}$ & 0.9 & 0.9 \\
\hline Days of pre-weatherization data & 74.5 & 68.6 \\
\hline Days of post-weatherization data & 92.2 & 95.4 \\
\hline Pre-weatherization air leakage $(\mathrm{cfm} 50)$ & 3580 & 3856 \\
\hline Post-weatherization air leakage ( $\mathrm{cm} 50)$ & 3290 & 3191 \\
\hline Air leakage difference (cfm50) & 290 & 665 \\
\hline Age of space-heating system & 25.8 & 20.6 \\
\hline Pre-weatherization steady-state efficiency & 76.5 & 72.9 \\
\hline Post-weatherization steady-state efficiency & 76.2 & 74.7 \\
\hline Difference in steady-state efficiency & -0.2 & 1.6 \\
\hline Pre-weatherization smoke number & 1.6 & 2.5 \\
\hline Post-weatherization smoke number & 1.9 & 2.1 \\
\hline Upper fan limit setting $\left({ }^{\circ} \mathrm{F}\right)$ & 135 & 137 \\
\hline Lower fan limit setting $\left({ }^{\circ} \mathbf{F}\right)$ & 94 & 101 \\
\hline Boiler run temperature $\left({ }^{\circ} \mathrm{F}\right)$ & 172 & 188 \\
\hline Boiler cutout switch $\left({ }^{\circ} \mathrm{F}\right)$ & 190 & 201 \\
\hline Annual savings $(\$)$ & -44 & 503 \\
\hline Program benefit-to-cost ratio at 15 years & -- & 2.96 \\
\hline
\end{tabular}




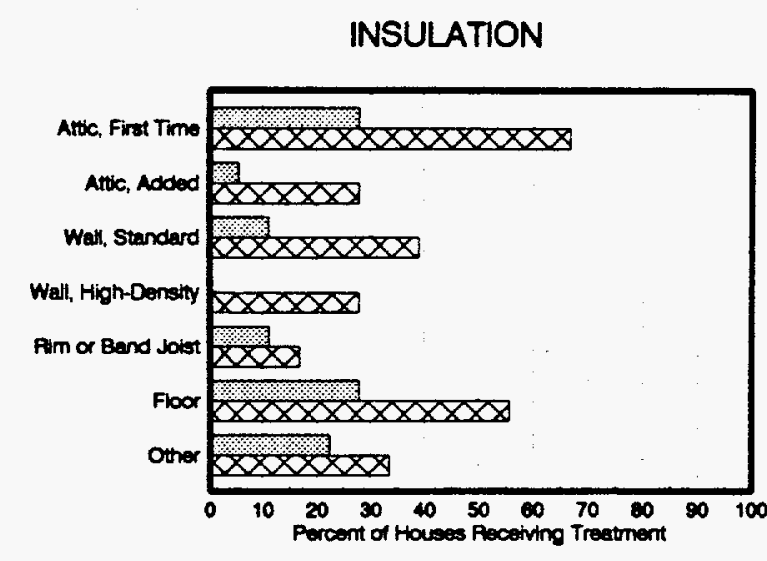

SPACE HEATING SYSTEM

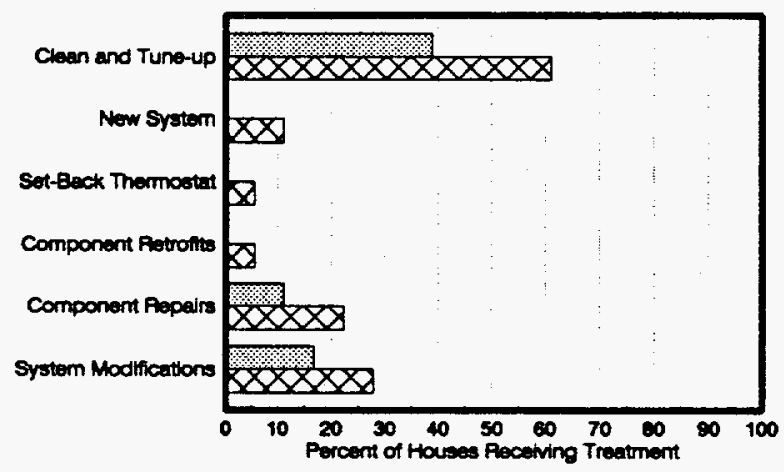

DOMESTIC WATER-HEATING SYSTEM

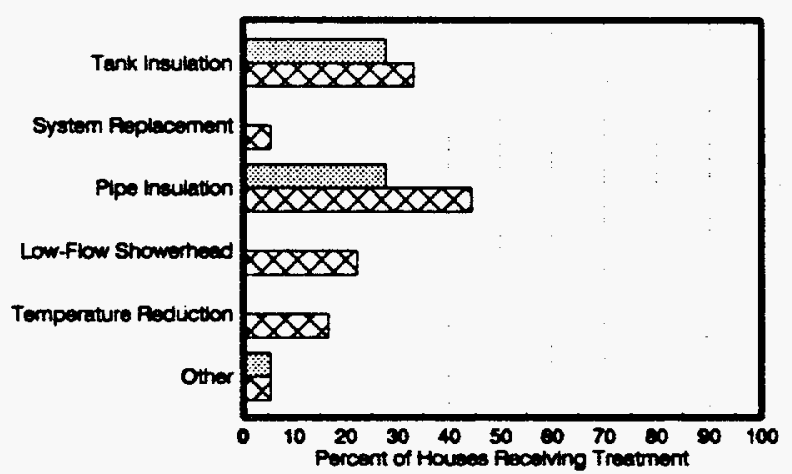

Bottom 12\%

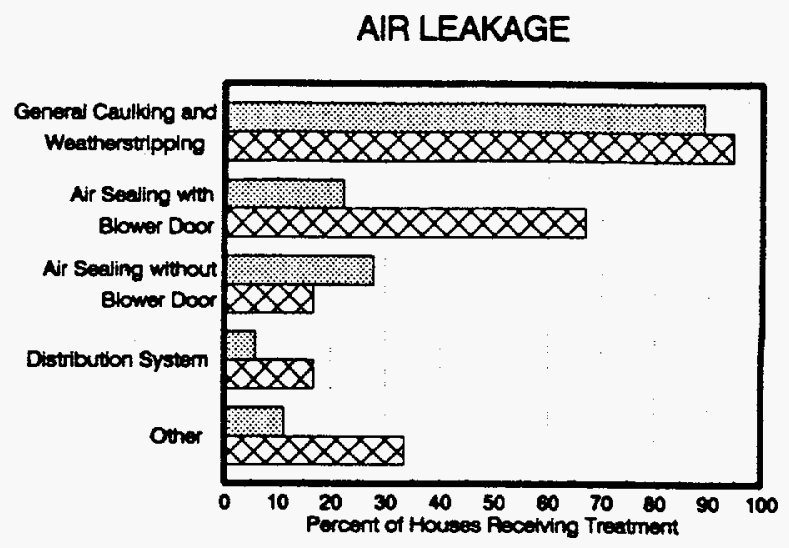

STRUCTURAL

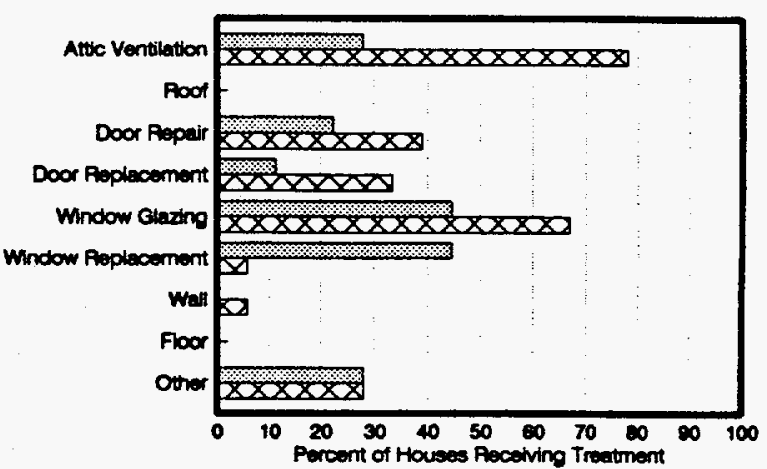

WINDOWS AND DOORS

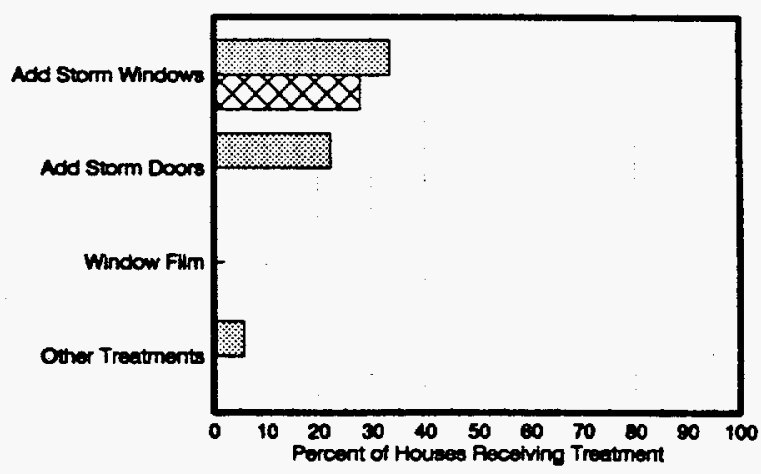

$\square$ Top $12 \%$

Fig. 11.5. Installation frequency of weatherization measures in high and low saver groups. 

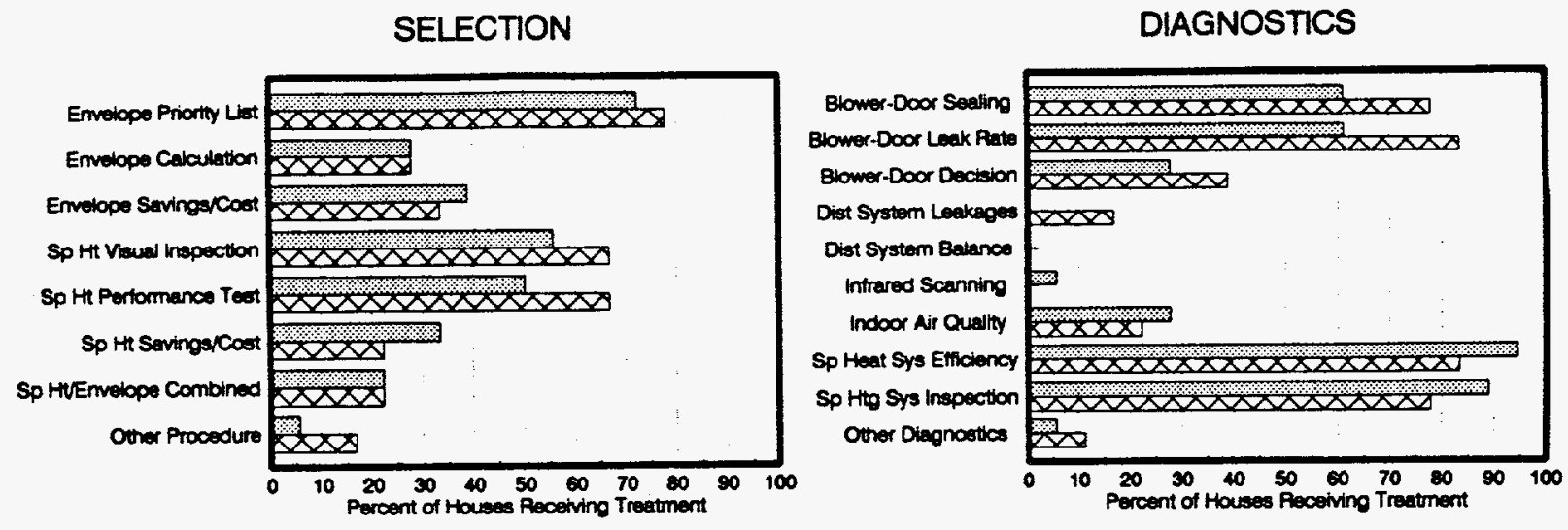

QUALTY CONTROL
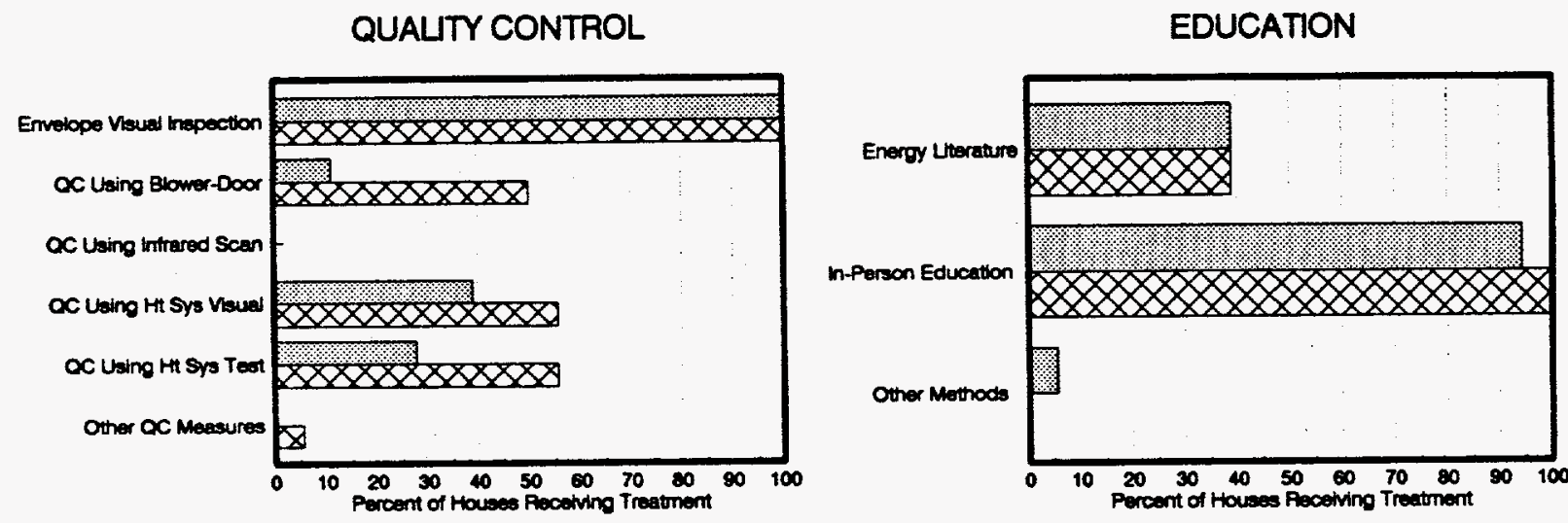

Bottom 12\%

$\square \times$ Top $12 \%$

Fig. 11.6. Frequency of use of different measure selection approaches, diagnostic techniques, quality control inspections, and client education.

A blower door was used to find and measure leakage areas in about $80 \%$ of the high savers compared to $60 \%$ of the low savers. About $90 \%$ of both groups measured the furnace steady-state efficiency before weatherization.

A visual inspection of envelope measures was performed in all houses of both groups after weatherization. A blower door was used on $50 \%$ of the high savers compared to $11 \%$ of the low savers for quality control of envelope measures. About $60 \%$ of the high savers conducted visual and testing inspections on heating systems compared to $35 \%$ of the low savers. 
All houses of both groups had in-person client education, and $40 \%$ of each received literature.

\subsection{AGENCY AND STATE-LEVEL ANALYSES}

Houses were grouped into their source agencies and states in order to get a more macroscopic view of weatherization performance,

Figure 11.7 shows the savings obtained by each individual agency along with the number of houses in the sample from that agency. One agency had no qualifying houses in the subset sample, so only 40 agencies are shown on the plot. Three agencies stand out as their average savings are above 400 gallons/year, but one of these agencies had only one house in its sample while a second had only two. However, one agency had four houses in its sample, so an annual savings of 400 gallons may be an attainable goal. Five agencies had mean annual savings of less than 50 gallons/house. The two lowest agencies had only one or two houses in their sample, but the other three agencies had four, three, and six houses, respectively.

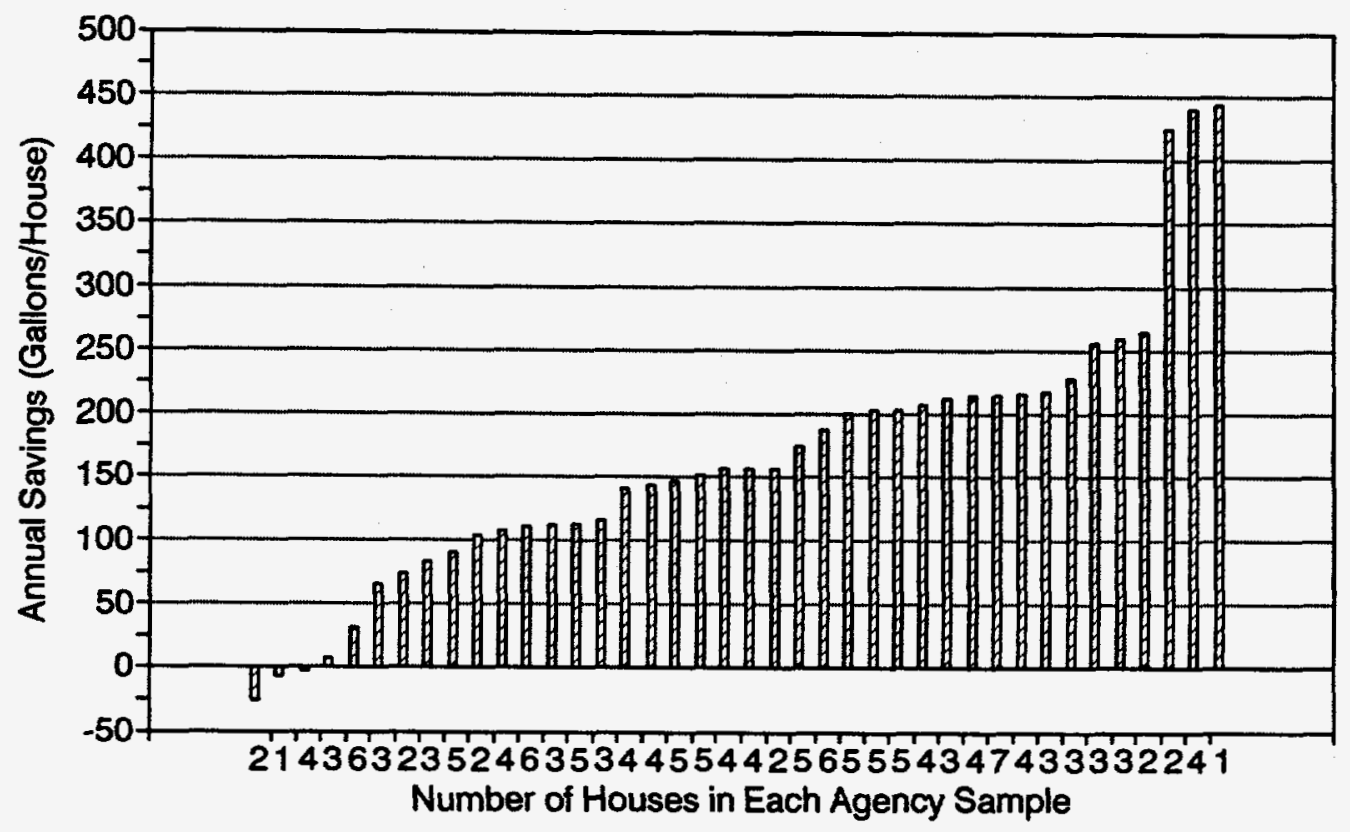

Fig. 11.7. Average annual fuel-oil savings for each local weatherization agency (in increasing order of savings) with the number of houses monitored in each agency identified along the abscissa ( $x$-axis). 


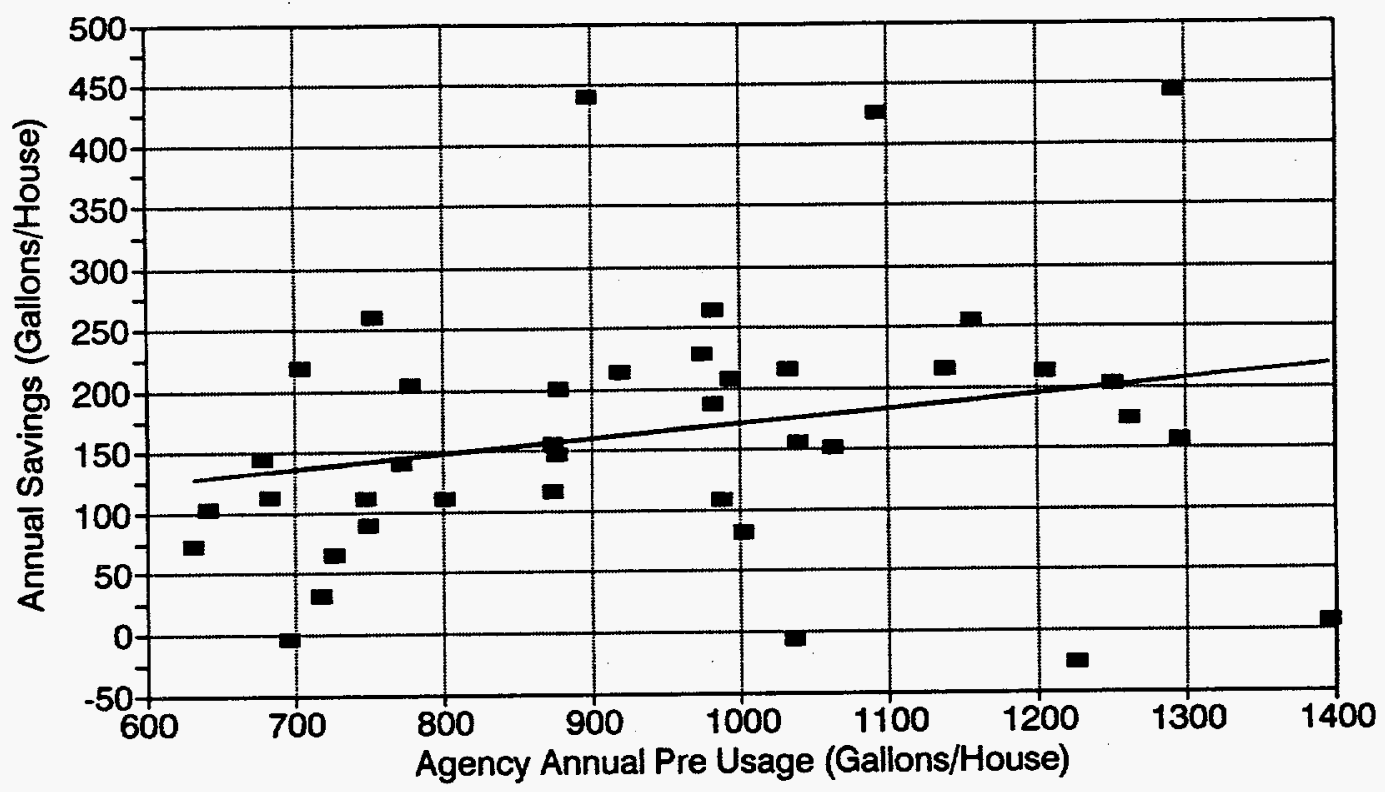

Fig. 11.8. Comparison of average annual fuel-oil savings for each local weatherization agency to the average pre-weatherization consumption.

Figure 11.8 shows a weak relationship between pre-weatherization consumption and savings at the agency level. However, some agencies having high pre-weatherization consumption houses had low savings and visa-versa. The agency having about 10 gallons/year savings at a preweatherization consumption of 1400 gallons/year had three houses. This appears to be poor performance, as many opportunities for savings must exist at this level of consumption. The agency having about $\mathbf{4 4 0}$ gallons/year savings at a pre-weatherization consumption of $\mathbf{9 0 0}$ gallons had four houses. This is indeed exemplary performance; the savings is extremely high, approaching $50 \%$, even though the pre-weatherization consumption is below the 930 gallon mean for all houses.

Figure 11.9 shows that about $63 \%$ of the agencies obtained an average annual savings between 100-250 gallons/house, while $23 \%$ averaged below 100 gallons/house and $15 \%$ averaged above 250 gallons/house. 


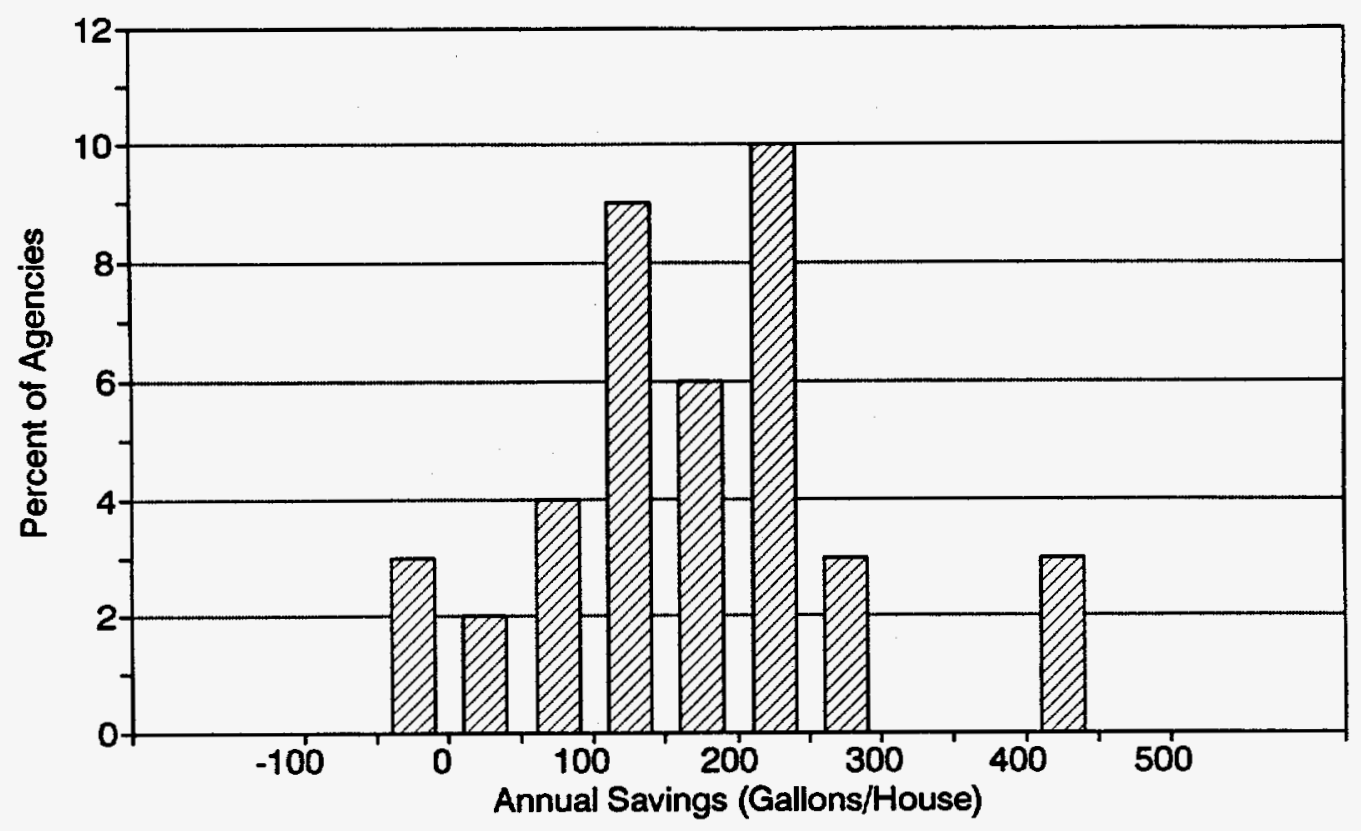

Fig. 11.9. Distribution of the average annual fuel-oil savings achieved by each local weatherization agency.

The preceding analyses show that differences exist in savings among agencies, although differing housing stocks in an agency (row houses vs detached, for instance) may affect the achieved savings.

Since the agencies are monitored by their respective states, Fig. 11.10 plots the annual savings per house attained by each of the nine states in which the Fuel-Oil Study was conducted. The plot shows that two states attained well below-average savings, five states attained average savings, and two states attained well above-average savings. However, an analysis of variance multiple comparison approach using a Tukey-Kramer adjusted test revealed that there was no significant difference in savings among the states at the $95 \%$ confidence level. We still believe, however, that differences in state policies toward weatherization have an impact on the achievable savings of the Program. 


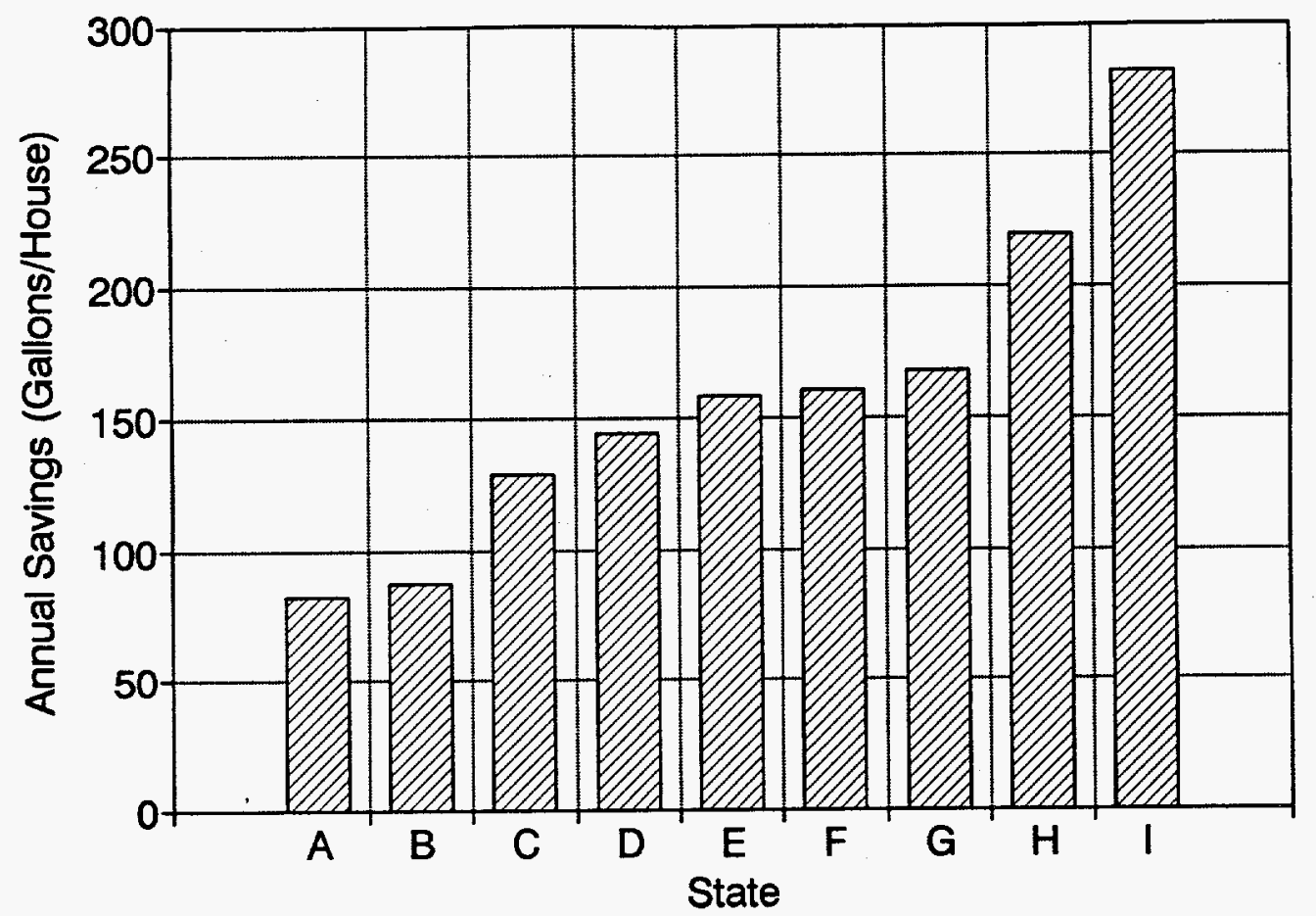

Fig. 11.10. Average annual fuel-oil savings for each state (in increasing order of savings). 


\section{CONCLUSIONS AND RECOMMENDATIONS}

The Weatherization Assistance Program cost-effectively weatherized a total of 23,400 single-family fuel-oil heated houses in the nine northeastern states during program years 1991 and 1992. An average annual net fuel-oil savings of 160 gallons (17.7\% of pre-weatherization consumption) was achieved at a total average cost of $\$ 1819$ ( $\$ 1192$ for installation labor and materials and $\$ 627$ for overhead and management); the resulting program-perspective benefit-tocost ratio was 1.48 and the societal perspective ratio was 2.01. Although indoor temperatures changed in individual houses following weatherization, there was no average difference when compared to the control houses; thus, there was no overall indoor-temperature take-back effect influencing fuel-oil savings.

A general trend toward higher-than-average fuel-oil savings was observed in houses with high pre-weatherization fuel-oil consumption, although high pre-weatherization consumption explains only a portion of the variance in savings. Program savings could likely be increased by targeting higher energy consumers for weatherization, although equity issues would have to be considered. An analysis of the top and bottom $12 \%$ of the sample showed that high savers had consumptions after weatherization about equal to that of the low savers before they were weatherized, indicting that the low savers were, on average, already more energy efficient than the high savers.

Weatherization measures associated with statistically significant, higher-than-average savings were use of a blower door for air-sealing, attic and wall insulation, and replacement spaceheating systems. More extensive analysis of the data should be performed to further investigate various interacting factors leading to improved fuel-oil savings and cost-effectiveness. An intangible factor of "state/local weatherization agency leadership and quality" that many practitioners feel is an important cause of improved performance could not be addressed by this study, although large differences in mean savings were observed among agencies and states.

Space-heating system tune-ups were not particularly effective at improving the steady-state efficiency of systems and were not associated with statistically significant, higher-than-average savings, although improved seasonal efficiency and system safety and reliability may have resulted. 
Tune-ups were performed on some systems that were already operating efficiently, and they did not achieve maximum savings potential on many inefficient systems. The need to use licensed technicians to audit systems and perform the tune-ups led to the extraneous tune-up problems and the increased costs, although increased use of fully qualified technicians might improve performance. The Weatherization Assistance Program should investigate methods of improving the selection and/or application of space-heating system tune-ups and actively study and promote adoption of improved tune-up procedures as a primary technology transfer activity. A committee composed of experts in the field could be assembled to develop recommended approaches and consult with states to verify benefits. State and local weatherization agency data should be collected to further study and refine tune-up techniques.

Air-leakage measurements showed that weatherized houses were more air-tight following weatherization, but still leakier than what is achievable. Although not statistically verifiable, the use of blower doors and installation of wall insulation were two measures that likely led to greater-than-average air-leakage reductions. Additional technology transfer effort is recommended to increase the use of blower doors considering that only half the weatherized houses used a blower door. A guidebook developed by a committee of experts and covering the following topic areas might be a useful technology transfer and training document: air-leakage theory, use of a blower door, measuring air leakage, finding and sealing leakage sites, and incorporating a blower door into a weatherization program. State and local weatherization agency data should be collected to further study the air-leakage reductions being achieved and the tightness of the houses before and after weatherization.

Weatherization appeared to make occupants feel better about their house and house environment. Most occupants felt that their houses were healthy and safe, and this was supported by field inspections. Occupants felt that weatherization made their houses much more affordable to heat and much less drafty.

The split-winter experimental design with submetering worked well in monitoring fuel-oil consumption and allowing fuel-oil savings to be estimated. An attrition rate of less than $15 \%$ is attainable in such a test. A service payment to participants approximating lost savings due to delayed weatherization (in order to collect pre-weatherization data) was beneficial to all and 
increased overall cooperation from agencies and clients. There is always a fear that the payment may be used to purchase additional fuel for space heating and thus add bias to the experiment, but our measurements of indoor temperatures lead us to conclude that this did not happen. 


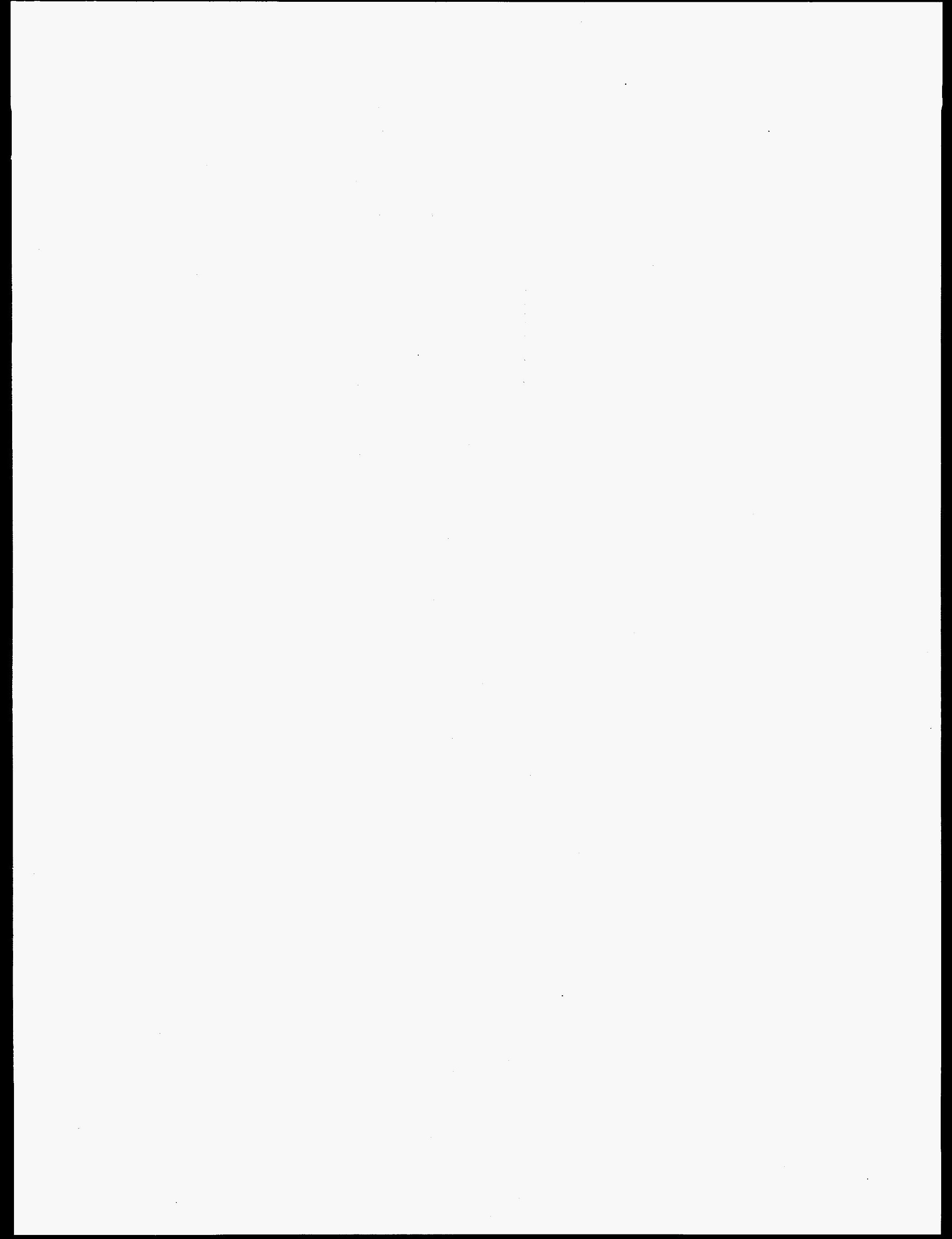




\section{REFERENCES}

Alliance to Save Energy, 1985, Technicians Manual: Low-Income Oilheat Retrofit Program.

ASHRAE, American Society of Heating, Refrigerating, and Air-Conditioning Engineers, Ventilation Standard 62-89, Atlanta, 1989.

ASTM, 1987, ASTM Standard E779-87, Standard Test Method for Determining Air Leakage Rate by Fan Pressurization, The American Society for Testing and Materials.

Bacharach, Testing and Measurement Brochure.

CGSB, 1986, Standard CAN/CGSB-149.10-M86, Determination of the Airtightness of Building Envelopes by Fan Depressurization Method, Canadian General Standards Board, December.

L. G. Berry, M. A. Brown, T. Wright, and D. L. White, 1991, Experimental Plan for the SingleFamily Study, ORNL/TM-11668/V3, Oak Ridge National Laboratory, August.

D. A. Beschen and M. A. Brown, 1991, Evaluation Plan for the Weatherization Assistance Program, ORNL/TM-11668/V1, Oak Ridge National Laboratory, August.

M. A. Brown, L. G. Berry, R. A. Balzer, and E. Faby, 1993, National Impacts of the Weatherization Assistance Program in Single-Family and Small Multifamily Dwellings, ORNL/CON-326, Oak Ridge National Laboratory, May.

Ecotope, 1989, Model Conservation Standards: Field Evaluation Protocol, 2812 East Madison, Seattle, Washington, July 14.

Energy Information Administration, 1989, Housing Characteristics 1987, DOE/EIA-0314 (87).

B. C. Lippiatt and R. T. Ruegg, 1990, Energy Prices and Discount Factors for Life-Cycle Cost Analysis 1991, NISTIR 85-3273-5 (Rev. 10/90), U.S. Department of Commerce, National Institute of Standards and Technology, October.

J. M. MacDonald, 1993, Description of the Weatherization Assistance Program in Large Multifamily Buildings for Program Year 1989, ORNL/CON-329, Oak Ridge National Laboratory, April.

L. N. McCold, J. A. Schlegel, L. A. O'Leary, and D. C. Hewitt, 1988, Field Test Evaluation of Conservation Retrofits of Low-Income, Single-Family Buildings in Wisconsin: Audit Field Test Implementation and Results, ORNL/CON-228/P2, Oak Ridge National Laboratory, June.

P. E. Mihlmester et al., 1992, Characterization of the Weatherization Assistance Program Network, ORNL/CON-324, Oak Ridge National Laboratory, February.

M. Sherman and M. Modera, 1984, Comparison of Measured and Predicted Infiltration Using the LBL Infiltration Model, LBL-17001, Lawrence Berkeley Laboratory, February. 
M. Sherman et al., 1984, Variability in Residential Air Leakage, LBL-17587, Lawrence Berkeley Laboratory, April.

M. P. Ternes, P. S. Hu, L. S. Williams, and P. Goewey, 1991, The National Fuel End-Use Efficiency Field Test: Energy Savings and Performance of an Improved Energy Conservation Measure Selection Technique, ORNL/CON-303, Oak Ridge National Laboratory, January.

M. P. Ternes and W. P. Levins, 1992, The Oklahoma Field Test: Air-conditioning Electricity Savings from Standard Energy Conservation Measures. Radiant Barriers, and High-Efficiency Window Air Conditioners, ORNL/CON-317, Oak Ridge National Laboratory, August:

M. P. Ternes, W. P. Levins, and M. A. Brown, 1992, Experimental Plan for the Fuel-Oil Study, ORNL/TM-11668/V2, January.

M. P. Ternes, K. E. Wilkes, and H. A. McLain, 1993, Cooling Season Performance of Retrofitted Exterior Wall Insulation, ORNL/CON-349 (Draft), Oak Ridge National Laboratory.

G. Tsongas, 1993 "Building Tightness Guidelines: When is a House Too Tight?" Home Energy, Vol. 10, No. 2, March/April. 


\section{APPENDIX A. HOUSE CHARACTERISTICS SURVEY}

Information on the physical characteristics of the houses and their mechanical systems (space-heating, space-cooling, and water-heating) was collected at the end of the postweatherization period using the first survey instrument in this appendix. Information on the floor area, volume, number of rooms, and number of heated rooms was also collected at the beginning of the pre-weatherization period using the second survey form. 


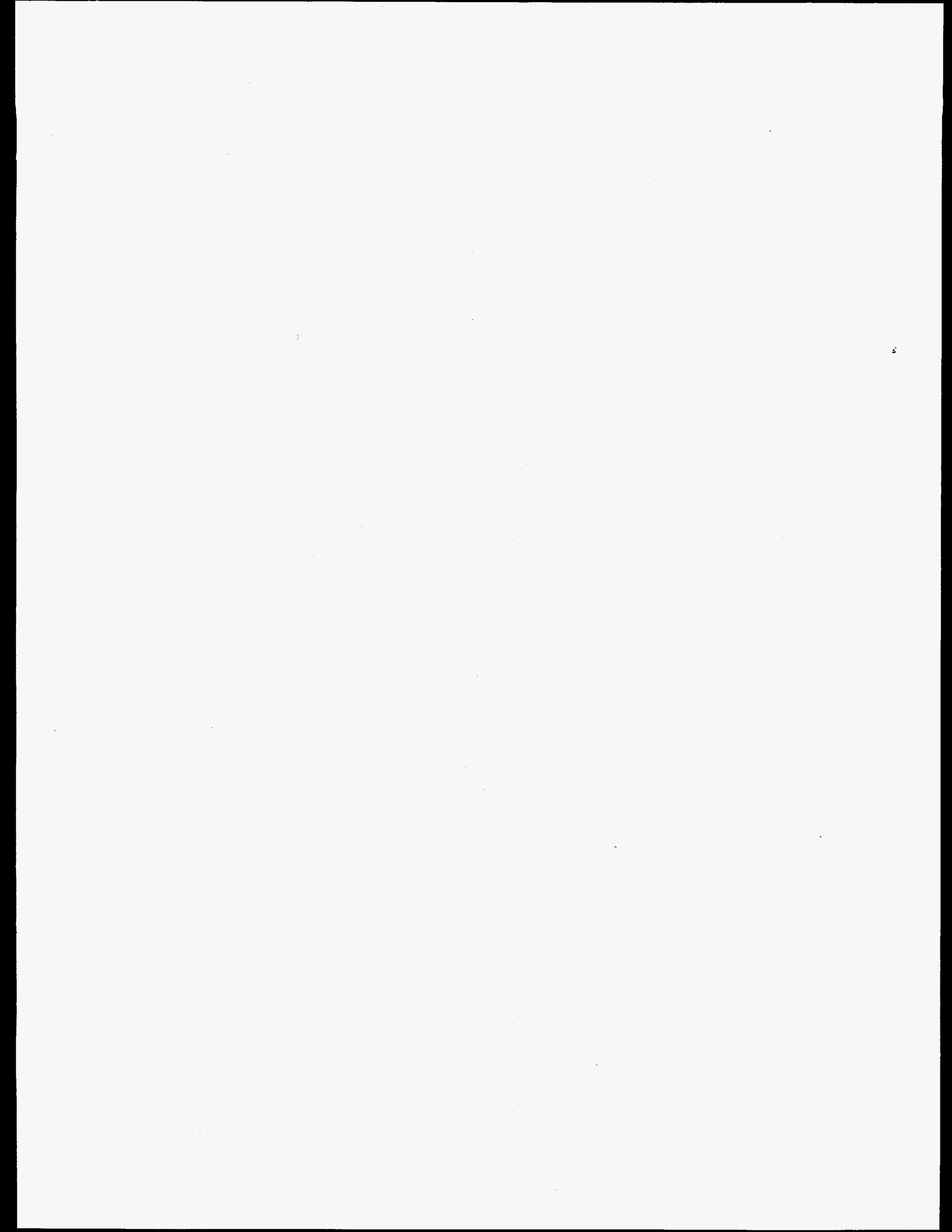


FUEL-OIL STUDY HOUSE CHARACTERISTICS SURVEY

\section{IDENTIFICATION}

House ID:

Subgrantee name:

Occupant name:

Phone number:

Occupant address:

\section{GENERAL}

Type:

SFD - single-family detached MFS - small (2-4 units) multifamily

$\mathrm{MH}$ - manufactured or SFA - single-family attached MFL - large (>4 units) multifamily mobile home

A single-family housing unit is a structure that provides living space for one household or family. The structure may be detached, attached on one side, or attached on two sides. Attached houses are considered single-family houses as long as the house itself is not divided into more than one housing unit and has an independent outside entrance. A single-family house is contained within walls that go from the basement (or ground floor, if there is no basement) to the roof. A mobile home with one or more rooms added is a single- family home. Row houses and side-by-side duplexes (twins) are typically single-family houses.

A small multifamily house or building is a structure that is divided into living quarters for two, three, or four families or households. This category also includes houses originally intended for occupancy by one family (or for some other use) that have since been converted to separate dwellings for two to four families. Typical arrangements in these types of living quarters are separate apartments downstairs and upstairs, or one apartment on each of three or four floors. Over-and-under duplexes are typically in this category.

A mobile or manufactured home is a structure that has all the facilities of a dwelling unit but is built on a movable chassis. It may be placed on a permanent or temporary foundation and may contain one room or more. If rooms are added to the structure, it is considered a single-family home.

Are the following systems shared with other housing units: space-heating system space-cooling system water-heating system $(\mathrm{Y}, \mathrm{N})$ $(\mathrm{Y}, \mathrm{N})$ $(\mathrm{Y}, \mathrm{N})$

If SFA, number of attached housing units: (NA, 1, 2, ...) (typically 2 or less)

\section{EXTERNAL DOORS}

\begin{tabular}{|c|c|c|}
\hline Door type & Number without storm door & Number with storm door \\
\hline \hline Hollow core wood door & & \\
\hline Solid core wood door & & \\
\hline Insulated metal door & & \\
\hline
\end{tabular}




\section{WINDOWS}

House ID:

\begin{tabular}{|c|c|c|c|}
\hline $\begin{array}{c}\text { Window } \\
\text { glazing } \\
\text { type }\end{array}$ & $\begin{array}{c}\text { Frame } \\
\text { type }\end{array}$ & $\begin{array}{c}\text { Storm } \\
\text { window }\end{array}$ & $\begin{array}{c}\text { Area } \\
\left(\mathrm{ft}^{2}\right)\end{array}$ \\
\hline \hline & & & \\
\hline & & & \\
\hline & & & \\
\hline & & & \\
\hline & & & \\
\hline & & & \\
\hline
\end{tabular}

\begin{tabular}{|l|l|}
\hline & $\begin{array}{l}\text { Window } \\
\text { glazing type }\end{array}$ \\
\hline SP & single pane \\
\hline DP & double pane \\
\hline TP & triple pane \\
\hline GB & glass block \\
\hline TE & $\begin{array}{l}\text { temporary } \\
\text { (cardboard, } \\
\text { plastic, etc.) }\end{array}$ \\
\hline
\end{tabular}

\begin{tabular}{|l|l|}
\hline \multicolumn{2}{|c|}{$\begin{array}{c}\text { Frame } \\
\text { type }\end{array}$} \\
\hline $\mathrm{W}$ & wood \\
\hline $\mathrm{M}$ & metal \\
\hline $\mathrm{V}$ & vinyl \\
\hline $\mathrm{X}$ & other \\
\hline $\mathrm{N}$ & none \\
\hline
\end{tabular}

\begin{tabular}{|c|c|}
\hline \multicolumn{2}{|c|}{$\begin{array}{c}\text { Storm } \\
\text { window }\end{array}$} \\
\hline $\mathrm{W}$ & wood \\
\hline $\mathrm{M}$ & metal \\
\hline $\mathrm{X}$ & other \\
\hline $\mathrm{N}$ & none \\
\hline
\end{tabular}

FLOOR AREAS AND VOLUMES

\begin{tabular}{|c|c|c|c|c||}
\hline Floor & $\begin{array}{c}\text { Total area } \\
\left(\mathrm{ft}^{2}\right)\end{array}$ & $\begin{array}{c}\text { Intentionally } \\
\text { heated area } \\
\left(\mathrm{ft}^{2}\right)\end{array}$ & $\begin{array}{c}\text { Intentionally } \\
\text { air-conditioned area } \\
\left(\mathrm{ft}^{2}\right)\end{array}$ & $\begin{array}{c}\text { Volume } \\
\left(\mathrm{ft}^{3}\right)\end{array}$ \\
\hline \hline Basement & & & & \\
\hline First floor & & & & \\
\hline Second floor & & & & \\
\hline All other floors & & & & \\
\hline Total & & & & \\
\hline
\end{tabular}

An intentionally heated (air conditioned) space is one with equipment and/or distribution outlets designed to maintain a desired temperature in the space. An unintentionally heated (air conditioned) space is one that is heated (cooled) primarily from equipment jacket and/or distribution losses (there is little control over the resulting temperature). A space is not heated (air conditioned) if there is no source of heating (cooling) to alter the natural temperature of the space. For example, a basement heated primarily from equipment jacket and/or distribution system losses is not considered to be an intentionally heated space. A window air conditioner cools only the room the unit is installed in, not adjacent rooms. If a space was designed to be intentionally heated (cooled) but is maintained by the occupant in an unheated (uncooled) condition (by closing registers and doors, for example), the space should still be considered a heated (cooled) space with one exception: an unfinished basement or other unfinished room with a distribution system that is always shut off should be considered unintentionally heated (cooled).

Floor heights used to calculate volume are floor to floor except for the top floor, which is floor to ceiling.

Number of intentionally heated stories: $(1,1.5,2,2.5,3,3.5,4$ or more) 
House ID:

\section{ATTICS}

\begin{tabular}{|c|c|c|c|}
\hline \multicolumn{4}{|c|}{ FINISHED ATTIC AREAS } \\
\hline & \multirow[b]{2}{*}{$\begin{array}{c}\text { Area } \\
\left(\mathrm{ft}^{2}\right)\end{array}$} & \multicolumn{2}{|c|}{$\begin{array}{l}\text { Existing } \\
\text { insulation }\end{array}$} \\
\hline & & Type & $\begin{array}{c}\text { Depth } \\
\text { (inches) }\end{array}$ \\
\hline \multicolumn{4}{|l|}{ Collar beam } \\
\hline \multicolumn{4}{|l|}{ Kneewall } \\
\hline Roof rafter & & & \\
\hline
\end{tabular}

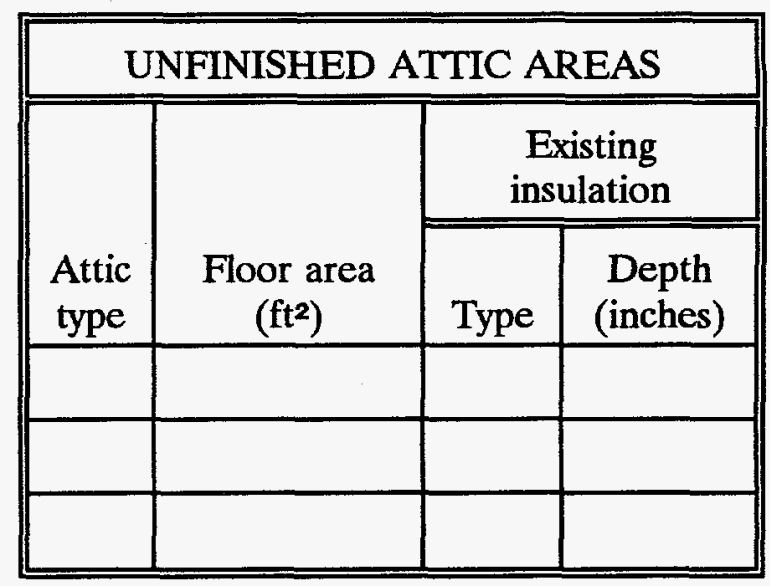

Finished attic areas are defined in the figures on the following page.

Areas pertain to attic areas adjacent to intentionally heated or air-conditioned spaces. For example, the area above an unconditioned garage should not be included.

\begin{tabular}{|l|l|}
\hline \multicolumn{2}{|c|}{ Existing insulation type } \\
\hline BC & blown cellulose \\
\hline BF & blown fiberglass \\
\hline FB & fiberglass batt \\
\hline RB & rigid board or foam \\
\hline BRW & blown rock wool \\
\hline RWB & rock wool batt \\
\hline V & vermiculite \\
\hline $\mathrm{X}$ & other \\
\hline $\mathrm{N}$ & none \\
\hline
\end{tabular}

\begin{tabular}{|l|l|}
\hline \multicolumn{2}{|c|}{ Attic type } \\
\hline$F$ & floored \\
\hline$U$ & unfloored \\
\hline$C$ & cathedral \\
\hline$L$ & flat roof \\
\hline
\end{tabular}

Are attic vents present: $(\mathrm{Y}, \mathrm{N})$ 

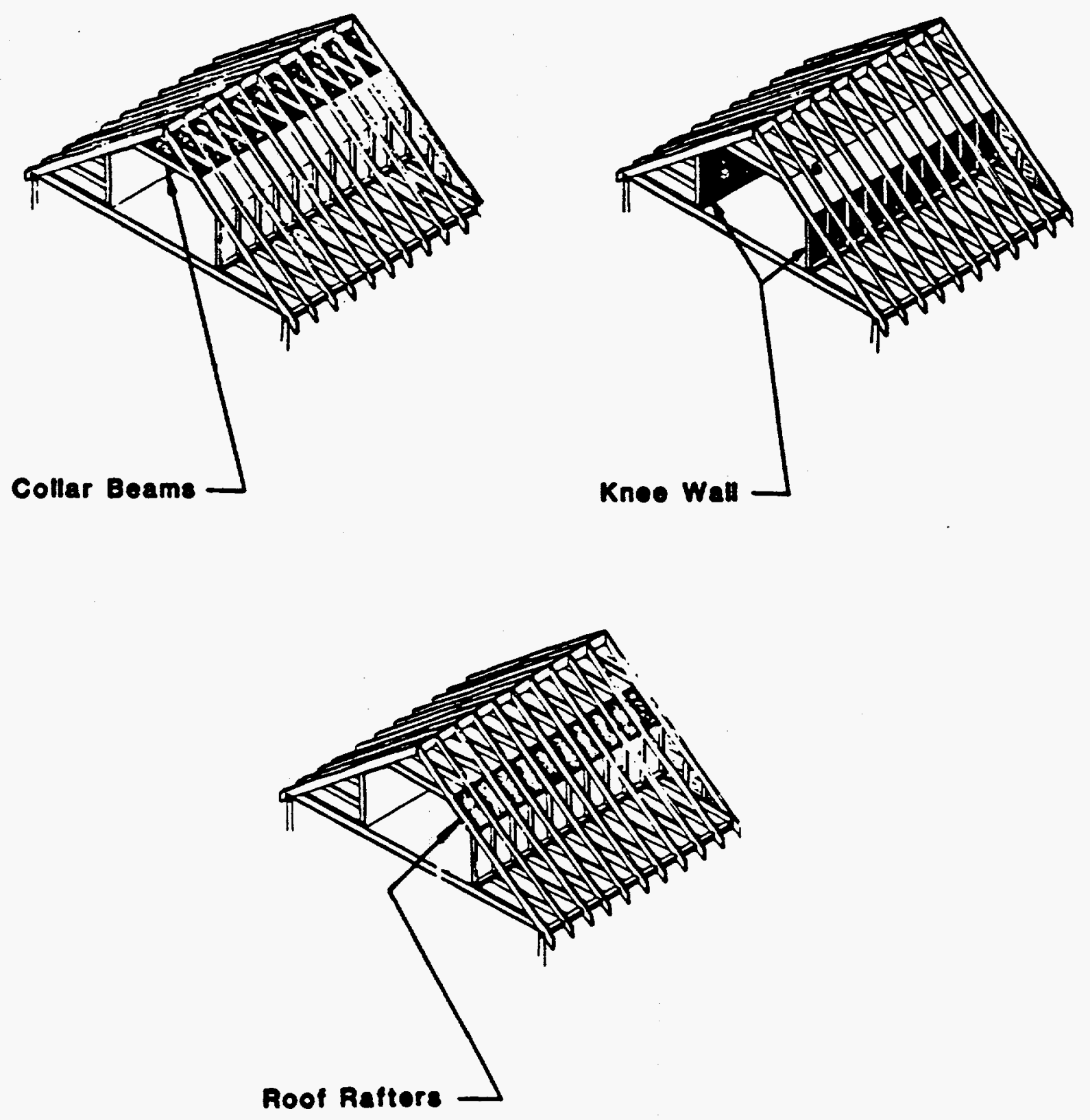
House ID:

\section{EXTERIOR WALLS}

\begin{tabular}{|c|c|c|c|c|c|c|}
\hline \multirow{2}{*}{$\begin{array}{c}\text { Wall } \\
\text { exposure }\end{array}$} & \multirow{2}{*}{$\begin{array}{c}\text { Exterior } \\
\text { type }\end{array}$} & \multirow{2}{*}{$\begin{array}{l}\text { Wall } \\
\text { type }\end{array}$} & \multirow{2}{*}{$\begin{array}{c}\text { Gross wall area } \\
\left(\mathrm{ft}^{2}\right)\end{array}$} & \multirow{2}{*}{$\begin{array}{c}\text { Insulated } \\
\text { sheathing } \\
(\mathrm{Y} / \mathrm{N})\end{array}$} & \multicolumn{2}{|c|}{$\begin{array}{l}\text { Existing } \\
\text { insulation }\end{array}$} \\
\hline & & & & & Type & Depth (inches) \\
\hline & & & & & & \\
\hline & & & & & & \\
\hline & & & & & & \\
\hline & & & & & & \\
\hline & & & & & & \\
\hline & & & & & & \\
\hline & & & & & & \\
\hline
\end{tabular}

Shared walls found in duplexes and row houses are not exterior walls.

The type of load bearing structure is the wall type. The type of facing on the wall is the exterior type.

\begin{tabular}{|c|l|}
\hline \multicolumn{2}{|c|}{ Wall exposure } \\
\hline $\mathrm{O}$ & outside \\
\hline $\mathbf{N}$ & $\begin{array}{l}\text { non-conditioned } \\
\text { attic space }\end{array}$ \\
\hline $\mathrm{B}$ & $\begin{array}{l}\text { buffered space } \\
\text { (garage, etc.) }\end{array}$ \\
\hline
\end{tabular}

\begin{tabular}{|l|l|}
\hline \multicolumn{2}{|c|}{ Exterior type } \\
\hline WO & $\begin{array}{l}\text { wood or } \\
\text { masonite }\end{array}$ \\
\hline AL & $\begin{array}{l}\text { aluminum, steel } \\
\text { or vinyl }\end{array}$ \\
\hline ST & stucco \\
\hline BR & brick or stone \\
\hline AS & asphalt shingle \\
\hline WS & wood shingle \\
\hline RA & rolled asphalt \\
\hline N & other \\
\hline N & none \\
\hline
\end{tabular}

\begin{tabular}{|l|l|}
\hline \multicolumn{2}{|c|}{ Wall type } \\
\hline PF & $\begin{array}{l}\text { platform } \\
\text { frame }\end{array}$ \\
\hline BF & $\begin{array}{l}\text { balloon } \\
\text { frame }\end{array}$ \\
\hline BL & block \\
\hline ST & $\begin{array}{l}\text { stone or } \\
\text { masonry }\end{array}$ \\
\hline $\mathrm{X}$ & other \\
\hline
\end{tabular}

\begin{tabular}{|l|l|}
\hline \multicolumn{2}{|c|}{ Insulation type } \\
\hline BC & $\begin{array}{l}\text { blown } \\
\text { cellulose }\end{array}$ \\
\hline BF & $\begin{array}{l}\text { blown } \\
\text { fiberglass }\end{array}$ \\
\hline FB & $\begin{array}{l}\text { fiberglass } \\
\text { batt }\end{array}$ \\
\hline RB & $\begin{array}{l}\text { rigid board } \\
\text { or foam }\end{array}$ \\
\hline BRW & $\begin{array}{l}\text { blown } \\
\text { rock wool }\end{array}$ \\
\hline RWB & $\begin{array}{l}\text { rock wool } \\
\text { batt }\end{array}$ \\
\hline $\mathrm{X}$ & other \\
\hline $\mathrm{N}$ & none \\
\hline
\end{tabular}


FOUNDATION SPACES

House ID:

\begin{tabular}{|c|c|c|c|c|c|c|c|c|c|}
\hline \multirow[b]{2}{*}{ Type } & \multirow[b]{2}{*}{$\begin{array}{l}\text { Space } \\
\text { status }\end{array}$} & \multirow{2}{*}{$\begin{array}{c}\text { Basement } \\
\text { or crawl } \\
\text { space } \\
\text { ceiling } \\
\text { area } \\
\left(\mathrm{ft}^{2}\right)\end{array}$} & \multirow{2}{*}{$\begin{array}{l}\text { Basement } \\
\text { or crawl } \\
\text { space } \\
\text { ceiling } \\
\text { insulation } \\
\text { thickness } \\
\text { (inches) }\end{array}$} & \multicolumn{2}{|c|}{$\begin{array}{c}\text { Perimeter } \\
\text { (band joist) }\end{array}$} & \multicolumn{2}{|c|}{ Wall height } & \multicolumn{2}{|c|}{$\begin{array}{l}\text { Existing wall } \\
\text { insulation }\end{array}$} \\
\hline & & & & $\begin{array}{c}\text { Length } \\
\text { (ft) }\end{array}$ & $\begin{array}{l}\text { Percent } \\
\text { exposed }\end{array}$ & $\begin{array}{c}\text { Total } \\
\text { (ft) }\end{array}$ & $\begin{array}{c}\text { Percent } \\
\text { above } \\
\text { ground }\end{array}$ & Type & $\begin{array}{c}\text { Thickness } \\
\text { (inches) }\end{array}$ \\
\hline & & & & & & & & & \\
\hline & & & & & & & & & \\
\hline & & & & & & & & & \\
\hline
\end{tabular}

Ceiling area - For slab-on-grade, the area of the intentionally conditioned slab floor.

Perimeter length - Do not include perimeter bordering another foundation space.

Percent exposed - For basements and crawlspaces, the percent of band joist length that is exposed to the outside and not insulated.

Total wall height - Height of basement or crawlspace wall; an estimated average if the height is not uniform.

\begin{tabular}{|l|l|}
\hline \multicolumn{2}{|c|}{ Foundation type } \\
\hline B & basement \\
\hline C & crawlspace \\
\hline US & uninsulated slab \\
\hline IS & insulated slab \\
\hline
\end{tabular}

\begin{tabular}{|l|l|}
\hline \multicolumn{2}{|c|}{ Foundation space status } \\
\hline NH & not heated \\
\hline IH & intentionally heated \\
\hline UH & unintentionally heated \\
\hline
\end{tabular}

\begin{tabular}{|l|l|}
\hline \multicolumn{2}{|c|}{ Existing wall insulation type } \\
\hline $\mathrm{BC}$ & blown cellulose \\
\hline $\mathrm{BF}$ & blown fiberglass \\
\hline FB & fiberglass batt \\
\hline $\mathrm{RB}$ & rigid board or foam \\
\hline BRW & blown rock wool \\
\hline $\mathrm{RWB}$ & rock wool batt \\
\hline $\mathrm{X}$ & other \\
\hline $\mathrm{N}$ & none \\
\hline
\end{tabular}

\section{DOMESTIC WATER-HEATING SYSTEM}

Fuel: (NG-natural gas, P-propane, O-oil, K-kerosene, E-electricity, W-wood, S-solar, X-other, N-None)

Type: (SA-stand alone system, T-tankless [integrated with space-heating system], X-other, N-None) Is an external blanket insulation used? (Y,N,NA)

Location: (NH - non-heated space, IH - intentionally heated space, $\mathrm{UH}$ - unintentionally heated space) 
House ID:

APPLIANCES

\begin{tabular}{|l|c|l|l||}
\hline \multicolumn{1}{|c|}{ Appliance } & Fuel & Quantity & Location \\
\hline Cooking range & & & \\
\hline Stove top & & & \\
\hline Detached oven & & & \\
\hline Microwave oven & E & & \\
\hline Refrigerator & E & & \\
\hline Dishwasher & E & & \\
\hline Deep freezer & E & & \\
\hline Clothes washer & E & & \\
\hline Clothes dryer & & & \\
\hline Whole house fan & E & & \\
\hline Attic ventilation fan & E & & \\
\hline Well pump & E & & \\
\hline Water bed heater & E & & \\
\hline Other: & & & \\
\hline
\end{tabular}

\begin{tabular}{|l|l|}
\hline \multicolumn{2}{|c|}{ Fuel } \\
\hline NG & natural gas \\
\hline P & propane \\
\hline O & oil \\
\hline K & kerosene \\
\hline E & electricity \\
\hline W & wood \\
\hline C & coal \\
\hline X & other \\
\hline
\end{tabular}

\begin{tabular}{|l|l|}
\hline \multicolumn{2}{|c|}{ Location } \\
\hline NH & non-heated space \\
\hline IH & intentionally heated space \\
\hline UH & unintentionally heated space \\
\hline
\end{tabular}

\section{AIR CONDITIONERS}

\begin{tabular}{|c|c|c|c|c|c|c|c|}
\hline \multirow{3}{*}{$\begin{array}{l}\text { Unit } \\
\text { type }\end{array}$} & \multicolumn{6}{|c|}{ Nameplate information } & \multirow{3}{*}{$\begin{array}{c}\text { Age } \\
\text { (years) }\end{array}$} \\
\hline & \multirow{2}{*}{$\begin{array}{l}\text { Input } \\
\text { (watts) }\end{array}$} & \multirow{2}{*}{$\begin{array}{c}\text { Voltage } \\
\text { (volts) }\end{array}$} & \multirow{2}{*}{$\begin{array}{c}\text { Current } \\
\text { (amps) }\end{array}$} & \multicolumn{2}{|c|}{ Efficiency } & \multirow{2}{*}{$\begin{array}{l}\text { Output } \\
\text { (Btu/h) }\end{array}$} & \\
\hline & & & & EER & SEER & & \\
\hline & & & & & & & \\
\hline & & & & & & & \\
\hline & & & & & & & \\
\hline & & & & & & & \\
\hline & & & & & & & \\
\hline & & & & & & & \\
\hline & & & & & & & \\
\hline
\end{tabular}

\begin{tabular}{|l|l|}
\hline \multicolumn{2}{|c|}{ Unit type } \\
\hline CAC & $\begin{array}{l}\text { central air } \\
\text { conditioner }\end{array}$ \\
\hline CHP & $\begin{array}{l}\text { central heat } \\
\text { pump }\end{array}$ \\
\hline WAC & $\begin{array}{l}\text { window air } \\
\text { conditioner }\end{array}$ \\
\hline WHP & $\begin{array}{l}\text { window heat } \\
\text { pump }\end{array}$ \\
\hline $\mathrm{EC}$ & $\begin{array}{l}\text { evaporative } \\
\text { cooler }\end{array}$ \\
\hline $\mathrm{X}$ & other \\
\hline
\end{tabular}


SPACE-HEATING SYSTEMS

House ID:

\begin{tabular}{||l|l||}
\hline \multicolumn{2}{|c||}{ PRIMARY OIL-FIRED SYSTEM } \\
\hline \hline System type (see next page) & \\
\hline System age & \\
\hline Original fuel if converted system (see next page or NA) & \\
\hline Location (see next page) & \\
\hline Actual installed nozzle size (value and units) & \\
\hline Vent damper present (Y,N) & \\
\hline Flame retention head burner present (Y,N) & \\
\hline Smart thermostat present (Y,N) & \\
\hline For boilers, outdoor temperature reset present (Y,N,NA) & \\
\hline
\end{tabular}

\begin{tabular}{||c|c|}
\hline \multicolumn{2}{||c|}{ AUXILIARY } \\
SYSTEMS \\
\hline \hline $\begin{array}{c}\text { Type (see } \\
\text { next page) }\end{array}$ & Fuel \\
\hline \hline & \\
\hline & \\
\hline & \\
\hline & \\
\hline
\end{tabular}

The primary oil-fired system is the system metered under the study.

\section{DISTRIBUTION SYSTEM}

\begin{tabular}{||l|c|c|c|}
\hline \multicolumn{1}{|c|}{ Location } & $\begin{array}{c}\text { Is any part of the } \\
\text { distribution system } \\
\text { present in this location? } \\
(\mathrm{Y}, \mathrm{N}, \mathrm{NA})\end{array}$ & $\begin{array}{c}\text { If present, is the } \\
\text { distribution } \\
\text { system insulated? } \\
(\mathrm{Y}, \mathrm{N})\end{array}$ & $\begin{array}{c}\text { If present, is the structural } \\
\text { integrity sound? }\end{array}$ \\
\hline Intentionally heated area & & & \\
\hline Unintentionally heated area & & & \\
\hline Un-heated area & & & \\
\hline
\end{tabular}

Does the distribution system include a return system? (Y,N,NA) 


\begin{tabular}{|l|l|}
\hline \multicolumn{2}{|c|}{ Fuel } \\
\hline NG & natural gas \\
\hline P & propane \\
\hline O & oil \\
\hline K & kerosene \\
\hline E & electricity \\
\hline W & wood \\
\hline C & coal \\
\hline$X$ & other \\
\hline
\end{tabular}

\begin{tabular}{|l|l|}
\hline \multicolumn{2}{|c|}{ Location } \\
\hline NH & non-heated space \\
\hline IH & intentionally heated space \\
\hline UH & unintentionally heated space \\
\hline
\end{tabular}

\begin{tabular}{|l|l|}
\hline \multicolumn{2}{|c}{ Central systems } \\
\hline 1 & forced air furnace \\
\hline 2 & gravity furnace \\
\hline 3 & steam boiler \\
\hline 4 & hot water boiler with radiators/convertors \\
\hline 5 & hot water boiler for slab heating \\
\hline 6 & heat pump \\
\hline & \\
\hline & \\
\hline 21 & wood or coal stove \\
\hline 22 & fireplace \\
\hline 23 & stove top or oven \\
\hline 24 & other \\
\hline
\end{tabular}

\begin{tabular}{|l|l|}
\hline \multicolumn{2}{|c|}{ In-space heaters } \\
\hline \multicolumn{2}{|l|}{ Fossil fueled: } \\
\hline 7 & room heater \\
\hline 8 & forced air wall furnace \\
\hline 9 & gravity wall furnace \\
\hline 10 & forced air floor furnace \\
\hline 11 & gravity floor furnace \\
\hline 12 & vaporizing pot heater (oil and kerosene) \\
\hline 13 & portable kerosene \\
\hline & \\
\hline Electric: \\
\hline 14 & wall \\
\hline 15 & floor \\
\hline 16 & baseboard \\
\hline 17 & ceiling radiant (imbedded cable) \\
\hline 18 & wall or floor radiant (imbedded cable) \\
\hline 19 & portable (cord-connected) \\
\hline 20 & window heat pump \\
\hline
\end{tabular}




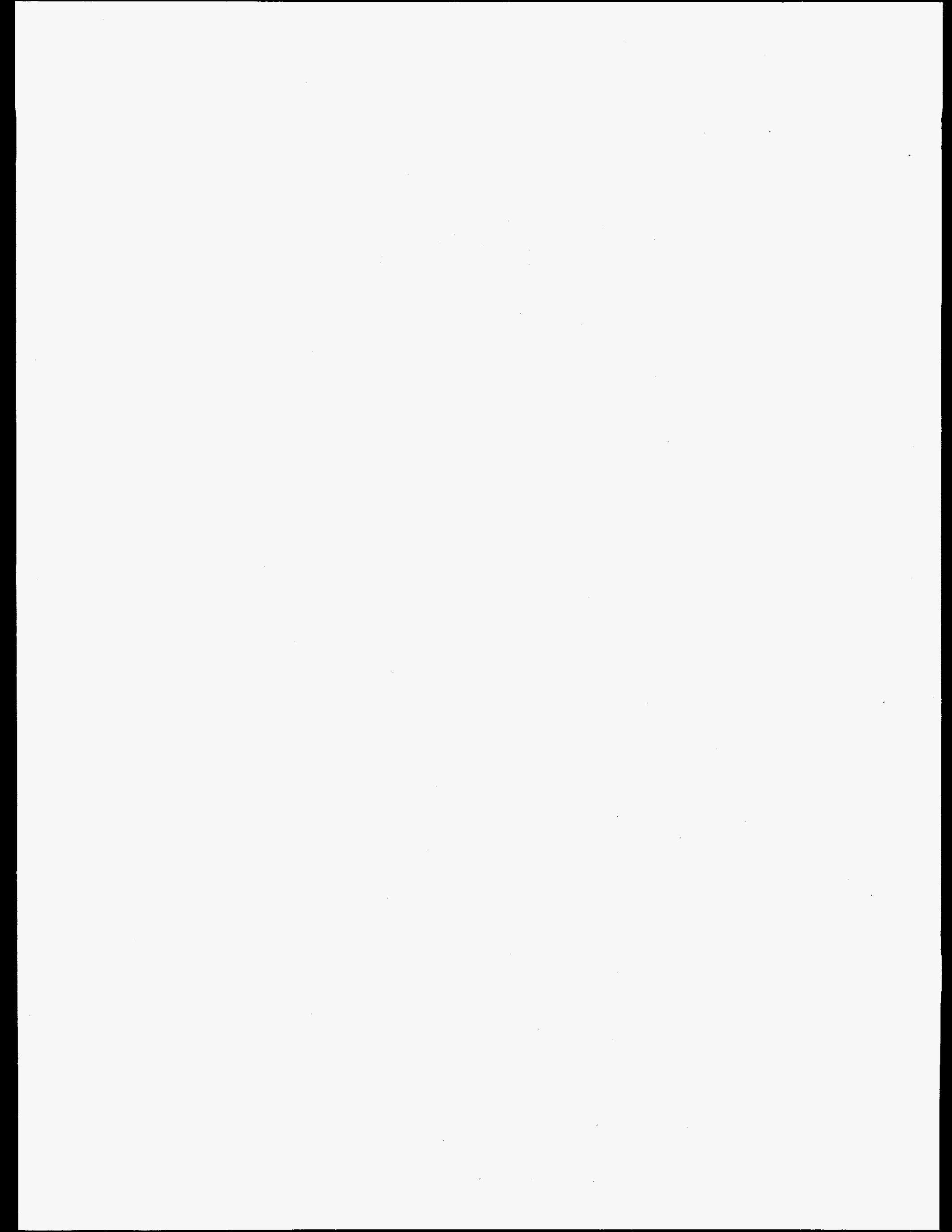


Version: February 6, 1991

Auditor:

Date:

FUEL-OIL STUDY PRE-WEATHERIZATION DATA COLLECTION FORM

\section{IDENTIFICATION}

House I.D.: Subgrantee name:

Occupant name: Phone number:

Occupant Address:

SPACE-HEATING SYSTEM NOZZLE SIZE: (value and units, likely GPH) HOUSE FLOOR AREA

excluding basement: square feet

basement only: square feet

\section{HOUSE VOLUME}

excluding basement: cubic feet

basement only: cubic feet

\section{ROOMS}

How many of each of the following rooms does this house have?

Bedrooms $^{1}$

\section{Number}

Full bathrooms ${ }^{2}$

Half bathrooms ${ }^{3}$

All other rooms ${ }^{4}$

How many rooms are currently being heated?

\footnotetext{
${ }^{1}$ For one-bedroom efficiency or studio apartment, record " 0 bedrooms" and correct number of bathrooms.

${ }^{2}$ Full bathroom is defined as having a sink with running water and flush toilet and bathtub or shower.

${ }^{3} \mathrm{Half}$ bathroom is defined as having a toilet or bathtub or shower.

${ }^{4}$ Do not count laundry rooms, foyers, or unfinished storage space. Only count porches if they are enclosed and used year-round.
} 


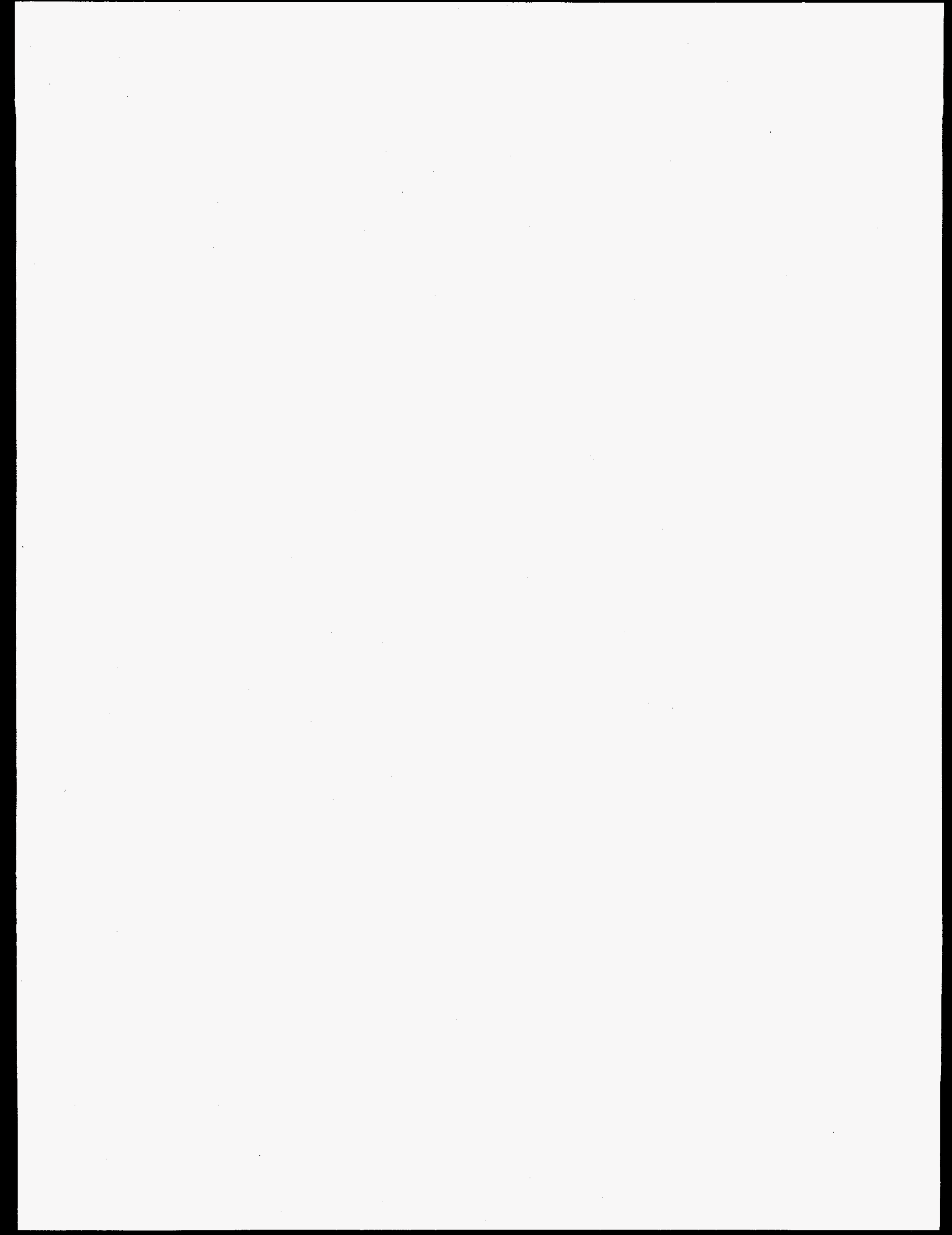




\section{APPENDIX B. OCCUPANT QUESTIONNAIRES}

Information was collected from the occupants of the houses at the end of the postweatherization period using the two questionnaires in this appendix. Separate questionnaires were developed for the weatherized and control houses because of slight wording differences that were required. 


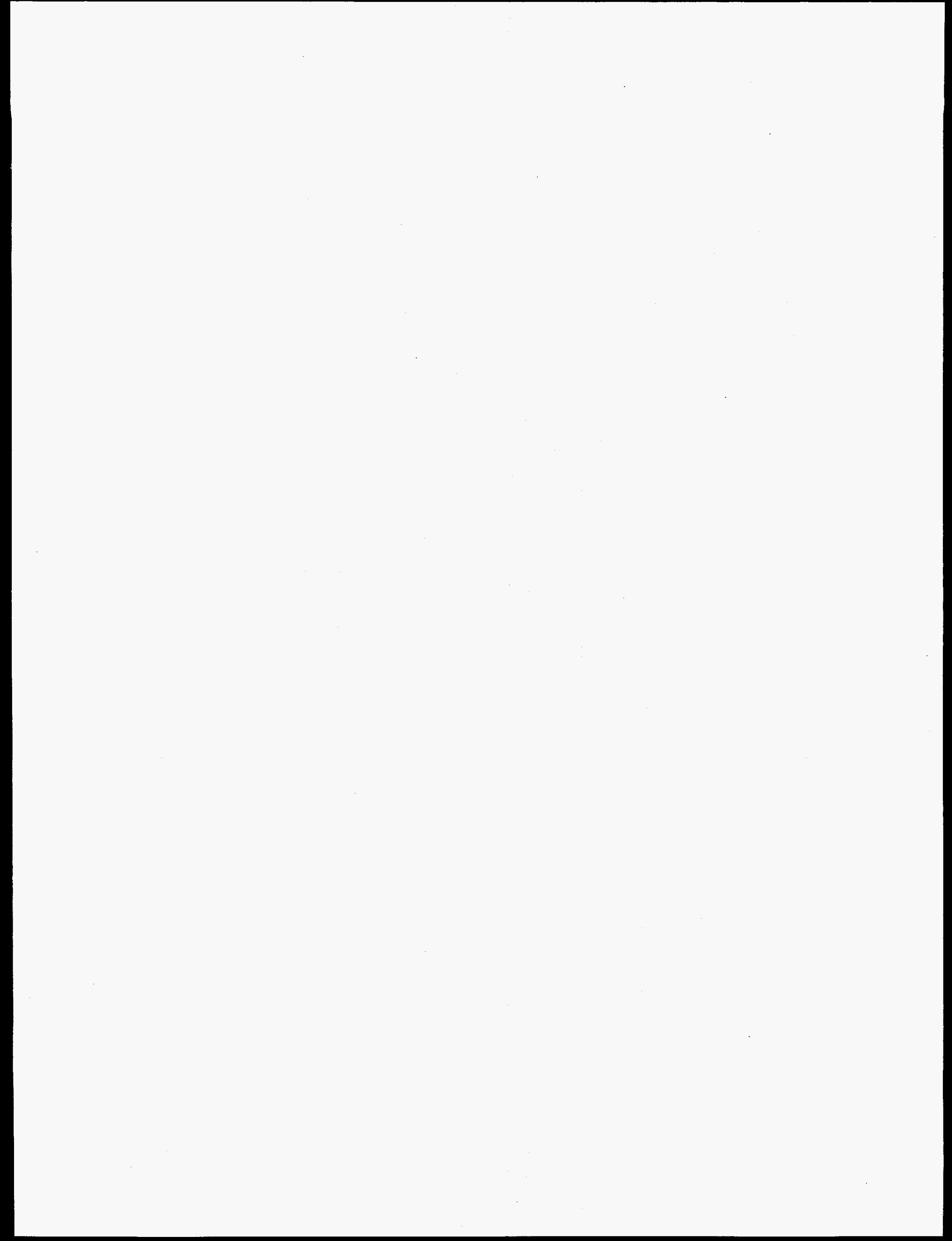


version $18 \mathrm{~W}$

$5 / 10 / 91$
Interviewer

Date of Interview

Time Started

\section{FUEL-OIL STUDY OCCUPANT QUESTIONNAIRE WEATHERIZED HOME}

\section{A. Identification}

\section{INTERVIEWER INSTRUCTIONS:}

Complete Questions A1, A2, and A4 using data from the information sheet before starting the interview.

A1. Household Identifier

A2. Name of WAP Applicant

\section{SCREENER:}

ASK TO SPEAK TO THE APPLICANT NAMED IN QUESTION A2. IF AVAILABLE, READ THE FOLLOWING AND GO TO QUESTION A3.

Your home was weatherized as a participant in the Weatherization Assistance Program. As a follow up to that we would like to conduct an interview to learn more about how that weatherization may have affected your energy use and ask your opinions regarding the value of weatherization.

IF THE APPLICANT NAMED IN QUESTION A2 IS NOT AVAILABLE, READ THE FOLLOWING AND THEN ASK QUESTION 1:

Your home was weatherized as a participant in the Weatherization Assistance Program. As a follow up to that we would like to conduct an interview to learn more about how that weatherization may have affected your energy use and ask your opinions regarding the value of weatherization. 
1. I'd like to speak to a person over eighteen years of age who is knowledgeable about paying the energy bills. Is that person available? (IN ORDER TO QUALIFY, THE RESPONDENT DOES NOT HAVE TO PAY THE CHECK. AS LONG AS THE RESPONDENT IS KNOWLEDGEABLE ABOUT THE ENERGY USE AND/OR BILLS, HE OR SHE QUALIFIES.)

1. YES, THE PERSON YOU ARE SPEAKING TO IS THE RESPONDENT

CONTINUE WITH QUESTION A3.

2. YES, RESPONDENT IS ANOTHER PERSON. .

ONCE A RESPONDENT IS PRESENT, RETURN TO THE INTRODUCTION AND CONFIRM THAT THE RESPONDENT IS OVER 18 AND IS KNOWLEDGEABLE ABOUT PAYING THE ENERGY BILLS. IF THE RESPONDENT QUALIFIES, CONTINUE WITH QUESTION A3.

3. NO, RESPONDENT IS NOT AVAILABLE. ..... (NAMES:

IDENTIFY NAMES OF SEVERAL PEOPLE WHO MIGHT BE SUITABLE RESPONDENTS. INFORM THE CURRENT RESPONDENT THAT WE WILL CONDUCT THE INTERVIEW OVER THE TELEPHONE AT A LATER DATE. LEAVE A COPY OF THE EXHIBITS AT THE HOUSE. DO NOT PROCEED WITH THE INTERVIEW.

\section{INTERVIEWER INSTRUCTIONS:}

IF RESPONDENT NEEDS INFO: The survey is a part of the Weatherization Assistance Program. The survey is required of every participant in the Fuel Oil Study.

IF RESPONDENT IS HESITANT: Your answers to these questions will provide valuable information to the Department of Energy. The interview will take approximately 30 minutes.

A3. Name of respondent

Relation to WAP applicant

[] RESPONDENT IS SAME AS WAP APPLICANT

A4. Dates of WAP weatherization work 
A5. I want to confirm that the weatherization work done by the Weatherization Assistance Program took place on (READ DATES FROM QUESTION A4). (RECORD DATES BELOW IF RESPONDENT GIVES DIFFERENT DATES.)

\section{DATES}

\section{[ ] RESPONDENT CONFIRMS THAT WEATHERIZATION TOOK PLACE ON THE SAME DATES AS QUESTION A4.}

\section{[ ] DON'T REMEMBER}

\section{INTERVIEWER INSTRUCTIONS:}

If respondent has trouble remembering the dates in Questions A6, A7, and A8, probe for:

- Season

- Major life event

- Major news story or political event happening at that time

Then, ask for year (and month) again.

A6. In what year was this home built? Just your estimate.*
[] Before 1900
[] 1900-1909
[ ] 1940-1949
[ ] 1950-1959
[ ] 1910-1919
[] 1960-1969
[ ] 1920-1929
[] 1970-1979
[] 1930-1939
[] 1980-1984
[] 1985
[] 1986
[] 1987
[] 1988
[] 1989
[] 1990

A7. In what year did your family move into this home?*
[] Before 1900
[] 1940-1949
[] 1900-1909
[] 1950-1959
[ ] 1985
[] 1910-1919
[] 1960-1969
[] 1920-1929
[] 1970-1979
[ ] $1930-1939$
[] $1980-1984$
[] 1986
[] 1987
[] 1988
[ ] 1989
[ ] 1990

IF "1989" OR LATER ON QUESTION A7, ASK:

A8. In which month did you move in?*
[] January
[] February
[] May
[] June
[] March
[] July
[] April
[] August
[ ] September
[] October
[] November
[] December 


\section{B. Major Heating Fuel}

Next, I will ask some questions about the fuels you used to heat your home last winter before and after weatherization on (READ DATES FROM QUESTION A4). Throughout the survey, when I ask about last winter before weatherization, I mean October, November, and December of 1990. When I ask about last winter after weatherization, I mean February, March, and April of 1991.

\section{INTERVIEWER INSTRUCTIONS:}

If two or more heating fuels are used, the main heating fuel is the one that provides most of the heat for the home. The main heating fuel may not necessarily be the one used for the central heating system.

\section{(HAND RESPONDENT EXHIBIT BOOKLET)}

B1. Please look at Exhibit B1. What was the one main heating fuel used for heating your home last winter before weatherization?*

B1

Main Fuel

Gas from underground pipes

serving the neighborhood. ........ [ ]

Bottled gas (LPG or Propane)....... [ ]

Fuel oil. . . . . . . . . . . . [ ]

Kerosene or coal oil. .......... [ ]

Electricity. .............. []

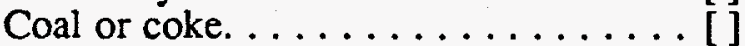

Wood. ................. [ ]

Solar collectors. . . . . . . . . . [ ]

Other (specify)

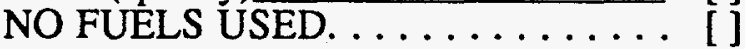

DON'T KNOW.
Fuel
ly one
B2

(Mark all other fuels that apply)

B2. Please look at Exhibit B1 again. You mentioned that your main heating fuel used last winter before weatherization was (FUEL FROM QUESTION B1). What other fuels were used to heat your home last winter before weatherization -including those used to provide heat just occasionally? Don't forget to include fuels that ran portable heaters if you used them. (MARK ALL THAT APPLY IN COLUMN B2. IF NONE, MARK "NO FUELS USED")*

IF ADDITIONAL FUELS ARE IDENTIFIED FROM QUESTION B2, ASK:

B3. Going back to your main heating fuel used last winter before weatherization-(FUEL FROM QUESTION B1) -- did this fuel provide all or almost all of the heat for your home, about three-fourths, or closer to half of the heat for your home?*

[ ] All or almost all (95\% or more)

[] About three-fourths $(67-94 \%)$

[ ] Closer to half (66\% or less)

[ ] DON'T KNOW/REMEMBER 
Now, I will ask similar questions about the fuels you used last winter after weatherization.

B4. Please look at Exhibit B1 again. What was the one main heating fuel used for heating your home last winter after weatherization?*

B4

Main Fuel

Gas from underground pipes

serving the neighborhood.......... [ ]

Bottled gas (LPG or Propane). . . . . . . [ ]

Fuel oil. . . . . . . . . . . . []

Kerosene or coal oil. ........... []

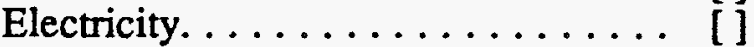

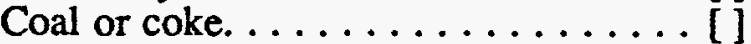

Wood. ................ []

Solar collectors. . . . . . . . . . []

Other (specify)

NO FUELS USED. . . . . . . . [ ]

DON'T KNOW. ............. [ ]
B5

(Mark all other fuels that apply)

B5. Please look at Exhibit B1 again. You mentioned that your main heating fuel used last winter after weatherization, was (FUEL FROM QUESTION B4). What other fuels were used to heat your home last winter after weatherization -including those used to provide heat just occasionally? Don't forget to include fuels that ran portable heaters if you used them. (MARK ALL THAT APPLY IN COLUMN B5. IF NONE, MARK "NO FUELS USED")*

IF ADDITIONAL FUELS ARE IDENTIFIED FROM QUESTION B5, ASK:

B6. Going back to your main heating fuel used last winter after weatherization -(FUEL FROM QUESTION B4) -- did this fuel provide all or almost all of the heat for your home, about three-fourths, or closer to half of the heat for your home?*

[] All or almost all (95\% or more)

[] About three-fourths $(67-94 \%)$

[] Closer to half (66\% or less)

[ ] DON'T KNOW/REMEMBER 
B7a. Please look at Exhibit B7. Last winter before the weatherization work was done, did you use any of the following to help heat your home? (CHECK AS MANY AS WERE USED.)

(B7a)

BEFORE AFTER

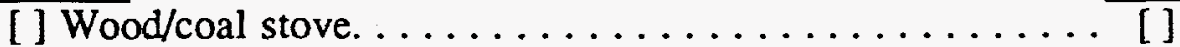

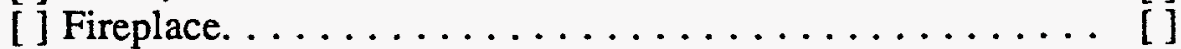

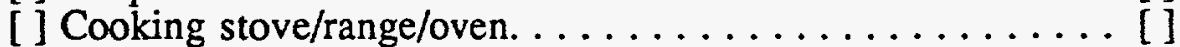

[ ] Non-portable room heater burning gas, oil, or kerosene. .... . []

[ ] Portable kerosene heater. . . . . . . . . . . . . [ ]

[ ] Non-portable electric heater . . . . . . . . . . . . []

[ ] Electric portable heater (cord-connected).......... []

[ ] Other (specify):

[ ] NONE.

B7b. Please look at Exhibit B7 again. Last winter after the weatherization work was done, did you use any of the following to help heat your home? (CHECK AS MANY AS WERE USED IN COLUMN B7b.)

\section{INTERVIEWER INSTRUCTIONS:}

Confirm that responses to $\mathrm{B} 7 \mathrm{a}$ do not contradict responses to $\mathrm{B} 1$ and $\mathrm{B} 2$. Confirm that responses to $\mathrm{B} 7 \mathrm{~b}$ do not contradict responses to $\mathrm{B} 4$ and $\mathrm{B} 5$. Probe the respondent if the responses contradict.

\section{ASK QUESTION B8 ONLY FOR EACH ITEM IN QUESTION B7 USED BOTH BEFORE AND AFTER WEATHERIZATION:}

\begin{tabular}{|c|c|c|c|}
\hline \multicolumn{4}{|c|}{$\begin{array}{l}\text { Please turn to Exhibit B8. Please tell me how often you used the following to } \\
\text { help heat your home last winter after the weatherization work was done, as } \\
\text { compared to last winter before the weatherization work was done. Did you use } \\
\text { it less, about the same, or more after weatherization as compared to before } \\
\text { weatherization? (CIRCLE ONE NUMBER IN EACH LINE ASKED.) }\end{array}$} \\
\hline & $\begin{array}{c}\text { Used Less } \\
\text { After }\end{array}$ & $\begin{array}{l}\text { Used About } \\
\text { The Same }\end{array}$ & $\begin{array}{c}\text { Used More } \\
\text { After }\end{array}$ \\
\hline 1. Wood/coal stove & 1 & 2 & 3 \\
\hline 2. Fireplace & 1 & 2 & 3 \\
\hline 3. Cooking stove/range/oven & 1 & 2 & 3 \\
\hline $\begin{array}{l}\text { 4. Non-portable room heater } \\
\text { burning gas, oil, or kerosene }\end{array}$ & 1 & 2 & 3 \\
\hline 5. Portable kerosene heater & 1 & 2 & 3 \\
\hline 6. Non-portable electric heater & 1 & 2 & 3 \\
\hline $\begin{array}{l}\text { 7. Electric portable heater } \\
\text { (cord-connected) }\end{array}$ & 1 & 2 & 3 \\
\hline 8. Other ( & 1 & 2 & 3 \\
\hline
\end{tabular}




\section{Demographics}

Now I have some questions about the people who live here and about your housing costs.

C1. Please tell me how many people living in your home last winter before weatherization were ... (READ EACH ITEM).

Under the age of 5

Between 5 and 17 years old

Between 18 and 64 years old

65 years old or older

TALLY -- so that is (READ NUMBER) in total?

\section{ENTER CORRECT TOTAL HERE}

C2. You have told me that there were (READ TOTAL NUMBER FROM QUESTION C1) people living in your home last winter before weatherization. How many people were living in your home last winter after weatherization?

\section{NUMBER OF RESIDENTS \\ [ ] SAME NUMBER AFTER WEATHERIZATION AS BEFORE WEATHERIZATION}

C3. Were any of the people living in your home last winter before weatherization handicapped? By handicapped, I mean a permanent condition. I do not mean a temporary condition, such as a short-term illness. (EYEGLASSES ARE NOT CONSIDERED A HANDICAP). (IF YES, ASK HOW MANY.)

NUMBER HANDICAPPED 
C4. Do you or members of your household own your home, or rent?*

[] Own (buying)

[] Rent

[] Occupied without payment of rent (SKIP TO SECTION D)

FROM QUESTION C4, IF HOUSEHOLD OWNS OR PAYS RENT, ASK:

C5. Please tell me which category best describes the monthly rent or mortgage payment the household pays for your home. Is it ...? Stop me when I reach the category. (READ CATEGORIES.)

[ ] less than $\$ 200$ per month

[] \$201-300 per month

[] $\$ 301-400$ per month

[] $\$ 401-500$ per month

[] $\$ 501-600$ per month

[] $\$ 601-700$ per month

[ ] $\$ 701$ - 800 per month

[ ] $\$ 801$ - 900 per month

[] more than $\$ 900$ per month

[] OWNED, MORTGAGE PAID OFF (SKIP TO SECTION D)

[] DON'T KNOW

C6. Does this payment include: (READ ITEMS AND PROBE FOR "YES" OR "NO".)

Yes

1. fuel oil. ............... [

2. electricity..........

3. natural gas. . . . . . .

4. property tax............ []

5. insurance (house or renter's)..... []

6. water............... []

7. garbage.............. [ ]

8. other (specify):

No DON'T

KNOW

$\begin{array}{ll}{[]} & {[]} \\ {[]} & {[]} \\ {[]} & {[]} \\ {[]} & {[]} \\ {[]} & {[]} \\ {[]} & {[]} \\ {[]} & {[]} \\ {[]} & {[]}\end{array}$




\section{Conditioned Living Space}

My next question is about the number of different types of rooms in your home. Remember that when I ask abour last winter before weatherization, I mean October, November, and December of 1990. When I ask about last winter after weatherization, I mean February, March, and April of 1991. Weatherization work was done to your home on (READ DATES FROM QUESTION A4).

\section{INTERVIEWER INSTRUCTIONS:}

For one-bedroom efficiency or studio apartment, record " 0 bedrooms" and number of bathrooms and other rooms.

Full Bathroom -- sink with running water and flush toilet and bathtub or shower.

Half Bathroom -- toilet or bathtub or shower

D1. How many of each of the following rooms does this home have? (ASK EACH ITEM AND RECORD NUMBER FOR EACH.)*

$\underline{\mathrm{D} 1}$

Total

Number
D2A

Number heated last winter before weatherization
D2B

Number heated

last winter after weatherization

Bedrooms?. . . . . . . . .

Full bathrooms?. . . . . . . .

Half bathrooms?. . . . . . . .

All other rooms:. . . . . . . . .

(Do not count laundry rooms, foyers or unfinished storage space.

Only count porches if they are enclosed and used year-round.)

D2. (FOR EACH TYPE OF ROOM THE RESPONDENT HAS IN THE HOME, ASK D2A, THEN D2B. A HEATED ROOM IS ONE THAT IS WARM ENOUGH TO BE USED.)

D2a. Of the (READ NUMBER OF ROOMS AND TYPE OF ROOM), how many were heated last winter before weatherization (RECORD ABOVE ON COLUMN D2A.)

D2b. And how many (READ TYPE OF ROOM) were heated last winter after weatherization? (RECORD ABOVE ON COLUMN D2B.) 


\section{E. Thermostat Management}

I would now like to ask you some questions about the temperature at which you kept your home.

\section{INTERVIEWER INSTRUCTIONS:}

Remember, we are interested in the respondent's perceptions. Ask the respondent for their opinion; avoid checking the thermostat for the actual settings.

If respondent keeps different sections of the home at different temperatures, we want to know the temperature in the part of the house where the people are. If, for example, the heat is turned off upstairs during the day because the family is downstairs, we want the downstairs temperature.

We would like to know the actual temperature of the home. If the respondent doesn't know the temperature, but does know the thermostat setting, record the thermostat setting. Otherwise, probe for best estimate.

E1a. Last winter before weatherization, did you keep your home at the same temperature at all times of the day, or did you change the temperature?

[ ] Kept home at same temperature (ASK QUESTION E1B)

[] Changed the temperature (GO TO QUESTION E1C)

IF KEPT HOME AT SAME TEMPERATURE ON QUESTION E1A, ASK:

E1b. Before weatherization, at what temperature did you usually keep your home?

Degrees Fahrenheit:

[] HEAT TURNED OFF

(GO TO QUESTION E2A)

IF CHANGED THE TEMPERATURE ON QUESTION E1A, ASK:

E1c. Before weatherization, at what temperature did you usually keep your home during the day when someone was at home?*

Degrees Fahrenheit:

[] HEAT TURNED OFF

E1d. Before weatherization, at what temperature did you usually keep your home during the day when no one was at home?*

Degrees Fahrenheit:

[] HEAT TURNED OFF

E1e. Before weatherization, at what temperature did you usually keep your home during sleeping hours?*

Degrees Fahrenheit:

[ ] HEAT TURNED OFF 


\section{(ASK EVERYONE:)}

E2a. Last winter after weatherization, did you keep your home at the same temperature at all times of the day, or did you change the temperature?

$\begin{array}{ll}\text { [ ] Kept home at same temperature (ASK QUESTION E2B) } \\ \text { [] Changed the temperature } & \text { (GO TO QUESTION E2C) }\end{array}$

IF KEPT HOME AT SAME TEMPERATURE ON QUESTION E2A, ASK:

E2b. After weatherization, at what temperature did you usually keep your home?

Degrees Fahrenheit:

[] HEAT TURNED OFF

(GO TO SECTION F)

IF CHANGED THE TEMPERATURE ON QUESTION E2A, ASK:

E2c. After weatherization, at what temperature did you usually keep your home during the day when someone was at home?*

Degrees Fahrenheit:

[] HEAT TURNED OFF

E2d. After weatherization, at what temperature did you usually keep your home during the day when no one was at home?*

Degrees Fahrenheit:

[] HEAT TURNED OFF

E2e. After weatherization, at what temperature did you usually keep your home during sleeping hours?*

Degrees Fahrenheit:

[ ] HEAT TURNED OFF 


\section{F. Events Affecting Energy Use}

The next questions are about events which may have affected your energy use last winter. (REMIND RESPONDENT IF NECESSARY): Remember that when I ask about last winter before weatherization, I mean October, November, and December of 1990. When I ask about last winter after weatherization, I mean February, March, and April of 1991. Weatherization work was done to your home on (READ DATES FROM QUESTION A4).

F1a. Last winter before your home was weatherized, was there ever a time when you wanted to use your fuel-oil heating system, but could not, for one or more of the following reasons?

\begin{tabular}{|c|}
\hline Your heating system was broken? ....... [ ] \\
\hline You ran out of fuel oil?............ [ ] \\
\hline $\begin{array}{l}\text { The utility company discontinued. ....... [ ] } \\
\text { our electric service? }\end{array}$ \\
\hline
\end{tabular}

IF "YES" TO ANY PART OF QUESTION F1A, ASK:

FIb. Thinking about these times that you went without heat, last winter before weatherization, how many separate times were there?

Total times:

F1c. Altogether, how many hours or days were you without heat?

Total hours without heat:

OR

Total days without heat: 
F2a. Last winter after your home was weatherized was there ever a time when you wanted to use your fuel-oil heating system, but could not, for one or more of the following reasons?
Your heating system was broken? ...... [ ]
Nos
You ran out of fuel oil?.......... []
[]
The utility company discontinued. ...... [ ]
[] your electric service?

IF "YES" TO ANY PART OF QUESTION F2A, ASK:

F2b. Thinking about these times that you went without heat, last winter after weatherization, how many separate times were there?

Total times:

F2c. Altogether, how many hours or days were you without heat?

Total hours without heat:

$$
\text { OR }
$$

Total days without heat: 
F3. Except for the weatherization of your home on (READ DATES FROM QUESTION A4), was any home repair or major house renovation that would affect energy use done on your home by yourself or other organization between November 1990 and April 1991 ?
[] Yes
[] No
[] DON'T KNOW
(GO TO QUESTION F6)
(GO TO QUESTION F6)

IF YES ON QUESTION F3, ASK:

F4. Please describe the home repair or renovation. (RECORD VERBATIM BELOW.)

MONTH

(1)

(2)

(3)

(4)

F5. In which month was the work done? (RECORD UNDER COLUMN FOR MONTH ABOVE.) 
Now I'm going to ask you to describe the number of people in your home during the 1990 Thanksgiving holiday period and the Christmas holiday period compared to the rest of the winter. By number of people in your home I am referring to overnight visiting not visiting for meals or parties.

F6. Please look at Exhibit F6. First, how did the number of people in your home during the 1990 Thanksgiving holiday and weekend compare to other parts of the winter? (PROBE IF NEEDED: By number of people in your home I am referring to overnight visiting not visiting for meals or parties.)

[ ] Fewer people than other parts of the winter

[ ] About the same number of people as other parts of the winter

[ ] More people than other parts of the winter

[ ] DON'T KNOW/DON'T REMEMBER

F7. Please look at Exhibit F6 again. And how did the number of people in your home during the 1990 Christmas holiday through New Year's compare to the other parts of the winter? (PROBE IF NEEDED: By number of people in your home I am referring to overnight visiting not visiting for meals or parties.)

[] Fewer people than other parts of the winter

[] About the same number of people as other parts of the winter

[ ] More people than other parts of the winter

[] DON'T KNOW/DON'T REMEMBER 


\section{G. Impacts on Health, Safety, Comfort, Affordability}

My next questions ask for your opinion about how weatherization affected the health, safety, comfort, and value of your home.

G1a. Please look at Scale G1. Using a scale of 1 to 7 , where 1 is too cold, 4 is comfortable, and 7 is too hot, how would you rate the temperature in your home last winter before weatherization?

BEFORE

1

too cold
2

2

(1)
3

$\stackrel{4}{\text { comfortable }}$
5

6

IF 1-3 OR 5-7 ON QUESTION G1A, ASK:

G1b. Why couldn't you keep your home the temperature you preferred last winter before weatherization? (DO NOT READ ANSWER CATEGORIES.) (CHECK ALL THAT APPLY.)*

[] Heating system problem

[ ] Landlord controls the temperature

[] Difference of opinion in household

[] Fuel shortage

[] High cost of fuel

[ ] Construction problem, such as broken windows, or holes in walls

[ ] Other (please specify)

\section{[] NOT SURE}

G1c. Using the same scale (REPEAT SCALE IF NECESSARY) how would you rate the temperature in your home last winter after weatherization?
AFTER
1
too cold
2
3
$\stackrel{4}{\text { comfortable }} \quad 5$
6
7
too hot
8
DON'T
REMEMBER

IF 1-3 OR 5-7 ON QUESTION GIC, ASK:

Gld. Why couldn't you keep your home the temperature you preferred last winter after weatherization? (DO NOT READ ANSWER CATEGORIES.) (CHECK ALL THAT

APPLY.)*

[ ] Heating system problem

[ ] Landlord controls the temperature

[ ] Difference of opinion in household

[] Fuel shortage

[] High cost of fuel

[] Construction problem such as broken windows, or holes in walls

[ ] Other (please specify)

\section{[] NOT SURE}


G2. Please look at Scale G2. Using a scale of 1 to 7 , where 1 is very drafty, 4 is somewhat drafty, and 7 is not at all drafty, how would you rate the draftiness of your home last winter before weatherization?

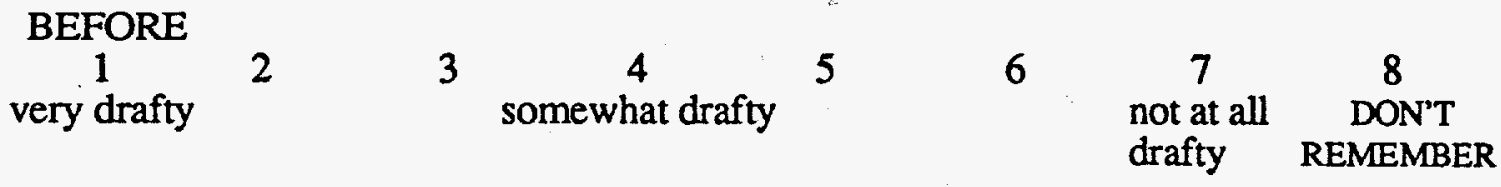

Using the same scale (REPEAT SCALE IF NECESSARY), how would you rate the draftiness in your home last winter after weatherization?

\begin{tabular}{|c|c|c|c|c|c|c|c|}
\hline $\begin{array}{c}\text { AFTER } \\
1 \\
\text { very drafty }\end{array}$ & 2 & 3 & $\stackrel{4}{\quad}$ & 5 & 6 & $\begin{array}{l}\quad 7 \\
\text { not at all } \\
\text { drafty }\end{array}$ & $\begin{array}{c}8 \\
\text { DON'T } \\
\text { REMEMBER }\end{array}$ \\
\hline
\end{tabular}

G3. Please look at Scale G3. Using a scale of 1 to 7 , where 1 is very poor, 4 is acceptable, and 7 is very healthy, how would you rate the health of household members last winter before weatherization? By health I mean illnesses such as colds, flus, allergies, frequent headaches, frequent nausea, or arthritis.

\begin{tabular}{|c|c|c|c|c|c|c|c|}
\hline $\begin{array}{l}\text { BEFORE } \\
1 \\
\text { very poor }\end{array}$ & 2 & 3 & $\begin{array}{c}4 \\
\text { acceptable }\end{array}$ & 5 & 6 & $\begin{array}{c}7 \\
\text { very healthy }\end{array}$ & $\begin{array}{c}8 \\
\text { DON'T }\end{array}$ \\
\hline
\end{tabular}

Using the same scale (REPEAT SCALE IS NECESSARY), how would you rate the health of household members last winter after weatherization?

AFTER

$\begin{array}{ccccccc}1 & 2 & 3 & 4 & 5 & 6 & \begin{array}{c}7 \\ \text { very poor }\end{array}\end{array}$

G4. Please look at Scale G4. Using a scale of 1 to 7 , where 1 is very unsafe, 4 is acceptable, and 7 is very safe, how would you rate the safety of your home last winter before weatherization? By safety, I mean absence of hazards. Some examples of hazards in the home are faulty electrical, heating, or plumbing systems; combustible materials or other fire hazards; unstable porches or broken doors; or the absence of safety precautions such as bolt locks or smoke detectors.

$\begin{array}{ccccccc}\begin{array}{c}\text { BEFORE } \\ 1\end{array} & 2 & 3 & \begin{array}{c}4 \\ \text { acceptable }\end{array} & 5 & 6 & \begin{array}{c}7 \\ \text { very unsafe }\end{array}\end{array}$

Using the same scale (REPEAT SCALE IF NECESSARY), how would you rate the safety of your home last winter after weatherization?

$\begin{array}{cccccccc}\begin{array}{c}\text { AFTER } \\ 1\end{array} & 2 & 3 & 4 & 5 & 6 & 7 & \begin{array}{c}8 \\ \text { very unsafe }\end{array} \\ \text { acceptable } & & & & \text { very safe } & \begin{array}{c}\text { DON'T } \\ \text { REMEMBER }\end{array}\end{array}$


G5. Please look at Scale G5. Using a scale of 1 to 7 , where 1 is very expensive, 4 is acceptable, and 7 is very inexpensive, how would you rate the cost of your heating bills last winter before weatherization?

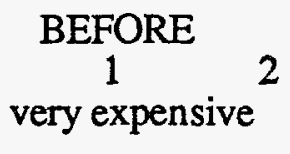
3
$\stackrel{4}{\text { acceptable }}$

5

6

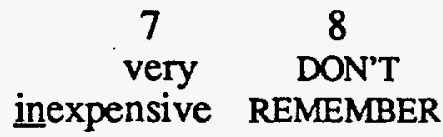

Using the same scale (REPEAT SCALE IF NECESSARY), how would you rate the cost of your heating bills last winter after weatherization?

AFTER

1

very expensive
3

$\stackrel{4}{\text { acceptable }}$
5

5
6

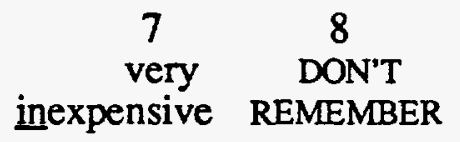

G6. Please look at Scale G6. Using a scale of 1 to 7 , where 1 is very much lower, 4 is about the same, and 7 is very much higher, how would you rate the property value of your home after weatherization as compared to before weatherization? By property value, I mean the dollar value of the home if sold.

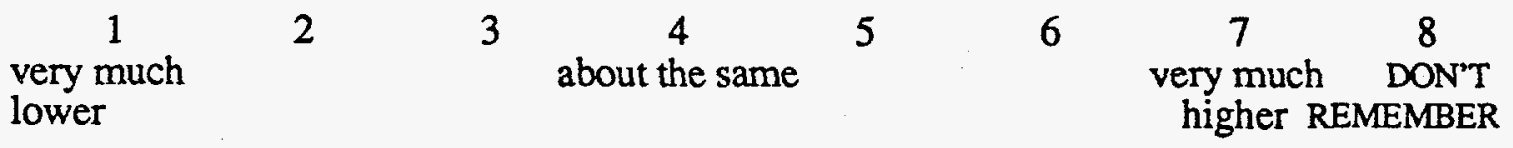

END

On behalf on the U.S. Department of Energy, I would like to thank you for your time and patience today. The information that you have shared with us will be helpful in our study.

*These items are modified versions of questions taken from the 1990 Residential Energy Consumption Survey (RECS) conducted by the Energy Information Administration.

\section{INTERVIEWER INSTRUCTIONS:}

Check to make sure each question has been answered and that verbatim responses are clear and legible.

TIME ENDED: 
version $18 \mathrm{C}$

$5 / 10 / 91$
Interviewer

Date of Interview

Time Started

\section{FUEL-OIL STUDY OCCUPANT QUESTIONNAIRE CONTROL HOME}

\section{A. Identification}

\section{INTERVIEWER INSTRUCTIONS:}

Complete Questions $\mathrm{A} 1$ and $\mathrm{A} 2$ using data from the information sheet before starting the interview.

A1. Household Identifier

A2. Name of WAP Applicant

\section{SCREENER:}

ASK TO SPEAK TO THE APPLICANT NAMED IN QUESTION A2. IF AVALABLE, READ THE FOLLOWING AND GO TO QUESTION A3.

Your home will be weatherized soon as a participant in the Weatherization Assistance Program. We would like to conduct an interview to learn more about your energy use.

IF THE APPLICANT NAMED IN QUESTION A2 IS NOT AVALABLE, READ THE FOLLOWING AND THEN ASK QUESTION 1:

Your home will be weatherized soon as a participant in the Weatherization Assistance Program. We would like to conduct an interview to learn more about your energy use. 
1. I'd like to speak to a person over eighteen years of age who is knowledgeable about paying the energy bills. Is that person available? (IN ORDER TO QUALIFY, THE RESPONDENT DOES NOT HAVE TO PAY THE CHECK. AS LONG AS THE RESPONDENT IS KNOWLEDGEABLE ABOUT THE ENERGY USE AND/OR BILLS, HE OR SHE QUALIFIES.)

1. YES, THE PERSON YOU ARE SPEAKING TO IS THE RESPONDENT.

CONTINUE WITH QUESTION A3.

2. YES, RESPONDENT IS ANOTHER PERSON... ONCE A RESPONDENT IS PRESENT, RETURN TO THE INTRODUCTION AND CONFIRM THAT THE RESPONDENT IS OVER 18 AND IS KNOWLEDGEABLE ABOUT PAYING THE ENERGY BILLS. IF THE RESPONDENT QUALIFIES, CONTINUE WTTH QUESTION A3.

3. NO, RESPONDENT IS NOT AVAILABLE. . . . . NAMES:

IDENTIFY NAMES OF SEVERAL PEOPLE WHO MIGHT BE SUITABLE RESPONDENTS. INFORM THE CURRENT RESPONDENT THAT WE WILL CONDUCT THE INTERVIEW OVER THE TELEPHONE AT A LATER DATE. LEAVE A COPY OF THE EXHIBITS AT THE HOUSE. DO NOT PROCEED WITH THE INTERVIEW.

\section{INTERVIEWER INSTRUCTIONS:}

IF RESPONDENT NEEDS INFO: The survey is a part of the Weatherization Assistance Program. The survey is required of every participant in the Fuel Oil Study.

IF RESPONDENT IS HESITANT: Your answers to these questions will provide valuable information to the Department of Energy. The interview will take approximately 30 minutes.

A3. Name of respondent

Relation to WAP contact

[ ] RESPONDENT IS SAME AS WAP CONTACT 
A3a. Has any weatherization work been done to your home by the Weatherization Assistance program before April 1991?

[ ] No (GO TO QUESTION A4)

[] Yes (PROBE AND INSPECT HOME, IFWEATHERIZED BY WAP, SWITCH TO WEATHERIZED HOME QUESTIONNAIRE.) 


\section{INTERVIEWER INSTRUCTIONS:}

If respondent has trouble remembering the dates in Questions $A 4, A 5$, and A6, probe for:

- Season

- Major life event

- Major news story or political event happening at that time

Then, ask for year (and month) again.

A4. In what year was this home built? Just your estimate.*
[] Before 1900
[ ] 1940-1949
[] 1900-1909
[ ] 1950-1959
[] 1910-1919
[] 1960-1969
[] $1920-1929$
[] $1970-1979$
[] 1930-1939
[] 1980-1984
[] 1985
[] 1986
[] 1987
[] 1988
[] 1989
[] 1990

A5. In what year did your family move into this home?*
[] Before 1900
[] 1900-1909
[] 1910-1919
[] 1920-1929
[] 1930-1939

[ ] $1940-1949$
[ ] $1950-1959$
[ ] $1960-1969$
[ ] 1970-1979
[ ] 1980-1984

[] 1985
[] 1986
[] 1987
[] 1988
[] 1989
[] 1990

IF "1989" OR LATER ON QUESTION A5, ASK:

A6. In which month did you move in?*
[] January
[] February
[] May
[] March
[] June
[] July
[] April
[] August
[] September
[] October
[] November
[] December 


\section{B. Major Heating Fuel}

Next, I will ask some questions about the fuels you used to heat your home last winter before January 1991 and after January 1991. Throughout the survey, when I ask about last winter before January 1991, I mean October, November, and December of 1990. When I ask about last winter after January 1991, I mean February, March, and April of 1991. We are asking about these time frames because other houses being studied were weatherized in January 1991.

\section{INTERVIEWER INSTRUCTIONS:}

If two or more heating fuels are used, the main heating fuel is the one that provides most of the heat for the home. The main heating fuel may not necessarily be the one used for the central heating system.

\section{(HAND RESPONDENT EXIHIBIT BOOKLET)}

B1. Please look at Exhibit B1. What was the one main heating fuel used for heating your home last winter before January 1991?*

B1

Main Fuel

Gas from underground pipes

serving the neighborhood......... []

Bottled gas (LPG or Propane)........ [ ]

Fuel oil................ [ ]

Kerosene or coal oil. ........... []

Electricity............... []

Coal or coke. .............. []

Wood................. []

Solar collectors. . . . . . . . . []

Other (specify)

NO FUELS. USED. . . . . . .

DON'T KNOW. . . . . . . . . . []
B2

(Mark all other fuels that apply)

B2. Please look at Exhibit B1 again. You mentioned that your main heating fuel used last winter before January 1991 was (FUEL FROM QUESTION B1). What other fuels were used to heat your home last winter before January 1991 -including those used to provide heat just occasionally? Don't forget to include fuels that ran portable heaters if you used them. (MARK ALL THAT APPLY IN COLUMN B2. IF NONE, MARK "NO FUELS USED")*

IF ADDITIONAL FUELS ARE IDENTIFIED FROM QUESTION B2, ASK:

B3. Going back to your main heating fuel used last winter before January 1991 -(FUEL FROM QUESTION B1) -- did this fuel provide all or almost all of the heat for your home, about three-fourths, or closer to half of the heat for your home?*

[] All or almost all (95\% or more)

[] About three-fourths (67-94\%)

[ ] Closer to half (66\% or less)

[] DON'T KNOW/REMEMBER 
Now, I will ask similar questions about the fuels you used last winter after January 1991.

B4. Please look at Exhibit B1 again. What was the one main heating fuel used for heating your home last winter after January 1991?*

B4

Main Fuel

Gas from underground pipes

\section{Mark only one)}

serving the neighborhood......... []

Bottled gas (LPG or Propane). . . . . . . [ ]

Fuel oil. . . . . . . . . . . . []

Kerosene or coal oil. . . . . . . []

Electricity.............. []

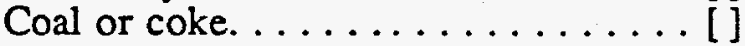

Wood. ................. []

Solar collectors. . . . . . . . . []

Other (specify)

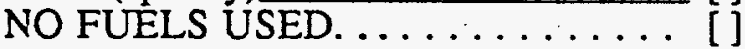

DON'T KNOW. ........... []
B5

(Mark all other fuels that apply)

[]
[]
[]
[]
[]
[]
[]
[]
[]
[]
[]

B5. Please look at Exhibit BI again. You mentioned that your main heating fuel used last winter after January 1991, was (FUEL FROM QUESTION B4). What other fuels were used to heat your home last winter after January 1991 .- including those used to provide heat just occasionally? Don't forget to include fuels that ran portable heaters if you used them. (MARK ALL THAT APPLY IN COLUMN B5. IF NONE, MARK "NO FUELS USED")*

IF ADDITIONAL FUELS ARE IDENTIFIED FROM QUESTION B5, ASK:

B6. Going back to your main heating fuel used last winter after January 1991 -(FUEL FROM QUESTION B4) -- did this fuel provide all or almost all of the heat for your home, about three-fourths, or closer to half of the heat for your home?*

[] All or almost all ( $95 \%$ or more)

[] About three-fourths $(67-94 \%)$

[ ] Closer to half (66\% or less)

[] DON'T KNOW/REMEMBER 
B7a. Please look at Exhibit B7. Last winter before January 1991, did you use any of the following to help heat your home? (CHECK AS MANY AS WERE USED.)

(B7a)

BEFORE

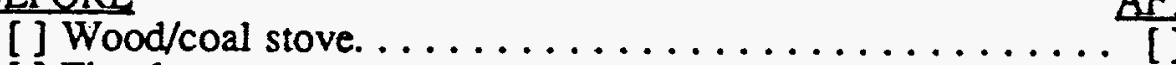

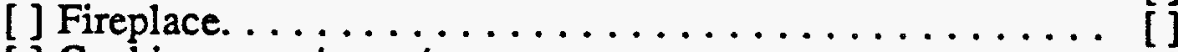

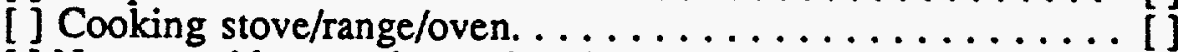

[ ] Non-portable room heater burning gas, oil, or kerosene. . . . [ ]

[ ] Portable kerosene heater. . . . . . . . . . . . . []

[ ] Non-portable electric heater . . . . . . . . . . . . [ ]

[ ] Electric portable heater (cord-connected).......... []

[] Other (specify):

[] NONE. $\ldots[]$

B7b. Please look at Exhibit B7 again. Last winter after January 1991, did you use any of the following to help heat your home? (CHECK AS MANY AS WERE USED IN COLUMN B7b.)

\section{INTERVIEWER INSTRUCTIONS: \\ Confirm that responses to $\mathrm{B} 7 \mathrm{a}$ do not contradict responses to $\mathrm{B} 1$ and $\mathrm{B} 2$. Confirm that responses to B7b do not contradict responses to B4 and B5. Probe the respondent if the responses contradict.}

\section{ASK QUESTION B8 ONLY FOR EACH TTEM IN QUESTION B7 USED BOTH} BEFORE AND AFTER JANUARY 1991:

B8. Please turn to Exhibit B8. Please tell me how often you used the following to help heat your home last winter after January 1991 as compared to last winter before January 1991. Did you use it less, about the same, or more after January 1991 as compared to before January 1991? (CIRCLE ONE NUMBER IN EACH LINE ASKED.)

1. Wood/coal stove

2. Fireplace

3. Cooking stove/range/oven

4. Non-portable room heater burning gas, oil, or kerosene

5. Portable kerosene heater

6. Non-portable electric heater

7. Electric portable heater (cord-connected)

8. Other

Used Less
After
$\begin{gathered}1 \\ 1 \\ 1 \\ 1 \\ 1 \\ 1 \\ 1 \\ \\ 1\end{gathered}$

Used More

The Same

2

2

2

2

2

2

2

2

\begin{tabular}{c} 
After \\
\hline 3 \\
3 \\
3 \\
3 \\
\\
3 \\
3 \\
3 \\
3
\end{tabular}




\section{Demographics}

Now I have some questions about the people who live here and about your housing costs.

C1. Please tell me how many people living in your home last winter before January 1991 were ... (READ EACH ITEM).

Under the age of 5

Between 5 and 17 years old

Between 18 and 64 years old

65 years old or older

TALLY -- so that is (READ NUMBER) in total?

C2. You have told me that there were (READ TOTAL NUMBER FROM QUESTION C1) people living in your home last winter before January 1991. How many people were living in your home last winter after January 1991?

\section{NUMBER OF RESIDENTS}

[ ] SAME NUMBER AFTER JANUARY 1991 AS BEFORE JANUARY 1991

C3. Were any of the people living in your home last winter before January 1991 handicapped? By handicapped, I mean a permanent condition. I do not mean a temporary condition, such as a short-term illness. (EYEGLASSES ARE NOT CONSIDERED A HANDICAP). (IF YES, ASK HOW MANY.) 
C4. Do you or members of your household own your home, or rent?*

[] Own (buying)

[1] Rent

[] Occupied without payment of rent (SKIP TO SECTION D)

FROM QUESTION C4, IF HOUSEHOLD OWNS OR PAYS RENT, ASK:

C5. Please tell me which category best describes the monthly rent or morgage payment the household pay's for your home. Is it ...? Stop me when I reach the category. (READ CATEGORIES.)

[] less than $\$ 200$ per month

[] $\$ 201-300$ per month

[] $\$ 301-400$ per month

[] $\$ 401-500$ per month

[] $\$ 501-600$ per month

[] $\$ 601-700$ per month

[] $\$ 701-800$ per month

[] $\$ 801-900$ per month

[] more than $\$ 900$ per month

[] OWNED, MORTGAGE PAID OFF (SKIP TO SECTION D)

[] DON'T KNOW

C6. Does this payment include: (READ ITEMS AND PROBE FOR "YES" OR "NO".)

1. fuel oil.............. []

2. electricity............. []

3. natural gas. ............... []

4. property tax............. []

5. insurance (house or renter's)...... []

6. water............... []

7. garbage.............. []

8. other (specify):

No DON'T

KNOW

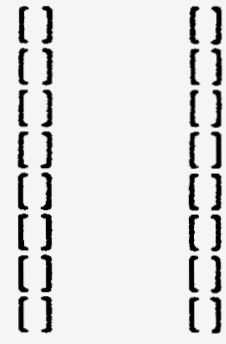




\section{Conditioned Living Space}

My next question is about the number of different types of rooms in your home. Remember that when I ask about last winter before January 1991, I mean October, November, and December of 1990. When I ask about last winter after January 1991, I mean February, March, and April of 1991.

\section{INTERVIEWER INSTRUCTIONS:}

For one-bedroom efficiency or studio apartment, record " 0 bedrooms" and number of bathrooms and other rooms.

Full Bathroom -- sink with running water and flush toilet and bathtub or shower.

Half Bathroom -- toilet or bathtub or shower

D1. How many of each of the following rooms does this home have? (ASK EACH ITEM AND RECORD NUMBER FOR EACH.)*

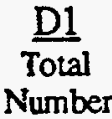

D2A

Number heared last winter before January 1991
D2B

Number heated last winter after January 1991

Bedrooms?. . . . . . . . . .

Full bathrooms?. . . . . . . .

Half bathrooms?. . . . . . .

All other rooms:. . . . . . . . .

(Do not count laundry rooms, foyers

or unfinished storage space.

Only count porches if they are

enclosed and used year-round.)

D2. (FOR EACH TYPE OF ROOM THE RESPONDENT HAS IN THE HOME, ASK D2A, THEN D2B. A HEATED ROOM IS ONE THAT IS WARM ENOUGH TO BE USED.)

D2a. Of the (READ NUMBER OF ROOMS AND TYPE OF ROOM), how many were heated last winter before January 1991 (RECORD ABOVE ON COLUNN D2A.)

D2b. And how many (READ TYPE OF ROOM) were heated last winter after January 1991? (RECORD ABOVE ON COLUMN D2B.) 


\section{E. Thermostat Management}

I would now like to ask you some questions about the temperature at which you kept your home

\section{INTERVIEWER INSTRUCTIONS:}

Remember, we are interested in the respondent's perceptions. Ask the respondent for their opinion; avoid checking the thermostat for the actual settings.

If respondent keeps different sections of the home at different temperatures, we want to know the temperature in the part of the house where the people are. If, for example, the heat is turned off upstairs during the day because the family is downstairs, we want the downstairs temperature.

We would like to know the actual temperature of the home. If the respondent doesn't know the temperature, but does know the thermostat setting, record the thermostat setting. Otherwise, probe for best estimate.

E1a. Last winter before January 1991, did you keep your home at the same temperature at all times of the day, or did you change the temperature?
[] Kept home at same temperature
[] Changed the temperature
(ASK QUESTION E1B)
(GO TO QUESTION E1C)

IF KEPT HOME AT SAME TEMPERATURE ON QUESTION EIA, ASK:

E1b. Before January 1991, at what temperature did you usually keep your home?

Degrees Fahrenheit

[] HEAT TURNED OFF

(GO TO QUESTION E2A)

IF CHANGED THE TEMPERATURE ON QUESTION E1A, ASK:

Elc. Before January 1991, at what temperature did you usually keep your home during the day when someone was at home?*

Degrees Fahrenheit

[] HEAT TURNED OFF

E1d. Before January 1991, at what temperature did you usually keep your home during the day when no one was at home?*

Degrees Fahrenheit: [] HEAT TURNED OFF

E1e. Before January 1991, at what temperature did you usually keep your home during sleeping hours?*

Degrees Fahrenheit: [] HEAT TURNED OFF 
(ASK EVERYONE:)

E2a. Last winter after January 1991, did you keep your home at the same temperature at all times of the day, or did you change the temperature?

[] Kept home at same temperature

[] Changed the temperature

(ASK QUESTION E2B)

(GO TO QUESTION E2C)

IF KEPT HOME AT SAME TEMPERATURE ON QUESTION E2A, ASK:

E2b. After January 1991, at what temperature did you usually keep your home?

Degrees Fahrenheit:

[] HEAT TURNED $\overline{\text { OFF }}$

(GO TO SECTION F)

IF CHANGED THE TEMPERATURE ON QUESTIDN E2A, ASK:

E2c. After January 1991, at what temperature did you usually keep your home during the day when someone was at home?*

Degrees Fahrenheit:

[] HEAT TURNED OFF

E2d. After January 1991, at what temperature did you usually keep your home during the day when no one was at home?*

Degrees Fahrenheit:

[] HEAT TURNED $\overline{\mathrm{OFF}}$

E2e. After January 1991, at what temperature did you usually keep your home during sleeping hours?*

Degrees Fahrenheit:

[] HEAT TURNED OFF 


\section{F. Events Affecting Energy Use}

The next questions are about events which may have affected your energy use last winter. (REMIND RESPONDENT IF NECESSARY): Remember that when I ask about last winter before January 1991, I mean October, November, and December of 1990. When I ask about last winter after January 1991, I mean February, March, and April of 1991.

F1a. Last winter before January 1991, was there ever a time when you wanted to use your fuel-oil heating system, but could not, for one or more of the following reasons?
Your heating system was broken?........ []
No
You ran out of fuel oil?.......... []
The utility company discontinued. ...... [ ]
your electric service?

IF "YES" TO ANY PART OF QUESTION FIA, ASK:

F1b. Thinking about these times that your went without heat, last winter before January 1991 , how many separate times were there?

Total times:

F1c. Altogether, how many hours or days were you without heat?

Total hours without heat:

OR

Total days without heat: 
F2a. Last winter after January 1991, was there ever a time when you wanted to use your fuel-oil heating system, but could not, for one or more of the following reasons?

\begin{tabular}{|c|}
\hline Your heating system was broken?........ [ [] \\
\hline You ran out of fuel oil?........... [ ] \\
\hline
\end{tabular}

IF "YES" TO ANY PART OF QUESTION F2A, ASK:

F2b. Thinking about these times that your went without heat, last winter after January 1991, how many separate times were there?

Total times:

F2c. Altogether, how many hours or days were you without heat?

Total hours without heat:

OR

Total days without heat: 
F3. Was any home repair or major house renovation that would affect energy use done on your home by yourself or other organization between November 1990 and April 1991 ?
[] Yes
[] No
[] DON'T KNOW
(GO TO QUESTION F6)
(GO TO QUESTION FG)

IF YES ON QUESTION F3, ASK:

F4. Please describe the home repair or renovation. (RECORD VERBATIM BELOW.)

MONTH

(1)

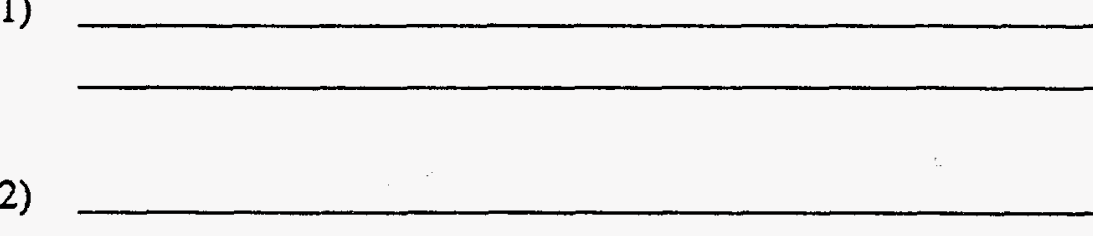

(2)

(3)

(4)

F5. In which month was the work done? (RECORD UNDER COLUMN FOR MONTH ABOVE.) 
Now I' $m$ going to ask you to describe the number of people in your home during the 1990 Thanksgiving holiday period and the Christmas holiday period compared to the rest of the winter. By number of people in your home I am referring to overnight visiting not visiting for meals or parties.

F6. Please look at Exhibit F6. First, how did the number of people in your home during the 1990 Thanksgiving holiday and weekend compare to other parts of the winter? (PROBE IF NEEDED: By number of people in your home I am referring to overnight visiting not visiting for meals or parties.)

[] Fewer people than other parts of the winter

[ ] About the same number of people as other parts of the winter

[] More people than other parts of the winter

[] DON'T KNOW/DON'T REMEMBER

F7. Please look at Exhibit F6 again. And how did the number of people in your home during the 1990 Christmas holiday through New Year's compare to the other parts of the winter? (PROBE IF NEEDED: By number of people in your home I am referring to overnight visiting not visiting for meals or parties.)

[] Fewer people than other parts of the winter

[] About the same number of people as other parts of the winter

[] More people than other parts of the winter

[] DON'T KNOW/DON'T REMEMBER 


\section{G. Impacts on Health, Safety, Comfort, Affordability}

My next questions ask for your opinion about the health, safety, comfort, and value of your home.

G1a. Please look at Scale G1. Using a scale of 1 to 7 , where 1 is too cold, 4 is comfortable, and 7 is too hot, how would you rate the temperature in your home last winter before January 1991 ?

BEFORE

12

too cold

$3 \quad \begin{array}{ll}4 \\ \text { comfortable }\end{array}$

6

$\begin{array}{cc}7 & 8 \\ \text { too hot } & \text { DON'T } \\ & \text { REMEMBER }\end{array}$

IF 1-3 OR 5-7 ON QUESTION G1A, ASK:

Gib. Why couldn't you keep your home the temperature you preferred last winter before January 1991? (DO NOT READ ANSWER CATEGORIES.) (CHECK ALL THAT APPLY.)*

[] Heating system problem

[] Landlord controls the temperature

[] Difference of opinion in household

[] Fuel shortage

[] High cost of fuel

[ ] Construction problem, such as broken windows, or holes in walls

[] Other (please specify)

\section{[] NOT SURE}

G1c. Using the same scale (REPEAT SCALE IF NECESSARY) how would you rate the temperature in your home last winter after January 1991?

\section{AFTER}

1

too cold

$2 \quad 3 \quad \begin{gathered}4 \\ \text { comforable }\end{gathered}$

6
$7 \quad 8$
DON'T
REMEMBER

IF 1-3 OR 5-7 ON QUESTION G1C, ASK:

GId. Why couldn't you keep your home the temperature you preferred last winter after January 1991? (DO NOT READ ANSWER CATEGORIES.) (CHECK ALL THAT APPLY.)*

[] Heating system problem

[] Landlord controls the temperature

[] Difference of opinion in household

[] Fuel shortage

[] High cost of fuel

[] Construction problem such as broken windows, or holes in walls

[] Other (please specify).

\section{[] NOT SURE}


G2. Please look at Scale G2. Using a scale of 1 to 7 , where 1 is very drafty, 4 is somewhat drafty, and 7 is not at all drafty, how would you rate the draftiness of your home last winter before January 1991 ?

\begin{tabular}{|c|c|c|c|c|c|c|c|}
\hline $\begin{array}{c}\text { BEFORE } \\
1 \\
\text { very drafty }\end{array}$ & 2 & 3 & $\begin{array}{c}4 \\
\text { somewhat drafty }\end{array}$ & 5 & 6 & \begin{tabular}{l}
\multicolumn{1}{c}{7} \\
not at all \\
drafty
\end{tabular} & $\begin{array}{c}8 \\
\text { DON'T } \\
\text { REMEMBER }\end{array}$ \\
\hline
\end{tabular}

Using the same scale (REPEAT SCALE IF NECESSARY), how would you rate the draftiness in your home last winter after January 1991?

$\begin{array}{cccccccc}\begin{array}{c}\text { AFTER } \\ 1\end{array} & 2 & 3 & \begin{array}{c}4 \\ \text { somewhat drafty }\end{array} & 5 & 6 & \begin{array}{c}7 \\ \text { not at all } \\ \text { drafty }\end{array} & \begin{array}{c}8 \\ \text { DON'T } \\ \text { REMEMBER }\end{array}\end{array}$

G3. Please look at Scale G3. Using a scale of 1 to 7 , where 1 is very poor, 4 is acceptable, and 7 is very healthy, how would you rate the health of household members last winter before January 1991? By health I mean illnesses such as colds, flus, allergies, frequent headaches, frequent nausea, or arthritis.

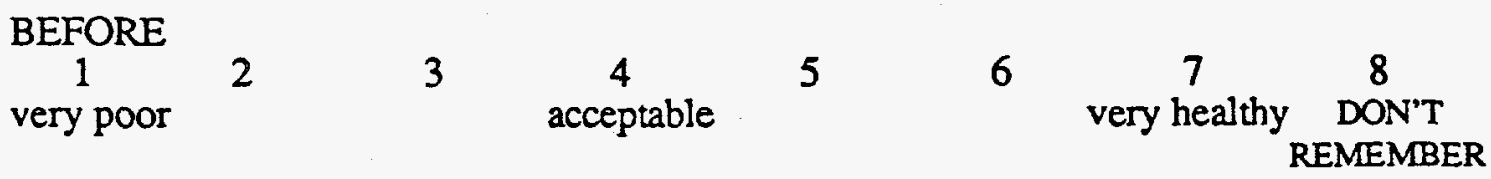

Using the same scale (REPEAT SCALE IS NECESSARY), how would you rate the health of household members last winter after January 1991 ?

AFTER

1

very poor
2

(1)

3

$\stackrel{4}{\text { acceptable }}$
5

56
6
$\begin{array}{cc}7 & 8 \\ \text { very healthy } & \stackrel{1}{ } \text { DON'T }\end{array}$
REMEMBER

G4. Please look at Scale G4. Using a scale of 1 to 7 , where 1 is very unsafe, 4 is acceptable, and 7 is very safe, how would you rate the safety of your home last winter before January 1991? By safety, I mean absence of hazards. Some examples of hazards in the home are faulty electrical, heating, or plumbing systems; combustible materials or other fire hazards; unstable porches or broken doors; or the absence of safety precautions such as bolt locks or smoke detectors.

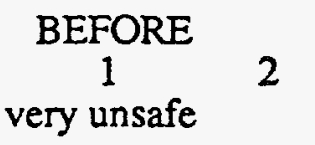
$3 \quad 4 \quad 5$ acceptable

6

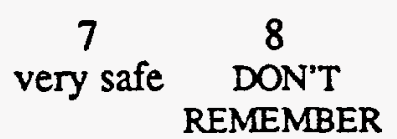

Using the same scale (REPEAT SCALE IF NECESSARY), how would you rate the safety of your home last winter after January 1991 ?
AFTER
12
very unsafe
$3 \quad 4$
5
6
$\begin{array}{cc}7 & 8 \\ \text { very safe } & \stackrel{8}{\text { DON'T }} \\ \text { REMEMBER }\end{array}$ 
G5. Please look at Scale G5. Using a scale of 1 to 7 , where 1 is very expensive, 4 is acceptable, and 7 is very inexpensive, how would you rate the cost of your heating bills last winter before January 1991 ?

\begin{tabular}{|c|c|c|c|c|c|c|}
\hline $\begin{array}{c}2 \\
1 \\
\text { very expensive }\end{array}$ & 2 & $\begin{array}{c}4 \\
\text { acceptable }\end{array}$ & 5 & 6 & $\begin{array}{c}7 \\
\text { very } \\
\text { ensive }\end{array}$ & $\begin{array}{c}8 \\
\text { DON'T } \\
\text { REMEMBER }\end{array}$ \\
\hline
\end{tabular}

Using the same scale (REPEAT SCALE IF NECESSARY), how would you rate the cost of your heating bills last winter after January 1991?

\section{AFTER}

$1 \quad 2$

3

4
acceptable

5

6 $\begin{array}{cc}7 & 8 \\ \text { very } & \text { DON'T } \\ \text { inexpensive } & \text { REMEMBER }\end{array}$

G6. Please look at Scale G6. Using a scale of 1 to 7 , where 1 is very much lower, 4 is about the same, and 7 is very much higher, how would you rate the property value of your home after January 1991 as compared to before January 1991? By property value, I mean the dollar value of the home if sold.

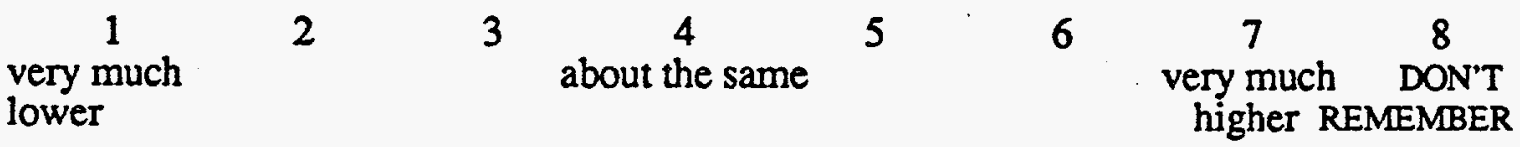

\section{END}

On behalf on the U.S. Department of Energy, I would like to thank you for your time and patience today. The information that you have shared with us will be helpful in our study.

*These items are modified versions of questions taken from the 1990 Residential Energy Consumption Survey (RECS) conducted by the Energy Information Administration.

INTERVIEWER INSTRUCTIONS:

Check to make sure each question has been answered and that verbatim responses are clear and legible.

TIME ENDED: 


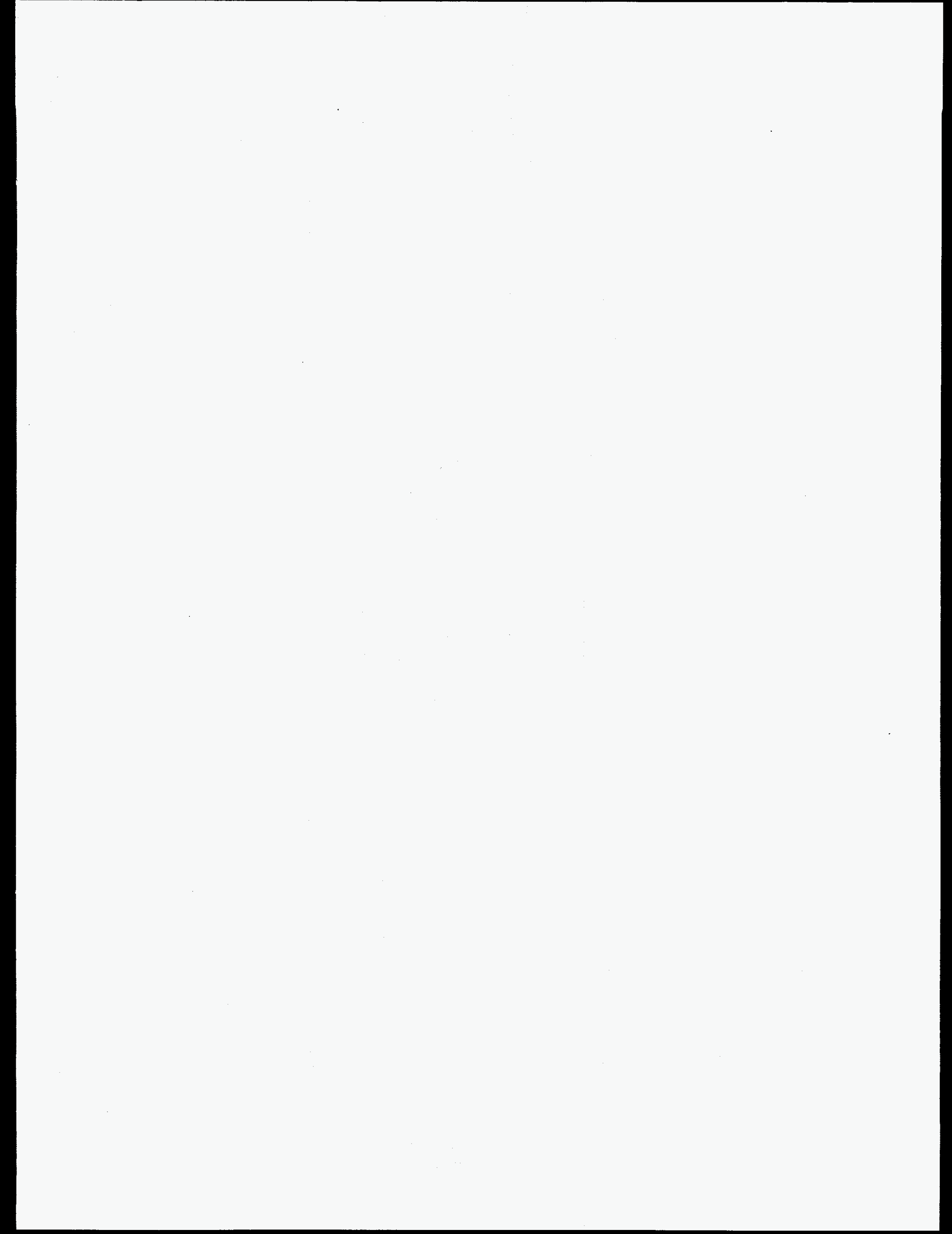




\section{APPENDIX C. WEATHERIZATION INFORMATION SURVEY}

Information on the weatherizations performed in each of the weatherized houses (installation dates, energy conservation measures installed, costs, etc.) and program and administration costs for each local weatherization agency was collected using the first survey provided in this appendix following weatherization. The second survey was used to collect a more limited amount of information on the control houses. 

Version 3

$2 / 21 / 91$

Form completed by:

Date:

FUEL-OIL STUDY WEATHERIZATION INFORMATION SURVEY

A. IDENTIFICATION

A1. House Identifier: (To be completed by ORNL)

A2. Subgrantee Name:

A3. Occupant Name:

A4. Occupant Phone Number:

A5. Occupant Address: 


\section{B. GENERAL INFORMATION}

B1. What was the household's income on the application form at the time when its eligibility was verified for the services it received in the 1990 program year?

\section{$\$$}

B2. Weatherization work was performed primarily in this house in January 1991. What were the exact start and stop dates for this work (month, day, and year)? (Dates for weatherization work performed at other times will be identified in Section G.)

Weatherization work started on

Weatherization work was completed on

B3. What electric utility company serviced this household and what was the household's utility account number?

Electric utility:

Account number: 


\section{WEATHERIZATION MEASURES INSTALLED}

Please check any of the measures listed that were installed in this dwelling during the time period identified in Question B2. (Measures installed at other times will be identified in Section G.) Indicate whether they were installed by in-house crew or contractor. If measures that are not listed were installed, please describe them in the appropriate "Other" category.

C1. Insulation

Installed by:
In-house Contractor
crew

Attic Insulation (installed for the first time)........ []

Attic Insulation (added to existing insulation)....... []

*Wall Insulation (normal technique).......... [ ]

*Wall Insulation (high-density technique)......... []

Floor Insulation. ................ []

Rim or Band Joist Insulation. . . . . . . . . . [ ]

Other Envelope Insulation. ............. []

[]
[]
[]
[]
[]

(Specify:

*The "normal technique" for installing wall insulation is characterized by blowing cellulose or fiberglass insulation into exterior wall cavitites to average densities using a two-hole, gravity-blow installation method. The "high-density technique" is characterized by blowing cellulose insulation into exterior wall cavities to high densities using a one-hole, tube-fill installation method. Under the "high-density technique," special attention is focused on sealing air leakage sites while insulating the walls; air bypasses are identified during the installation process and sealed by plugging the airleakage pathways with cellulose.

C2. Air Leakage Control

General Caulking and Weatherstripping. ....... [ ]

(door and window)

Air sealing, emphasizing by-passes with blower. .... [] door testing)

Air sealing, emphasizing by-passes without blower door testing)

Distribution System. . . . . . . . . . . . . [ ]

Other Infiltration Reduction. . . . . . . . . . []

(Specify: 
3. Water Heating System

Water Heater Tank Insulation. . . . . . . . . . . . . []

Entire Water Heating System Replacement. ....... []

Pipe Insulation. . . . . . . . . . . . . . []

Low Flow Shower Heads. . . . . . . . . . . [ ]

Temperature Reduction. ............... []

Other Water Heater Measures. . . . . . . . . . . . []

Installed by:

In-house

Contractor

(Specify:

C4. Structural Repairs (full or partial)

Attic Ventilation. . . . . . . . . . . . . [ ]

Roof. ..................... []

Doors. ....................... [ ]

Replacement of doors. ............. []

Windows/Glazing. . . . . . . . . . . . . [ ]

Replacement of windows. . . . . . . . . . . []

Walls. ................... [ ]

Floor. . . . . . . . . . . . . . . . . []

Other Structural Repairs. . . . . . . . . . . []

(Specify:

C5. Windows and Doors

Storm Windows (How many?

)..... []

Storm Doors. . . . . . . . . . . . . . . [ ]

Window Films or Shades. . ............. [ ]

Other Window or Door Treatments.

(Specify: 
C6. Space Heating System

Installed by:

In-house

Contractor

crew

Clean and Tune-up. ................. []

Entire Heating System Replacement. ........... []

Set-back Thermostat. ................. []

Heating System Component Retrofits. ......... []

(Specify:

Safety Problem Fixed. ............... [ ]

[ ]

(Specify:

Repairs.................... []

(Specify:

Other Heating System Modifications. .......... []

(Specify:

C7. Space Cooling System

Tune-up. .................. [ ]

(e.g., cleaning, controls adjustment, filter replaced)

Entire Air-conditioning System Replacement ....... [ ]

Fans Installed or Replaced. . . . . . . . . . . . . . []

Set-back Thermostat. ................ []

Other Cooling System Modifications. .......... []

[]

(Specify:

C8. Other Health and Safety Repairs or Improvements

Smoke Detectors. .................. []

Radon Testing. .................. []

Carbon Monoxide Testing. ............... []

Other. ..................... []

[]

(Specify: 


\section{SERVICE DELIVERY PROCEDURES}

\section{Selection of Measures}

D1. Please check the type of procedure that was used to select the measures that were installed in this dwelling during the time period identified in Question B2. (CHECK ALL THAT APPLY)

[ ] Envelope measures were selected using a priority list (i.e., a checklist or prescribed list of measures)

[ ] Envelope measures were selected using a decision approach or scoring (calculation) developed for each house

[] Envelope measures were selected based on an analysis of energy savings per dollar invested

[] Space-heating system measures were selected based on physical characteristics or a standard approach

[ ] Space-heating system measures were selected using a decision approach or scoring (calculations) based on operating performance

[ ] Space-heating system measures were selected based on an analysis of energy savings per dollar invested

[ ] Selection of envelope and space-heating system measures was made simultaneously under one approach rather than separately using two distinct procedures.

[] Other measure selection procedures. (Specify:

Use of Diagnostics

D2. Please check the type of diagnostic procedures that were used in this dwelling to perform the work during the time period identified in Question B2. (CHECK ALL THAT APPLY)

[] Blower door testing was used to find leakage areas for sealing

[ ] Blower door testing was used to measure air leakage rates

[] Blower door testing was used to determine when to stop work using costeffectiveness guidelines (not minimum ventilation guidelines)

[ ] Distribution system diagnostics were used to find leakage areas for sealing

[ ] Distribution system diagnostics were used to determine system balancing

[ ] Infrared scanning was used

[] Indoor air quality testing was used

[] Heating system efficiency testing was used

[] A heating system safety inspection was conducted

[] Other diagnostic procedures. (Specify: 


\section{Ouality Control}

D3. Please indicate the type of quality control inspection this house received following the work performed during the time period identified in Question B2. (CHECK ALL THAT APPLY)

[] A visual quality control inspection after weatherization for envelope measures

[1] A quality control inspection after weatherization for envelope measures that used blower door testing as a diagnostic tool

[] A quality control inspection after weatherization for envelope measures that used infrared scanning as a diagnostic tool

[] A visual quality control inspection after weatherization for heating system measures

[] A quality control inspection after weatherization for heating system measures that used diagnostic tools such as combustion efficiency testing

[ ] Other quality control procedures. (Specify:

\section{Client Education}

D4. Please check the types of client education that were provided to this house during the time period identified in Question B2. (CHECK ALL THAT APPLY)

[ ] Literature was mailed or left with client

[] In-person client education was provided

[] Other (Specify: 


\section{E. COSTS: MATERIALS, LABOR, INSTALLATION OVERHEAD AND PROGRAM MANAGEMENT}

\section{Definitions and Instructions}

This page and Figure 1 on the following page provide background information for completing questions $\mathrm{E} 1$ to $\mathrm{E} 4$ on pages 10 to 12 . The total cost of a program can be divided into installation costs and program management costs (Fig.1). Total installation costs include the costs of materials, direct labor and overhead expenses that are directly related to the installation process, such as the costs of vehicles, travel, equipment, insurance, field supervision, and training. When contractors deliver services, these installation overhead expenses are included, along with a profit, in the charges made for a job. When agency crews do the work, some of the installation overhead expenses may not be tracked directly on a per-house basis. As a result, there are separate questions for crew vs. contractor installation costs.

If a job is crew-based, supply the materials costs (Question E1), calculate the direct labor costs (Question E2), and estimate the average per-house cost of installation-related overhead expenses (Question E2). To arrive at the overhead expense estimate, for example, your agency's costs for vehicles, equipment, liability insurance, training, travel time, field supervision and any other installation-related expenses in the 1990 program year (PY) should be summed and then divided by the number of homes weatherized in the 1990 program year. If a job is contractor-based, supply the materials costs (Question E1) and the total installed costs (Question E3). If both crews and contractors worked on a house, complete all three questions (Questions E1, E2, and E3). In completing Questions E1, E2, and E3, costs should be for measures installed in this dwelling during the time period identified in Question B2. (Costs for weatherization work performed at other times will be identified in Section G.)

In addition, both crew-based and contractor-based programs should estimate an average program management cost per house weatherized. The program management cost should be calculated by subtracting the total installation costs (labor + materials + installation-related overhead) for all houses weatherized in PY 1990 from the total agency budget (in PY 1990). The total program management cost should then be divided by the number of houses weatherized (in PY 1990) to produce an average per-house program management cost (Question E4).

We realize that different agencies track costs in different ways. Please just use your best judgement in estimating the average installation-related overhead and the average program management expenses. 
Figure 1. Program Cost Categories

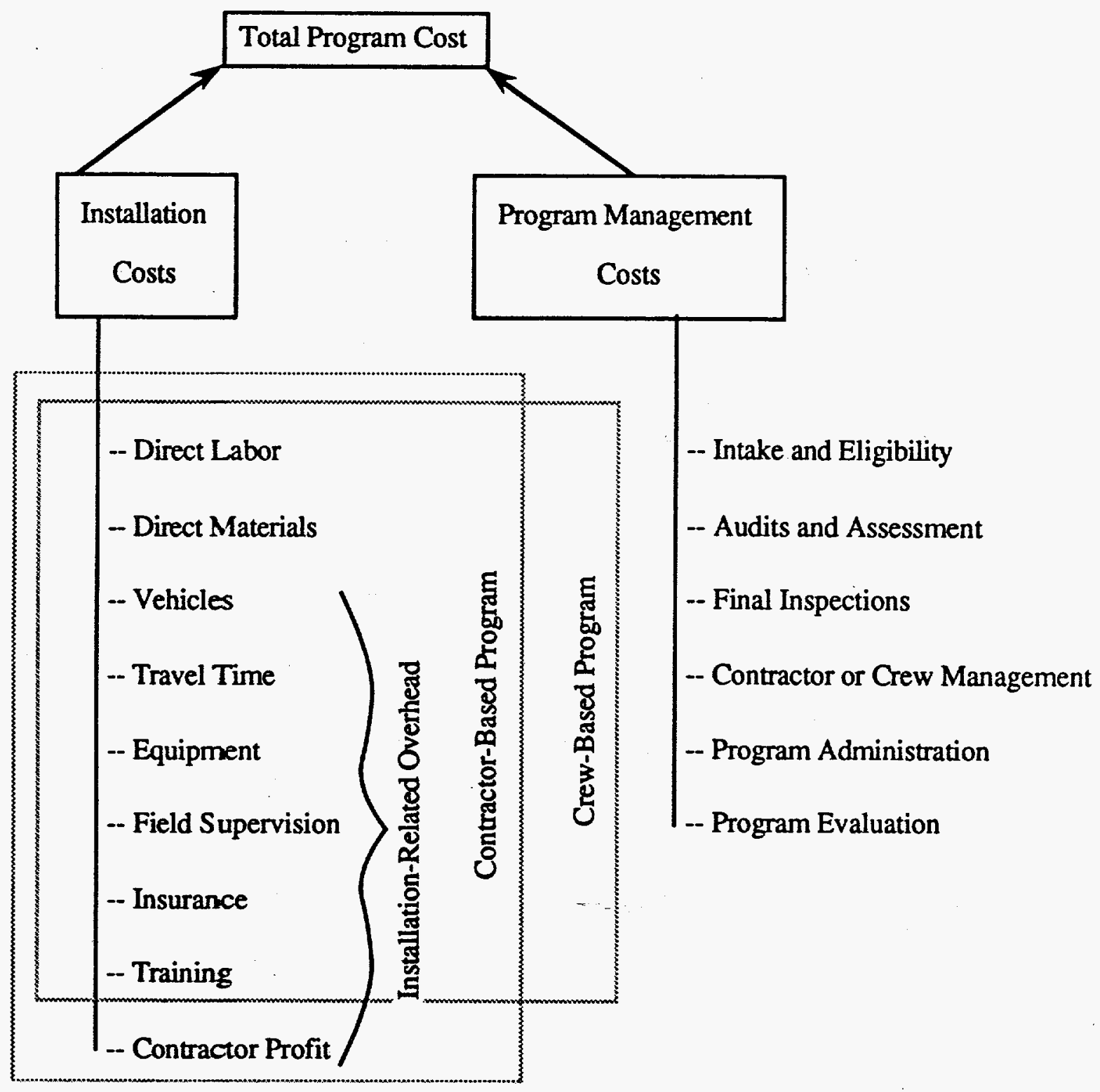




\section{QUESTION EI: BREAKDOWN OF MATERIALS COSTS}

In the chart below please fill in the crew-based and/or contractor-based materials cost of the measures that were installed in this dwelling during the time period identified in Question B2. Do nor include labor, administrative or program support costs here. Do include costs covered by all sources of funding (i.e., PVE, LIHEAP, or utilities). If you cannot provide the costs by measure, just enter the TOTAL materials costs in the box at the bottom.

Insulation

$\begin{array}{cc}\text { Crew-Based } & \text { Contractor-Based } \\ \text { Materials } & \text { Materials } \\ \text { Costs } & \text { Costs }\end{array}$

attic
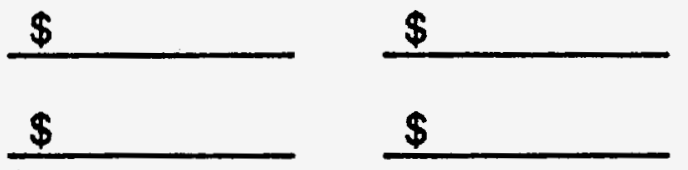

other

$$
\$
$$

Air Leakage Control

$\$$

$\$$

$\$$

Water Heating System Measures

$\$$

$\$$

Structural Repairs

$\$$

Windows and Doors

$\$$

$\$$

Space Heating System

retrofit

$\$$

replacement

$\$$

$\$$

Space Cooling System

retrofit

$\$$

replacement

Other

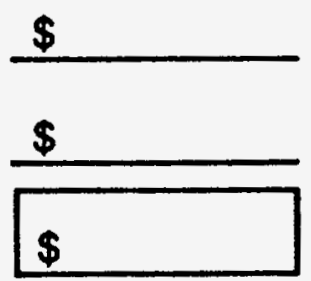

Crew-Based

Total Materials

Costs
$\$$

$\$$

$\$$

$\$$

Contractor-Based

Total Materials

Costs 


\section{QUESTION E2: CREW-BASED INSTALLATION COSTS}

Directions: Please fill in the number of crew hours for this house from information in your files for work performed during the time period identified in Question B2.

Please fill in your best estimate of the average hourly rate for your crew and multiply this by the number of hours to produce an estimate of the direct labor costs. Estimate the average installation-related overhead by following the directions in the box at the beginning of Section E (page 8).

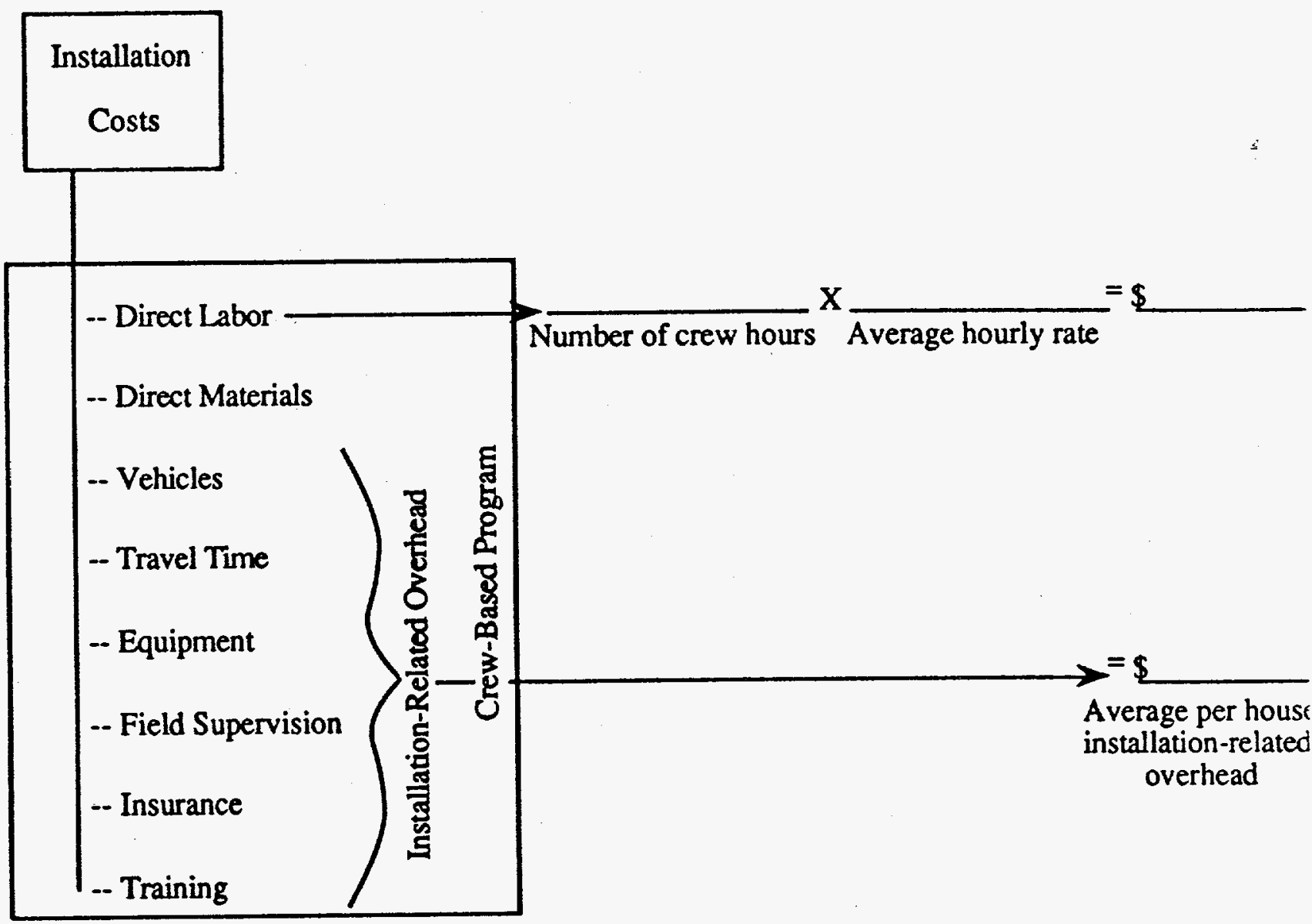

\section{QUESTION E3: CONTRACTOR-BASED INSTALLATION COSTS}

Directions: Please fill in the total installation costs billed by contractors for this house for work performed during the time period identified in Question B2. This should include all the cost categories listed above (include the materials costs reported on page 10 in this total, as well as labor costs and installation-related overhead) plus the contractor's profit.

Total Installed Cost $\$$ 
Total Program Costs for PY 1990

- Total Installation Costs* for All Houses Weatherized in PY 1990

*Add all direct materials costs, labor costs, and installationrelated overhead together to obtain this cost figure.

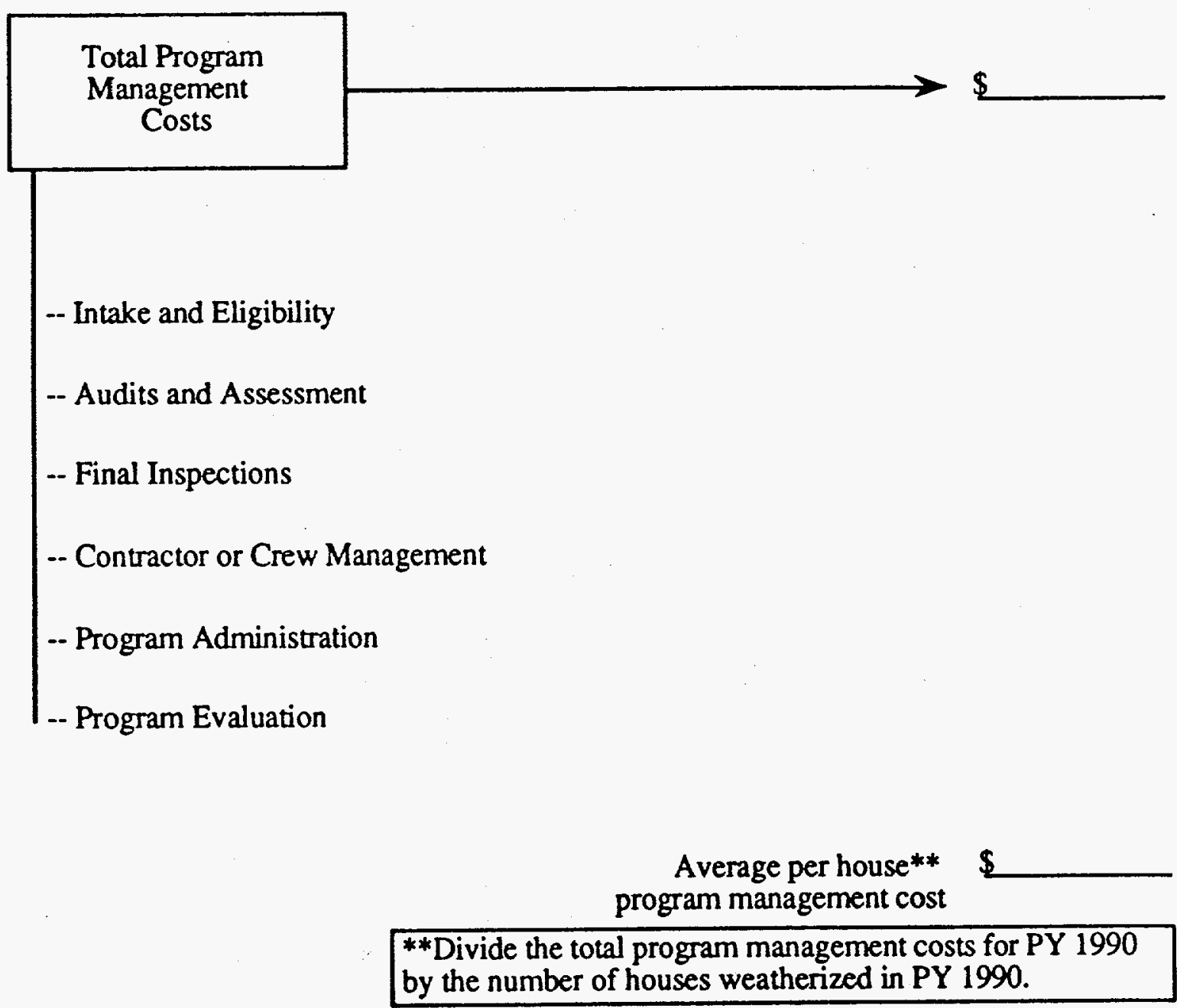




\section{F. FUNDING SOURCES}

F1. What percentage of the funds spent on this house as identified in Section $E$ were funds from DOE's WAP?

$\%$

F2. If funds from non-DOE sources were used, were they all used according to DOE guidelines?
[] Yes
[] No

F3. Some program management costs (such as client intake and eligibility checks, or office space and expenses) may be absorbed by other programs or agencies (e.g., LIHEAP, Councils on Aging). What percentage of your program management costs would you estimate are absorbed by other programs or agencies? 


\section{G. OTHER WEATHERIZATION MEASURES INSTALLED AND THEIR Costs}

G1. Space-heating system measures may have been installed in this dwelling at a different time period than that identified in Question B2 (at the time houses were selected for the study, for example). If so, check any of the measures that were installed. Indicate whether they were installed by in-house crew or contractor.

\section{Installed by: \\ In-house Contractor crew}

Clean and Tune-up. ................ []

Entire Heating System Replacement. . . . . . . . . []

Set-back Thermostat. . . . . . . . . . . . []

Repairs. . . . . . . . . . . . . []

[ ]
[]
[]

(Specify:

Heating System Component Retrofits. ......... []

(Specify:

Safety Problem Fixed. .............. []

(Specify:

Other Heating System Modifications.

(Specify:

G2. What were the costs of the measures identified in Question G1 (refer to Section E for directions)?

Material costs:

crew-based

retrofit

replacement

Total
$\$$

$\$$

$\$$ contractor-based

$\$$

$\$$

$\$$

Crew-based installation costs:

Number of crew hours

$$
X
$$

Average hourly rate

$=\$$

Direct labor costs

Contractor-based installation costs:

Total installation cost: $\$$ 
G3. What percent of the funds identified in Question G2 were funds from DOE's WAP? $\%$

G4. In Question G2 if funds from non-DOE sources were used, were they all used according to DOE guidelines?

$$
\text { [] Yes }
$$

G5. What were the exact installation dates (month, day, and year) for the measures identified in Question G1?

Installation started on

Installation completed on

G6. Were any measures other than those identified in Questions C1 - C8 and G1 installed in this dwelling? If so, please describe the measures installed, their costs, the percentage of funds from DOE's WAP, whether the funds were used according to DOE guidelines, and when the installations were performed. 


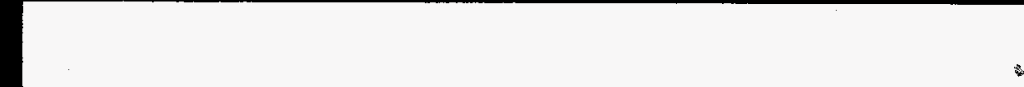


Version: March 20, 1991

Form Completed by:

Date:

\section{FUEL-OIL STUDY CONTROL HOUSE INFORMATION SURVEY}

\section{IDENTIFICATION}

House identifier:

Subgrantee name:

Occupant name:

Occupant phone number:

Occupant address:

\section{GENERAL INFORMATION}

What was the household's income on the application form at the time when its eligibility was verified for the weatherization services it will receive in May or June 1991?

$\$$

What electric utility company serviced this household and what was the household's utility account number?

Electric utility:

Account number:

\section{WEATHERIZATION MEASURES}

The control houses will not be weatherized by your agency until May or June 1991. Nevertheless, your agency may have already installed some measures in this dwelling for various reasons (for safety reasons at the time houses were selected for the study, for example). If any measures were installed, please describe them and identify when the installations were performed. 


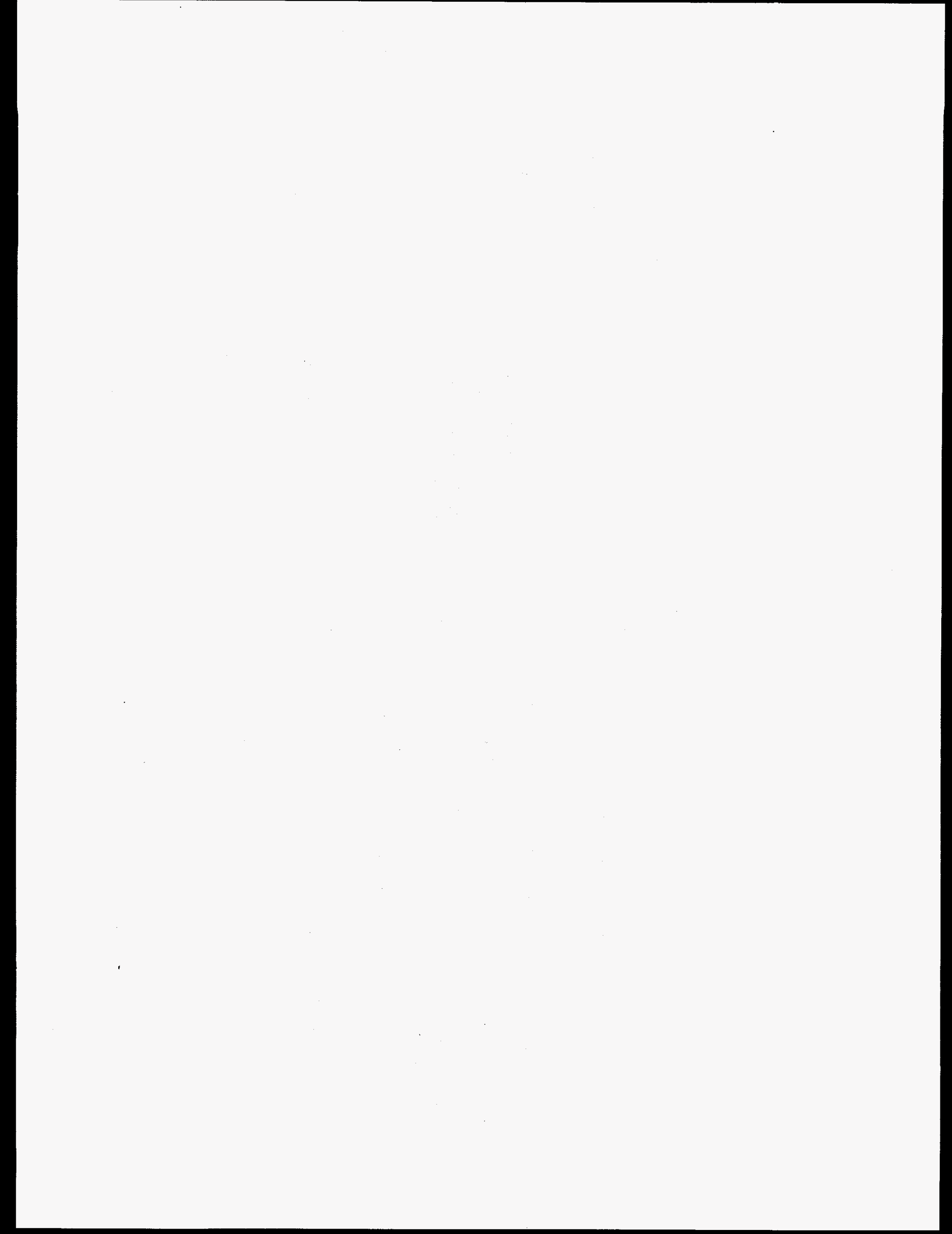




\section{APPENDIX D. AIR-LEAKAGE MEASUREMENT TEST PROCEDURE}

Air-leakage measurements were made in all the houses before and after weatherization following this procedure. 

Version: April 26, 1991

\section{AIR-LEAKAGE MEASUREMENT TEST PROCEDURE}

\section{OBJECTIVE}

The objectives of this procedure are to

1. provide the necessary measurements to calculate, for single-family houses, the air flow rate with the house depressurized $50 \mathrm{~Pa}$ below ambient, the equivalent or effective leakage area $^{1}$, and air exchange rate ${ }^{1}$ (if the number of conditioned stories is known);

2. examine the air tightness of the house as constructed, including all intentional and nonintentional openings in the envelope; and

3. ensure comparability of measurements performed by different contractors using different brands of blower doors.

Although this procedure does not fully comply with ASTM Standard E779-87 2 especially regarding pressurized measurements, it generally follows the principles contained in the standard.

\section{PRE-TEST PROCEDURE}

\section{House Preparation}

The house should be prepared for measurement as follows:

1. Close all fireplace and wood stove dampers, glass doors, and other flue openings. Have occupant extinguish all fires. Remove ashes or place wet cloths or newspapers over cold ashes.

2. Turn off exhaust fans, dryers, space-heating systems, water-heating systems, and gas-stoves.

3. Close all windows and exterior doors, including doors to garages and other such buffer spaces that are not heated. A heated space is defined to be a space with permanent space-heating equipment and/or distribution outlets designed to maintain a desired temperature in the space. A space (such as a basement) that is heated primarily from equipment jacket and/or distribution losses (there is little control over the resulting temperature) is not a heated space.

\footnotetext{
${ }^{1}$ Handbook of Fundamentals, American Society of Heating, Refrigerating, and Air Conditioning Engineers, 1989.

${ }^{2}$ Standard Test Method for Determining Air Leakage Rate by Fan Pressurization, The American Society for Testing and Materials, 1987.
} 
4. Open all interior doors (except for closets) so that all interior heated space is connected, including heated basements (if only portions of the basement are heated, open all doors necessary to connect these heated basement areas with other heated areas). If a space was designed to be a heated space but is maintained by the occupant in an unheated condition, the space should still be considered a heated space with one exception: an unfinished basement or other unfinished room with a distribution system that is always closed off should not be considered a heated space.

5. Record on the Blower-Door Test Data Sheet the exclusion/inclusion of buffer spaces, zoned rooms, and basements in order that the post-weatherization test can be performed on the same heated space of the house.

\section{Equipment Set-Up}

All equipment should be kept at as close to $70^{\circ} \mathrm{F}$ as possible while in transit and brought into the house immediately upon arrival. Equipment should be set-up as specified below.

1. Deploy a thermometer outside away from the door in a shaded area, and one inside in the same room as the blower door.

2. Zero the gauge to be used to measure air flow through the fan after removing all hoses from the gauge so that both pressure taps are exposed to room air.

3. Install the fan on an exterior door for depressurizing the house. The chosen door must be free of wind interference and obstructions for at least $4 \mathrm{ft}$ upstream of the fan. Install the hose measuring the outside pressure out of line of the blower-door fan. Multiple outside hoses or pressure equalizing boxes must not be used. Set up the gauges inside the house and out of the direct flow of air through the blower-door fan (if a hose is used to measure the inside pressure, ensure that it is out of the direct flow of air as well). Check all hose fittings for tightness and trim or tighten as necessary. Connect all hoses. Check for leaks around the fan and door.

4. The gauge used to measure pressure difference across the house envelope is zeroed to remove the natural pressure difference that may exist between the inside and outside of the house due to thermal or wind effects. Cover the fan opening (using the "shower cap" provided by the manufacturer, plugging or taping all holes with the orifice plate on, or some other equivalent technique). Zero the gauge. Remove the fan opening cover. Rezero the gauge in this manner each time a new run is started.

5. Briefly walk through the house while maintaining a negative pressure difference across the house of 20-40 Pa to check for previously undetected operable openings in the envelope (i.e. open windows, attic hatches, dampers) and other significant sources of air leakage. Identify on the Blower-Door Test Data Sheet any unusual sources of air leakage. Also, look for indications of weak areas (ceilings, windows) that could be damaged with increased negative pressures.

6. Establish a negative pressure difference across the house of $50 \mathrm{~Pa}$ for 15 seconds. Do not pressurize the house after this step. 


\section{TEST PROCEDURE}

\section{Starting the Test}

1. Record the identification number of the blower door so that the same door can be used for future tests.

2. Record the indoor and outdoor temperatures.

3. Record the average wind speed, maximum wind gust, and location of the wind measurement (so that same spot can be used for future tests). The measuring device should be deployed three to five building heights away from buildings and other major obstructions and be faced into the wind. Average wind speed should generally not exceed $10 \mathrm{mph}$; greater speeds and gusty wind conditions can cause difficulty in obtaining quality air-leakage measurements.

4. Record the local shielding class.

\section{Pressure Station Measurements}

A test entails making measurements at all pressure stations identified on the Blower-Door Test Data Sheet unless the maximum pressure generated by the fan is insufficient. In this case, make measurements at as many of the assigned pressure stations as possible. Make measurements starting at the lowest pressure station and proceeding in ascending order.

\section{Orifice Plates}

For blower doors with orifice plates, at least one (and possibly two) changes in orifice plates should be expected during any particular test. The number and size of orifice plates used must be recorded with each pressure station.

1. The initial orifice plate should be the smallest allowed by the blower-door manufacturer. Using this plate, attempt to make a measurement at the first pressure station. If this is not possible, move to the next larger orifice until the measurement can be made.

2. As measurements are made at higher pressure stations, change to the next largest orifice plate only when it is no longer possible to reach $5 \mathrm{~Pa}$ above the desired pressure station.

\section{Gauge Reading Procedures}

1. To make a measurement at each pressure station, first raise the house to about $5 \mathrm{~Pa}$ above the desired pressure. Then slowly reduce the pressure until the desired pressure is reached. If the pressure is undershot, raise the pressure again to $5 \mathrm{~Pa}$ over the desired pressure and repeat the process.

2. Tap the gauges continuously while adjusting the pressure down to the desired station as the stored spring energy will cause the gauge needles to jump slightly. 
3. Set the gauge needle on the indicated pressure stations, within $+/-2 \mathrm{~Pa}$.

4. Wait $\mathbf{3 0}$ seconds for the blower-door readings to stabilize. Record the actual house pressure reading, the fan pressure or flow rate reading, and the orifice configuration on the Blower-Door Test Data Sheet. When lining the gauge needle up with the marks on the gauge, read the gauge from directly in front to avoid parallax. Always take readings off of the gauge with the lowest range possible. For example, when measuring a flow pressure of less than $125 \mathrm{~Pa}$, read from a gauge with a range of 0-125 $\mathrm{Pa}$ rather than from one with a range of $0-750 \mathrm{~Pa}$. Note the reason for any alternate pressure station readings.

\section{Acceptable Error Level}

Input the data collected at eight of the nine pressure stations into the blower-door computer: do not use the $10 \mathrm{~Pa}$ data if a $60 \mathrm{~Pa}$ reading was made. The test must be repeated if the percent error in the flow data at each pressure station is more than $5 \%$, the correlation coefficient is less than 0.99 , or the flow exponent $(\mathrm{n})$ is less than 0.5 or greater than 1.0. These numbers appear on the blower-door tape. Before re-doing a test, examine all hoses and fittings for leakage and carefully re-zero the gauges as these could be the cause of excessive error.

\section{Completing the Test}

1. Record the indoor temperature.

2. Return ventilation controls, vents, and thermostats to their original settings. Make sure all space- and water-heating systems are operating correctly. Make sure all pilot lights are lit. Close interior doors to restore the house to it's original state.

3. The printout from each test must be included with the Blower-Door Test Data Sheet.

4. Extreme care must be taken in recording all data points as tests with unacceptable levels of accuracy must be repeated. 
Version: April 26, 1991

Technician:

Date:

BLOWER-DOOR TEST DATA SHEET: INFILTEC BLOWER DOOR

House ID: Subgrantee name:

Occupant name: Phone number:

Occupant address:

Procedures to prepare house for test: Basement door (closed or open)

Unusual sources of leakage:

Test equipment identification number:

\begin{tabular}{|c|c|c|c|c|c|c|}
\hline $\begin{array}{c}\text { Indoor temperature } \\
\left({ }^{\circ} \mathrm{F}\right)\end{array}$ & $\begin{array}{c}\text { Outdoor } \\
\text { temperature } \\
\left({ }^{\circ} \mathrm{F}\right)\end{array}$ & $\begin{array}{c}\text { Average } \\
\text { wind speed } \\
(\mathrm{MPH})\end{array}$ & $\begin{array}{c}\text { Maximum } \\
\text { wind gust } \\
(\mathrm{MPH})\end{array}$ & $\begin{array}{c}\text { Location } \\
\text { of wind } \\
\text { measurement }\end{array}$ & $\begin{array}{c}\text { Local } \\
\text { shielding } \\
\text { class }\end{array}$ \\
\hline \hline Start & Finish & & & & & \\
\hline & & & & & \\
\hline
\end{tabular}

\begin{tabular}{|c|c|c|c|c|}
\hline \multicolumn{3}{|c|}{ Pressure station } & \multirow[b]{3}{*}{$\begin{array}{c}\text { Flow rate } \\
\text { (cfm) }\end{array}$} & \multirow[b]{3}{*}{ Orifice } \\
\hline \multicolumn{2}{|c|}{ Goal } & \multirow[b]{2}{*}{ Actual } & & \\
\hline$(\mathrm{Pa})$ & $\begin{array}{l}\text { (inches } \\
\text { of water) }\end{array}$ & & & \\
\hline 10 & 0.04 & & & \\
\hline 15 & 0.06 & & & \\
\hline 20 & 0.08 & & & \\
\hline 25 & 0.10 & & & \\
\hline 30 & 0.12 & & & \\
\hline 35 & 0.14 & & & \\
\hline 40 & 0.16 & & & \\
\hline 50 & 0.20 & & & \\
\hline 60 & 0.24 & & & \\
\hline
\end{tabular}

\begin{tabular}{|l|l|}
\hline \multicolumn{2}{|c|}{ Local shielding classes } \\
\hline 1 & No obstructions or local shielding \\
\hline 2 & $\begin{array}{l}\text { Light local shielding; few obstruc- } \\
\text { tions, a few trees, or small shed }\end{array}$ \\
\hline 3 & $\begin{array}{l}\text { Moderate local shielding; some } \\
\text { obstructions within two house } \\
\text { heights, thick hedge, solid fence, or } \\
\text { one neighboring house }\end{array}$ \\
\hline 4 & $\begin{array}{l}\text { Heavy shielding; obstructions around } \\
\text { most of perimeter, building or trees } \\
\text { within 30 ft in most directions; } \\
\text { typical suburban shielding }\end{array}$ \\
\hline 5 & $\begin{array}{l}\text { Very heavy shielding; large obstruc- } \\
\text { tions surrounding perimeter within } \\
\text { two house heights; typical downtown } \\
\text { shielding }\end{array}$ \\
\hline \hline
\end{tabular}

Notes: 
APPENDIX E STEADY-STATE EFFICIENCY MEASUREMENT PROCEDURE

The steady-state efficiencies of the space-heating systems were measured in all houses before and after weatherization following this procedure. 


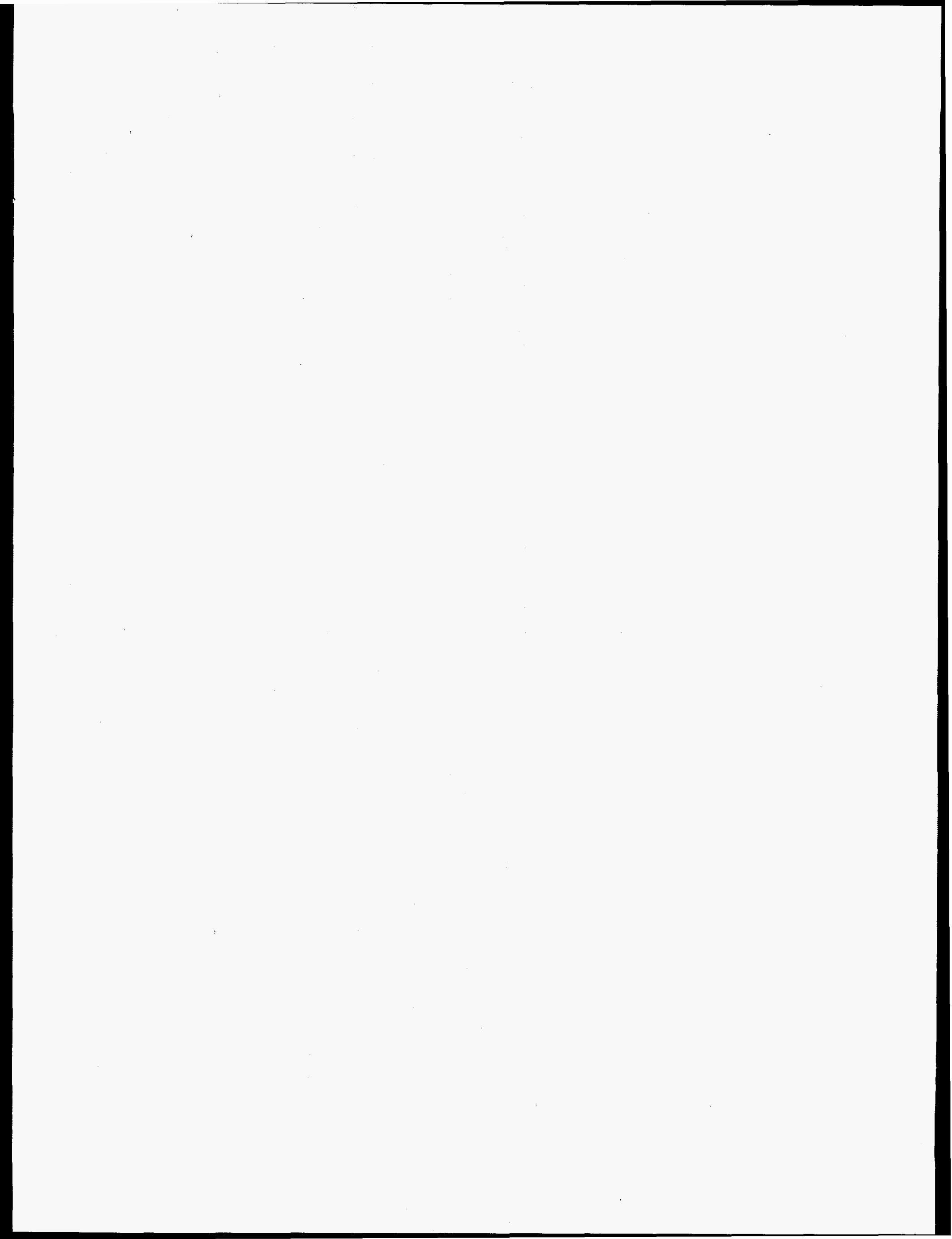


Version: April 11, 1991

SPACE-HEATING SYSTEM STEADY-STATE EFFICIENCY

MEASUREMENT PROCEDURE

\section{OBJECTIVE}

The objectives of this procedure are to

1. provide the necessary measurements to calculate the steady-state efficiency of residential space-heating systems fueled by natural gas or fuel oil; and

2. ensure comparability of measurements performed by different contractors using different brands of combustion efficiency test equipment.

This procedure assumes that the combustion efficiency test equipment has been calibrated following the manufacturer's recommendations. The procedure also assumes the use of electronic test equipment (the procedure should be followed with modifications made as necessary if other types of equipment are used).

\section{SET-UP PROCEDURE}

1. When testing units in confined spaces, ensure there is adequate ventilation to exhaust any carbon monoxide or other toxic gases.

2. Set up the test equipment according to the manufacturer's instructions. Be sure all connections are tight. The equipment should be placed indoors for at least fifteen minutes to reach room temperature. If applicable, aspirate room air through the equipment for at least five minutes.

3. If applicable, calibrate the equipment to $20.9 \%$ oxygen in a well ventilated area.

4. Identify a location in the system's flue sufficiently large to insert the test probe. The location must be located upstream of any dampers or other sources of air entering the flue. If needed, a $5 / 16^{\prime \prime}$ hole should be drilled into the flue pipe as close to the breech as possible, leaving enough clearance for the probe assembly handle.

5. Install the probe into the flue pipe's test location following the manufacturer's instructions. Make sure all tubing and wiring are free of kinks and away from hot areas of the heating system.

6. Turn on the heating system and allow the system to operate for at least five minutes.

7. Record the type of test to be performed.

8. Record the identification number of the test equipment so that the same equipment can be used for future tests. 


\section{MEASUREMENTS}

Record the following measurements on the Steady-State Efficiency Data Sheet when the oxygen and temperature measurements do not fluctuate over a one-minute interval (when the temperature measurement does not change more than $5^{\circ} \mathrm{F}$ ):

1. Measure the percent oxygen in the flue gas following the manufacturer's instructions.

2. Measure the room and flue gas temperatures (or net stack temperature) following the manufacturer's instructions.

3. For heating systems using fuel oil, measure the smoke number following the manufacturer's instructions. When using smoke paper to make the measurements, comparisons to charts (scales) must be made in daylight or incandescent light (never fluorescent light). Two pieces of unused smoke paper must be placed behind the test paper to make a comparison because of the transparency of the smoke paper.

\section{COMPLETING THE TEST}

1. Turn off the heating system and allow metal parts to cool before removing test equipment.

2. If a hole was drilled into the flue pipe, seal the hole using plugs approved for this purpose.

3. Using charts provided with the test equipment, record the unadjusted steady-state efficiency of the system (disregarding any adjustments for smoke numbers) and, for fuel-oil systems, the adjusted efficiency.

4. Note the condition of the battery in battery-operated test equipment. If the voltage is low, be sure to charge the battery according to manufacturer's instructions. 
Version: April 11, 1991

Technician:

Date:

\section{FUEL-OIL STUDY STEADY-STATE EFFICIENCY DATA SHEET}

House I.D.: Subgrantee name:

Occupant name: Phone number:

Occupant Address:

Type of test: Pre-weatherization Post-weatherization

\begin{tabular}{||l|r|}
\hline Test equipment identification number & \\
\hline Percent oxygen reading & $\%$ \\
\hline Net stack temperature, or & ${ }^{\circ} \mathrm{F}$ \\
\hline Room temperature & ${ }^{\circ} \mathrm{F}$ \\
\hline Flue gas temperature & ${ }^{\circ} \mathrm{F}$ \\
\hline Unadjusted steady-state efficiency & $\%$ \\
\hline \hline
\end{tabular}

\begin{tabular}{||l|l|}
\hline \multicolumn{2}{|c|}{ For fuel-oil systems: } \\
\hline Smoke number & \\
\hline Adjusted steady-state efficiency & \\
\hline $\begin{array}{c}\text { If the smoke number is: } 1,2,3,4,5,6,7,8,9 \\
\text { subtract: } 0,0,0,1,2,3,4,6,7\end{array}$ \\
\hline
\end{tabular}

Notes: 



\section{APPENDIX F. SAFETY INSPECTION PROCEDURE}

The safety and integrity of the space- and water-heating systems of all the houses were evaluated at the end of the post-weatherization period using this procedure. 

Version: April 26, 1991

OIL-FIRED SPACE- AND WATER-HEATING SYSTEM INSPECTION PROCEDURE

\section{OBJECTIVE}

The objectives of this procedure are to

1. provide the necessary measurements and evaluations to assess the safety and integrity of oil-fired space-heating systems, and

2. provide the necessary measurements and evaluations to assess the safety and integrity of oil-fired domestic water-heating systems.

The procedure is limited to an inspection of the space- and water-heating systems. It does not address other safety or health issues related to the house such as radon levels, structural integrity, code violations, unsanitary conditions, and moisture problems.

The procedure is intended to be a data collection instrument only, with the intent being that an overall assessment of these systems will not be made until sometime after the information has been collected in the field. Some guidelines are provided in the procedure to help make immediate interpretations of the collected data. Guidelines regarding repairs or remedies are beyond the scope of this procedure. Unsafe conditions found while following this procedure should be forwarded immediately to the occupants and proper organization or authority.

The procedure was written assuming two separate oil-fired systems. If the domestic waterheating system uses another fuel or is an integral part of the space-heating system (tankless), then some parts of the procedure will not apply. In developing the procedure, the term furnace strictly refers to space-heating systems that heat and distribute air, and the term boiler refers to hydronic systems. A Fuel-Oil System Inspection Form is included as part of this procedure to record all observations and measured data. This form parallels the procedure with the exception of heat exchanger information which is grouped together on the form.

\section{GENERAL SPACE-HEATING SYSTEM INSPECTION}

Any cracks in the heat exchanger of an oil-fired forced-air or gravity furnace presents a dangerous situation as flue gasses can enter the hot-air supply system and be distributed throughout the house. Both visual and metered inspections of the heat exchanger will be performed, even though it is often difficult to spot cracks visually.

1. Identify the system type.

2. Check the onloff operation of the thermostat.

3. Determine if the space-heating system has its own emergency electrical cutoff switch.

4. Determine if all $117 \mathrm{VAC}$ wiring is secure.

5. For a furnace, identify the fan on/off temperature settings. For a boiler, identify the operating setpoint temperature (hot water systems) or operating pressure (steam systems).

6. Determine if a high limit switch is present and identify its setting (their functionality will not be tested under this procedure). 
7. Note the presence of any combustible materials, including urethane (flexible foam) pipe insulation, immediately adjacent to the flue pipe or too close to the heating system.

8. Note the presence of any asbestos insulation on the system.

9. For a forced-air or gravity furnace, visually inspect the heat exchanger for cracks with the furnace off. Use a strong light and mirror to see as much of the heat exchanger as possible. Pay special attention to all gaskets and joints between sections, and areas that could be damaged by a leaking humidifier.

10. While performing the draft or carbon monoxide measurements that follow, or in coordination with an efficiency measurement, measure the oxygen levels in the flue with the burner running just before and after the distribution blower turns on. A change of $1 \%$ (e.g., from $8 \%$ to $9 \%$ ) may indicate a cracked heat exchanger. (Usually, the oxygen levels will stabilize within 30-60 seconds after the system is turned on and before the distribution blower turns on.)

\section{GENERAL DOMESTIC WATER-HEATING SYSTEM INSPECTION}

1. Identify the system and fuel type.

2. If fossil-fuel-fired, note the presence of any combustible materials, including urethane (flexible foam) insulation, immediately adjacent to the flue pipe or too close to the system.

3. Note the presence of a pressure relief valve on the system.

4. Note the hot water setpoint temperature.

\section{LEAKING FUEL SOURCES}

Even small leaks in fuel-oil lines are relatively easy to detect. The inspection for fuel-oil leaks will be accomplished visually and by noting any fuel-oil odors in the vicinity of the supply lines. Leaks in outdoor tanks can be difficult to detect, especially if the tank is buried. Therefore, only visual and odor detection methods will be used for above-ground tanks; underground tanks will not be evaluated. Propane or natural gas is often used for domestic water heating in a dwelling heated by fuel oil. Under this procedure, an inspection for combustible gas from such a waterheating system will be performed based on smell; use of a combustible gas analyzer would be an improvement to the procedure if available.

1. Visually inspect the fuel-oil supply line from the space-heating system to the supply tank. Note if there are any leaks as indicated by the presence of fuel on the floor or supply lines, or strong fuel-oil odors in the vicinity of the lines.

2. Visually inspect the fuel-oil supply line (if present) from the water-heating system to the supply tank. Note if there are any leaks as indicated by the presence of fuel on the floor or supply lines, or strong fuel-oil odors in the vicinity of the lines. If the system is heated by gas rather than fuel oil, a leak may be indicated if there are any gas odors in the vicinity of the system or gas lines.

3. Visually inspect the above ground supply tank (if present). Note if there are any leaks as indicated by the presence fuel oil on the ground or lines, abnormal corrosion, or strong fuel odors in the vicinity of the tank.

4. Visually inspect the fuel-oil supply line from the supply tank to determine if a filter and shutoff valve are present. 


\section{SPACE-HEATING DISTRIBUTION SYSTEM}

1. Check the operation of the circulating fan or pump of non-gravity systems.

2. For a forced-air or gravity furnace, check the condition of air filters and the exiting temperature of the supply air.

3. For a boiler, check the operation of any zone valves and inspect the piping for leaks.

4. Check for the presence of any asbestos insulation on the distribution system.

\section{FLUE AND CHIMNEY INSPECTION (SPACE- AND WATER-HEATING SYSTEMS)}

1. Visually check the chimney from the ground outside the structure to ascertain overall soundness. If there is an indication of a serious problem, take a closer view from the roof if practical.

2. Determine if the chimney extends above the roof at least $2 \mathrm{ft}$ and that there is $10 \mathrm{ft}$ of horizontal clearance around the top of the chimney.

3. Inspect the chimney and flue pipes from inside the house. Note any obvious holes, leaks, and untight connections in either system.

4. Remove the flue pipe if practical and inspect the chimney using a flashlight and mirror. Note any debris or deposits of more than $1 / 4$ inch thick on the inside of the chimney. Note the presence or absence of a flue liner.

5. For space-heating systems only, check for the existence and correct function (damper swings, has a counterweight, and opens when the system is firing) of the barometric damper.

\section{SPACE- AND WATER-HEATING SYSTEM DRAFTS}

Both the time necessary to establish a proper draft and the steady-state draft are important quantities. There usually is no problem if a draft is established within $\mathbf{3 0}$ seconds; the system should be examined if a draft takes between 30 and 180 seconds to be established; a problem likely exists if a draft takes longer than 180 seconds to become established. An acceptable steady-state draft depends upon the outside air temperature. In all cases, however, any spillage (backdrafting) from the flue to the room containing the system is unacceptable once the draft has been established. The following table may be used as a guide:

\begin{tabular}{||c||c|c|}
\hline Outdoor temperature & Acceptable Draft & Unacceptable Draft \\
\hline$>80^{\circ} \mathrm{F}$ & -0.005 to -0.20 inches water & 0 inches water or greater \\
\hline between $30^{\circ} \mathrm{F}$ and $80^{\circ} \mathrm{F}$ & -0.01 to -0.20 inches water & -0.01 inches water or greater \\
\hline$<30^{\circ} \mathrm{F}$ & -0.02 to -0.20 inches water & -0.02 inches water or greater \\
\hline
\end{tabular}

In addition, if the room where the systems are located is maintained at a pressure $5 \mathrm{~Pa}$ less than ambient, backdrafting is a potential problem.

1. Turn off the space- and water-heating systems for at least 20 minutes. 
2. Turn on all exhaust fans in the house (except whole house ventilation fans), including the clothes dryer if one is present. Close all interior doors and the door to the room containing the systems.

3. Measure the outdoor temperature.

4. Measure the draft of the systems between the breech and barometric damper with the distribution fan and systems off.

5. Turn on the space-heating system. Measure the time required for backdrafting to stop (for a draft to become established). Measure the draft of the system at the following intervals from the time the system was turned on: 30 seconds, 1 minute, 2 minutes, and 3 minutes. Use a smoke pencil to detect airflow.

6. With the space-heating system operating, measure the pressure difference between the room containing the systems and the outside. If the basement is depressurized more than 0.02 inches water $(5 \mathrm{~Pa})$ relative to the outside, than make a second measurement with the space-heating system off.

7. Turn the space-heating system off and the water-heating system on. Repeat steps 4 and 5 for the water-heating system.

\section{CARBON MONOXIDE}

Carbon monoxide $(\mathrm{CO})$ is extremely dangerous since it is both odorless and colorless as well as being toxic. However, if emanating from an oil burner, $\mathrm{CO}$ will often be accompanied by other combustion gases and fuels which do emit odors. $\mathrm{CO}$ readings should be made with an appropriate meter following the manufacturer's instructions. Readings will be recorded in parts per million (ppm) and only after they have become reasonably stable.

Any levels of $\mathrm{CO}$ in the household proper above $40 \mathrm{ppm}$ warrants a closer inspection of the space-heating system. A level of $\mathrm{CO}$ greater than $100 \mathrm{ppm}$ in the flue gas signals that the oil burner should be inspected (higher CO levels may occur in gas-fired systems). High smoke numbers measured during an efficiency test will likely accompany high $\mathrm{CO}$ readings in oil-burning systems.

1. Turn the carbon monoxide monitoring instrument on and allow it to warm up for one minute. Carefully obtain a "zero" instrument reading outside the house away from any combustion sources (running automobile engines, lawn mowers, etc.) The meter will usually not read zero, so note the reading.

2. After turning on the space- and water-heating systems, measure the $\mathrm{CO}$ in both flue gases before the barometric damper (this step can be coordinated with an efficiency test if one is to be performed).

3. Measure the $\mathrm{CO}$ in the room containing the space-heating system within 5 feet of the system.

4. Measure the $\mathrm{CO}$ in the kitchen and living room (the living room is defined to be the main living area of the house, usually characterized by the room with a television in it). Note if a gas stove top, gas oven, or fossil-fueled space heater were operating during the tests. Note any flue-gas odors in the house (also determine if the occupants have noticed any odors in the house when the system is operating).

5. For a forced-air or gravity furnace, measure the $\mathrm{CO}$ in the register with the shortest ducting from the space-heating system. 
Version: April 26, 1991

Inspector:

Date:

FUEL-OIL STUDY SYSTEM SAFETY INSPECTION FORM

\section{IDENTIFICATION}

House ID: Subgrantee name:

Occupant name: Phone number:

Occupant address:

\section{GENERAL SPACE-HEATING SYSTEM INSPECTION}

\begin{tabular}{|l|l||}
\hline $\begin{array}{l}\text { Type (FAF-central forced-air furnace, GF-central gravity } \\
\text { furnace, SB-steam boiler, HWBR-hot water boiler with radiators } \\
\text { or convertors, HWBS-hot water boiler for slab heating) }\end{array}$ & \\
\hline Thermostat on/off operating (Y,N) & \\
\hline Electrical cutoff switch present (Y,N) & \\
\hline Wiring secure (Y,N) & \\
\hline Furnace fan on/off temperature switches present (Y,N,NA) & \\
\hline \multicolumn{1}{|c||}{ If yes: Upper setting ${ }^{\circ} \mathrm{F}$ Lower setting ${ }^{\circ} \mathrm{F}$} & \\
\hline Boiler operating temperature ( ${ }^{\circ} \mathrm{F}$ or NA) & \\
\hline High limit switch settings (none, $\left.{ }^{\circ} \mathrm{F}, \mathrm{psi}\right)$ & \\
\hline Combustible materials near flue (Y,N) & \\
\hline Asbestos insulation present on system (Y,N) & \\
\hline
\end{tabular}

\section{GENERAL DOMESTIC WATER-HEATING SYSTEM INSPECTION}

\begin{tabular}{||l|c|}
\hline Type (SA-stand alone, T-tankless) & \\
\hline Fuel (NG-natural gas, P-propane, O-oil, E-electricity) & \\
\hline Combustible materials near flue (Y,N,NA) & \\
\hline Pressure relief valve present (Y,N) & \\
\hline $\begin{array}{l}\text { Temperature setting ( }{ }^{\circ} \mathrm{F} \text { or NA) (record highest } \\
\text { setting for electrically heated systems) }\end{array}$ & \\
\hline
\end{tabular}


House ID:

FUEL LEAKS

\begin{tabular}{||l|c|}
\hline & Leak \\
\hline Space-heating system supply line (Y,N) & \\
\hline Water-heating system supply line (Y,N,NA) & \\
\hline Above ground storage tank (Y,N,NA) & \\
\hline
\end{tabular}

Is a filter and shutoff valve present in the supply line leading from the storage tank? $(\mathrm{Y}, \mathrm{N})$

\section{SPACE-HEATING DISTRIBUTION SYSTEM}

\begin{tabular}{|l|c|}
\hline \multicolumn{2}{|c|}{ Forced-air or gravity furnaces } \\
\hline \hline Circulating fan operating (Y,N,NA) & \\
\hline Condition of air filters (N-none, C-clean, D-dirty, P-plugged) & \\
\hline Exit temperature of supply air & \\
\hline \hline
\end{tabular}

\begin{tabular}{|l|l|}
\hline \multicolumn{2}{|c|}{ Boilers } \\
\hline \hline Circulating pump operating $(\mathrm{Y}, \mathrm{N}, \mathrm{NA})$ & \\
\hline Zone valves operating $(\mathrm{Y}, \mathrm{N}, \mathrm{NA})$ & \\
\hline Leaks exist $(\mathrm{Y}, \mathrm{N})$ & \\
\hline
\end{tabular}

Is asbestos insulation present on the distribution system? $(\mathrm{Y}, \mathrm{N})$ 
House ID:

FLUE AND CHIMNEY INSPECTION

\begin{tabular}{|c|c|c|}
\hline & $\begin{array}{l}\text { Space-heating } \\
\text { system }\end{array}$ & $\begin{array}{c}\text { Water-heating } \\
\text { system }\end{array}$ \\
\hline \multicolumn{3}{|l|}{ Structurally sound (Y,N,NA) } \\
\hline \multicolumn{3}{|c|}{ Chimney extends $>2 \mathrm{ft}$ above roof $(\mathrm{Y}, \mathrm{N}, \mathrm{NA})$} \\
\hline \multicolumn{3}{|c|}{ Clearance at chimney top $>10 \mathrm{ft}(\mathrm{Y}, \mathrm{N}, \mathrm{NA})$} \\
\hline \multicolumn{3}{|l|}{ Leaks exist (Y,N,NA) } \\
\hline \multicolumn{3}{|l|}{ Thick debris present (Y,N,NA) } \\
\hline \multicolumn{3}{|l|}{ Flue liner present $(\mathrm{Y}, \mathrm{N}, \mathrm{NA})$} \\
\hline \multicolumn{3}{|c|}{ Barometric damper (space-heating systems only): } \\
\hline \multicolumn{3}{|l|}{ Exists $(Y, N)$} \\
\hline Functions correctly $(\mathrm{Y}, \mathrm{N}, \mathrm{NA})$ & & \\
\hline
\end{tabular}

\section{SPACE- AND WATER-HEATING SYSTEM DRAFTS}

\begin{tabular}{|c|c|c|}
\hline Outdoor temperature: ${ }^{\circ} \mathrm{F}$ & Space-heating system & Water-heating system \\
\hline Draft with system off & in. water & in. water \\
\hline Time to stop backdrafting & seconds & seconds \\
\hline \multicolumn{3}{|l|}{ Draft with system on } \\
\hline 30 seconds & in. water & in. water \\
\hline 1 minute & in. water & in. water \\
\hline 2 minutes & in. water & in. water \\
\hline 3 minutes & in. water & in. water \\
\hline \multicolumn{3}{|c|}{$\begin{array}{l}\text { Pressure difference between space-heating system room and outside (positive number } \\
\text { indicates that the basement is depressurized relative to the outside): }\end{array}$} \\
\hline space-heating system on & in. water & \\
\hline space-heating system off & in. water & \\
\hline
\end{tabular}


CARBON MONOXIDE TESTING

House ID:

\begin{tabular}{|l|r|}
\hline Ambient & $\mathrm{ppm}$ \\
\hline Space-heating system flue gas & $\mathrm{ppm}$ \\
\hline Water-heating system flue gas & $\mathrm{ppm}$ \\
\hline Five feet from space-heating system & $\mathrm{ppm}$ \\
\hline Kitchen & $\mathrm{ppm}$ \\
\hline Living room & $\mathrm{ppm}$ \\
\hline Register (ppm or NA) & $\mathrm{ppm}$ \\
\hline \multicolumn{2}{|c|}{} \\
\hline Were the following operating during the test: \\
\hline Gas stove top (Y,N) & \\
\hline Gas oven (Y,N) & \\
\hline Fossil-fuel space-heater (Y,N) & \\
\hline
\end{tabular}

\section{HEAT EXCHANGER}

\begin{tabular}{||l|r|}
\hline Cracks observed visually (Y,N,NA) & \\
\hline Percent oxygen reading before blower turns on & $\%$ \\
\hline Percent oxygen reading after blower turns on & $\%$ \\
\hline Flue gas odor noticed in house (Y,N,NA) & \\
\hline
\end{tabular}

\section{COMMENTS}


APPENDIX G. TABLES OF OCCUPANT AND HOUSE CHARACTERISTICS 

Table G.1. Summary statistics concerning occupants

CONTROL HOUSES (TOTAL OBSERVATIONS: 99)

\begin{tabular}{||c|c|c|c|c|c|}
\hline Statistics & Year built & Year moved in & Age < 5 & Age 5-17 & Age 18-64 \\
\hline \hline Number & 92 & 95 & 30 & 37 & 71 \\
Minimum & 1890.000 & 1935.000 & 1.000 & 1.000 & 1.000 \\
Maximum & 1990.000 & 1991.000 & 4.000 & 5.000 & 5.000 \\
Mean & 1930.511 & 1972.242 & 1.767 & 2.108 & 1.901 \\
Standard deviation & 30.545 & 16.214 & 0.817 & 1.173 & 0.897 \\
\hline Statistics & Age $65+$ & Total 0ccupants & Income (\$/year) & Mortgage (\$/month) & Rent (\$/month) \\
\hline \hline Number & 39 & 97 & 89 & 86 & 9 \\
Minimum & 1.000 & 1.000 & 2840.000 & 0.000 & 100.000 \\
Maximum & 3.000 & 9.000 & 22588.000 & 950.000 & 650.000 \\
Mean & 1.333 & 3.247 & 11101.910 & 199.430 & 355.556 \\
Standard deviation & 0.530 & 1.877 & 4718.910 & 261.978 & 170.375 \\
\hline
\end{tabular}

WEATHERIZED HOUSES (TOTAL OBSERVATIONS: 207)

\begin{tabular}{||c|c|c|c|c|c||}
\hline Statistics & Year built & Year moved in & Age < 5 & Age 5-17 & Age 18-64 \\
\hline Number & 191 & 195 & 43 & 78 & 137 \\
Minimum & 1890.000 & 1915.000 & 1.000 & 1.000 & 1.000 \\
Maximum & 1986.000 & 1991.000 & 3.000 & 6.000 & 5.000 \\
Mean & 1927.209 & 1972.364 & 1.395 & 2.090 & 1.752 \\
Standard deviation & 30.356 & 17.360 & 0.583 & 1.164 & 0.784 \\
\hline Statistics & Age 65+ & Total occupants & Income (\$/year) & Mortgage (\$/month) & Rent (\$/month) \\
\hline \hline Number & 86 & 198 & 196 & 161 & 28 \\
Minimum & 1.000 & 1.000 & 1096.960 & 0.000 & 100.000 \\
Maximum & 2.000 & 10.000 & 25049.000 & 950.000 & 650.000 \\
Mean & 1.186 & 2.843 & 10763.451 & 192.547 & 326.786 \\
Standard deviation & 0.391 & 1.842 & 5029.347 & 262.988 & 157.810 \\
\hline
\end{tabular}

ALL HOUSES (TOTAL OBSERVATIONS: 306)

\begin{tabular}{|c|c|c|c|c|c||}
\hline Statistics & Year built & Year moved in & Age < 5 & Age 5-17 & Age 18-64 \\
\hline Number & 283 & 290 & 73 & 115 & 208 \\
Minimum & 189.000 & 1915.000 & 1.000 & 1.000 & 1.000 \\
Maximum & 1990.000 & 1991.000 & 4.000 & 6.000 & 5.000 \\
Mean & 1928.283 & 1972.324 & 1.548 & 2.096 & 1.803 \\
Standard deviation & 30.403 & 16.965 & 0.708 & 1.162 & 0.825 \\
\hline \hline Statistics & Age 65+ & Total occupants & Income (\$/year) & Mortgage (\$/month) & Rent (\$/month) \\
\hline Number & 125 & 295 & 285 & 247 & 37 \\
Minimum & 1.000 & 1.000 & 1096.960 & 0.000 & 100.000 \\
Maximum & 3.000 & 10.000 & 25049.000 & 950.000 & 650.000 \\
Mean & 1.232 & 2.976 & 10869.017 & 194.943 & 333.784 \\
Standard deviation & 0.442 & 1.860 & 4928.711 & 262.125 & 159.013 \\
\hline
\end{tabular}


Table G.2. Distribution of various house parameters for the control and weatherized houses

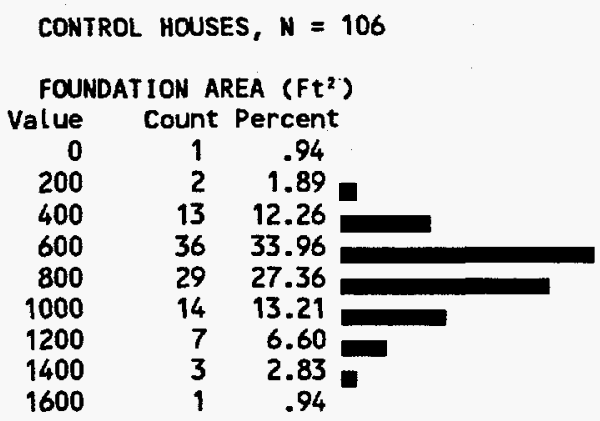

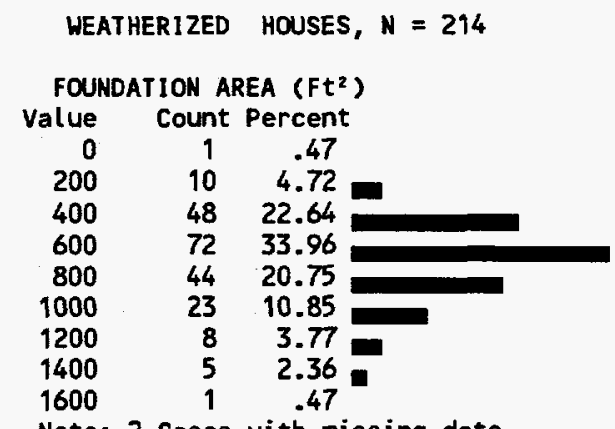

Note: 2 Cases with missing data.

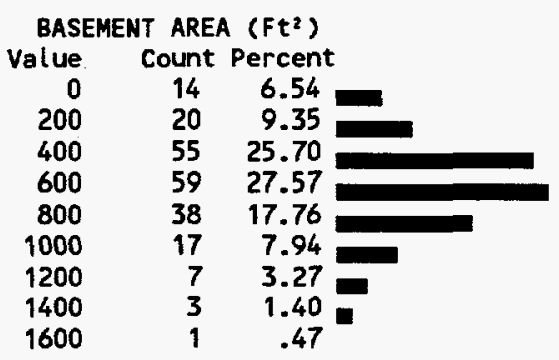

LIVING AREA ( $F \mathrm{t}^{2}$ )

Value Count Percent

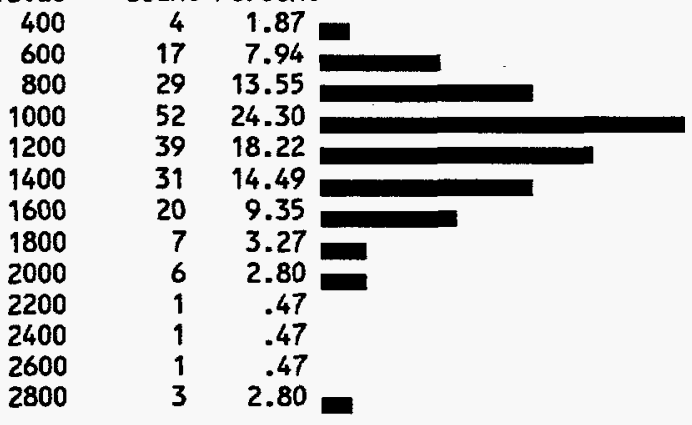

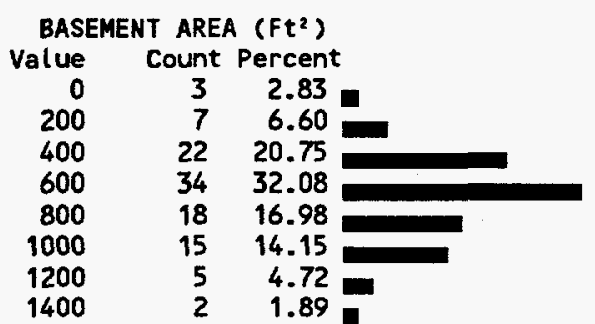

LIVING AREA ( $\mathrm{Ft}^{2}$ )

$\begin{array}{rrrl}\text { Value } & \text { Count } & \text { Percent } \\ 400 & 0 & .00 \\ 600 & 7 & 6.60 & = \\ 800 & 12 & 11.32 & \\ 1000 & 20 & 18.87 & \\ 1200 & 21 & 19.81 & \\ 1400 & 21 & 19.81 & \\ 1600 & 11 & 10.38 & \\ 1800 & 6 & 5.66 & \square \\ 2000 & 3 & 2.83 & \square \\ 2200 & 0 & .00 \\ 2400 & 4 & 3.77 & \\ 2600 & 1 & .94\end{array}$

HEATED LIVING AREA $\left(\mathrm{Ft}^{2}\right)$

\begin{tabular}{|c|c|c|}
\hline $\begin{array}{l}\text { Value } \\
400.000 \\
600.000 \\
800.000 \\
1000.000 \\
1200.000 \\
1400.000 \\
1600.000 \\
1800.000 \\
2000.000 \\
2200.000 \\
2400.000 \\
2600.000\end{array}$ & $\begin{array}{c}\text { Count } \\
0 \\
8 \\
13 \\
19 \\
20 \\
21 \\
12 \\
4 \\
3 \\
1 \\
3 \\
1\end{array}$ & $\begin{array}{c}\text { Percent } \\
.00 \\
7.62 \\
12.38 \\
18.10 \\
19.05 \\
20.00 \\
11.43 \\
3.81= \\
2.86= \\
.95 \\
2.86= \\
.95\end{array}$ \\
\hline
\end{tabular}

Note: 1 Case with missing data.
HEATED LIVING AREA (Ft ${ }^{2}$ )

Value count Percent

$400 \quad 7 \quad 3.27=$

$\begin{array}{lll}600 & 22 & 10.28\end{array}$

$800 \quad 37 \quad 17.29$

$1000 \quad 50 \quad 23.36$

$1200 \quad 32 \quad 14.95$

$\begin{array}{lll}1400 & 27 & 12.62\end{array}$

1600

1800

2000

2200

2400

2600

$2800+$
12.62

$2.80=$

2.34

.47

.47

.00

1.86 
Table G.2. Distribution of various house parameters for the control and weatherized houses (continued)

CONTROL HOUSES, $N=106$

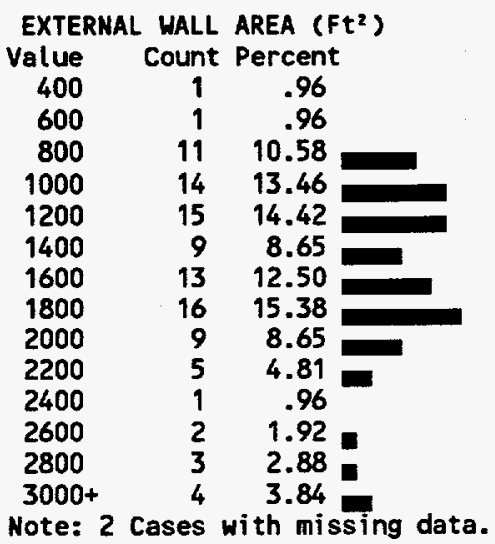

WINDOW AREA ( $\mathrm{Ft}^{2}$ )

\begin{tabular}{|c|c|c|}
\hline $\begin{array}{c}25 \\
50 \\
75 \\
100 \\
125 \\
150 \\
175 \\
200 \\
225 \\
250 \\
275 \\
300 \\
325 \\
350 \\
375+\end{array}$ & $\begin{array}{r}0 \\
3 \\
5 \\
15 \\
18 \\
17 \\
16 \\
11 \\
4 \\
6 \\
3 \\
5 \\
0 \\
0 \\
3\end{array}$ & $\begin{array}{r}.00 \\
2.83 \\
4.72 \\
14.15 \\
16.98 \\
16.04 \\
15.09 \\
10.38 \\
3.77 \\
5.66 \\
2.83 \\
4.72 \\
.00 \\
.00 \\
2.83\end{array}$ \\
\hline
\end{tabular}

FINISHED ATTIC AREA (Ft' $\left.{ }^{2}\right)$

Value Count Percent

$\begin{array}{rrr}0 & 2 & 7.69 \\ 200 & 1 & 3.85 \\ 400 & 4 & 15.38 \\ 600 & 6 & 23.08 \\ 800 & 6 & 23.08 \\ 1000 & 3 & 11.54 \\ 1200 & 3 & 11.54 \\ 1400 & 0 & .00 \\ 1600 & 1 & 3.85 \\ \text { Note: } 2 & \text { Cases with missing data. }\end{array}$

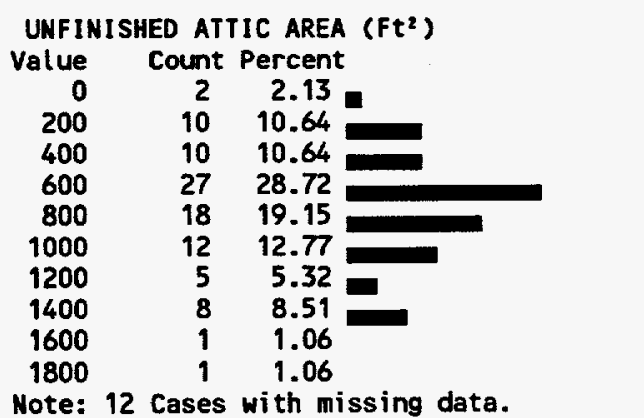

HEATHERIZED HOUSES, $N=214$

EXTERNAL WALL AREA ( $\mathrm{Ft}^{2}$ )

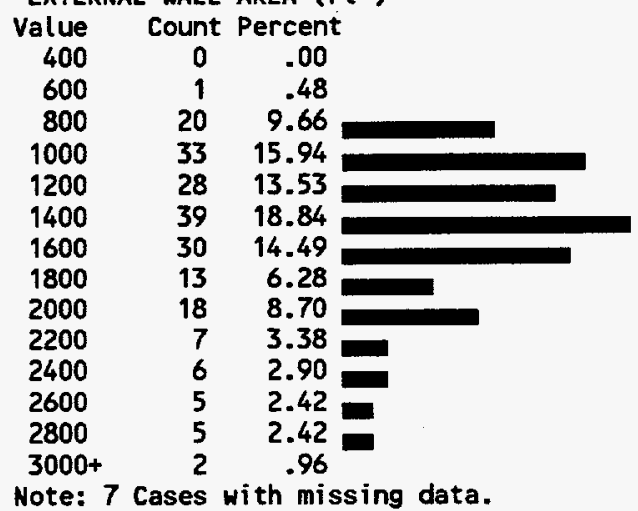

WINDOW AREA $\left(\mathrm{Ft}^{2}\right)$

Value Count Percent

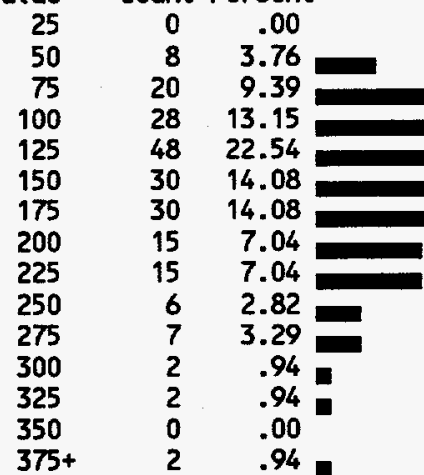

Note: 1 Case with missing data.

$\begin{array}{lcc}\text { FINISHED ATtIC AREA (Ft } & \text { ) } \\ \text { Value } & \text { Count } & \text { Percent } \\ 0 & 1 & 1.59 \\ 200 & 10 & 15.87 \\ 400 & 12 & 19.05 \\ 600 & 14 & 22.22 \\ 800 & 15 & 23.81 \\ 1000 & 9 & 14.29 \\ 1200 & 1 & 1.59 \\ 1400 & 0 & .00 \\ 1600 & 1 & 1.59 \\ \text { Note: } 151 \text { Cases with missing data. }\end{array}$

UNFINISHED ATTIC AREA $\left(\mathrm{Ft}^{2}\right)$

Value Count Percent

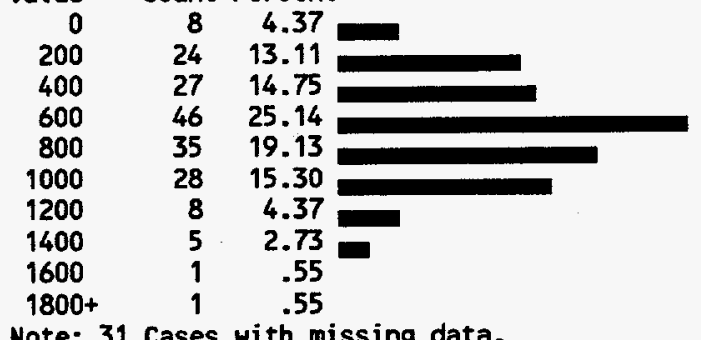


Table G.2. Distribution of various house parameters for the control and weatherized houses (continued)

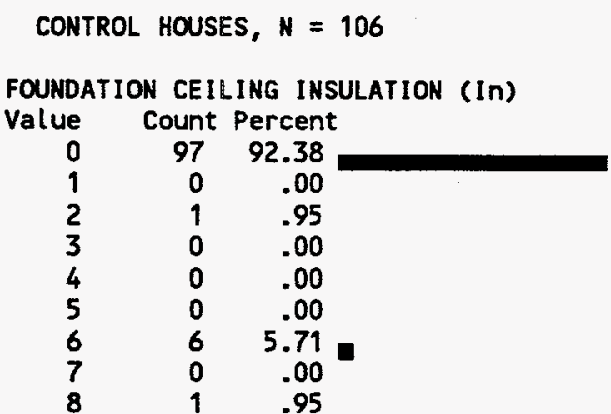

Note: 1 Case with missing data.

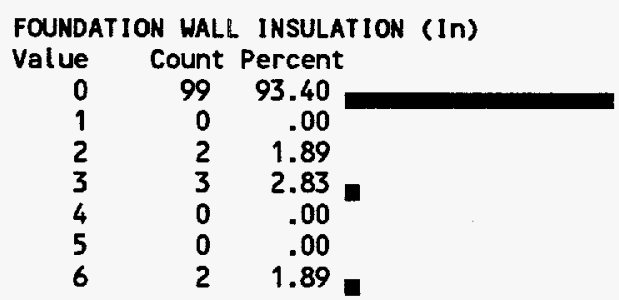

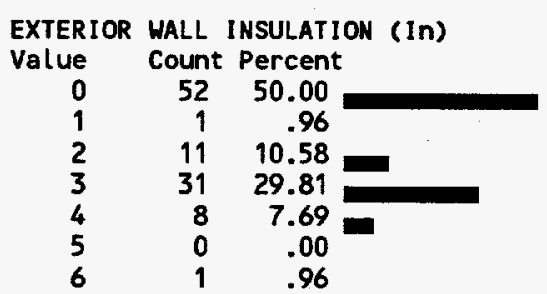

Note: 2 Cases with missing data.

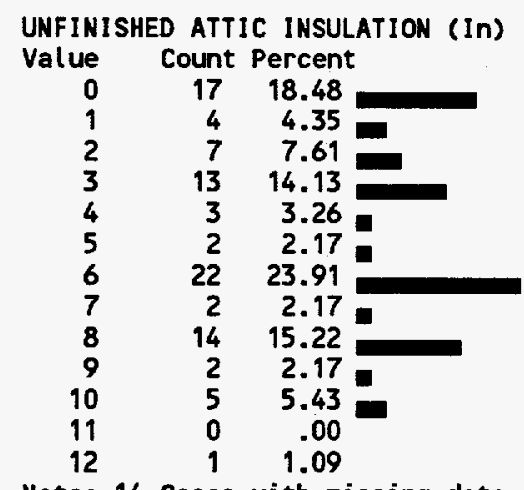

Note: 14 Cases with missing data.
WEATHERIZED HOUSES, $N=214$

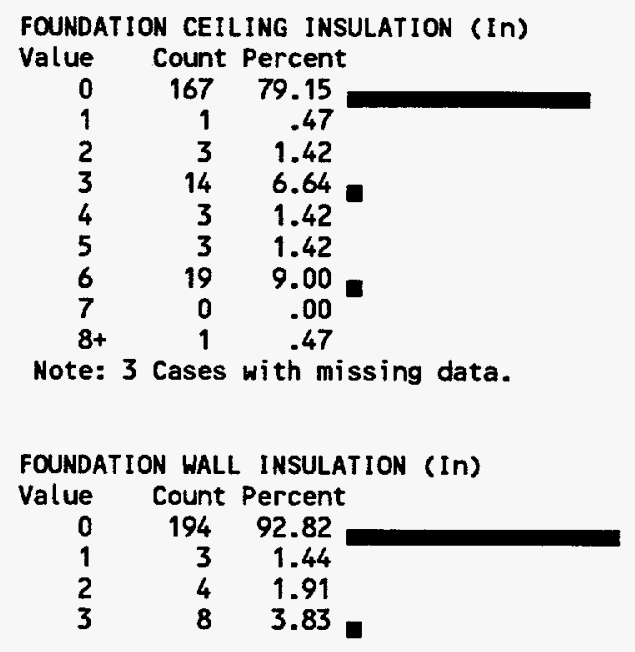

Note: 34 Cases with missing data.

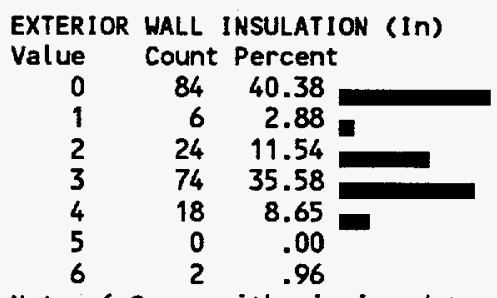

Note: 6 Cases with missing data.

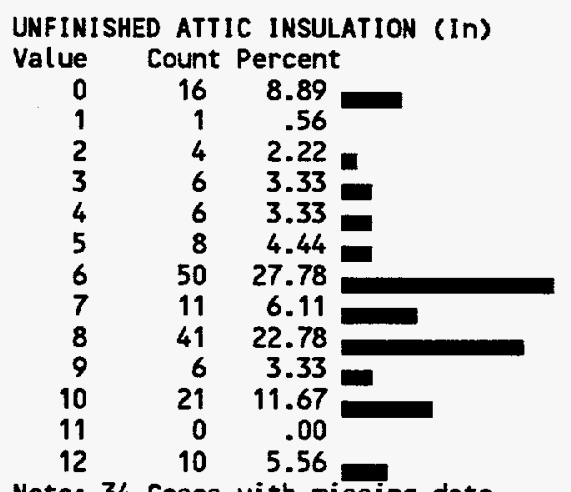

Note: 34 Cases with missing data. 
Table G.2. Distribution of Various House Parameters for the control and weatherized houses (continued)

CONTROL HOUSES, $N=106$

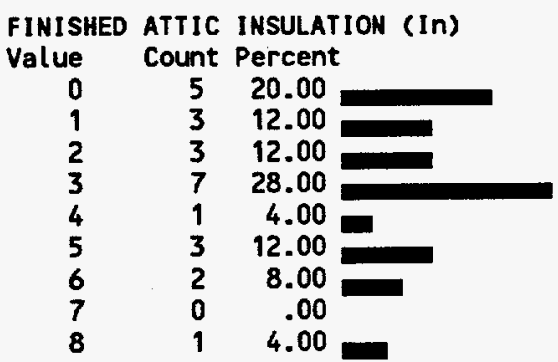

Note: 81 Cases with missing data.

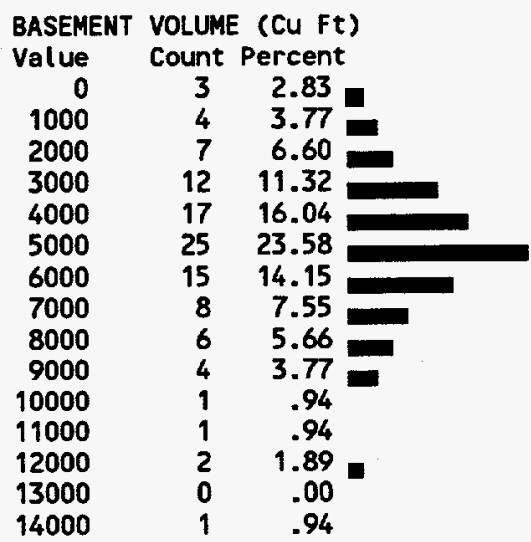

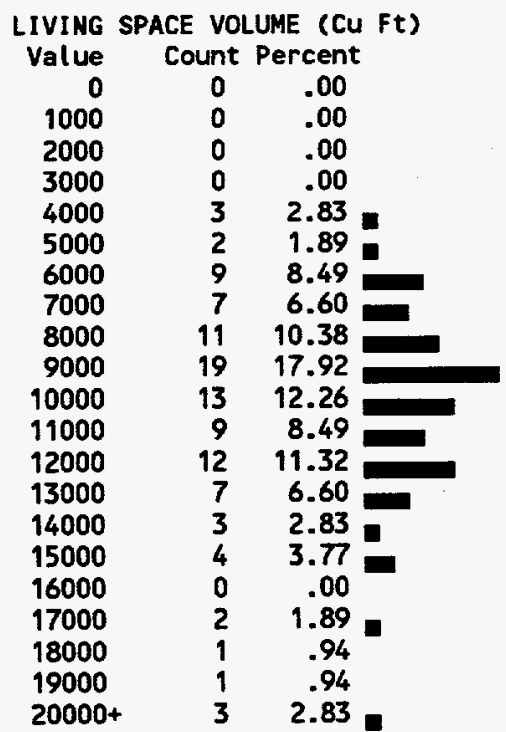

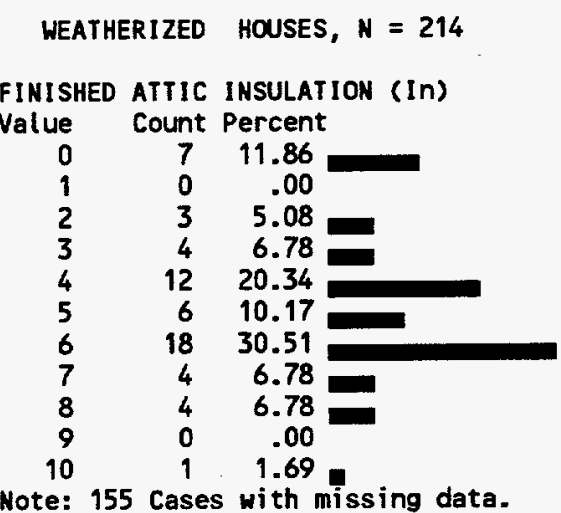

BASEMENT VOLUME (CU Ft)

Value Count Percent

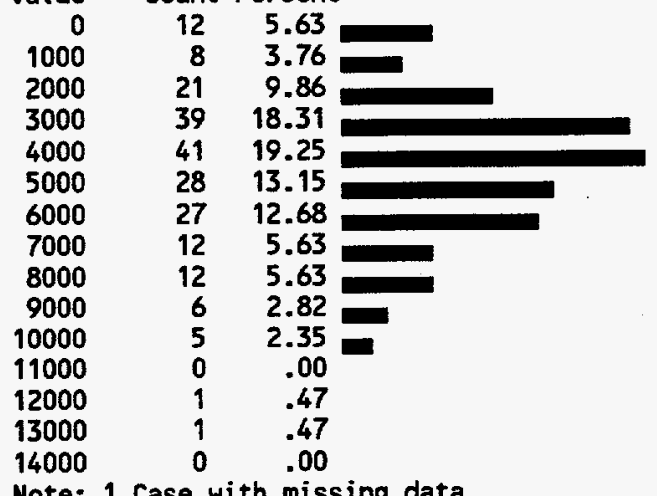

Note: 1 Case with missing data.

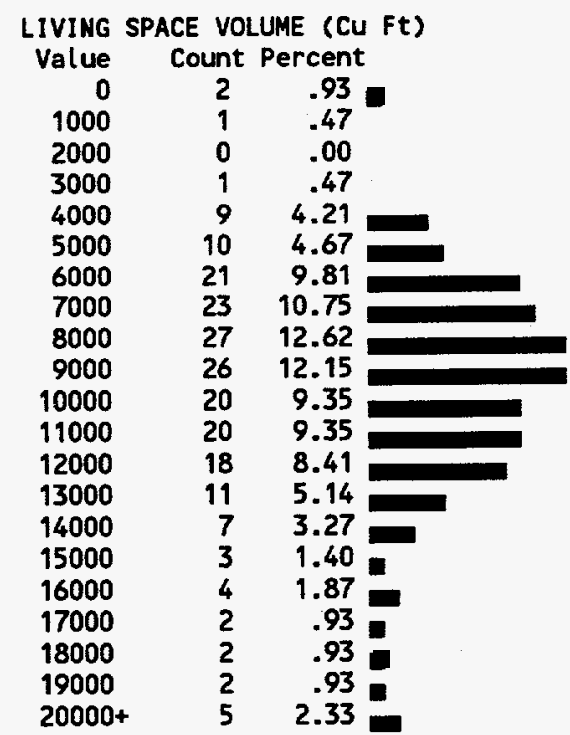


Table G.2. Distribution of various house parameters for the control and weatherized houses (continued)

ESTIMATED YEAR IN WHICH HOUSE WAS BUILT

\begin{tabular}{lcc}
\multicolumn{3}{c}{ CONTROL HOUSES, $N=92$} \\
Value & Count & Percent \\
1890 & 24 & 26.09 \\
1900 & 6 & 6.52 \\
1910 & 6 & 6.52 \\
1920 & 5 & 5.43 \\
1930 & 9 & 9.78 \\
1940 & 9 & 9.78 \\
1950 & 15 & 16.30 \\
1960 & 11 & 11.96 \\
1970 & 5 & 5.43 \\
1980 & 1 & 1.09 \\
1990 & 1 & 1.09 \\
Note: 4 Cases with missing data
\end{tabular}

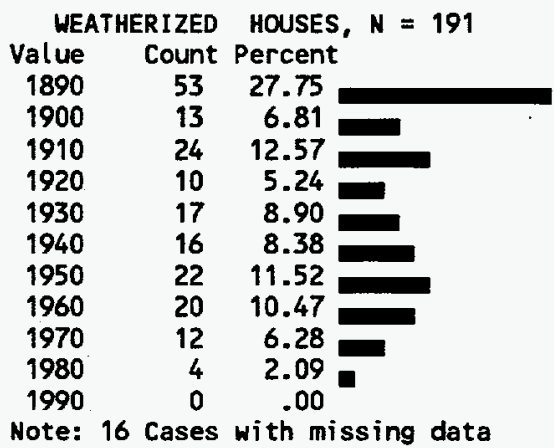

YEAR THAT OCCUPANT MOVED INTO HOUSE

CONTROL HOUSES, $N$ a 95

value Count Percent

1910

1920

1930

1940

1950

1960

1970

1980

1990

Note: 4 Cases with missing data

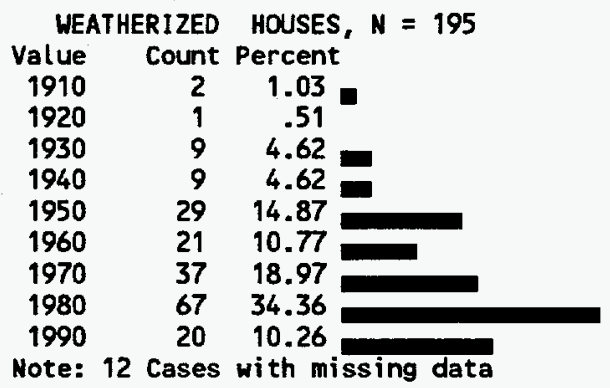

NUMBER OF OCCUPANTS IN EACH HOUSE
CONTROL HOUSES, $\mathrm{N}=97$

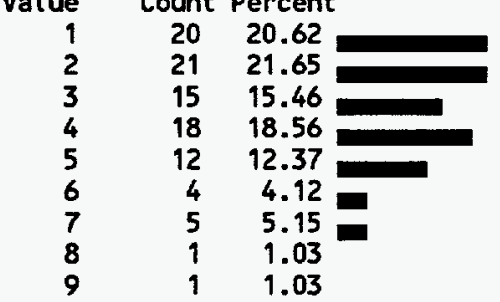

Note: 2 Cases with missing data

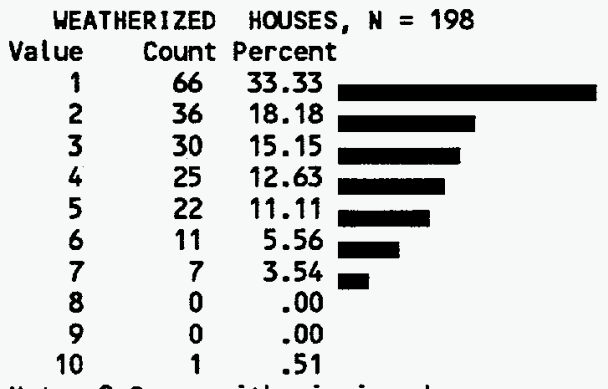

Note: 9 Cases with missing daxa 
Table G.2. Distribution of various house parameters for the control and weatherized houses (continued)

MONTHLY RENTAL/MORTGAGE PAYMENTS BY OCCUPANTS

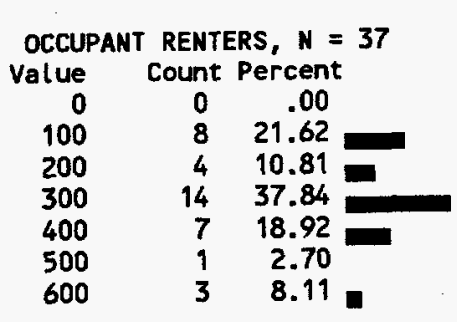

\begin{tabular}{rrr}
\multicolumn{3}{c}{ OCCUPANT OHNERS, $N=249$} \\
Value & Count & Percent \\
0 & 131 & 52.61 \\
100 & 18 & 7.23 \\
200 & 28 & 11.24 \\
300 & 18 & 7.23 \\
400 & 19 & 7.63 \\
500 & 9 & 3.61 \\
600 & 8 & 3.21 \\
700 & 8 & 3.21 \\
800 & 5 & 2.01 \\
900 & 5 & 2.01
\end{tabular}

ANNUAL INCOME

\begin{tabular}{rrr}
\multicolumn{4}{c}{ CONTROL } & HOUSES, $N=104$ \\
Value & Count & Percent \\
0 & 0 & .00 \\
2000 & 4 & 3.85 \\
4000 & 11 & 10.58 \\
6000 & 13 & 12.50 \\
8000 & 24 & 23.08 \\
10000 & 18 & 17.31 \\
12000 & 12 & 11.54 \\
14000 & 2 & $1.92=$ \\
16000 & 8 & 7.69 \\
18000 & 5 & $4.81=$ \\
20000 & 3 & 2.88 \\
22000 & 4 & 3.85
\end{tabular}

Note: 7 Cases with missing data

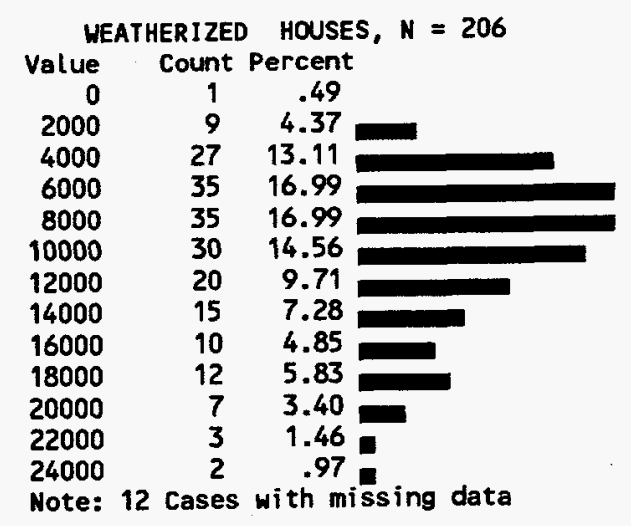


Table G.3. Survey statistics concerning house physical characteristics

\begin{tabular}{|c|c|c|c|}
\hline Statistics & $\begin{array}{c}\text { Foundation } \\
\text { ceiling area }\end{array}$ & $\begin{array}{c}\text { Basement } \\
\text { area }\end{array}$ & $\begin{array}{c}\text { Basement } \\
\text { volume }\end{array}$ \\
\hline \hline Number & 318 & 320 & 319 \\
Minimum & 150.000 & 0.000 & 0.000 \\
Maximum & 1752.000 & 1752.000 & 14688.000 \\
Mean & 786.506 & 693.672 & 5094.364 \\
Standard deviation & 268.926 & 307.457 & 2490.794 \\
\hline
\end{tabular}

\begin{tabular}{|c|c|c|c|}
\hline Statistics & $\begin{array}{c}\text { Living space } \\
\text { total area }\end{array}$ & $\begin{array}{c}\text { Living space } \\
\text { heated area }\end{array}$ & $\begin{array}{c}\text { Living space } \\
\text { volume }\end{array}$ \\
\hline Number & 320 & 320 & 320 \\
Minimum & 480.000 & 0.000 & 89.000 \\
Maximum & 3520.000 & 3452.000 & 26926.000 \\
Mean & 1332.300 & 1274.188 & 10239.353 \\
Standard deviation & 464.954 & 451.237 & 3832.519 \\
\hline
\end{tabular}

\begin{tabular}{|c|c|c|}
\hline Statistics & Exterior wall area & Window area \\
\hline \hline Number & 311 & 319 \\
Minimum & 448.000 & 50.000 \\
Maximum & 5240.000 & 563.000 \\
Mean & 1608.942 & 169.107 \\
Standard deviation & 582.297 & 68.835 \\
\hline
\end{tabular}

\begin{tabular}{|c|c|c|}
\hline Statistics & Finished attic area & Unfinished attic area \\
\hline \hline Number & 89 & 277 \\
Minimum & 52.000 & 78.000 \\
Maximum & 1700.000 & 2329.000 \\
Mean & 736.472 & 782.068 \\
Standard deviation & 328.717 & 362.325 \\
\hline
\end{tabular}


Table G.4. Summary statistics concerning windows and exterior doors

\begin{tabular}{||c|c|c|c|c|c|c||}
\hline \multirow{2}{*}{ Type of window } & \multicolumn{2}{|c|}{ Control } & \multicolumn{2}{c|}{ Weatherized } & \multicolumn{2}{c|}{ All houses } \\
\cline { 2 - 8 } & Number & Percent & Number & Percent & Number & Percent \\
\hline \hline Single pane total & 95 & 90 & 179 & 85 & 274 & 87 \\
Wood & 92 & 96 & 175 & 97 & 267 & 97 \\
Metal & 3 & 4 & 3 & 2 & 6 & 2 \\
Vinyl & 0 & 0 & 1 & 1 & 1 & 1 \\
\hline Double pane total & 10 & 10 & 32 & 15 & 42 & 13 \\
Hood & 3 & 30 & 12 & 38 & 15 & 36 \\
Metal & 2 & 20 & 5 & 15 & 7 & 17 \\
Vinyl & 5 & 50 & 15 & 47 & 20 & 47 \\
Storm window total & 83 & 79 & 150 & 71 & 233 & 74 \\
Wood & 5 & 6 & 8 & 5 & 13 & 6 \\
Metal & 77 & 93 & 141 & 94 & 218 & 93 \\
Vinyl & 1 & 1 & 1 & 1 & 2 & 1 \\
\hline
\end{tabular}

Note: Number means number of houses, rather than number of windows.

Total means number of houses with window type.

\begin{tabular}{|c|c|c|c|c|c|c|c|c|}
\hline & \multicolumn{8}{|c|}{ Number of exterior doors } \\
\hline & 0 & 1 & 2 & 3 & 4 & 5 & 6 & 7 \\
\hline $\begin{array}{l}\text { Control houses: } \\
\text { All doors } \\
\text { Doors with storm doors }\end{array}$ & 14 & $\begin{array}{c}4 \\
12 \\
\end{array}$ & $\begin{array}{l}70 \\
62 \\
\end{array}$ & $\begin{array}{l}30 \\
17 \\
\end{array}$ & $\begin{array}{l}1 \\
1 \\
\end{array}$ & $\begin{array}{l}1 \\
0 \\
\end{array}$ & $\begin{array}{l}0 \\
0 \\
\end{array}$ & $\begin{array}{l}0 \\
0\end{array}$ \\
\hline $\begin{array}{l}\text { Weatherized houses: } \\
\text { All doors } \\
\text { Doors with storm doors }\end{array}$ & 26 & $\begin{array}{l}10 \\
38 \\
\end{array}$ & $\begin{array}{l}145 \\
120 \\
\end{array}$ & $\begin{array}{l}50 \\
27 \\
\end{array}$ & $\begin{array}{l}6 \\
1 \\
\end{array}$ & $\begin{array}{l}1 \\
0 \\
\end{array}$ & $\begin{array}{l}0 \\
0 \\
\end{array}$ & $\begin{array}{l}1 \\
0\end{array}$ \\
\hline $\begin{array}{l}\text { All houses: } \\
\text { All doors } \\
\text { Doors with storm doors }\end{array}$ & 40 & $\begin{array}{l}14 \\
50\end{array}$ & $\begin{array}{l}215 \\
182\end{array}$ & $\begin{array}{l}80 \\
44\end{array}$ & $\begin{array}{l}7 \\
2\end{array}$ & $\begin{array}{l}2 \\
0\end{array}$ & $\begin{array}{l}0 \\
0\end{array}$ & $\begin{array}{l}1 \\
0\end{array}$ \\
\hline
\end{tabular}

\begin{tabular}{|c|c|c|c|c|c|c|}
\hline \multirow{2}{*}{ Type of exterior door } & \multicolumn{2}{|c|}{ Control } & \multicolumn{2}{c|}{ Weatherized } & \multicolumn{2}{c|}{ All houses } \\
\cline { 2 - 8 } & Number & Percent & Number & Percent & Number & Percent \\
\hline \hline Wood, raised panel & 81 & 77 & 160 & 75 & 241 & 76 \\
Wood, solid core & 12 & 11 & 32 & 15 & 44 & 13 \\
Wood, hollow core & 11 & 10 & 17 & 8 & 28 & 9 \\
Metal, insulated & 2 & 2 & 3 & 2 & 5 & 2 \\
\hline
\end{tabular}


Table G.5. Summary of insulation types

CONTROL HOUSES

\begin{tabular}{||c|c|c|c|c|}
\hline Insulation type & $\begin{array}{c}\text { External } \\
\text { wall }\end{array}$ & $\begin{array}{c}\text { Unfinished } \\
\text { attic }\end{array}$ & $\begin{array}{c}\text { Finished } \\
\text { attic }\end{array}$ & $\begin{array}{c}\text { Foundation } \\
\text { wall }\end{array}$ \\
\hline \hline None & 50 & 17 & 5 & 99 \\
Blown cellulose & 17 & 35 & 4 & 0 \\
Blown fiberglass & 0 & 0 & 1 & 0 \\
Fiberglass batt & 30 & 33 & 10 & 7 \\
Blown rock wool & 2 & 4 & 2 & 0 \\
Rock wool batt & 1 & 2 & 2 & 0 \\
Rigid board, foam & 2 & 0 & 0 & 0 \\
Other & 2 & 2 & 1 & 0 \\
\hline Total & 104 & 93 & 25 & 106 \\
\hline
\end{tabular}

WEATHERIZED HOUSES

\begin{tabular}{|c|c|c|c|c|}
\hline Insulation type & $\begin{array}{c}\text { External } \\
\text { wall }\end{array}$ & $\begin{array}{c}\text { Unfinished } \\
\text { attic }\end{array}$ & $\begin{array}{c}\text { Finished } \\
\text { attic }\end{array}$ & $\begin{array}{c}\text { Foundation } \\
\text { wall }\end{array}$ \\
\hline \hline None & 83 & 16 & 7 & 195 \\
Blown cellulose & 66 & 110 & 37 & 2 \\
Blown fiberglass & 6 & 5 & 2 & 0 \\
Fiberglass batt & 45 & 37 & 12 & 10 \\
Blown rock wool & 1 & 9 & 0 & 0 \\
Rock wool batt & 4 & 2 & 0 & 0 \\
Rigid board, foam & 2 & 0 & 1 & 2 \\
Other & 1 & 0 & 0 & 0 \\
\hline \hline Total & 208 & 179 & 59 & 209 \\
\hline
\end{tabular}

AVERAGE INSULATION DEPTH IN INCHES

\begin{tabular}{|c|c|c|c|c|c|}
\hline & $\begin{array}{c}\text { External } \\
\text { wall }\end{array}$ & $\begin{array}{c}\text { Unfinished } \\
\text { attic }\end{array}$ & $\begin{array}{c}\text { Finished } \\
\text { attic }\end{array}$ & $\begin{array}{c}\text { Foundation } \\
\text { wall }\end{array}$ & $\begin{array}{c}\text { Foundation } \\
\text { ceiling }\end{array}$ \\
\hline Control house & 1.62 & 4.59 & 2.84 & 0.25 & 0.44 \\
\hline Weatherized house & 1.90 & 6.57 & 4.68 & 0.19 & 0.97 \\
\hline $\begin{array}{c}\text { Difference } \\
\text { (Weatherized minus } \\
\text { Control) }\end{array}$ & 0.28 & 1.98 & 1.84 & -0.06 & 0.53 \\
\hline
\end{tabular}


Table G.6. Occupant responses to type and amount of auxiliary fuel usage

\begin{tabular}{|c|c|c|c|c|c|c|c|c|}
\hline \multirow{3}{*}{$\begin{array}{c}\text { Auxiliary fuel type } \\
\text { No response }\end{array}$} & \multicolumn{4}{|c|}{ Control house usage } & \multicolumn{4}{|c|}{ Weatherized house usage } \\
\hline & \multicolumn{2}{|c|}{$\begin{array}{c}\text { Pre- } \\
\text { weatherization } \\
\text { period }\end{array}$} & \multicolumn{2}{|c|}{$\begin{array}{c}\text { Post- } \\
\text { weatherization } \\
\text { period }\end{array}$} & \multicolumn{2}{|c|}{$\begin{array}{c}\text { Pre- } \\
\text { weatherization } \\
\text { period }\end{array}$} & \multicolumn{2}{|c|}{$\begin{array}{c}\text { Post- } \\
\text { weatherization } \\
\text { period }\end{array}$} \\
\hline & 33 & $33 \%$ & 34 & $34 \%$ & 64 & $31 \%$ & 64 & $31 \%$ \\
\hline Did not use any & 47 & $71 \%$ & 49 & $74 \%$ & 92 & $64 \%$ & 110 & $77 \%$ \\
\hline Electricity & 9 & $14 \%$ & 6 & $9 \%$ & 17 & $12 \%$ & 12 & $8 \%$ \\
\hline Wood & 5 & $8 \%$ & 5 & $8 \%$ & 13 & $9 \%$ & 11 & $8 \%$ \\
\hline Kerosene & 2 & $3 \%$ & 2 & $3 \%$ & 7 & $5 \%$ & 3 & $2 \%$ \\
\hline Natural gas & 0 & $0 \%$ & 0 & $0 \%$ & 3 & $2 \%$ & 1 & $1 \%$ \\
\hline Coal & 0 & $0 \%$ & 0 & $0 \%$ & 2 & $1 \%$ & 1 & $1 \%$ \\
\hline More than one type & 3 & $4 \%$ & 3 & $4 \%$ & 9 & $7 \%$ & 5 & $3 \%$ \\
\hline Totals of responses & 66 & $100 \%$ & 65 & $100 \%$ & 143 & $100 \%$ & 143 & $100 \%$ \\
\hline
\end{tabular}

\begin{tabular}{|c|c|c|c|c|c|c|c|c|}
\hline \multirow{3}{*}{$\begin{array}{c}\begin{array}{c}\text { Percentage } \\
\text { of time } \\
\text { auxiliary fuel } \\
\text { used }\end{array} \\
\text { No response }\end{array}$} & \multicolumn{4}{|c|}{ Control house usage } & \multicolumn{4}{|c|}{ Weatherized house usage } \\
\hline & \multicolumn{2}{|c|}{$\begin{array}{c}\text { Pre- } \\
\text { weatherization } \\
\text { period }\end{array}$} & \multicolumn{2}{|c|}{$\begin{array}{c}\text { Post- } \\
\text { weatherization } \\
\text { period }\end{array}$} & \multicolumn{2}{|c|}{$\begin{array}{c}\text { Pre- } \\
\text { weatherization } \\
\text { period }\end{array}$} & \multicolumn{2}{|c|}{$\begin{array}{c}\text { Post- } \\
\text { weatherization } \\
\text { period }\end{array}$} \\
\hline & 33 & $33 \%$ & 34 & $34 \%$ & 64 & $31 \%$ & 64 & $31 \%$ \\
\hline Never used & 47 & $48 \%$ & 49 & $51 \%$ & 92 & $64 \%$ & 110 & $77 \%$ \\
\hline $50 \%$ of time & 0 & $0 \%$ & 0 & $0 \%$ & 9 & $6 \%$ & 4 & $3 \%$ \\
\hline $75 \%$ of time & 4 & $4 \%$ & 4 & $4 \%$ & 13 & $9 \%$ & 8 & $5 \%$ \\
\hline All the time & 15 & $15 \%$ & 12 & $12 \%$ & 29 & $20 \%$ & 22 & $15 \%$ \\
\hline Totals & 66 & $100 \%$ & 65 & $100 \%$ & 143 & $100 \%$ & 143 & $100 \%$ \\
\hline
\end{tabular}


Table G.7. Weatherized homes using auxiliary heat in both pre and post periods

\begin{tabular}{|c|c|c|c|c|c|}
\hline \multirow{2}{*}{$\begin{array}{l}\text { Number of } \\
\text { houses }\end{array}$} & \multicolumn{2}{|c|}{ Pre-weatherization } & \multicolumn{2}{|c|}{ Post-weatherization } & \multirow{2}{*}{$\begin{array}{c}\text { Change in } \\
\text { usage }\end{array}$} \\
\hline & $\begin{array}{c}\text { Type of } \\
\text { auxiliary heat }\end{array}$ & $\begin{array}{c}\text { Use } \\
\text { (\% of time) }\end{array}$ & $\begin{array}{c}\text { Type of } \\
\text { auxiliary heat }\end{array}$ & $\begin{array}{c}\text { Use } \\
\text { (\% of time) }\end{array}$ & \\
\hline 1 & Coal & $50 \%$ & Coal & $50 \%$ & None \\
\hline 7 & Electric & $100 \%$ & Electric & $100 \%$ & None \\
\hline 1 & Elec/Wood & $100 \%$ & Elec/Wood & $100 \%$ & None \\
\hline 1 & Elec/Wood & $50 \%$ & Elec/Wood & $75 \%$ & Increase \\
\hline 1 & Elec/Wood & $75 \%$ & Electric & $100 \%$ & Increase \\
\hline 2 & Kerosene & $100 \%$ & Kerosene & $100 \%$ & None \\
\hline 1 & Kerosene & $75 \%$ & Kerosene & $75 \%$ & None \\
\hline 1 & Kero/Elec & $?$ & Kero/Elec & $?$ & None \\
\hline 1 & Nat Gas & $75 \%$ & Nat Gas & $100 \%$ & Increase \\
\hline 1 & Other & $100 \%$ & Other & $100 \%$ & None \\
\hline 1 & Other & $75 \%$ & Other & $75 \%$ & None \\
\hline 5 & Wood & $100 \%$ & Wood & $100 \%$ & None \\
\hline 2 & Wood & $50 \%$ & Wood & $100 \%$ & Increase \\
\hline 1 & Wood & $50 \%$ & Wood & $50 \%$ & None \\
\hline 1 & Wood & $50 \%$ & Wood & $75 \%$ & Increase \\
\hline 2 & Wood & $75 \%$ & Wood & $75 \%$ & None \\
\hline
\end{tabular}


APPENDIX H. TABLES OF FUEL-OIL CONSUMPTIONS AND SAVINGS 


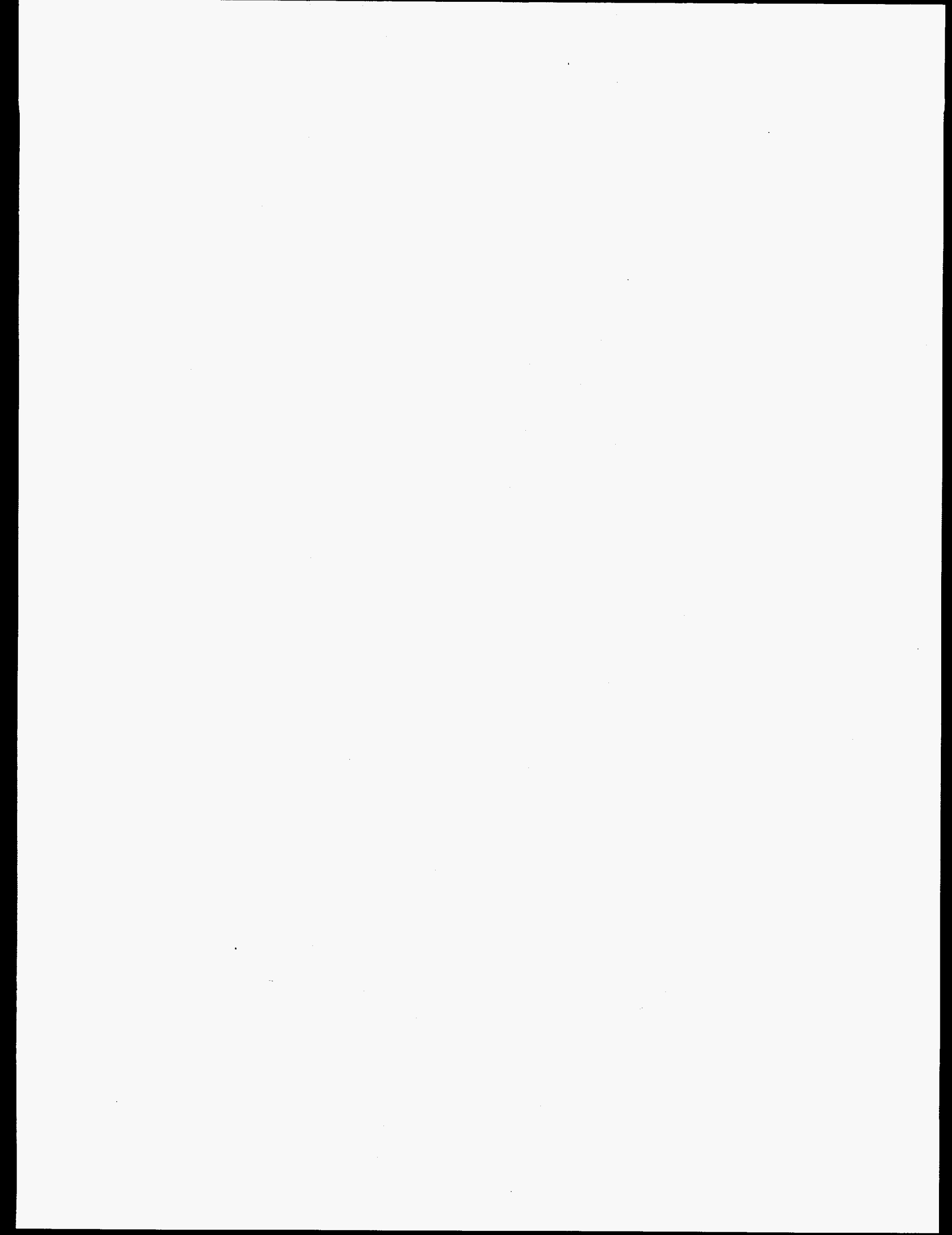


Table H.1. TMY weather file used for each local weatherization agency

\begin{tabular}{|c|c|c|c|}
\hline Agency & Location & TMY City & Heating degree days \\
\hline Community Action of Greater Middletown & Middletown, CT & Hartford, CT & 5900 \\
\hline The Community Renewal Team of Greater Hartford & Hartford, CT & Hartford, CT & 5900 \\
\hline Thames Valley Council Weatherization & Jewett City, CT & Hartford, CT & 5900 \\
\hline Franklin Community Action Corporation & Greenfield, MA & Albany, NY & 6205 \\
\hline North Shore Community Action Program & Peabody, MA & Boston, MA & 5336 \\
\hline South Shore Community Action Council & Plymouth, MA & Boston, MA & 5336 \\
\hline Springfield Action Commission & Springfield, MA & Hartford, CT & 5900 \\
\hline Community Action Program Inner City & Chelsea, MA & Boston, MA & 5366 \\
\hline Berkshire County Action Council Weatherization & Pittsfield, MA & Albany, NY & 6205 \\
\hline Lynn Economic Opportunity & Lynn, MA & Boston, MA & 5336 \\
\hline Kennebeck Valley Community Action Program & Waterville, ME & Bangor, ME & 7220 \\
\hline Southern Maine Technical College & So. Portland, ME & Portland, ME & 6523 \\
\hline Community Concepts, Inc. & So. Paris, ME & Bangor, ME & 7220 \\
\hline Southern New Hampshire & Manchester, NH & Concord, $\mathrm{NH}$ & 6728 \\
\hline Tri-County Community Action & Berlin, NH & Burlington, VT & 7123 \\
\hline Rockingham County Community Action & Portsmouth, NH & Portland, ME & 6523 \\
\hline Camden County Council of Economic Opportunity & Camden, NJ & Philadelphia, PA & 4780 \\
\hline Puerto Rican Action Board & New Brunswick, NJ & Newark, NJ & 4775 \\
\hline Test City Child Care Center & Bridgeton, NJ & Wilmington, DE & 4807 \\
\hline Cayuga County Action Program & Auburn, NY & Binghamton, NY & 6821 \\
\hline Stonleigh Housing, Inc. & Canastota, NY & Syracuse, NY & 6328 \\
\hline Greene County Community Action Agency & Catskill, NY & Albany, NY & 6205 \\
\hline People's Equal Action and Community Effort & Syracuse, NY & Syracuse, NY & 6328 \\
\hline Tompkins County Equal Opportunity Council & Ithaca, NY & Binghamton, NY & 6821 \\
\hline Albany County Opportunity, Inc. & Albany, NY & Albany, NY & 6205 \\
\hline Wyoming County Office for the Aging & Warsaw, NY & Buffalo, NY & 6116 \\
\hline Seneca County Weatherization & Seneca Falls, NY & Syracuse, NY & 6328 \\
\hline Livingston County Weatherization & Mt. Morris, NY & Buffalo, NY & 6116 \\
\hline Bedford County Weatherization & Everett, PA & Harrisburg, PA & 5016 \\
\hline Berks Community Action Program & Reading, PA & Allentown, PA & 5489 \\
\hline Council on Economic Opportunity & Wilkes-Barre, PA & Wilkes-Barre, PA & 5848 \\
\hline Weatherization Incorporated & Huntingdon, PA & Harrisburg, PA & 5016 \\
\hline Equal Opportunity Cabinet & Pottsville, PA & Allentown, PA & 5489 \\
\hline SEDA - Council of Governments & Lewisburg, PA & Wilkes-Barre, PA & 5848 \\
\hline South Central Community Action Program & Gettysburg, PA & Harrisburg, PA & 5016 \\
\hline Tri-Town Equal Opportunity Program & Johnson, RI & Providence, $\mathrm{RI}$ & 5617 \\
\hline Warwick Community Action & Warwick, RI & Providence, RI & 5617 \\
\hline Self Help, Inc. & E. Providence, RI & Providence, RI & 5617 \\
\hline Champlain Valley Office of Economic Opportunity & Burlington, VT & Burlington, VT & 7123 \\
\hline Northeast Employment and Training Organization & St. Johnsbury, VT & Burlington, VT & 7123 \\
\hline Central Vermont Community Action Council & Barre, VT & Burlington, VT & 7123 \\
\hline
\end{tabular}


Table H.2. Sumary of sample (Uneighted) results for 1990-1992

\begin{tabular}{|c|c|c|c|c|c|c|c|c|c|c|c|c|c|c|c|c|c|}
\hline 10 & $\begin{array}{l}\text { Test } \\
\text { Year }\end{array}$ & Type & $\mid \begin{array}{c}\text { Heated } \\
\text { Area } \\
\left(\mathrm{Ft}^{2}\right)\end{array}$ & \multicolumn{3}{|c|}{ Temperature $\left({ }^{\circ} \mathrm{F}\right)$} & \multicolumn{4}{|c|}{ Fuel-oil Usage Data (Gal/Year) } & \multicolumn{4}{|c|}{ Measured Statistics } & $\begin{array}{l}\text { HVAC } \\
\text { Type }\end{array}$ & \multicolumn{2}{|c|}{ DHW System } \\
\hline $\begin{array}{l}1 \\
2 \\
3 \\
4 \\
5 \\
6 \\
7 \\
8 \\
9 \\
10 \\
11 \\
12 \\
13 \\
14 \\
15 \\
16 \\
17 \\
18 \\
19 \\
20 \\
21 \\
22 \\
23 \\
24 \\
25 \\
26 \\
27 \\
28 \\
29 \\
30 \\
31 \\
32 \\
33 \\
34 \\
35 \\
36 \\
37 \\
38 \\
39 \\
40 \\
41 \\
42 \\
43 \\
44 \\
45 \\
46 \\
47 \\
48 \\
49 \\
50 \\
51 \\
52 \\
53 \\
54 \\
55 \\
56 \\
57 \\
58 \\
59 \\
60 \\
61 \\
62 \\
63 \\
64 \\
65 \\
66 \\
68 \\
\end{array}$ & $\begin{array}{l}1 \\
1 \\
1 \\
1 \\
1 \\
2 \\
1 \\
1 \\
1 \\
1 \\
2 \\
1 \\
1 \\
1 \\
1 \\
2 \\
1 \\
1 \\
2 \\
1 \\
2 \\
2 \\
1 \\
1 \\
1 \\
2 \\
2 \\
1 \\
1 \\
2 \\
1 \\
2 \\
1 \\
1 \\
2 \\
2 \\
2 \\
1 \\
2 \\
1 \\
1 \\
1 \\
1 \\
2 \\
1 \\
1 \\
2 \\
1 \\
1 \\
1 \\
1 \\
2 \\
2 \\
1 \\
2 \\
2 \\
2 \\
2 \\
1 \\
2 \\
1 \\
2 \\
1\end{array}$ & $\begin{array}{l}W \\
W \\
W \\
W \\
C \\
C \\
W \\
W \\
W \\
W \\
W \\
W \\
W \\
W \\
W \\
W \\
W \\
W \\
W \\
W \\
W \\
W \\
W \\
W \\
W \\
C \\
C \\
W \\
W \\
W \\
W \\
C \\
W \\
W \\
W \\
C \\
C \\
W \\
W \\
W \\
W \\
C \\
C \\
W \\
W \\
W \\
C \\
W \\
W \\
W \\
C \\
C \\
W \\
W \\
W \\
W \\
W \\
W \\
W \\
W \\
W \\
W \\
W \\
W\end{array}$ & 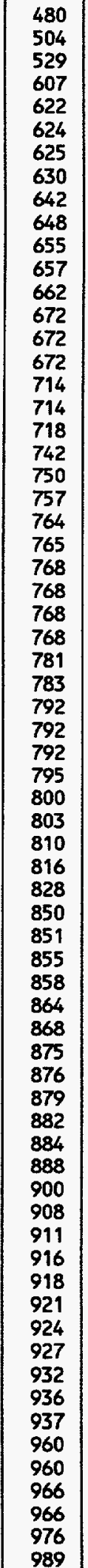 & 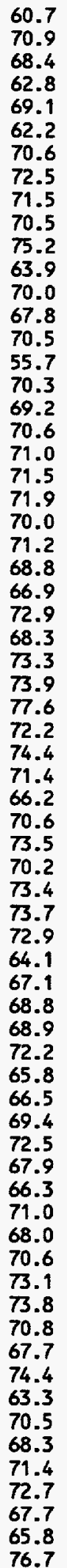 & $\begin{array}{l}62.4 \\
70.5 \\
69.1 \\
63.1 \\
69.0 \\
61.4 \\
70.9 \\
71.6 \\
71.6 \\
70.0 \\
76.7 \\
67.3 \\
70.4 \\
68.4 \\
70.5 \\
56.4 \\
70.5 \\
66.5 \\
68.5 \\
68.8 \\
72.4 \\
71.4 \\
71.5 \\
71.6 \\
69.3 \\
68.2 \\
72.9 \\
68.8 \\
73.7 \\
72.2 \\
71.6 \\
72.7 \\
75.1 \\
71.8 \\
70.4 \\
70.5 \\
72.7 \\
69.7 \\
72.3 \\
74.3 \\
74.0 \\
62.6 \\
66.5 \\
68.6 \\
67.1 \\
67.6 \\
64.9 \\
76.0 \\
71.6 \\
66.3 \\
66.1 \\
64.5 \\
69.4 \\
69.4 \\
72.9 \\
68.5 \\
64.8 \\
71.0 \\
68.7 \\
69.6 \\
72.2 \\
68\end{array}$ & 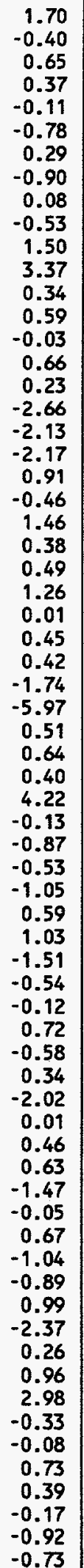 & 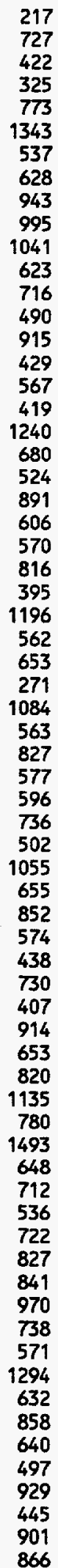 & 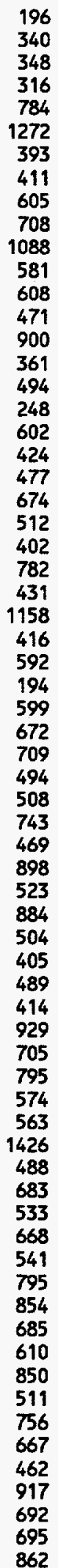 & 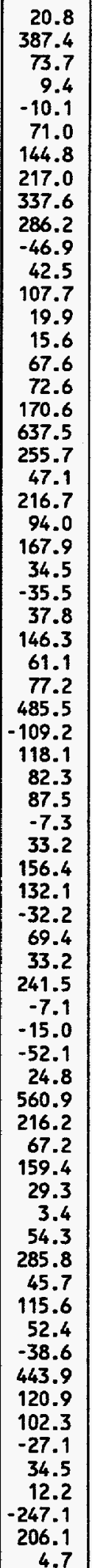 & 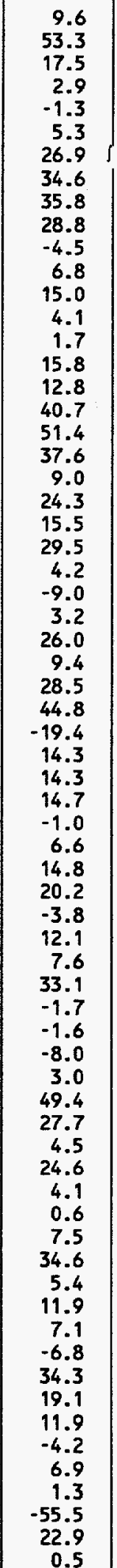 & $\begin{array}{l}0.252 \\
0.626 \\
0.912 \\
0.763 \\
0.934 \\
0.318 \\
0.637 \\
0.977 \\
0.888 \\
0.709 \\
0.980 \\
0.824 \\
0.946 \\
0.958 \\
0.928 \\
0.916 \\
0.922 \\
0.912 \\
0.876 \\
0.803 \\
0.966 \\
0.763 \\
0.823 \\
0.968 \\
0.935 \\
0.912 \\
0.958 \\
0.872 \\
0.930 \\
0.401 \\
0.935 \\
0.772 \\
0.946 \\
0.083 \\
0.738 \\
0.965 \\
0.850 \\
0.934 \\
0.954 \\
0.975 \\
0.409 \\
0.774 \\
0.849 \\
0.933 \\
0.842 \\
0.943 \\
0.904 \\
0.699 \\
0.957 \\
0.945 \\
0.802 \\
0.855 \\
0.957 \\
0.801 \\
0.955 \\
0.859 \\
0.501 \\
0.785 \\
0.916 \\
0.878 \\
0.669 \\
0.954 \\
0.891 \\
0.820 \\
0.966 \\
0.216 \\
0.958 \\
0.447\end{array}$ & 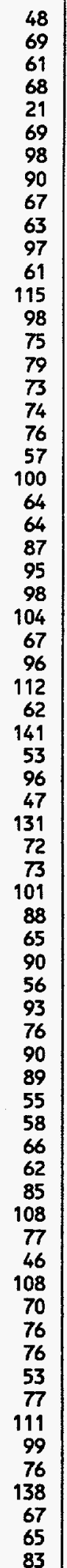 & $\begin{array}{l}0.793 \\
0.881 \\
0.878 \\
0.879 \\
0.932 \\
0.460 \\
0.584 \\
0.940 \\
0.858 \\
0.563 \\
0.966 \\
0.836 \\
0.956 \\
0.946 \\
0.940 \\
0.908 \\
0.940 \\
0.926 \\
0.872 \\
0.862 \\
0.915 \\
0.868 \\
0.851 \\
0.940 \\
0.916 \\
0.909 \\
0.934 \\
0.874 \\
0.917 \\
0.383 \\
0.950 \\
0.504 \\
0.955 \\
0.534 \\
0.710 \\
0.949 \\
0.900 \\
0.927 \\
0.937 \\
0.970 \\
0.703 \\
0.793 \\
0.794 \\
0.939 \\
0.889 \\
0.930 \\
0.920 \\
0.625 \\
0.866 \\
0.937 \\
0.880 \\
0.852 \\
0.955 \\
0.935 \\
0.935 \\
0.833 \\
0.706 \\
0.868 \\
0.920 \\
0.899 \\
0.780 \\
0.952 \\
0.801 \\
0.682 \\
0.932 \\
0.757 \\
0.913 \\
0.869\end{array}$ & 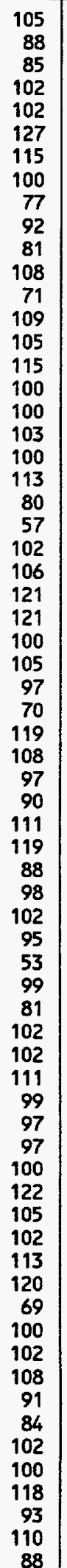 & $\begin{array}{l}\text { FA } \\
\text { Gr } \\
\text { FA } \\
\text { FA } \\
\text { Gr } \\
\text { HWB } \\
\text { HWB } \\
\text { FA } \\
\text { FA } \\
\text { FA } \\
\text { FA } \\
\text { FA } \\
\text { HWB } \\
\text { FA } \\
\text { FA } \\
\text { StB } \\
\text { StB } \\
\text { FA } \\
\text { StB } \\
\text { FA } \\
\text { FA } \\
\text { ?? } \\
\text { FA } \\
\text { HWB } \\
\text { HWB } \\
\text { FA } \\
\text { HWB } \\
\text { FA } \\
\text { HWB } \\
\text { FA } \\
\text { FA } \\
\text { HWB } \\
\text { StB } \\
\text { FA } \\
\text { FA } \\
\text { HWB } \\
\text { FA } \\
\text { HWB } \\
\text { FA } \\
\text { HWB } \\
\text { FA } \\
\text { HWB } \\
\text { HWB } \\
\text { FA } \\
\text { FA } \\
\text { HWB } \\
\text { FA } \\
\text { FA } \\
\text { FA } \\
\text { StB } \\
\text { HWB } \\
\text { HWB } \\
\text { HWB } \\
\text { HWB } \\
\text { HWB } \\
\text { HWB } \\
\text { HWB } \\
\text { FA } \\
\text { HWB } \\
\text { HWB } \\
\text { HWB } \\
\text { FA } \\
\text { HWB } \\
\text { HWB } \\
\text { HWB } \\
\text { FA } \\
\text { FA } \\
\text { HWB }\end{array}$ & 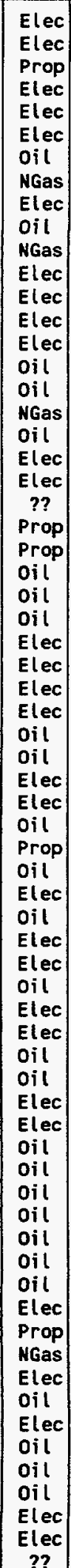 & \begin{tabular}{|} 
SA \\
SA \\
SA \\
SA \\
SA \\
SA \\
None \\
SA \\
SA \\
None \\
SA \\
SA \\
SA \\
SA \\
SA \\
None \\
None \\
SA \\
None \\
SA \\
SA \\
?? \\
SA \\
SA \\
None \\
SA \\
None \\
SA \\
SA \\
SA \\
SA \\
None \\
None \\
SA \\
SA \\
None \\
SA \\
None \\
SA \\
None \\
SA \\
SA \\
None \\
SA \\
SA \\
None \\
SA \\
SA \\
SA \\
None \\
None \\
None \\
SA \\
None \\
None \\
None \\
None \\
SA \\
None \\
SA \\
None \\
SA \\
SA \\
SA \\
?o \\
No \\
Sone
\end{tabular} \\
\hline
\end{tabular}


Table H.2. Sumary of sample (uneighted) results for 1990-1992 (continued).

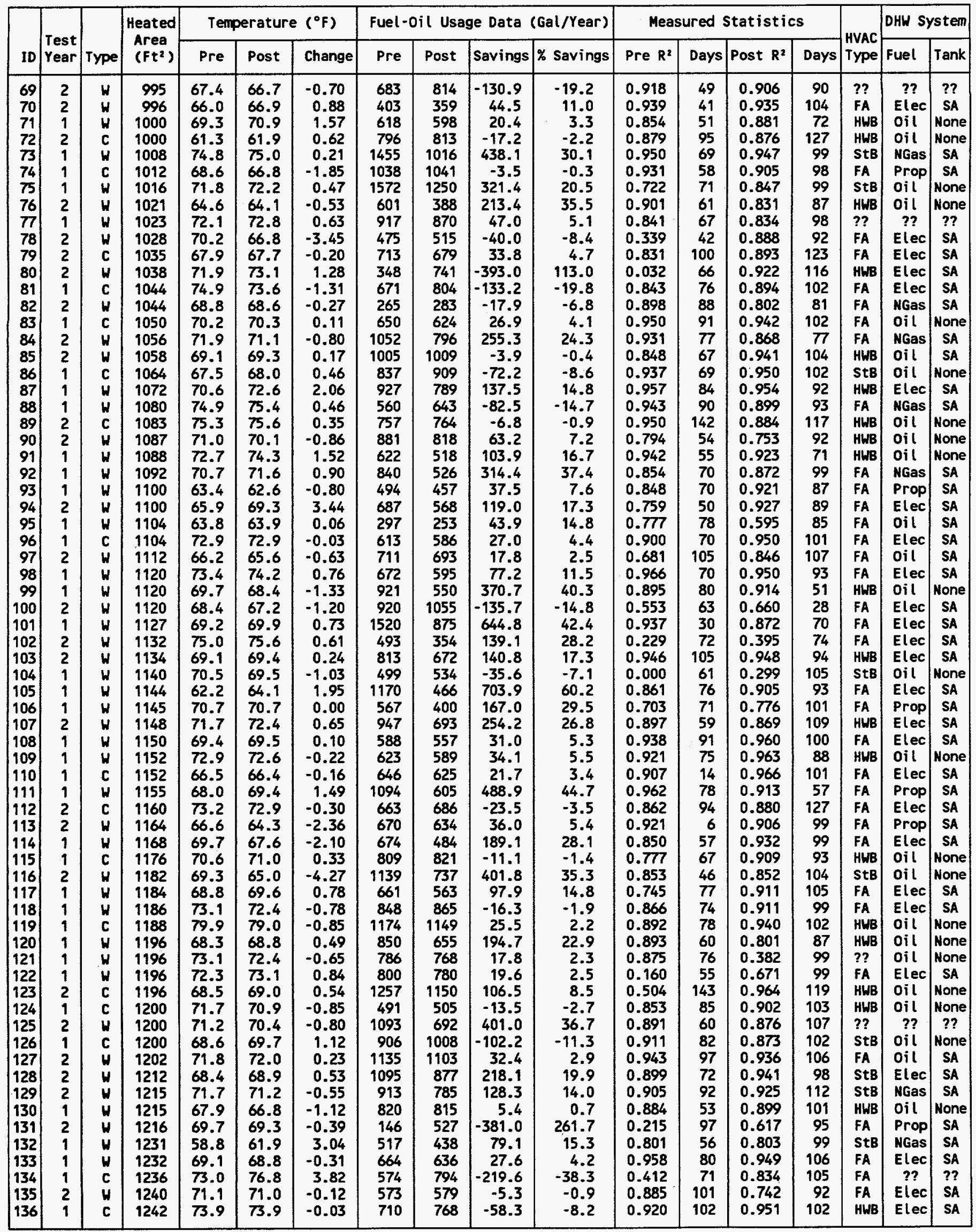


Table H.2. Summary of sample (unweighted) results for 1990-1992 (continued)

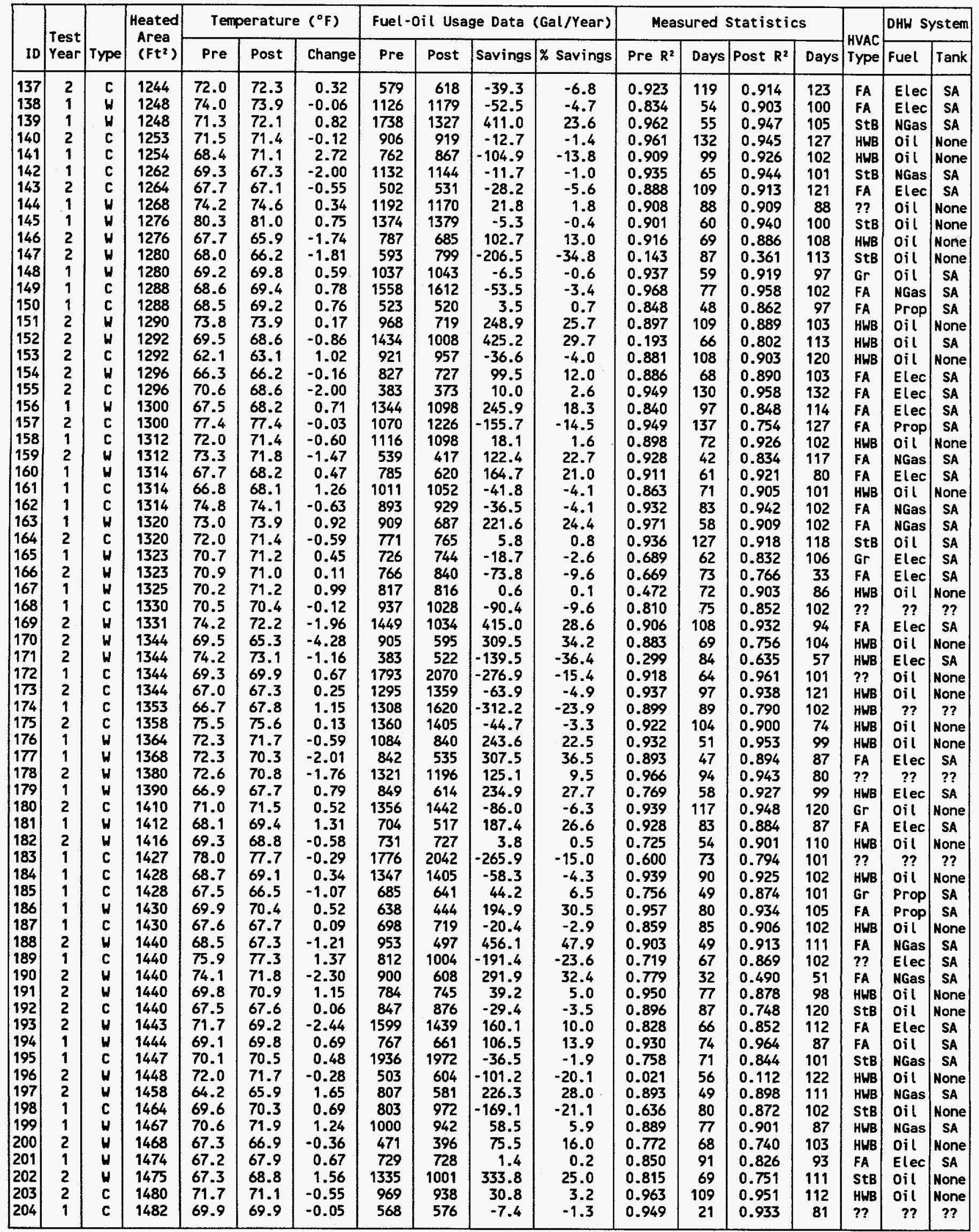


Table H.2. Sumbary of sample (unueighted) results for 1990-1992 (continued)

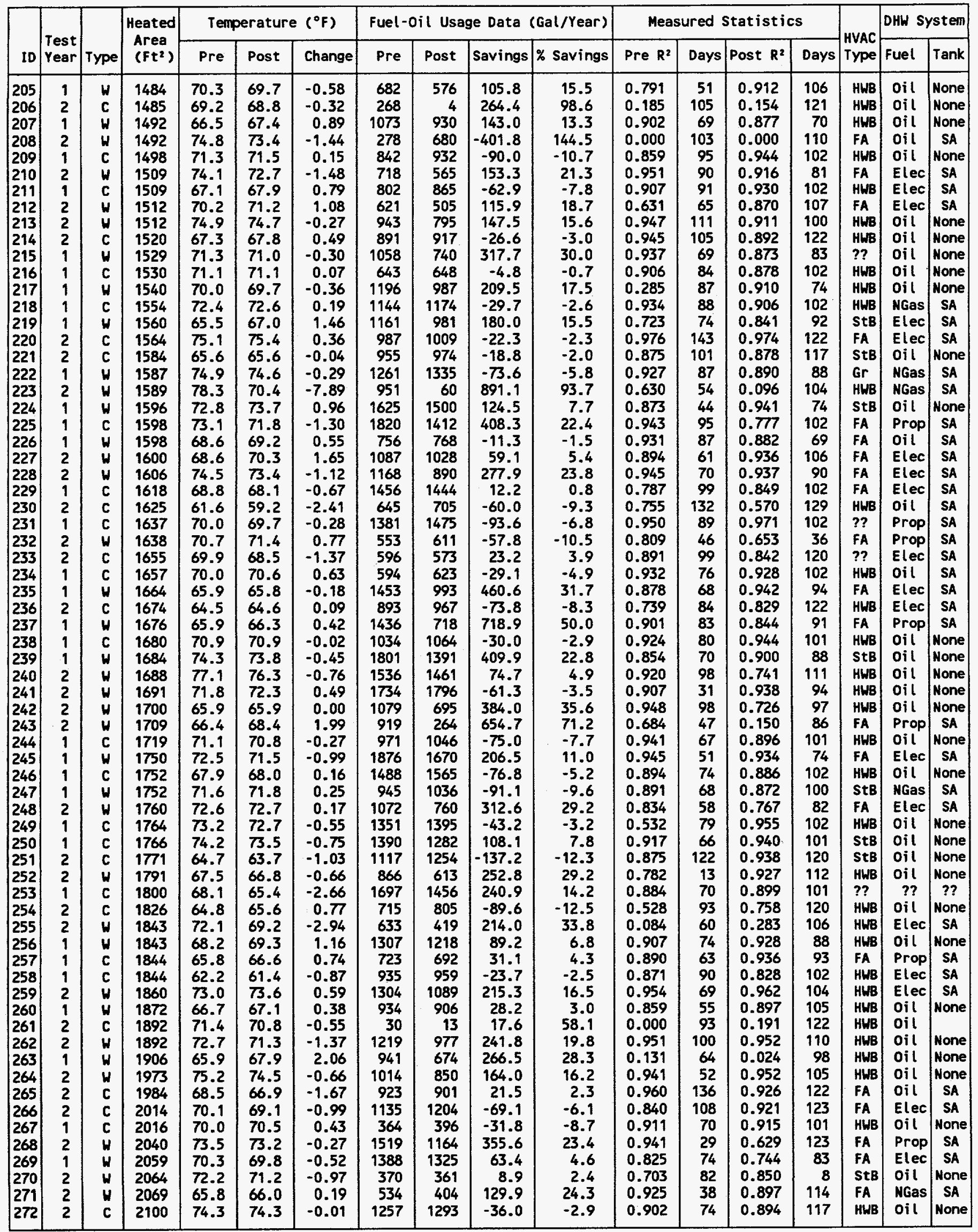


Table H.2. Sumary of sample (unweighted) results for 1990-1992 (continued)

\begin{tabular}{|c|c|c|c|c|c|c|c|c|c|c|c|c|c|c|c|c|c|}
\hline ID & $\mid \begin{array}{l}\text { Test } \\
\text { Year }\end{array}$ & Type & $\left|\begin{array}{c}\text { Heated } \\
\text { Area } \\
\left(\mathrm{Ft}^{2}\right)\end{array}\right|$ & \multicolumn{3}{|c|}{ Temperature $\left({ }^{\circ} \mathrm{F}\right)$} & \multicolumn{4}{|c|}{ Fuel-oil Usage Data (Gal/Year) } & \multicolumn{4}{|c|}{ Measured Statistics } & $\begin{array}{l}\text { HVAC } \\
\text { Type }\end{array}$ & \multicolumn{2}{|c|}{ DHW system } \\
\hline $\begin{array}{l}273 \\
274 \\
275 \\
276 \\
277 \\
278 \\
279 \\
280 \\
281 \\
282 \\
283 \\
284 \\
285 \\
286 \\
287 \\
288 \\
289 \\
290 \\
291 \\
292 \\
293 \\
294 \\
295 \\
296 \\
297 \\
298\end{array}$ & $\begin{array}{l}1 \\
1 \\
2 \\
2 \\
2 \\
2 \\
1 \\
2 \\
1 \\
2 \\
2 \\
2 \\
2 \\
2 \\
1 \\
2 \\
2 \\
2 \\
1 \\
1 \\
2 \\
1 \\
1 \\
2 \\
1 \\
1\end{array}$ & $\begin{array}{l}C \\
C \\
C \\
W \\
C \\
W \\
C \\
W \\
W \\
W \\
C \\
W \\
C \\
C \\
W \\
W \\
W \\
W \\
C \\
C \\
C \\
H \\
W \\
W \\
W \\
W\end{array}$ & $\begin{array}{l}2140 \\
2154 \\
2160 \\
2172 \\
2242 \\
2250 \\
2266 \\
2294 \\
2380 \\
2414 \\
2448 \\
2472 \\
2476 \\
2488 \\
2524 \\
2576 \\
2578 \\
2632 \\
2640 \\
2736 \\
2763 \\
2800 \\
2824 \\
2922 \\
3230 \\
3312\end{array}$ & $\begin{array}{l}74.2 \\
68.7 \\
72.6 \\
78.8 \\
70.1 \\
67.4 \\
70.8 \\
71.5 \\
66.7 \\
71.6 \\
70.1 \\
71.6 \\
65.5 \\
64.8 \\
71.5 \\
72.1 \\
67.1 \\
69.2 \\
70.5 \\
71.4 \\
70.4 \\
74.8 \\
69.2 \\
71.9 \\
72.3 \\
66.4\end{array}$ & $\begin{array}{l}69.0 \\
71.6 \\
77.8 \\
70.3 \\
67.4 \\
69.9 \\
71.1 \\
67.3 \\
72.1 \\
71.5 \\
70.9 \\
64.9 \\
62.5 \\
71.8 \\
72.7 \\
66.2 \\
69.8 \\
68.5 \\
71.9 \\
69.8 \\
74.9 \\
69.4 \\
70.9 \\
71.5 \\
66.9\end{array}$ & $\begin{array}{r}-1.00 \\
0.26 \\
-0.97 \\
-0.94 \\
0.18 \\
0.04 \\
-0.95 \\
-0.31 \\
0.65 \\
0.49 \\
1.42 \\
-0.68 \\
-0.64 \\
-2.25 \\
0.36 \\
0.59 \\
-0.89 \\
0.59 \\
-1.98 \\
0.50 \\
-0.65 \\
0.13 \\
0.24 \\
-0.95 \\
-0.80 \\
0.54\end{array}$ & $\begin{array}{r}1214 \\
2419 \\
546 \\
227 \\
781 \\
825 \\
644 \\
593 \\
1129 \\
1041 \\
2002 \\
597 \\
716 \\
667 \\
995 \\
1192 \\
565 \\
1979 \\
998 \\
929 \\
2077 \\
1070 \\
552 \\
2131 \\
2136\end{array}$ & $\begin{array}{r}1739 \\
1076 \\
2349 \\
562 \\
225 \\
728 \\
835 \\
320 \\
567 \\
904 \\
814 \\
1556 \\
620 \\
1116 \\
461 \\
1066 \\
1045 \\
549 \\
1585 \\
1310 \\
700 \\
1494 \\
650 \\
646 \\
2084 \\
2407\end{array}$ & $\begin{array}{r}33.9 \\
137.9 \\
69.9 \\
-15.6 \\
2.3 \\
53.3 \\
-10.3 \\
324.1 \\
26.4 \\
224.3 \\
227.3 \\
445.6 \\
-23.2 \\
-400.4 \\
205.9 \\
-70.4 \\
147.4 \\
16.4 \\
394.8 \\
-312.1 \\
228.4 \\
583.2 \\
420.6 \\
-94.1 \\
46.2 \\
-271.2\end{array}$ & $\begin{array}{r}1.9 \\
11.4 \\
2.9 \\
-2.9 \\
1.0 \\
6.8 \\
-1.2 \\
50.3 \\
4.5 \\
19.9 \\
21.8 \\
22.3 \\
-3.9 \\
-56.0 \\
30.9 \\
-7.1 \\
12.4 \\
2.9 \\
19.9 \\
-31.3 \\
24.6 \\
28.1 \\
39.3 \\
-17.1 \\
2.2 \\
-12.7\end{array}$ & $\begin{array}{l}0.792 \\
0.797 \\
0.960 \\
0.784 \\
0.244 \\
0.898 \\
0.913 \\
0.829 \\
0.630 \\
0.929 \\
0.841 \\
0.876 \\
0.776 \\
0.346 \\
0.878 \\
0.934 \\
0.757 \\
0.942 \\
0.912 \\
0.949 \\
0.923 \\
0.880 \\
0.894 \\
0.839 \\
0.921 \\
0.784\end{array}$ & $\begin{array}{r}64 \\
67 \\
115 \\
90 \\
143 \\
98 \\
88 \\
46 \\
69 \\
72 \\
119 \\
112 \\
121 \\
85 \\
87 \\
75 \\
68 \\
69 \\
96 \\
99 \\
128 \\
74 \\
66 \\
71 \\
61 \\
83\end{array}$ & $\begin{array}{l}0.871 \\
0.744 \\
0.966 \\
0.768 \\
0.201 \\
0.847 \\
0.944 \\
0.686 \\
0.393 \\
0.834 \\
0.078 \\
0.938 \\
0.727 \\
0.769 \\
0.904 \\
0.906 \\
0.859 \\
0.119 \\
0.636 \\
0.000 \\
0.649 \\
0.928 \\
0.839 \\
0.874 \\
0.926 \\
0.688\end{array}$ & $\begin{array}{r}100 \\
100 \\
122 \\
81 \\
117 \\
104 \\
102 \\
93 \\
88 \\
104 \\
121 \\
121 \\
123 \\
120 \\
98 \\
98 \\
107 \\
81 \\
102 \\
101 \\
120 \\
105 \\
98 \\
111 \\
94 \\
85\end{array}$ & $\begin{array}{l}\text { FA } \\
\text { HWB } \\
\text { HWB } \\
\text { FA } \\
\text { FA } \\
\text { HWB } \\
\text { FA } \\
\text { FA } \\
\text { HWB } \\
\text { HWB } \\
\text { HWB } \\
\text { HWB } \\
\text { HWB } \\
\text { FA } \\
\text { FA } \\
\text { HWB } \\
\text { HWB } \\
\text { FA } \\
\text { StB } \\
\text { StB } \\
\text { HWB } \\
\text { StB } \\
\text { HWB } \\
\text { HWB } \\
\text { StB } \\
\text { StB }\end{array}$ & $\begin{array}{l}\text { Elec } \\
\text { Elec } \\
\text { Elec } \\
\text { oil } \\
\text { Elec } \\
\text { oil } \\
\text { Oil } \\
\text { Elec } \\
\text { Oil } \\
\text { oil } \\
\text { NGas } \\
\text { Oil } \\
\text { Elec } \\
\text { Elec } \\
\text { Prop } \\
\text { Oil } \\
\text { Oil } \\
\text { Elec } \\
\text { Oil } \\
\text { Elec } \\
\text { Oil } \\
\text { Oil } \\
\text { NGas } \\
\text { Oil } \\
\text { Oil } \\
\text { NGas }\end{array}$ & $\begin{array}{c}\text { SA } \\
\text { SA } \\
\text { SA } \\
\text { SA } \\
\text { SA } \\
\text { None } \\
\text { SA } \\
\text { SA } \\
\text { None } \\
\text { None } \\
\text { SA } \\
\text { None } \\
\text { SA } \\
\text { SA } \\
\text { SA } \\
\text { None } \\
\text { None } \\
\text { SA } \\
\text { None } \\
\text { None } \\
\text { None } \\
\text { None } \\
\text { SA } \\
\text { None } \\
\text { None } \\
\text { SA }\end{array}$ \\
\hline
\end{tabular}

Notes:

$$
\begin{aligned}
& \text { Test Year - } 1 \text { means 1990-1991 heating season, } 2 \text { means 1991-1992 heating season. } \\
& \text { Type - C means control house, W means weatherized house. } \\
& \text { Temperature - Average indoor temperature for pre- or post-weatherization period, and } \\
& \text { - average indoor temperature change from pre- to post-weatherization period. } \\
& \text { Days - Days of data used for regression analysis. } \\
& \text { HVAC System - FA means a forced-air furnace. } \\
& \text { HWB means a hot water boiler with convectors or radiators. } \\
& \text { StB means a steam boiler with convectors or radiators. } \\
& \text { Gr means a boiler with no circulating pump, or a gravity hot-air furnace. }
\end{aligned}
$$


Table H.3. Distributions of energy related parameters for the control houses
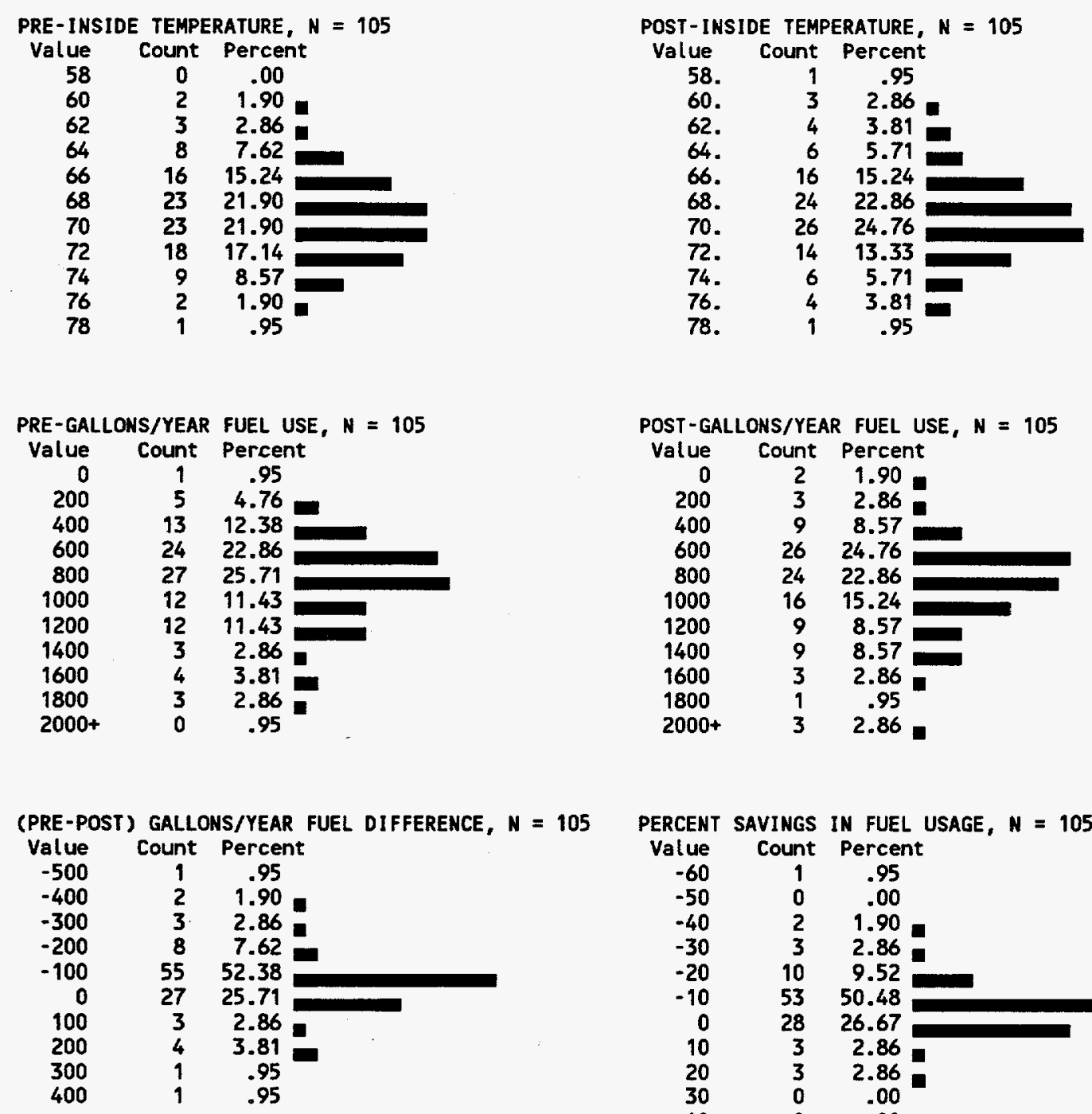

PERCENT SAVINGS IN FUeL USAGE, $N=105$

Value
-60
-50
-40
-30
-20
-10
0
10
20
30
40
$50+$
Count Percent

$\begin{array}{rc}1 & .95 \\ 0 & .00 \\ 2 & 1.90= \\ 3 & 2.86= \\ 10 & 9.52= \\ 53 & 50.48= \\ 28 & 26.67 \\ 3 & 2.86= \\ 3 & 2.86= \\ 0 & .00 \\ 0 & .00 \\ 2 & 1.90\end{array}$


Table H.4. Distribution of energy related parameters for the weatherized houses

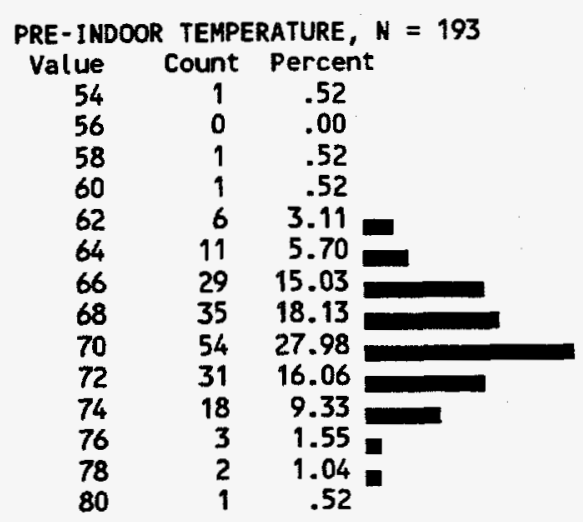

PRE-GALLONS/YEAR FUEL USE, $N=193$

\begin{tabular}{|c|c|c|}
\hline $\begin{array}{r}\text { Value } \\
0 \\
200 \\
400 \\
600 \\
800 \\
1000 \\
1200 \\
1400 \\
1600 \\
1800 \\
2000\end{array}$ & $\begin{array}{c}\text { Count } \\
1 \\
9 \\
36 \\
45 \\
42 \\
29 \\
11 \\
11 \\
3 \\
2 \\
4\end{array}$ & $\begin{array}{c}\text { Percent } \\
.52 \\
4.66 \\
18.65 \\
23.32 \\
21.76 \\
15.03 \\
5.70 \\
5.70 \\
1.55= \\
1.04= \\
2.07\end{array}$ \\
\hline
\end{tabular}
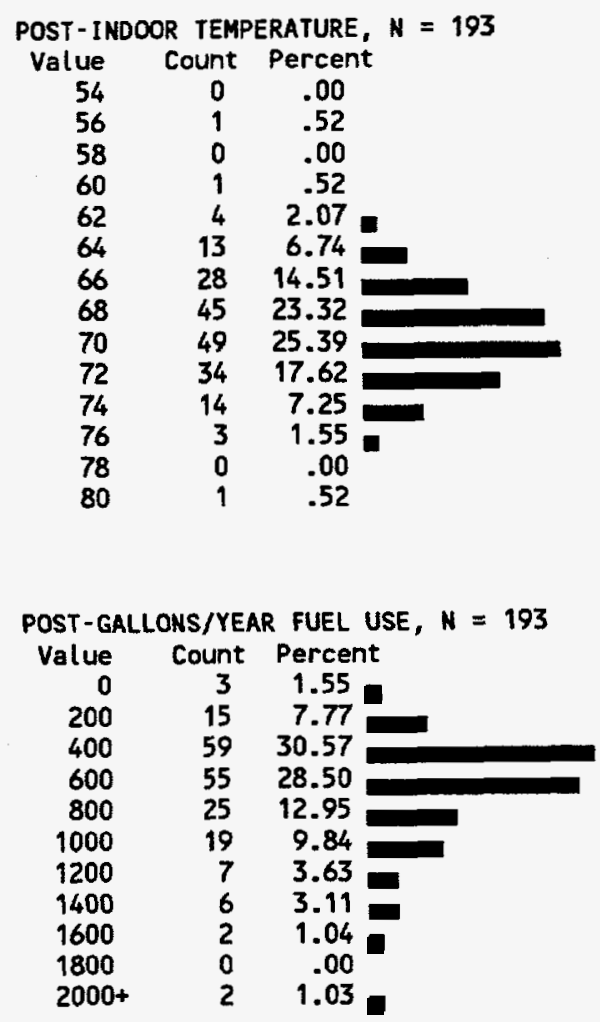

PERCENT SAVINGS IN FUEL USE, $N=193$

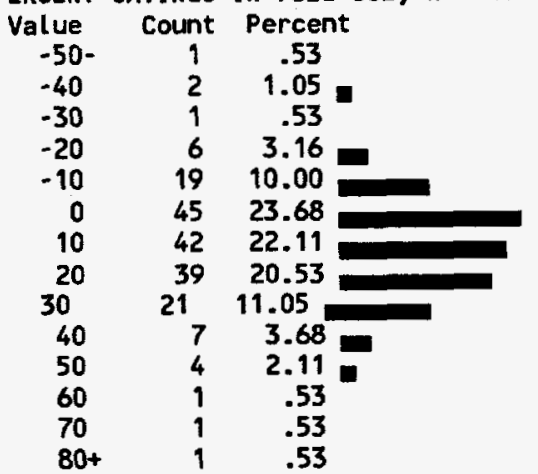


Table H.5. Summary statistics for different control house data sets

(a)

CONTROL HOUSES - ALL DATA

\begin{tabular}{||l|c|c|c|c|c|c|c||}
\hline \multirow{2}{*}{ Statistics } & \multirow{2}{*}{$\begin{array}{c}\text { Heated Area } \\
\left(\mathrm{Ft}^{2}\right)\end{array}$} & \multicolumn{2}{|c|}{ Inside Temperature $\left({ }^{\circ} \mathrm{F}\right)$} & \multicolumn{4}{c|}{ Fuel-Oil Usage (Gallons Year) } \\
\cline { 3 - 8 } & & Pre & Post & Pre & Post & Pre-Post & $\%$ Saving \\
\hline No. of Cases & 105 & 105 & 105 & 105 & 105 & 105 & 105 \\
\hline Minimum & 622.000 & 61.260 & 59.210 & 30.300 & 3.700 & -400.400 & -55.953 \\
\hline Maximum & 2763.000 & 79.850 & 79.000 & 2418.900 & 2349.000 & 408.300 & 98.620 \\
\hline Mean & 1447.219 & 69.888 & 69.762 & 937.759 & 958.133 & -20.374 & $-2.172^{*}$ \\
\hline Standard Dev & 465.503 & 3.529 & 3.689 & 406.221 & 409.496 & 116.526 & 15.902 \\
\hline
\end{tabular}

(b)

CONTROL HOUSES - R2 $>.5$

\begin{tabular}{||l|c|c|c|c|c|c|c||}
\hline \multirow{2}{*}{ Statistics } & \multirow{2}{*}{$\begin{array}{c}\text { Heated Area } \\
\left(\mathrm{Ft}^{2}\right)\end{array}$} & \multicolumn{2}{|c|}{ Inside Temperature $\left({ }^{\circ} \mathrm{F}\right)$} & \multicolumn{4}{c|}{ Fuel-Oil Usage (Gallons Year) } \\
\cline { 3 - 8 } & & Pre & Post & Pre & Post & Pre-Post & $\%$ Saving \\
\hline \hline No. of Cases & 97 & 97 & 97 & 97 & 97 & 97 & 97 \\
\hline Minimum & 622.000 & 61.260 & 59.210 & 364.000 & 372.600 & -312.200 & -23.872 \\
\hline Maximum & 2763.000 & 79.850 & 79.000 & 2418.900 & 2349.000 & 408.300 & 24.596 \\
\hline Mean & 1410.381 & 69.960 & 69.803 & 961.523 & 979.974 & -18.452 & $-1.919^{*}$ \\
\hline Standard Dev & 422.116 & 3.527 & 3.585 & 394.883 & 392.051 & 101.542 & 8.437 \\
\hline
\end{tabular}

(c)

CONTROL HOUSES - R2 $>.7$

\begin{tabular}{||l|c|c|c|c|c|c|c||}
\hline \multirow{2}{*}{ Statistics } & \multirow{2}{*}{$\begin{array}{c}\text { Heated Area } \\
\left(\mathrm{Ft}^{2}\right)\end{array}$} & \multicolumn{2}{|c|}{ Inside Temperature $\left({ }^{\circ} \mathrm{F}\right)$} & \multicolumn{4}{c|}{ Fuel-Oil Usage (Gallons Year) } \\
\cline { 3 - 9 } & & Pre & Post & Pre & Post & Pre-Post & $\%$ Saving \\
\hline \hline No. of Cases & 88 & 88 & 88 & 88 & 88 & 88 & 88 \\
\hline Minimum & 622.000 & 61.260 & 61.370 & 364.000 & 372.600 & -312.200 & -23.872 \\
\hline Maximum & 2476.000 & 79.850 & 79.000 & 2418.900 & 2349.000 & 408.300 & 22.429 \\
\hline Mean & 1378.523 & 69.971 & 69.836 & 946.030 & 966.285 & -20.256 & $-2.141^{*}$ \\
\hline Standard Dev & 385.055 & 3.418 & 3.429 & 381.531 & 383.064 & 85.947 & 7.224 \\
\hline
\end{tabular}

(d)

CONTROL HOUSES - R2 > .85

\begin{tabular}{|l|c|c|c|c|c|c|c||}
\hline \multirow{2}{*}{ Statistics } & \multirow{2}{*}{$\begin{array}{c}\text { Heated Area } \\
\left(\mathrm{Ft}^{2}\right)\end{array}$} & \multicolumn{2}{|c|}{ Inside Temperature $\left({ }^{\circ} \mathrm{F}\right)$} & \multicolumn{4}{c|}{ Fuel-Oil Usage (Gallons Year) } \\
\cline { 3 - 9 } & & Pre & Post & Pre & Post & Pre-Post & \% Saving \\
\hline \hline No. of Cases & 62 & 62 & 62 & 62 & 62 & 62 & 62 \\
\hline Minimum & 622.000 & 61.260 & 61.880 & 364.000 & 372.600 & -276.900 & -15.443 \\
\hline Maximum & 2266.000 & 79.850 & 79.000 & 2418.900 & 2349.000 & 240.900 & 14.197 \\
\hline Mean & 1363.452 & 70.114 & 70.036 & 942.942 & 966.395 & -23.453 & $-2.487^{*}$ \\
\hline Standard Dev & 358.573 & 3.303 & 3.269 & 371.999 & 377.059 & 63.747 & 5.294 \\
\hline
\end{tabular}

- Mean of $\%$ savings calculated from means of pre- and past-weatherization usage values. 
Table H.6. Summary statistics for different weatherized house data sets

(a)

\begin{tabular}{|l|c|c|c|c|c|c|c||}
\hline \multirow{2}{*}{ Statistics } & \multirow{2}{*}{ Heated Area } & \multicolumn{2}{|c|}{ Inside Temperature $\left({ }^{\circ} \mathrm{F}\right)$} & \multicolumn{4}{c|}{ Fuel-Oil Usage (Gallons Year) } \\
\cline { 3 - 8 } & & Pre & Post & Pre & Post & Pre-Post & \% Saving \\
\hline \hline No. of Cases & 193 & 193 & 193 & 193 & 193 & 193 & 193 \\
\hline Minimum & 480.000 & 55.690 & 56.350 & 145.600 & 60.100 & -401.800 & -261.676 \\
\hline Maximum & 3312.000 & 80.270 & 81.020 & 2135.900 & 2407.100 & 891.100 & 93.682 \\
\hline Mean & 1313.192 & 70.169 & 70.079 & 881.707 & 738.856 & 142.851 & $16.202^{*}$ \\
\hline Standard Dev & 521.809 & 3.485 & 3.267 & 378.726 & 340.092 & 195.220 & 30.812 \\
\hline
\end{tabular}

(b)

\begin{tabular}{||l|c|c|c|c|c|c|c||}
\hline \multirow{2}{*}{ Statistics } & \multirow{2}{*}{ Heated Area } & \multicolumn{2}{|c|}{ Inside Temperature $\left.{ }^{\circ} \mathrm{F}\right)$} & \multicolumn{4}{c|}{ Fuel-Oil Usage (Gallons Year) } \\
\cline { 3 - 8 } & & Pre & Post & Pre & Post & Pre-Post & \% Saving \\
\hline \hline No. of Cases & 166 & 166 & 166 & 166 & 166 & 166 & 166 \\
\hline Minimum & 504.000 & 55.690 & 56.350 & 265.100 & 248.300 & -271.200 & -19.160 \\
\hline Maximum & 3312.000 & 80.270 & 81.020 & 2135.900 & 2407.100 & 718.900 & 60.168 \\
\hline Mean & 1309.735 & 70.032 & 70.019 & 921.508 & 764.348 & 157.161 & $17.054^{*}$ \\
\hline Standard Dev & 530.718 & 3.439 & 3.302 & 375.560 & 348.158 & 171.797 & 15.646 \\
\hline
\end{tabular}

WEATHERIZED HOUSES - R2 > .5 (c) WEATHERIZED HOUSES - R2 $>.7$

\begin{tabular}{||l|c|c|c|c|c|c|c||}
\hline \multirow{2}{*}{ Statistics } & \multirow{2}{*}{ Heated Area } & \multicolumn{2}{|c|}{ Inside Temperature $\left.{ }^{\circ} \mathrm{F}\right)$} & \multicolumn{4}{c|}{ Fuel-Oil Usage (Gallons Year) } \\
\cline { 3 - 8 } & & Pre & Post & Pre & Post & Pre-Post & \% Saving \\
\hline \hline No. of Cases & 149 & 149 & 149 & 149 & 149 & 149 & 149 \\
\hline Minimum & 529.000 & 55.690 & 56.350 & 265.100 & 248.300 & -130.900 & -19.160 \\
\hline Maximum & 3230.000 & 80.270 & 81.020 & 2130.600 & 2084.400 & 718.900 & 60.168 \\
\hline Mean & 1309.832 & 70.109 & 70.077 & 930.101 & 768.099 & 162.002 & $17.418^{*}$ \\
\hline Standard Dev & 510.313 & 3.478 & 3.322 & 368.775 & 328.527 & 166.735 & 14.836 \\
\hline
\end{tabular}

(d)

WEATHERIZED HOUSES - R2 > .85

\begin{tabular}{||l|c|c|c|c|c|c|c||}
\hline \multirow{2}{*}{ Statistics } & \multirow{2}{*}{ Heated Area } & \multicolumn{2}{|c|}{ Inside Temperature $\left({ }^{\circ} \mathrm{F}\right)$} & \multicolumn{4}{c|}{ Fuel-Oil Usage (Gallons Year) } \\
\cline { 3 - 8 } & & Pre & Post & Pre & Post & Pre-Post & \% Saving \\
\hline \hline No. of Cases & 101 & 101 & 101 & 101 & 101 & 101 & 101 \\
\hline Minimum & 529.000 & 55.690 & 56.350 & 403.300 & 248.300 & -130.900 & -19.160 \\
\hline Maximum & 3230.000 & 80.270 & 81.020 & 2130.600 & 2084.400 & 703.900 & 60.168 \\
\hline Mean & 1264.782 & 70.630 & 70.583 & 970.300 & 799.951 & 170.349 & $17.556^{*}$ \\
\hline Standard Dev & 485.143 & 3.330 & 3.300 & 377.495 & 341.049 & 175.399 & 15.229 \\
\hline
\end{tabular}

- Mean of \% savings calculated from means of pre- and post-weatherization usage values. 
Table H.7. Distribution of energy related parameters for control houses with $\mathbf{R}^{2}>0.7$
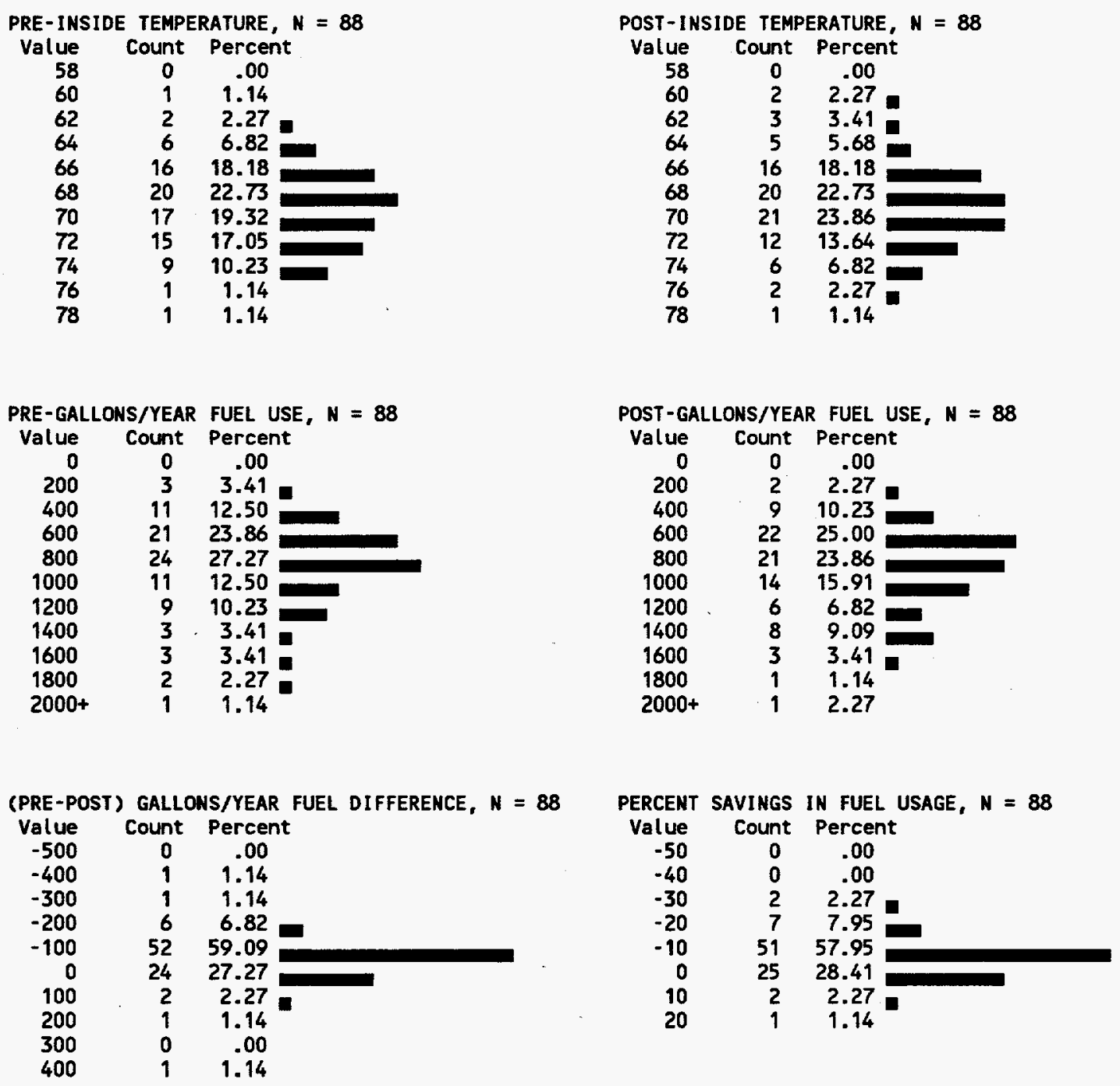
Table H.8. Distribution of energy related parameters for weatherized houses with $\mathbf{R}^{2}>0.7$
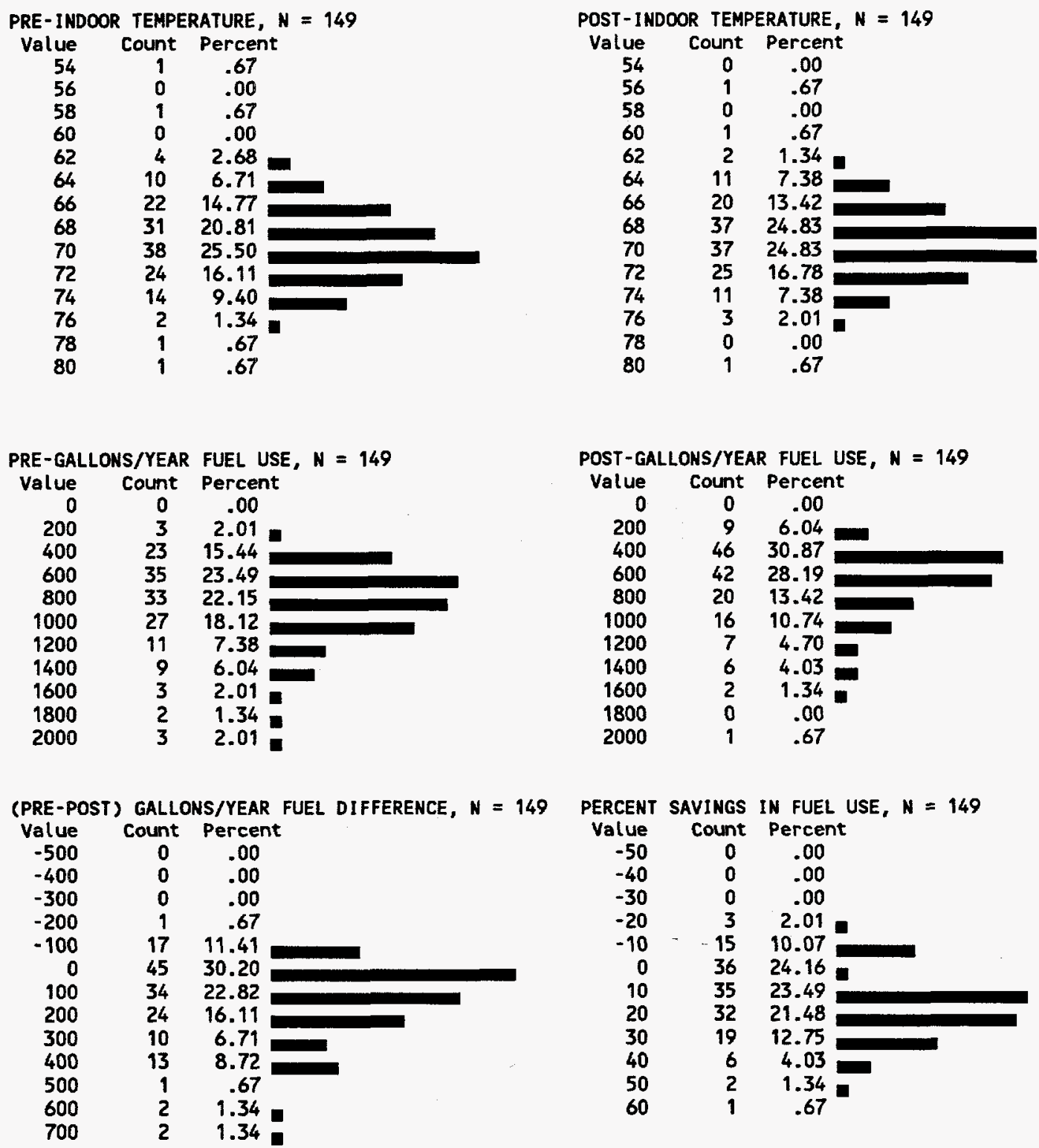


\section{APPENDIX I. SAMPLE WEIGHTING METHODOLOGY}

The equations used to calculate the average regional values under the weighted ratioestimator averaging procedure are provided at the end of this Appendix.

A weight was defined in this study as the number of houses in the overall population of single-family fuel-oil heated houses that were weatherized in the nine northeast states during program years 1991 and 1992 that a monitored house represented. Table I.1 contains the weights used for calculations in this study. The first entry in Table I.1, Community Action of Greater Middletown (CAGM) of Connecticut, will be used as an example of estimating a weight.

Four houses in CAGM were assigned to the weatherized group. CAGM weatherized 98 single-family fuel-oil heated houses during the program year. Therefore, each monitored house represented

$$
(98 / 4)=24.50 \text { single-family fuel-oil heated houses }
$$

in CAGM. On a statewide basis, Connecticut had 15 agencies administering the Weatherization Assistance Program. We monitored two agencies during the first heating season, so each agency represented

$$
(15 / 2)=7.50 \text { agencies }
$$

in the state of Connecticut. Again on a state-wide basis, each house monitored in CAGM represented

$$
(24.5 * 7.5)=183.75 \text { single-family fuel-oil heated houses }
$$

in Connecticut. Therefore, the combined four houses monitored at CAGM represented

$$
(4)^{*}(183.75)=735.00 \text { single-family fuel-oil heated houses }
$$


in Connecticut.

Control houses in the sample were treated in the same manner as weatherized houses. Since only three control houses were monitored from CAGM, each control house in CAGM represented

$(98 / 3) *(15 / 2)=245.00$ single-family fuel-oil heated houses

in Connecticut, with the combined three houses representing

$$
(3) *(245.00)=735.00 \text { single-family fuel-oil heated houses }
$$

in the state of Connecticut. Note that the representations of combined weatherized and combined controls were equal.

Weighted results for any individual variable were estimated by adding the products of weight times variable for each house and dividing by the sum of the weights of those houses (which equals 735 for CAGM). For example, if three control houses in CAGM had inside temperatures of 70,71 , and $72^{\circ} \mathrm{F}$, respectively, the weighted average is

$$
\left(70^{*} 245+71^{*} 245+72 * 245\right) /(245+245+245)=71^{\circ} \mathrm{F}
$$

which is also the same as the arithmetic average. If the next agency in Connecticut, the Community Resource Team of Greater Hartford (CRT) has three control houses with inside temperatures of 67,68 , and $69^{\circ} \mathrm{F}$, the weighted average of the CAGM and CRT houses is

$$
\begin{gathered}
{\left[\left(70^{*} 245+71^{*} 245+72 * 245\right)+\left(67^{*} 325+68^{*} 325+69^{*} 325\right)\right]} \\
/[(245+245+245)+(325+325+325)]=69.29^{\circ} \mathrm{F}
\end{gathered}
$$

which is different from the arithmetic average of $69.50^{\circ} \mathrm{F}$. 
The above examples are included to demonstrate that weighted results and arithmetic averages can differ, with differences increasing as respective weights and sums of respective weights differ. This same summing method is used to estimate weighted results for the entire sample by simply summing the weight times variable terms for the entire sample and dividing by the sum of the weights for the sample. Simply stated,

$$
\Sigma(\text { Weight } * \text { Variable }) / \Sigma(\text { Weights })=\text { Weighted Average of Variable. }
$$


Table I.1. Summary of weights used for energy-use calculations

\begin{tabular}{|c|c|c|c|c|c|c|c|c|c|c|c|c|}
\hline \multirow[b]{2}{*}{ st } & \multirow{2}{*}{$\begin{array}{r}\text { Ho. } \\
\text { state } \\
\text { CAPS }\end{array}$} & \multirow[b]{2}{*}{ CAP } & \multicolumn{3}{|c|}{ Test_Houses } & \multirow{2}{*}{$\begin{array}{l}\text { Total CAP } \\
\text { S-Fami ly } \\
\text { Fo WX }\end{array}$} & \multirow{2}{*}{$\begin{array}{l}\text { WX'd } \\
\text { CAP } \\
\text { Factor }\end{array}$} & \multirow{2}{*}{$\begin{array}{l}\text { Control } \\
\text { CAP } \\
\text { Factor }\end{array}$} & \multirow{2}{*}{$\begin{array}{l}\text { State } \\
\text { Factor }\end{array}$} & \multirow{2}{*}{$\begin{array}{l}\text { WX'd } \\
\text { House } \\
\text { Weight }\end{array}$} & \multirow{2}{*}{$\begin{array}{l}\text { Control } \\
\text { House } \\
\text { Height }\end{array}$} & \multirow{2}{*}{$\begin{array}{l}\text { Fuel-oil } \\
\text { S-Family } \\
\text { WX Homes }\end{array}$} \\
\hline & & & $w x$ & Cont & Tot & & & & & & & \\
\hline CT & 15 & CAGM & 4 & 3 & 7 & 98 & 24.50 & 32.67 & 7.50 & 183.75 & 245.00 & 735.0 \\
\hline CT & 15 & & & 3 & 7 & & & & & & & \\
\hline CT & 15 & TVCCA & 7 & 4 & 11 & 100 & 14.29 & 25.00 & 15.00 & 214.29 & 375.00 & 1500.0 \\
\hline MA & 24 & FCAC & 5 & 3 & 8 & 54 & 10.80 & 18.00 & 6.00 & 64.80 & 108.00 & 324.0 \\
\hline MA & 24 & NSCAP & 5 & 3 & 8 & 53 & & & & 63. & jo & 318.0 \\
\hline MA & 24 & SSCAC & 5 & 2 & 7 & 132 & & & & & & 792 \\
\hline MA & 24 & SAC & 4 & 3 & 7 & 90 & 0 & 30. & 6. & 135. & 180. & 540.0 \\
\hline MA & 24 & CAPIC & 5 & 0 & 5 & 36 & $7 \cdot$ & 0 & 8. & 57. & 0. & \\
\hline MA & 24 & BCAC & 7 & 4 & 11 & 25 & 3. & & 8.00 & 28. & & 200.0 \\
\hline MA & 24 & LEO & 6 & 2 & 8 & 75 & 12.50 & 37.50 & 8.00 & 100.00 & 300.00 & 600.0 \\
\hline MI & 12 & KVCAP & 5 & 2 & 7 & 51 & 0.20 & 5.50 & 6.00 & 61.20 & 153.00 & 306.0 \\
\hline ME & 12 & SMT & 4 & 3 & 7 & 60 & & & & & & 60.0 \\
\hline ME & 12 & CCI & 7 & 4 & 11 & 184 & 26.29 & 46.00 & 12.00 & 315.43 & 552.00 & 2208.0 \\
\hline NH & 6 & SNH & 4 & 3 & 7 & 98 & 0 & 32.67 & 3.00 & 73.50 & 98.00 & 294.0 \\
\hline NH & 6 & TCCA & 5 & 3 & 8 & 109 & & & 3. & 65 & & \\
\hline NH & 6 & RCCA & 5 & 2 & 7 & 98 & 19.60 & 49.00 & 6.00 & 117.60 & 294.00 & 588.0 \\
\hline NJ & 22 & CCCEO & 4 & 3 & 7 & 63 & 5.75 & 21.00 & 11.00 & 173.25 & 231.00 & \\
\hline NJ & 22 & PRAB & 4 & 2 & 6 & & & & & & & \\
\hline NJ & 22 & TCCCC & 7 & 4 & 11 & 45 & 6.2 & 11.25 & 22.00 & 141.43 & 247.50 & 990.0 \\
\hline WY & 74 & CCAP & 3 & 3 & 6 & 23 & & & & 113.47 & & \\
\hline W) & 7 & SHI & 4 & 2 & 6 & 19 & & & & & & \\
\hline NY & 74 & GCCA & 3 & 2 & 5 & 28 & & 14 & & & & \\
\hline NY & 7 & PEA & 2 & 2 & 4 & 4 & & & & & & \\
\hline NY & 74 & TCE & & 9 & 4 & 13 & & & & & & \\
\hline NY & 7 & ACOI & 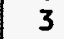 & 1 & 4 & 4 & & & & & & \\
\hline NY & 7 & & & 3 & 9 & 11 & & & & & & \\
\hline NY & 7 & SCW & & 0 & 3 & 6 & 2. & & & & & \\
\hline NY & 74 & LCCAP & 6 & 4 & 10 & 15 & 2.50 & 3.75 & 18.50 & 46.25 & 69.38 & 277.5 \\
\hline PA & 4 & & 3 & 1 & 4 & 66 & 22. & 6 & 11. & & & \\
\hline $\mathrm{PA}$ & 4 & & & 2 & 5 & 93 & & & & & & \\
\hline$P A$ & 4 & & 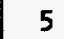 & 3 & 8 & 123 & & & & & & \\
\hline$P A$ & 4 & $w$ & 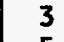 & 3 & 6 & 68 & & & & & & \\
\hline PA & 4 & & & 4 & 9 & 14 & & & & & & \\
\hline $\mathbf{P A}$ & 4 & & & 4 & 10 & 41 & & & & & & \\
\hline PA & 44 & SCCAP & 7 & 2 & 0 & 42 & 6.00 & 21.00 & 14.67 & 88.00 & 308.00 & 616.0 \\
\hline RI & 6 & $\mathrm{TTC}$ & 5 & 3 & 8 & 49 & 98 & 16.33 & 3.00 & 29. & & \\
\hline RI & 6 & & & 2 & 7 & & & & & & & \\
\hline RI & 6 & SHINC & 7 & 4 & 11 & 72 & 10.29 & 18.00 & 6.00 & 61.71 & 108.00 & 432.0 \\
\hline VT & 5 & CVOEO & 5 & 3 & 8 & 45 & 9.0 & 15.00 & 2.50 & 22. & 37. & \\
\hline VT & 5 & & 5 & 0 & 5 & 53 & & & 2. & & & \\
\hline VT & 5 & CVCAC & 4 & 3 & 7 & 162 & 40.50 & 54.00 & 5.00 & 202.50 & 270.00 & 810.0 \\
\hline & 208 & & & 105 & 298 & 2673 & & & 416.00 & & & 23420.6 \\
\hline
\end{tabular}

Notes:

WX = Weatherized

S-Fami ly = single-Family home.

Total CAP S-Family FO WX = Estimated number of single-family homes weatherized by CAP in test year.

W'd House Weight $=$ Weight appl ied to each weatherized home.

Fuel-oil S-Family WX Hones = Estimated number of single-family homes weatherized in two test years. 


$$
\begin{aligned}
& \text { DIFFERENT ESTIMATES OF } \overline{\bar{Y}}_{t s} \text { and } \overline{\bar{Y}}_{t} \text {, and } \overline{\bar{Y}} \\
& \text { WHICH DO NOT REQUIRE PRIOR KNOWLEDGE OF } M \text {..., } \\
& \qquad M_{t, \ldots}, M_{t s}, \text { and } M_{t s c} .
\end{aligned}
$$

(Alternative IIa)

I. SETTING FOR STATE $s$ DURING WINTER $t$

Let $M_{L s} .=$ the number of home units in the $s^{\text {th }}$ state (where $s=1,2, \ldots, 9$ ) of the $t^{\text {th }}$ winter (where $t=1,2$ ),

$N_{L s}=$ the number of CAPS in the $s^{\text {th }}$ state of the $t^{\text {th }}$ winter,

and $n_{t s}=$ the number of CAPS in the sample selected from the $s^{\text {th }}$ state during the $t^{\text {th }}$ winter.

II. SAMPLE STATISTICS FOR STATE $s$ DURING THE $t^{\text {th }}$ WINTER

Using the same notation as before, we have a sample of $n_{t s}$ CAPS:

$$
C A P_{t s 1}, C A P_{t s 2}, \ldots, C A P_{t s c}, \ldots, C A P_{t s n_{t s}}
$$

$t^{\text {th }}$ Winter

$$
\text { All Known! } \quad\left\{\begin{array}{c}
M_{t s c} \\
m_{t s c} \\
\bar{y}_{t s c} \\
s_{t s c}^{2} \\
\hat{Y}_{t s c}=M_{t s c} \bar{y}_{t s c}
\end{array}\right.
$$

III. ESTMMATES FOR STATE $s$ IN WINTER $t$

A "ratio" estimator of $\overline{\bar{Y}}_{t s}$ is

$$
\hat{\bar{Y}}_{L s(R)}=\frac{\sum_{c=1}^{n_{L s}} \hat{Y}_{t s c} \cdot}{\sum_{c=1}^{n_{L s}} M_{t s c}}=\frac{\sum_{c=1}^{n_{L S}} M_{L s c} \bar{y}_{L s c}}{\sum_{c=1}^{n_{L S}} M_{t s c}}
$$

(The above is equation (11.25) in Cochran (1977).)

The approximate sampling variance of $\hat{\bar{Y}}_{t s(R)}$ is 


$$
\begin{aligned}
\operatorname{Var}\left(\hat{\bar{Y}}_{t s(R)}\right) & =\frac{1}{M_{t s}^{2}}\left[\frac{N_{t s}^{2}}{n_{t s}}\left[\frac{N_{t s}-n_{t s}}{N_{t s}}\right] \frac{\sum_{c=1}^{N_{t s}} M_{t s c}^{2}\left(\overline{\bar{Y}}_{t s c}-\overline{\bar{Y}}_{t s}\right)^{2}}{N_{t s}-1}\right. \\
& \left.+\frac{N_{t s}}{n_{t s}} \sum_{c=1}^{N_{t s}} M_{t s c}^{2}\left[\frac{M_{t s c}-m_{t s c}}{M_{t s c}}\right] \frac{S_{t s c}^{2}}{m_{t s c}}\right]
\end{aligned}
$$

(The above is equation (11.27) in Cochran (1977).)

An approximate estimate of $\operatorname{Var}\left(\hat{\overline{\bar{Y}}}_{t(R)}\right)$ is

$$
\begin{aligned}
\operatorname{Var}\left(\hat{\overline{\bar{Y}}}_{t s(R)}\right) & =\frac{1}{M_{t s}^{2}}\left[\frac{N_{t s}^{2}}{n_{t s}}\left[\frac{N_{t s}-n_{t s}}{N_{t s}}\right] \frac{\left.\sum_{c=1}^{n_{t s}} M_{t s c}^{2} \overline{\bar{Y}}_{t s c}-\hat{\overline{\bar{Y}}}_{t s(R)}\right)^{2}}{n_{t s}-1}\right. \\
& \left.+\frac{N_{t s}}{n_{t s}} \sum_{c=1}^{n_{t s}} M_{t s c}^{2}\left[\frac{M_{t s c}-m_{t s c}}{M_{t s c}}\right] \frac{s_{t s c}^{2}}{m_{t s c}}\right]
\end{aligned}
$$

One need only be concemed about computing $\hat{\overline{\bar{Y}}}_{t s(R)}$ and $\operatorname{Var}\left(\hat{\overline{\bar{Y}}}_{t s(R)}\right)$ for $s=1,2, \ldots, 9$ and $t=1,2$. Because $M_{t s}$. is unknown, estimate it by

$$
\hat{M}_{t s}=N_{t s}\left(\sum_{c=1}^{n_{L}} M_{L s c} / n_{t s}\right) \text { for } t=1,2 \text { and } s=1,2, \ldots, 9
$$

IV. ESTIMATES FOR THE ENTIRE NORTHEAST DURING WINTER $t$

$$
\text { Let } \hat{M}_{t-\infty}=\sum_{s=1}^{9} \hat{M}_{t s} \text { and } P_{t s}=\hat{M}_{t s} \cdot \hat{M}_{t} . . \text { for } s=1,2, \ldots, 9 \text {. }
$$

An estimate of $\overline{\bar{Y}}_{t}$ is given by

$$
\hat{\overline{\bar{Y}}}_{t(R)}=\sum_{s=1}^{9} P_{t s} \hat{\overline{\bar{Y}}}_{t s(R)} .
$$

The approximate sampling variance of $\hat{\bar{Y}}_{t(R)}$ is

$$
\operatorname{Var}\left(\hat{\overline{\bar{Y}}}_{t(R)}\right) \approx \sum_{s=1}^{9} P_{t s}^{2} \operatorname{Var}\left(\hat{\overline{\bar{Y}}}_{t s(R)}\right),
$$


and an approximate estimate of $\operatorname{Var}\left(\hat{\bar{Y}}_{t(R)}\right)$ is

$$
\operatorname{Var}\left(\hat{\overline{\bar{Y}}}_{l(R)}\right) \approx \sum_{s=1}^{9} P_{L s}^{2} \operatorname{Var}\left(\hat{\overline{\bar{Y}}}_{t s(R)}\right) .
$$

Our concern is in computing $\hat{\overline{\bar{Y}}}_{t(R)}$ and $\operatorname{Var}\left(\hat{\bar{Y}}_{t(R)}\right)$.

V. ESTIMATES FOR THE ENTIRE NORTHEAST OVER BOTH WINTERS

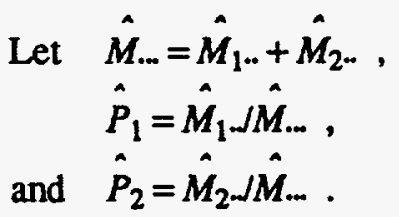

An estimate of $\overline{\bar{Y}}$ is

$$
\hat{\overline{\bar{Y}}}=\hat{P}_{1} \hat{\overline{\bar{Y}}}_{1(R)}+\hat{P}_{2} \hat{\bar{Y}}_{2(R)} .
$$

The approximate sampling variance of $\hat{\bar{Y}}$ is

$$
\operatorname{Var}(\hat{\bar{Y}}) \approx\left(\hat{P}_{1}\right)^{2} \operatorname{Var}\left(\hat{\bar{Y}}_{1(R)}\right)+\left(\hat{P}_{2}\right)^{2} \operatorname{Var}\left(\hat{\bar{Y}}_{2(R)}\right),
$$

and an approximate estimate of $\operatorname{Var}(\hat{\bar{Y}})$ is

$$
\operatorname{Var}(\hat{\bar{Y}})=\left(\hat{P}_{1}\right)^{2} \operatorname{Var}\left(\hat{\overline{\bar{Y}}}_{1(R)}\right)+\left(\hat{P}_{2}\right)^{2} \operatorname{Var}\left(\hat{\overline{\bar{Y}}}_{2(R)}\right) .
$$

Our concern is in computing $\hat{\bar{Y}}$ and $\operatorname{Var}(\hat{\bar{Y}})$. 
APPENDIX J. TABLES FOR STEADY-STATE EFFICIENCY 

Table J.1. Combustion steady-state efficiency chart for No. 2 fuel oil

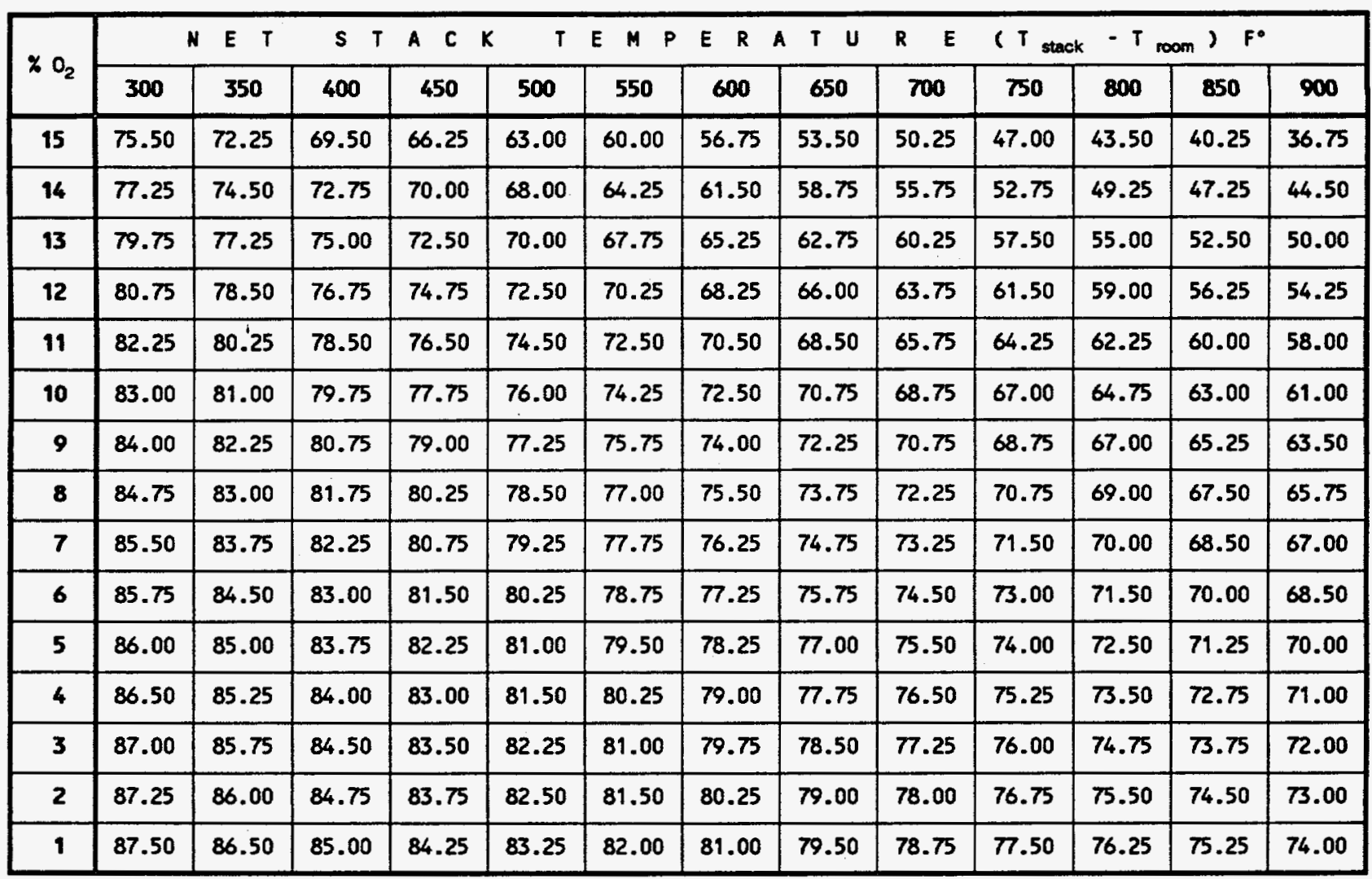

The following adjustments to the steady-state efficiency must be made based on the measured smoke number:

\begin{tabular}{|c|c|c|c|c|c|c|c|c|c|c|}
\hline If smoke number is $\rightarrow$ & 0 & 1 & 2 & 3 & 4 & 5 & 6 & 7 & 8 & 9 \\
\hline act fro & 0 & 0 & 0 & 0 & 1 & 2 & 3 & 4 & 6 & 7 \\
\hline
\end{tabular}


Table J.2. Mean values and standard errors of steady-state efficiencies for different heating system types

\begin{tabular}{|c|c|c|c|c|c|c|c|}
\hline \multirow{3}{*}{$\begin{array}{c}\text { Type } \\
\text { of } \\
\text { heating system/house }\end{array}$} & \multirow{3}{*}{$\begin{array}{l}\text { Number } \\
\text { in } \\
\text { sample }\end{array}$} & \multicolumn{6}{|c|}{ Adjusted steady-state efficiency ${ }^{1}$} \\
\hline & & \multicolumn{2}{|c|}{$\begin{array}{c}\text { Pre- } \\
\text { weatherization }\end{array}$} & \multicolumn{2}{|c|}{$\begin{array}{c}\text { Post- } \\
\text { weatherization }\end{array}$} & \multicolumn{2}{|c|}{ Difference } \\
\hline & & $\begin{array}{l}\text { Mean } \\
\text { value }\end{array}$ & $\begin{array}{l}\text { Std. } \\
\text { error }\end{array}$ & $\begin{array}{l}\text { Mean } \\
\text { value }\end{array}$ & $\begin{array}{l}\text { Std. } \\
\text { error }\end{array}$ & $\begin{array}{l}\text { Mean } \\
\text { value }\end{array}$ & $\begin{array}{l}\text { Std. } \\
\text { error }\end{array}$ \\
\hline All Systems - Weatherized & 136 & & & & & & \\
\hline No clean \& tune-up & 65 & 77.2 & 0.8 & 77.7 & 0.6 & 0.51 & 0.54 \\
\hline Clean \& tune-up & 71 & 75.0 & 0.7 & 75.8 & 0.7 & 0.80 & 0.60 \\
\hline All Systems - Control & 72 & & & & & & \\
\hline No clean \& tune-up & 72 & 75.0 & 0.6 & 76.6 & 0.6 & 1.54 & 0.43 \\
\hline Forced-Air - Weatherized & 65 & & & & & & \\
\hline No clean \& tune-up & 32 & 77.7 & 0.9 & 77.6 & 0.9 & -0.09 & 0.74 \\
\hline Clean \& tune-up & 33 & 75.9 & 0.9 & 76.3 & 0.9 & 0.38 & 0.77 \\
\hline Forced-Air - Control & 16 & & & & & & \\
\hline No clean \& tune-up & 16 & 76.5 & 1.2 & 77.7 & 1.1 & 1.16 & 1.32 \\
\hline Hydronic - Weatherized & 45 & & & & & & \\
\hline No clean \& tune-up & 18 & 79.1 & 0.9 & 78.9 & 1.1 & -0.17 & 0.63 \\
\hline Clean \& tune-up & 27 & 76.0 & 1.0 & 76.9 & 1.0 & 0.96 & 0.89 \\
\hline Hydronic - Control & 44 & & & & & & \\
\hline No clean \& tune-up & 44 & 74.9 & 0.8 & 76.6 & 0.7 & 1.72 & 0.48 \\
\hline
\end{tabular}

\footnotetext{
${ }^{1}$ Steady-state efficiencies were adjusted for smoke numbers.
} 
Table J.3. Mean values and standard errors of steady-state efficiencies for systems with and without flame-retention burners

\begin{tabular}{|c|c|c|c|c|c|c|c|}
\hline \multirow{3}{*}{$\begin{array}{c}\text { Type } \\
\text { of } \\
\text { oil burner/house }\end{array}$} & \multirow{3}{*}{$\begin{array}{l}\text { Number } \\
\text { in } \\
\text { sample }\end{array}$} & \multicolumn{6}{|c|}{ Adjusted steady-state efficiency ${ }^{1}$} \\
\hline & & \multicolumn{2}{|c|}{$\begin{array}{c}\text { Pre- } \\
\text { weatherization }\end{array}$} & \multicolumn{2}{|c|}{$\begin{array}{c}\text { Post- } \\
\text { weatherization }\end{array}$} & \multicolumn{2}{|c|}{ Difference } \\
\hline & & $\begin{array}{l}\text { Mean } \\
\text { value }\end{array}$ & $\begin{array}{l}\text { Std. } \\
\text { error }\end{array}$ & $\begin{array}{l}\text { Mean } \\
\text { value }\end{array}$ & $\begin{array}{l}\text { Std. } \\
\text { error }\end{array}$ & $\begin{array}{l}\text { Mean } \\
\text { value }\end{array}$ & $\begin{array}{l}\text { Std. } \\
\text { error }\end{array}$ \\
\hline FR Burners - Weatherized & 66 & & & & & & \\
\hline No clean \& tune-up & 40 & 79.0 & 0.7 & 79.5 & 0.6 & 0.58 & 0.49 \\
\hline Clean \& tune-up & 26 & 77.2 & 1.0 & 78.4 & 1.1 & 1.18 & 1.01 \\
\hline FR Burners - Control & 34 & & & & & & \\
\hline No clean \& tune-up & 34 & 76.7 & 0.8 & 78.8 & 0.7 & 2.05 & 0.67 \\
\hline No FR Burners - Weatherized & 65 & & & & & & \\
\hline No clean \& tune-up & 22 & 73.9 & 1.6 & 74.5 & 1.0 & 0.59 & 1.32 \\
\hline Clean \& tune-up & 43 & 74.1 & 0.9 & 74.4 & 0.8 & 0.27 & 0.74 \\
\hline No FR Burners - Control & 36 & & & & & & \\
\hline No clean \& tune-up & 36 & 73.2 & 0.9 & 74.6 & 0.8 & 1.37 & 0.54 \\
\hline
\end{tabular}

${ }^{1}$ Steady-state efficiencies were adjusted for smoke numbers. 

APPENDIX K K OCCUPANT RESPONSES TO QUESTIONNAIRES 
CONTROL HOUSES

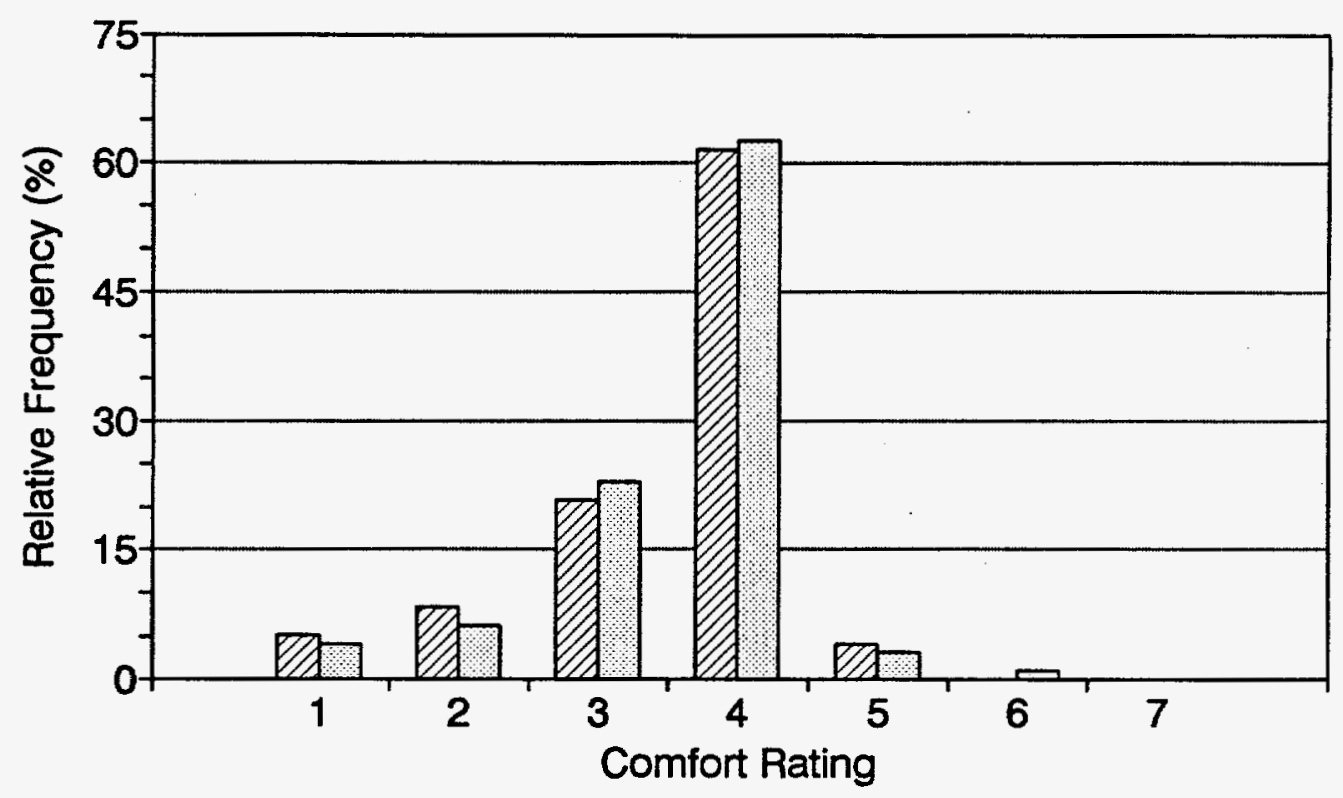

WEATHERIZED HOUSES

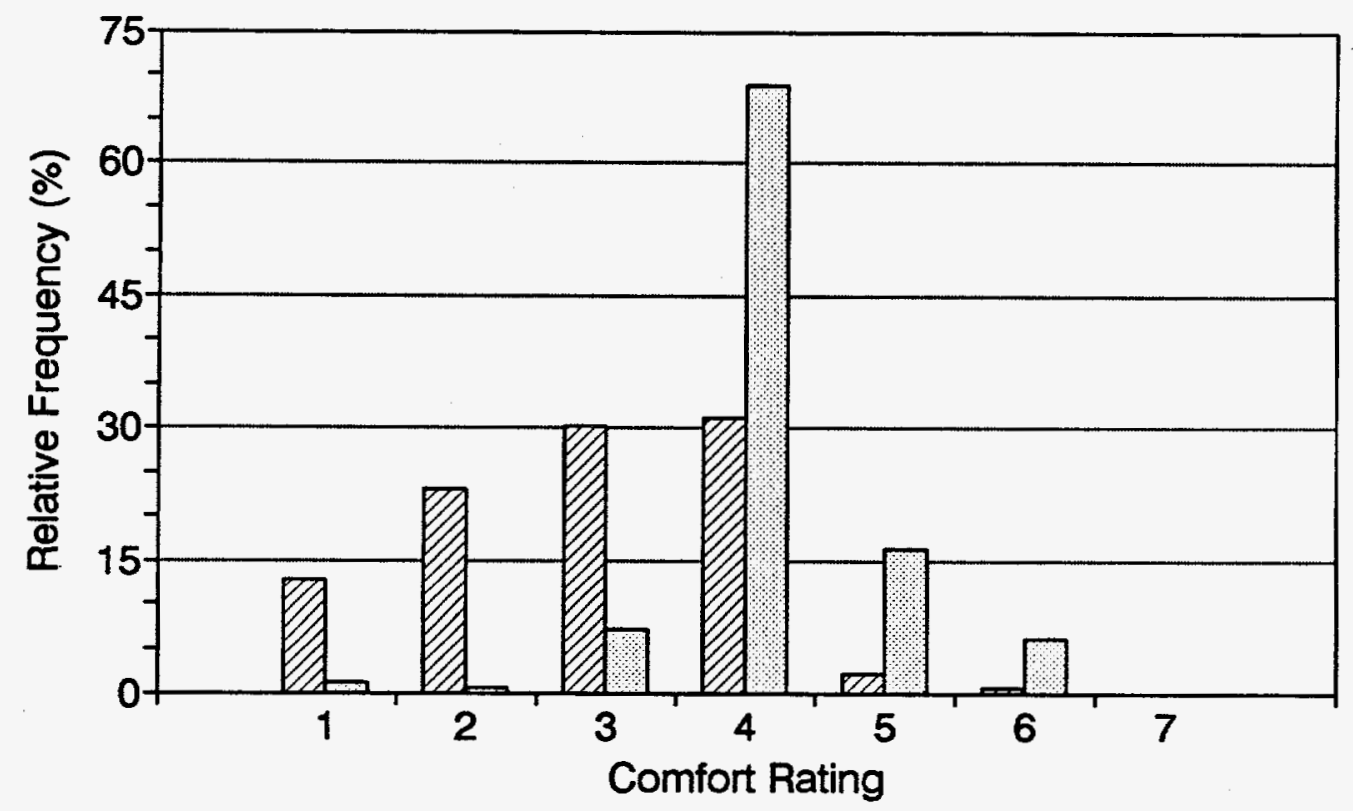

एTII Pre Period $\square$ Post Period

Fig. K.1. Distribution of occupant ratings for indoor comfort for control and weatherized houses. A scale of 1 to 7 was used, where 1 was poor and 7 was excellent. 
CONTROL HOUSES

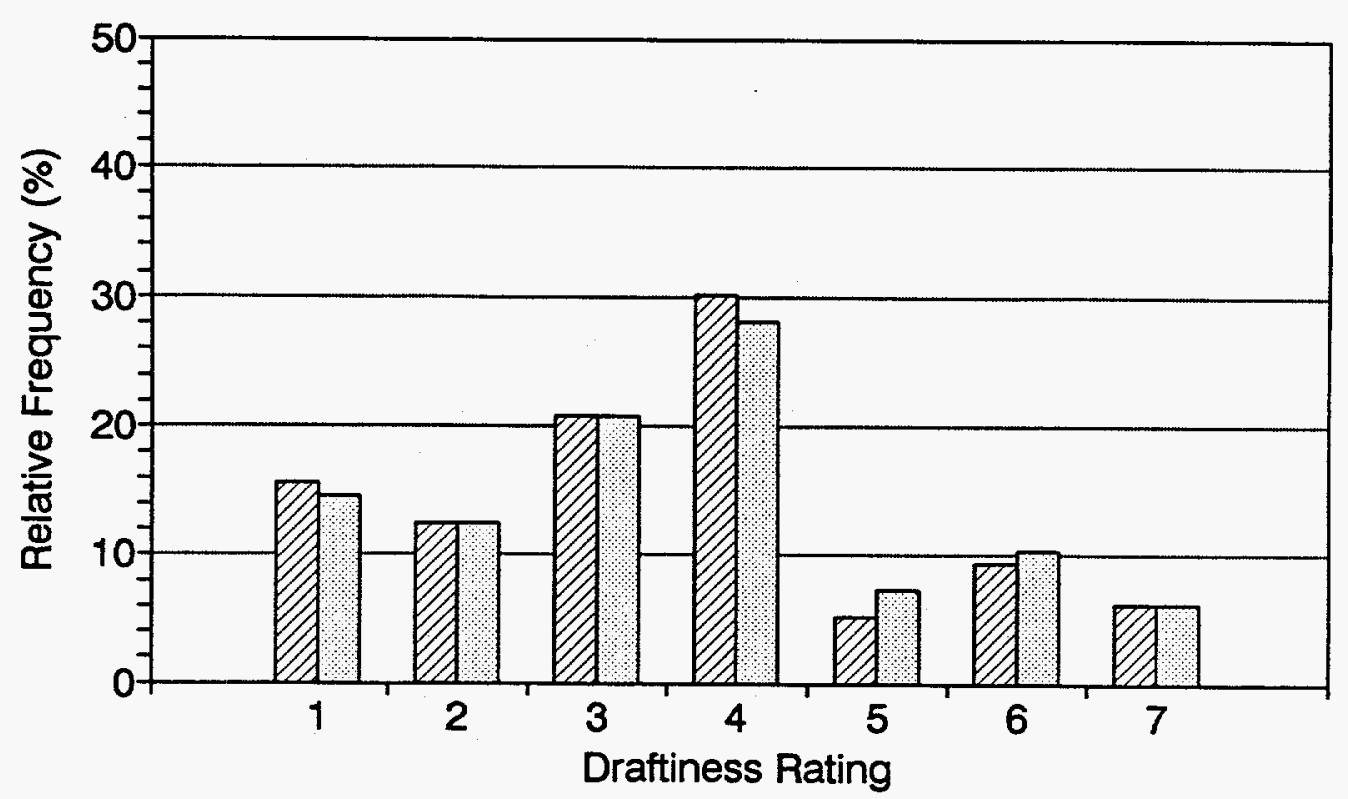

WEATHERIZED HOUSES

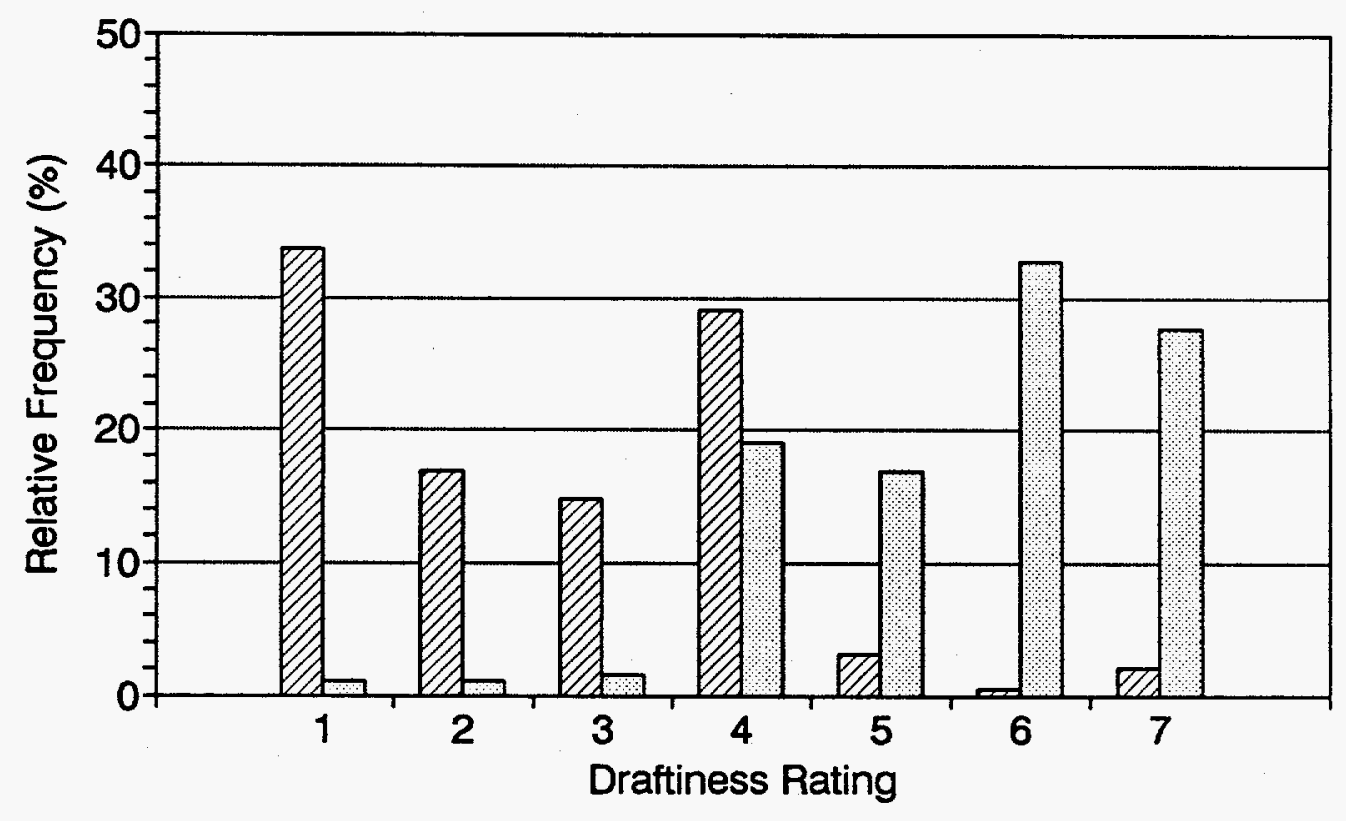

Pre Period $\square$ Post Period

Fig. K.2. Distribution of occupant ratings for house draftiness for control and weatherized houses. A scale of 1 to 7 was used, where 1 was poor and 7 was excellent. 

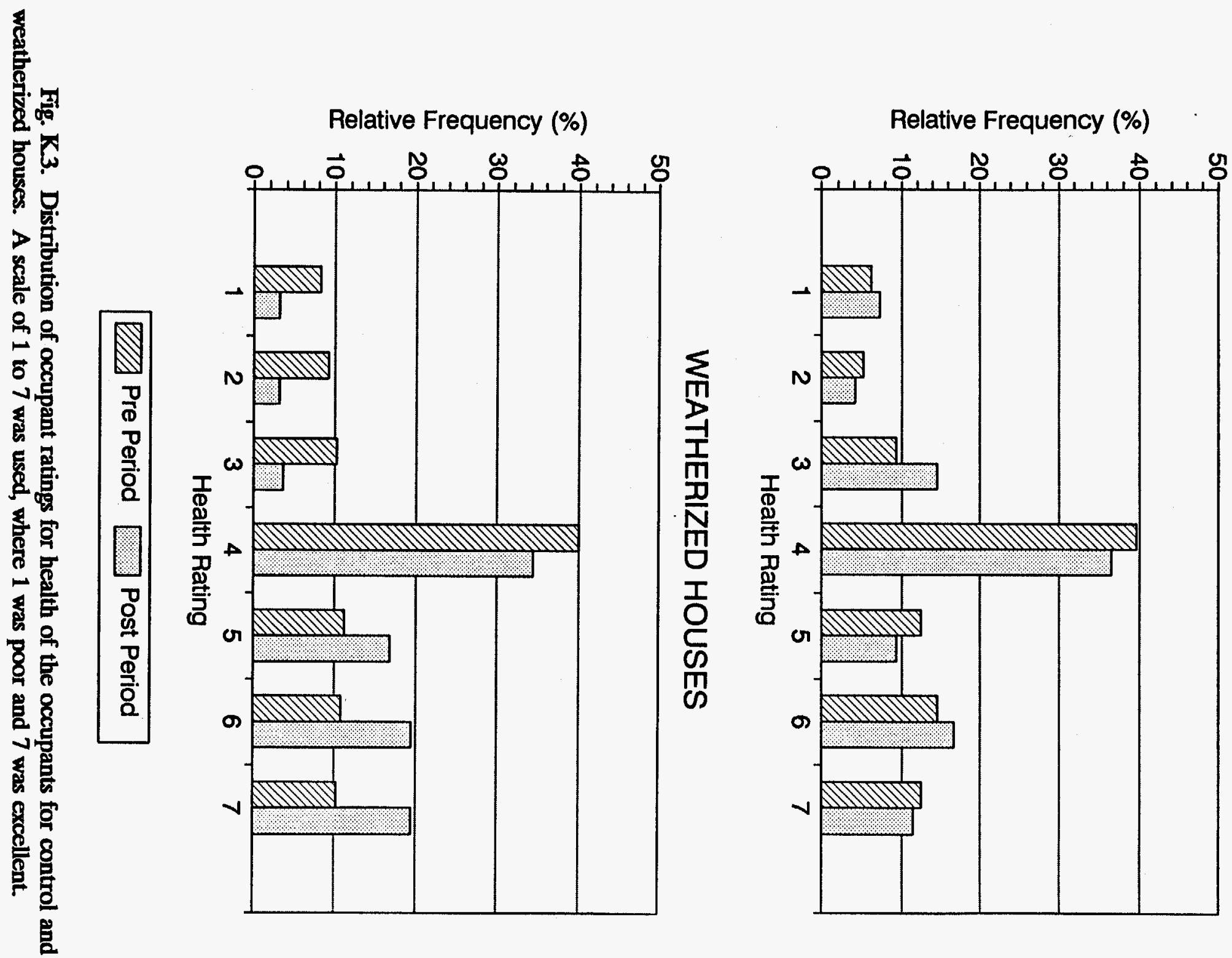

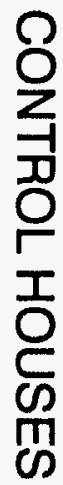


CONTROL HOUSES

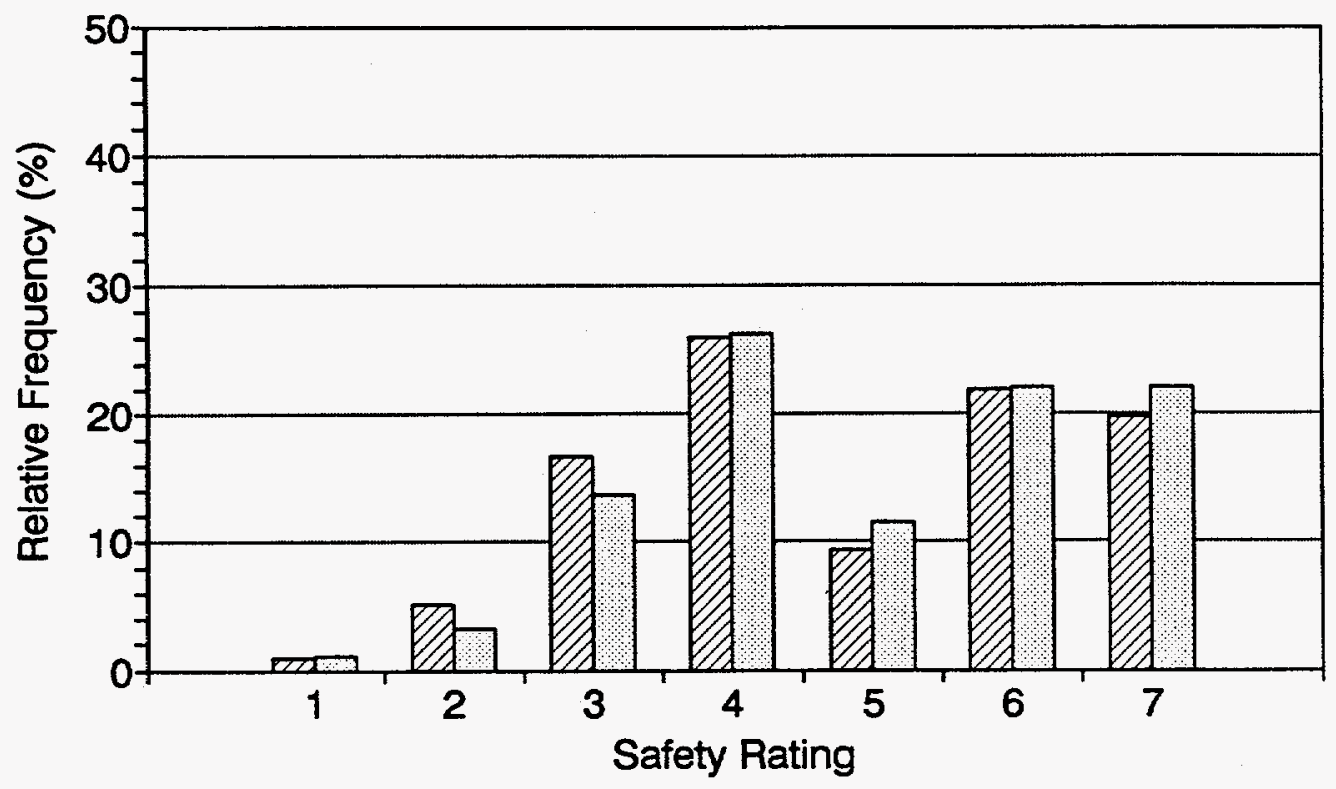

WEATHERIZED HOUSES

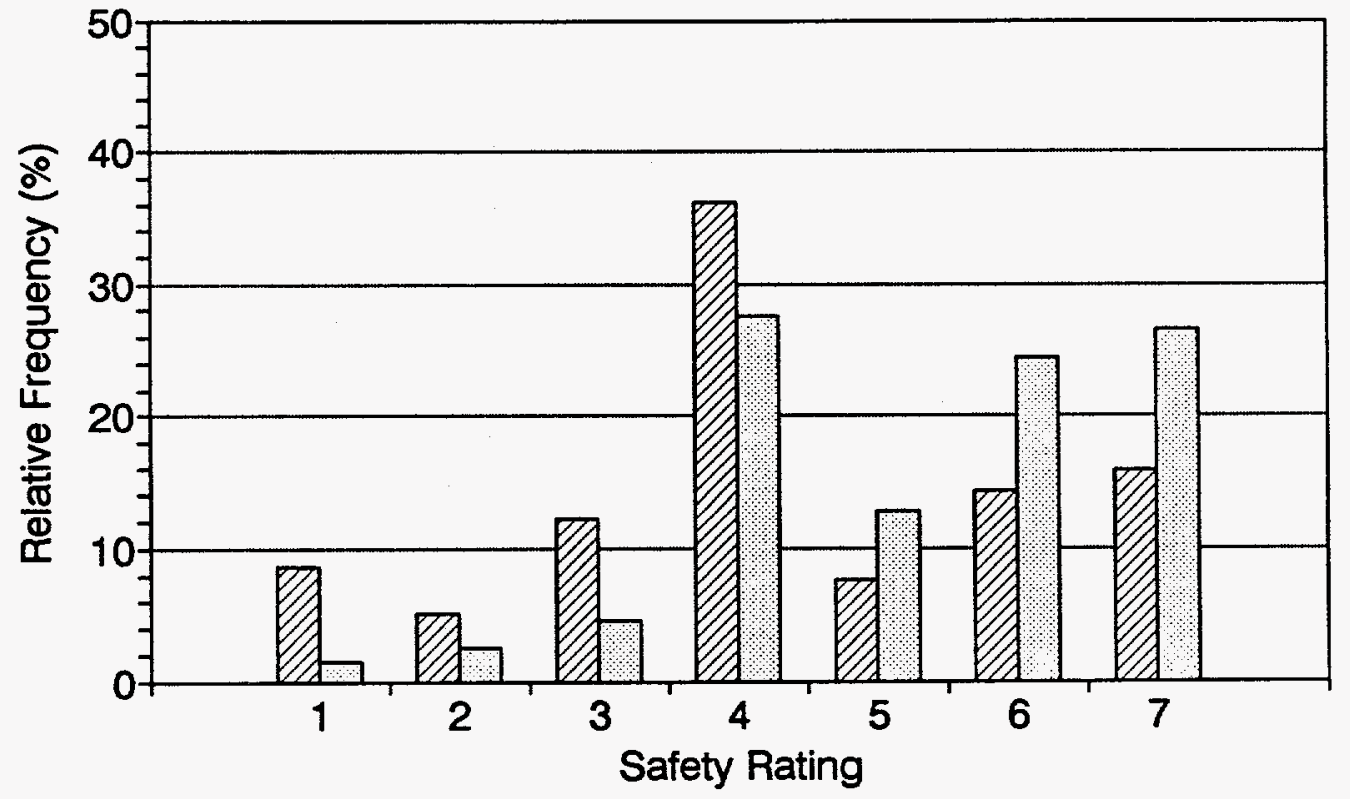

WIIA Pre Period $\square$ Post Period

Fig. K.4. Distribution of occupant ratings for house safety for control and weatherized houses. A scale of 1 to 7 was used, where 1 was poor and 7 was excellent. 
CONTROL HOUSES

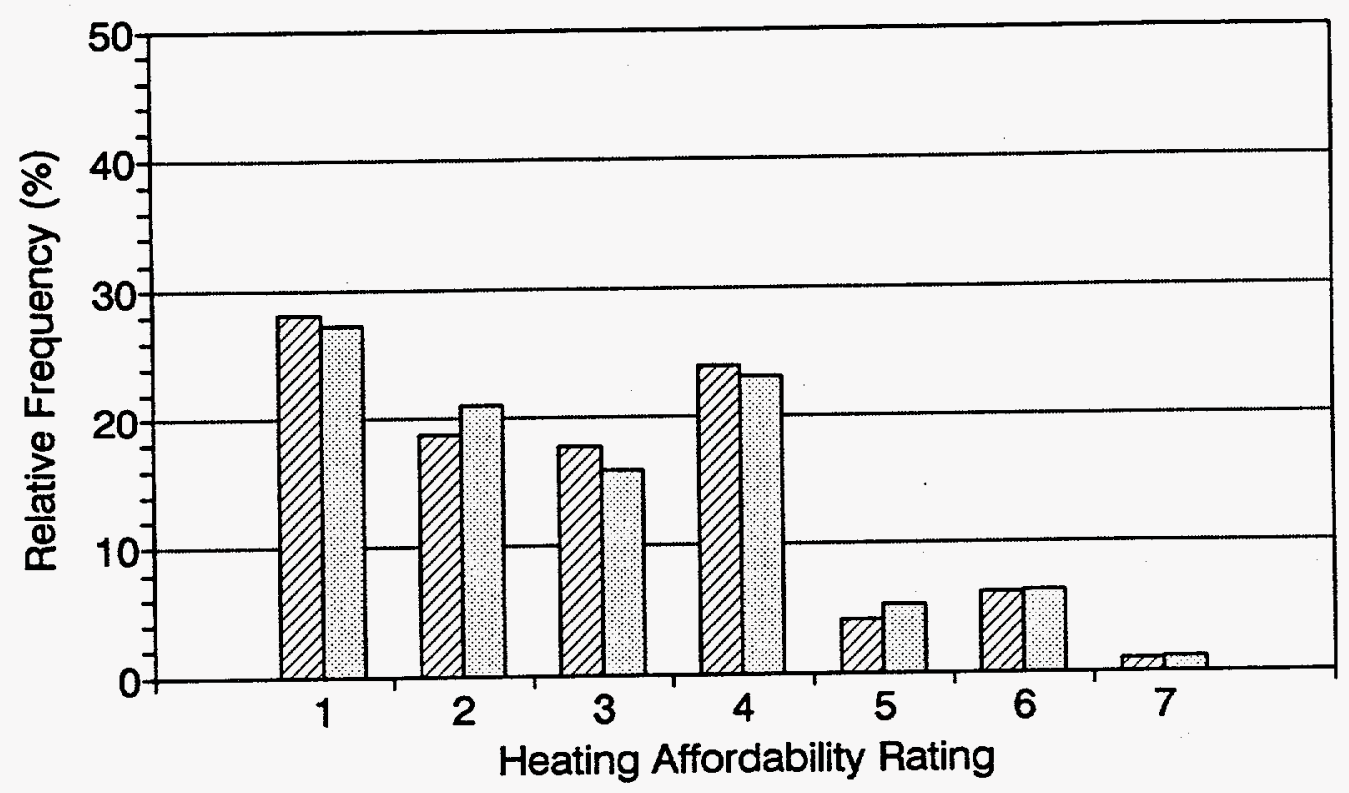

WEATHERIZED HOUSES

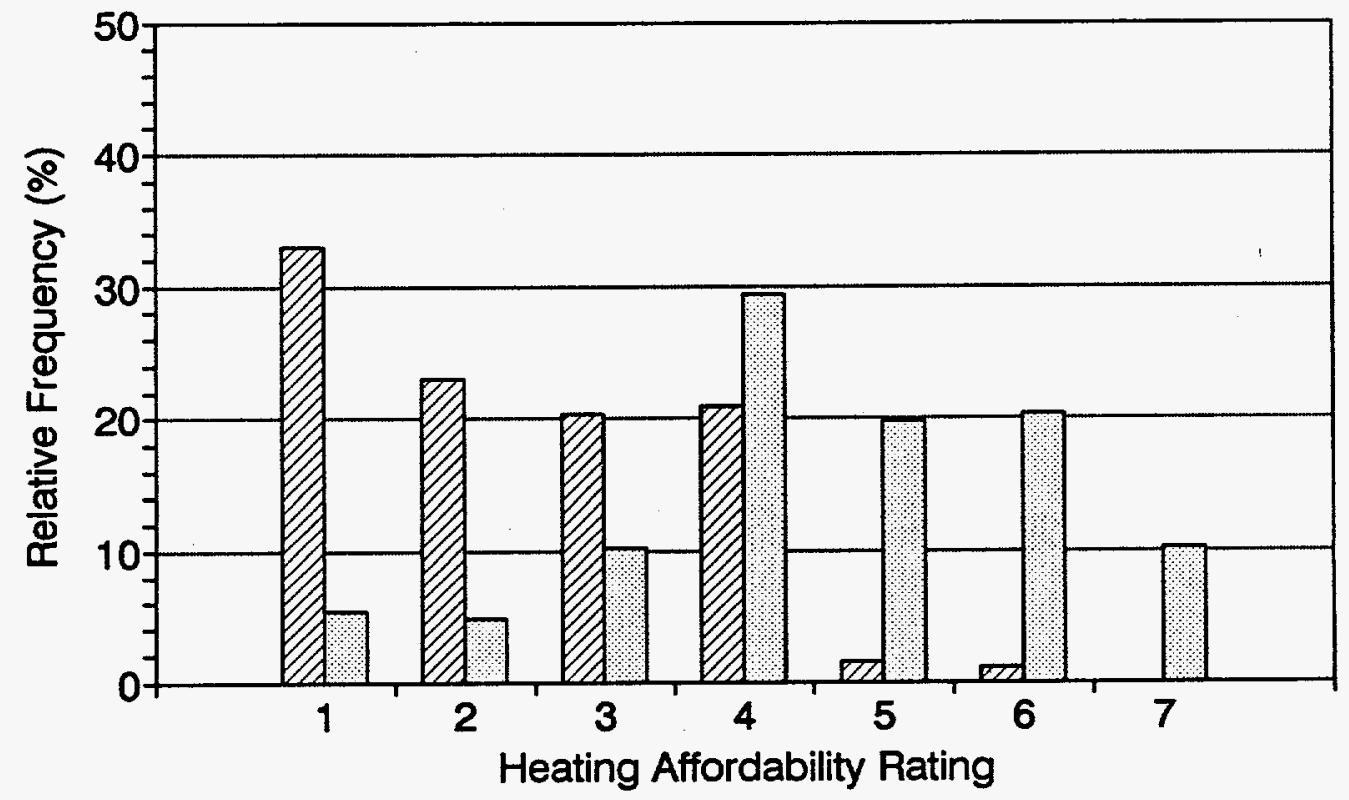

WIIT Pre Period

Fig. K.5. Distribution of occupant ratings for heating affordability for control and weatherized houses. A scale of 1 to 7 was used, where 1 was poor and 7 was excellent. 
Table K.1. Occupant survey summary

\begin{tabular}{|c|}
\hline QUESTIONS FROM CLOSEOUT SURVEY \\
\hline Was Home Kept at Same Temperature All Day? \\
\hline $\begin{array}{l}\text { What Temperature (No Change Group)? } \\
\text { What Day Temperature when Occupied? } \\
\text { What Day Temperature when Unoccupied? } \\
\text { What Night Temperature when Sleeping? }\end{array}$ \\
\hline $\begin{array}{l}\text { Any Heating System Problems? } \\
\text { Run out of Fuel? } \\
\text { Did Utility Disconnect Service? }\end{array}$ \\
\hline $\begin{array}{l}\text { Number of Times with No Heat? } \\
\text { Control Homes } \\
\text { Weatherized Homes }\end{array}$ \\
\hline
\end{tabular}

\begin{tabular}{|c|c|c|c|c|c|c|}
\hline \multirow[b]{2}{*}{ No. } & \multicolumn{3}{|c|}{ WEATHERIZED } & \multicolumn{3}{|c|}{ CONTROL } \\
\hline & Same & Changed & Percent & Same & Changed & Percent \\
\hline E & 92 & 106 & 53.5 & 42 & 54 & 56.3 \\
\hline \multirow[b]{2}{*}{$\begin{array}{l}\text { E1k } \\
\text { E10 } \\
\text { E10 } \\
\text { E1e }\end{array}$} & \multicolumn{2}{|c|}{ Avg Temp ${ }^{\circ} \mathrm{F}$} & Number & \multicolumn{2}{|c|}{ Avg Temp ${ }^{\circ} \mathrm{F}$} & Number \\
\hline & \multicolumn{2}{|r|}{$\begin{array}{l}69.6 \\
68.8 \\
63.4 \\
64.0\end{array}$} & $\begin{array}{r}88 \\
104 \\
97 \\
101\end{array}$ & \multicolumn{2}{|c|}{$\begin{array}{l}68.7 \\
68.7 \\
62.7 \\
63.9\end{array}$} & $\begin{array}{l}40 \\
54 \\
47 \\
54\end{array}$ \\
\hline & Yes & No & Percent & Yes & No & Percent \\
\hline $\begin{array}{l}\text { F1a } \\
\text { F1a } \\
\text { F1a }\end{array}$ & $\begin{array}{r}31 \\
28 \\
9\end{array}$ & $\begin{array}{l}163 \\
162 \\
161\end{array}$ & $\begin{array}{r}16.0 \\
14.7 \\
5.3\end{array}$ & $\begin{array}{r}16 \\
11 \\
0\end{array}$ & $\begin{array}{l}80 \\
80 \\
80\end{array}$ & $\begin{array}{r}16.7 \\
12.1 \\
0.0\end{array}$ \\
\hline F 1b & 1 & 2 & 3 & 4 & 5 & 8 \\
\hline & $\begin{array}{l}14 \\
28\end{array}$ & $\begin{array}{l}4 \\
9\end{array}$ & $\begin{array}{l}3 \\
5\end{array}$ & $\begin{array}{l}1 \\
4\end{array}$ & $\begin{array}{l}1 \\
2\end{array}$ & $\begin{array}{l}0 \\
1\end{array}$ \\
\hline
\end{tabular}

\begin{tabular}{|c|c|c|c|c|c|c|}
\hline \multirow[b]{2}{*}{ No. } & \multicolumn{3}{|c|}{ WEATHERIZED } & \multicolumn{3}{|c|}{ CONTROL } \\
\hline & Same & Changed & Percent & Same & Changed & Percent \\
\hline \multirow[t]{2}{*}{$E 2 a$} & 95 & 100 & 51.3 & 43 & 53 & 55.2 \\
\hline & \multicolumn{2}{|c|}{ Avg Temp ${ }^{\circ} \mathrm{F}$} & Number & \multicolumn{2}{|c|}{ Avg Temp ${ }^{\circ} \mathrm{F}$} & Number \\
\hline \multirow[t]{2}{*}{$\begin{array}{l}E 2 b \\
E 2 c \\
E 2 d \\
E 2 e\end{array}$} & \multicolumn{2}{|c|}{$\begin{array}{l}68.2 \\
68.3 \\
63.1 \\
63.1\end{array}$} & $\begin{array}{l}87 \\
98 \\
90 \\
95\end{array}$ & \multicolumn{2}{|c|}{$\begin{array}{l}68.8 \\
68.7 \\
63.0 \\
64.2\end{array}$} & $\begin{array}{l}53 \\
46 \\
52 \\
52\end{array}$ \\
\hline & Yes & No & Percent & Yes & No & Percent \\
\hline $\begin{array}{l}\mathrm{F} 2 \mathrm{a} \\
\mathrm{F} 2 \mathrm{a} \\
\mathrm{F} 2 \mathrm{a}\end{array}$ & $\begin{array}{r}25 \\
21 \\
6\end{array}$ & $\begin{array}{l}169 \\
175 \\
169\end{array}$ & $\begin{array}{r}12.9 \\
10.7 \\
3.4\end{array}$ & $\begin{array}{r}11 \\
8 \\
5\end{array}$ & $\begin{array}{l}85 \\
86 \\
77\end{array}$ & $\begin{array}{r}11.5 \\
8.5 \\
6.1\end{array}$ \\
\hline$F 2 b$ & 1 & 2 & 3 & 4 & 5 & 8 \\
\hline & $\begin{array}{l}11 \\
23\end{array}$ & $\begin{array}{l}5 \\
7\end{array}$ & $\begin{array}{l}0 \\
6\end{array}$ & $\begin{array}{l}2 \\
0\end{array}$ & $\begin{array}{l}0 \\
0\end{array}$ & $\begin{array}{l}0 \\
0\end{array}$ \\
\hline
\end{tabular}

What was Total Time with No Heat?

\begin{tabular}{|c|c|c|}
\hline Duration & Weather. & Control \\
\hline $\begin{array}{r}4 \mathrm{Hrs} \\
<\quad 8 \mathrm{Hrs} \\
<12 \mathrm{Hrs} \\
<24 \mathrm{Hrs} \\
1 \text { Day } \\
2 \text { Days } \\
3 \text { Days } \\
4 \text { Days } \\
5 \text { Days } \\
7 \text { Days } \\
8 \text { Days } \\
10 \text { Days } \\
13 \text { Days } \\
14 \text { Days } \\
21 \text { Days } \\
36 \text { Days } \\
\text { ? Days }\end{array}$ & $\begin{array}{r}25 \\
7 \\
4 \\
7 \\
7 \\
7 \\
3 \\
1 \\
2 \\
0 \\
0 \\
1 \\
1 \\
3 \\
0 \\
2 \\
0\end{array}$ & $\begin{array}{r}10 \\
3 \\
2 \\
4 \\
2 \\
1 \\
2 \\
1 \\
0 \\
1 \\
1 \\
0 \\
0 \\
0 \\
1 \\
0 \\
0\end{array}$ \\
\hline
\end{tabular}

\begin{tabular}{|c|c|c|}
\hline Duration & Weather. & Control \\
\hline$<4$ Hrs & 23 & 9 \\
$<$ 8 Hrs & 4 & 3 \\
$<12$ Hrs & 13 & 2 \\
$<24$ Hrs & 3 & 2 \\
1 Day & 4 & 2 \\
2 Days & 5 & 3 \\
3 Days & 1 & 0 \\
4 Days & 0 & 0 \\
5 Days & 0 & 1 \\
7 Days & 0 & 0 \\
8 Days & 0 & 1 \\
10 Days & & \\
13 Days & & \\
14 Days & & \\
21 Days & & \\
36 Days & & \\
? Days & 1 & 0 \\
\hline No-Heat Days & 31 & 26
\end{tabular}




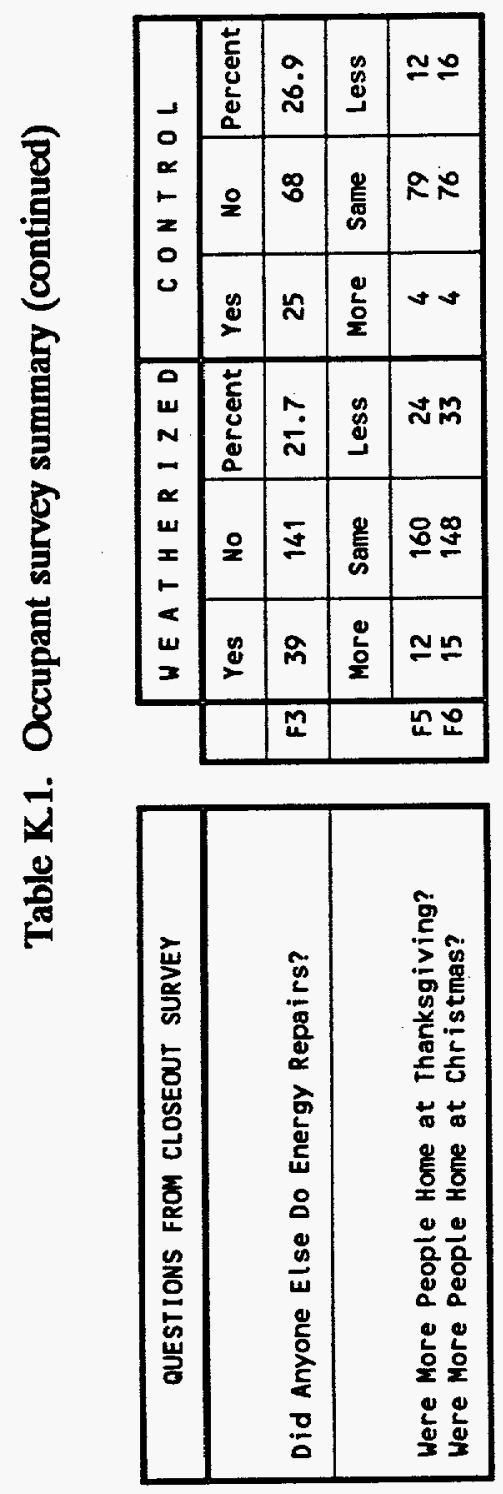

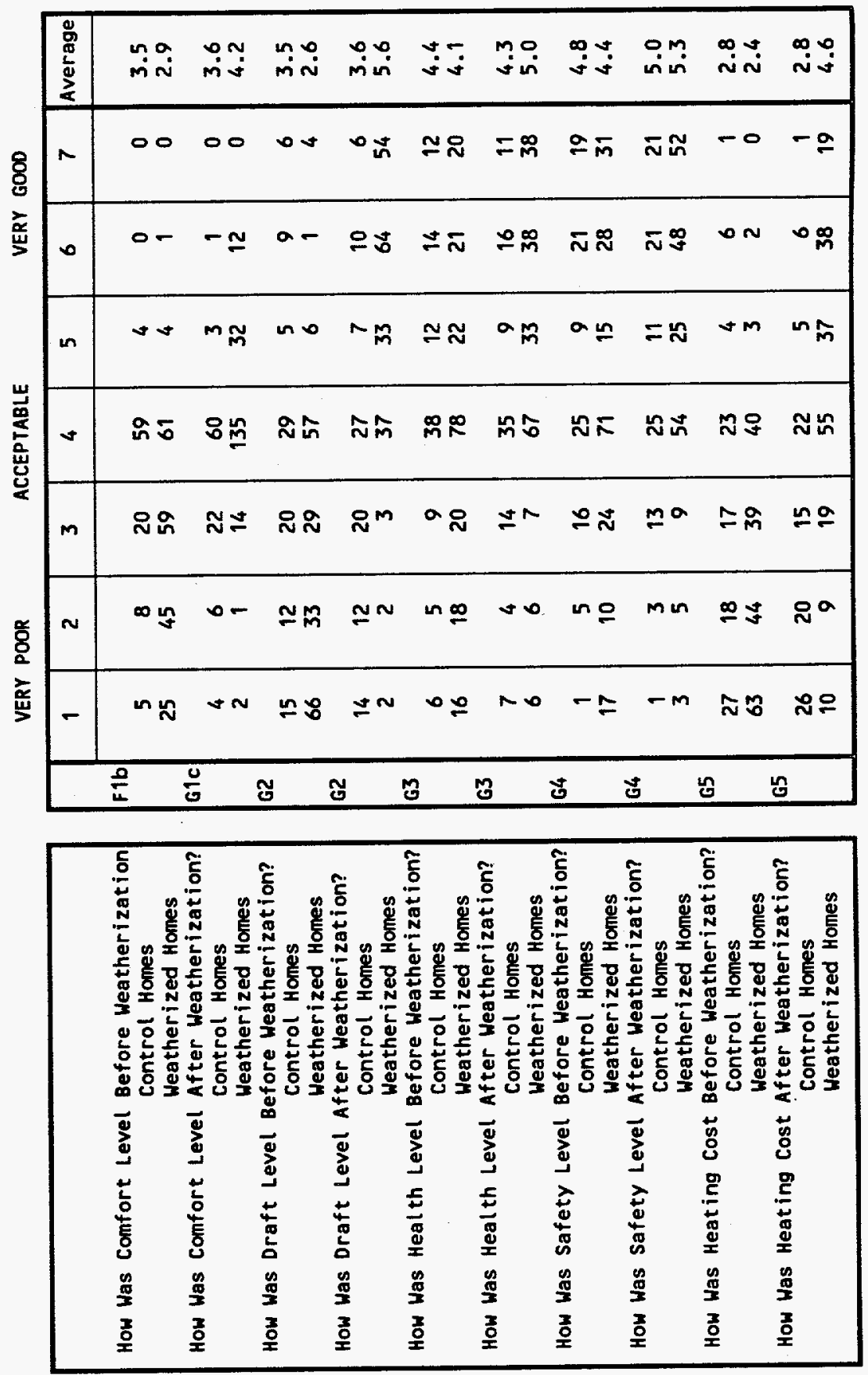

